\title{
ACBAR
}

\section{DIRECTORY OF HUMANITARIAN AGENCIES WORKING FOR AFGHANS}

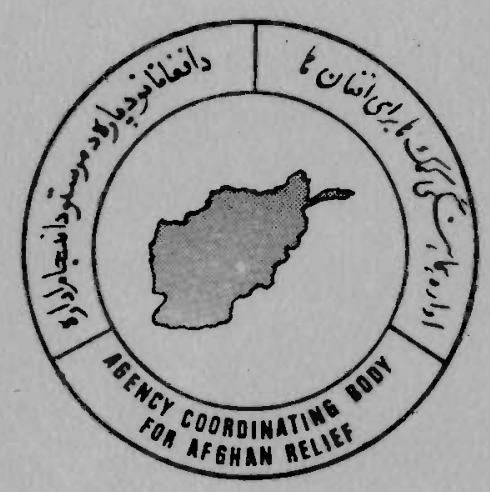

AGENCY COORDINATING BODY FOR AFGHAN RELIEF

2 REHMAN BABA ROAD

U.P.O. BOX 1084

UNIVERSITY TOWN

PESHAWAR, NWFP

PAKISTAN

TEL: 091-44392/40839/45316

FAX: 092-91 -840471

EMAIL: acbaar@radio.psh.brain.net.pk 


\section{INTRODUCTION}

I am pleased to be able finally to make available the ACBAR "Directory of Humanitarian Agencies working for Afghans" for 1997.

This document has taken considerable time and effort to prepare and it is regretted that it has taken so long to finalise.

Whilst the majority of agencies, included in this publication, are based in Peshawar, this Directory also covers a number of agencies located in Islamabad and Quetta as well as others located inside Afghanistan.

The details are largely as reported by agencies. ACBAR has only limited ability to confirm the information provided. However, I am confident that the publication will prove to be a very usefiul document to those that are involved or interested in the Afghanistan aid process. This publication provides a useful insight into the scope and size of the aid process in which the NGO community is involved.

I would express my thanks to all the agencies and their staff for providing the information. I hope that it has been correctly noted and regret any errors that may have been made. I would especially thank Liz Spencer, my Personal Assistant and Jawed Ludin, ACBAR Programme Manager and members of the Programme Department for their efforts.

We hope that the various users, the agencies themselves, the donor community, the Afghan authorities, the Pakistan Federal and Provincial Governments and all others will find the data informative and of value.

Charles A MacFadden

Executive Director

July 1998

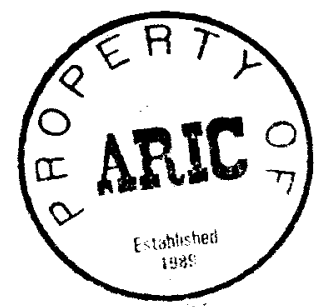




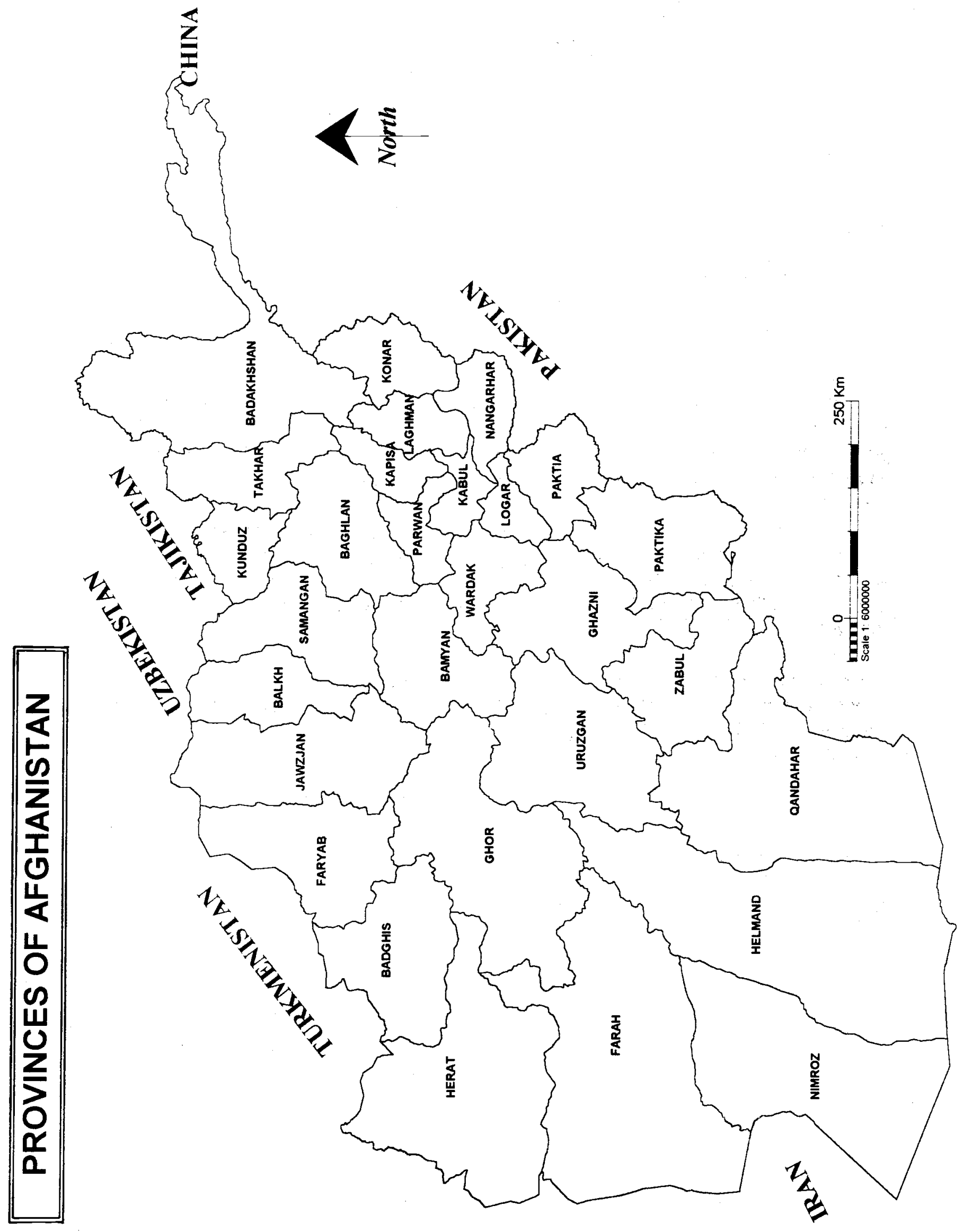




\section{CONTENTS}

\section{STATISTICAL SUMMARY}

Agencies as Employers......................................................

1997 Budget Allocation, by Sector.....................................vi

ACBAR Members Budget, as \% of total...........................vi

1997 NGO Funding Sources...........................................vii

1997 Budget Allocation, by Provinces................................viii

Total Budget Expenditure, 1992-1997................................ix

1997 Budget Allocation, Refugee/Afgh. Programmes........ix

AGENCIES

CODE

NAME

A-AID

AFGHANAID

AAA

AFGHAN AID ASSOCLATION

AABRAR

AFGHAN AMPUTEE BICYCLISTS FOR REHAB. \& RECREATION

AFGHAN AGRICULTURAL \& ENGINEERING AGENCY 8

AAEA

AFGHAN COMMUNITY DEVELOPMENT ORGANISATION

ACDO

ACF

ACLU

ACTION CONTRE LA FAIM

AFGHAN CONSTRUCTION \& LOGISTIC UNIT

ACRD

ADA

ADAg

ADS

AFGHAN DEVELOPMENT ASSOCIATION

AFGHAN DEVELOPMENT AGENCY 20

AFGHAN DISABLED SOCIETY

AFRANE AMITE FRANCE-AFGHANE AIDE HUMANITAIRE ET INFORMATION 24

AFS $\begin{array}{ll}\text { AGENCY FOR FARMING SUPPORT } & 26\end{array}$

AG BAS-Ed AFGHAN GERMAN BASIC EDUCATION 28

AG-TTP AFGHAN-GERMAN TECHNICAL TRAINING PROGRAMME $\quad 30$

AGHCO AFGHAN/GERMAN HELP COORDINATION OFFICE

AHDS AFGHAN HEALTH \& DEVELOPMENT SERVICES

AHSAO AFGHANS HEALTH AND SOCIAL ASSISTANCE ORGANISATION : 36

$\begin{array}{lll}\text { AIL } & \text { AFGHAN INSTITUTE OF LEARNING } & 38\end{array}$

AITM $\quad$ AFGHAN INKISHAFEE TARBIAWEE MARKAZ 40

AMA AFGHAN MEDICAL AID $\quad 42$

AMI AIDE MEDICALE INTERNATIONALE-AFGHANISTAN

AMRAN AFGHAN MOBILE RECONSTRUCTION ASSOCIATION

APWO AFGHAN PUBLIC WELFARE ORGANISATION

$\begin{array}{lll}\text { ARC } & \text { AUSTRIAN RELIEF COMMITTEE }\end{array}$

ARCAR ARIANA REHAB COMMITTEE FOR AFGHANISTAN RECONST

ARCON AFGHANISTAN RECONSTRUCTION CONSULTANTS

ARCS $\quad$ AFGHAN RED CRESCENT SOCIETY $\quad 56$

ARDA AGENCY FOR RURAL DEVELOPMENT OF AFGHANISTAN

ARDO AFGHANISTAN REHAB.\& DEVELOPMENT ORGANISATION 6

ARDP AFGHANISTAN REHAB. \& DEVELOPMENT PROGRAMME $\quad 62$

ARDU AFGHAN RECONSTRUCTION AND DEVELOPMENT UNIT

AREA AGENCY FOR REHAB. \& ENERGY-CONSERVATION IN AFGHANISTAN 66

*AReA * AFGHANISTAN RECONSTRUCTION ASSOCIATION

ARF AFGHAN RELIEF FOUNDATION $\quad 70$

ARIA AUTHORITY FOR RECONST. OF INFRASTRUC.IN AFGHANISTAN $\quad 72$

ARLO AFGHAN REHABILITATION AND LOGISTICAL ORGANISATION $\quad 74$

$\begin{array}{lll}\text { ARR } & \text { AFGHAN RELIEF AND REHABILITATION } & 76\end{array}$ 
ASWCNA AFGHAN STREET WORKING CHILDREN \& NEW APPROACH

ATA-AP ANTI-TUBERCULOSIS ASSOC. GENEVA AFGHANISTAN PROJECTS $\quad 80$

ATC AFGHAN TECHNICAL CONSULTANTS

AWEC

AFGHAN WOMEN'S EDUCATION CENTER

AWRC

AFGHAN WOMEN'S RESOURCE CENTER

AWWD

AFGHAN WOMEN WELFARE DEPARTMENT

BAT

BRITISH AFGHANISTAN TRUST FOR EDUCATION \& DEVELOP

BCU BOST CONSTRUCTION UNIT

BCURA

BAZ CONSTRUCTION UNIT FOR REHAB. OF AFGHANISTAN

BDA

BAKHTAR DEVELOPMENT AGENCY

96

BEFARe

BASIC EDUCATION FOR AFGHAN REFUGEES

98

BURC

BAKHTAR UNITY RECONSTRUCTION COMMITTEE

CARITAS

CARITAS-AFGHAN REFUGEE PROGRAMME

102

CAWC

CBR

CCA

CHA

CI

CIC

CoAR

CENTRAL AFGHANISTAN WELFARE COMMITTEE

104

CONSULTANT BUREAU FOR RECONSTRUCTION

106

COOPERATION CENTER FOR AFGHANISTAN

108

COORDINATION OF HUMANITARIAN ASSISTANCE

110

CARE INTERNATIONAL

CHILDREN IN CRISIS

114

COORDINATION OF AFGHAN RELIEF

116

CRAA

COMMITTEE FOR REHABILITATION AID TO AFGHANISTAN

DACAAR

DANISH COMMITTEE FOR AID TO AFGHAN REFUGEES

DAFA

DEMINING AGENCY FOR AFGHANISTAN

122

DCA-VET

DUTCH COMMITTEE FOR AFGHANISTAN VETERINARY PROG

124

DS

DARUS SALAM

EAFA

ENVIRONMENTAL AWARENESS FOUNDATION FOR AFGHANISTAN

ERU

EMERGENCY RELIEF UNIT

130

ESAR

ENGINEERING SERVICES FOR AFGHANISTAN RECONST

FOCUS

FOCUS HUMANITARIAN ASSISTANCE EUROPE

134

FRF

FARAH RECONSTRUCTION FOUNDATION

GAA

GERMAN AGRO ACTION/DEUTSCHE WELTHUNGERHILFE

138

GAF

GERMAN AFGHANISTAN FOUNDATION

140

GP

GLOBAL PARTNERS (UK)

142

GUARDIANS GUARDIANS

HAF

HELP THE AFGHANS FOUNDATION

HAFO

HELP AFGHAN FARMERS ORGANISATION

148

HCI

HG

HUMAN CONCERN INTERNATIONAL

1.50

HELP-GERMANY

152

HANDICAP INTERNATIONAL

HI

HEALTHNET INTERNATIONAL

156

HN

HEWAD REHABILITATION PROJECT

158

HRP

HALO TRUST

IAAAE

ISLAMIC ASSOCIATION OF AFGHAN ARCHITECTS/ENGINEERS 


\begin{tabular}{|c|c|c|}
\hline IBNSINA & IBNSINA (PUBLIC HEALTH PROG. FOR AFGHANISTAN & 168 \\
\hline ICD & ITALIAN COOPERATION FOR DEVELOPMENT & 170 \\
\hline IFRCS & INT. FED. OF RED CROSS \& RED CRESCENT SOCIETIES & 172 \\
\hline IHSAN & INDEPENDENT HUMANITARIAN SERVICES ASSOCIATION & 174 \\
\hline IIRO & ISLAMIC INTERNATIONAL RELIEF ORGANISATION & 176 \\
\hline IRC & INTERNATIONAL RESCUE COMMITTEE & 178 \\
\hline ISRA & ISLAMIC RELIEF AGENCY & 180 \\
\hline JAMS & JAPAN AFGHAN MEDICAL SERVICES & 182 \\
\hline JCE & JEHAD CONSULTING ENGINEERS & 184 \\
\hline JIFF & JAPANESE INTERNATIONAL WELFARE FOUNDATION & 186 \\
\hline JWMM & JACOB'S WELL MEDICAL MISSION & 188 \\
\hline KJRC & KUWAIT JOINT RELIEF COMMITTEE & 190 \\
\hline KNF & KOHI NOOR FOUNDATION & 192 \\
\hline LDI & LAJNAT AL-DAWA AL-ISLAMIA & 194 \\
\hline LEPCO & LEPCO & 196 \\
\hline MADERA & MADERA & 198 \\
\hline MARUF & MULTI-ACTIVITY RURAL REHABILITATION FOUNDATION & 200 \\
\hline MAWA & MUSLIM ASSISTANCE AND WELFARE ASSOCIATION & 202 \\
\hline MCI & MERCY CORPS INTERNATIONAL & 204 \\
\hline MCPA & MINE CLEARANCE PLANNING AGENCY & 206 \\
\hline MDC & MINE DETECTION DOG CENTER & 208 \\
\hline MDM & MEDICINS DU MONDE & 210 \\
\hline MEDAIR & MEDAIR & 212 \\
\hline MERLIN & MEDICAL EMERGENCY RELIEF INTERNATIONAL & 214 \\
\hline MRC & MAIWAND RECONSTRUCTION COUNCIL & 216 \\
\hline MRCA & MEDICAL REFRESHER COURSES FOR AFGHANS & 218 \\
\hline MRORA & MARUF RELIEF ORG. FOR RECONST. OF AFGHANISTAN & 220 \\
\hline MSF & MEDICINS SANS FRONTIERES & 222 \\
\hline MSOA & MUSLIM SISTERS ORGANISATION OF AFGHANISTAN & 224 \\
\hline NAC & NORWEGIAN AFGHANISTAN COMMITTEE & 226 \\
\hline NCA & NORWEGLAN CHURCH AID & 228 \\
\hline NPO/RRAA & NORWEGLAN PROJ OFFICE/RURAL REHAB.ASSOC.FOR AFGHAN & 230 \\
\hline NSP/GTZ & NSP/GTZ & 232 \\
\hline OMAR & ORGANISATION FOR MINE AWARENESS AND RECONSTRUCTION & 234 \\
\hline ORA & ORPHANS REFUGEES AND AID INTERNATIONAL. & 236 \\
\hline OV & OCKENDEN VENTURE & 238 \\
\hline OXFAM & OXFAM & 240 \\
\hline PDA & PAMIR DEVELOPMENT AUTHORITY & 242 \\
\hline PETRA & PROGRESSIVE EXPERTS TEAM FOR REHAB. OF AFGHANISTAN & 244 \\
\hline PRB & PAMIR RECONSTRUCTION BUREAU & 246 \\
\hline PRS & PAKTEKA RECONSTRUCTION SERVICES & 248 \\
\hline PSD & PARTNERS FOR SOCIAL DEVELOPMENT & 250 \\
\hline PSF & PHARMACIENS SANS FRONTIERES & 252 \\
\hline RADA & REHAB. AGENCY FOR DEVELOPMENT OF AFGHANISTAN & 254 \\
\hline RAFA & RECONSTRUCTION AUTHORITY FOR AFGHANISTAN & 256 \\
\hline
\end{tabular}




\begin{tabular}{|c|c|}
\hline RAH & REHABILITATION AGENCY FOR HINDUKUSH \\
\hline RBS & RADDA BARNEN \\
\hline RDM & RURAL DEVELOPMENT OF MAIHAN \\
\hline ROAOW & RELIEF ORGANISATION FOR AFGHAN ORPHANS AND WIDOWS \\
\hline RPSA & REHABILITATION OF PROFESSIONAL SCHOOLS IN AFGHANISTAN \\
\hline SAA & SWISS AID FOR AFGHANISTAN \\
\hline SAB & SOLIDARITES AFGHANISTAN BELGIUM \\
\hline SAVE & SAMSOR AFGHANISTAN VOLUNTEER ENVIRONMENTALISTS \\
\hline SC-US & SAVE THE CHILDREN-USA \\
\hline SCA & SWEDISH COMMITTEE FOR AFGHANISTAN \\
\hline SCF-UK & SAVE THE CHILDREN FUND-UK \\
\hline SERVE & SERVING EMERGENCY RELIEF AND VOCATIONAL ENTERPRISES \\
\hline SGAA & SANDY GALL'S AFGHANISTAN APPEAL \\
\hline SJAWO & SAYED JAMALUDDIN AFGHAN WELFARE ORGANISATION \\
\hline SNI & SHELTER NOW INTERNATIONAL \\
\hline SO & SHUHADA ORGANISATION \\
\hline SOLID & SOLIDARITES \\
\hline SRCS & SAUDI RED CRESCENT SOCIETY \\
\hline SRO & SHORAWAK REHABILITATION ORGANISATION \\
\hline START & SHORT TERM ASSISTANCE FOR REHABILITATION TEAM \\
\hline TDH & TERRE DES HOMMES \\
\hline TODAI & TODAI \\
\hline UMCA & UNITED MEDICAL CENTRE FOR AFGHANS \\
\hline UNO & UNIVERSITY OF NEBRASKA AT OMAHA \\
\hline VARA & VOLUNTARY ASSOCIATION FOR REHAB OF AFGHANISTAN \\
\hline WAMY & WORLD ASSEMBLY OF MUSLIM YOUTH \\
\hline WRO & WATAN RECONSTRUCTION ORGANISATION \\
\hline WUFA & WRITERS UNION OF FREE AFGHANISTAN \\
\hline
\end{tabular}

\section{COORDINATION BODIES}

ACBAR $\quad$ AGENCY COORDINATING BODY FOR AFGHAN RELIEF

$\begin{array}{lll}\text { ANCB } & \text { AFGHAN NGO COORDINATION BUREAU } & 318\end{array}$

ICC $\quad$ ISLAMIC COORDINATION COUNCIL $\quad 320$

SWABAC SOUTHERN \& WESTERN AFGHANISTAN BALUCHISTAN

ASSOCIATION FOR COORDINATION $\quad .322$

COORDINATION BODIES MEMBERSHIP LISTS

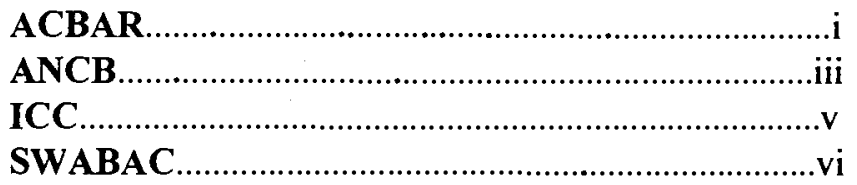




\section{Agencies as Employers}

\begin{tabular}{|c|c|c|c|}
\hline Afghan & Pakistani & Expatriates & Total \\
\hline 23,591 & 766 & 597 & 24,954 \\
\hline & & & \\
\hline Technical & Administrative & Support & Total \\
\hline 9,962 & 3,305 & 11,687 & 24,954 \\
\hline & & & \\
\hline Pakistan-based & Afghanistan-based & Cross-Border & Total \\
\hline 5,129 & 16,341 & 3,484 & 24,954 \\
\hline
\end{tabular}

\section{Breakdown of Agencies by Country}

\begin{tabular}{|l|l|l|l|}
\hline Europe & $\#$ & Arab Countries & $\#$ \\
\hline Belgium & 2 & Kuwait & 1 \\
\hline Denmark & 1 & Saudi Arabia & 5 \\
\hline France & 10 & Sudan & 1 \\
\hline Germany & 7 & & \\
\hline Italy & 1 & & \\
\hline Netherlands & 3 & & \\
\hline Norway & 2 & & \\
\hline Sweden & 2 & & \\
\hline Switzerland & 3 & & \\
\hline United Kingdom & 12 & & \\
\hline sub Total & 43 & sub Total & 7 \\
\hline & & & \\
\hline North America & & Other Countries & \\
\hline Canada & 1 & Afghanistan & 95 \\
\hline United States & 5 & Japan & 3 \\
\hline & & Pakistan & 1 \\
\hline alb Total & 6 & sub Total & 99 \\
\hline
\end{tabular}

Total number of agencies covered is 155, excluding the 4 Coordination Bodies.

\section{Affiliation of Agencies}

\begin{tabular}{|c|c|c|c|c|c|}
\hline $\begin{array}{c}\text { Member } \\
\text { Agencies }\end{array}$ & $\begin{array}{c}\text { ACBAR } \\
\text { Members }\end{array}$ & $\begin{array}{c}\text { ANCB } \\
\text { Members }\end{array}$ & $\begin{array}{c}\text { ICC } \\
\text { Members }\end{array}$ & $\begin{array}{c}\text { SWABAC } \\
\text { Members }\end{array}$ & $\begin{array}{c}\text { Other } \\
\text { Agencies }\end{array}$ \\
\hline Total & 74 & 89 & 18 & 90 & $\ldots$ \\
\hline $\begin{array}{c}\text { Included in } \\
\text { Directory }\end{array}$ & 74 & 22 & 5 & 7 & 54 \\
\hline
\end{tabular}

- Note: membership of some Coordinating Bodies is not up to date. 


\section{BUDGET ALLOCATION (BY MAIN SECTORS)}

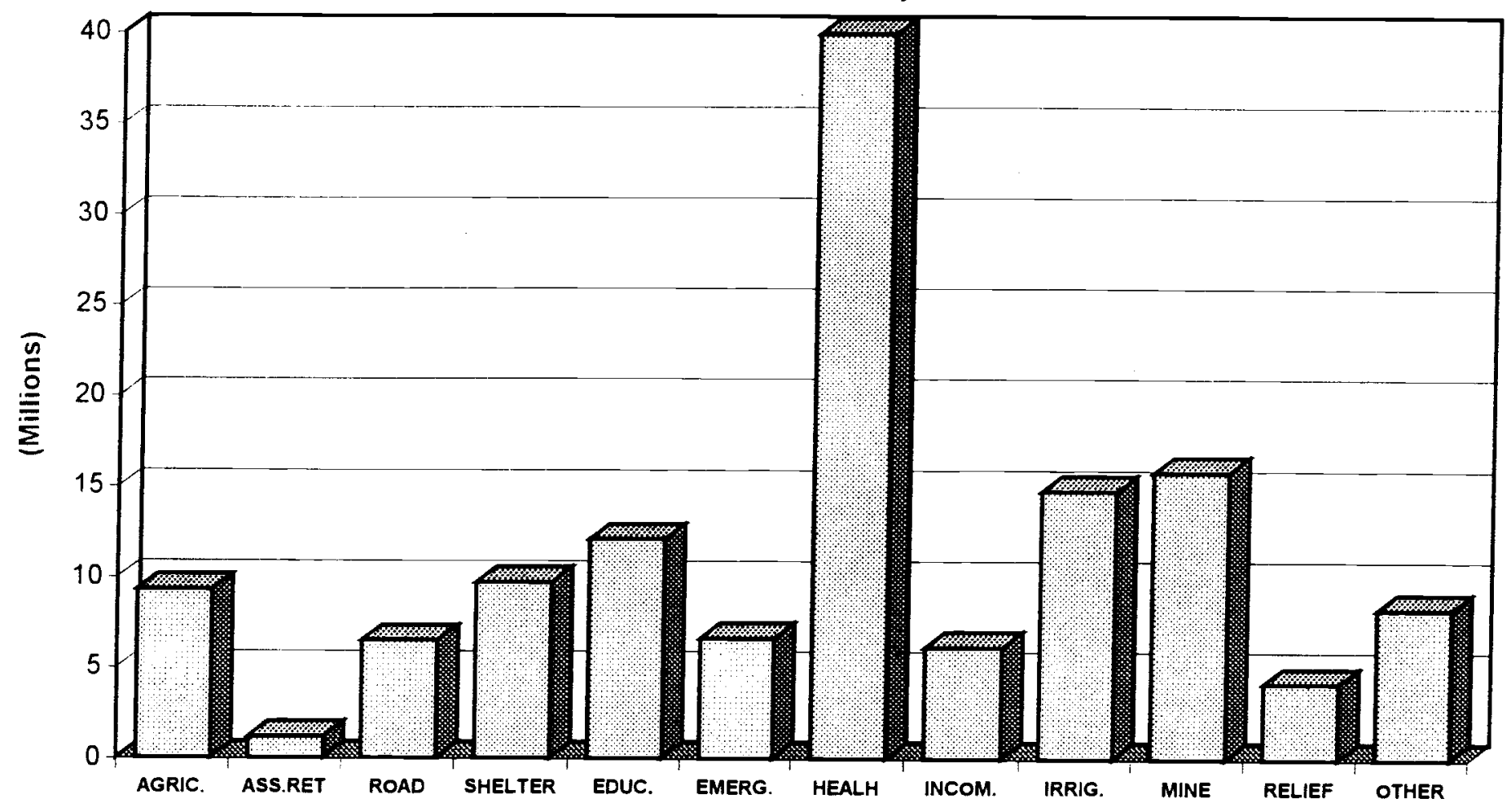

ACBAR MEMBERS BUDGET 1997 AS \% OF TOTAL

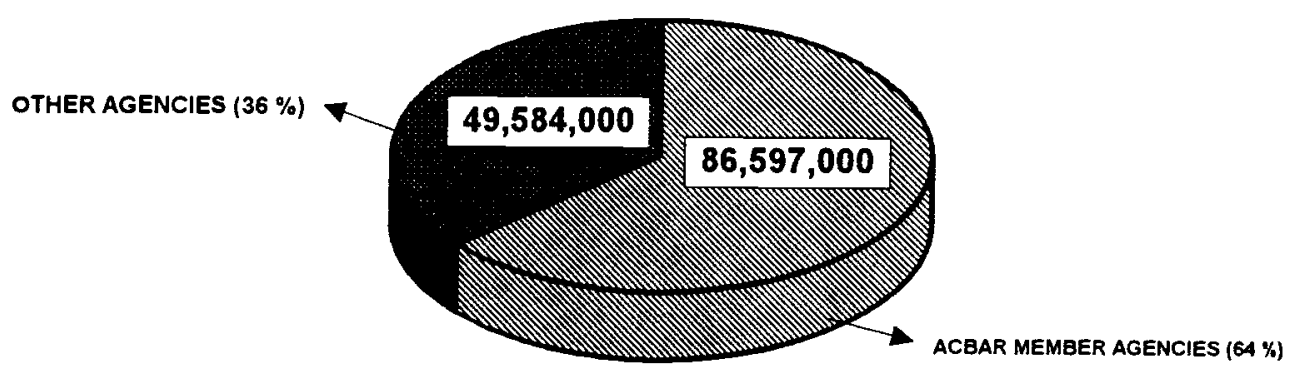

TOTAL BUDGET US \$ 136,181,000 


\section{NGO FUNDING SOURCES}
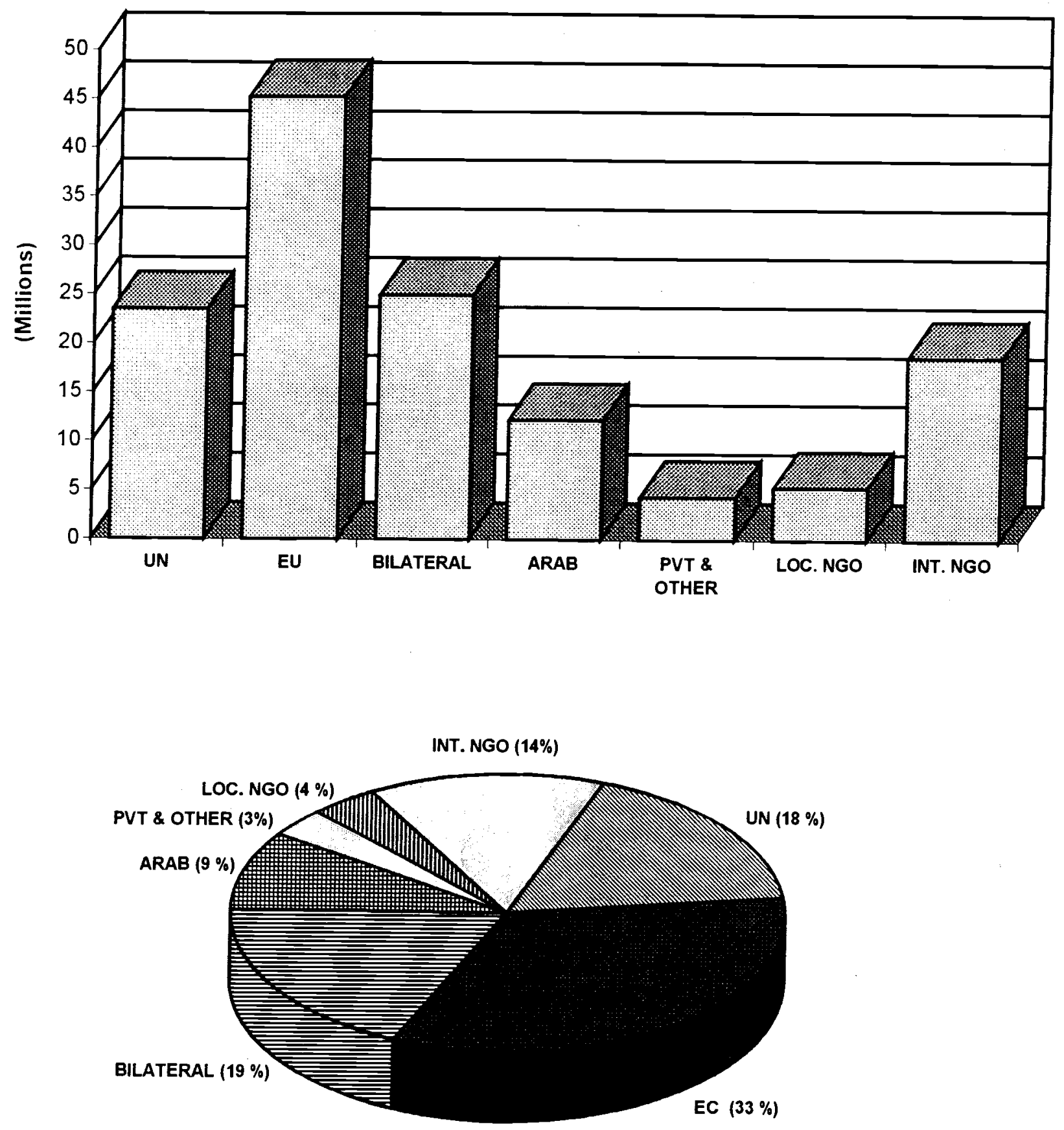

UN Funding received through UN system

EU Funding received through European Union

Bilateral Funding received from various governments

Arab Funding received through Arab countries

Private Private donation, mainly by individuals

Other Any other sources, including membership fees, training fees, sales etc.

Local NGO Funding provided through international NOGs based in Pakistan and Afghanistan

Inter. NGO Funding received from international NGOs based overseas 


\section{BUDGET ALLOCATION BY PROVINCE IN AFGHANISTAN (US \$)}

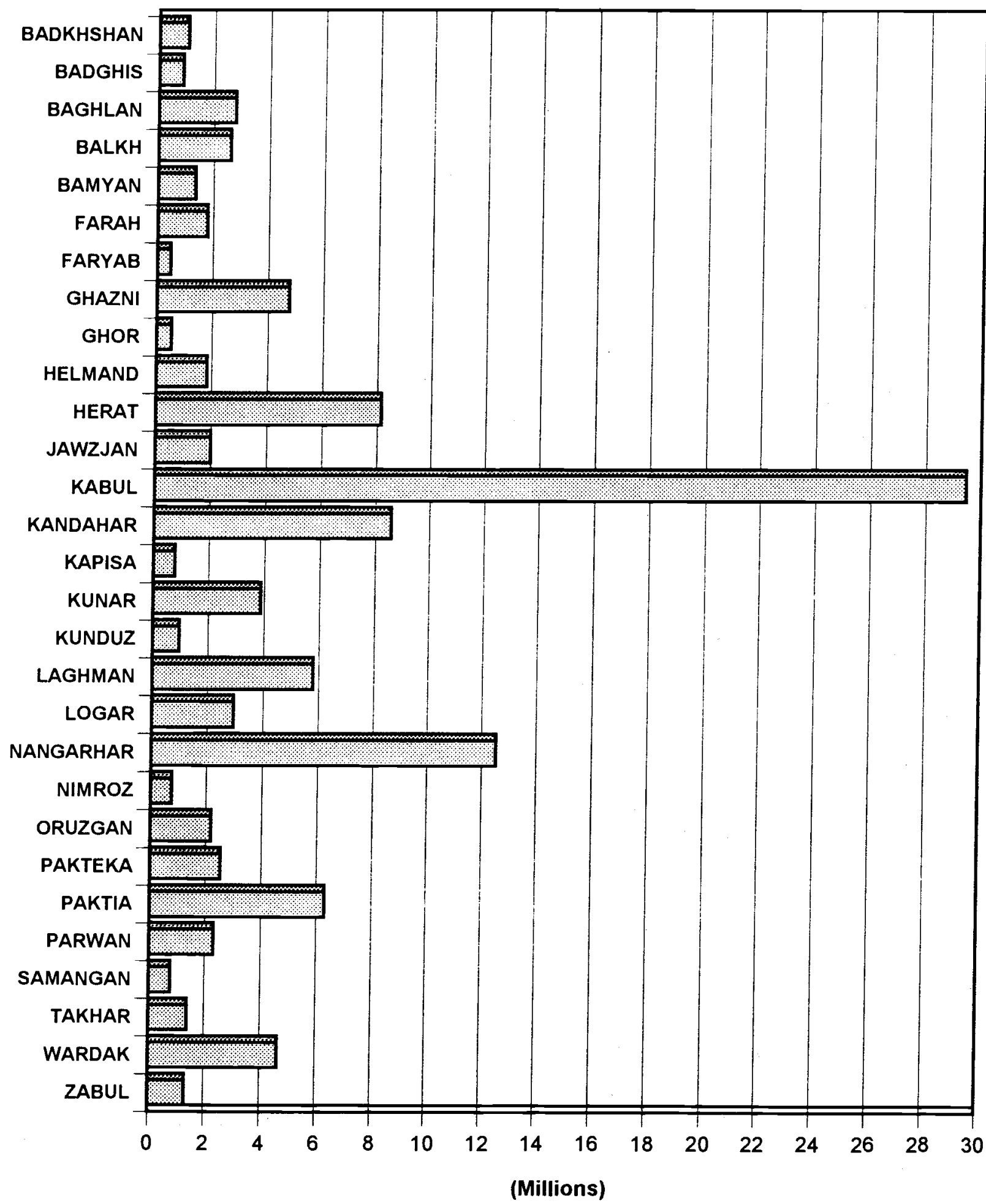


TOTAL BUDGET EXPENDITURE 1992 - 1997

(US \$ MILLION)

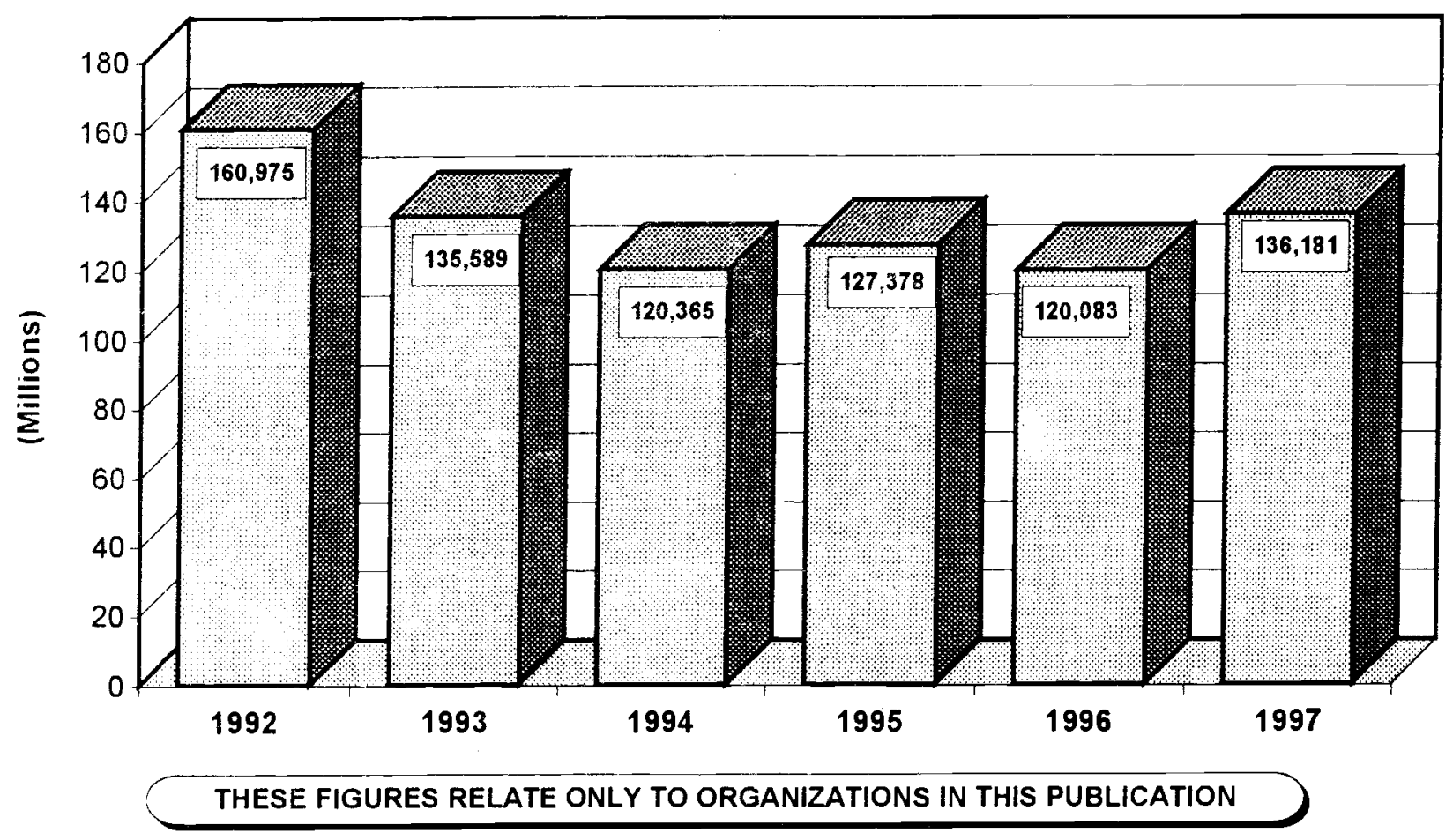

\section{BUDGET ALLOCATION \\ (AFGH. PROGRAMS/REFUGEE PROGRAMS PAK)}

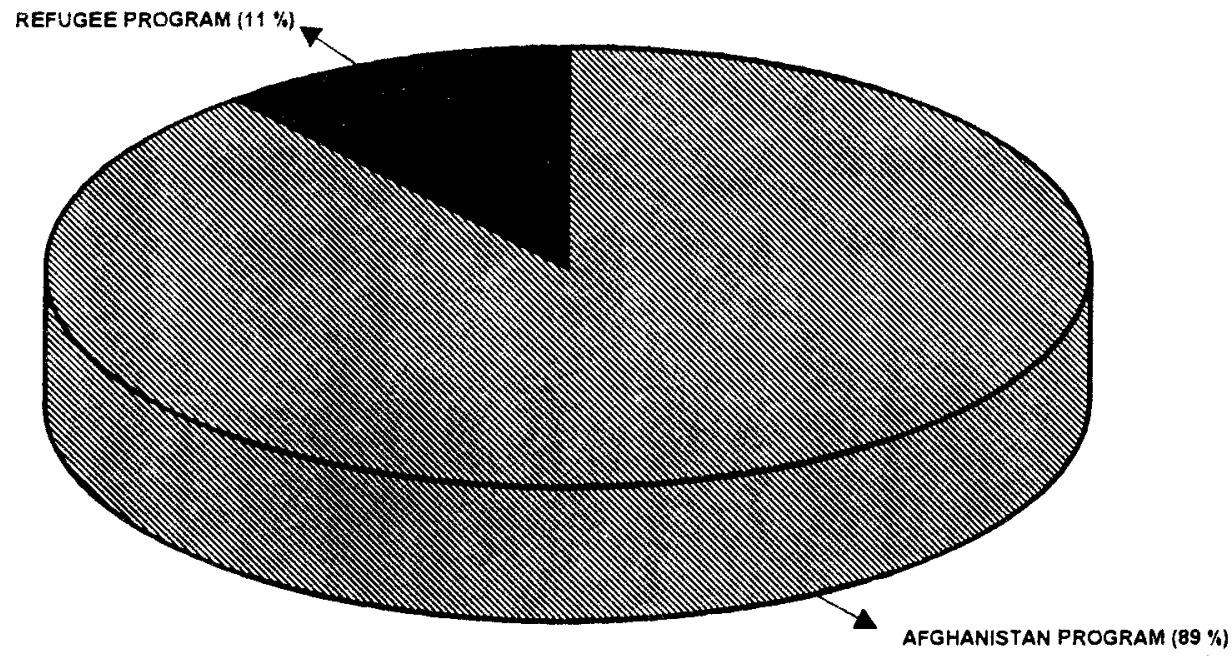


THE AGENCIES

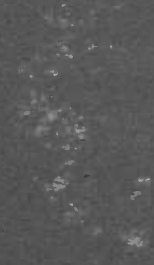


$5 B$ GULMOHAR ROAD

UNIVERSITY TOWN

PESHAWAR, PAKISTAN
COMMUNICATION LINES

PHONE: $42030 / 841083$

F A X: 840322

TELEX:
1. CHARLES GRADER

2. KERRY-JANE WILSON

3. LONG KHAN

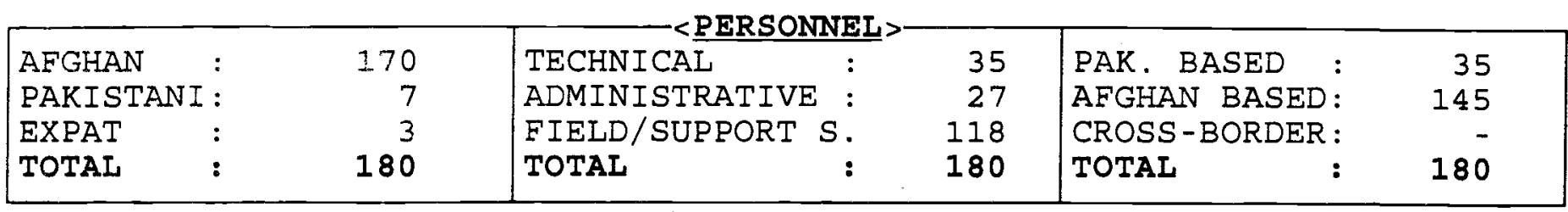

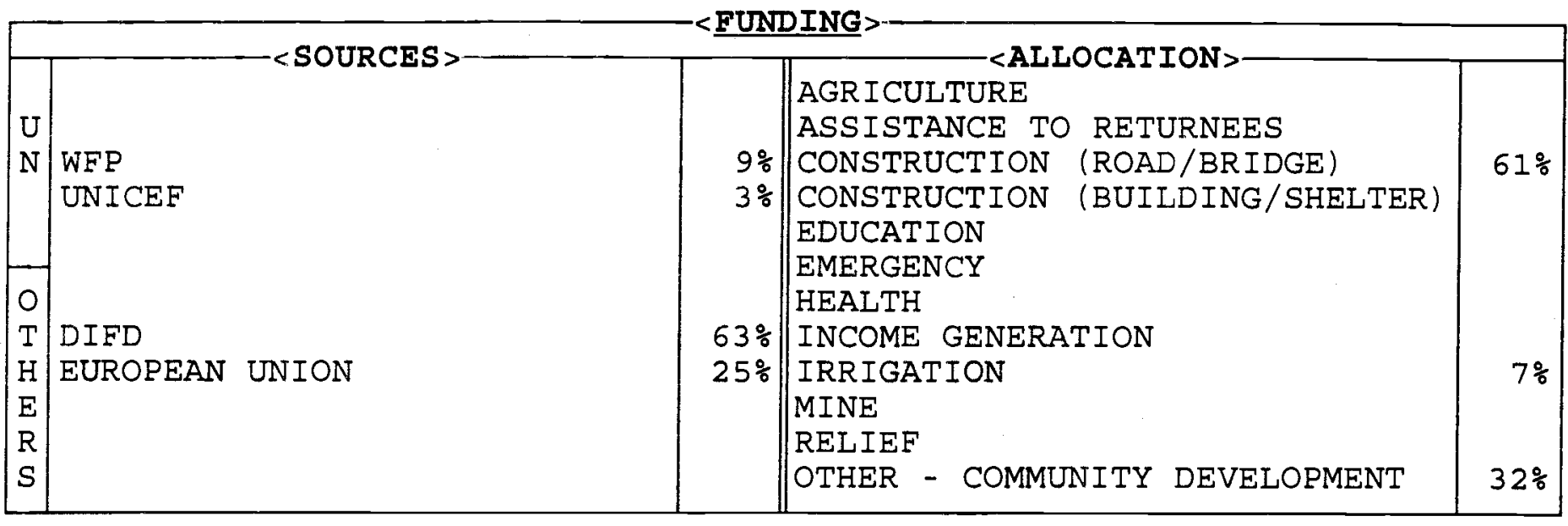

\begin{tabular}{|c|c|c|c|c|c|c|}
\hline $\begin{array}{l}\text { AFGHANISTAN : } \\
\text { REFUGEES : } \\
\text { T O T A L: }\end{array}$ & $\begin{array}{r}1992 \\
2,654,000 \\
611,500 \\
3,265,500\end{array}$ & $\begin{array}{c}\frac{1993}{2,858,800} \\
2,850,800\end{array}$ & $\begin{array}{c}\frac{1994}{1,866,900} \\
-- \\
1,866,900\end{array}$ & 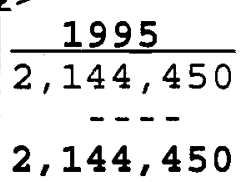 & $\begin{array}{c}\frac{1996}{2,320,000} \\
-\cdots \\
2,320,000\end{array}$ & $\begin{array}{c}\frac{1997}{3,840,000} \\
3,840,000\end{array}$ \\
\hline 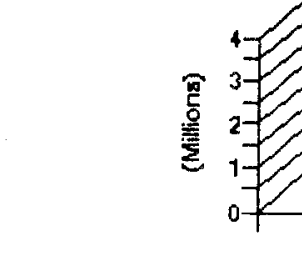 & 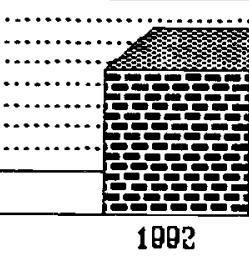 & 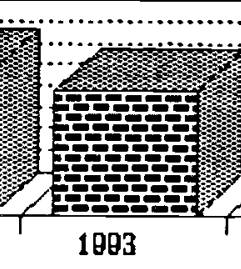 & 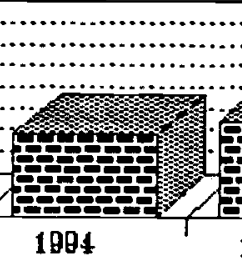 & 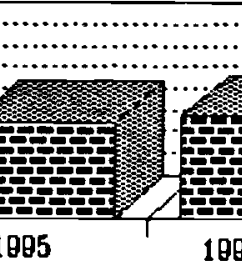 & 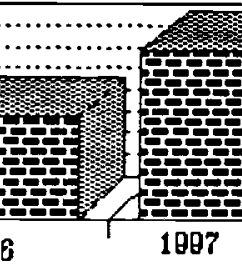 & …... \\
\hline
\end{tabular}

\begin{tabular}{|c|c|c|c|c|c|}
\hline PROVINCES & SECTOR & $\frac{\circ}{6}$ & PROVINCES & SECTOR & $\%$ \\
\hline $\begin{array}{l}\text { BADAKSHAN } \\
\text { BADGHIS } \\
\text { BAGHLAN } \\
\text { BALKH } \\
\text { BAMYAN } \\
\text { FARAH } \\
\text { FARYAB } \\
\text { GHAZNI } \\
\text { GHOR } \\
\text { HELMAND } \\
\text { HERAT } \\
\text { JAWZJAN } \\
\text { KABUL } \\
\text { KANDAHAR } \\
\text { KAPISA }\end{array}$ & $\begin{array}{l}\text { COMM DEV/CONST/IRRIG } \\
\text { COMM DEV/CONST }\end{array}$ & 16 & $\begin{array}{l}\text { KUNAR } \\
\text { KUNDUZ } \\
\text { LAGHMAN } \\
\text { LOGAR } \\
\text { NANGARHAR } \\
\text { NIMROZ } \\
\text { ORUZGAN } \\
\text { PAKTEKA } \\
\text { PAKTIA } \\
\text { PARWAN } \\
\text { SAMANGAN } \\
\text { TAKHAR } \\
\text { WARDAK } \\
\text { ZABUL } \\
\text { PAKISTAN }\end{array}$ & 更 & 15 \\
\hline
\end{tabular}


AFGHANAID (A-AID)

Afghanaid's basic mission is to assist poor rural Afghans to develop their own capacity to improve the quality of their lives on a sustainable basis.

To serve this mission, Afghanaid has for some years concentrated its programme activities in the general areas of engineering and agriculture. Building on this experience, Afghanaid initiated a pilot community development project 3 year's ago in Badakhshan Province, with a view to using the village organisation as the vehicle for working with villagers to introduce improved technology and management practices.

With the success of this pilot effort, the agency has expanded the programme in Badakhshan Province and introduced it into Jawzjan Province, using community development to focus and integrate the various interventions. Thus, the agriculture work, including, forestry, animal husbandry, horticulture, apiculture, etc., as well as health and rug education, are being channeled through the community development framework to generate income and improve the living conditions of the villagers.

Afghanaid's civil engineering activities complement the community development programme at the Provincial level by providing essential access to rural villages and directly at the village level by contributing to community projects.

Afghanaid currently works in three Provinces in northern Afghanistan: Badakhshan, Jawzjan and Parwan. 


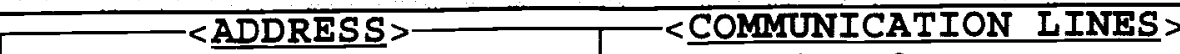

ABONOMAN PLAZA, UNIV.

ROAD, GPO 299

PESHAWAR， PAKISTAN
PHONE : 45519

F A X:

TELEX :
1. ENG. K ASSADULLAH

2. MR. S N HADI

3. MR. MOHAMMAD MUSA

\begin{tabular}{|c|c|c|c|c|c|}
\hline AFGHAN : & 31 & TECHNICAL : & 12 & PAK. BASED : & 8 \\
\hline PAKISTANI : & 2 & ADMINISTRATIVE : & 16 & AFGHAN BASED : & - \\
\hline EXPAT : & - & FIELD/SUPPORT S. & 5 & CROSS-BORDER : & 25 \\
\hline TOTAL & 33 & TOTAL : & 33 & TOTAL : & 33 \\
\hline
\end{tabular}

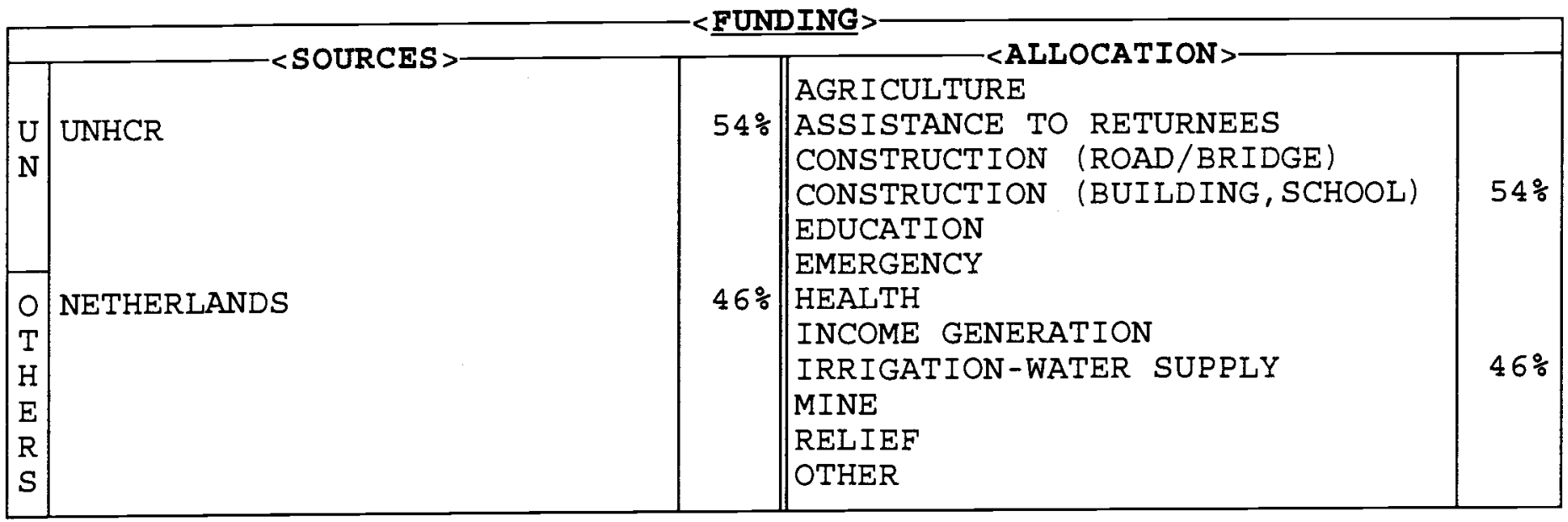

\begin{tabular}{|c|c|c|c|c|c|c|}
\hline & 1992 & 1993 & 1994 & 1995 & 1996 & 1997 \\
\hline AFGHANISTAN : & 55,000 & 80,000 & 49,150 & 56,350 & 100,000 & 20,000 \\
\hline REFUGEES : & --- & --- & $-\cdots$ & $=--$ & ---- & ---- \\
\hline T O T A L: & 55,000 & 80,000 & 49,150 & 56,350 & 100,000 & 20,000 \\
\hline
\end{tabular}

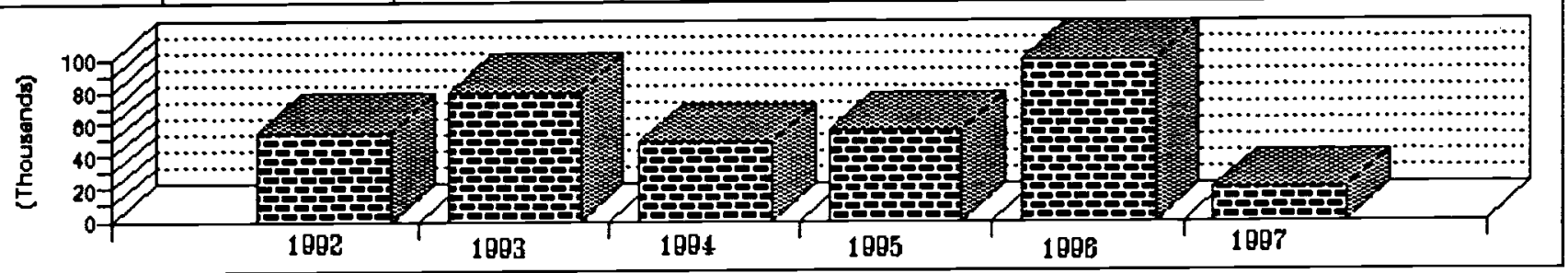

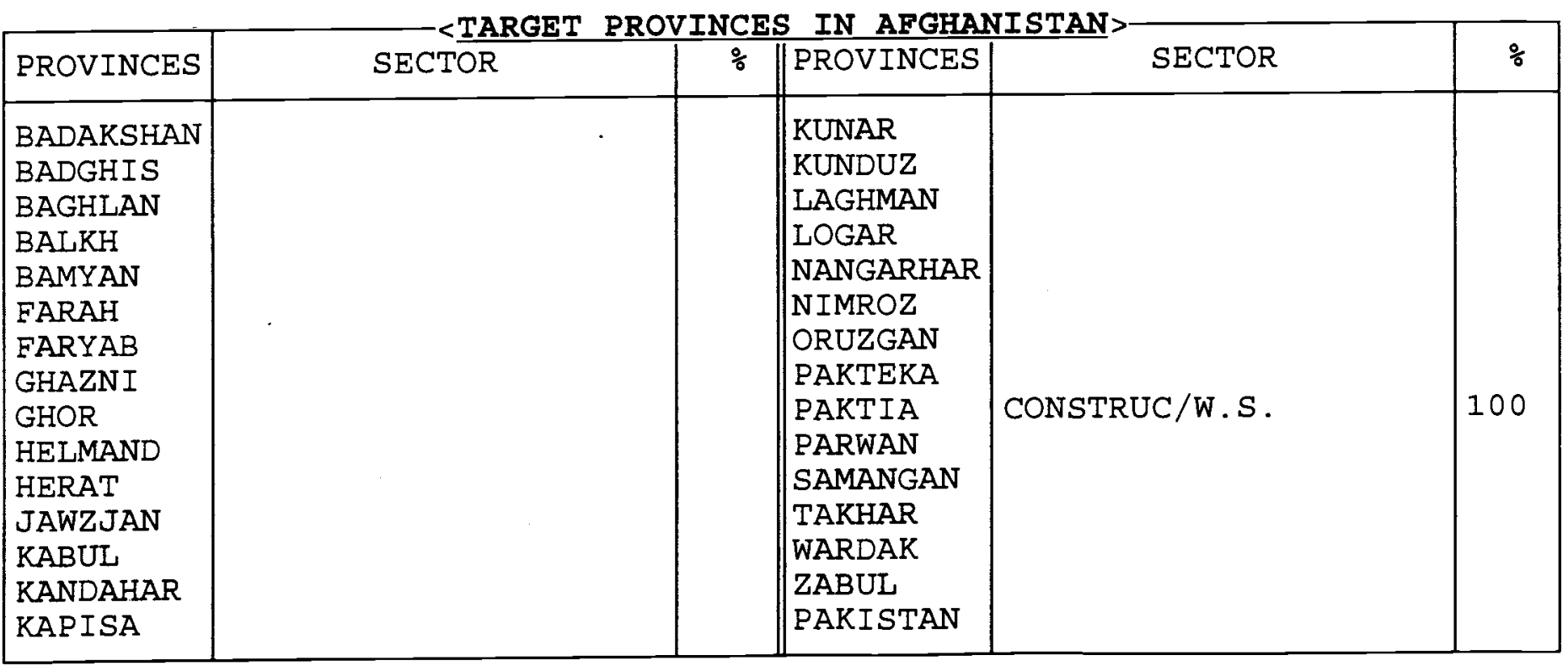




\section{AFGHAN AID ASSOCIATION (AAA)}

AAA was founded in 1983 and is registered with UNOCHA and the Government of NWFP. The organisation is an active member of ACBAR, ANCB and SWABAC.

\section{Sectors of Operation}

The organisation works in health, agriculture, irrigation, construction and water supply for the rehabilitation of Afghanistan.

\section{Health}

AAA opened a clinic in 1983 which provided medical treatment to 4,500-5,000 men, women and children, monthly. Three and six month male health workers programmes were conducted. Until 1991, 4 clinics were operating in Laghman, Parwan, Jawzjan and Nangarhar plus an ob/gyn clinic in the refugee camps in Peshawar. These centres provided training for some 53 women in mid-level health care.

\section{Agriculture}

At present there are seed multiplication projects ongoing in Nangarhar and fruit tree improvement projects. Professional staff give technical advice to the farmers. A Poultry distribution project was completed in 1992.

Two nursery projects and the construction of a school were completed in 1994.

\section{Irrigation}

Several irrigation projects have been undertaken and completed in a number of Provinces of Afghanistan. Recently a flood control project, funded by UNOPS, in Laghman was successfully completed.

A water supply project in Paktia Province was completed in August 1997, funded by the Royal Netherlands Embassy.

Several project proposals have been submitted to various donors for approval for 1997/98. 
AFGHAN AUPOTEE BICYCLISTS FOR REHABILITATION AND RECREATION (AABRAR)

<ADDRESS>- - COMLUNICATION LINES>

KJRC COMPOUND, JAMRUD ROAD, P.O.BOX 782, U/T PESHAWAR, PAKISTAN
PHONE : 841306

F A X: 840521

TELEX :
1. DR. ABDUL BASEER

2. HAJI OMARAKHAN

3 .

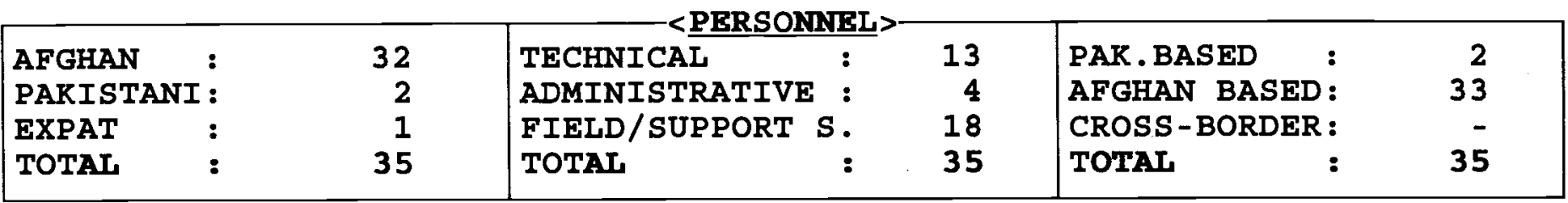

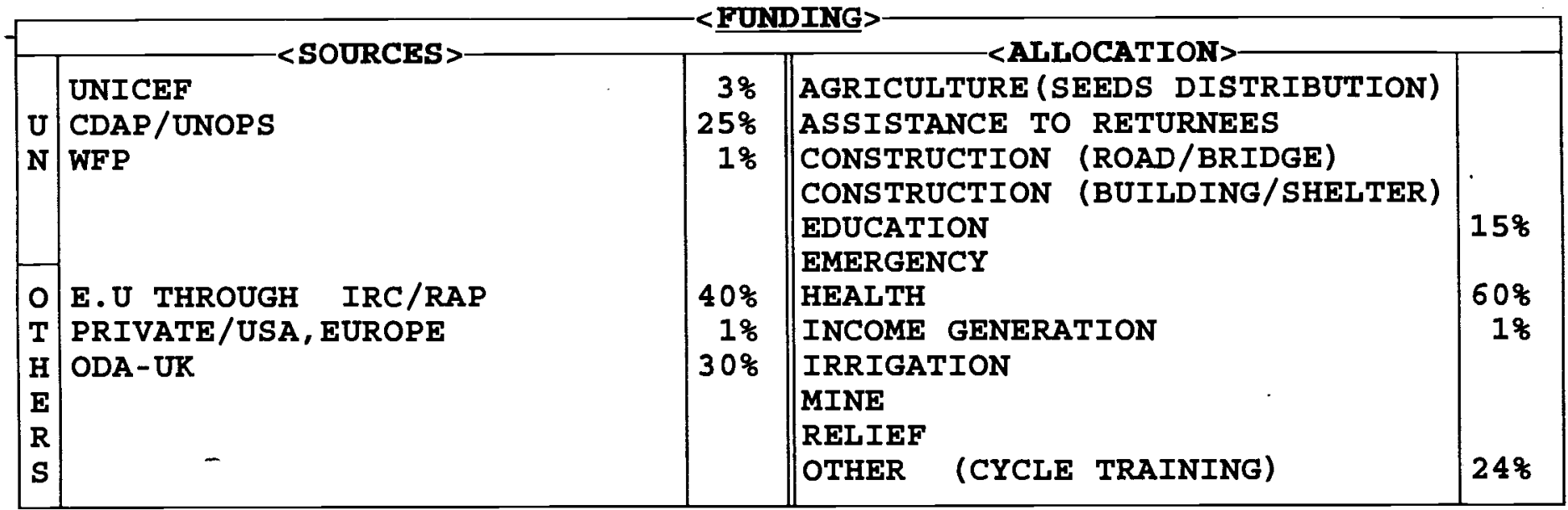

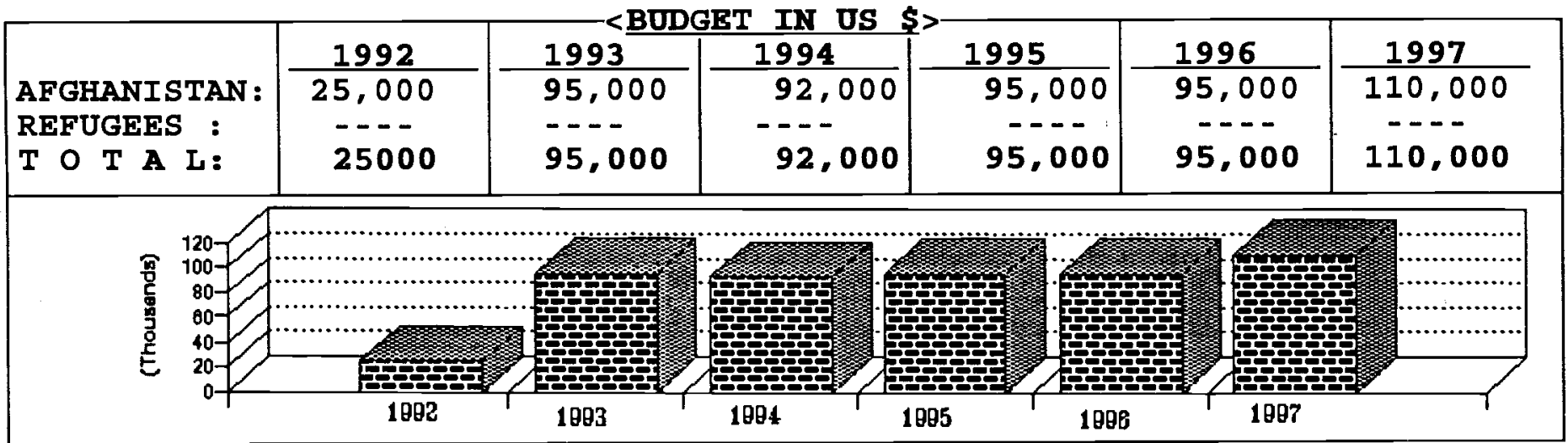

<TARGET PROVINCES IN AFGHANISTAN>

\begin{tabular}{|c|c|c|c|c|c|}
\hline PROVINCES & SECTOR & 8 & PROVINCES & SECTOR & 8 \\
\hline $\begin{array}{l}\text { BADAKSHAN } \\
\text { BADGHIS } \\
\text { BAGHLAN } \\
\text { BALKH } \\
\text { BAMYAN } \\
\text { FARAH } \\
\text { FARYAB } \\
\text { GHAZNI } \\
\text { GHOR } \\
\text { HELMAND } \\
\text { HERAT } \\
\text { JAWZJAN } \\
\text { KABUL } \\
\text { KANDAHAR } \\
\text { KAPISA }\end{array}$ & & & $\begin{array}{l}\text { KUNAR } \\
\text { KUNDUZ } \\
\text { LAGHMAN } \\
\text { LOGAR } \\
\text { NANGARHAR } \\
\text { NIMROZ } \\
\text { ORUZGAN } \\
\text { PAKTEKA } \\
\text { PAKTIA } \\
\text { PARWAN } \\
\text { SAMANGAN } \\
\text { TAKHAR } \\
\text { WARDAR } \\
\text { ZABUL }\end{array}$ & $\begin{array}{c}\text { EDUC/HLTH/CYCLE TRNG } \\
\text { VOCATIONAL TRAINING }\end{array}$ & 100 \\
\hline
\end{tabular}




\section{AFGHAN AMPUTEE BICYCLISTS FOR REHABILITATION AND RECREATION \\ (AABRAR)}

Afghan Amputee Bicyclists for Rehabilitation and Recreation (AABRAR) was founded in July 1992 in Peshawar. A centre providing rehabilitation and physical therapy for disabled Afghans was established in Jalalabad in August 1992. The centre is named the Shaheed Qazi Mohammed Nazir Sayeed Center after the early martyr of the Afghan Jihad.

Most of AABRAR's funds come from UK DFID, CDAP/UNOPS, UNICEF, IRC/RAP and WFP. Some private donations have been received from USA and Europe.

AABRAR's objectives in Jalalabad are to provide physical and educational rehabilitation to disabled Afghans. To provide physical therapy to the disabled and the general public and to provide supplemental health care to disabled and nondisabled persons. In addition, AABRAR has furnished other services in response to the various identified needs in the area.

AABRAR offers six main services on a regular basis at our Center for Disabled Afghans in Jalalabad. Since August 1992 - Physical Therapy for men, women and children, AABRAR was the first organization to do this and employ female Physiotherapists in the Eastern Zone.

In September 1992, a Rehabilitation Course for lower limb disabled men and boys was taught. This course provides classes in Pashto literacy, First Aid and Basic Health, Bicycling for physical, economic and rehabilitation as well as for transportation. Job skills are also taught on a limited basis.

Since September 1993 AABRAR has operated the Jalalabad Screening Clinic for Peshawar's Darus Salam (DS) Hospital. DS provides reconstructive Plastic Surgery free to disabled Afghans and Pakistanis. Referrals to DS are done through the clinic.

In January 1994, an Outpatient Clinic service to the general population in Nangarhar was set up, with a grant of medicines from ICRC.
AABRAR's special services have included Disabled orphans sponsorship scheme, organising bicycle races, wheelchair basket ball, wheelchair races, foot ball and volley ball for the disabled people in Kabul, Jalalabad and Peshawar. Assistance to the 1994 - 1997 vaccination campaigns in Jalalabad.

Projects for 1997/98 include construction of a building for wheelchair maintenance, production of cushions for the chairs by disabled persons, bicycle mechanic vocational training for disabled and orphans as well as those ongoing projects cited above. Mine awareness programme for the disabled people with the collaboration of MCPA and $A C B L$. 


\begin{tabular}{|l|l|l|}
\hline 30，3RD FLOOR, SPINGAR & PHONE: 842378 & <COMEY STAFF>- \\
PLAZA, JAMRUD ROAD & F A X: 842378 & 1. ENG. ABDUL RAHIM \\
PESHAWAR, PAKISTAN & TELEX: & 2. ENG. NAQIB-U-RAHMAN \\
\end{tabular}

\begin{tabular}{|c|c|c|c|c|c|}
\hline $\begin{array}{l}\text { AFGHAN : } \\
\text { PAKISTANI: } \\
\text { EXPAT : } \\
\text { TOTAL }\end{array}$ & $\begin{array}{r}18 \\
- \\
18\end{array}$ & $\begin{array}{l}\text { TECHNICAL : } \\
\text { ADMINISTRATIVE : } \\
\text { FIELD/SUPPORT S: } \\
\text { TOTAL }\end{array}$ & $\begin{array}{r}4 \\
5 \\
9 \\
18\end{array}$ & $\begin{array}{l}\text { PAK. BASED : } \\
\text { AFGHAN BASED : } \\
\text { CROSS-BORDER : } \\
\text { TOTAL : }\end{array}$ & $\begin{array}{r}9 \\
9 \\
- \\
18\end{array}$ \\
\hline
\end{tabular}

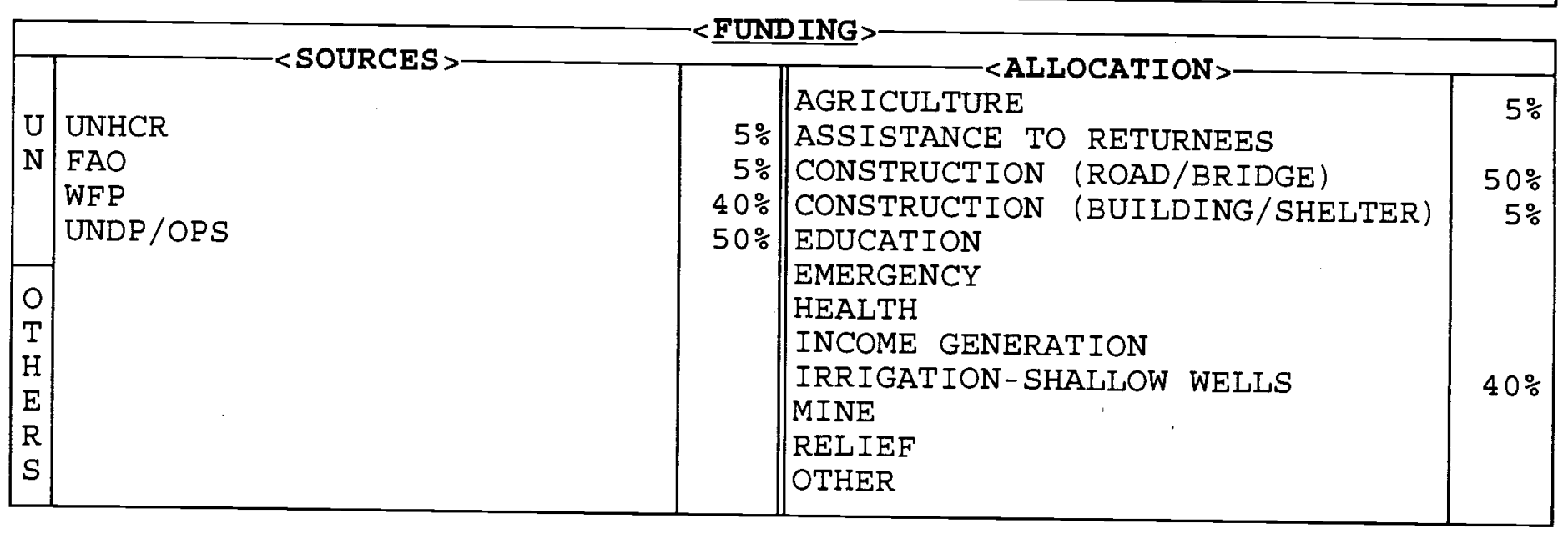

\begin{tabular}{|c|c|c|c|c|c|c|}
\hline $\begin{array}{l}\text { AFGHANISTAN: } \\
\text { REFUGEES : } \\
\text { TO T A L: }\end{array}$ & $\begin{array}{l}1992 \\
--- \\
---- \\
-\ldots--\end{array}$ & $\begin{array}{l}\frac{1993}{95,000} \\
-95,000\end{array}$ & $\begin{array}{l}1994 \\
55,000 \\
55,000\end{array}$ & $\begin{array}{l}\frac{1995}{20,000} \\
-\cdots \\
20,000\end{array}$ & $\begin{array}{c}\frac{1996}{100,000} \\
100,000\end{array}$ & $\begin{array}{c}1997 \\
100,000 \\
--- \\
100,000\end{array}$ \\
\hline 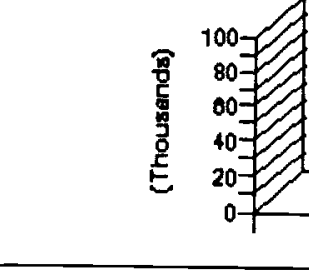 & $\begin{array}{l}1882 \\
1802\end{array}$ & 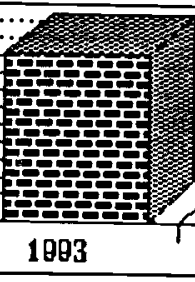 & 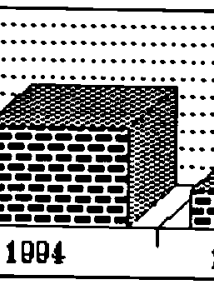 & 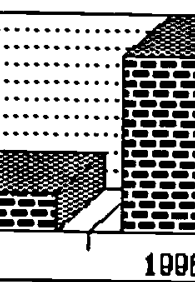 & 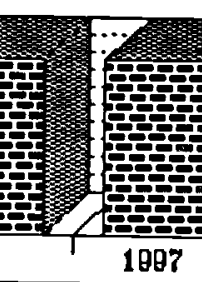 & ( \\
\hline
\end{tabular}

\begin{tabular}{|c|c|c|c|c|c|}
\hline PROVINCES & SECTOR & $\%$ & PROVINCES & SECTOR & $\%$ \\
\hline $\begin{array}{l}\text { BADAKSHAN } \\
\text { BADGHIS } \\
\text { BAGHLAN } \\
\text { BALKH } \\
\text { BAMYAN } \\
\text { FARAH } \\
\text { FARYAB } \\
\text { GHAZNI } \\
\text { GHOR } \\
\text { HELMAND } \\
\text { HERAT } \\
\text { JAWZJAN } \\
\text { KABUL } \\
\text { KANDAHAR } \\
\text { KAPISA }\end{array}$ & & & $\begin{array}{l}\text { KUNAR } \\
\text { KUNDUZ } \\
\text { LAGHMAN } \\
\text { LOGAR } \\
\text { NANGARHAR } \\
\text { NIMROZ } \\
\text { ORUZGAN } \\
\text { PAKTEKA } \\
\text { PAKTIA } \\
\text { PARWAN } \\
\text { SAMANGAN } \\
\text { TAKHAR } \\
\text { WARDAK } \\
\text { ZABUL } \\
\text { PAKISTAN }\end{array}$ & $\begin{array}{l}\text { AGR I CULTURE/CONST } \\
\text { CONSTRUC/IRRIG } \\
\text { CONSTRUCTION }\end{array}$ & 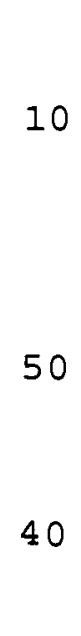 \\
\hline
\end{tabular}




\section{AFGHAN AGRICULTURAL AND ENGINEERING AGENCY (AAEA)}

AAEA was founded in 1992. It is an Afghan managed and operated organisation, dedicated to the sustainable rehabilitation and reconstruction of Afghanistan. Headquarters are in Peshawar, Pakistan, with sub-offices in Jalalabad, Kabul, Kandahar, Wardak and Khost.

The Agency is well qualified to implement all types of agricultural and engineering projects inside Afghanistan.

\section{AAEA projects:}

\section{Irrigation:}

Cleaning of three canals (Naghrak, Mirzayan and Sawaty) in Surkhrod district and karezes and two canals in Rodat district of Nangarhar have boen completed. Work on one canal is ongoing.

\section{Agriculture:}

Wheat seed multiplication in Qarghayee district of Laghman Province has been completed. Ongoing agricultural projects in Laghman Qarghayee include a fruit/forest nursery, sugar cane, maize, mung beans and rice. Other projects in Basawool and Gushta districts are the production of sugar cane, mung beans and rice.

\section{Construction:}

Construction of a culvert in Surkhrod, Nangarhar.

Construction of 600 latrines in Hesar Shahi refugee camp in Nangarhar were completed.

AAEA is registered with ACBAR and ANCB coordinating agencies. 
169, ST. 7, J-5, PH. 2 PO BOX 859, HAYATABAD PESHAWAR， PAKISTAN
PHONE : 811582

F A X:

TELEX :
1. MR. GUL WAIZ KAKA

2. M. WAIZ

3. DR.MATIULLAH

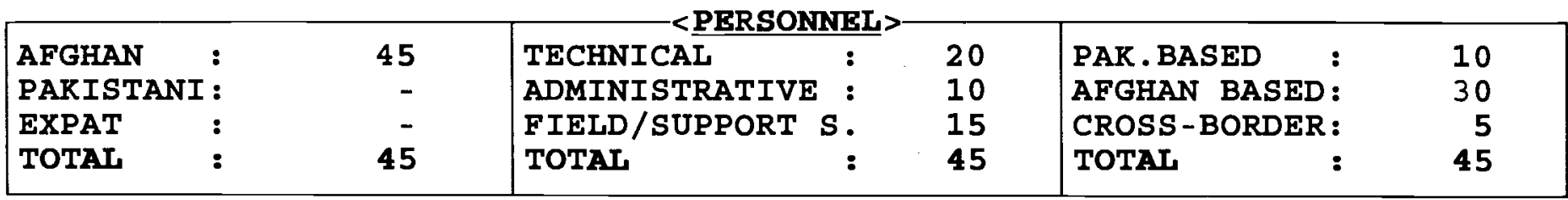

\begin{tabular}{|c|c|c|c|c|}
\hline & <SUURCESS & & WHCAIUN & \\
\hline & UNOPS & $5 \%$ & AGRICULTURE & $40 \%$ \\
\hline $\mathrm{U}$ & UNHCR & $20 \%$ & ASSISTANCE TO RETURNEES & \\
\hline $\mathbf{N}$ & UNICEF & $30 \%$ & CONSTRUCTION (ROAD/BRIDGE) & \\
\hline & WHO & $20 \%$ & CONSTRUCTION (BUILDING/SHELTER) & $29 \%$ \\
\hline & WFP & $10 \%$ & EDUCATION & \\
\hline 0 & ACDO & $10 \%$ & HEALTH & \\
\hline $\mathbf{T}$ & PRIVATE & $5 \%$ & INCOME GENERATION & \\
\hline $\mathbf{H}$ & & & IRRIGATION & $31 \%$ \\
\hline $\mathbf{E}$ & & & MINE & \\
\hline $\mathbf{R}$ & & & RELIEF & \\
\hline $\mathbf{S}$ & & & OTHER & \\
\hline
\end{tabular}

\begin{tabular}{|c|c|c|c|c|c|c|}
\hline & 1992 & 1993 & 1994 & 1995 & 1996 & 1997 \\
\hline $\begin{array}{l}\text { AFGHANISTAN : } \\
\text { REFUGEES : } \\
\text { T O T A L: }\end{array}$ & $\begin{array}{c}12,000 \\
12,000\end{array}$ & $\begin{array}{r}37,600 \\
9,300 \\
46,900\end{array}$ & $\begin{array}{l}68,300 \\
27,600 \\
95,900\end{array}$ & $\begin{array}{l}50,000 \\
15,000 \\
65,000\end{array}$ & N/A & $\begin{array}{c}261,100 \\
\cdots \\
261,100\end{array}$ \\
\hline
\end{tabular}

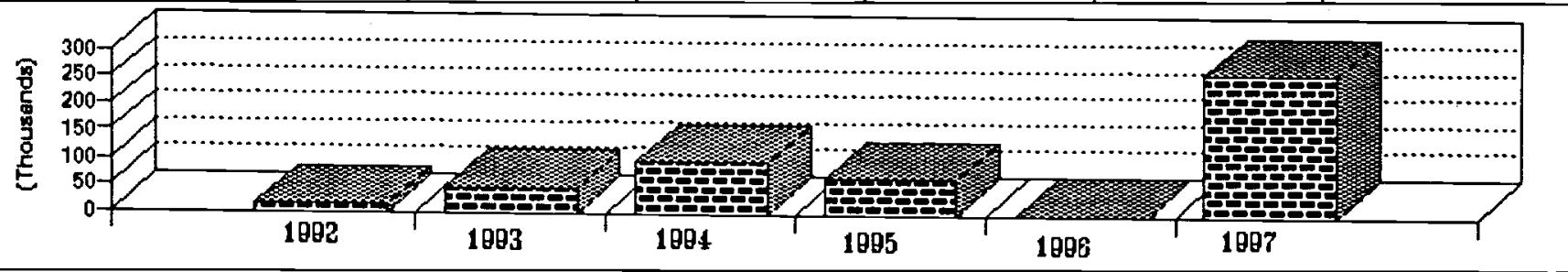

\begin{tabular}{|c|c|c|c|c|c|}
\hline PROVINCES & SECTOR & $\%$ & PROVINCES & SECTOR & q \\
\hline $\begin{array}{l}\text { BADAKSHAN } \\
\text { BADGHIS } \\
\text { BAGHLAN } \\
\text { BALKH } \\
\text { BAMYAN } \\
\text { FARAH } \\
\text { FARYAB } \\
\text { GHAZNI } \\
\text { GHOR } \\
\text { HELMAND } \\
\text { HERAT } \\
\text { JAWZJAN } \\
\text { KABUL } \\
\text { KANDAHAR } \\
\text { KAPISA }\end{array}$ & CONST/IRRIG & 20 & $\begin{array}{l}\text { KUNAR } \\
\text { KUNDUZ } \\
\text { LAGHMAN } \\
\text { LOGAR } \\
\text { NANGARHAR } \\
\text { NIMROZ } \\
\text { ORUZGAN } \\
\text { PAKTERA } \\
\text { PAKTIA } \\
\text { PARWAN } \\
\text { SAMANGAN } \\
\text { TAKHAR } \\
\text { WARDAR } \\
\text { ZABUL } \\
\text { REFUGEES }\end{array}$ & $\begin{array}{l}\text { CONSTRUCTION } \\
\text { IRRIG/CONST/AGRIC }\end{array}$ & 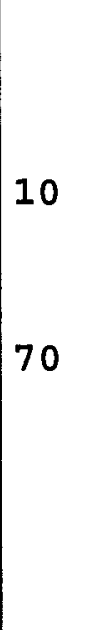 \\
\hline
\end{tabular}




\section{AFGHAN COMMUNITY \\ DEVELOPMENT ORGANIZATION \\ (ACDO)}

ACDO is a non-government, non-political and non-profit making organization founded in January 1991.

\section{Aims of ACDO}

The agency's main aim is to contribute to reconstruction and rehabilitation of

infrastructure in Afghanistan. It also assists the farming community and contributes to the social activities inside Afghanistan. The following sectors have been given priority:

\section{Education}

The Education programme includes English Language Development, Public Administration, accountancy, management, typing, computer training and literacy courses, primary, middle and secondary high school education.

\section{Vocational Training}

A vocational training programme - carpentry training, tailoring for women and the disabled, weaving, small business projects and poultry training for women.

\section{Construction}

Building plans include schools, roads, mosques, bridges and Government buildings

\section{Agriculture}

The Agriculture programme includes improved seed multiplication, fertilizer distribution, fruit and forest tree distribution and general horticulture rehabilitation.

\section{Irrigation}

The organisation is involved in the cleaning of canals and karezes and general rehabilitation of irrigation systems. Active coordination with other agencies in efforts to implement the rehabilitation / reconstruction of social and economic assistance.

\section{Locations}

The agency's activities are focused mainly in eastern and south-eastern Provinces but it is hoped to encompass all major regions in the future. 
ACTION CONTRE LA FAIM (ACF)

<ADDRESS>

CHARAHI FAIZ MOHAMMAD

KHAN, SHAHR-E-NAW

RABUL, AFGHANISTAN
PHONE : 33104

F A X: $00873 \quad 682 \quad 041 \quad 197$ TELEX :
1. CHRISTIAN HELL

2. DR. MONIQUE LHUSSIER

3. PHILIPPE LE JALLE

\begin{tabular}{|c|c|c|c|c|c|}
\hline $\begin{array}{l}\text { AFGHAN : } \\
\text { PARISTANI : } \\
\text { EXPAT : } \\
\text { TOTAL : }\end{array}$ & $\begin{array}{r}191 \\
\overline{9} \\
200\end{array}$ & $\begin{array}{l}\text { TECHNICAL } \\
\text { ADMINISTRATIVE } \\
\text { FIELD/SUPPORT } \\
\text { TOTAL }\end{array}$ & $\begin{array}{r}91 \\
109 \\
200\end{array}$ & $\begin{array}{l}\text { PAK, BASED : } \\
\text { AFGHAN BASED: } \\
\text { CROSS-BORDER: } \\
\text { TOTAL : }\end{array}$ & $\begin{array}{r}6 \\
194 \\
- \\
200\end{array}$ \\
\hline
\end{tabular}

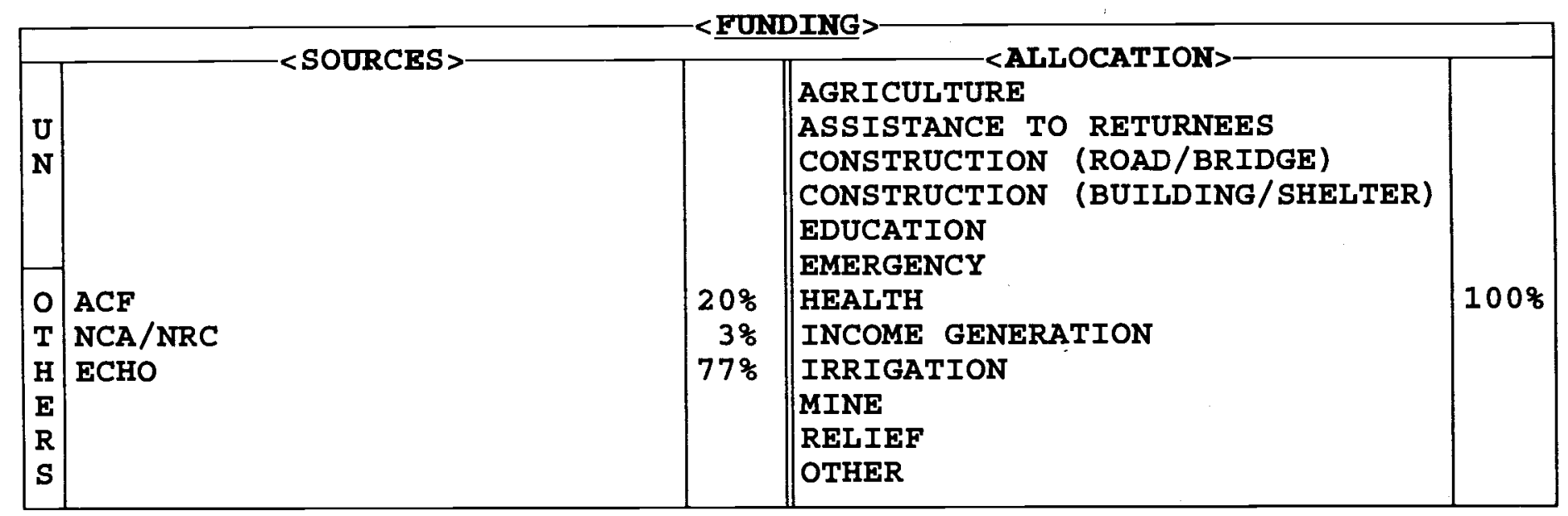

\begin{tabular}{|c|c|c|c|c|c|c|}
\hline $\begin{array}{l}\text { AFGHANISTAN: } \\
\text { REFUGEES : } \\
\text { T O T A L: }\end{array}$ & $\begin{array}{c}1992 \\
--- \\
---- \\
----\end{array}$ & $\begin{array}{l}1993 \\
-\cdots \\
\cdots- \\
\cdots-\end{array}$ & $\begin{array}{r}1994 \\
0- \\
-\end{array}$ & $\begin{array}{c}1995 \\
105,000 \\
105,000\end{array}$ & \begin{tabular}{l}
1996 \\
670,000 \\
\hdashline 670,000
\end{tabular} & $\frac{1997}{1,042,300}=$ \\
\hline . & 1892 & 1803 & 1804 & $5 \quad 108$ & 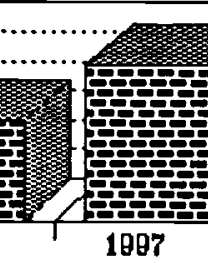 & …... \\
\hline
\end{tabular}

\begin{tabular}{|c|c|c|c|c|c|}
\hline PROVINCES & SECTOR & $\frac{8}{6}$ & PROVINCES & SECTOR & $\%$ \\
\hline $\begin{array}{l}\text { BADAKSHAN } \\
\text { BADGHIS } \\
\text { BAGHLAN } \\
\text { BALKH } \\
\text { BAMYAN } \\
\text { FARAH } \\
\text { FARYAB } \\
\text { GHAZNI } \\
\text { GHOR } \\
\text { HELMAND } \\
\text { HERAT } \\
\text { JAWZJAN } \\
\text { KABUL } \\
\text { KANDAHAR } \\
\text { KAPISA }\end{array}$ & HEALTH & 100 & \begin{tabular}{|l|} 
KUNAR \\
KUNDUZ \\
LAGHMAN \\
LOGAR \\
NANGARHAR \\
NIMROZ \\
ORUZGAN \\
PAKTEKA \\
PAKTIA \\
PARWAN \\
SAMANGAN \\
TAKHAR \\
WARDAR \\
ZABUL \\
REFUGEES
\end{tabular} & & \\
\hline
\end{tabular}




\section{ACTION CONTRE LA FAIM (ACF)}

$\mathrm{ACF}$ is a French, non-political, non-religious and non-profit organisation set up in Paris in 1979 with branches in Madrid, London and

New York. It endeavours to bring assistance to people adversely affected by either natural or man-made disaster whenever food, water and sanitation or medical care are not available. $\mathrm{ACF}$ is currently working in more than 25 countries in Asia, Africa, Central America and Europe.

Since the first victims of famine are usually the same - women and children - ACF has learned to provide targeted responses through its four main approaches to the fight against hunger. Its 250 professional volunteers undertake programmes in the field of Nutrition, Food Security, Water and Sanitation and Health.

$\mathrm{ACF}$ will intervene either during the crisis through emergency action or after the crisis with rehabilitation and restoration programmes. The ultimate aim of these programmes is to enable the beneficiaries to regain their autonomy and self sufficiency as soon as possible as well as to contribute to the capacity building of local authorities in the different sectors of intervention.

\section{ACF in Afghanistan:}

The first projects undertaken were with the Afghan refugees in the camps in Quetta. The programme focused on food, nutrition, sanitation, primary health care and training TBAs.

In September 1995, a nutritional assessment was undertaken in Kabul to establish facts on malnutrition before the winter season. This provided the knowledge needed to run a good nutritional feeding programme. A nutrition surveillance and protocol system has been set up for all $\mathrm{MCHs}$.

Moderately and severely malnourished children are treated within the 29 supplementary feeding centres the 15 day centres and the therapeutic feeding centres in Kabul, all of which are supported by ACF.
Frequent nutrition and anthropometric surveys are carried out in all urban areas and water potability test analysis is conducted in $\mathrm{MCHs}$ and clinics. 
AFGHAN CONSTRUCTION AND LOGISTICS UNIT (ACLU)

ACBAR

PROPERTY NO 123 A, ST 6 PHONE: 812471/816751

INDUSTRIAL AREA

PESHAWAR， PAKISTAN

F A X: 816751

1. ENG. MOHAMMAD KARIM email:aclu@kabul.psw.erum 3. MOH'D OSMAN WAHIDI

\begin{tabular}{|c|c|c|c|c|c|}
\hline AFGHAN & 201 & TECHNICAL & 125 & PAK BASED & \\
\hline PAKISTANI: & 10 & ADMINISTRATIVE & 24 & AFGHAN BASED: & \\
\hline EXPAT : & - & FIELD/SUPPORT S & 82 & CROSS-BORDER & \\
\hline TOTAL & 231 & TOTAL & 231 & TOTAL : & \\
\hline
\end{tabular}

$<$ FUNDING $>$

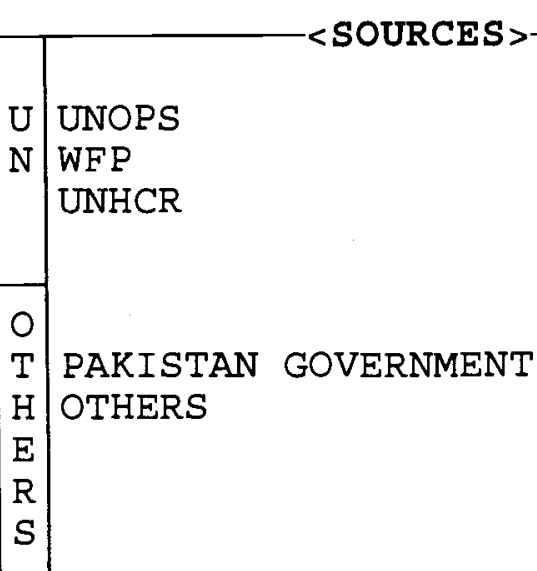

\begin{tabular}{l||l}
$16 \%$ & AGRICULTURE \\
$28 \%$ & ASSISTANCE TO RETURNEES \\
$10 \%$ & CONSTRUCTION (ROAD/BRIDGE) \\
& CONSTRUCTION (BUILDING/SHELTER) \\
& EDUCATION \\
& EMERGENCY \\
$27 \%$ & HEALTH \\
$19 \%$ & INCOME GENERATION \\
& IRRIGATION \\
& MINE \\
& RELIEF \\
& OTHER \\
\hline
\end{tabular}

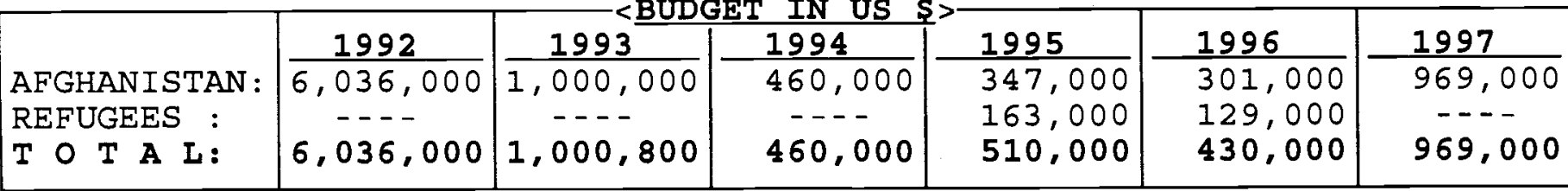

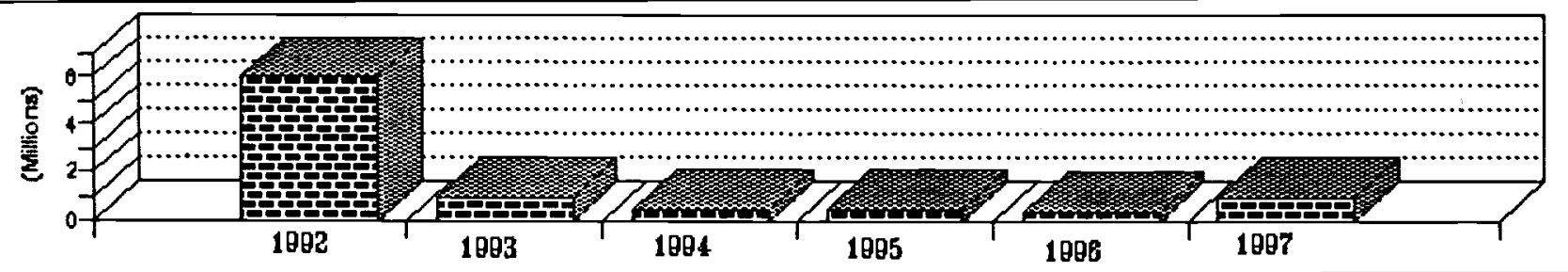

\begin{tabular}{|c|c|c|c|c|c|}
\hline PROVINCES & SECTOR & $\%$ & PROVINCES & SECTOR & $\%$ \\
\hline $\begin{array}{l}\text { BADAKSHAN } \\
\text { BADGHIS } \\
\text { BAGHLAN } \\
\text { BALKH } \\
\text { BAMYAN } \\
\text { FARAH } \\
\text { FARYAB } \\
\text { GHAZNI } \\
\text { GHOR } \\
\text { HELMAND } \\
\text { HERAT } \\
\text { JAWZJAN } \\
\text { KABUL } \\
\text { KANDAHAR } \\
\text { KAPISA }\end{array}$ & $\begin{array}{l}\text { CONST - BRIDGE } \\
\text { CONST - BRIDGE } \\
\text { CONST - ROAD }\end{array}$ & $\begin{array}{l}17 \\
18\end{array}$ & $\begin{array}{l}\text { KUNAR } \\
\text { KUNDUZ } \\
\text { LAGHMAN } \\
\text { LOGAR } \\
\text { NANGARHAR } \\
\text { NIMROZ } \\
\text { ORUZGAN } \\
\text { PAKTEKA } \\
\text { PAKTIA } \\
\text { PARWAN } \\
\text { SAMANGAN } \\
\text { TAKHAR } \\
\text { WARDAK } \\
\text { ZABUL } \\
\text { PAKISTAN }\end{array}$ & $\begin{array}{l}\text { CONST - ROAD/BRIDGE } \\
\text { BUILDING } \\
\text { IRRIGATION }\end{array}$ & $\begin{array}{r}26 \\
15 \\
4\end{array}$ \\
\hline
\end{tabular}




\section{AFGHAN CONSTRUCTION \& \\ LOGISTICS UNIT (ACLU)}

ACLU was founded with the financial assistance of USAID in 1988. In June 1993, USAID support ended and the agency reorganized itself as an Afghan NGO.

The objectives of the organisation are:

- to assemble construction teams to repair and reconstruct roads and bridges when conditions permit.

- to plan and design work to be accomplished.

With the support of USAID and since then as an independent NGO ACLU has completed the following projects in Kunar, Paktia, Kabul, Wardak, Zabul, Laghman, Nangarhar, Kandahar, Ghazni, Badakshan and Pakistan:

Total road works $\quad 886 \mathrm{kms}$ Bridges $\quad 32$

Tube wells 7

Other structural works and equipment rental are ongoing.

ACLU is well equipped with all types of heavy construction equipment/machinery and has the capacity to design and construct various projects. It is ready to accept any construction order and contract from donor organisations, NGOs, companies and Government organisations. 
AFGHAN CENTER FOR RURAL DEVELOPMENT (ACRD)

ANCB

25-B, RAHMAN BABA RD, U.P.O. BOX 849, U/T PESHAWAR, PARISTAN
PHONE : 43335

F A X: 843261

TELEX :
1. MR. G. ROHANI WARDAK

2 .

3 .

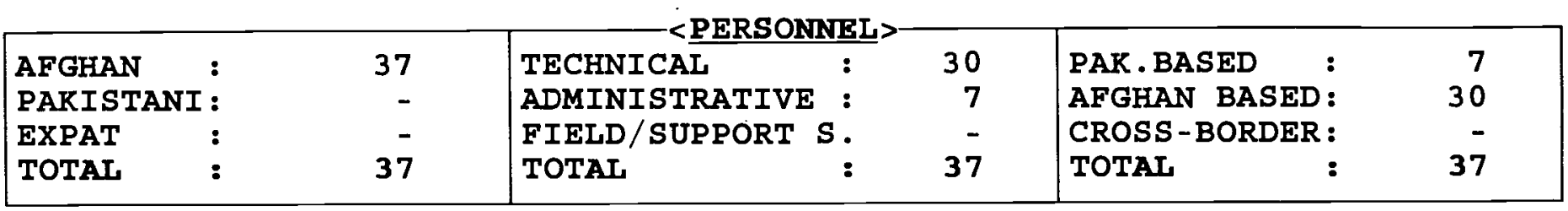

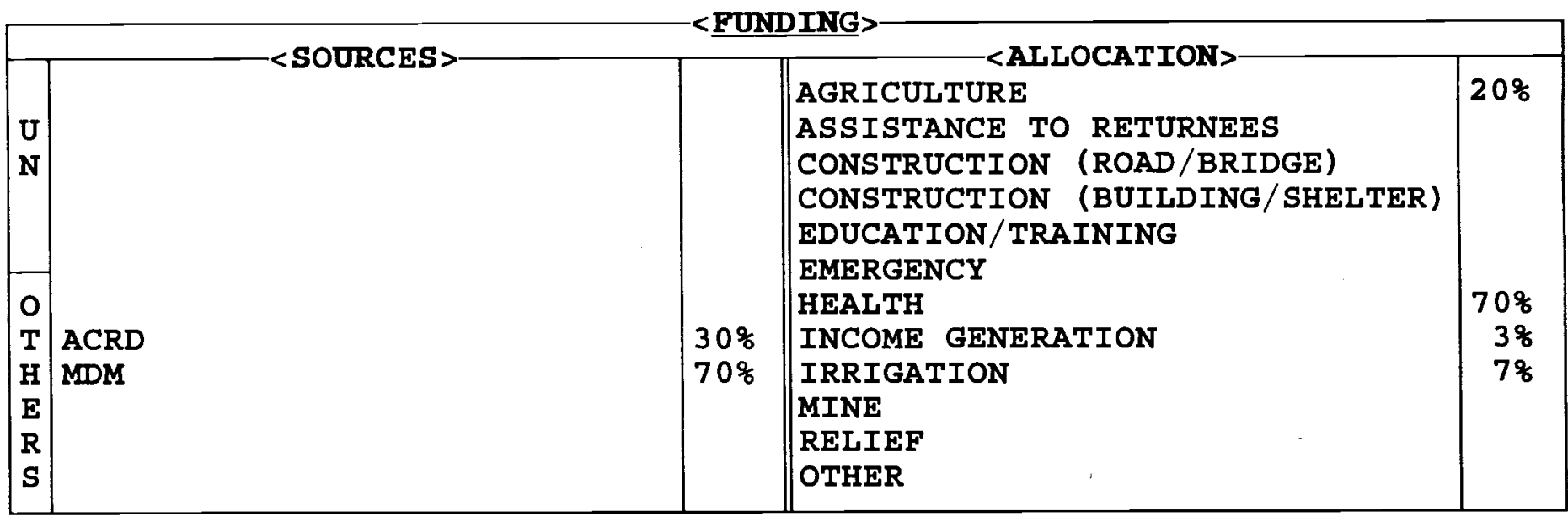

\begin{tabular}{|c|c|c|c|c|c|c|}
\hline $\begin{array}{l}\text { AFGHANISTAN: } \\
\text { REFUGEES : } \\
\text { T O T A L: }\end{array}$ & $\begin{array}{l}\frac{1992}{128,700} \\
-\overline{128,700}\end{array}$ & $\begin{array}{l}\frac{1993}{258,800} \\
258,800\end{array}$ & $\begin{array}{l}1994 \\
405,400 \\
--- \\
405,400\end{array}$ & $\begin{array}{c}\frac{1995}{395,000} \\
-- \\
395,000\end{array}$ & $\begin{array}{c}1996 \\
50,000 \\
-\cdots \\
50,000\end{array}$ & $\begin{array}{c}1997 \\
35,000 \\
35,000\end{array}$ \\
\hline 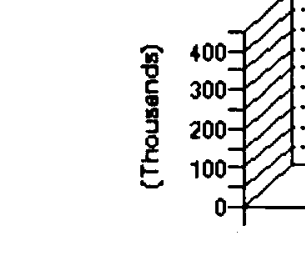 & 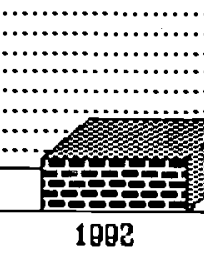 & 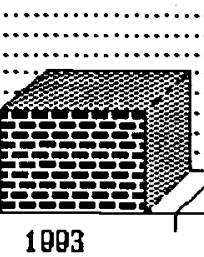 & 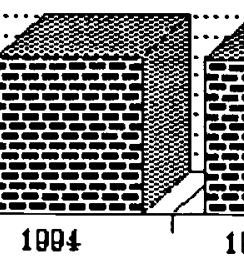 & 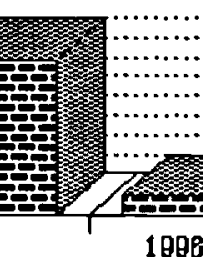 & $\frac{1087}{1007}$ & 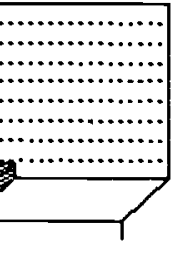 \\
\hline
\end{tabular}

\begin{tabular}{|c|c|c|c|c|c|}
\hline PROVINCES & SECTOR & $\%$ & PROVINCES & SECTOR & $\%$ \\
\hline $\begin{array}{l}\text { BADAKSHAN } \\
\text { BADGHIS } \\
\text { BAGHLAN } \\
\text { BALKH } \\
\text { BAMYAN } \\
\text { FARAH } \\
\text { FARYAB } \\
\text { GHAZNI } \\
\text { GHOR } \\
\text { HELMAND } \\
\text { HERAT } \\
\text { JAWZJAN } \\
\text { RABUL } \\
\text { KANDAHAR } \\
\text { RAPISA }\end{array}$ & & & $\begin{array}{l}\text { KUNAR } \\
\text { KUNDUZ } \\
\text { LAGHMAN } \\
\text { LOGAR } \\
\text { NANGARHAR } \\
\text { NIMROZ } \\
\text { ORUZGAN } \\
\text { PAKTEKA } \\
\text { PAKTIA } \\
\text { PARWAN } \\
\text { SAMANGAN } \\
\text { TAKHAR } \\
\text { WARDAK } \\
\text { ZABUL }\end{array}$ & $\begin{array}{c}\text { AGRIC/HEALTH/IRRIG/ } \\
\text { IN. GEN }\end{array}$ & 100 \\
\hline
\end{tabular}




\section{AFGHAN CENTER FOR RURAL DEVELOPMENT (ACRD)}

ACRD was established in 1990 and is registered with UNOCHA. It started as a development programme in Wardak, led by members of the local Council and its first rehabilitation work was in Health and Education.

\section{Aims of ACRD}

To contribute to the reconstruction and development of rural Afghanistan. To progressively attempt to restore administration in rural areas emphasizing on training of local staff.

\section{Sectors of operation:}

\section{Agriculture}

ACRD distributes fruit tree saplings under the FAO and IRC/RAP orchard rehabilitation programme. The agency also distributes seed, fertilizer and wheat. ACRD can provide threshers, tractors and harvesters.

\section{Irrigation}

ACRD are involved in the rehabilitation of karezes and canals.

\section{Engineering and Construction}

The engineering department of ACRD has a modern and well equipped auto workshop to meet the growing need for vehicle and machinery repair.

\section{Income Generation Programme}

ACRD promote the traditional handicrafts of Afghanistan.

\section{Wardak-Ghazni Health Programme}

ACRD provides health services to almost 131,000 inhabitants of Wardak and Ghazni. These services include: medical, surgical, obstetrics, X-ray, laboratory tests, dentistry, immunization, health education and TB control.

\section{Proposed Projects}

Promotion of Traditional Handicrafts as household business among women to improve rural economy.

Rehabilitation and vocational management of disabled.

Irrigation Projects:

- cleaning of $19 \mathrm{~km}$ canals and rehabilitation of Sar Lukh Diversion in Jaghatu, Wardak; - established five jeribs of plant nursery in Jaghatu, Wardak;

- establish a vocation training and skill development centre in Jaghatu, Wardak; - build a water fountain compartment at the outlet of 26 karezes; - construct $20 \mathrm{~km}$ of road from Khwaja Omri Karez to Saleh-Hkel; - construct $28.5 \mathrm{~km}$ of road from Sayed Abad to Abdul Muhayuddin village, Wardak.

Projects ongoing in 1997

- Medical project.

- Veterinary project.

- Public Health

- Bee-keeping project. 
AFGHAN DEVELOPMENT ASSOCIATION (ADA)

ACBAR

<ADDRESS >

HOUSE 432 , OLD BARA RD

UNI. TOWN GPO 922

PESHAWAR， PAKISTAN
<COMMUNICATION LINES>-

PHONE : $45333 / 42230 / 844825$

F A X: 42230 net.pk

email:Afgdevas@psh.brain.
1. JELANI POPAL

2. MOHAMMAD SULEMAN

3. A SALAAM KAKAR

\begin{tabular}{|c|c|c|c|c|c|}
\hline AFGHAN & 420 & TECHN I CA $\bar{L}$ & 337 & PAK. BASED & 36 \\
\hline PAKISTANI : & 2 & ADMINISTRATIVE : & 21 & AFGHAN BASED: & 386 \\
\hline EXPAT : & - & FIELD/SUPPORT S. & 64 & CROSS-BORDER : & - \\
\hline TOTAL & 422 & TOTAL : & 422 & TOTAL : & 422 \\
\hline
\end{tabular}

\begin{tabular}{|c|c|c|c|c|}
\hline & $\langle$ SOURCES $\rangle-$ & & $-<$ ALLOCATION $>$ & \\
\hline & & & AGRICULTURE & $23 \%$ \\
\hline $\mathrm{U}$ & FAO & $7 \%$ & ASSISTANCE TO RETURNEES & \\
\hline$N$ & UNHCR & $5 \%$ & CONSTRUCTION (ROAD/BRIDGE) & $2 \%$ \\
\hline & UNDCP & $1 \%$ & CONSTRUCTION (BUILDING/SHELTER) & $8 \%$ \\
\hline 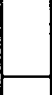 & & & $\begin{array}{l}\text { EDUCATION - VOCATIONAL } \\
\text { EMERGENCY }\end{array}$ & $26 \%$ \\
\hline 0 & $\mathrm{NCA}$ & $48 \%$ & HEALTH & $14 \%$ \\
\hline $\mathrm{T}$ & SAFE & $18 \%$ & INCOME GENERATION & \\
\hline $\mathrm{H}$ & EUROPEAN UNION & $15 \%$ & IRRIGATION-MICRO HYDRO & $20 \%$ \\
\hline $\mathrm{E}$ & GTZ & $4 \%$ & MINE & \\
\hline$\overline{\mathrm{R}}$ & ADA & $2 \%$ & RELIEF & \\
\hline$S$ & & & OTHER & $7 \%$ \\
\hline
\end{tabular}

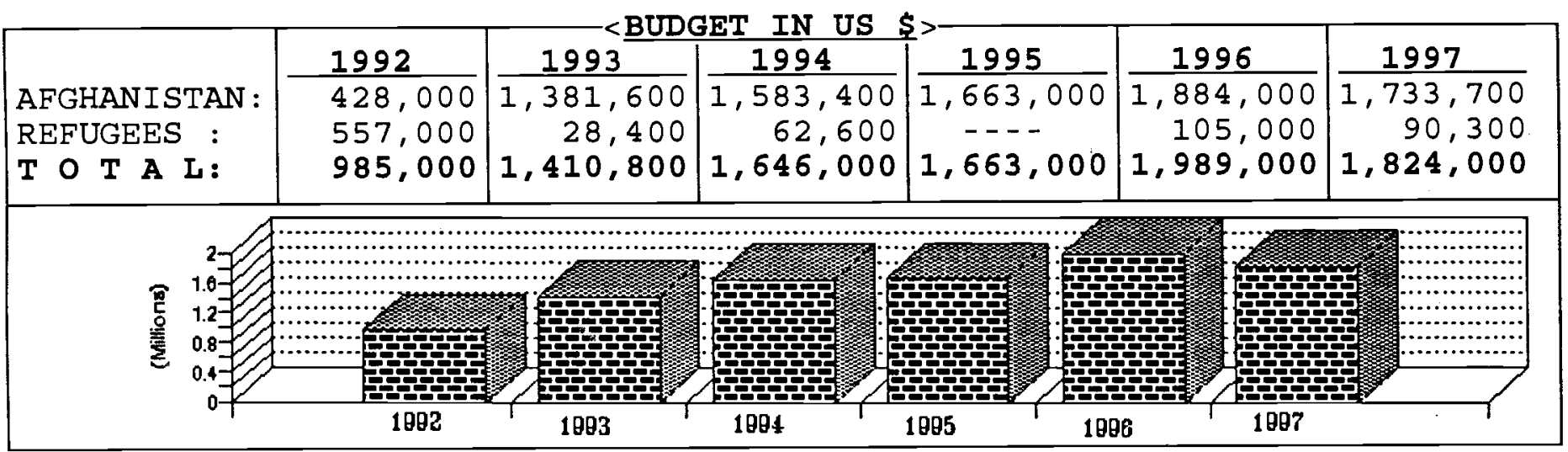

\begin{tabular}{|c|c|c|c|c|c|}
\hline PROVINCES & SECTOR & $\%$ & PROVINCES & SECTOR & $\%$ \\
\hline $\begin{array}{l}\text { BADAKSHAN } \\
\text { BADGHIS } \\
\text { BAGHLAN } \\
\text { BALKH } \\
\text { BAMYAN } \\
\text { FARAH } \\
\text { FARYAB } \\
\text { GHAZNI } \\
\text { GHOR } \\
\text { HELMAND } \\
\text { HERAT } \\
\text { JAWZJAN } \\
\text { KABUL } \\
\text { KANDAHAR } \\
\text { KAPISA }\end{array}$ & $\begin{array}{l}\text { CONST/EDUC/HORT/VET } \\
\text { HORTICULTURE } \\
\text { EDUCATION/AGRIC } \\
\text { EDUC/CONST/VOC/VET/ }\end{array}$ & $\begin{array}{r}20 \\
5\end{array}$ & $\begin{array}{l}\text { KUNAR } \\
\text { KUNDUZ } \\
\text { LAGHMAN } \\
\text { LOGAR } \\
\text { NANGARHAR } \\
\text { NIMROZ } \\
\text { ORUZGAN } \\
\text { PAKTEKA } \\
\text { PAKTIA } \\
\text { PARWAN } \\
\text { SAMANGAN } \\
\text { TAKHAR } \\
\text { WARDAK } \\
\text { ZABUL } \\
\text { PAKISTAN }\end{array}$ & $\begin{array}{l}\text { AGRIC/EDUC/CONST/VOC } \\
\text { AGRIC/EDUC/VOC/VET }\end{array}$ & $\begin{array}{l}15 \\
15\end{array}$ \\
\hline
\end{tabular}




\section{AFGHAN DEVELOPMENT ASSOCIATION (ADA)}

ADA is an Afghan NGO created October 1990. ADA aims to implement multi-sectoral rehabilitation and development projects designed to foster self-reliance and self sufficiency and empower Afghans to mect their future needs while creating the socio-cconomic conditions fostering peace, stability and repatriation.

\section{Sectors}

Sectors of opcration are:

- Integrated Education;

- Soil Conscrvation;

- Micro Hydro;

- Horticulturc Rchabilitation;

- Agriculture;

- Road Repair/Construction;

- Veterinary services;

- Vocational Training;

- Farm Mechanisation;

- Irrigation and water supply.

\section{Future plans}

A. to strengthen capacity building and human resource devclopment in ADA to ensure a high quality of service to the community;

B to empower the poor and powerless and strengthen their capacity to take more responsibility in development activitics;

C to encourage peace and repatriation of refugees;

D to implement integrated education, soil conservation, Micro Hydro. horticulture Rehabilitation, road repair/construction, veterinary scrvices, vocational training, farm mechanisation, irrigation and water supply projects in Afghanistan;

E to include environmental conservation awareness as an integrated component in every field of activity;

\section{Planned projects}

- Integrated Education

- Horticulture Rehabilitation and Development

- $\quad$ Soil conservation (Protection of Agricultural land and irrigation structures)

- $\quad$ Road repair

- Vetcrinary

- $\quad$ Rencwable energy (micro-Hydro)

- Vocational Training

- $\quad$ Farm mechanisation

- Human resource development. 
5, MURAD PLAZA UNIVERSITY ROAD PESHAWAR, PAKISTAN

\section{PHONE : 841743}

F A X:

TELEX :
1. QAMARUDDIN

2. SAADULLAH SAFI

3. ENG - RAHMATULLAH

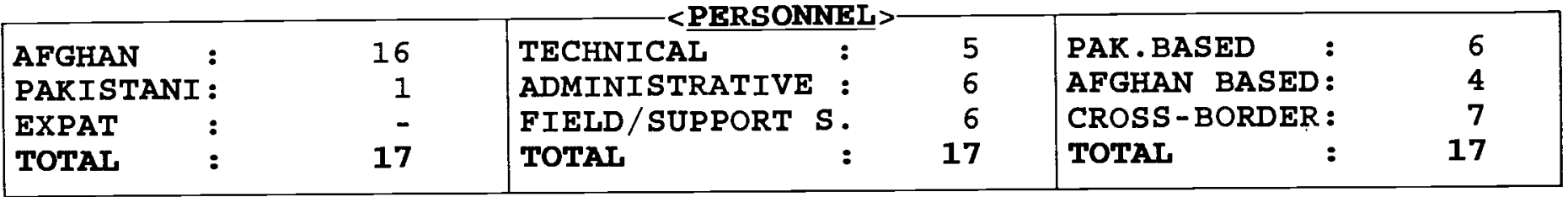

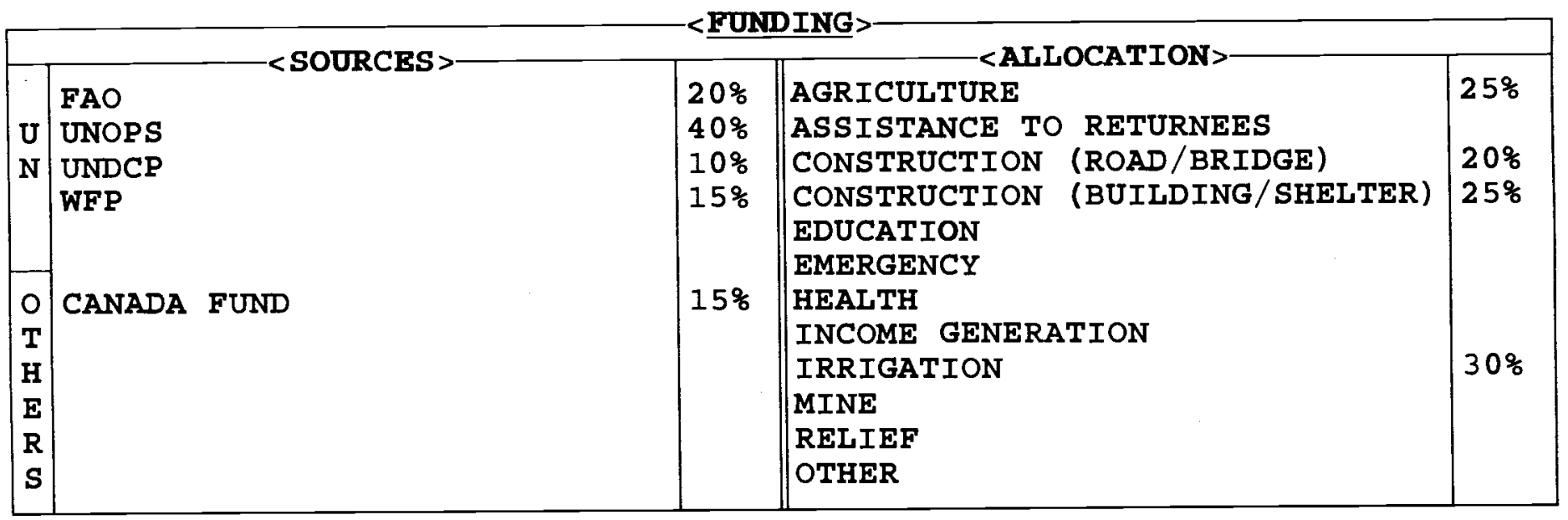

\begin{tabular}{|c|c|c|c|c|c|c|}
\hline $\begin{array}{l}\text { AFGHANISTAN : } \\
\text { REFUGEES : } \\
\text { T O T A L: }\end{array}$ & $\begin{array}{c}1992 \\
253,600 \\
--- \\
253,600\end{array}$ & $\begin{array}{c}1993 \\
82,200 \\
-\overline{82,200}\end{array}$ & $\begin{array}{c}1994 \\
27,300 \\
- \\
27,300\end{array}$ & $\begin{array}{l}1995 \\
67,700 \\
---- \\
67,700\end{array}$ & $\begin{array}{l}1996 \\
67,700 \\
---- \\
67,700\end{array}$ & $\begin{array}{c}1997 \\
40,000 \\
-\cdots \\
40,000\end{array}$ \\
\hline 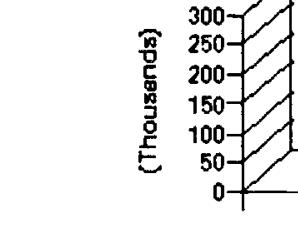 & 1902 & ( & 1004 & $\ldots \ldots$. & 1007 & 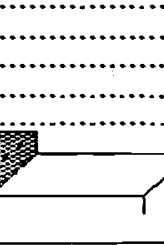 \\
\hline
\end{tabular}

\begin{tabular}{|c|c|c|c|c|c|}
\hline PROVINCES & SECTOR & $\%$ & PROVINCES & SECTOR & $\%$ \\
\hline $\begin{array}{l}\text { BADAKSHAN } \\
\text { BADGHIS } \\
\text { BAGHLAN } \\
\text { BALKH } \\
\text { BAMYAN } \\
\text { FARAH } \\
\text { FARYAB } \\
\text { GHAZNI } \\
\text { GHOR } \\
\text { HELMAND } \\
\text { HERAT } \\
\text { JAWZJAN } \\
\text { KABUL } \\
\text { KANDAHAR } \\
\text { RAPISA }\end{array}$ & $x^{2}$ & $\begin{array}{l}20 \\
10\end{array}$ & $\begin{array}{l}\text { KUNAR } \\
\text { KUNDUZ } \\
\text { LAGHMAN } \\
\text { LOGRR } \\
\text { NANGARHAR } \\
\text { NINROZ } \\
\text { ORUZGAN } \\
\text { PAFTEKA } \\
\text { PAFTIA } \\
\text { PARWAN } \\
\text { SAMANGAN } \\
\text { TAKHAR } \\
\text { WARDAK } \\
\text { ZABUL }\end{array}$ & $\begin{array}{l}\text { AGRICULTURE/IRRIG } \\
\text { AGRIC/IRRIG/CONST }\end{array}$ & $\begin{array}{l}25 \\
45\end{array}$ \\
\hline
\end{tabular}




\section{AFGHAN DEVELOPMENT AGENCY \\ (ADAg)}

ADAg was established in carly 1990 and started work in mid-1991. It aims to contributc to the rehabilitation and development of

Afghanistan through the planning, designing and undertaking of cconomic and humanitarian assistance programmes.

\section{Sectors of Operation}

Sectors of operation are as follows:

- Agricultural assistance programme;

- Irrigation;

- Construction;

- Road repair.

\section{Future/present objectives:}

To plan, design and implement rehabilitation and development projects in Afghanistan. To offer help and emergency rclief assistance such as food supply, clothing, shelter, medicine ctc. to needy Afghans. To cooperate with any other organisation which has aims and objectives similar to the aims and objectives of ADAg.

\section{Further information:}

ADAg will be involved in the rehabilitation programme for Afghanistan as long as needed.

After completion of the rehabilitation programme and refugees repatriation, the agency will design and undertake development projects for the bencfit of Afghanistan. 


\section{AFGHAN DISABLED SOCIET (ADS)}

\begin{tabular}{|l|l|}
\hline C/O U.P.O.BOX 1463, & PHONE: 42854 \\
UNIVERSITY TOWN & F A X: 40706 \\
PESHAWAR, PAKISTAN & TELEX: \\
\hline
\end{tabular}

1. 2 KEY STAFF>

ABDUL RAHIMAN SAHAK

2 .

3 .

\begin{tabular}{|c|c|c|c|c|c|c|}
\hline \multirow{2}{*}{\multicolumn{2}{|c|}{$\begin{array}{l}\text { AFGHAN : } \\
\text { PAKISTANI : }\end{array}$}} & 18 & TECHNICAL & & & \\
\hline & & - & ADMINISTRATIVE: & & PAK.BASED : & 2 \\
\hline EXPAT & : & - & FIELD/SUPPORT $s$ : & 3 & AFGHAN BASED: & 16 \\
\hline TOTAL & : & 18 & TOTAL & $\begin{array}{r}4 \\
70\end{array}$ & CROSS - BORDER : & - \\
\hline & & & - & 10 & TOTAI & 18 \\
\hline
\end{tabular}

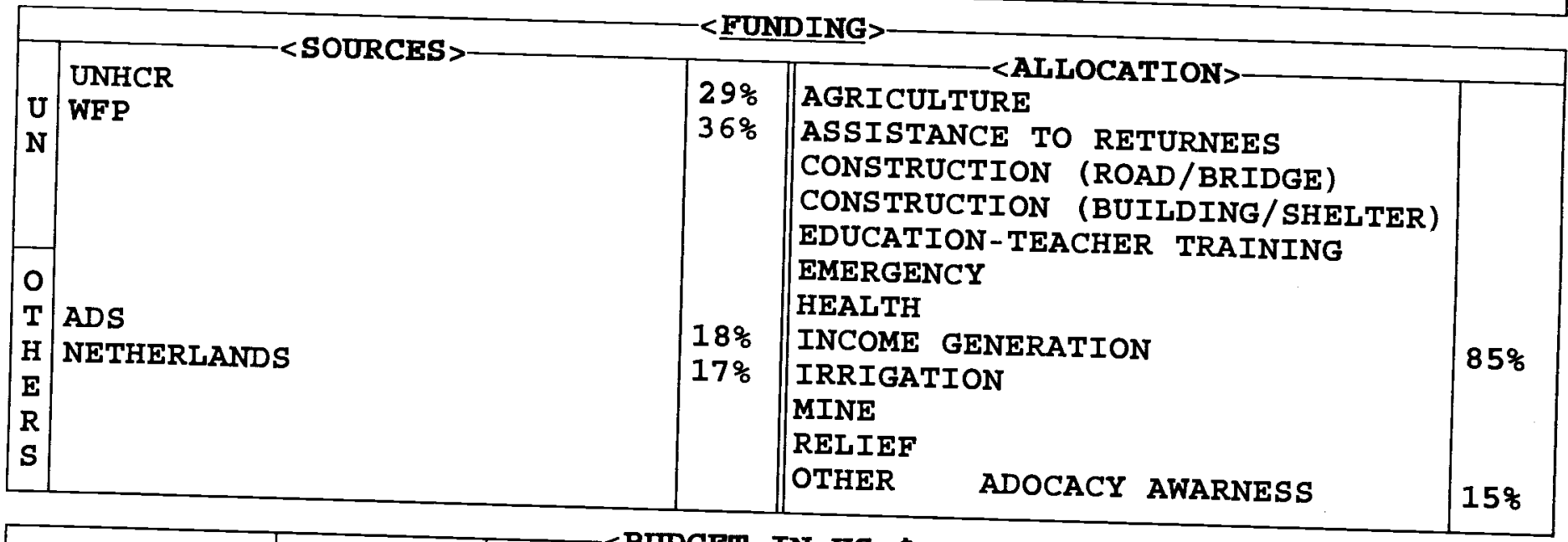

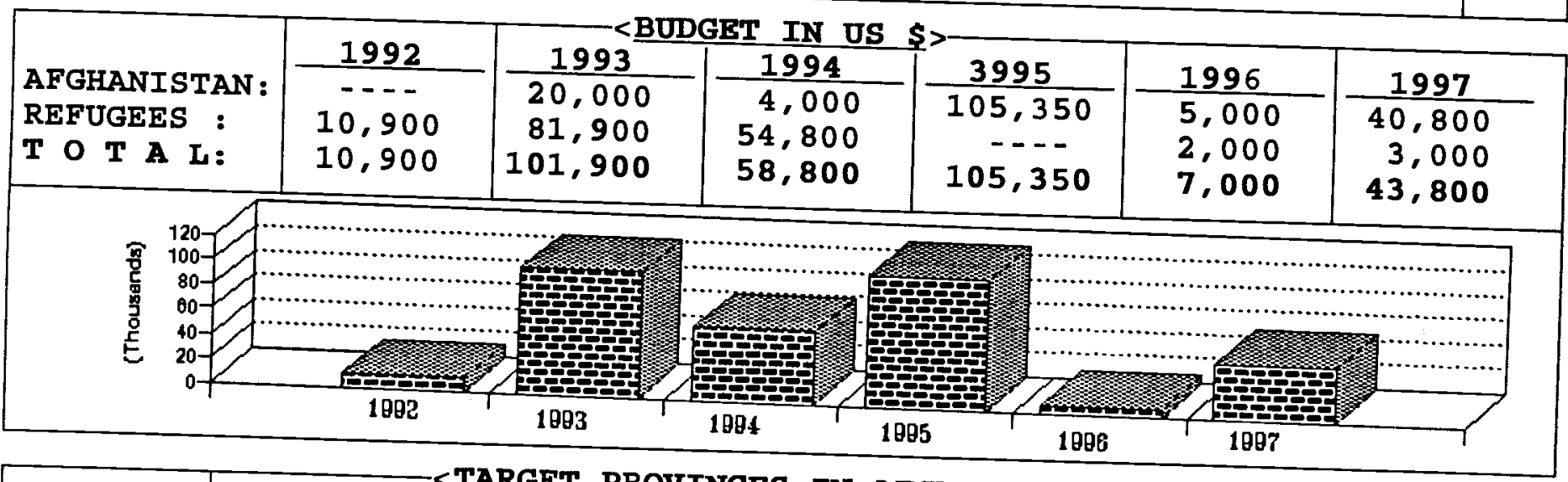

\begin{tabular}{|c|c|c|c|c|c|}
\hline \multirow{2}{*}{ PROVINCES } & \multirow{2}{*}{ SECTOR } & \multicolumn{4}{|c|}{ IN AFGHANISTAN > } \\
\hline & & $\%$ & PROVINCES & SECTOR & $\%$ \\
\hline $\begin{array}{l}\text { BADAKSHAN } \\
\text { BADGHIS } \\
\text { BAGHLAN } \\
\text { BALKH } \\
\text { BAMYAN } \\
\text { FARAH } \\
\text { FARYAB } \\
\text { GHAZNI } \\
\text { GHOR } \\
\text { HELMAND } \\
\text { HERAT } \\
\text { JAWZJAN } \\
\text { KABUL } \\
\text { KANDAHAR } \\
\text { KAPISA }\end{array}$ & $\begin{array}{l}\text { DISABILITY RELATED } \\
\text { PUBLICATION DIST. } \\
\text { PUBLICATION DIST. } \\
\text { PUBLICATION DIST. }\end{array}$ & $\begin{array}{l}1 \\
1\end{array}$ & \begin{tabular}{||l|} 
KUNAR \\
KUNDUZ \\
LAGHMAN \\
LOGAR \\
NANGARHAR \\
NIMROZ \\
ORUZGAN \\
PAKTEKA \\
PAKTIA \\
PARWAN \\
SAMANGAN \\
TAKHAR \\
WARDAK \\
ZABUL \\
REFUGEES
\end{tabular} & $\begin{array}{l}\text { ACCESSIBILITY ASSESS } \\
\text {-MENT } \\
\text { ASSESSMENT SURVEY } \\
\text { VOCATIONAL TRAINING } \\
\text { ADOCACY AWARNESS }\end{array}$ & $\begin{array}{r}1 \\
1 \\
93 \\
2\end{array}$ \\
\hline
\end{tabular}


The key objectives of ADS are to assist disabled Afghans in all aspects of their lives. ADS is committed to independent living, economic independence, full participation, equalization of opportunitics and empowerment of disabled persons.

Vocational Training Programmes are run to empower and train disabled in skills i.e. tailoring, leather craft, carpet weaving, embroidery, metal works, carpentry, soap making, bicycle and watch repairs. Over 1,200 disabled have been trained in the well equipped training centers in Afghanistan. The capacity of these centres is 200 trainees per annum.

Sclf reliance; a credit/loan scheme has been set up with somc 300 applicants having becn monitored and found suitable. More funding is required for this project.

Advocacy department - local administration and NGOs are requested to employ disabled.

Information Management (Survey) A survey was undertaken in Logar, Paktia, Khost, Kandahar and Ghazni Provinces and a database designed and some 30,000 disabled registered.

Integration to Education Through advocacy, awareness and teacher training it is hoped the integration of disabled children to regular schools can be increased.

Advocacy and awareness are highlighted in seminars and workshops. Lobbying is undertaken to improve accessibility and security of the disabled.

Relicf Distribution of wheelchairs, crutches, blankets and clothing itcms has been a priority.

Information from around the world, relating to disability, is gathered and distributed to interested parties.

The future objectives of ADS are to further consolidatc, devclop, standardize and expand the existing programmes and emphasize community participation to strengthen the role of the disabled in socicty. 
AMITIE FRANCO-AFGHANE AIDE HUMANITAIRE ET INFORMATION (AFRANE)

$<$ ADDRESS $>-$

7 REHMAN BABA R

PESHAWAR， PAKISTAN

PHONE : 41492

F A X: 41492

emai 1:
1. YVES FAIVRE

2. MUNAWAR AHMAD

3. FAZAL QADER

ACBAR

\begin{tabular}{|c|c|c|c|c|c|}
\hline $\begin{array}{l}\text { AFGHAN : } \\
\text { PAKISTANI: } \\
\text { EXPAT : } \\
\text { TOTAL : }\end{array}$ & $\begin{array}{r}70 \\
1 \\
1 \\
72\end{array}$ & $\begin{array}{l}\text { TECHNICAL : } \\
\text { ADMINISTRATIVE : } \\
\text { FIELD/SUPPORT S: } \\
\text { TOTAL }\end{array}$ & $\begin{array}{r}8 \\
12 \\
52 \\
72\end{array}$ & $\begin{array}{l}\text { PAK. BASED : } \\
\text { AFGHAN BASED : } \\
\text { CROSS-BORDER : } \\
\text { TOTAL : }\end{array}$ & $\begin{array}{r}10 \\
62 \\
- \\
72\end{array}$ \\
\hline
\end{tabular}

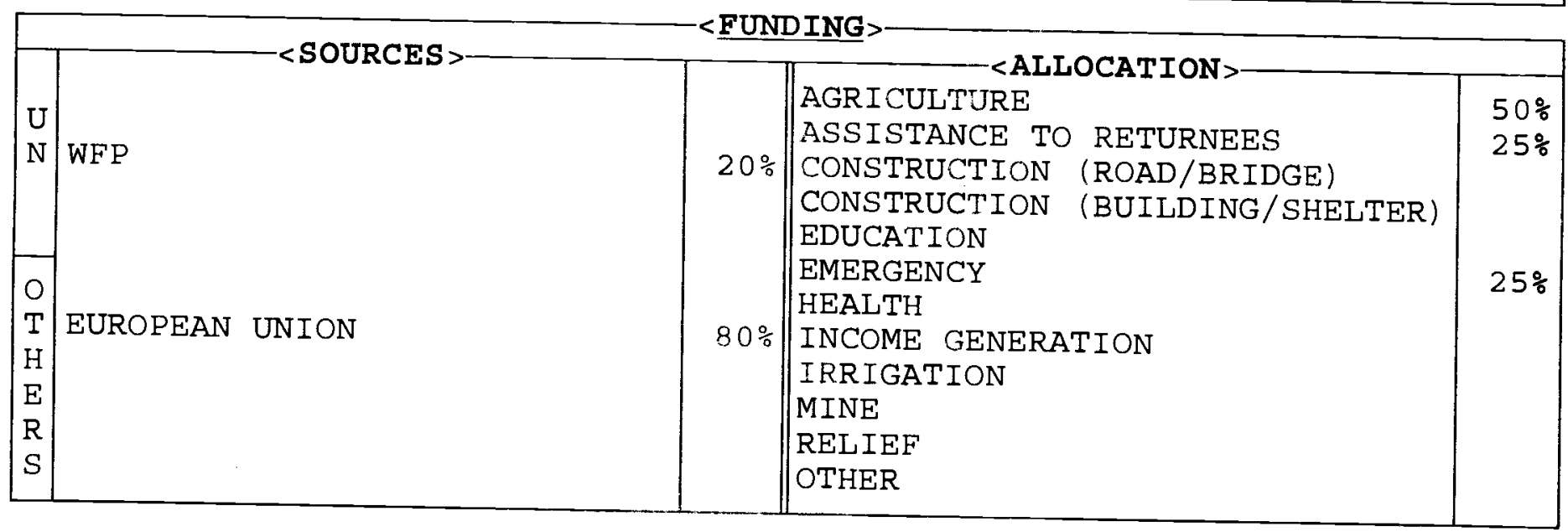

\begin{tabular}{|c|c|c|c|c|c|c|c|}
\hline \multicolumn{2}{|c|}{$\begin{array}{l}\text { AFGHANISTAN: } \\
\text { REFUGEES : } \\
\text { T O T A L: }\end{array}$} & $\begin{array}{l}\frac{1992}{300,000} \\
300,000\end{array}$ & 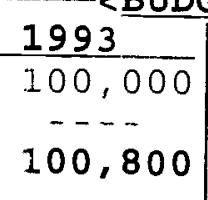 & 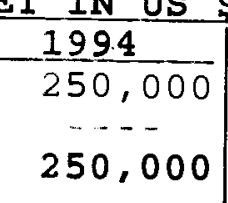 & $\begin{array}{l}\frac{1995}{480,000} \\
480,000\end{array}$ & $\begin{array}{l}\frac{1996}{230,000} \\
230,000\end{array}$ & $\frac{1997}{100,000}$ \\
\hline 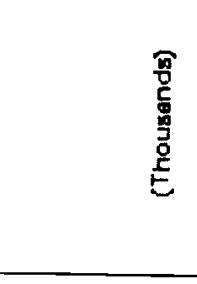 & $\begin{array}{l}{ }^{5} 00= \\
{ }^{400}=8\end{array}$ & 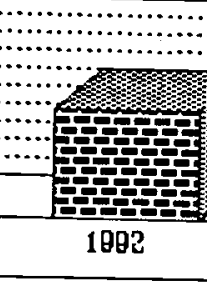 & 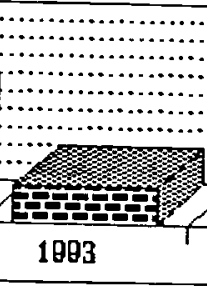 & 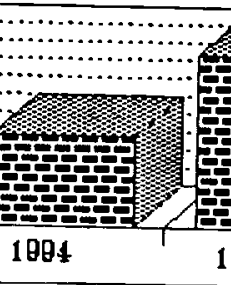 & 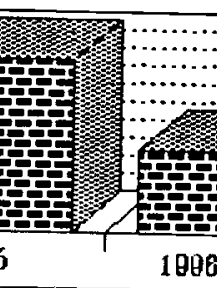 & (1.:.: & 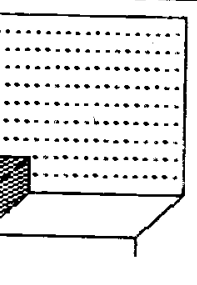 \\
\hline
\end{tabular}

\begin{tabular}{|c|c|c|c|c|c|}
\hline PROVINCES & SECTOR & $\%$ & PROVINCES & SECTOR & $\div$ \\
\hline $\begin{array}{l}\text { BADAKSHAN } \\
\text { BADGHIS } \\
\text { BAGHLAN } \\
\text { BALKH } \\
\text { BAMYAN } \\
\text { FARAH } \\
\text { FARYAB } \\
\text { GHAZNI } \\
\text { GHOR } \\
\text { HELMAND } \\
\text { HERAT } \\
\text { JAWZJAN } \\
\text { KABUL } \\
\text { KANDAHAR } \\
\text { KAPISA }\end{array}$ & \begin{tabular}{|l} 
AGRICULTURE/ASSIS RET \\
AGRICULTURE/EMERGENCY
\end{tabular} & 50 & \begin{tabular}{|l|} 
KUNAR \\
KUNDUZ \\
LAGHMAN \\
L,OGAR \\
NANGARHAR \\
NIMROZ \\
ORUZGAN \\
PAKTEKA \\
PAKTIA \\
PARWAN \\
SAMANGAN \\
TAKHAR \\
WARDAK \\
ZABUL \\
PAKISTAN
\end{tabular} & AGRICULTURE/ASSIS RET & 20 \\
\hline
\end{tabular}


AMITIE FRANCO-AFGHANE AIDE HUMANITAIRE ET INFORMATION (AFRANE)

AFRANE was founded - by pcople familiar with Afghanistan, most of whom had worked there previously - in 1979.

From its foundation to 1986, AFRANE focuscd on humanitarian help and information about the situation in Afghanistan, through a periodical review "Les Nouvelles d'Afghanistan", and through the collection of documentation in collaboration with the Center de Recherches ct d'Etudes Documentaires sur l'Afghanistan (CEREDAF).

The first humanitarian aid missions were launched in 1980 inside Afghanistan, by providing cash for food and clothes, under dangerous circumstances. Expatriate volunteers supervised the progranme.

From 1986 the programmes moved from pure humanitarian help towards agricultural assistance, with the emphasis on irrigation rehabilitation and implementation of a mechanisatioon programme, with tractors, equipment and workshops.

From this period, the activities of AFRANE became more and more specialised, with permanent staff inside Afghanistan based in its Rural Devclopment centres. It increased its cooperation with Afghan and European Agencies working in neighbouring arcas.

Its Rural Development Centres cstablished, in Logar and Ghazni Provinces, are now running continuous programmes in the following arcas:

- water management, preservation of soils and reforestation, communications, cereals, meat and dairy, vegetables, fruit, mechanisation, encrgy saving programmes and education. Some of these programmes are producing income and providing employment;
Field rescarch is carried out by AAEC (Afghan Agriculture Experimental Centre), created by CoAR and AFRANE in 1991. It is presently running some 50 ficld experiments on cereals, vegetables and fruit trees; thus enabling the financing of pilot projects (e.g. soil rchabilitation in lalmi areas) which are not traditionally funded by the institutional donors.

The agcncy is also involved in emergency work in Kabul, particularly in the arcas of water and sanitation, feeding programmes for the most needy and shclter. 
133, GUL HAJI PLAZA, G.P.O BOX 615 PESHAWAR, PAKISTAN
844TION LINES PHONE : 844513

F A X: TELEX :
1. A . AZIZ ORIAKHIL

2. M AKBAR SAFDARI

3. ENG. M ARIF MIAKHIL

\begin{tabular}{|c|c|c|c|c|c|}
\hline $\begin{array}{l}\text { AFGHAN : } \\
\text { PARISTANI : } \\
\text { EXPAT : } \\
\text { TOTAL : }\end{array}$ & $\begin{array}{r}31 \\
- \\
31\end{array}$ & $\begin{array}{l}\text { TECHNICAL : } \\
\text { ADMINISTRATIVE : } \\
\text { FIELD/SUPPORT S : } \\
\text { TOTAL }\end{array}$ & $\begin{array}{r}17 \\
7 \\
7 \\
31\end{array}$ & $\begin{array}{l}\text { PAK. BASED : } \\
\text { AFGHAN BASED : } \\
\text { CROSS-BORDER : } \\
\text { TOTAL : }\end{array}$ & $\begin{array}{r}6 \\
23 \\
2 \\
31\end{array}$ \\
\hline
\end{tabular}

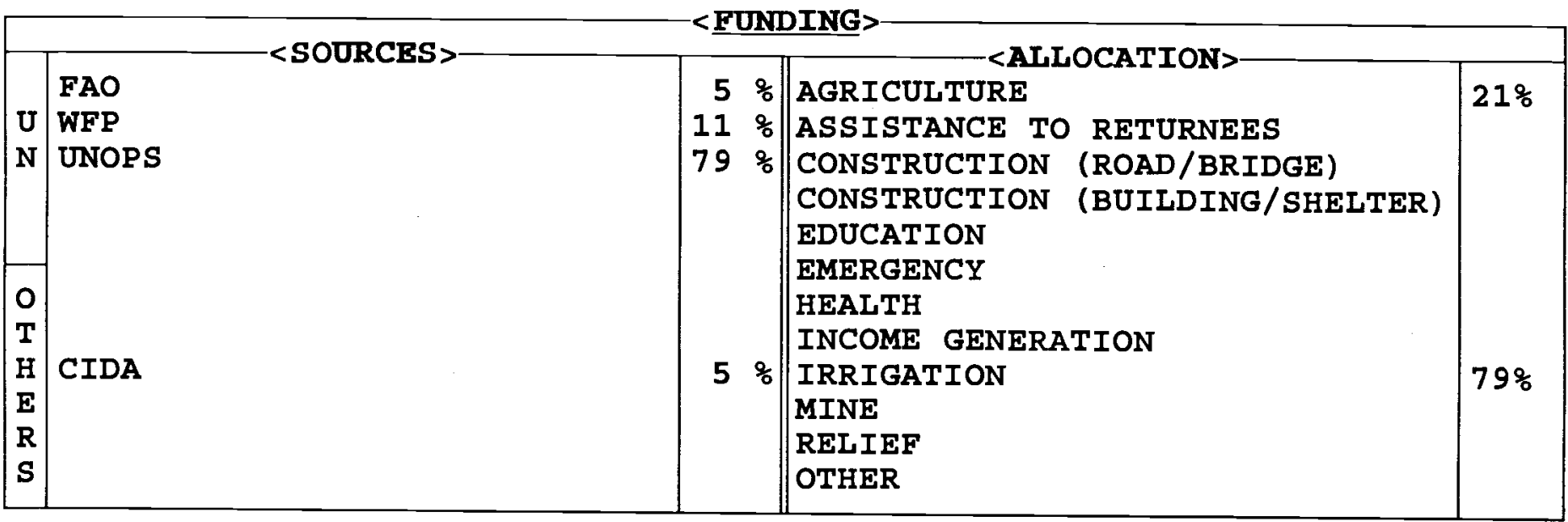

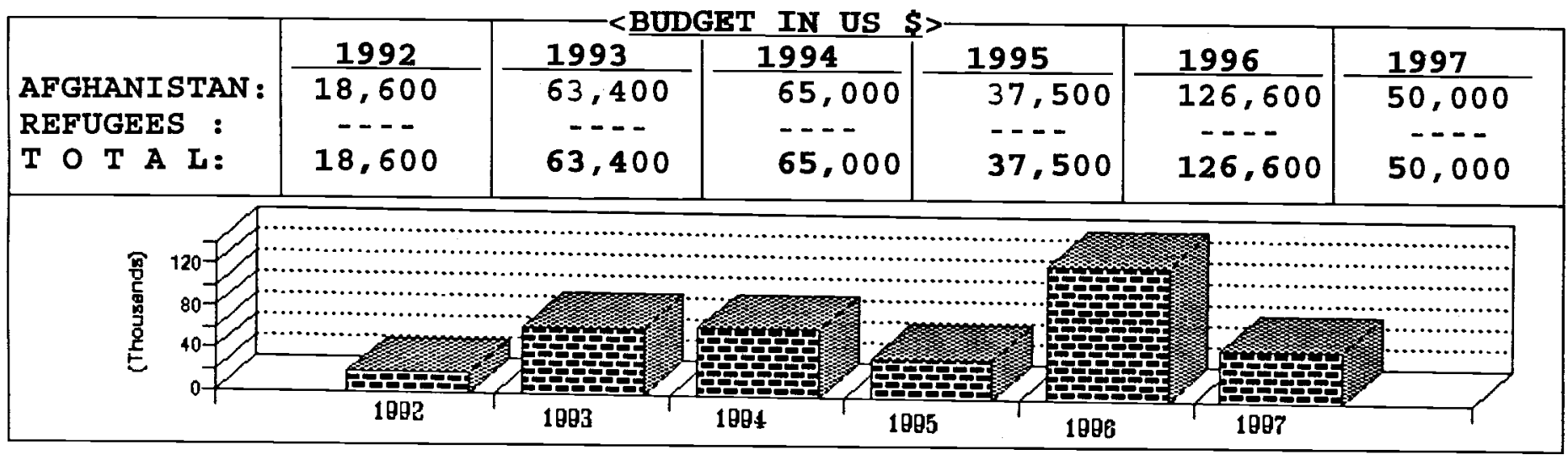

\begin{tabular}{|c|c|c|c|c|c|}
\hline PROVINCES & SECTOR & $\frac{9}{0}$ & PROVINCES & SECTOR & $\frac{q}{c}$ \\
\hline $\begin{array}{l}\text { BADAKSHAN } \\
\text { BADGHIS } \\
\text { BAGHLAN } \\
\text { BALKH } \\
\text { BAMYAN } \\
\text { FARAH } \\
\text { FARYAB } \\
\text { GHAZNI } \\
\text { GHOR } \\
\text { HELMAND } \\
\text { HERAT } \\
\text { JAWZJAN } \\
\text { KABUL } \\
\text { KANDAHAR } \\
\text { KAPISA }\end{array}$ & IRRIGATION & 7 & $\begin{array}{l}\text { KUNAR } \\
\text { KUNDUZ } \\
\text { LAGHMAN } \\
\text { LOGAR } \\
\text { NANGARHAR } \\
\text { NIMROZ } \\
\text { ORUZGAN } \\
\text { PAKTEKA } \\
\text { PAKTIA } \\
\text { PARWAN } \\
\text { SAMANGAN } \\
\text { TAKHAR } \\
\text { WARDAK } \\
\text { ZABUL }\end{array}$ & $\begin{array}{l}\text { AGRICULTURE } \\
\text { AGRIC/IRRIG } \\
\text { AGRIC/IRRIG }\end{array}$ & $\begin{array}{r}3 \\
3 \\
87\end{array}$ \\
\hline
\end{tabular}




\section{AGENCY FOR FARMING SUPPORT}

(AFS)

AFS was established in Peshawar in 1991 and has sub offices in Nangarhar, Khost and Kabul. Being optimistic about ensuring overall peace and security in Afghanistan AFS started its activities in January 1991 and successfully implemented a number of projects in Kabul, Ghazni, Laghman, Nangarhar, Khost and other Provinces. The main sector of interest is agricultural rehabilitation in Afghanistan.

The agency's major aims and objectives are:

-Active and direct participation in rehabilitation / restoration of agriculture through production, distribution and multiplication of improved seeds and fertilizers; establishment of fruit and forest tree nurseries; veterinary and extension services; and setting up dairy / cattle farms.

Meanwhile, the agricultural activities will help replace opium and hashish cultivation with useful crops so that the economic condition of the farming families is improved and livelihood is promoted in rural areas.

To take an active part in reconstruction of irrigation systems in rural areas such as canals, dams, karezes and weirs.

The following services are also offered:

- urgent assistance is offered to affected people through implementation of multi-sectoral projects in rural areas;

- provision of opportunities for poor women in community development and household economy, through income generation such as poultry production and distribution, honey bee kceping, embroidery ctc. to promote self sufficiency;

- training to farmers, on site, in the proper use of improved seeds, saplings; and scientific application of pesticides and insecticides;

- training to Afghans to upgrade their knowledge and skills for employment;
- to take a direct and active part in the rehabilitation of war ravaged Afghanistan through repair and restoration of infrastructure in the countryside e.g. bridges, dams, roads and public buildings such as schools, hospitals, clinics, mosques etc. 
AFGHAN GERMAN BASIC EDUCATION (AG BAS-Ed)

ACBAR

<ADDRESS >- - COMMUNICATION LINES $>$

HSE 1, STR 1, JEHANGIR- PHONE: 843063

ABAD, UNIVERSITY ROAD

PESHAWAR, PAKISTAN
F A X: 842693

email:
1. DR YUSUF NURISTANI

2. MOH'D RAHIM QASIMI

3. ENG FAZAL AHAD

\begin{tabular}{|lrl|lr|lrr|}
\hline AFGHAN & $:$ & 35 & TECHNICAL & $:$ & 12 & PAK. BASED : & 4 \\
PAKISTANI : & - & ADMINISTRATIVE : & 8 & AFGHAN BASED : & 29 \\
EXPAT & $:$ & - & FIELD/SUPPORT S : & 15 & CROSS-BORDER : & 2 \\
TOTAL & $:$ & 35 & TOTAL & $:$ & 35 & TOTAL & $\mathbf{3}$ \\
\hline
\end{tabular}

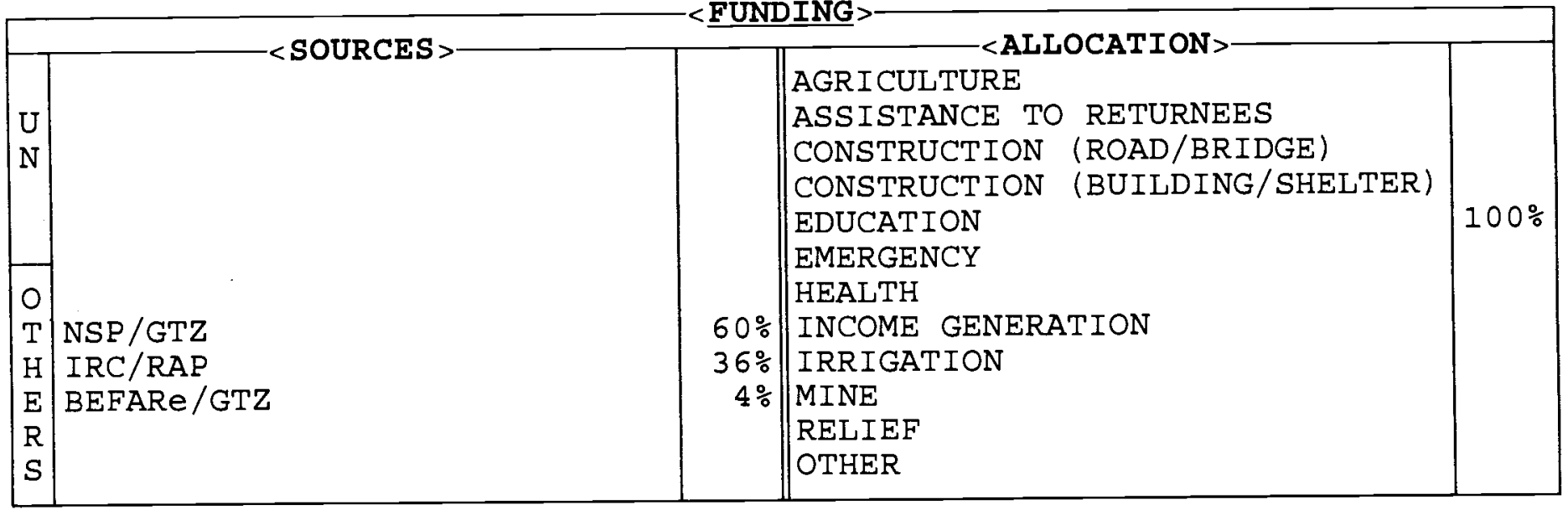

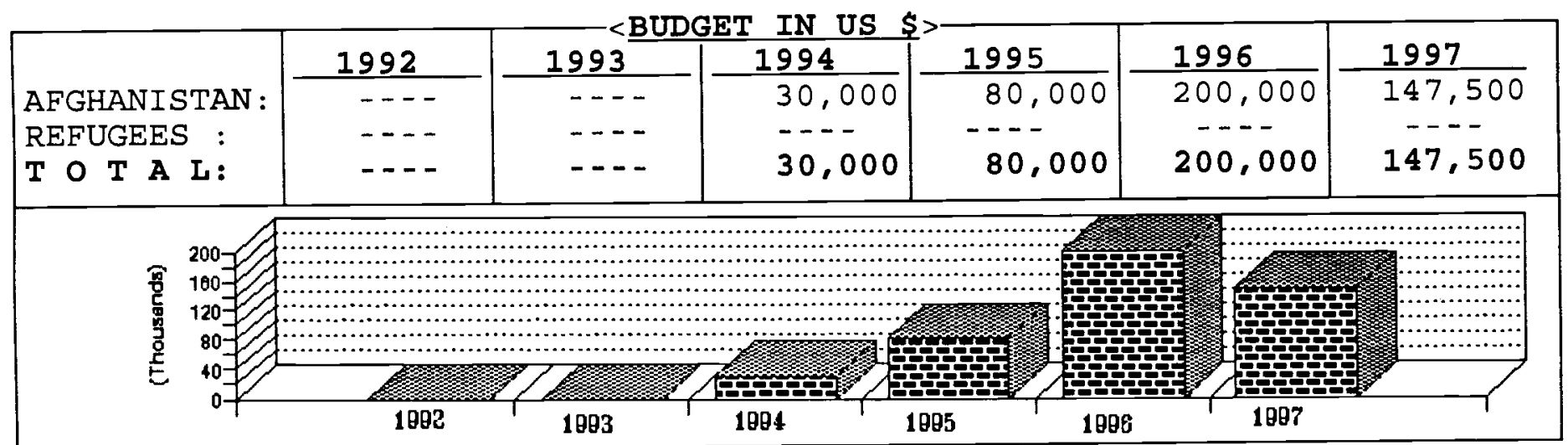

<TARGET PROVINCES IN AFGHANISTAN>

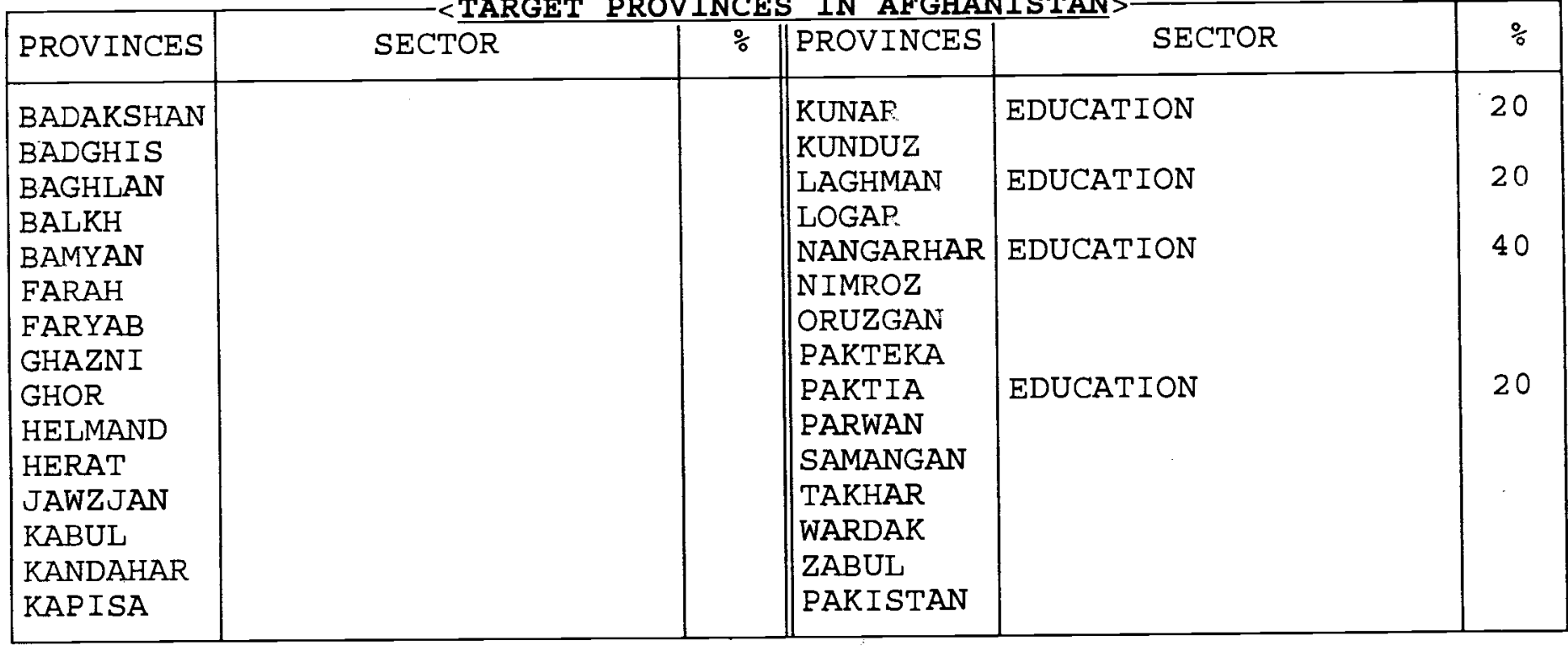


AG BAS-Ed was created as a follow up project of Basic Education for Afghan Refugecs (BEFARe) to work inside Afghanistan. In Junc 1996 it was set up as an independent NGO with its main office in Nangarhar and area offices in Khost and Kunar Provinces.

During the last two years the project has successfully implemented a number of education activities in the fields of formal, nonformal and mother and child health care.

There is also a Literacy programme for males and females. This course is in Pashto and teaches basic literacy and numcracy skills.

AG BAS-Ed is at present in four Provinces of Afghanistan and hopes to expand its programme in Nooristan, Kabul, Paktia and Mazar-i-Sharif.

\section{Objectives}

The project wants to contribute to the improvement of Basic Education for Afghans and achieve the following:

- $\quad$ teachers trained to work with project and non-project produced materials;

- $\quad$ provide appropriate teaching/learning and training materials;

- $\quad$ improve literacy skills of male and female participants;

- $\quad$ establish and strengthen links with the Afghan education authorities;

- $\quad$ strengthen own management skills.

The programme will encourage the students in their learning, to try to help them understand and apply rules rather than to learn them by heart with no meaning. The curriculum is designed to satisfy the needs of both the teachers and the students. 
$<$ ADDRESS $>-<$ COMMUNICATION LINES $>$

25-B/2 REHMAN BABA ROAD UNIVERSITY TOWN PESHAWAR, PAKISTAN
PHONE : 43572

F A X: 43572

email:
1. ENG ZAKARIA HASSAN

2. ATTA M TANIWAL

3. SHAH NAZAR

\begin{tabular}{|c|c|c|c|c|c|}
\hline AFGHAN & 86 & TECHNICAL : & 68 & PAK. BASED & 21 \\
\hline PAKISTANI : & - & ADMINISTRATIVE : & 18 & AFGHAN BASED : & 65 \\
\hline EXPAT : & - & FIELD/SUPPORT $\mathrm{S}$. & - & CROSS-BORDER : & - \\
\hline TOTAL & 86 & TOTAL : & 86 & TOTAL : & 86 \\
\hline
\end{tabular}

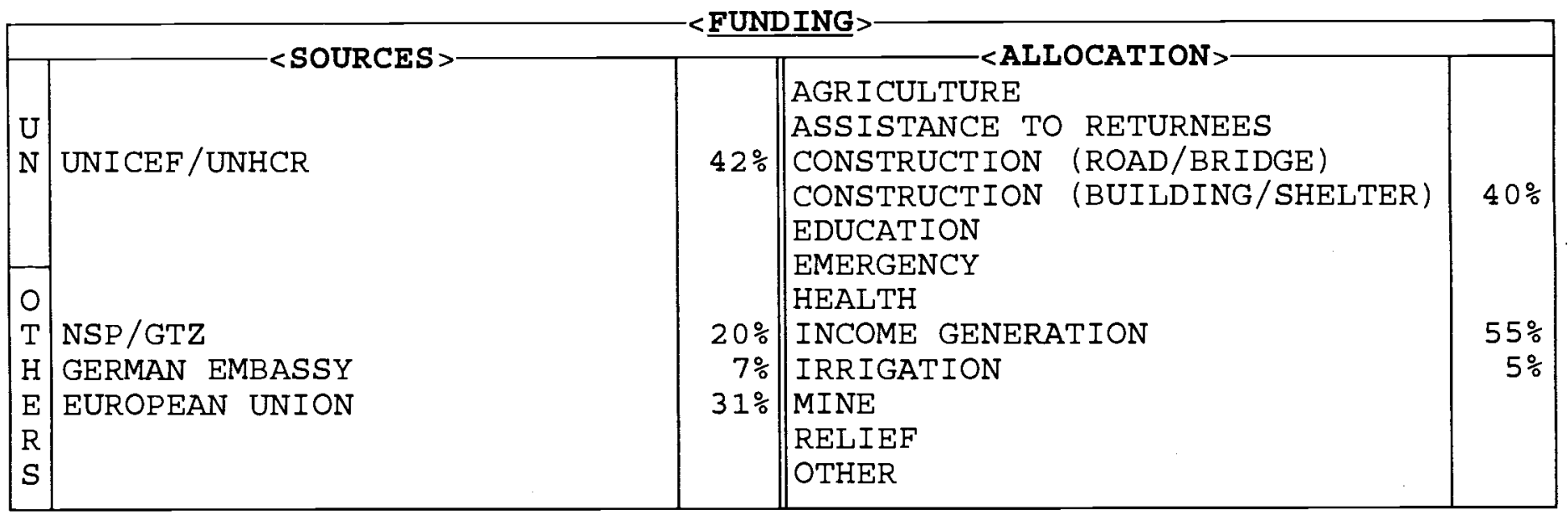

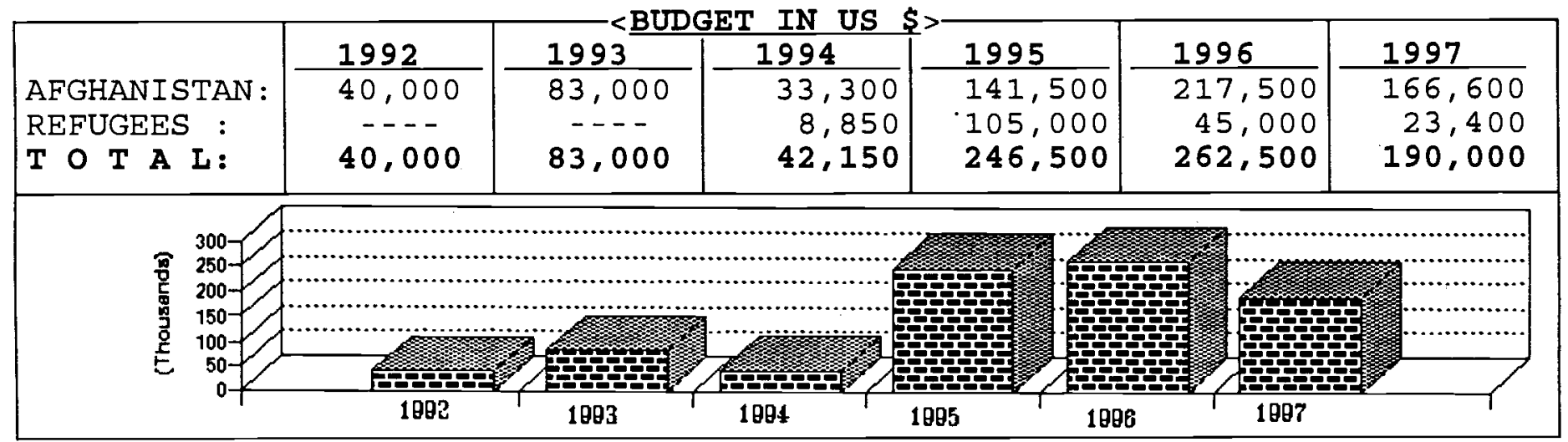

\begin{tabular}{|c|c|c|c|c|c|}
\hline PROVINCES & SECTOR & $\%$ & PROVINCES & SECTOR & $\%$ \\
\hline $\begin{array}{l}\text { BADAKSHAN } \\
\text { BADGHIS } \\
\text { BAGHLAN } \\
\text { BALKH } \\
\text { BAMYAN } \\
\text { FARAH } \\
\text { FARYAB } \\
\text { GHAZNI } \\
\text { GHOR } \\
\text { HELMAND } \\
\text { HERAT } \\
\text { JAWZJAN } \\
\text { KABUL } \\
\text { KANDAHAR } \\
\text { KAPISA }\end{array}$ & WATER \& SANITATION & 5 & $\begin{array}{l}\text { KUNAR } \\
\text { KUNDUZ } \\
\text { LAGHMAN } \\
\text { LOGAR } \\
\text { NANGARHAR } \\
\text { NIMROZ } \\
\text { ORUZGAN } \\
\text { PAKTEKA } \\
\text { PAKTIA } \\
\text { PARWAN } \\
\text { SAMANGAN } \\
\text { TAKHAR } \\
\text { WARDAK } \\
\text { ZABUL } \\
\text { PAKISTAN }\end{array}$ & $\begin{array}{l}\text { VOCATIONAL TRAINING } \\
\text { VOCATIONAL TRAINING }\end{array}$ & $\begin{array}{l}10 \\
10 \\
40\end{array}$ \\
\hline
\end{tabular}


In 1991, Afghan employees of Pak-German TTP founded the Afghan German TTP (AGTTP) as an NGO.

AG-TTP has been both involved in training in Afghanistan and of refugees in NWFP. At present AG-TTP runs 5 centres in Kunar, Laghman, Paktia and Khost Provinces; and 4 in the refugee camps of Kacha Gari, Khurassan, Spin Kani and the Women's Centre in Peshawar in NWFP. A total of 1,975 Afghan youths have been trained in carpentry, masonry and tailoring. Qualification for the training courses is:

- illiterate or low education

- between 15 - 30 years old

- unemployed or under-employed.

Graduates can progress to Skills for Employment/Self Employment and Construction (SESC) which includes: advanced training, workshops, practical training and a loan scheme.

With the help of the different components of SESC, AG-TTP hopes to play a role in the rehabilitation of Afghanistan:

- promote income generation;

- help in infrastructure reconstruction /rehabilitation;

- strengthen and cncourage small businesses.

\section{Basic training}

5 month course teaching a trade and numeracy classes. Goods are produced in this period and sold on the open market.

\section{Practical training}

To increase their practical experience graduates can attend a 5 month course. Contracts/work for customers are undertaken and all work is produced under supervision of an instructor

\section{Supervised workshop}

A further 5 months spent in a supervised workshop. The trainee undertakes work in the local market, under supervision.

\section{Apprenticeship programme}

Where not possible to set up training units, apprenticeship training is offered. A master trainer (Ustad) is sclected and paid to train the apprentice. On graduation the USTAD is paid an additional amount.

\section{Loan Scheme}

Loans of Rs2,500 - Rs3,500 are available for the graduates to commence their own busincsses - to be repaid in 12 installments (monthly), after a two month start up time.

\section{Production Workshops}

Workshops are set up and trained personnel hircd. They are run on a profit basis and are idcal for the trainces practical work and apprenticeships.

\section{Activities of AG-TTP to present}

AG-TTP has its main office in Peshawar. 1975 trainees have graduated in the basic masonry, carpentry and tailoring courses. Numeracy classes offered to 366 trainces on the basic courses.

In practical training AG-TTP received funds for the repair and improvement of the Training Centre and a public building in Asad Abad.

A carpentry workshop was set up in Khost produced 6 graduates; and apprenticeship training in Khost with 12 graduates. 
AFGHAN/GERMAN HELP COORDINATION OFFICE (AGHCO)

ACBAR

\begin{tabular}{|c|c|c|c|c|}
\hline$<$ ADDRESS $>$ & $-<$ COMMUNICATION & S > & $<$ KEY STAI & \\
\hline $\begin{array}{l}\text { HSE } 106 / \overline{H-4, ~ S T R ~} 5 \text { PHS2 } \\
\text { HAYATABAD, GPO BOX } 679 \\
\text { PESHAWAR, PAKISTAN }\end{array}$ & $\begin{array}{l}\text { PHONE: } 811342 \\
\text { F A X: } 811342 \\
\text { email: }\end{array}$ & & $\begin{array}{l}\text { 1. HAJI S F WI } \\
\text { 2. PACHA } \\
\text { 3. }\end{array}$ & \\
\hline AFGHAN & TECHNICAL & 20 & PAK. BASED & 9 \\
\hline PAKISTANI : & ADMINISTRATIVE & 10 & AFGHAN BASED: & 59 \\
\hline EXPAT : & FIELD/SUPPORT S. & 38 & CROSS-BORDER : & - \\
\hline TOTAL & TOTAL : & 68 & TOTAL : & 68 \\
\hline
\end{tabular}

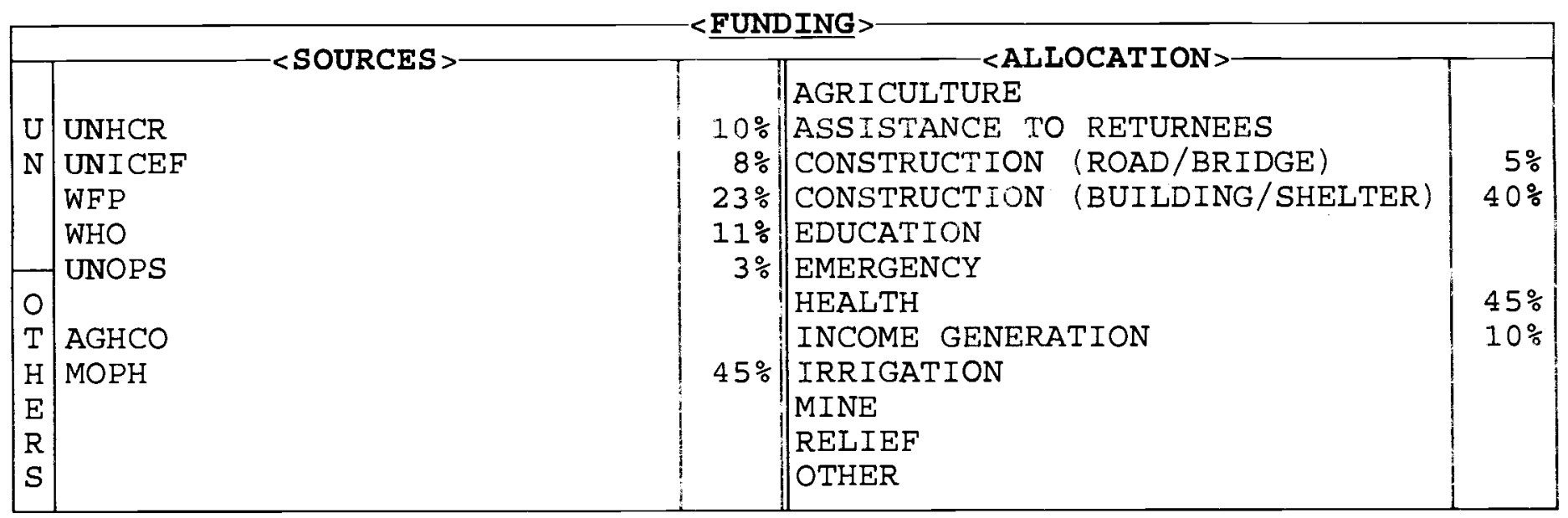

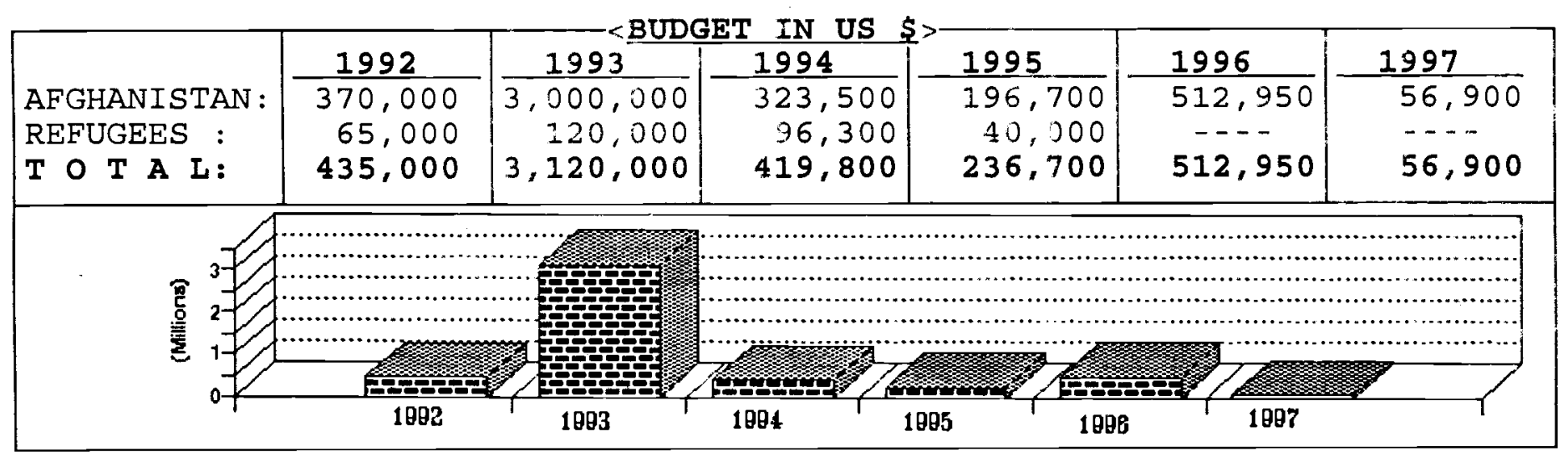

\begin{tabular}{|c|c|c|c|c|c|}
\hline PROVINCES & SECTOR & $\%$ & PROVINCES & SECTOR & $\%$ \\
\hline $\begin{array}{l}\text { BADAKSHAN } \\
\text { BADGHIS } \\
\text { BAGHLAN } \\
\text { BALKH } \\
\text { BAMYAN } \\
\text { FARAH } \\
\text { FARYAB } \\
\text { GHAZNI } \\
\text { GHOR } \\
\text { HELMAND } \\
\text { HERAT } \\
\text { JAWZJAN } \\
\text { KABUL } \\
\text { KANDAHAR } \\
\text { KAPISA }\end{array}$ & & & $\begin{array}{l}\text { KUNAR } \\
\text { KUNDUZ } \\
\text { LAGHMAN } \\
\text { LOGAR } \\
\text { NANGARHAR } \\
\text { NIMROZ } \\
\text { ORUZGAN } \\
\text { PAKTEKA } \\
\text { PAKTIA } \\
\text { PARWAN } \\
\text { SAMANGAN } \\
\text { TAKHAR } \\
\text { WARDAK } \\
\text { ZABUL } \\
\text { PAKISTAN }\end{array}$ & $\begin{array}{l}\text { HLTH / CONST / BLDING } \\
\text { HLTH / CONST / BRIDGE } \\
\text { HLTH / CONST / BLDNG } \\
\text { INCOME GENERATION }\end{array}$ & $\begin{array}{l}35 \\
30 \\
25\end{array}$ \\
\hline
\end{tabular}




\section{AFGHAN/GERMAN HELP COORDINATION OFFICE (AGHCO) was}

(ANH)

AGHCO is a non-government and non-political organisation established to assist in the rehabilitation of Afghanistan. The main concern of the organisation is to render humanitarian assistance without discrimination.

Originally founded in 1983 as $\mathrm{ANH}$, in January 1991 changed its name to AGHCO.

The main objectives of the agency are to implement relief programmes and rehabilitate the economic and social infrastructure in Afghanistan and facilitate the resettlement of returning refugees. Scctors of work include: construction of public buildings, irrigation, potable water supply, road repair and construction, bridges and culverts, sanitation, health services and income generating programmes for both male and female.

\section{Previous activity}

\section{Health}

With the support of ANH-Germany, WHO, UNICEF, MSF-France, AMI, AMAA-USA and $\mathrm{MoPH}$ medical scrvices in Nangarhar, the running of Metherlam and Assadabad hospitals was undertaken.

\section{Construction}

Many projects in various locations of Afghanistan were undertaken, such as the construction of Faqrullah High School in Surkhrud district, construction of a teaching block for Nangarhar University and road and culverts were repaired in Nangarhar Province. Roads, bridges, schools, washes and retaining walls were constructed/rcpaired in Laghman and Kunar Provinces. In Paktia and Khost reconstruction work included clinics and roads.

The above projects were supported by WFP, UNHCR and UNOPS.

\section{Income generating projects}

WFP supported Tailoring training and the making of shopping bags for women in Nangarhar and Paktia Provinces.

\section{Present activity}

\section{Health}

The before mentioned hospitals are still supported. A malnutrition programme is currently running in these hospitals and includes some basic health training.

\section{Construction}

At present there are no programmes in this sector.

\section{Future plans}

AGHCO would like to expand its services and accelcrate the construction/rchabilitation of health scrvices and income generation programmes. It would also like to continue to repair irrigation systems, roads, bridges and culverts, sanitation and health education.

Several proposals have been submitted to funding agencies. 


\begin{tabular}{|l|l|l|}
\hline $\begin{array}{l}\text { 178, D-1, PH 1, } \\
\text { HAYATABAD, GPO BOX 631, } \\
\text { PESHAWAR, PAKISTAN }\end{array}$ & $\begin{array}{l}\text { PHONE: } 810151 \\
\text { F A X: 810599 } \\
\text { TELEX: }\end{array}$ & $\begin{array}{l}\text { 1. AZIZ R. QARG STAFF } \\
\text { 2. DR. SHAH WALIULLAH } \\
\text { 3. KHALILULLAH FURMULY }\end{array}$ \\
\hline
\end{tabular}

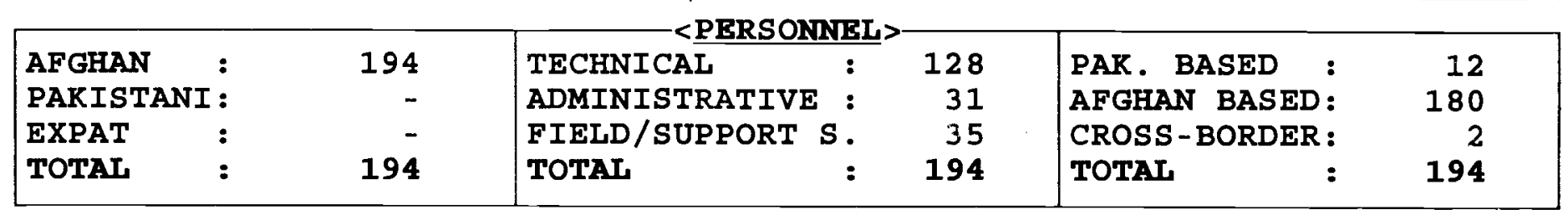

\begin{tabular}{|c|c|c|c|c|}
\hline & $-<$ SOURCES $>$ & & $-<$ ALLOCATION $>$ & \\
\hline & UNICEF & $6 \%$ & AGRICULTURE & \\
\hline $\mathbf{U}$ & UNHCR & $6 \%$ & ASSISTANCE TO RETURNEES & \\
\hline $\mathbf{N}$ & & & CONSTRUCTION (ROAD/BRIDGE) & \\
\hline & & & CONSTRUCTION (BUILDING/SHELTER) & $6 \%$ \\
\hline & & & EDUCATION & \\
\hline & & & EMERGENCY & \\
\hline 0 & EUROPEAN UNION & $67 \%$ & HEALTH & $94 \%$ \\
\hline $\mathbf{T}$ & MSF HOLLAND & $21 \%$ & INCOME GENERATION & \\
\hline $\mathbf{H}$ & & & IRRIGATION & \\
\hline $\mathbf{E}$ & & & MINE & \\
\hline $\mathbf{R}$ & & & RELIEF & \\
\hline $\mathbf{S}$ & & & OTHER & \\
\hline
\end{tabular}

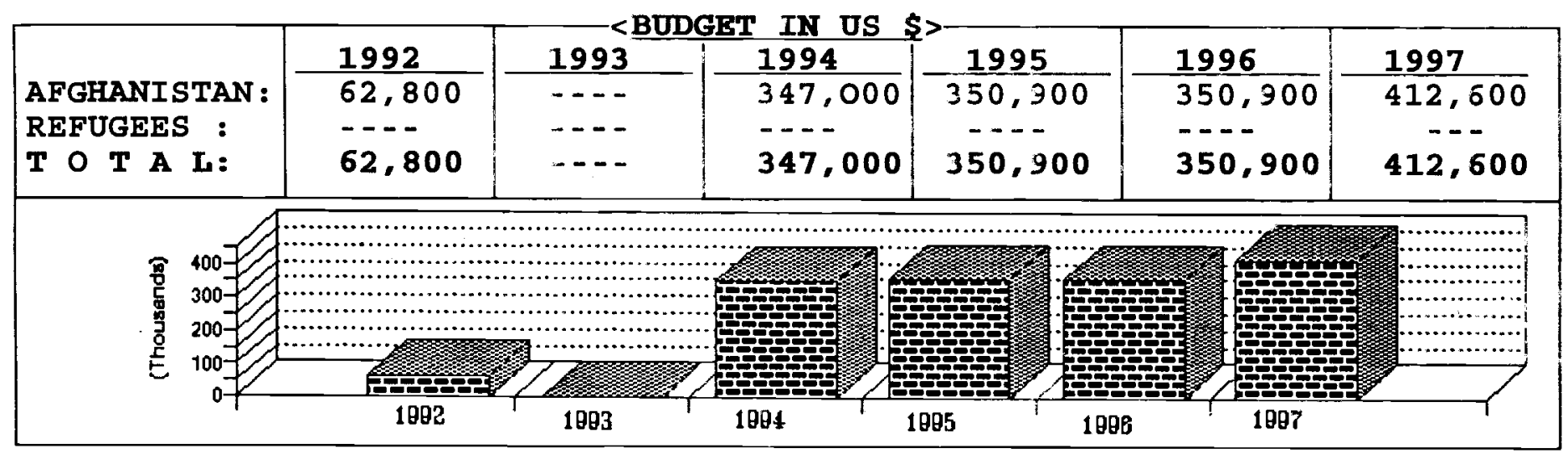

\begin{tabular}{|c|c|c|c|c|c|}
\hline PROVINCES & SECTOR & $\%$ & PROVINCES & SECTOR & $\%$ \\
\hline $\begin{array}{l}\text { BADAKSHAN } \\
\text { BADGHIS } \\
\text { BAGHLAN } \\
\text { BALKH } \\
\text { BAMYAN } \\
\text { FARAH } \\
\text { FARYAB } \\
\text { GHAZNI } \\
\text { GHOR } \\
\text { HELMAND } \\
\text { HERAT } \\
\text { JAWZJAN } \\
\text { KABUL } \\
\text { KANDAHAR } \\
\text { KAPISA }\end{array}$ & 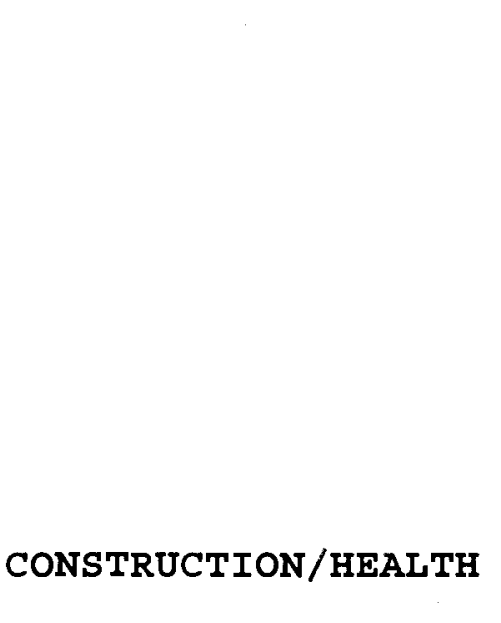 & . & $\begin{array}{l}\text { KUNAR } \\
\text { KUNDUZ } \\
\text { LAGHMAN } \\
\text { LOGAR } \\
\text { NANGARHAR } \\
\text { NIMROZ } \\
\text { ORUZGAN } \\
\text { PAKTEKA } \\
\text { PAKTIA } \\
\text { PARWAN } \\
\text { SAMANGAN } \\
\text { TAKHAR } \\
\text { WARDAR } \\
\text { ZABUL }\end{array}$ & & \\
\hline
\end{tabular}




\section{AFGHAN HEALTH AND \\ DEVELOPMENT SERVICES (AHDS)}

AHDS is a non-profit, non-governmental and non-political organisation founded by Afghans with expertise and training in health, development and education.

It was established in April 1990 and began to work inside Afghanistan in July 1990. The prime objectives are the rehabilitation of the health care system and the provision of development services to meet the current and future needs of Afghan people.

Since the establishment of AHDS a number of health and construction related proposals have bcen submitted to different donor agencies. These proposals which have been approved were implemented to the donors satisfaction.

One proposal concerning an Integrated rural Development Project which had been submitted to the Europcan Union (EU) together with Afghan Development Association (ADA) in 1993; it was approved for November 1994 October 1996. This project was extended at no extra cost to the donor up to October 1997.

The above mentioned project encompassed the rehabilitation and running of a Regional Training centre, Mother and Child Health Care clinics, rehabilitation, construction and operation of 30 different health facilities in Kandahar Province.

On September 91995 the organisation signed a Contract for establishing $2 \mathrm{MCH} / \mathrm{CHC}, 10$ BHPs and rehabilitating one provincial hospital and one comprehensive health centre buildings in two district of Urozgan Province, Trin Kot and Deh Roud, with MSF Holland.

The actual plan was to operate these facilities jointly and in due course AHDS would take over the administration of the whole programme. Since January 1997 AHDS independently operates these facilities with MSF financial and technical support.
In November 1997 AHDS/MSF signed another eight month contract for the continuation of the same services in the 2 districts of Urozgan.

AHDS's proposal for the continuation of the services from the existing facilities in Kandahar Province and the establishment of same kind of health services with the special emphasis on mother and child health care in four other districts of Kandahar Province has been approved by the EU for the year 1998 .

AHDS has a proven track record of building and administering health facilities in Afghanistan, including training, hiring and maintaining of health workers. The agency has worked cooperatively with other national and international NGOs to jointly manage some of the health facilities.

AHDS is striving to develop a viable and sustainable system to reach the most remote communities in different parts of Afghanistan. AHDS believes that one of the effective ways of addressing this essential goal would be the implementation of various integrated projects by a number of organisations working together with the active participation of the local communities. 
AFGHANS HEALTH \& SOCIAL ASSISTANCE ORGANISATION (AHSAO) <ADDRESS >- $\mid-$ COMMUNICATION LINES $>$

HSE 143 OLD BARA ROAD ADBARA ROAD PESHAWAR, PAKISTAN
PHONE : 45577

$F$ A X:

email:

ACBAR

\begin{tabular}{|c|c|c|c|c|c|}
\hline AFGHAN & 34 & TECHNICA $\bar{L}$ & 16 & PAK. BASED & 15 \\
\hline PAKISTANI : & 1 & ADMINISTRATIVE : & 4 & AFGHAN BASED : & 20 \\
\hline EXPAT : & - & FIELD/SUPPORT S. & 15 & CROSS-BORDER : & - \\
\hline TOTAL & 35 & TOTAL : & 35 & TOTAL : & 35 \\
\hline
\end{tabular}

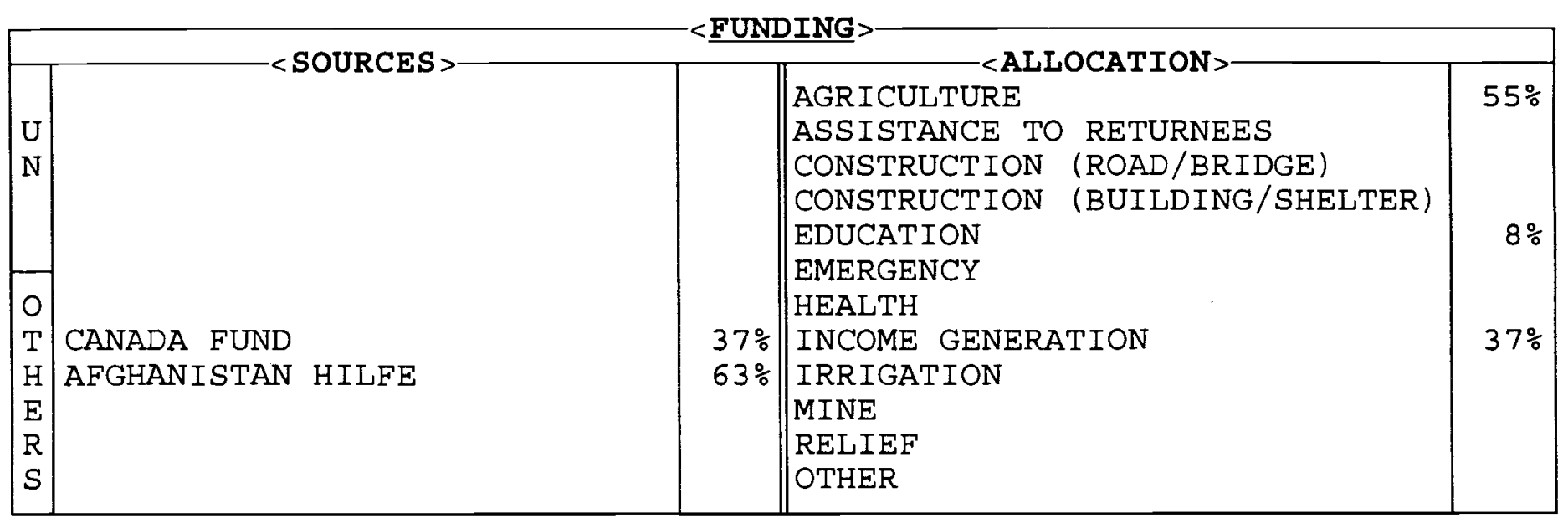

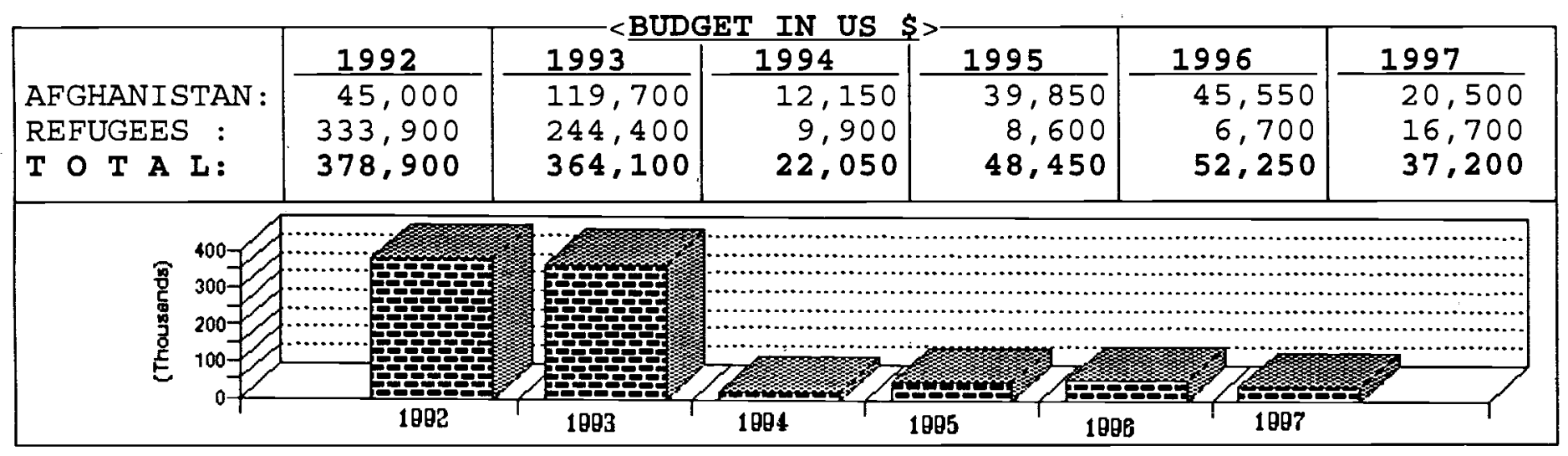

\begin{tabular}{|c|c|c|c|c|c|}
\hline PROVINCES & SECTOR & $\%$ & PROVINCES & SECTOR & $\%$ \\
\hline $\begin{array}{l}\text { BADAKSHAN } \\
\text { BADGHIS } \\
\text { BAGHLAN } \\
\text { BALKH } \\
\text { BAMYAN } \\
\text { FARAH } \\
\text { FARYAB } \\
\text { GHAZNI } \\
\text { GHOR } \\
\text { HELMAND } \\
\text { HERAT } \\
\text { JAWZJAN } \\
\text { KABUL } \\
\text { KANDAHAR } \\
\text { KAPISA }\end{array}$ & & & $\begin{array}{l}\text { KUNAR } \\
\text { KUNDUZ } \\
\text { LAGHMAN } \\
\text { LOGAR } \\
\text { NANGARHAR } \\
\text { NIMROZ } \\
\text { ORUZGAN } \\
\text { PAKTEKA } \\
\text { PAKTIA } \\
\text { PARWAN } \\
\text { SAMANGAN } \\
\text { TAKHAR } \\
\text { WARDAK } \\
\text { ZABUL } \\
\text { PAKISTAN }\end{array}$ & $\begin{array}{l}\text { AGR ICULTURE } \\
\text { AGR ICULTURE } \\
\text { AGR IC/ INCOM. GEN/EDUC }\end{array}$ & 22 \\
\hline
\end{tabular}


AHSAO was establishcd in June 1985 in Peshawar, Pakistan. It is an Afghan NGO and registered with the Government of Pakistan.

The Organisation started its health serviccs by establishing a 40 bed childrcn's hospital in June 1985 in Peshawar; agriculture and reconstruction projects in Kunar and some liberated areas of Nangarhar Province in 1988.

\section{Aims}

- to provide health services to the people of Afghanistan..

- to provide income generating sources by implementing training projects such as bce keeping, sericulture, poultry etc.

- to take an active part in the rehabilitation of orchards, gardens and forcsts.

\section{Sectors of Operation}

\section{Agriculture}

- Fruit and forest tree nursery in Serajul Emarat Garden, Jalalabad City, Nangarhar Province. This nursery is the biggest (20 acres) nursery and produces various kinds of fruit and non-fruit seedlings and saplings.

- Fruit and forest tree nursery in Markander refugee camp, Peshawar.

- Reforestation and nursery project in Jaji district, Paktia Province.

\section{Education}

Primary school in Bada Bera refugee camp, Peshawar for Afghan rcfugce children. This school provides primary education to 200 Afghan refugee children up to grade six.

\section{Income generation}

Poultry Training Project in Kababyan refugee camp, Peshawar. This project is providing practical training in poultry industry to 300 vulncrable women including new arrivals. Furthcrmore 12 Faumie chicks along with $20 \mathrm{~kg}$ feed and iron nets have been distributed to the trainccs.

\section{Future Objectives}

AHSAO plans to expand its services to income gencration sector in order to provide work opportunities for the people of Afghanistan. It is also planning to expand the agriculture and rcforcstation activitics in order to help the rchabilitation of the country. 
AFGHAN INSTITUTE OF LEARNING (AIL)

\begin{tabular}{l|l|l}
\hline 171, SADIQABAD, BILAL & PHONE: 42697 & 1. PROF. S YACOOBI \\
LANE, ARBAB RD, & F A X: & 2. ENG. NAZIFA AABEDI \\
PESHAWAR, PAKISTAN & TELEX: & 3. PARWIN RAHIM
\end{tabular}

\begin{tabular}{|c|c|c|c|c|c|}
\hline $\begin{array}{l}\text { AFGHAN : } \\
\text { PAKISTANI: } \\
\text { EXPAT : } \\
\text { TOTAL : }\end{array}$ & $\begin{array}{r}44 \\
- \\
45\end{array}$ & $\begin{array}{l}\text { TECHNICAL : } \\
\text { ADMINISTRATIVE : } \\
\text { FIELD/SUPPORT S. } \\
\text { TOTAL }\end{array}$ & $\begin{array}{r}31 \\
4 \\
10 \\
45\end{array}$ & $\begin{array}{l}\text { PAK. BASED : } \\
\text { AFGHAN BASED : } \\
\text { CROSS-BORDER : } \\
\text { TOTAL : }\end{array}$ & $\begin{array}{r}35 \\
10 \\
- \\
45\end{array}$ \\
\hline
\end{tabular}

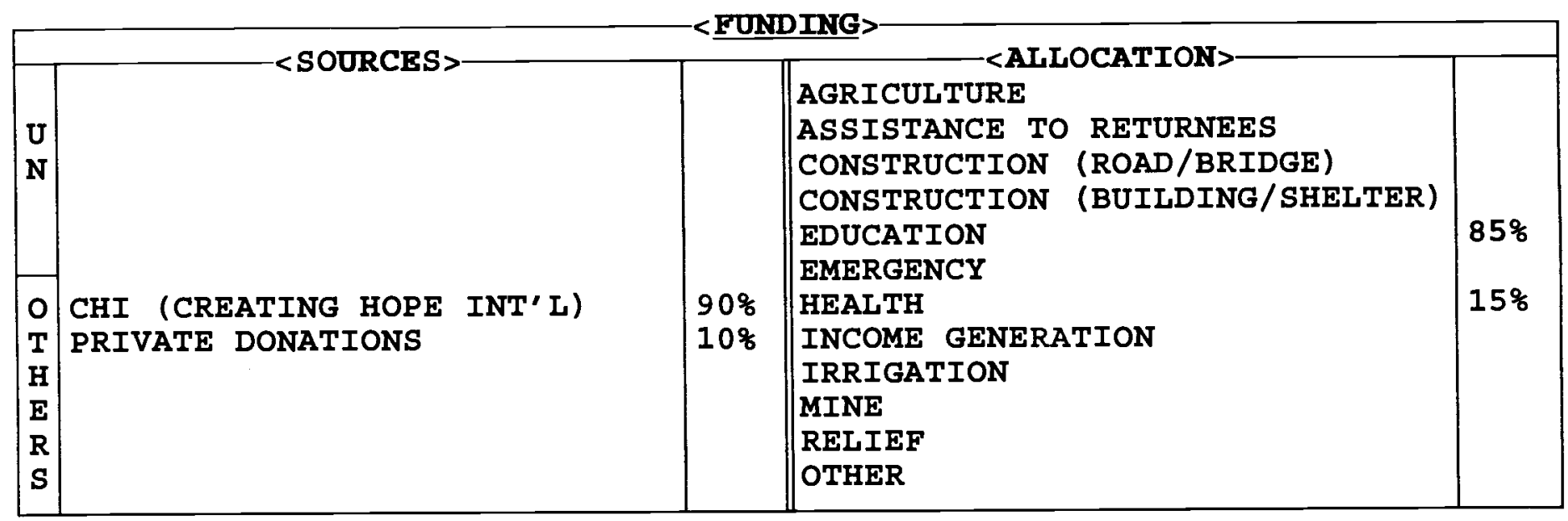

\begin{tabular}{|c|c|c|c|c|c|c|}
\hline & 1992 & 1993 & 1994 & 1995 & 1996 & 1997 \\
\hline $\begin{array}{l}\text { AFGHANISTAN : } \\
\text { REFUGEES : } \\
\text { TO T A L : }\end{array}$ & $\begin{array}{l}---- \\
---- \\
----\end{array}$ & $\begin{array}{l}---- \\
---- \\
----\end{array}$ & $\begin{array}{l}-\cdots \\
\cdots- \\
-\cdots\end{array}$ & $\begin{array}{l}20,000 \\
20,000\end{array}$ & $\begin{array}{l}46,250 \\
46,250\end{array}$ & $\begin{array}{l}12,000 \\
60,000 \\
72,000\end{array}$ \\
\hline $\begin{array}{ll}00- \\
0 \\
0.00\end{array}$ & 189 & 1983 & 1894 & & 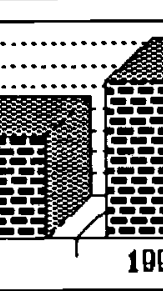 & \\
\hline
\end{tabular}

\begin{tabular}{|c|c|c|c|c|c|}
\hline PROVINCES & SECTOR & $\%$ & PROVINCES & SECTOR & $\%$ \\
\hline $\begin{array}{l}\text { BADAKSHAN } \\
\text { BADGHIS } \\
\text { BAGHLAN } \\
\text { BALKH } \\
\text { BAMYAN } \\
\text { FARAH } \\
\text { FARYAB } \\
\text { GHAZNI } \\
\text { GHOR } \\
\text { HELMAND } \\
\text { HERAT } \\
\text { JAWZJAN } \\
\text { RABUL } \\
\text { KANDAHAR } \\
\text { RAPISA }\end{array}$ & $\begin{array}{l}\text { HEALTH } \\
\text { HEALTH }\end{array}$ & $\begin{array}{l}50 \\
50\end{array}$ & $\begin{array}{l}\text { KUNAR } \\
\text { KUNDUZ } \\
\text { LAGHMAN } \\
\text { LOGAR } \\
\text { NANGARHAR } \\
\text { NIMROZ } \\
\text { ORUZGAN } \\
\text { PAKTERA } \\
\text { PAKTIA } \\
\text { PARWAN } \\
\text { SAMANGAN } \\
\text { TAKHAR } \\
\text { WARDAK } \\
\text { ZABUL }\end{array}$ & & \\
\hline
\end{tabular}




\section{AFGHAN INSTITUTE OF LEARNING}

(AIL)

AlL is an Afghan non-govcrnment organisation that was founded in 1995 and is run entirely by women. The primary objective is to expand education opportunities in many different areas for all Afghans, providc educational assistance to the most needy Afghans and to foster selfreliance and community participation among Afghans.

Presently AIL's focus is to provide health education for women and children through a variety of means; to upgrade the quality of education in schools by providing teacher training to Afghan female school teachers; to support pre-schools and primary and sccondary schools (with a particular emphasis on supporting girls schools) which are already partially supporting themselves; and to support education programmes for older girls and women.

Currently AIL has the following projects:

- provision of health education to more than 400 women per week in 5 clinics (two clinics in Jalouzai, Jiff centre, Eye clinic and Aria clinic);

- training female primary school teachers to teach health message - to date 140 teachers have been trained;

- provision of pedagogical and subject matter and administration seminars and workshops to fenale primary school teachers in order to upgrade the quality of education in the schools to date 300 teachers have been trained in seminars and more than 200 teachers have bcen traincd in workshops;

- provision of support to schools which are. partially self-supporting. Currently AIL is assisting seven schools with 2,685 students, 2,000 of whom are girls;

- provision of support to pre-schools which are partially self-supporting. Currently AIL is assisting 12 out reach pre-schools with approximately 220 children ( 108 boys and 42 girls) and two model pre-schools with 29 children ( 18 boys and 11 girls);
- provision of support to home literacy classes for older girls and women Currently AIL supports 1 literacy class and 11 home schools, five in Kabul, five in Herat and one in Haripoor Camp. 
AFGHAN INKISHAAFEE TARBIAWEE MARKAZ (AITM)

ACBAR

<ADDRESS >- $-<$ COMMUNICATION LINES

60-C UNIVERSITY ROAD

UNI TOWN GPO BOX 1117

PESHAWAR， PAKISTAN
PHONE : 45306

F A X: 45306

email:
1.DR FAIZ MOHAMMAD

2. NAIK MOHAMMAD

3 .

\begin{tabular}{|c|c|c|c|c|c|}
\hline AFGHAN & 9 & TECHNICAL : & 4 & PAK. BASED & 5 \\
\hline PAKISTANI : & 2 & ADMINISTRATIVE : & 2 & AFGHAN BASED: & - \\
\hline EXPAT : & - & FIELD/SUPPORT $S$. & 5 & CROSS-BORDER: & 6 \\
\hline TOTAL & 11 & TOTAL : & 11 & TOTAL : & 11 \\
\hline
\end{tabular}

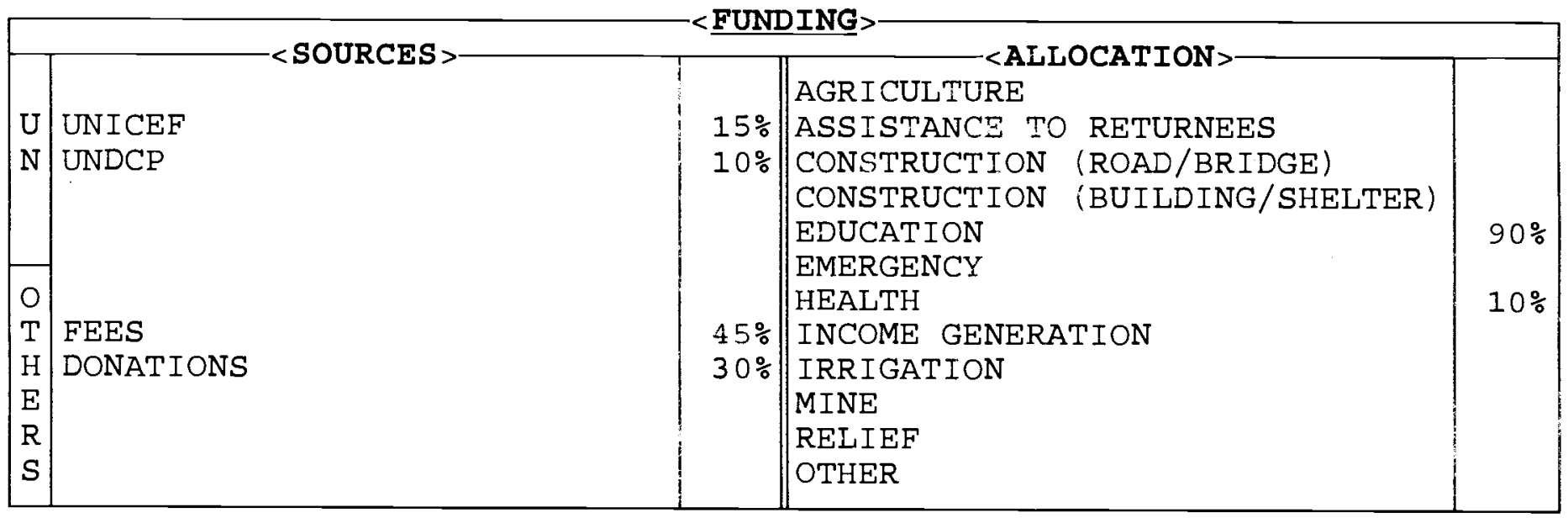

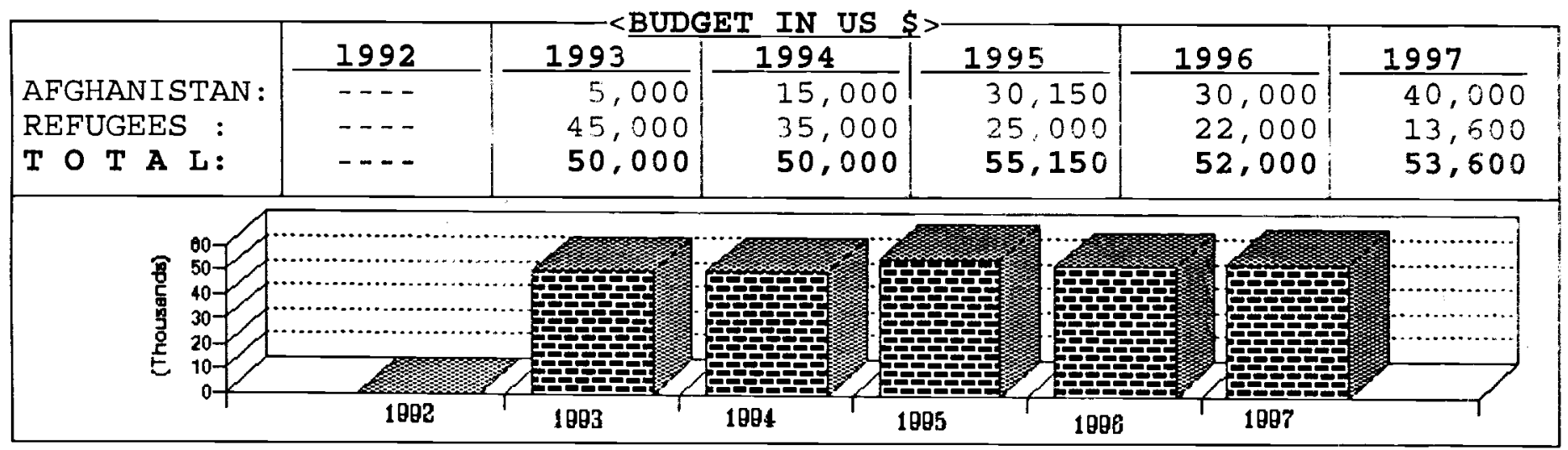

\begin{tabular}{|c|c|c|c|c|c|}
\hline PROVINCES & SECTOR & $\div$ & PROVINCES & SECTOR & $\%$ \\
\hline $\begin{array}{l}\text { BADAKSHAN } \\
\text { BADGHIS } \\
\text { BAGHLAN } \\
\text { BALKH } \\
\text { BAMYAN } \\
\text { FARAH } \\
\text { FARYAB } \\
\text { GHAZNI } \\
\text { GHOR } \\
\text { HELMAND } \\
\text { HERAT } \\
\text { JAWZJAN } \\
\text { KABUL } \\
\text { KANDAHAR } \\
\text { KAPISA }\end{array}$ & $\begin{array}{l}\text { EDUCATION } \\
\\
\text { TRAINING } \\
\text { TRAINING } \\
\text { TRAINING/HEALTH }\end{array}$ & $\begin{array}{l}10 \\
25 \\
20\end{array}$ & \begin{tabular}{|l|} 
KUNAR \\
KUNDUZ \\
LAGHMAN \\
LOGAR \\
NANGARHAR \\
NIMROZ \\
ORUZGAN \\
PAKTEKA \\
PAKTIA \\
PARWAN \\
SAMANGAN \\
TAKHAR \\
WARDAK \\
ZABUL \\
PAKISTAN
\end{tabular} & TRAINING/HEALTH & . \\
\hline
\end{tabular}




\section{AFGHAN INKISHAFEE TARBIAWEE MARKAZ (AITM)}

AITM has run successful courses in development skills since 1989.

\begin{abstract}
Aims
To develop skills in teaching, management, communication, motivation, community participation, extension and to contribute to the well being of Afghans through health training and health education.
\end{abstract}

\section{General}

Since the organisation was founded, more than 2,579 staff of 131 local and international NGOs, UN organisations and Government agencies have been trained.

The training programmes are run in different parts of Afghanistan and Pakistan.

Participants are generally involved in the implementation of NGO, UN and Government projects.

Training comprises input and practical work, drawing on the experiences of the participants.

Training techniques include the use of discussion sessions, case studies, role play, lectures, films, story telling, demonstrations, simulation exercises and presentations. Printed outlines and reference materials for self study are distributed.

Courses are in Pushto or Dari.

Tutors are all highly educated and experienced Afghans who have much experience of working in Afghanistan. Some have attended management and training courses in the UK. Guest tutors are also invited to speak at particular courses.

\section{Future Objectives}

AITM tries to accelerate the rehabilitation and reconstruction process of Afghanistan by improving the performance skills of those who are working for the prosperity of Afghan society, with the welfare and development organisation.
To achieve this goal the objectives are as follows:

1 to train mid level mangers, supervisors, monitors, surveyors, team leaders, field workers, master trainers, teachers, community health upervisors and community health workers of Afghans involved welfare and development organisation in order to make them more effective in their present roles;

2 to improve competence and organising skills of the community based indigenous organisation / groups to enable them to organise themselves for the establishment of joint development efforts to benefit the neglected groups

- women, children and the poor;

3 to collaborate with other relevant organisation for the achievement of the above mentioned objectives.

\section{Activities}

To achieve its objectives AITM runs the following courses on a regular basis:

- Training of Trainers/Teachers.

- Curricula designing.

- Project Management.

- Business Management.

- Monitoring and Data Collection.

- Agriculture Measurement and Calculation.

- Extension Worker Skills.

- Survey and Sampling.

- Motivation and Community Participation.

- Primary Health Care.

Running courses on a tailor-made basis to meet the specific training requirements of organisations,

Providing feed back through follow-up a system for ex-trainees.

Playing consultant role to help other organisation in planning and organising their projects. 
AFGHAN MEDICAL AID (AMA)

\begin{tabular}{|l|l|l|}
\hline 53 C GUL MOHAR LANE & PHONE: 43283 & 1. DR A S ZAMANI \\
U/T P O BOX 869 & F A X: 41314 & 2. WAHEED PAUL \\
PESHAWAR, PAKISTAN & email: & 3. DR TAROON
\end{tabular}

\begin{tabular}{|c|c|c|c|c|c|}
\hline AFGHAN : & 35 & TECHN ICAL & 6 & PAK. BASED : & 33 \\
\hline PAKISTANI : & 4 & ADMINISTRATIVE : & 6 & AFGHAN BASED: & 4 \\
\hline EXPAT : & 1 & FIELD/SUPPORT S. & 28 & CROSS-BORDER : & 3 \\
\hline TOTAL & 40 & TOTAL : & 40 & TOTAL : & 40 \\
\hline
\end{tabular}

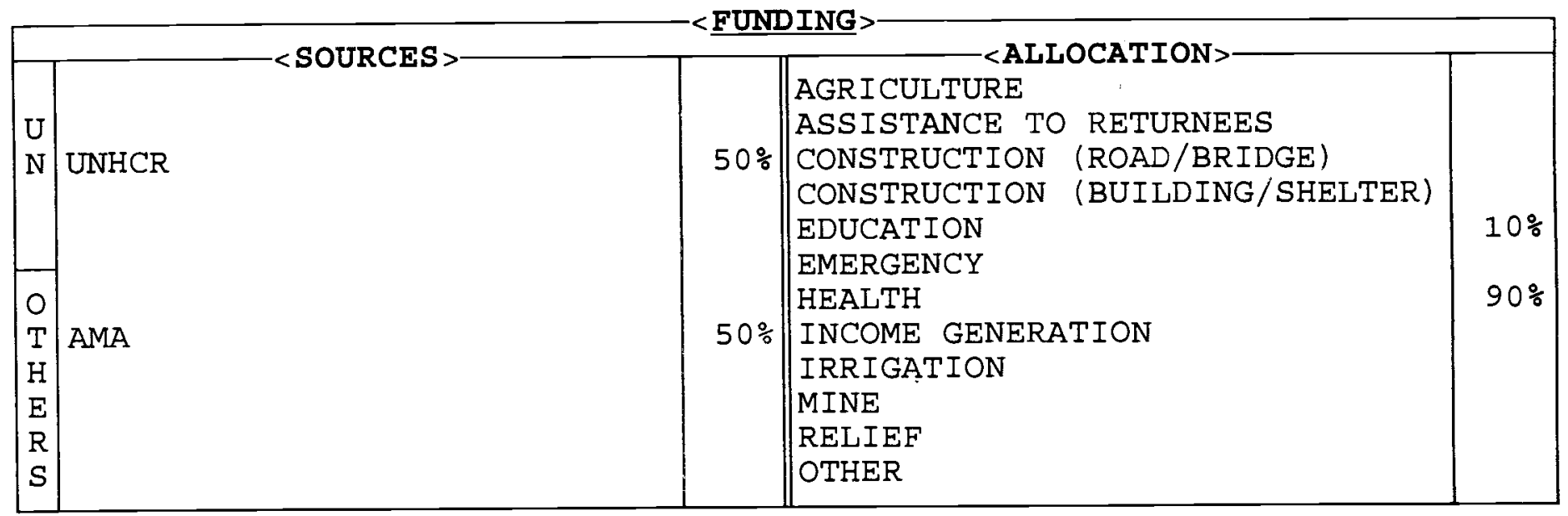

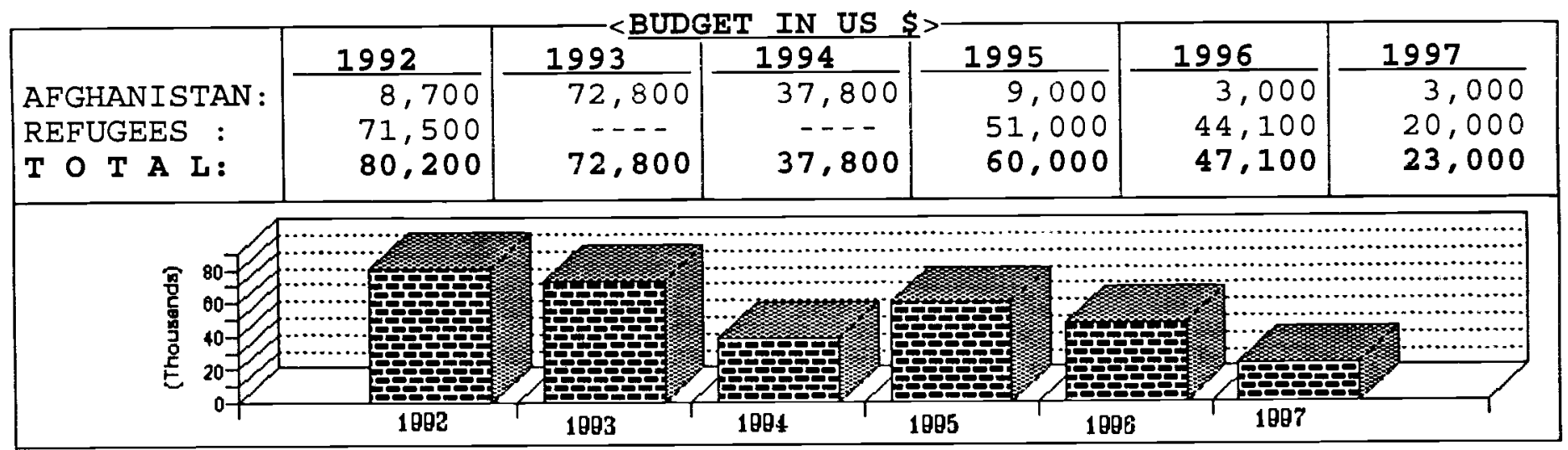

\begin{tabular}{|c|c|c|c|c|c|}
\hline PROVINCES & SECTOR & $\%$ & PROVINCES & SECTOR & $\%$ \\
\hline $\begin{array}{l}\text { BADAKSHAN } \\
\text { BADGHIS } \\
\text { BAGHLAN } \\
\text { BALKH } \\
\text { BAMYAN } \\
\text { FARAH } \\
\text { FARYAB } \\
\text { GHAZNI } \\
\text { GHOR } \\
\text { HELMAND } \\
\text { HERAT } \\
\text { JAWZJAN } \\
\text { KABUL } \\
\text { KANDAHAR } \\
\text { KAPISA }\end{array}$ & & & $\begin{array}{l}\text { KUNAR } \\
\text { KUNDUZ } \\
\text { LAGHMAN } \\
\text { LOGAR } \\
\text { NANGARHAR } \\
\text { NIMROZ } \\
\text { ORUZGAN } \\
\text { PAKTEKA } \\
\text { PAKTIA } \\
\text { PARWAN } \\
\text { SAMANGAN } \\
\text { TAKHAR } \\
\text { WARDAK } \\
\text { ZABUL } \\
\text { PAKISTAN }\end{array}$ & $\begin{array}{l}\text { HEALTH / EDUCATION } \\
\text { - } \\
\text { HEALTH }\end{array}$ & 10 \\
\hline
\end{tabular}




\section{AFGHAN MEDICAL AID (AMA)}

AMA was established in November 1983 in Peshawar and was registered with the

Government of Pakistan in 1985. It works both, in the refugee camps in Pakistan and inside

Afghanistan.

\section{Sectors of Operation}

Health: AMA currently run 6 Basic Health Units (BHUs). Three in Peshawar and three in Kohat.

Education: AMA has an involvement in a primary school in Sirkanay District, Kunar Province.

Road/Bridge Construction: AMA is seeking funding for various activities in the Peche Valley, Kunar.

\section{Further Information}

AMA has provided a milk distribution service for children. It also ran $\mathrm{TB}$ and $\mathrm{MCH}$ (ob/gyn) programs and offered a Dai (Traditional Birth Attendant) training program. It repaired Asadabad hospital and the Sirkanay-Khas, Kunar Road. The Agency extended a mobile paramedic service and malaria control program in Peche Valley, Nooristan and Narang. Relief services were provided to the Kabul displaced in Jalalabad. 
AIDE MEDICALE INTERNATIONALE (AMI)

ACBAR

10 PARK AVENUE

UNIVERSITY TOWN

PESHAWAR， PAKISTAN
PHONE : 43631

F A X: 840419

email: $A M S @ A F G$
1.MR RIDDE VALERY

2.MR MOHAMMED ASRAF

3.MR YOUSEF SANESHEDI

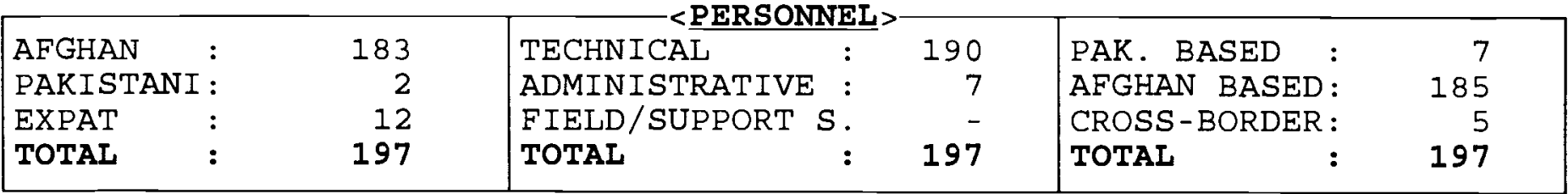

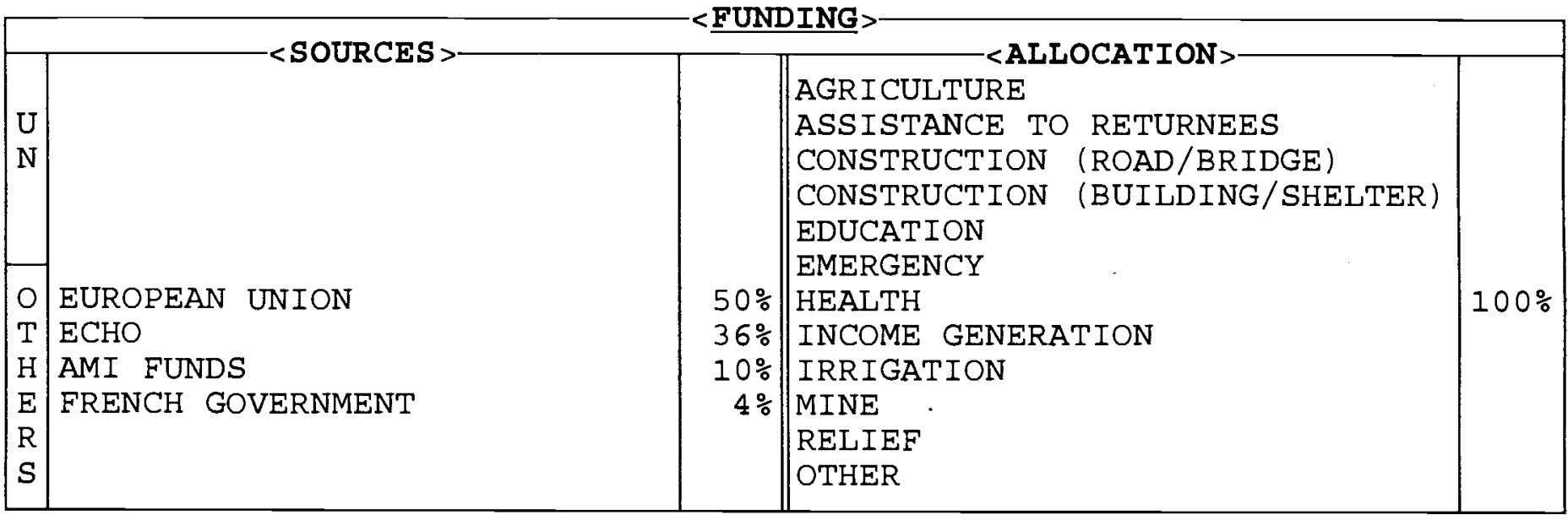

\begin{tabular}{|c|c|c|c|c|c|c|}
\hline & 1992 & 1993 & 1994 & 1995 & 1996 & 1997 \\
\hline AFGHANISTAN : & 550,000 & 623,000 & 550,500 & 560,000 & 965,000 & $1,320,000$ \\
\hline REFUGEES : & 177,000 & 43,000 & --- & --- & --- & ---- \\
\hline T O T A L: & 727,000 & 666,000 & 550,500 & 560,000 & 965,000 & $1,320,000$ \\
\hline
\end{tabular}

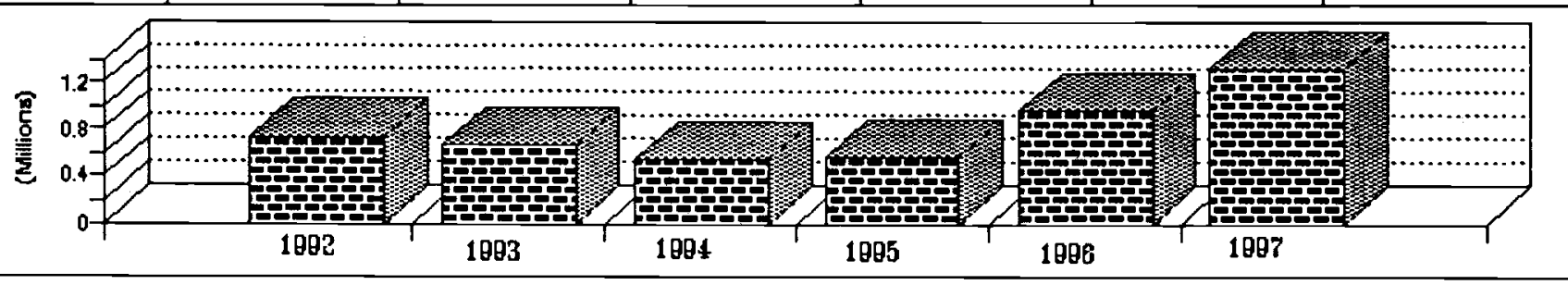

\begin{tabular}{|c|c|c|c|c|c|}
\hline PROVINCES & SECTOR & $\div$ & PROVINCES & SECTOR & $\%$ \\
\hline $\begin{array}{l}\text { BADAKSHAN } \\
\text { BADGH IS } \\
\text { BAGHLAN } \\
\text { BALKH } \\
\text { BAMYAN } \\
\text { FARAH } \\
\text { FARYAB } \\
\text { GHAZN I } \\
\text { GHOR } \\
\text { HELMAND } \\
\text { HERAT } \\
\text { JAWZJAN } \\
\text { KABUL } \\
\text { KANDAHAR } \\
\text { KAPISA }\end{array}$ & HEALTH & 50 & $\begin{array}{l}\text { KUNAR } \\
\text { KUNDUZ } \\
\text { LAGHMAN } \\
\text { LOGAR } \\
\text { NANGARHAR } \\
\text { NIMROZ } \\
\text { ORUZGAN } \\
\text { PAKTEKA } \\
\text { PAKTIA } \\
\text { PARWAN } \\
\text { SAMANGAN } \\
\text { TAKHAR } \\
\text { WARDAK } \\
\text { ZABUL } \\
\text { PAKISTAN }\end{array}$ & $\begin{array}{l}\text { HEALTH } \\
\text { HEALTH } \\
\text { HEALTH }\end{array}$ & $\begin{array}{l}15 \\
15\end{array}$ \\
\hline
\end{tabular}


AMI is a French humanitarian agency, based in Paris. It provides emergency relief and medical training to rural populations in developing countries. In 1980 AMI sent its first medical team inside Afghanistan to assist in an emergency mission for rural populations. Later, a separate programme was set up - as Aide Medicale Internationale Afghanistan, (AMI-A).

AMI focuses on medical training. From 1982 onwards AMI's expatriate medical volunteers set up short training programmes to train health workers and TBAs. As the war continued, it became impractical to carry out intensive courses inside Afghanistan and in 1985 AMI started Medical Training for Afghans (MTA) in conjunction with Solidarite Afghanistan Belgium, to train health workers in Peshawar. It also started separate courses for laboratory technicians, X-ray and dental technicians. Since 1989 these courses were based at the ITC, Hayatabad, funded by the EU.

Since 1985, AMI trained more than 104 assistant doctors at MTA on 16 month courses; 26 laboratory technicians on 4 month courses; and 9 others received one month refresher courses. Also over $25 \mathrm{X}$-ray technicians on 4 month courses - in conjunction with MRCA; and 66 dental students on 3 month courses.

In June 1993 the agency shifted its focus to upgrading skills of existing health staff in the rural areas of Afghanistan.

Inside Afghanistan, AMI's major project was the installation of a 40 bed district hospital, Baraki Barak, Logar. The hospital provides medical and surgical care services. A training centre was built within the hospital premises; seminars for hospital staff and all health workers in the area are organised.

The hospital is funded by the European Union, the French Government and the Ministry of Public Health, Afghanistan.
Arising from an evaluation mission with MADERA agency, basic health clinics have been established in Kamdesh, Nooristan and Asnan clinic in Kunar.. The clinics serves the basic medical needs of the local rural population, with little access to medical facilities in the area.

In June 1995 a sub-office was opened in Kabul and in October 1995 started the rehabilitation and of $10 \mathrm{MCH}$ clinics in Kabul city. All $\mathrm{MCH}$ staff attended a two-month training course, focusing on the major risk factors for this target population (pregnant women, young mothers and children under 5 years of age). This programme is funded by ECHO and is carried out in cooperation with the $\mathrm{MoPH}$.

Since September 1996 AMI has been running two provincial hospitals in Laghman and Kunar.

In January 1997 the central laboratory of Kabul was reopened - rehabilitating the building and training 50 people.

In June 1997 new clinics were opened in Laghman, Nangaraj and Nooristan. 
311，3RD FLOOR, GUL HAJI PLAZA, JAMROD RD PESHAWAR， PAKISTAN

\section{PHONE : 845446}

F A X:

TELEX :
1. QAYUM SAYEDI

2. ENG. KARIMULLAH

3. SAYED ABDUL HAQ

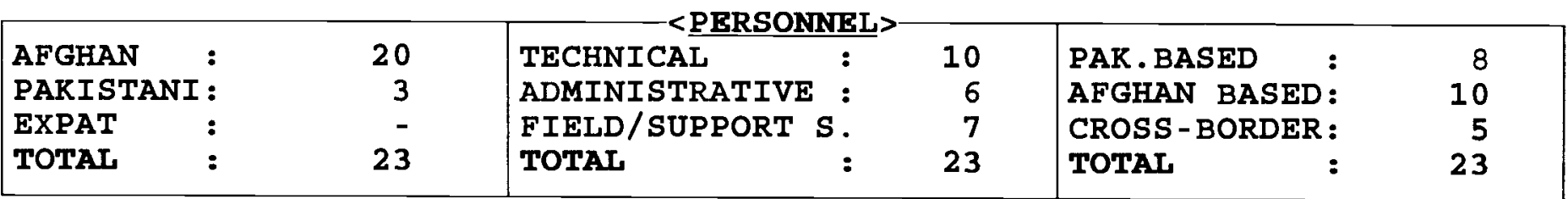

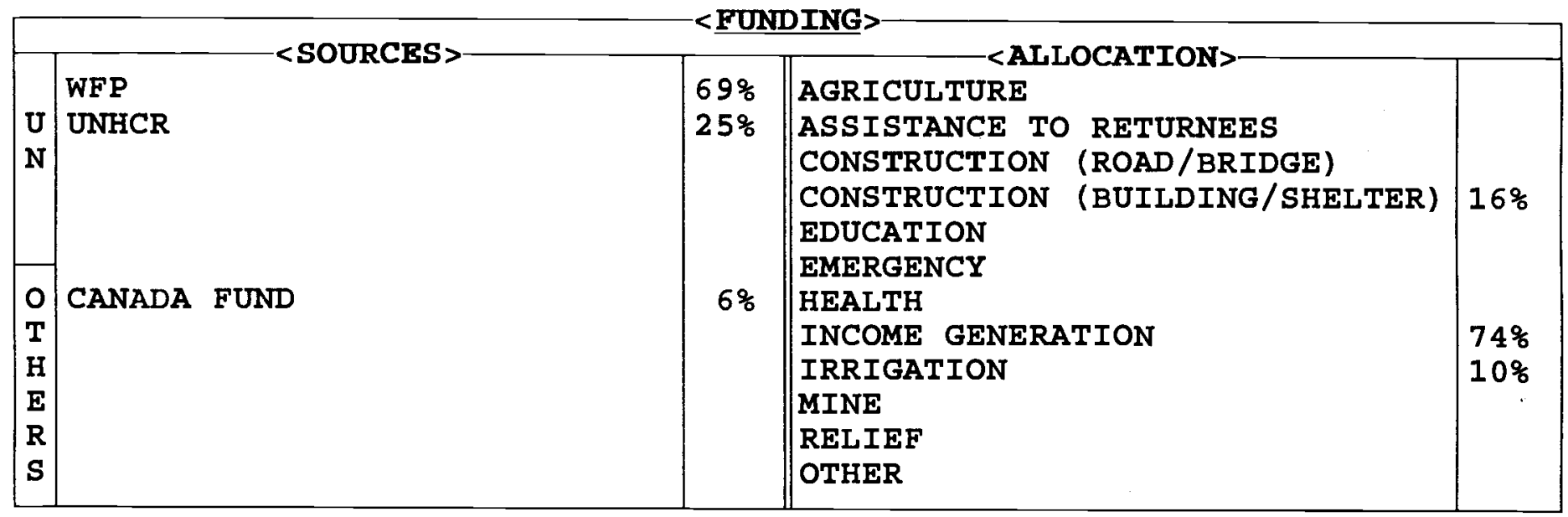

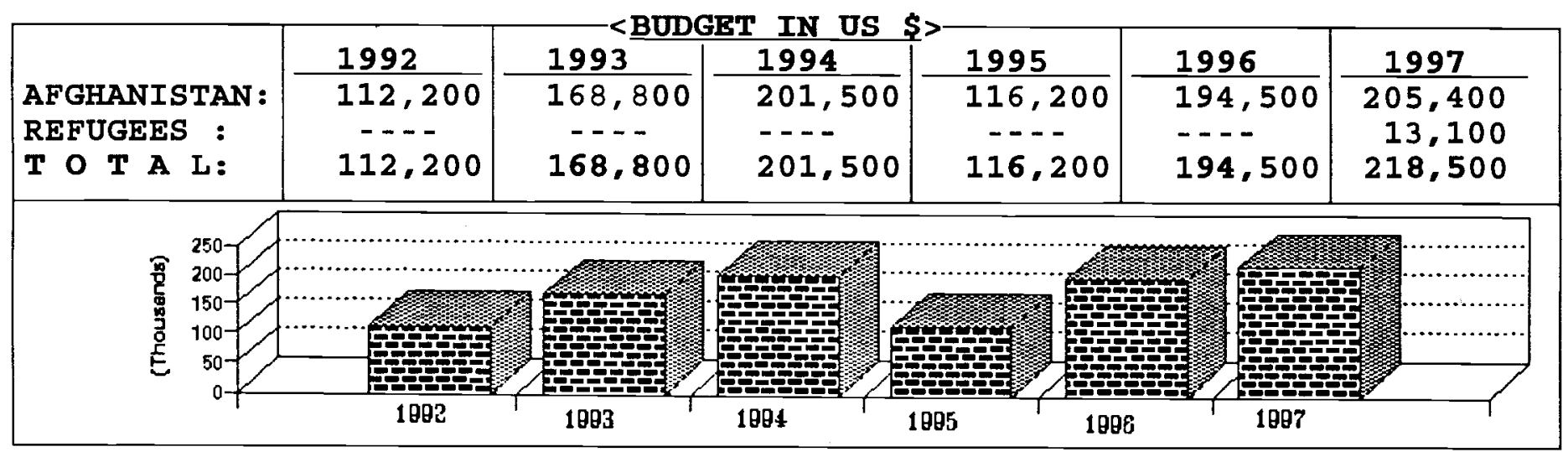

\begin{tabular}{|c|c|c|c|c|c|}
\hline PROVINCES & SECTOR & $\frac{\%}{0}$ & PROVINCES & SECTOR & \% \\
\hline $\begin{array}{l}\text { BADAKSHAN } \\
\text { BADGHIS } \\
\text { BAGHLAN } \\
\text { BALKH } \\
\text { BAMYAN } \\
\text { FARAH } \\
\text { FARYAB } \\
\text { GHAZNI } \\
\text { GHOR } \\
\text { HELMAND } \\
\text { HERAT } \\
\text { JAWZJAN } \\
\text { KABUL } \\
\text { KANDAHAR } \\
\text { KAPISA }\end{array}$ & & & $\begin{array}{l}\text { KUNAR } \\
\text { KUNDUZ } \\
\text { LAGHMAN } \\
\text { LOGAR } \\
\text { NANGARHAR } \\
\text { NIMROZ } \\
\text { ORUZGAN } \\
\text { PAKTEKA } \\
\text { PAKTIA } \\
\text { PARWAN } \\
\text { SAMANGAN } \\
\text { TAKHAR } \\
\text { WARDAR } \\
\text { ZABUL } \\
\text { REFUGEES }\end{array}$ & INCOME GENERATION & 94 \\
\hline
\end{tabular}


AMRAN is a non-political, non-profit, humanitarian Afghan NGO. It was founded in 1992. The main office of the Association is presently located in Peshawar with sub offices in Jalalabad, Kabul and Khost.

With the aim of participating in rehabilitation/ reconstruction of Afghanistan, AMRAN is active in the sectors of housing, agriculture, road construction, irrigation, education, skills training, income gencration and health. It is committed to close coordination with other organisations.

The agency has an Exccutive Board which plans and supervises all activities. Projects are surveyed, designed and implemented in consultation with the local shuras.

Morc than 53 projects have been implemented so far, mainly in the eastern Provinces of Afghanistan (Nangarhar, Laghman, Paktia, Kabul and Kunar). An outline of completed projects is as follows:

\section{Agriculture}

Distribution, multiplication and extension of improved seeds (wheat, rice, maize, cotton, sugar cane, vegetable and beseem clover) honey bee project, poultry and fruit saplings distribution.

\section{Irrigation}

Repair and rehabilitation of 30 canals.

\section{Road Repair/rehabilitation}

A number of road have bcen repaired in Laghman, Kunar, Paktia and Kabul Provinces.

\section{Education}

Establishment of a literacy course in Jaji district.

\section{Skill Training}

Skills training course, mainly Handicrafts and Gabion weaving have been conducted in Nangarhar and Kabul.

\section{Construction}

A mosque has been built in Kunar Province and a school in under construction in Nangarhar.

The agency has submitted a number of project proposals including Road rehabilitation, bridge reconstruction, school construction, vocational training and other proposals to different donors. 


\begin{tabular}{|c|c|c|c|c|c|}
\hline$-<\mathrm{AD}$ & $=$ & <COMMUNICATION & $\mathbf{E S}=$ & $-<$ KEY STA & \\
\hline $\begin{array}{l}3, \text { OPPOSITE } \\
\text { RHALIL TOW } \\
\text { PESHAWAR, }\end{array}$ & $\begin{array}{l}\text { OARD, } \\
\text { AN }\end{array}$ & $\begin{array}{l}\text { PHONE: } 840386 \\
\text { F A X: } \\
\text { TELEX: }\end{array}$ & & $\begin{array}{l}\text { 1. ENG. S. RA } \\
\text { 2. ENG. JUMA } \\
\text { 3. LAL PACHA }\end{array}$ & SATTAR \\
\hline AFGHAN & 23 & TECHNICAL & 9 & PAK . BASED & 11 \\
\hline PAKISTANI : & - & ADMINISTRATIVE & 8 & AFGHAN BASED: & 6 \\
\hline EXPAT : & - & FIELD/SUPPORT S. & 6 & CROSS - BORDER : & 6 \\
\hline TOTAL & 23 & TOTAL : & 23 & TOTAL : & 23 \\
\hline
\end{tabular}

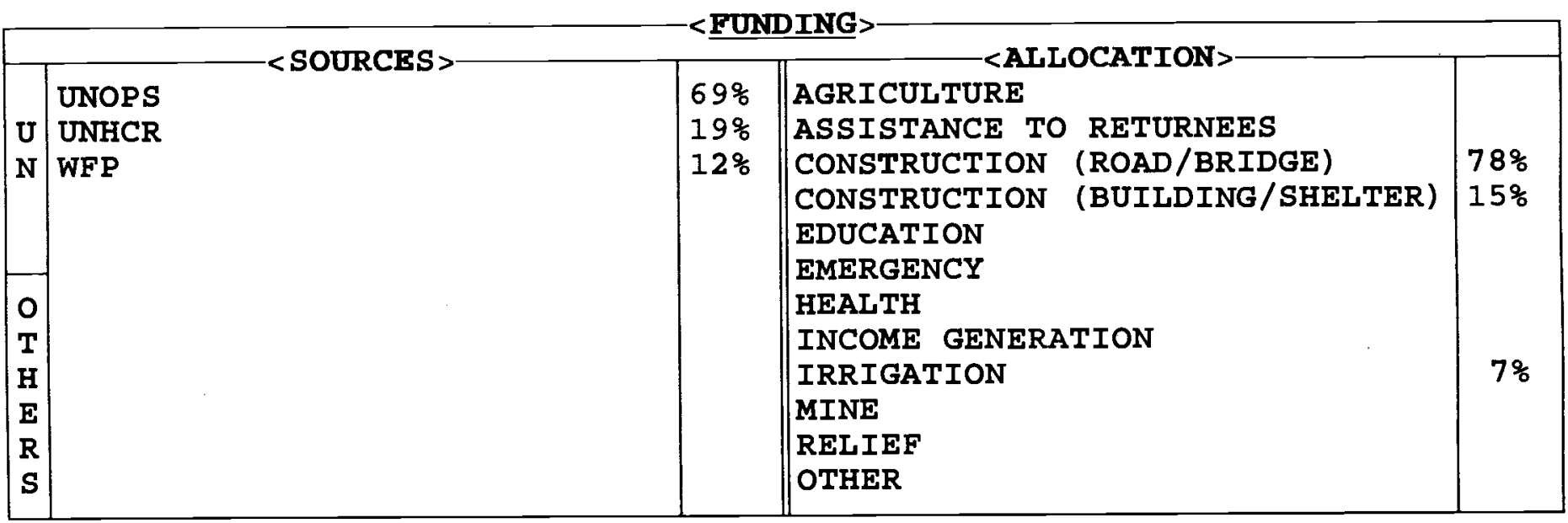

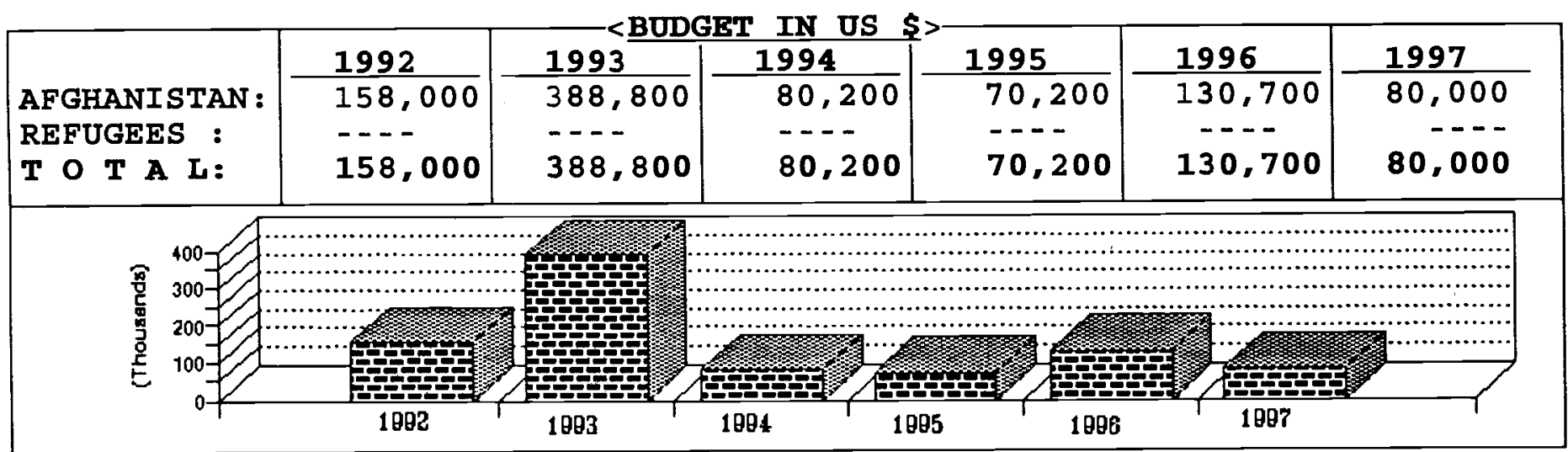

\begin{tabular}{|c|c|c|c|c|c|}
\hline PROVINCES & SECTOR & $\%$ & PROVINCES & SECTOR & $\%$ \\
\hline $\begin{array}{l}\text { BADAKSHAN } \\
\text { BADGHIS } \\
\text { BAGHLAN } \\
\text { BALKH } \\
\text { BAMYAN } \\
\text { FARAH } \\
\text { FARYAB } \\
\text { GHAZNI } \\
\text { GHOR } \\
\text { HELMAND } \\
\text { HERAT } \\
\text { JAWZJAN } \\
\text { KABUL } \\
\text { RANDAHAR } \\
\text { KAPISA }\end{array}$ & & & \begin{tabular}{|l} 
KUNAR \\
KUNDUZ \\
LAGHMAN \\
LOGAR \\
NANGARHAR \\
NIMROZ \\
ORUZGAN \\
PAKTEKA \\
PAKTIA \\
PARWAN \\
SAMANGAN \\
TAKHAR \\
WARDAK \\
ZABUL
\end{tabular} & $\begin{array}{l}\text { IRRIG/CONST . (ROADS) } \\
\text { IRRIGATION/CONST . } \\
\text { CONSTRUCTION/ROADS }\end{array}$ & $\begin{array}{l}64 \\
14\end{array}$ \\
\hline
\end{tabular}




\section{AFGHAN PUBLIC WELFARE \\ ORGANISATION \\ (APWO)}

APWO was established in 1989, with its headquarters in Peshawar and sub-offices in Jalalabad and Khost.

Aims of APWO:

To assist the oppressed people of Afghanistan in different fields e.g. agriculture, irrigation, construction and emergency food supplies.

\section{Sectors of Operation}

\section{Construction}

Reconstruction of Najmudeen Akhondzada Shrine, Hada area of Jalalabad, Nangarhar Province.

\section{Agriculture}

Provision of agricultural inputs in Qarghaie district, Laghman Province.

Wheat seed multiplication in Qarghaie district, Laghman Province.

Fruit trees Nursery in Maidani area, centre of Laghman.

\section{Irrigation}

Cleaning of eight canals in different districts of Paktia e.g. Alisher, Gurboz, Bak.

\section{Road Rehabilitation}

Road rehabilitation of Ayubkhil in Paktia is underway.

\section{Future Objectives}

APWO plans to continue to be active in the rehabilitation process of Afghanistan.

Presently the organisation has sub-offices in Jalalabad and Khost to enable improved participation and implementation of projects inside Afghanistan.

\section{Further Information}

Initially the organisation worked in refugee camps in Pakistan. In 1990, APWO commenced work inside Afghanistan. 
AFGHAN RELIEF COMMITTEE (ARC)

ACBAR

9 CIRCULAR LANE U/T

G P O BOX 489

PESHAWAR, PAKISTAN
PHONE : $849592 / 40791$

F A X: 42584

email:
1. PROF. A G SAFI

2. GHULAM JAILANI

3 .

\begin{tabular}{|c|c|c|c|c|c|}
\hline AFGHAN & 28 & TECHNICAL : & 13 & PAK. BASED : & 10 \\
\hline PAKISTANI : & 1 & ADMINISTRATIVE : & 8 & AFGHAN BASED: & 16 \\
\hline EXPAT : & - & FIELD/SUPPORT $S$. & 8 & CROSS-BORDER : & 3 \\
\hline TOTAL & 29 & TOTAL : & 29 & TOTAL : & 29 \\
\hline
\end{tabular}

$<$ SOURCES $>$

U UNOPS

$\mathrm{N}$ WFP

0

T GTZ

$\mathrm{H}$ NAC

E AL BASAR INTERNATIONAL FOUND.

$\mathrm{R}$

$\mathrm{R}$
$\mathrm{S}$
$<$ FUNDING $>$

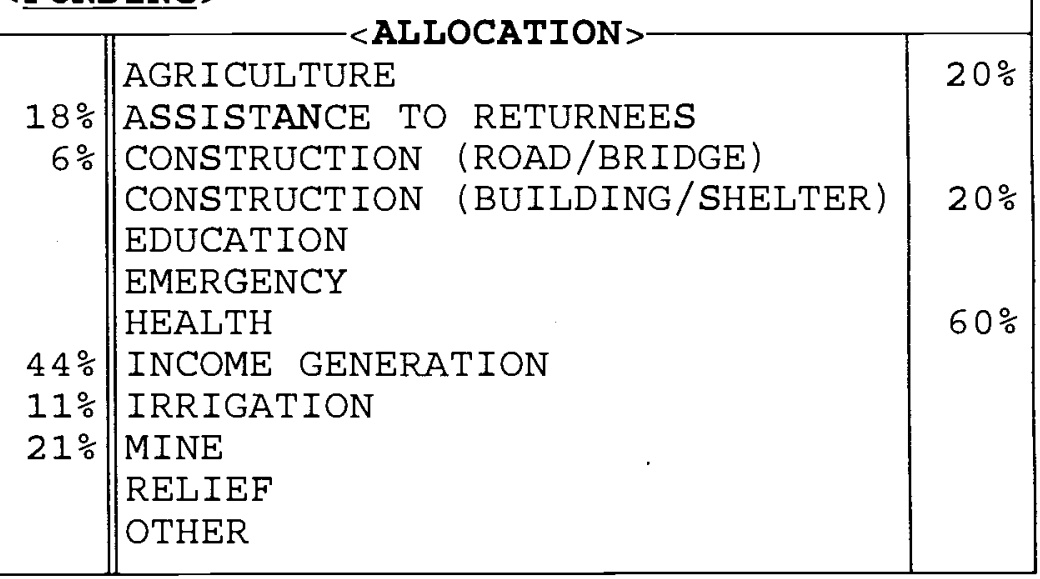

\begin{tabular}{|c|c|c|c|c|c|c|}
\hline & 1992 & 1993 & 1994 & 1995 & 1996 & 1997 \\
\hline AFGHANISTAN : & 765,000 & 433,600 & 66,200 & 117,800 & 199,500 & 63,500 \\
\hline REFUGEES : & 635,000 & 543,800 & --- & ---- & ---- & --- \\
\hline T O T A L: & $1,400,000$ & 977,400 & 66,200 & 117,800 & 199,500 & 63,500 \\
\hline
\end{tabular}

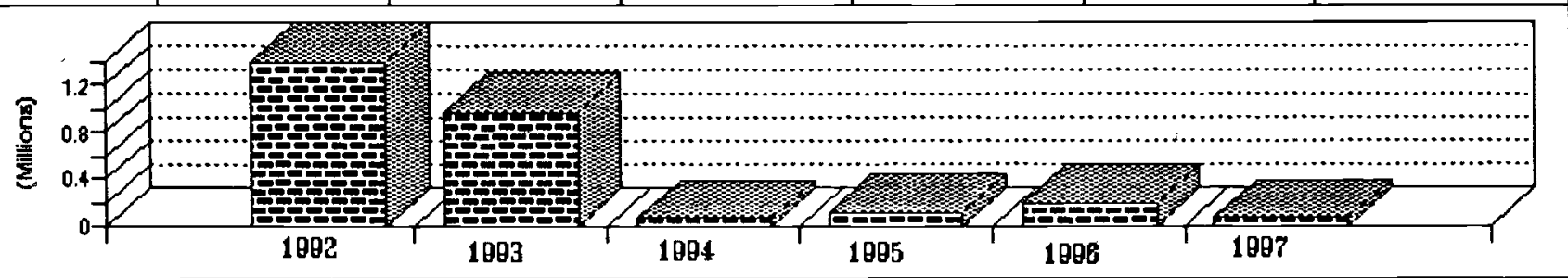

\begin{tabular}{|c|c|c|c|c|c|}
\hline PROVINCES & SECTOR & $\frac{\circ}{0}$ & PROVINCES & SECTOR & $\%$ \\
\hline $\begin{array}{l}\text { BADAKSHAN } \\
\text { BADGHIS } \\
\text { BAGHLAN } \\
\text { BALKH } \\
\text { BAMYAN } \\
\text { FARAH } \\
\text { FARYAB } \\
\text { GHAZNI } \\
\text { GHOR } \\
\text { HELMAND } \\
\text { HERAT } \\
\text { JAWZJAN } \\
\text { KABUL } \\
\text { KANDAHAR } \\
\text { KAPISA }\end{array}$ & & & $\begin{array}{l}\text { KUNAR } \\
\text { KUNDUZ } \\
\text { LAGHMAN } \\
\text { LOGAR } \\
\text { NANGARHAR } \\
\text { NIMROZ } \\
\text { ORUZGAN } \\
\text { PAKTEKA } \\
\text { PAKT IA } \\
\text { PARWAN } \\
\text { SAMANGAN } \\
\text { TAKHAR } \\
\text { WARDAK } \\
\text { ZABUL } \\
\text { PAKISTAN }\end{array}$ & $\begin{array}{l}\text { AGRIC/CONST/HLTH } \\
\text { AGRIC/CONST/HLTH } \\
\text { AGRIC/CONST/HLTH }\end{array}$ & 35 \\
\hline
\end{tabular}


$\triangle \mathrm{RC}$ was established, as the Austrian Relief Committee, in Vienna in 1980 as a relief organisation to help Afghan refugees in Pakistan. The name was changed in 1997.

\section{Aims of ARC \\ To "Help Afghans to Help Themselves" through a comprehensive management and staff training programme. The agency initially offered medical assistance to refugees, but later expanded its activities to sanitation and technical training. It is now involved in long term rural development projects in Afghanistan.}

\section{Sector of Operation}

\section{Primary Health Care Programmes:}

These have operated in Pakistan, and crossborder in Nangarhar, Ghazni and Logar. Today, cross-border activities are restricted to Nangarhar Province.

\section{Vocational Training:}

This was offered by two training centers at Akora Khatak and Canal Road (formerly Munda) in Pakistan. A trial cross-border mobile TTC was established in Malistan, Ghazni in 1993. Training was provided in the fields of carpentry, welding, tinsmithry, blacksmithry, electrical wiring and radio repair.

\section{Sanitation:}

In 1982 ARC operated a Sanitation programme in refugee villages in NWFP. The programme aimed to reduce the incidence of sanitation related diseases by the construction of latrines, and provision of health education. In 1992 the programme moved cross-border to implement activities in rural Afghanistan, initially in Logar and later in Nangarhar Province.

\section{Rural Development Programmes:}

These have been conducted in Ghazni, Logar and Nangarhar Provinces of Afghanistan. The aim was to increase food production and rural incomes, to enable families to remain in their homes, and to promote refugee returns.
In 1993 ARC developed integrated communitybased programmes in Afghanistan. Target areas were agriculture, health, irrigation, construction, income generation livestock, veterinary services and sanitation.

\section{Laghman}

Construction of Basram High School for

Alingar communities.

\section{Nangarhar}

Jalalabad Eye hospital, construction project. Primary Health care services for Behsud and Mohmand Dara districts.

\section{Paktia}

Khost Delpuri irrigation improvement project.

Tera farm rehabilitation project.

Gardez civil hospital rehabilitation project. Khost Orthopaedic workshop rehabilitation.

\section{Future Objectives}

Future plans are to include areas of central, western and northern Afghanistan. 
ARIANA REHABILITATION COMMITTEE FOR AFGHANISTAN RECON. (ARCAR) ACBAR <ADDRESS > 18 -B SPINGAR PLAZA JAHANGIRABAD PESHAWAR, PAKISTAN

PHONE : 44986

F A X:

email:
1.DR MOHAMMAD HUMAYUN

2. ENG M KABIR

3. ENG SHUMSURAHMAN

\begin{tabular}{|c|c|c|c|c|c|}
\hline AFGHAN & 24 & TECHNICAL : & 5 & PAK. BASED : & 3 \\
\hline PAKISTANI : & - & ADMINISTRATIVE : & 6 & AFGHAN BASED : & 21 \\
\hline EXPAT : & - & FIELD/SUPPORT S. & 13 & CROSS-BORDER : & - \\
\hline TOTAL & 24 & TOTAL : & 24 & TOTAL : & 24 \\
\hline
\end{tabular}

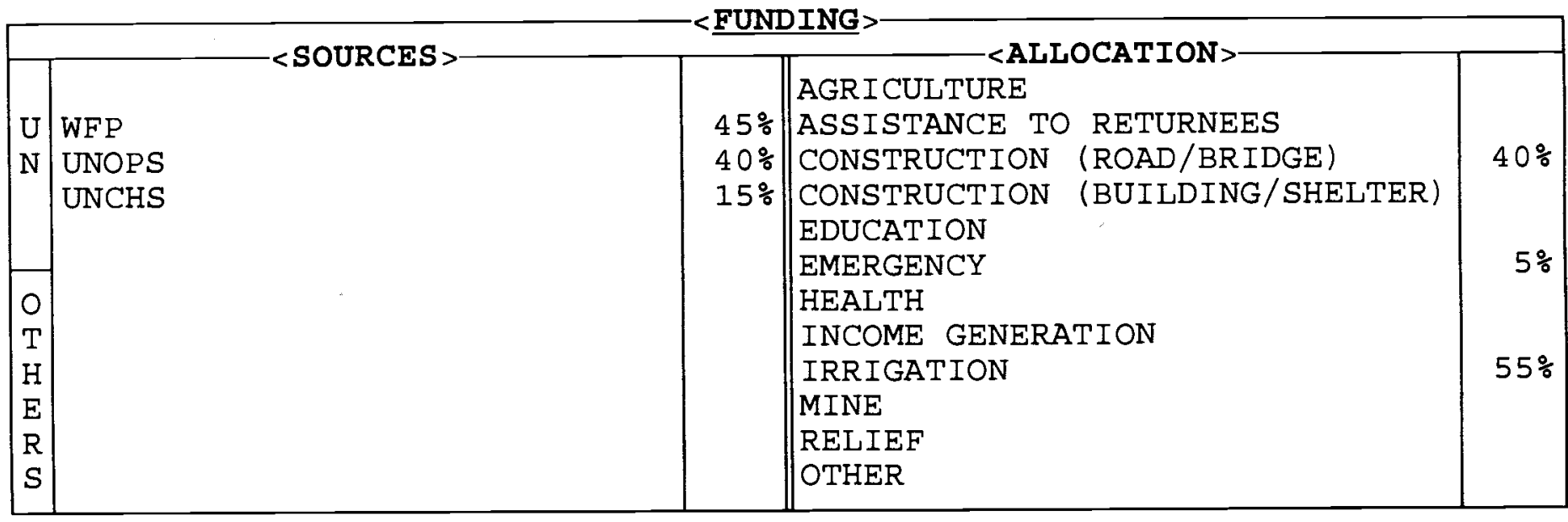

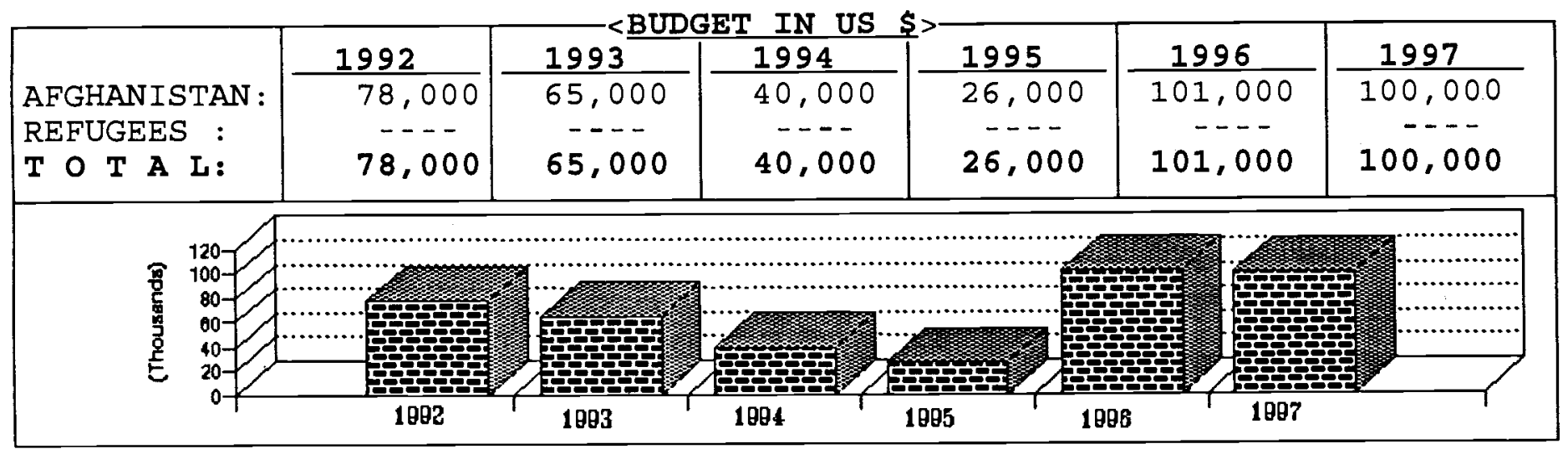

\begin{tabular}{|c|c|c|c|c|c|}
\hline PROVINCES & SECTOR & $\div$ & PROVINCES & SECTOR & $\%$ \\
\hline $\begin{array}{l}\text { BADAKSHAN } \\
\text { BADGHIS } \\
\text { BAGHLAN } \\
\text { BALKH } \\
\text { BAMYAN } \\
\text { FARAH } \\
\text { FARYAB } \\
\text { GHAZNI } \\
\text { GHOR } \\
\text { HELMAND } \\
\text { HERAT } \\
\text { JAWZJAN } \\
\text { KABUL } \\
\text { KANDAHAR } \\
\text { KAPISA }\end{array}$ & $\begin{array}{l}\text { IRRIGATION } \\
\text { EMERGENCY }\end{array}$ & 32 & $\begin{array}{l}\text { KUNAR } \\
\text { KUNDUZ } \\
\text { LAGHMAN } \\
\text { LOGAR } \\
\text { NANGARHAR } \\
\text { NIMROZ } \\
\text { ORUZGAN } \\
\text { PAKTEKA } \\
\text { PAKTIA } \\
\text { PARWAN } \\
\text { SAMANGAN } \\
\text { TAKHAR } \\
\text { WARDAK } \\
\text { ZABUL } \\
\text { PAKISTAN }\end{array}$ & $\begin{array}{l}\text { IRRIGATION } \\
\text { IRRIGATION } \\
\text { CONSTRUCTION (ROAD) } \\
\text { CONSTRUCTION (ROAD) }\end{array}$ & $\begin{array}{r}8 \\
15\end{array}$ \\
\hline
\end{tabular}




\section{ARIANA REHABILITATION \\ COMMITTEE FOR AFGHANISTAN \\ RECONSTRUCTION (ARCAR)}

ARCAR is an Afghan non-governmental and non-political organisation established in 1991 with the sole aim of helping in the rehabilitation and reconstruction of war ravaged Afghanistan.

It comprises a group of skilled Afghans who wish to use their expertise and professional experience to serve their countrymen.

The main office is now located in Kabul city.

\section{Objectives}

- $\quad$ to take a direct and active part in the reconstruction of Afghanistan;

- $\quad$ to improve the social and economic status of the people of Afghanistan;

- $\quad$ to provide opportunities for income generation for skilled Afghans to support their families;

- $\quad$ to offer training to Afghans to encourage self sufficiency.

Staff are proficient in different sectors including agriculture, irrigation systems, infrastructure, education, health, and other rehabilitation and development programmes, in which the agency is involved.

A summary of ARCAR projects:

\section{Nangarhar}

- Rehabilitation/ reconstruction of Shewa main canal;

- $\quad$ Rehabilitation of Zangoie canal;

\section{Logar}

- Carpentry and masonry training project in Mohd Agha district

- $\quad$ Improved seed multiplication project in Puli Alam and Mohd Agha;

\section{Kunar}

- Construction of a secondary school in Sheegal;

\section{Laghman}

- $\quad$ Carpentry and masonry training;

Jawzjan

- Construction of Yangi Qala reservoir;

- Construction of Beshpakar reservoir;

Balkh

- Construction of water intake in

Chemtal district;

\section{Paktia}

- Poultry distribution in Sabari district. 
AFGHANISTAN RECONSTRUCTION CONSULTANTS (ARCON)

52 B, PARK AVENUE, P.O. BOX 991, U/T PESHAWAR, PAKISTAN
PHONE: 840241

$F$ A X: 840241

TELEX :
1. DR. A. F. MUSTAPHA

2. ENG. AFMAD SHAH

3. ENG. M. TAMIM

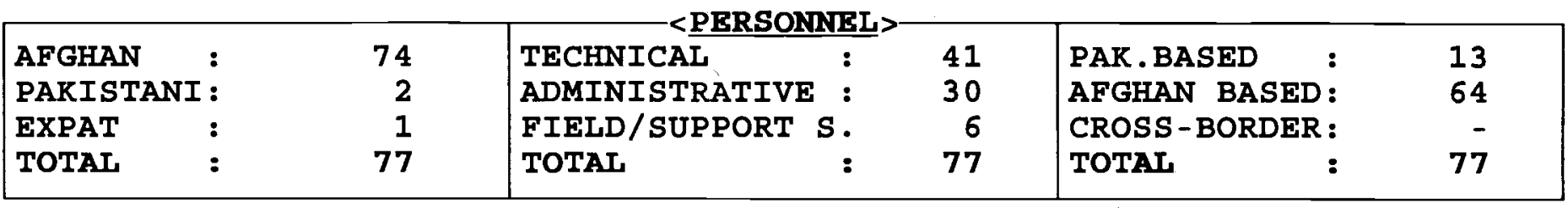

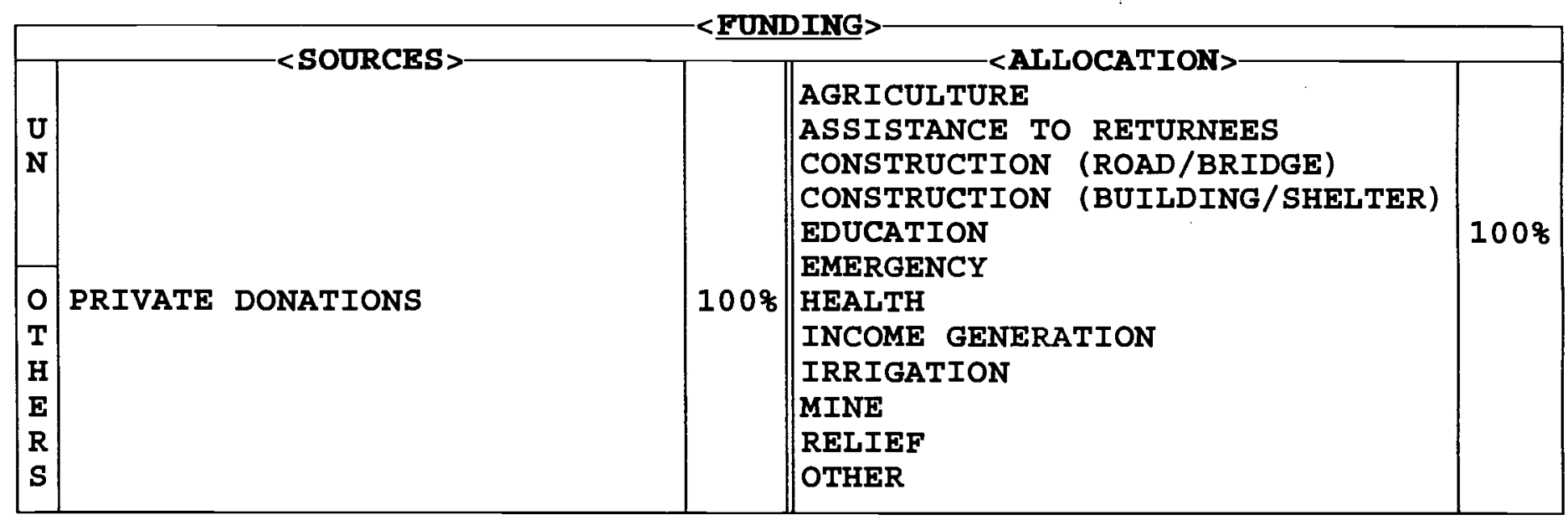

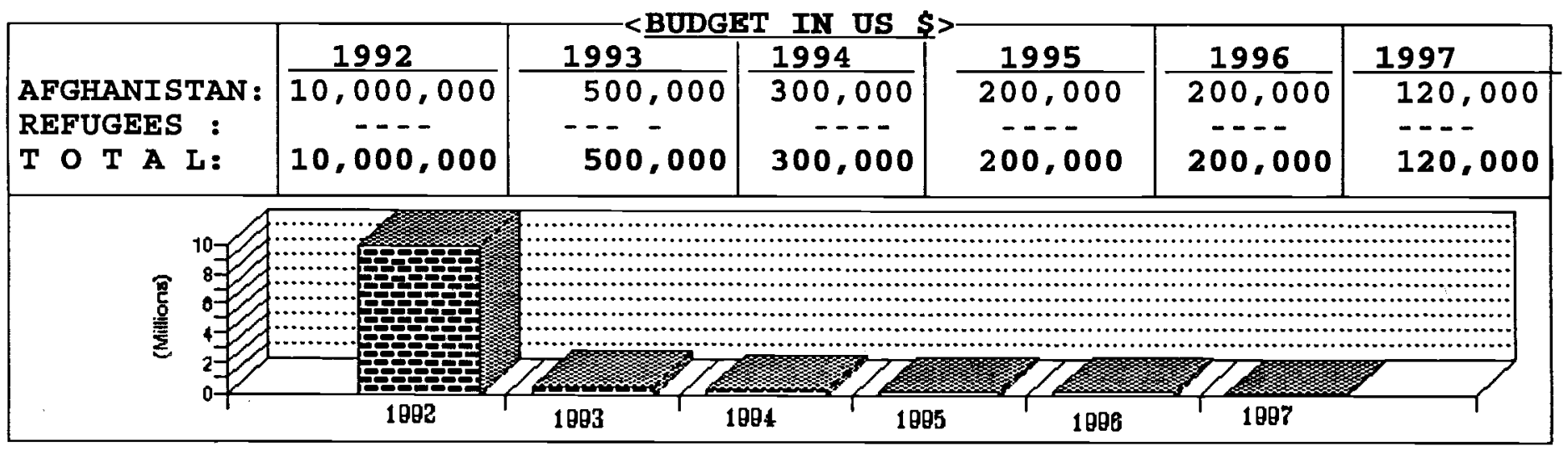

\begin{tabular}{|c|c|c|c|c|c|}
\hline PROVINCES & SECTOR & $\%$ & PROVINCES & SECTOR & $\%$ \\
\hline $\begin{array}{l}\text { BADARSHAN } \\
\text { BADGHIS } \\
\text { BAGHLAN } \\
\text { BALKH } \\
\text { BAMYAN } \\
\text { FARAH } \\
\text { FARYAB } \\
\text { GHAZNI } \\
\text { GHOR } \\
\text { HELMAND } \\
\text { HERAT } \\
\text { JAWZJAN } \\
\text { RABUL } \\
\text { RANDAHAR } \\
\text { KAPISA }\end{array}$ & EDUCATION & 100 & $\begin{array}{l}\text { KUNAR } \\
\text { KUNDUZ } \\
\text { LAGHMAN } \\
\text { LOGAR } \\
\text { NANGARHAR } \\
\text { NIMROZ } \\
\text { ORUZGAN } \\
\text { PAKTEKA } \\
\text { PAKTIA } \\
\text { PARWAN } \\
\text { SAMANGAN } \\
\text { TAKHAR } \\
\text { WARDAK } \\
\text { ZABUL } \\
\text { REFUGEES }\end{array}$ & & \\
\hline
\end{tabular}




\section{AFGHANISTAN RECONSTRUCTION \\ CONSULTANTS \\ (ARCON)}

ARCON opened its branch office in Peshawar in 1987.

As a donor and also implementor of its own projects, ARCON undertook a number of projects in rehabilitation/reconstruction of different sectors including education, health, agriculture, public buildings and irrigation systems. It has also provided relief assistance on different occasions, based on needs.

ARCON aims for an even distribution of projects relevant to Province and population distribution. Provinees with fewer programmes were given more priority.

During 1991 and 1992, the agency provided financial support to more than 15 local NGOs who implemented hundreds of projects mainly in the sector of infrastructure, including construction of public buildings (mosques, schools, clinics, hospitals etc.), road repair and irrigation systems rehabilitation. It has also provided funds to public institutions and invested money to restore governmental revenue, such as small industries and state farms.

For the time being, ARCON's rehabilitation activities inside Afghanistan have been suspended awaiting a more stable and secure situation in the country. However, it continues to support a University for Afghan refugees in Peshawar. 
AFGHAN RED CRESCENT SOCIETY (ARCS)

\begin{tabular}{|c|c|c|}
\hline - < ADDRESS $>$ & $-<$ COMMUNICATION LINES $>$ & $-<$ KEY STAFF $>$ \\
\hline $\begin{array}{l}\text { SHAHR - I-NOW, KABUL, } \\
\text { AFGHANISTAN }\end{array}$ & $\begin{array}{l}\text { PHONE : } 34288 \\
\text { F A X: } 008-731754347 \\
\text { TELEX : }\end{array}$ & $\begin{array}{l}\text { 1. M. S. AHMAD GHAFOOR] } \\
\text { 2. HAFIZ NAQIB AHMAD } \\
\text { 3. MHD OMAR AMIN }\end{array}$ \\
\hline
\end{tabular}

\begin{tabular}{|l|l|l|}
\hline AFGHAN : & TECHNICAL CPERONREL>- & PAK. BASED : \\
PAKISTANI: & ADMINISTRATIVE : & AFGHAN BASED: \\
EXPAT : & FIELD/SUPPORT S. & CROSS BORDER: \\
TOTAL : & TOTAL & TOTAL $:$ \\
\hline
\end{tabular}

\begin{tabular}{|c|c|c|c|c|}
\hline \multirow{7}{*}{$\begin{array}{l}\mathbf{U} \\
\mathbf{N}\end{array}$} & \multirow{13}{*}{$\begin{array}{l}\text { ICRC } \\
\text { IFRC } \\
\text { PEATE VILLAGE INTERNATIONAL } \\
\text { PRIVATE DONATIONS }\end{array}$} & \multirow{13}{*}{\begin{tabular}{l|} 
\\
$10 \%$ \\
$30 \%$ \\
$50 \%$ \\
$10 \%$
\end{tabular}} & CAWLOCATION> & \multirow{13}{*}{$\begin{array}{l}10 \% \\
30 \% \\
20 \% \\
10 \% \\
10 \% \\
20 \%\end{array}$} \\
\hline & & & AGRICULTURE & \\
\hline & & & ASSISTANCE TO RETURNEES & \\
\hline & & & CONSTRUCTION（ROAD/BRIDGE） & \\
\hline & & & CONSTRUCTION (BUILDING/SHELTER) & \\
\hline & & & EDUCATION & \\
\hline & & & EMERGENCY & \\
\hline 0 & & & HEALTH & \\
\hline $\mathbf{T}$ & & & |INCOME GENERATION & \\
\hline $\mathbf{H}$ & & & IRRIGATION & \\
\hline $\mathbf{E}$ & & & MINE & \\
\hline$\overline{\mathbf{R}}$ & & & RELIEF & \\
\hline $\mathbf{S}$ & & & OTHER & \\
\hline
\end{tabular}

\begin{tabular}{|c|c|c|c|c|c|c|}
\hline $\begin{array}{l}\text { AFGHANISTAN: } \\
\text { REFUGEES : } \\
\text { T O T A L: }\end{array}$ & $\begin{array}{l}1992 \\
\ldots-- \\
\ldots- \\
\ldots--\end{array}$ & $\begin{array}{l}\frac{1993}{1,000,000} \\
1,000,000\end{array}$ & $\begin{array}{l}\frac{1994}{1,000,000} \\
\ldots \\
1,000,000\end{array}$ & $\mid \begin{array}{c}\frac{1995}{1,000,000} \\
-- \\
1,000,000\end{array}$ & $\begin{array}{c}1996 \\
900,000 \\
--- \\
900,000\end{array}$ & $\begin{array}{c}\frac{1997}{1,000,000} \\
-\ldots \\
1,000,000\end{array}$ \\
\hline 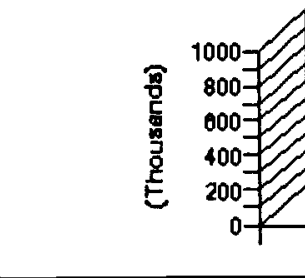 & 68: & ר.:. & 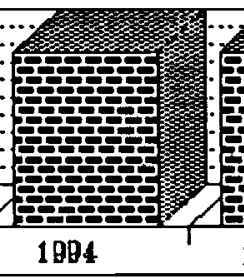 & 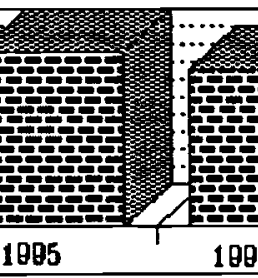 & 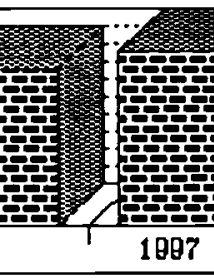 & (a............... \\
\hline
\end{tabular}

\begin{tabular}{|c|c|c|c|c|c|}
\hline PROVINCES & SECTOR & $\%$ & PROVINCES & SECTOR & $\%$ \\
\hline $\begin{array}{l}\text { BADAKSHAN } \\
\text { BADGHIS } \\
\text { BAGHLAN } \\
\text { BALKH } \\
\text { BAMYAN } \\
\text { FARAH } \\
\text { FARYAB } \\
\text { GHAZNI } \\
\text { GHOR } \\
\text { HELMAND } \\
\text { HERAT } \\
\text { JAWZJAN } \\
\text { RABUL } \\
\text { RANDAHAR } \\
\text { RAPISA }\end{array}$ & $\begin{array}{l}\text { HEALTH } \\
\text { HEALTH / RELIEF } \\
\text { HEALTH/RELIEF } \\
\text { HEALTH } \\
\text { EDUC/HLTH/IG/MIN/REL } \\
\text { HEALTH } \\
\text { HEALTH/RELIEF }\end{array}$ & $\begin{array}{r}56 \\
2 \\
5\end{array}$ & $\begin{array}{l}\text { KUNAR } \\
\text { KUNDUZ } \\
\text { LAGHMAN } \\
\text { LOGAR } \\
\text { NANGARHAR } \\
\text { NIMROZ } \\
\text { ORUZGAN } \\
\text { PAKTERA } \\
\text { PARTIA } \\
\text { PARWAN } \\
\text { SAMANGAN } \\
\text { TAKHAR } \\
\text { WARDAK } \\
\text { ZABUL }\end{array}$ & $\begin{array}{l}\text { HEALTH } \\
\text { HEALTH/RELIEF } \\
\text { HEALTH } \\
\text { HEALTH } \\
\text { HEALTH/RELIEF } \\
\text { HEALTH/RELIEF }\end{array}$ & $\begin{array}{l}3 \\
3 \\
5 \\
5\end{array}$ \\
\hline
\end{tabular}




\section{AFGHAN RED CRESCENT SOCIETY (ARCS)}

ARCS is the only official charity organisation in the country:

It is governed by a Grand and a Central assembly, who select the Director General and key staff.

The agency has 4 main departments (health, relief, Marastoon and voluntary self help) and 8 supporting sections with 16 branches in the Provinces.

With an annual budget of several million Afghanis its activities are maintained from year to year.

ARCS has spent a lot of time and energy developing a well organised system of listing and identifying those families where scverc hardship is faced.

ARCS is a member of the International Federation of Red Cross and Red Crescent Societies. 
AGENCY FOR RURAL DEVELOPMEANT OF AFGHANISTAN (ARDA)

\begin{tabular}{|c|c|c|c|c|}
\hline$-<A D D R E S S>$ & $-<$ COMMUNICATION & INES & $-<$ REY STI & \\
\hline $\begin{array}{l}\text { 184, UPPER CANAL LANE } \\
\text { P.O.BOX } 540, \text { U/T } \\
\text { PESHAWAR, PAKISTAN }\end{array}$ & $\begin{array}{l}\text { PHONE: } 842189 \\
\text { F A X: } 841982 \\
\text { TELEX: }\end{array}$ & & $\begin{array}{l}\text { 1. M. KHALID } \\
\text { 2. JAMAL ABDL } \\
\text { 3. M HAROON } 1\end{array}$ & $\begin{array}{l}\text { IEED } \\
\text { SIR } \\
\text { R }\end{array}$ \\
\hline $\begin{array}{l}\text { AFGHAN : } \\
\text { PAKISTANI: } \\
\text { EXPAT : } \\
\text { TOTAL : }\end{array}$ & $\begin{array}{l}\text { TECHNICAL : } \\
\text { ADMINISTRATIVE : } \\
\text { FIELD/SUPPORT S: } \\
\text { TOTAL : }\end{array}$ & $\begin{array}{r}160 \\
11 \\
- \\
171\end{array}$ & $\begin{array}{l}\text { PAK. BASED : } \\
\text { AFGHAN BASED: } \\
\text { CROSS-BORDER: } \\
\text { TOTAL }\end{array}$ & $\begin{array}{r}11 \\
158 \\
2 \\
171\end{array}$ \\
\hline
\end{tabular}

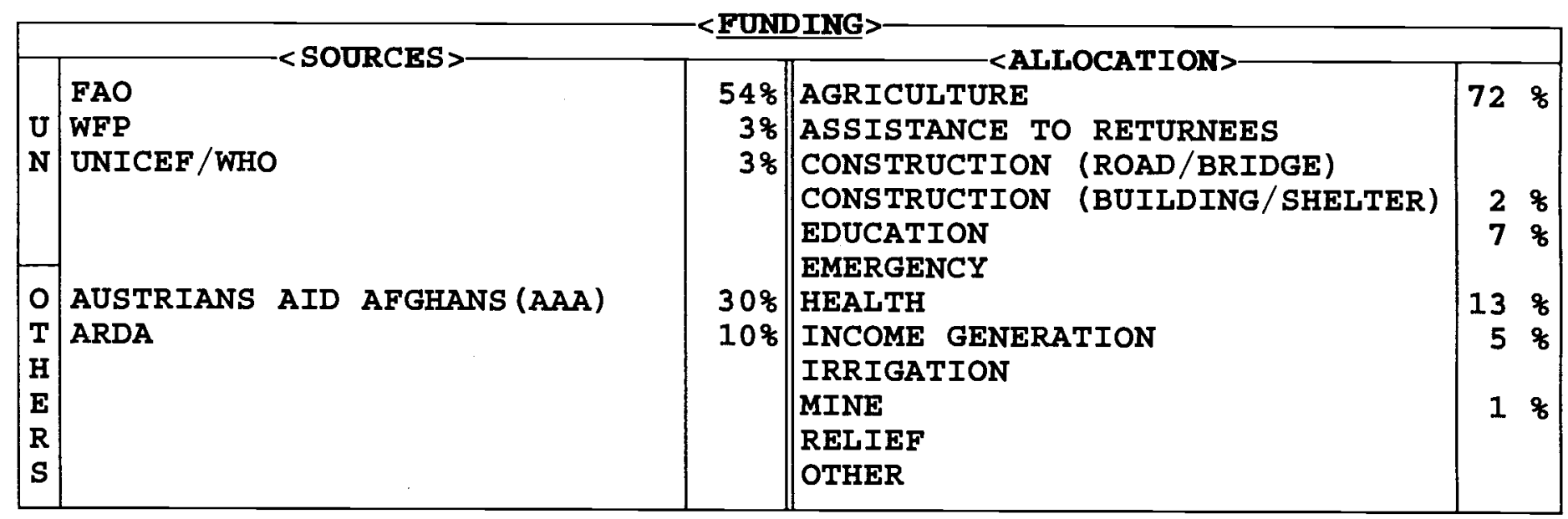

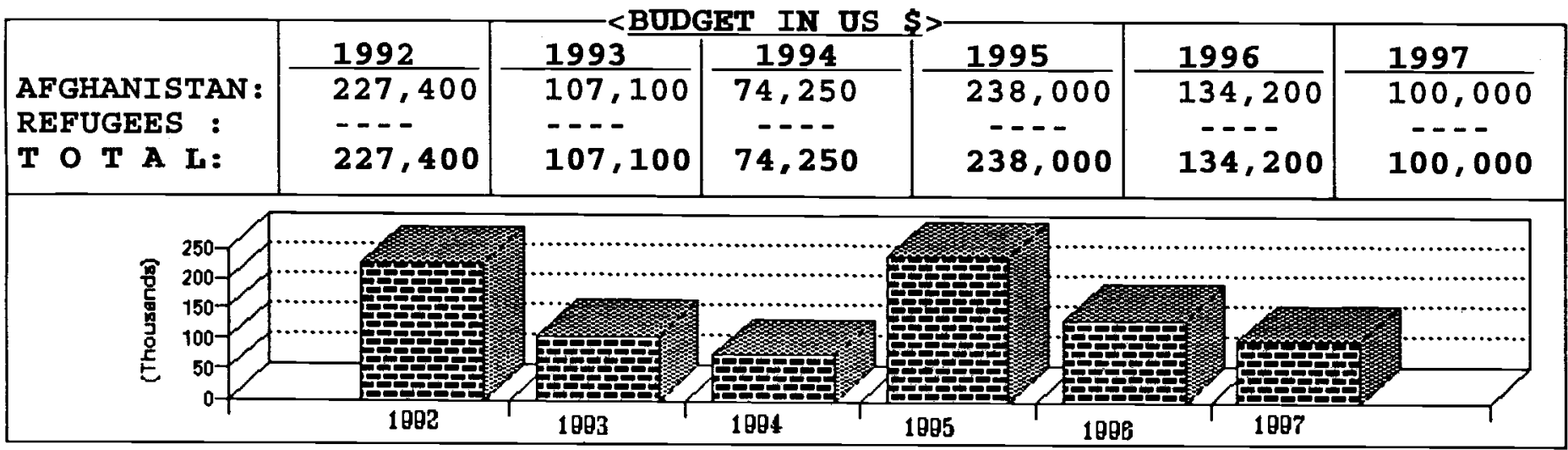

\begin{tabular}{|c|c|c|c|c|c|}
\hline PROVINCES & SECTOR & $\%$ & PROVINCES & SECTOR & q \\
\hline $\begin{array}{l}\text { BADAKSHAN } \\
\text { BADGHIS } \\
\text { BAGHLAN } \\
\text { BALKH } \\
\text { BAMYAN } \\
\text { FARAH } \\
\text { FARYAB } \\
\text { GHAZNI } \\
\text { GHOR } \\
\text { HELMAND } \\
\text { HERAT } \\
\text { JAWZJAN } \\
\text { KABUL } \\
\text { RANDAHAR } \\
\text { KAPISA }\end{array}$ & $\begin{array}{l}\text { AGRICULTURE } \\
\text { AGRICLUTURE } \\
\text { AGRICULTURE }\end{array}$ & 5 & $\begin{array}{l}\text { KUNAR } \\
\text { KUNDUZ } \\
\text { LAGHMAN } \\
\text { LOGAR } \\
\text { NANGARHAR } \\
\text { NIMROZ } \\
\text { ORUZGAN } \\
\text { PAKTEKA } \\
\text { PARTIA } \\
\text { PARWAN } \\
\text { SAMANGAN } \\
\text { TAKHAR } \\
\text { WARDAK } \\
\text { ZABUL }\end{array}$ & $\begin{array}{l}\text { AGRICULTURE/INCOM GEN } \\
\text { INCOM. GEN. } \\
\text { AGRI/EDU/DEMNG / HEALTH } \\
\text {. / INCOM. GEN } \\
\text { INCOM. GEN. } \\
\text { AGRICULTURE }\end{array}$ & $\begin{array}{r}5 \\
2 \\
81\end{array}$ \\
\hline
\end{tabular}




\section{AGENCY FOR RURAL DEVELOPMENT OF AFGHANISTAN \\ (ARDA)}

ARDA is a non-political, non-governmental and non-profit organisation established in January 1991.

ARDA has a number of experienced instructors and technicians in vocational sectors including the following:

\section{Health}

Running Khogyani hospital and health clinic funded by Austrians Aid Afghans.

\section{Education}

Running Khogyani primary school, and construction of a new building for this school, funded by Austrians Aid Afghans.

\section{Mine Clearance}

Until recently it ran a self help mine clearance programme, funded by Austrians Aid Afghans.

\section{Poultry Production}

Poultry farms in Peshawar, Nangarhar, Kabul, Parwan and Helmand Provinces where

incubators of different capacities are also built.

\section{Animal Health and Livestock Programme}

23 Veterinary clinics are being run in Nangarhar, Kunar and Laghman Provinces, funded by FAO.

\section{Agriculture}

Fruit and amenity tree nursery to replace poppy cultivation. Other agricultural programmes.

\section{Handicrafts}

Carpet weaving programmes in Kunar, Nangarhar, Laghman, Paktika and Peshawar.

\section{Industries}

Soup factory in Jalalabad.

Oil extraction plant, Jalalabad.

Incubator manufacturing in sevcral Provinces. 
AFGHANISTAN REHABILITATION AND DEVELOPMENT ORGANIZATION (ARDO)

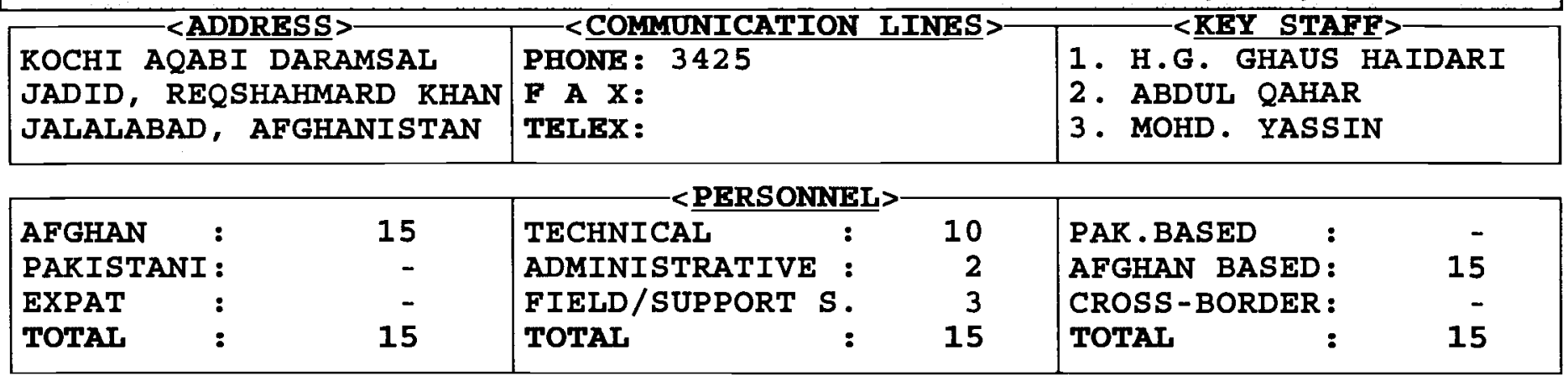

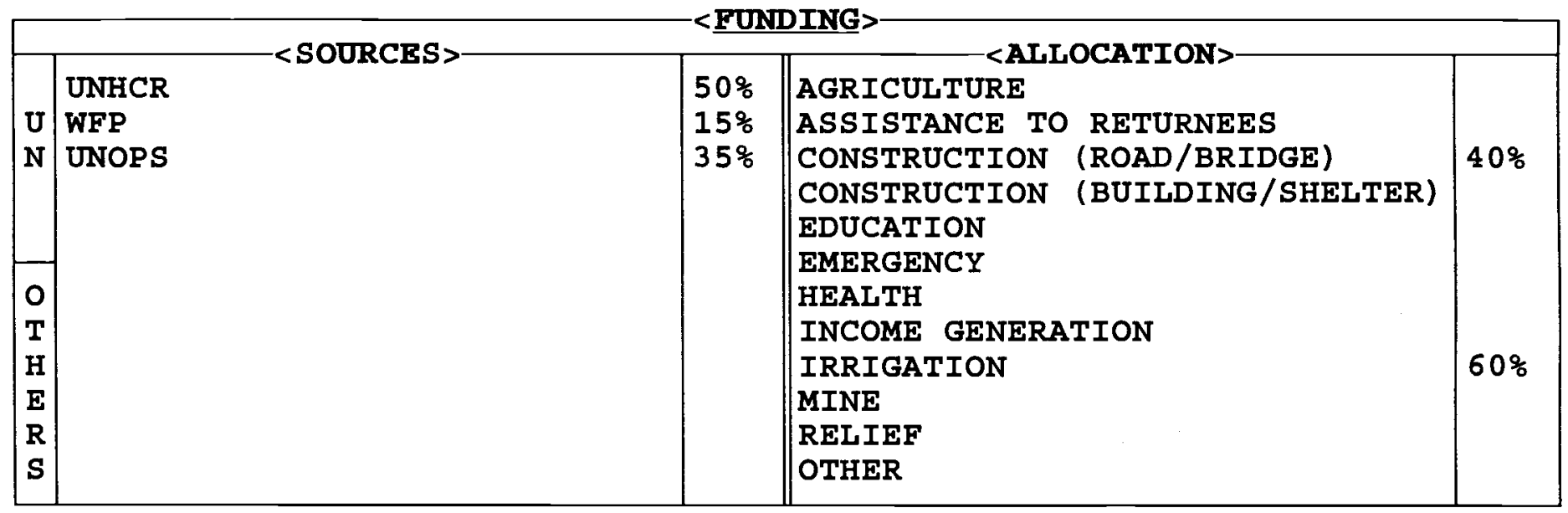

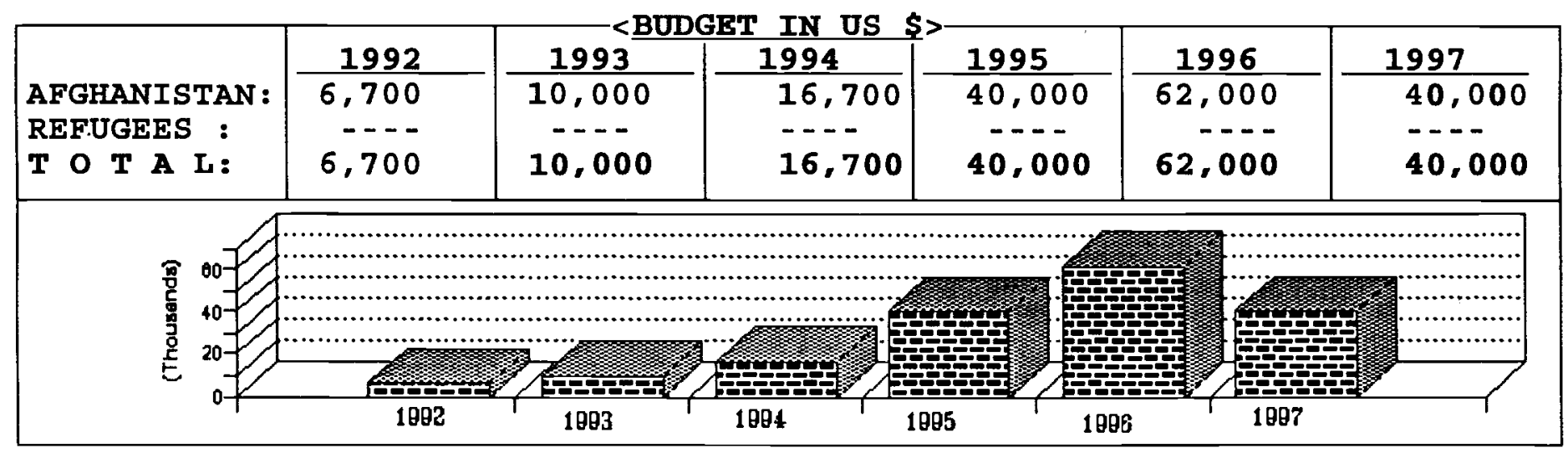

\begin{tabular}{|c|c|c|c|c|c|}
\hline PROVINCES & SECTOR & $\%$ & PROVINCES & SECTOR & $\%$ \\
\hline $\begin{array}{l}\text { BADAKSHAN } \\
\text { BADGHIS } \\
\text { BAGHLAN } \\
\text { BALKH } \\
\text { BAMYAN } \\
\text { FARAH } \\
\text { FARYAB } \\
\text { GHAZNI } \\
\text { GHOR } \\
\text { HELMAND } \\
\text { HERAT } \\
\text { JAWZJAN } \\
\text { KABUL } \\
\text { KANDAHAR } \\
\text { KAPISA }\end{array}$ & & & $\begin{array}{l}\text { KUNAR } \\
\text { KUNDUZ } \\
\text { LAGHMAN } \\
\text { LOGAR } \\
\text { NANGARHAR } \\
\text { NIMROZ } \\
\text { ORUZGAN } \\
\text { PARTEKA } \\
\text { PAKTIA } \\
\text { PARWAN } \\
\text { SAMANGAN } \\
\text { TAKHAR } \\
\text { WARDAR } \\
\text { ZABUL }\end{array}$ & $\begin{array}{l}\text { CONSTRUCTION } \\
\text { IRRIGATION } \\
\text { CONSTRUCTION } \\
\text { CONSTRUCTION }\end{array}$ & $\begin{array}{l}30 \\
35 \\
20\end{array}$ \\
\hline
\end{tabular}


AFGHANISTAN REHABILITATION

AND DEVELOPMENT ORGANIZATION

(ARDO)

ARDO is an Afghan NGO established in

March 1992.

Sectors of Operation:

\section{Construction}

In 1996 implemented various construction projects in Nangarhar, Kunar and Paktia

Provinces, funded by UNHCR.

\section{Irrigation}

In 1996 constructed irrigation systcm (intakc), funded by UNOPS. 
AFGHANISTAN REHABILITATION AND DEVELOPMENT PROGRAMME (ARDP)

$414,4 \mathrm{TH}$ FLR, GUL HAJI PLAZA, UPO BOX 937 , PESHAWAR, PARISTAN

\section{PHONE : 44750}

F A X:

TELEX :
1. DR. M SEDIQ ASIF

2. M. AMAN WAK

3. A. RAHIMAN

\begin{tabular}{|c|c|c|c|c|c|}
\hline AFGHAN & 16 & TECHNICAL : & 8 & PAR. BASED : & 3 \\
\hline PAKISTANI : & - & ADMINISTRATIVE : & 3 & AFGHAN BASED: & 12 \\
\hline EXPAT : & - & FIELD/SUPPORT S. & 5 & CROSS-BORDER : & 1 \\
\hline TOTAT & 16 & TOTAL : & 16 & TOTAL : & 16 \\
\hline
\end{tabular}

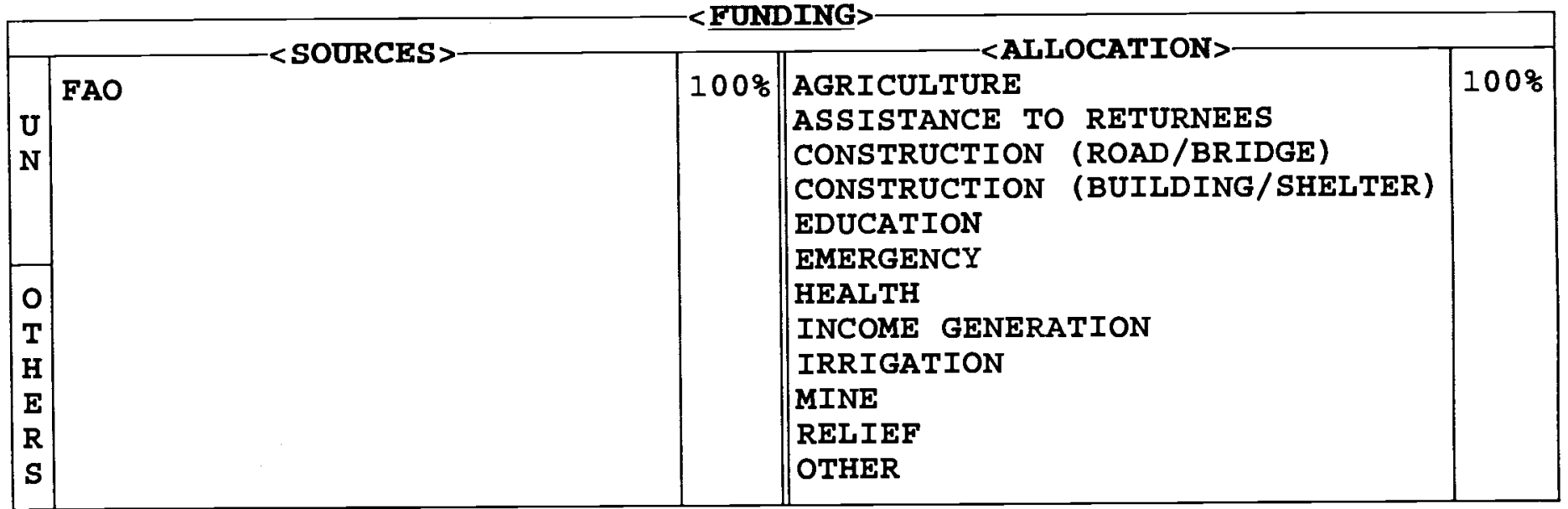

\begin{tabular}{|c|c|c|c|c|c|c|}
\hline & 1992 & 1993 & 1994 & 1995 & 1996 & 1997 \\
\hline AFGHANISTAN : & 50,000 & 48,000 & 55,000 & 50,000 & 50,000 & 30,000 \\
\hline REFUGEES : & --- & --- & --- & --- & ---- & $---\overline{-}$ \\
\hline $\mathbf{T} O \mathbf{T} \mathbf{A}=$ & 50,000 & 48,000 & 55,000 & 50,000 & 50,000 & 30,000 \\
\hline
\end{tabular}

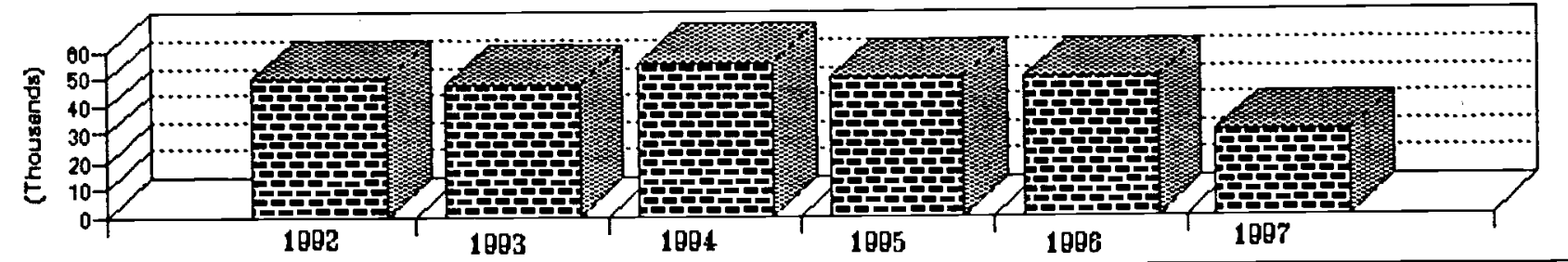

<TARGET PROVINCES IN AFGHANISTAN>

\begin{tabular}{|c|c|c|c|c|c|}
\hline PROVINCES & SECTOR & $\%$ & PROVINCES & SECTOR & $\%$ \\
\hline $\begin{array}{l}\text { BADAKSHAN } \\
\text { BADGHIS } \\
\text { BAGHLAN } \\
\text { BALKH } \\
\text { BAMYAN } \\
\text { FARAH } \\
\text { FARYAB } \\
\text { GHAZNI } \\
\text { GHOR } \\
\text { HELMAND } \\
\text { HERAT } \\
\text { JAWZJAN } \\
\text { RABUL } \\
\text { KANDAHAR } \\
\text { KAPISA }\end{array}$ & & & \begin{tabular}{|l|} 
KUNAR \\
KUNDUZ \\
LAGHMAN \\
LOGAR \\
NANGARHAR \\
NIMROZ \\
ORUZGAN \\
PAKTERA \\
PAKTIA \\
PARWAN \\
SAMANGAN \\
TAKHAR \\
WARDAR \\
ZABUL
\end{tabular} & $\begin{array}{l}\text { AGRICULTURE/HORT } \\
\text { IRRIGATION/HORT } \\
\text { IRRIGATION/HORT }\end{array}$ & $\begin{array}{l}50 \\
25 \\
25\end{array}$ \\
\hline
\end{tabular}




\section{AFGHANISTAN REHABILITATION \& DEVELOPMENT PROGRAM}

(ARDP)

ARDP, an Afghan NGO, was cstablished in 1988

ARDP has no specific work area in Afghanistan, but is presently working in the Provinces of Nangarhar, Paktia, Paktika, Kunar, Nooristan, Kabul and Kandahar.

\section{Sectors of Operation}

ARDP have undertaken projects in irrigation, wheat. nurseries, fertilizer, and agriculture.

\section{Further Information}

ARDP is registered with the Nangarhar Shura and the Government of Pakistan and has an NOC certificate from UNOCHA. 
AFGHAN RECONSTRUCTION AND DEVELOPMEAT UNIT (ARDU)

CHARAHI ANSARI, SHAHR - I -NAW, KABUL, AFGHANISTAN
PHONE: 34261

F A X:

TELEX :
1.

1. ENG. ZIA AHMAD

2. M. ASHRAF

3. MOHD HAROON

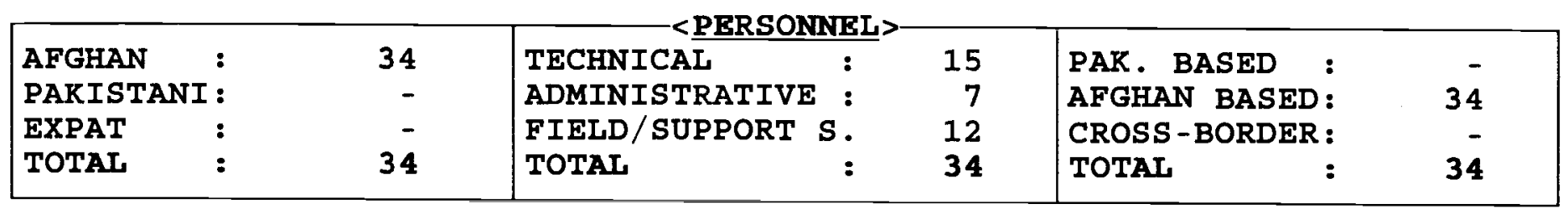

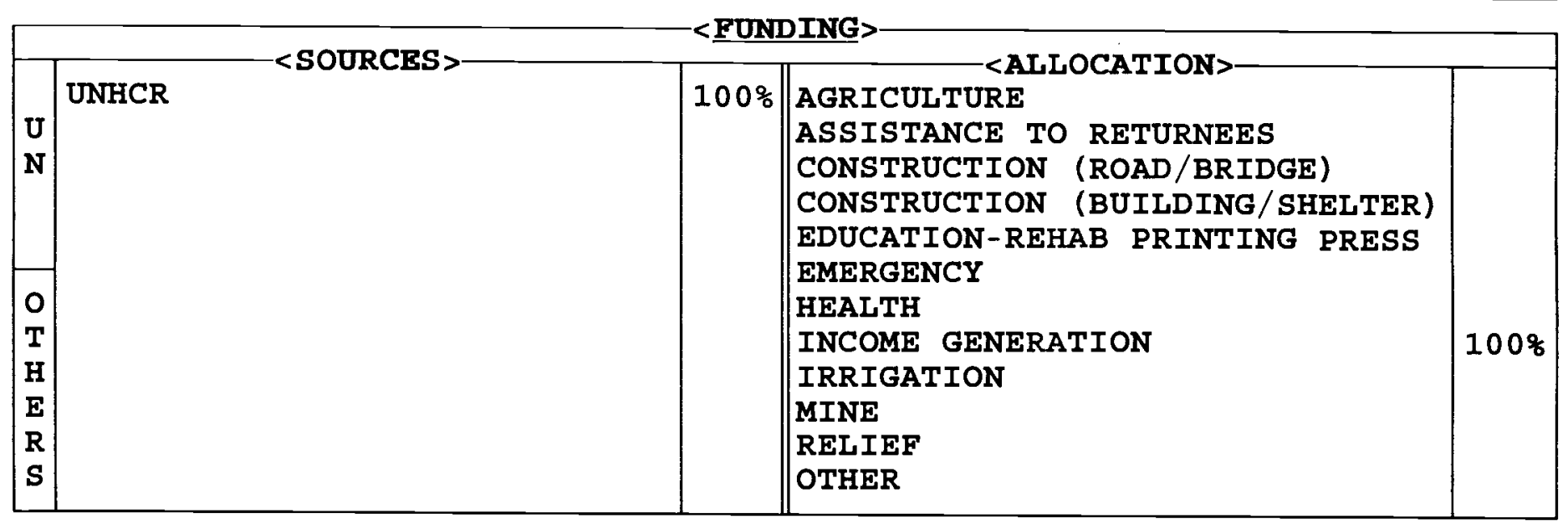

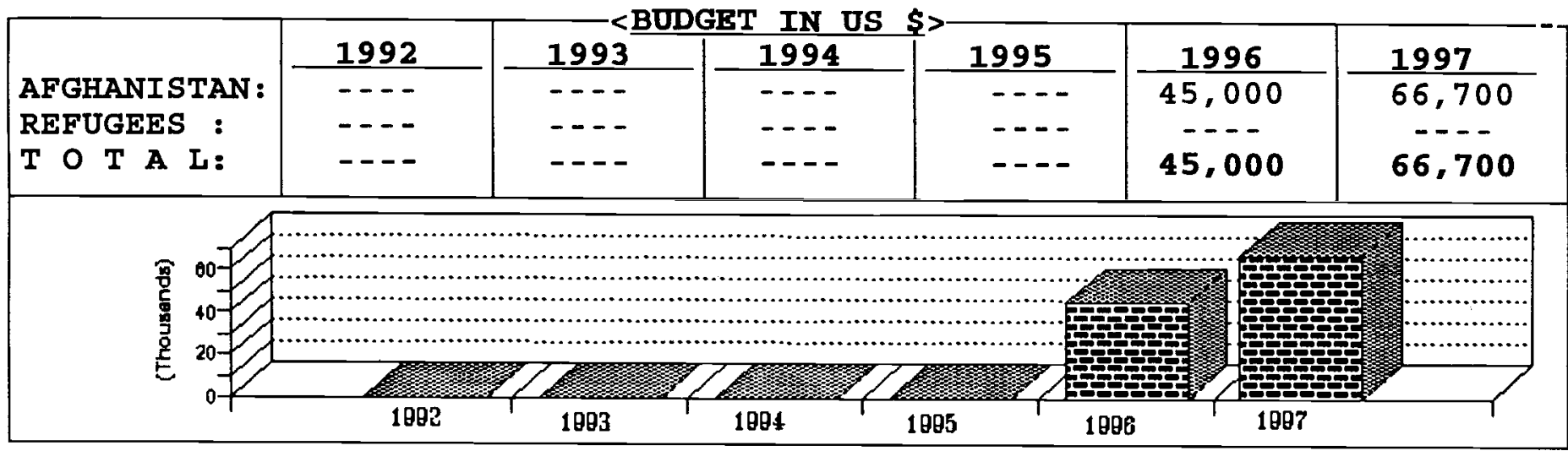

\begin{tabular}{|c|c|c|c|c|c|}
\hline PROVINCES & SECTOR & 8 & PROVINCES & SECTOR & $\%$ \\
\hline $\begin{array}{l}\text { BADAKSHAN } \\
\text { BADGHIS } \\
\text { BAGHLAN } \\
\text { BALKH } \\
\text { BAMYAN } \\
\text { FARAH } \\
\text { FARYAB } \\
\text { GHAZNI } \\
\text { GHOR } \\
\text { HELMAND } \\
\text { HERAT } \\
\text { JAWZJAN } \\
\text { RABUL } \\
\text { KANDAHAR } \\
\text { RAPISA }\end{array}$ & INCOME GENERATION & 100 & $\begin{array}{l}\text { KUNAR } \\
\text { KUNDUZ } \\
\text { LAGHMAN } \\
\text { LOGAR } \\
\text { NANGARHAR } \\
\text { NIMROZ } \\
\text { ORUZGAN } \\
\text { PAKTEKA } \\
\text { PAKTIA } \\
\text { PARWAN } \\
\text { SAMANGAN } \\
\text { TAKHAR } \\
\text { WARDAK } \\
\text { ZABUL }\end{array}$ & & \\
\hline
\end{tabular}




\section{AFGHAN RECONSTRUCTION AND DEVELOPMENT UNIT \\ (ARDU)}

ARDU is a non-governmental, non-partisan, non-political Afghan organisation, founded in February 1995.

The organisation works in the Provinces where least relicf has been extended. The staff are: agriculturists, engineers and administrators all with vast experience in their respective fields.

The aim of the organisation is to contributc to the development and reconstruction of Afghanistan

\section{Construction}

Reconstruction of infrastructurcs, irrigation systcm, rchabilitation of access road and shelters.

\section{Agriculture}

- Multiplication and distribution of improved vegetable sceds;

- Distribution of fertilizers, agrochemical and farm machinery;

- Bee keeping, poultry farming, silk worm, fish farming and mushroom cultivation;

- Rehabilitation of nurseries.

\section{Income generation}

- Provide vocational training to vulnerable and poor families;

- Provide job opportunities.

ARDU is registered with ANCB and the Ministry of Planning, Kabul. Most of the funding of the organisation comes from UN agencics and Canada Fund. 
AGENCY FOR REHAB. AND ENERGY CONSERVATION IN AFGHANISTAN (AREA) ACBAR

<ADDRESS >

$17-E$ ABDARA ROAD

UNIVERSITY TOWN

PESHAWAR, PAKISTAN
PHONE : $41993 / 45417$

F A X: 41993

email:area@pas.comsats.
1. ENG RAFAAT B LUDIN

2. S M HASHIMI

3. FARIDOON DUADZAI

\begin{tabular}{|c|c|c|}
\hline AFGHAN & 727 & TECHNTCAT \\
\hline PAKISTANI : & 1 & ADMINISTRATIVE \\
\hline EXPAT : & 1 & FIELD/SUPPORT S. \\
\hline TOTAL & 729 & TOTAL : \\
\hline
\end{tabular}

SOURCES

U UNI CEF / UNDP / UNOPS

$\mathrm{N}$

O SOS-PG/HELP

$T$ HELP GERMANY

$\mathrm{H}$ SV

E ICRC

R GTZ/SCA

S SELF FUNDING

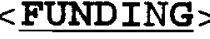

\begin{tabular}{r||l}
4 & AGRICULTURE \\
$4 \%$ & ASSISTANCE TO RETURNEES \\
& CONSTRUCTION (ROAD/BRIDGE) \\
CONSTRUCTION (BUILDING/SHELTER) \\
EDUCATION \\
$5 \%$ & EMERGENCY \\
$57 \%$ & HEALTH \\
$10 \%$ & INCOME GENERATION \\
$2 \%$ & IRRIGATION \\
$2 \%$ & MINE \\
$20 \%$ & RELIEF \\
\hline
\end{tabular}

$\begin{array}{lr}\text { PAK. BASED : } & 28 \\ \text { AFGHAN BASED: } & 701 \\ \text { CROSS-BORDER : } & - \\ \text { TOTAL : } & 729\end{array}$

\begin{tabular}{|c|c|c|c|c|c|c|}
\hline & 1992 & 1993 & 1994 & 1995 & 1996 & 1997 \\
\hline AFGHANISTAN : & 228,000 & 85,000 & 400,000 & 477,600 & 605,700 & 640,900 \\
\hline REFUGEES : & 330,000 & 243,000 & ---- & ---- & --- & --- \\
\hline T O T A L: & 558,000 & 328,000 & 400,000 & 477,600 & 605,700 & 640,900 \\
\hline
\end{tabular}

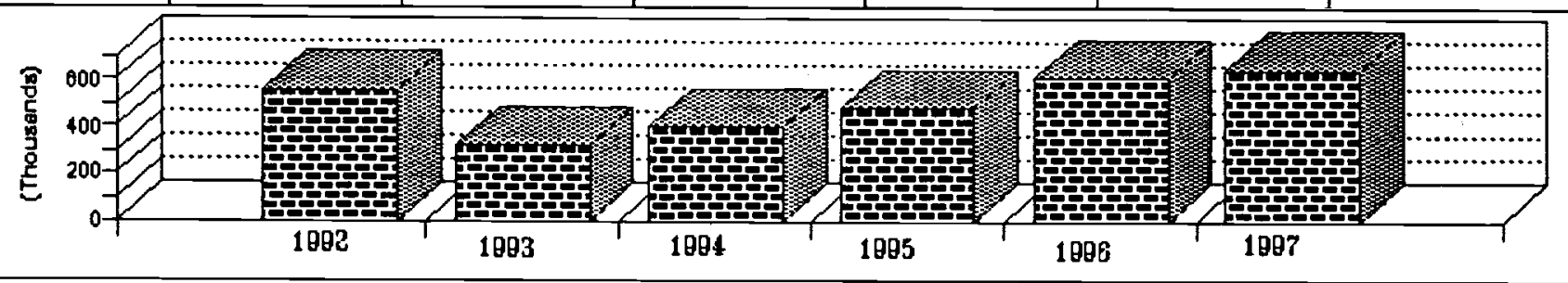

\begin{tabular}{|c|c|c|c|c|c|}
\hline PROVINCES & SECTOR & $\%$ & PROVINCES & SECTOR & $\%$ \\
\hline $\begin{array}{l}\text { BADAKSHAN } \\
\text { BADGHIS } \\
\text { BAGHLAN } \\
\text { BALKH } \\
\text { BAMYAN } \\
\text { FARAH } \\
\text { FARYAB } \\
\text { GHAZNI } \\
\text { GHOR } \\
\text { HELMAND } \\
\text { HERAT } \\
\text { JAWZJAN } \\
\text { KABUL } \\
\text { KANDAHAR } \\
\text { KAPISA }\end{array}$ & $\begin{array}{l}\text { IRRIGATION } \\
\text { ALT TECH } \\
\text { CONST/AGRIC/IN GEN/ } \\
\text { SHLTR/WS } \\
\text { CONST/ALT TECH/IN GEN }\end{array}$ & $\begin{array}{l}13 \\
71\end{array}$ & $\begin{array}{l}\text { KUNAR } \\
\text { KUNDUZ } \\
\text { LAGHMAN } \\
\text { LOGAR } \\
\text { NANGARHAR } \\
\text { NIMROZ } \\
\text { ORUZGAN } \\
\text { PAKTEKA } \\
\text { PAKTIA } \\
\text { PARWAN } \\
\text { SAMANGAN } \\
\text { TAKHAR } \\
\text { WARDAK } \\
\text { ZABUL } \\
\text { PAKISTAN }\end{array}$ & $\begin{array}{l}\text { CONSTRUCTION } \\
\text { CONSTRUCTION } \\
\text { CONST/ALT TECH/COMDEV } \\
\text { ALT . TECH }\end{array}$ & $\begin{array}{r}1 \\
1 \\
12\end{array}$ \\
\hline
\end{tabular}




\section{AGENCY FOR REHABILITATION AND ENERGY-CONSERVATION IN AFGHANISTAN (AREA)}

\begin{abstract}
AREA is the continuation of a GTZ project called Domestic Energy Saving Project (DESP), Established in 1984, the aim of DESP was to assist in the reduction of pressure on the NWFP bio-mass resources, by introduction of wood saving cooking, baking and heating systems among the Afghan refugees. In 1992, DESP started cross-border activities, which led to an expansion of its work.
\end{abstract}

In 1994, problems with the Pakistani counterpart of GTZ led to the closure of DESP. In the absence of a bilateral agreement with the Afghan Government, GTZ was unable to operate inside Afghanistan. In order to maintain the experience gained and the continuation of the programme, AREA was created. Soon after its creation, AREA was able to stand on its own feet and continue the activities independent from its GTZ initiator.

The main objective of AREA was to contribute to rehabilitation and development of Afghanistan in an environmentally sound manner. Projects were designed and implemented, which directly or indirectly contributed towards wood saving, energyconservation and environmental protection.

In order to strengthen the institutional character, AREA established three main bodies of control:

\footnotetext{
- the General Assembly (the policy making organ);

- $\quad$ the Managing Director (the operative organ); and

- $\quad$ the Board of Trustees (the advisory and control organ).
}

The Board of Trustees presently consists of 3 Afghan and 4 expatriate members. The Afghan members are elected by the General Assembly and the expatriate members represent donor and other international organizations. The following organizations are represented as Trustees:

GTZ, DACAAR, Afghanaid, HELP-Germany.
During 1995, with the possibility of receiving semi-direct EU funding, AREA planned to commence a new phase of extended operations in Afghanistan. The expected annual budget is ECU 1 million for projects in Herat and Kandahar Provinces. Furthermore, through a more intensive cooperation with HELPGermany AREA hopes to increase its fund raising capabilities in Germany, and thus improve its work in Afghanistan.

Keeping in mind the long term plans, to achieve 100 percent self-sufficiency, AREA will continue in its chosen field. It is with a hope that through the continued cooperation between the communities and the agencies working in Afghanistan that AREA will be able to continue its activities in the years to come. 
AFGHANISTAN RECONSTRUCTION ASSOCIATION (*AREA*)

\begin{tabular}{|l|l|l|}
\hline TORKHAM ADA, BEYOND & PHONE: & \multicolumn{1}{|c|}{$<$ COMMY STAFF } \\
MEDICAL FACULTY, & F A X: & 1. MOHAMMAD YOUSUF \\
JALALABAD, AFGHANISTAN & TELEX: & 2. ENG. MOHAMMAD ISMAIL \\
\hline
\end{tabular}

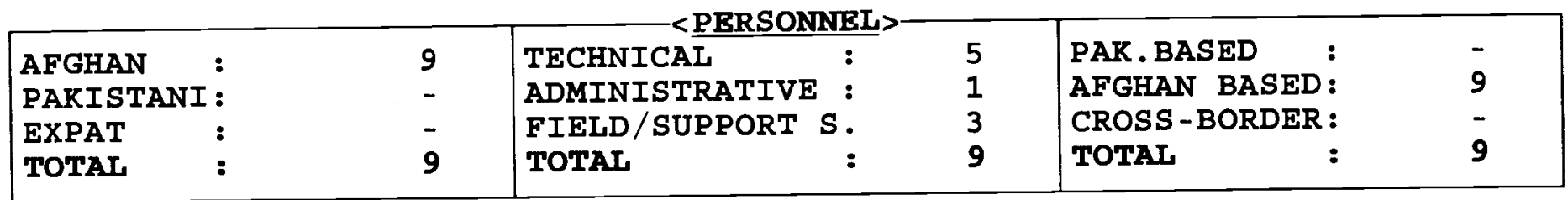

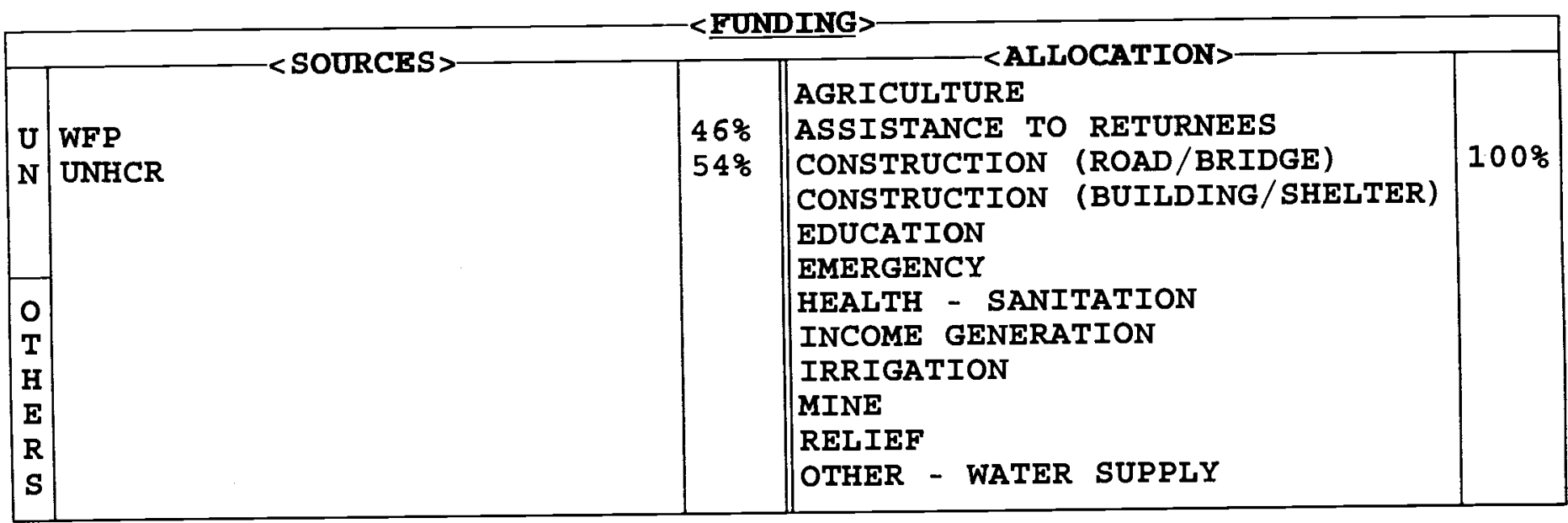

\begin{tabular}{|c|c|c|c|c|c|c|}
\hline & 1992 & 1993 & 1994 & 1995 & 1996 & 1997 \\
\hline AFGHANISTAN : & 100,000 & 40,000 & 10,000 & 19,700 & 87,000 & 16,800 \\
\hline REFUGEES : & $-\overline{-1}$ & $-\overline{-}$ & $\overline{10}$ & $\overline{19}-\overline{700}$ & 87.000 & 16.800 \\
\hline T A $\mathbf{I}:$ & 100,000 & 40,000 & & & & \\
\hline
\end{tabular}

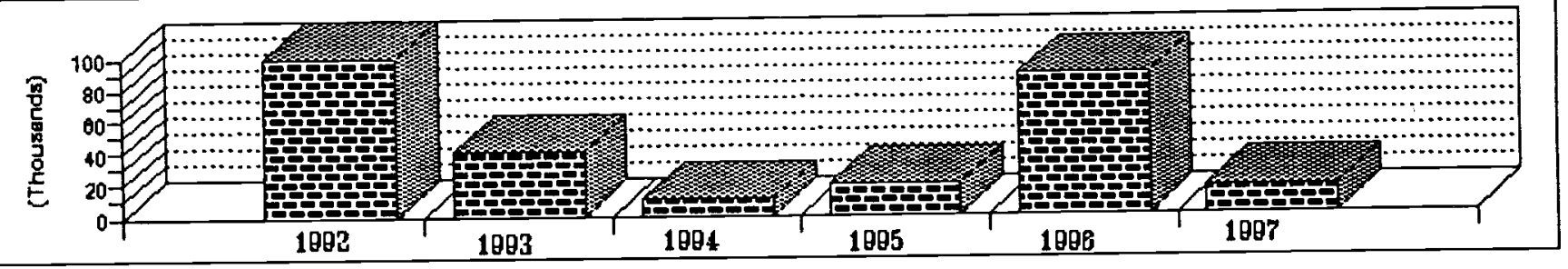

\begin{tabular}{|c|c|c|c|c|c|}
\hline PROVINCES & SECTOR & $\%$ & PROVINCES & SECTOR & $\%$ \\
\hline $\begin{array}{l}\text { BADAKSHAN } \\
\text { BADGHIS } \\
\text { BAGHLAN } \\
\text { BALKH } \\
\text { BAMYAN } \\
\text { FARAH } \\
\text { FARYAB } \\
\text { GHAZNI } \\
\text { GHOR } \\
\text { HELMAND } \\
\text { HERAT } \\
\text { JAWZJAN } \\
\text { KABUL } \\
\text { KANDAHAR } \\
\text { KAPISA }\end{array}$ & & & \begin{tabular}{|l|} 
KUNAR \\
KUNDUZ \\
LAGHMAN \\
LOGAR \\
NANGARHAR \\
NIMROZ \\
ORUZGAN \\
PAKTEKA \\
PAKTIA \\
PARWAN \\
SAMANGAN \\
TAKHAR \\
WARDAK \\
ZABUL
\end{tabular} & CONSTRUCTION & 100 \\
\hline
\end{tabular}




\section{AFGHAN RECONSTRUCTION \\ ASSOCIATION \\ (AReA)}

ARcA is an Afghan NGO which was set up in 1990 to undertake reconstruction and relief projects to facilitate the repatriation of refugees. The agency provides technical consultation for planning and building of architectural, civil and agricultural projects.

The agency works in all parts of Afghanistan but is particularly intercsted in the central Provinces.

AReA has specialized personnel in construction, engineering, agriculture, health, irrigation and education.

Projects undertaken by AReA so far include road repair, culvert and ring construction, installation of hand pumps and repair of several mosques, drug control and sanitation projects.

Several proposals have been designed and submitted to donor organisations. 
AFGHAN RELIEF FOUNDATION (ARF)

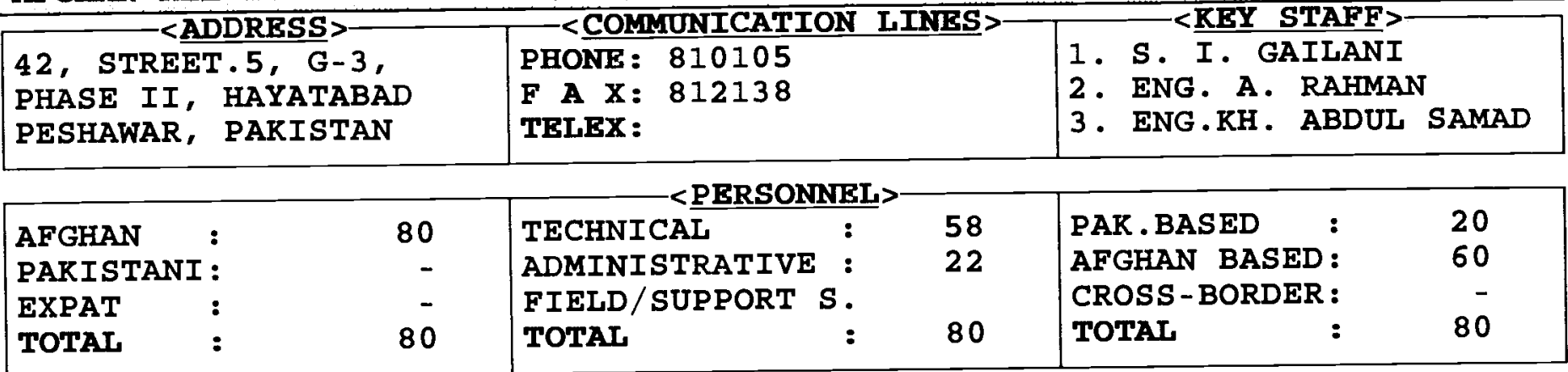

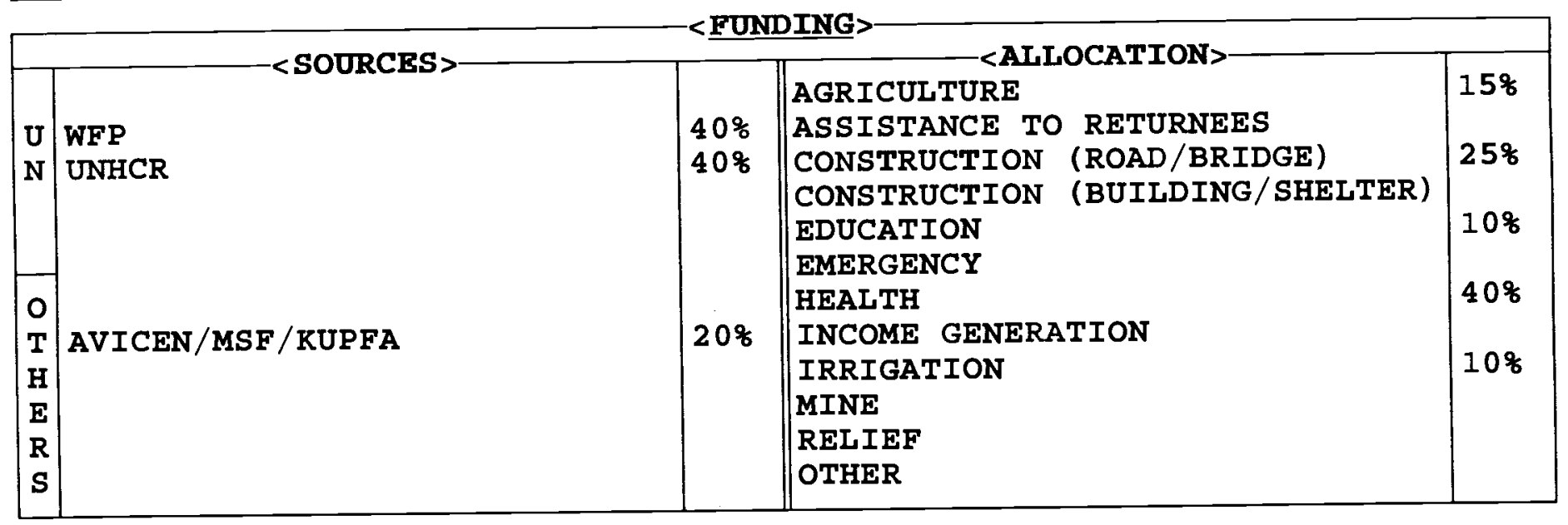

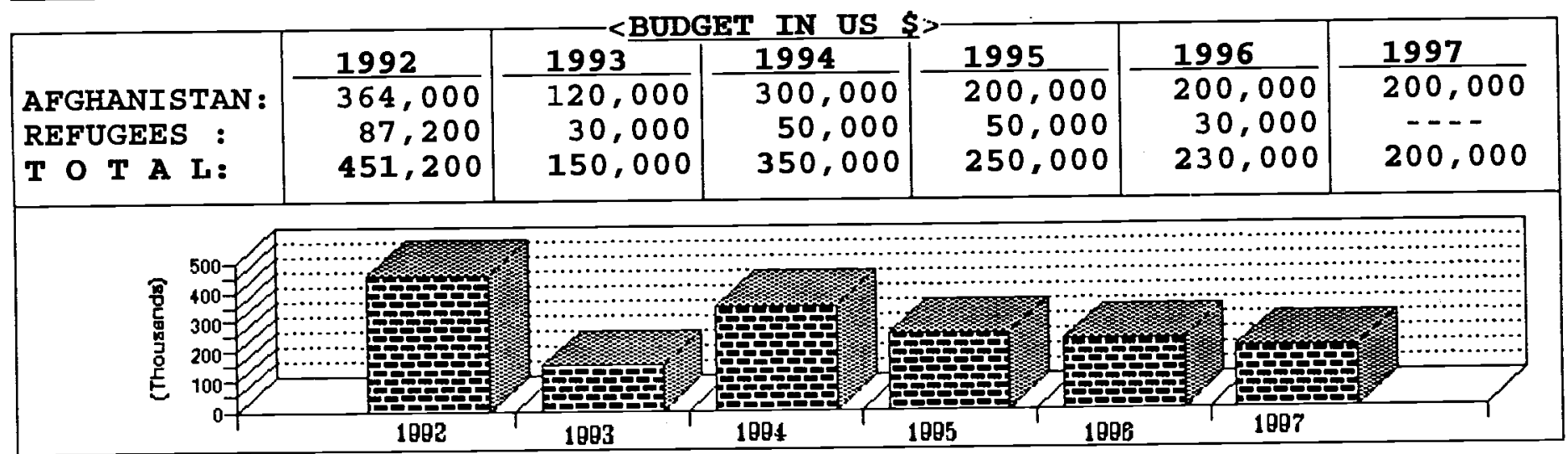

\begin{tabular}{|c|c|c|c|c|c|}
\hline PROVINCES & SECTOR & $\frac{q}{0}$ & PROVINCES & SECTOR & 8 \\
\hline $\begin{array}{l}\text { BADAKSHAN } \\
\text { BADGHIS } \\
\text { BAGHLAN } \\
\text { BALKH } \\
\text { BAMYAN } \\
\text { FARAH } \\
\text { FARYAB } \\
\text { GHAZNI } \\
\text { GHOR } \\
\text { HELMAND } \\
\text { HERAT } \\
\text { JAWZJAN } \\
\text { KABUL } \\
\text { KANDAHAR } \\
\text { KAPISA }\end{array}$ & HEALTH & 30 & $\begin{array}{l}\text { KUNAR } \\
\text { KUNDUZ } \\
\text { LAGHMAN } \\
\text { LOGAR } \\
\text { NANGARHAR } \\
\text { NIMROZ } \\
\text { ORUZGAN } \\
\text { PARTEKA } \\
\text { PAKTIA } \\
\text { PARWAN } \\
\text { SAMANGAN } \\
\text { TAKHAR } \\
\text { WARDAR } \\
\text { ZABUL }\end{array}$ & $\begin{array}{l}\text { AGRICULTURE / EDUCATION } \\
\text { AGRICULTURE } \\
\text { AGRICULTURE / EDUCATION } \\
\text { CONSTRUCTION, AGRI , IRR }\end{array}$ & $\begin{array}{l}10 \\
10 \\
10\end{array}$ \\
\hline
\end{tabular}




\section{AFGHAN RELIEF FOUNDATION}

(ARF)

An Afghan run non-governmental organisation, the ARF was founded in 1986 with the support of Help the Afghans Foundation (HAF).

ARF started its relief work for the destitutc peoplc of Afghanistan by providing food commodities like wheat, rice, edible oil, tca, soap etc. Later on the organisation established an $\mathrm{MCH}$ clinic. This clinic is run by 3 doctors, 5 nurses, 2 laboratory assistants and 14 support staff. The clinic is situated in Peshawar and assists some 100-150 outpatients per day.

In Afghanistan ARF has provided emergency aid in various Provinces including Kabul.

In addition to relicf activities since 1991, ARF has implemented rehabilitation programmes involving engineering. The activities were repairing, reconstruction and construction of irrigation systems, roads and buildings and including several projects inside Afghanistan.

In 1993 ARF established a primary school. This school was later promoted to a high school and now has 1200 students.

In 1992 ARF established an ob/gyn hospital in Kabul city. This hospital is run by 29 technical and 11 administrative staff. Approximately 300 patients are seen every day.

ARF also established an agriculture section in 1993. This section raised chicks for distribution among local people and returnees. Seed and fertilizer distribution took place in Laghman and Nangarhar Provinces.

\section{Main aims:}

- to take an active part in more effective and efficient ways to implement projects;

-to develop new ideas for rehabilitation projects by qualified and experienced Afghans 
AUTHORITY FOR THE RECONST. OF INPRASTRUCTURE OF AFGHANISTAN (ARIA) ANCB 57, GULSHAN IQBAL TOWN UNIVERSITY ROAD PESHAWAR, PAKISTAN

PHONE : 840539

F A X:

TELEX :
1. DR FAROOQ AZAM

2. ENG $M$ JAN

3. J YOUSOFZAI

\begin{tabular}{|c|c|c|c|c|c|}
\hline $\begin{array}{l}\text { AFGHAN : } \\
\text { PARISTANI : } \\
\text { EXPAT : } \\
\text { TOTAL : }\end{array}$ & $\begin{array}{r}11 \\
- \\
- \\
11\end{array}$ & $\begin{array}{l}\text { TECHNICAL : } \\
\text { ADMINISTRATIVE : } \\
\text { FIELD/SUPPORT S: } \\
\text { TOTAL }\end{array}$ & $\begin{array}{r}6 \\
2 \\
3 \\
11\end{array}$ & $\begin{array}{l}\text { PAK. BASED : } \\
\text { AFGHAN BASED : } \\
\text { CROSS -BORDER : } \\
\text { TOTAL : }\end{array}$ & $\begin{array}{r}5 \\
6 \\
- \\
11\end{array}$ \\
\hline
\end{tabular}

\begin{tabular}{|c|c|c|c|c|}
\hline \multirow{7}{*}{$\begin{array}{l}\mathbf{U} \\
\mathbf{N}\end{array}$} & \multirow{6}{*}{ FAO } & \multirow{7}{*}{$52 \%$} & CALLUCAIIUN & \\
\hline & & & AGRICULTURE & \multirow{6}{*}{$20 \%$} \\
\hline & & & ASSISTANCE TO RETURNEES & \\
\hline & & & CONSTRUCTION（ROAD/BRIDGE) & \\
\hline & & & CONSTRUCTION (BUILDING/SHELTER) & \\
\hline & & & EDUCATION & \\
\hline & \multirow{7}{*}{ SELF } & & EMERGENCY & \\
\hline 0 & & \multirow[t]{6}{*}{$48 \%$} & HEALTH & \\
\hline $\mathbf{T}$ & & & INCOME GENERATION & \\
\hline $\mathbf{H}$ & & & IRRIGATION & $80 \%$ \\
\hline $\mathbf{E}$ & & & MINE & \\
\hline $\mathbf{R}$ & & & RELIEF & \\
\hline $\mathbf{S}$ & & & OTHER & \\
\hline
\end{tabular}

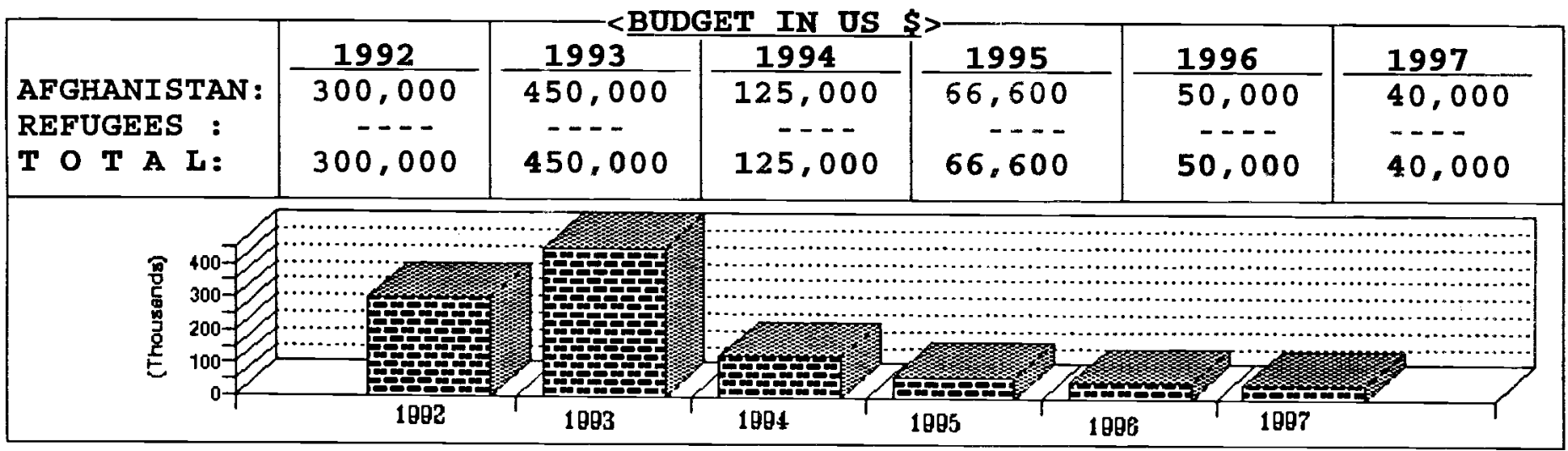

\begin{tabular}{|c|c|c|c|c|c|}
\hline PROVINCES & SECTOR & $\%$ & PROVINCES & SECTOR & $\%$ \\
\hline $\begin{array}{l}\text { BADARSHAN } \\
\text { BADGHIS } \\
\text { BAGHLAN } \\
\text { BALKH } \\
\text { BAMYAN } \\
\text { FARAH } \\
\text { FARYAB } \\
\text { GHAZNI } \\
\text { GHOR } \\
\text { HELMAND } \\
\text { HERAT } \\
\text { JAWZJAN } \\
\text { KABUL } \\
\text { KANDAHAR } \\
\text { KAPISA }\end{array}$ & 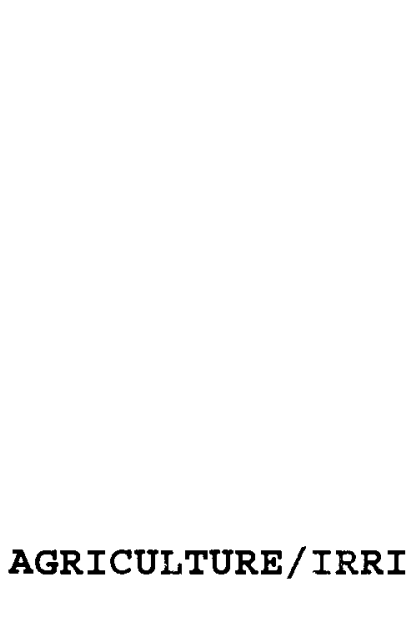 & 35 & $\begin{array}{l}\text { KUNAR } \\
\text { KUNDUZ } \\
\text { LAGHMAN } \\
\text { LOGAR } \\
\text { NANGARHAR } \\
\text { NIMROZ } \\
\text { ORUZGAN } \\
\text { PAKTEKA } \\
\text { PAKTIA } \\
\text { PARWAN } \\
\text { SAMANGAN } \\
\text { TAKHAR } \\
\text { WARDAK } \\
\text { ZABUL } \\
\text { REFUGEES }\end{array}$ & IRRIGATION & 65 \\
\hline
\end{tabular}




\section{AUTHORITY FOR THE RECONSTRUCTION OF INFRASTRUCTURE OF AFGHANISTAN (ARIA)}

Established in September, 1991 ARIA was an initiative of Dr. Farouq Azam, a former Minister of Education.

The Agency's major aim is to establish an organisation capable of implementing rehabilitation projects in Afghanistan.

It's fields of activities are reconstruction, agriculture, irrigation and education; in short, infrastructure reconstruction in Afghanistan.

It's activitics also focus on;

- vocational training for disabled Afghans and others;

- conducting research on hand run machines such as water pumps, spinning machines, oil presses and animal operated mills.

In its first year, ARIA completed a boundary wall of approximately 60 Jeribs, reserved for building a training centre in Mirwais-Mina district of Kandahar Province.

Other projects in the field of reconstruction are: - rehabilitation of canals, culverts, canal intakes, bridges, road and other hydraulic structures;

- training courses for disabled Afghans in Peshawar and Kandahar.

ARIA completed 12 projects in 1993 and has ongoing community based rehabilitation and tractor lending programmes in Kandahar.

\section{Social Infrastructure}

The agency is also concerned with the peace efforts and is in touch with local Shuras in their areas of operation.

They are also working on the formulation of a suitable constitution for Afghanistan and the logistics of the Election process.

ARIA is a member of ANCB. 
AFGEAN REHABILITATION AND LOGISTICAL ORGANIZATION (ARLO) WAS (ARLS) UNIVERSITY RD TAMBOAN PESHAWAR, PAKISTAN

PHONE : 843096

$F$ A $X$ :

TELEX :
1. HAJI HAMID'N SEDIQI

2. HAJI M.SEDIQ SANGEEN 3 .

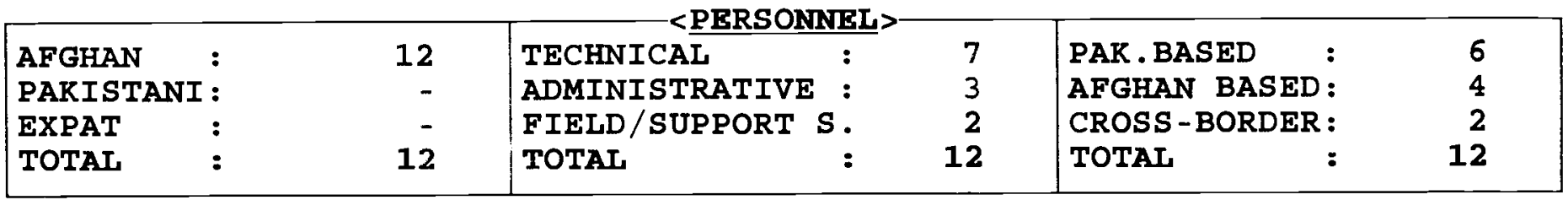

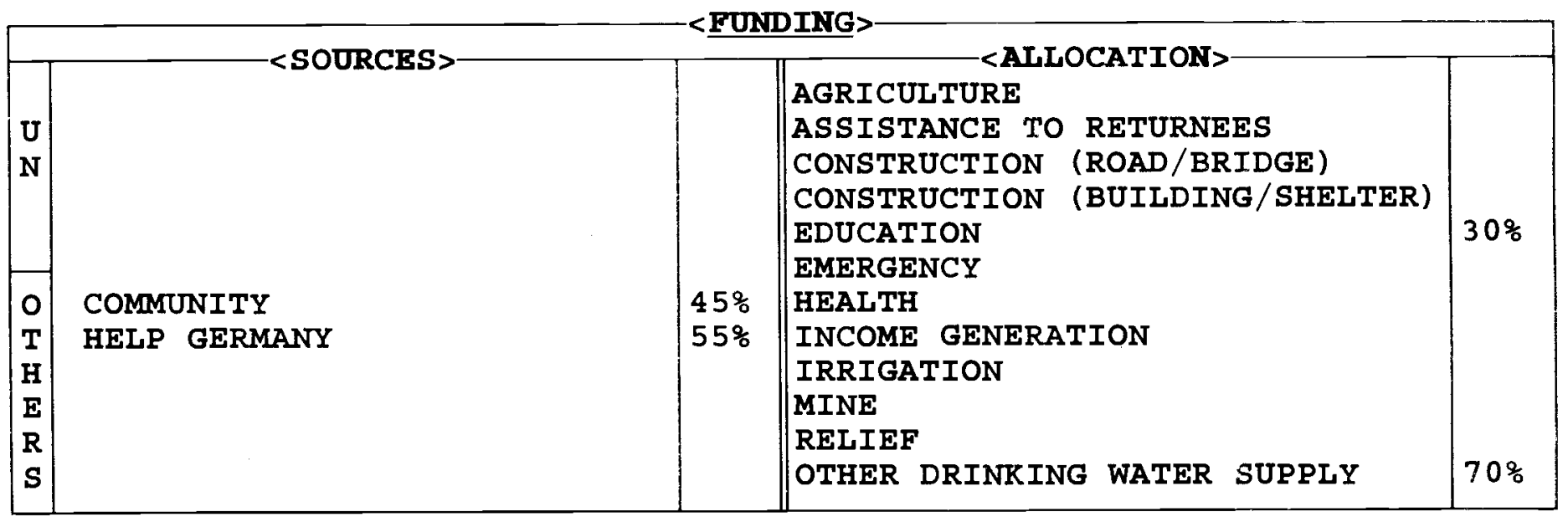

\begin{tabular}{|c|c|c|c|c|c|c|}
\hline & 1992 & 1993 & 1994 & 1995 & 1996 & 1997 \\
\hline AFGHANISTAN : & $\ldots-$ & $-\cdots$ & 105,600 & 188,800 & 18,850 & 10,000 \\
\hline REFUGEES : & --- & $-\ldots$ & $\ldots$ & --- & $\ldots .-$ & $-\cdots$ \\
\hline$T O T A L:$ & ---- & $\ldots$ & 105,600 & 105,600 & 18,850 & 10,000 \\
\hline
\end{tabular}

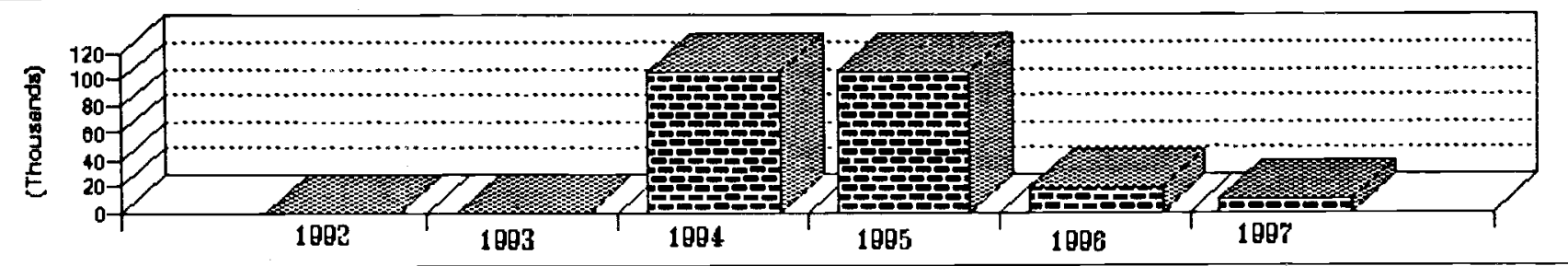

\begin{tabular}{|c|c|c|c|c|c|}
\hline PROVINCES & SECTOR & $\%$ & PROVINCES & SECTOR & $\%$ \\
\hline $\begin{array}{l}\text { BADARSHAN } \\
\text { BADGHIS } \\
\text { BAGHLAN } \\
\text { BALKH } \\
\text { BAMYAN } \\
\text { FARAH } \\
\text { FARYAB } \\
\text { GHAZNI } \\
\text { GHOR } \\
\text { HELMAND } \\
\text { HERAT } \\
\text { JAWZJAN } \\
\text { KABUL } \\
\text { KANDAHAR } \\
\text { RAPISA }\end{array}$ & & & $\begin{array}{l}\text { KUNAR } \\
\text { KUNDUZ } \\
\text { LAGHMAN } \\
\text { LOGAR } \\
\text { NANGARHAR } \\
\text { NIMROZ } \\
\text { ORUZGAN } \\
\text { PARTERA } \\
\text { PAKTIA } \\
\text { PARWAN } \\
\text { SAMANGAN } \\
\text { TAKHAR } \\
\text { WARDAK } \\
\text { ZABUL } \\
\text { REFUGEES }\end{array}$ & $\begin{array}{l}\text { EDUCATION/DRINKING } \\
\text { WATER SUPPLY }\end{array}$ & 100 \\
\hline
\end{tabular}




\section{AFGHAN REHABILITATION AND \\ LOGISTICAL ORGANIZATION \\ (ARLO)}

ARLO was founded in 1993 as a nonGovernmental, non-political, non-profit organization.

\section{Sectors of Operation}

ARLO works in several different sectors i.e. health. education, reconstruction, rehabilitation, irrigation, agriculture, social welfarc, relief, vocational training and logistical programmes in Afghan refugee camps in Peshawar and inside Afghanistan.

\section{Education}

ARLO has bcen working in education in Paktia Jaji Aryoub District, running two schools with local donations.

ARLO has been supporting schools and their staff for three years including books and teaching materials donated by the University of Nebraska, which had supported projects inside Afghanistan for many ycars.

\section{Construction}

ARLO has completed the construction of several mosques in Khost, Kunar and Nowshera Khishkai Camp, Peshawar.

\section{Relief}

ARLO has undertaken emergency food distribution projects in Displaced Persons camps in Nangarhar Province and in the refugee camps in Peshawar. 
AFGHAN RELIEF AND REHABILITATION (ARR)

$<$ ADDRESS $>-<$ COMMUNICATION LINES

$402 / 403$ GUL HAJI PLAZA

UNIVERSITY ROAD

PESHAWAR， PAKISTAN
PHONE : 843255

F A X:

email:
1. ABDUL AZIZ

2. A J SHEGIWAL

3. A S QAZIZADAH

\begin{tabular}{|c|c|c|c|c|c|}
\hline AFGHAN & 26 & TECHNICAL & 15 & PAK. BASED : & 10 \\
\hline PAKISTANI : & 1 & ADMINISTRATIVE : & 5 & AFGHAN BASED : & 17 \\
\hline EXPAT : & - & FIELD/SUPPORT S. & 7 & CROSS-BORDER : & - \\
\hline TOTAL & 27 & TOTAL : & 27 & TOTAL : & 27 \\
\hline
\end{tabular}

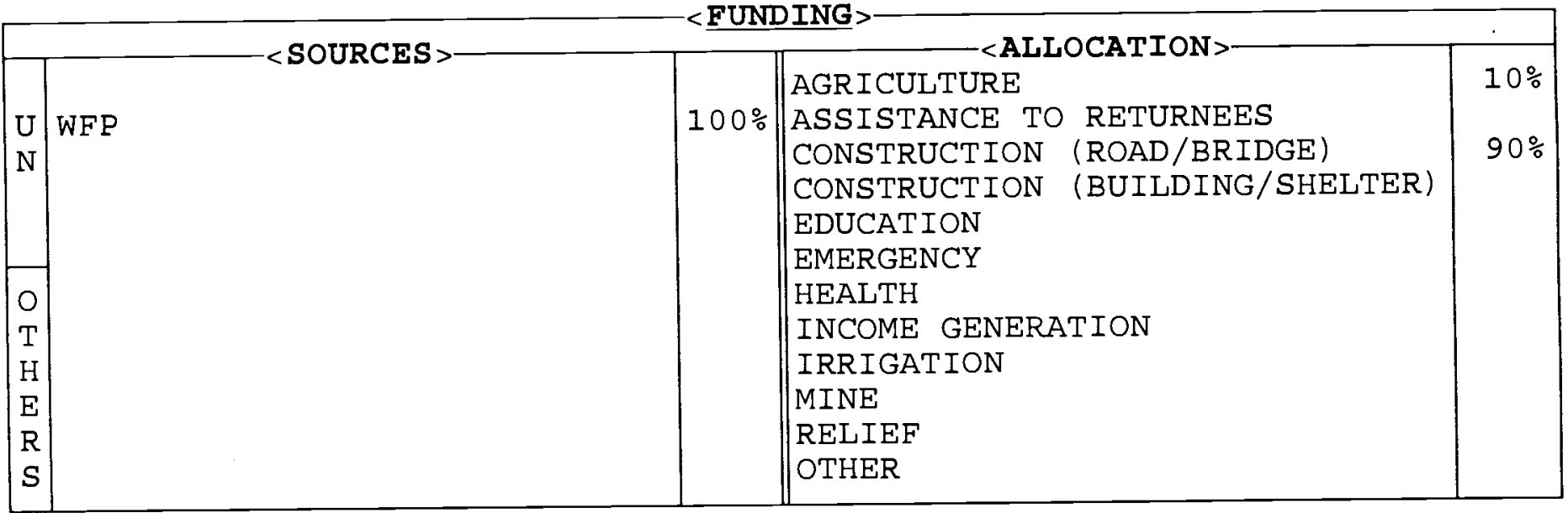

\begin{tabular}{|c|c|c|c|c|c|c|}
\hline & 1002 & 1002 & 1904 & 1995 & 1996 & 1997 \\
\hline AFGHANISTAN : & 248,700 & 586,900 & 365,000 & 68,000 & 80,000 & 50,000 \\
\hline REFUGEES : & - - . & --- & $-\ldots$ & $-\ldots$ & $\ldots$ & $\ldots$ \\
\hline$T \circ T A L:$ & 248,700 & 586,900 & 365,000 & 68,000 & 80,000 & 50,000 \\
\hline
\end{tabular}

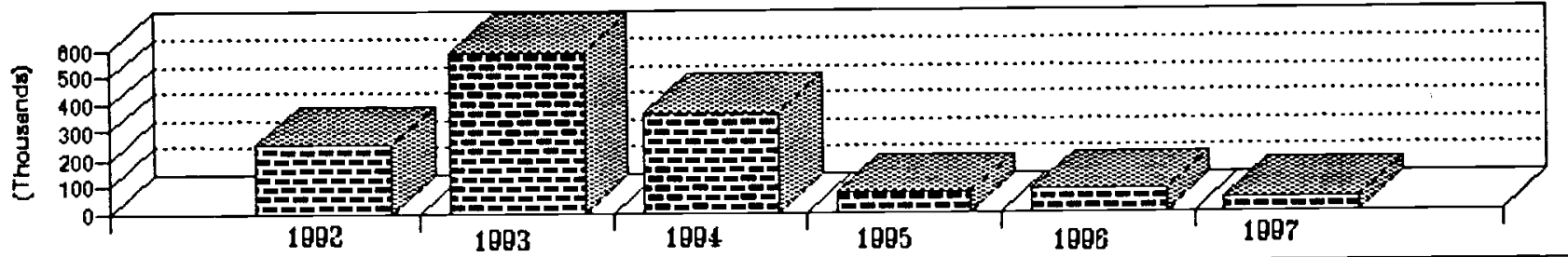

CTARGET PROVINCES IN AFGHANISTAN

\begin{tabular}{|c|c|c|c|c|c|}
\hline PROVINCES & SECTOR & $\%$ & PROVINCES & SECTOR & $\%$ \\
\hline $\begin{array}{l}\text { BADAKSHAN } \\
\text { BADGHIS } \\
\text { BAGHLAN } \\
\text { BALKH } \\
\text { BAMYAN } \\
\text { FARAH } \\
\text { FARYAB } \\
\text { GHAZNI } \\
\text { GHOR } \\
\text { HELMAND } \\
\text { HERAT } \\
\text { JAWZJAN } \\
\text { KABUL } \\
\text { KANDAHAR } \\
\text { KAPISA }\end{array}$ & & & $\begin{array}{l}\text { KUNAR } \\
\text { KUNDUZ } \\
\text { LAGHMAN } \\
\text { LOGAR } \\
\text { NANGARHAR } \\
\text { NIMROZ } \\
\text { ORUZGAN } \\
\text { PAKTEKA } \\
\text { PAKTIA } \\
\text { PARWAN } \\
\text { SAMANGAN } \\
\text { TAKHAR } \\
\text { WARDAK } \\
\text { ZABUL } \\
\text { PAKISTAN }\end{array}$ & $\begin{array}{l}\text { CONSTRUCTION (ROADS) } \\
\text { AGRICULTURE } \\
\text { CONSTRUCTION (ROADS) }\end{array}$ & 10 \\
\hline
\end{tabular}




\section{AFGHAN RELIEF AND REHABILITATION (ARR)}

ARR was founded in 1990 as an implementing organization in Quetta, Pakistan. A second office was established in Peshawar in 1991.

Each office works independently although both have the same Board of Directors.

ARR provides assistance to the people of Afghanistan through a sustainable rehabilitation programme.

\section{Sectors of operation}

- Rehabilitation of agriculture

- Irrigation systems

- Roads and public buildings

\section{Further information}

ARR's Peshawar programme covers several Provinces of Afghanistan:

Nangarhar, Laghman, Paktia, Pakteka, Khost, Ghazni and Wardak.

The Quetta office supervises work in Kandahar, Helmand and Zabul. The agency would like to expand its operations to other Provinces, depending on funding.

Staff are highly trained and experienced and include, engineers, agriculturists, administrators and support staff. 
AFGHAN STREET WORKING CHILDREN \& NEW APPROACH (ASWCNA)

\begin{tabular}{|l|l|l|}
\hline INFRONT OF INDUSTRIAL & PHONE: KABUL 33125 & 1. MUHAMAD YUSUF \\
BANK, SHAHR-I-NAW & F A X: & 2. \\
RABUL, AFGHANISTAN & TELEX: & 3. \\
\hline
\end{tabular}

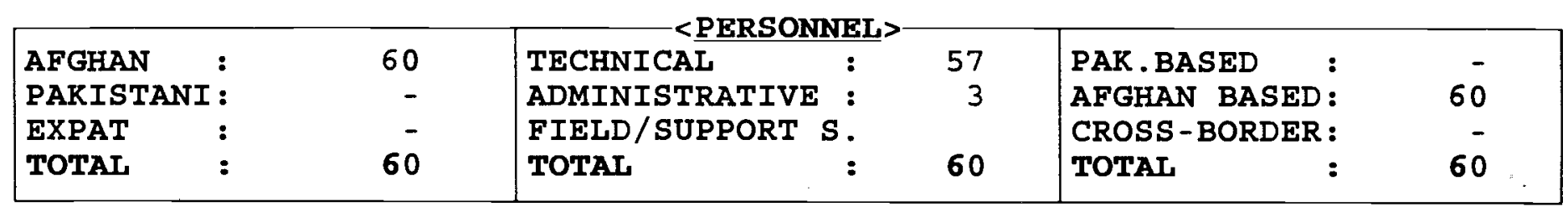

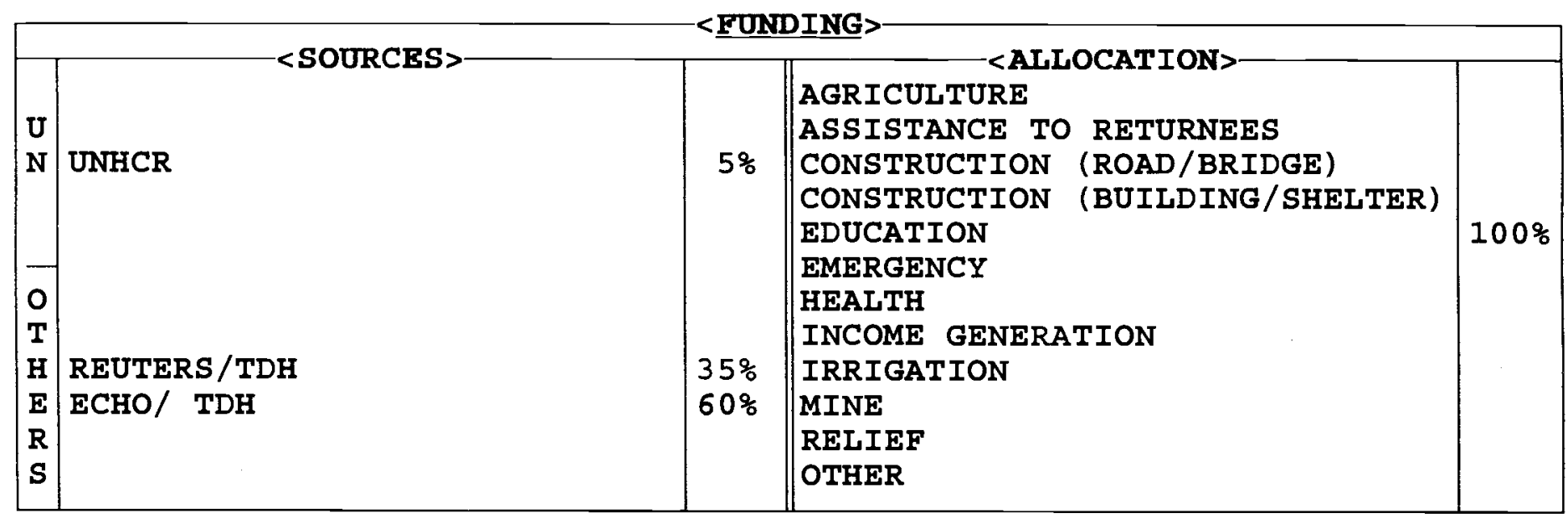

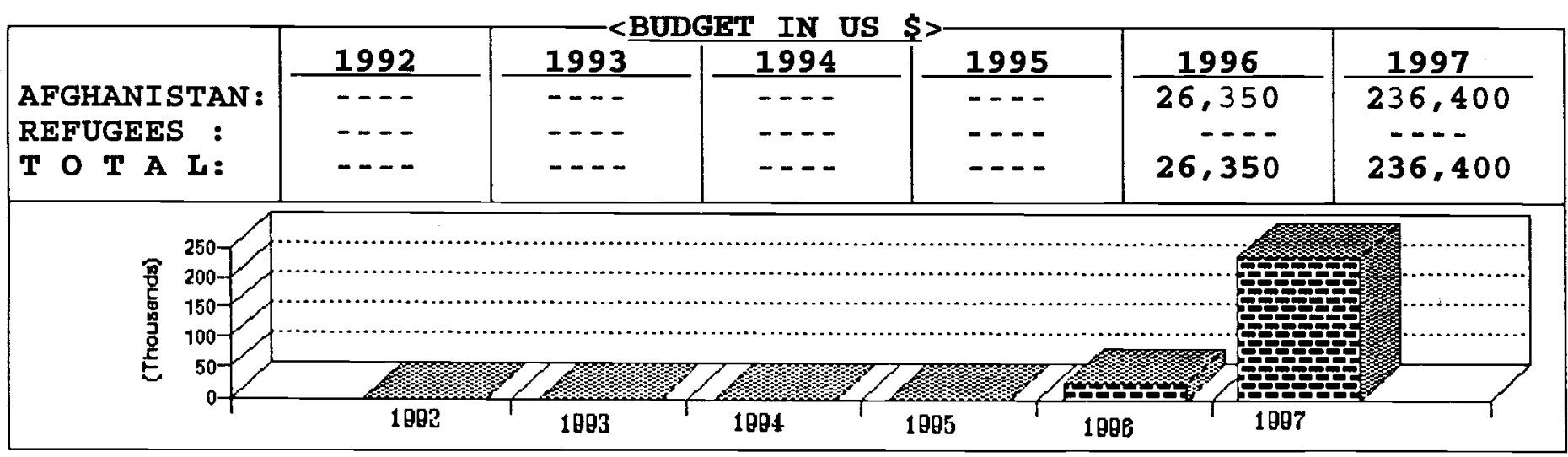

\begin{tabular}{|c|c|c|c|c|c|}
\hline PROVINCES & SECTOR & $\%$ & PROVINCES & SECTOR & $\%$ \\
\hline $\begin{array}{l}\text { BADAKSHAN } \\
\text { BADGHIS } \\
\text { BAGHLAN } \\
\text { BALKH } \\
\text { BAMYAN } \\
\text { FARAH } \\
\text { FARYAB } \\
\text { GHAZNI } \\
\text { GHOR } \\
\text { HELMAND } \\
\text { HERAT } \\
\text { JAWZJAN } \\
\text { KABUL } \\
\text { KANDAHAR } \\
\text { KAPISA }\end{array}$ & TRAINING AND FEEDING & 100 & $\begin{array}{l}\text { KUNAR } \\
\text { KUNDUZ } \\
\text { LAGHMAN } \\
\text { LOGAR } \\
\text { NANGARHAR } \\
\text { NIMROZ } \\
\text { ORUZGAN } \\
\text { PARTEKA } \\
\text { PAKTIA } \\
\text { PARWAN } \\
\text { SAMANGAN } \\
\text { TAKHAR } \\
\text { WARDAK } \\
\text { ZABUL }\end{array}$ & & \\
\hline
\end{tabular}




\section{AFGHAN STREET WORKING \\ CHILDREN AND NEW APPROACH \\ (ASWCNA)}

ASWCNA was established in Kabul in March 1995.

\section{Objectives:}

To provide 250 street working children with:

- basic pre-school and hcalth education;

- at least one nutritious meal per day;

- facilities for personal hygiene:

- a caring environment for play and interaction;

- the opportunity to address was induced stress.

Children between the ages of 6-14 are the main target group.

Achievements

Some 26 children have left the centre to go onto schools in grade 3 and 4.

Disabled children were introduced to and are now attending the disabled's tailoring training centre.

\section{Future plans}

The organisation plan to set up vocational training centres for those children who cannot continue their education. The training is to give family members employment opportunities to enable them to send their children to school. 


- ADDRESS $>$

FLAT 4 1ST FLOOR KHYBER VIEW PLAZA PESHAWAR, PAKISTAN
PHONE : 840126

F A X: 840126

TELEX :
1. DR MOHD AYUB ZHIAN

2. BRIG F KHATTAK (RETD)

3 .

\begin{tabular}{|c|c|c|c|c|c|}
\hline AFGHAN & 74 & TECHNICAL : & 63 & PAK. BASED & 4 \\
\hline PAKISTANI : & 1 & ADMINISTRATIVE : & 10 & AFGHAN BASED : & 71 \\
\hline EXPAT : & - & FIELD/SUPPORT S. & 2 & CROSS-BORDER : & - \\
\hline TOTAL & 75 & TOTAL : & 75 & TOTAL : & 75 \\
\hline
\end{tabular}

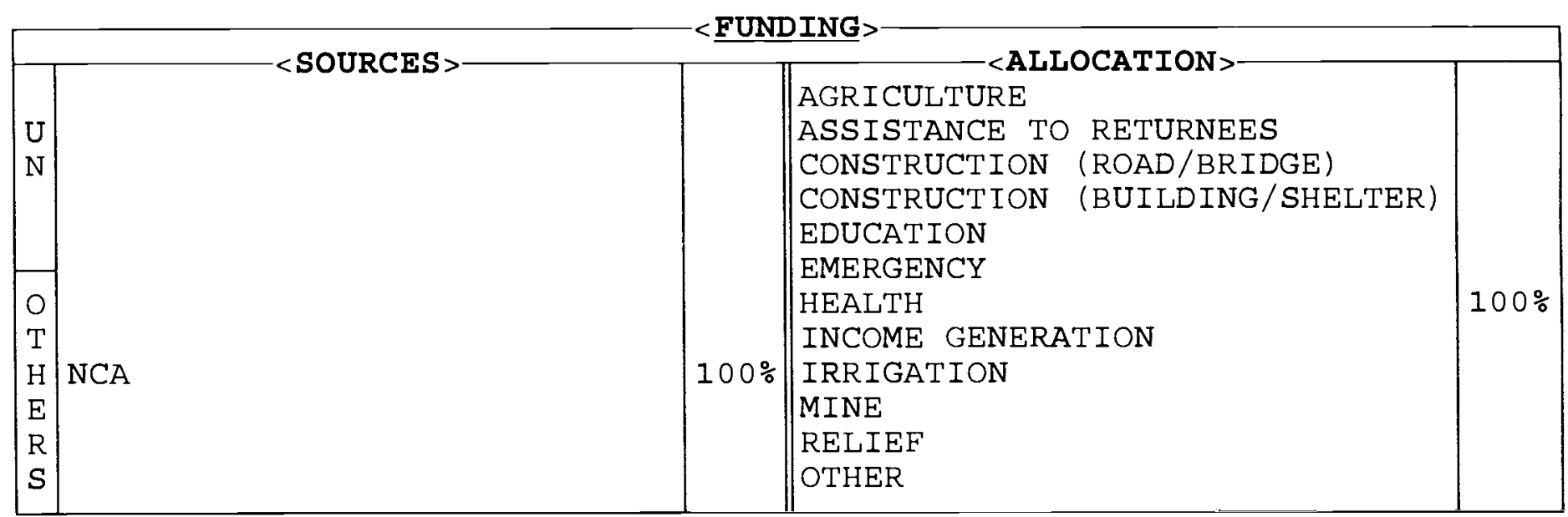

\begin{tabular}{|c|c|c|c|c|c|c|}
\hline & 1992 & 1993 & 1994 & 1995 & 1996 & 1997 \\
\hline AFGHANISTAN : & 120,000 & 120,000 & 150,000 & 200,000 & 250,000 & 200,000 \\
\hline REFUGEES : & 72,000 & 72,000 & $-\cdots$ & --- & $-\cdots$ & --- \\
\hline T O T A L: & 192,000 & 192,000 & 150,000 & 200,000 & 250,000 & 200,000 \\
\hline
\end{tabular}

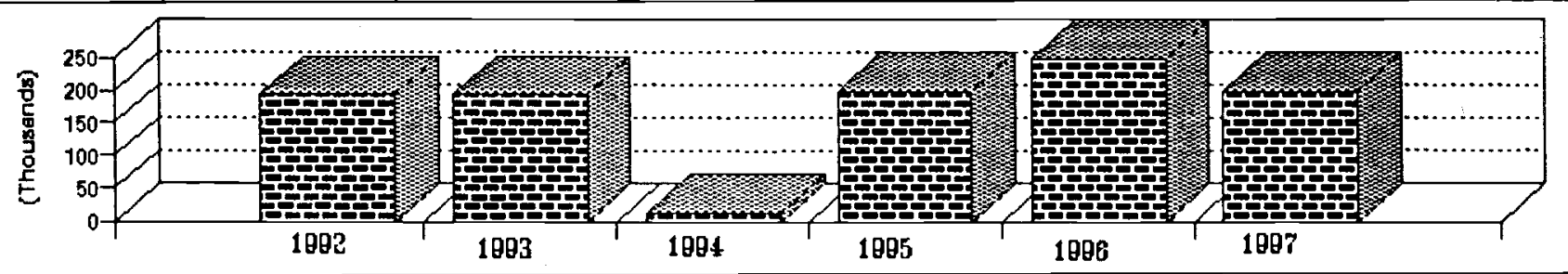

\begin{tabular}{|c|c|c|c|c|c|}
\hline PROVINCES & SECTOR & $\%$ & PROVINCES & SECTOR & $\%$ \\
\hline $\begin{array}{l}\text { BADAKSHAN } \\
\text { BADGHIS } \\
\text { BAGHLAN } \\
\text { BALKH } \\
\text { BAMYAN } \\
\text { FARAH } \\
\text { FARYAB } \\
\text { GHAZNI } \\
\text { GHOR } \\
\text { HELMAND } \\
\text { HERAT } \\
\text { JAWZJAN } \\
\text { KABUL } \\
\text { KANDAHAR } \\
\text { KAPT SA }\end{array}$ & & & $\begin{array}{l}\text { KUNAR } \\
\text { KUNDUZ } \\
\text { LAGHMAN } \\
\text { LOGAR } \\
\text { NANGARHAR } \\
\text { NIMROZ } \\
\text { ORUZGAN } \\
\text { PAKTEKA } \\
\text { PAKTIA } \\
\text { PARWAN } \\
\text { SAMANGAN } \\
\text { TAKHAR } \\
\text { WARDAK } \\
\text { ZABUL } \\
\text { REFUGEES }\end{array}$ & $\begin{array}{l}\text { HEALTH } \\
\text { HEALTH }\end{array}$ & 25 \\
\hline
\end{tabular}




\section{ANTI TUBERCULOSIS ASSOCIATION AFGHANISTAN PROGRAM (ATA/AP)}

ATA/AP was previously the Afghanistan wing of Anti-TB Association Geneva, founded in 1983. In $1992 \mathrm{ATA} / \mathrm{AP}$ formed a separate NGO and continued its work.

In June 1990 a TB Hospital was established in Asadabad, Kunar Province with a 15 bed isolation ward - 10 for men and 5 for women.

TB Control sub-centers were established in Khas Kunar, Peche Darra, Kamdesh and Barge-Matal to screen suspected TB Patients.

Six Health Education Centers were established in Chawki, Khas Kunar, Peche Darra, Asmar, Kamdesh and Barge-e-Matal.

Since January 1995 the ATA/AP in collaboration with UNICEF, the Ministry of Public Health, East Zone, and NRC/NCA have participated in the EPI Programme in Kunar and Nooristan. There are 20 teams of 2 vaccinators each, who promote the campaign according to the guidelines of UNICEF.

\section{Major aims of the organisation}

The major aim of the organisation is to combat TB in Afghanistan with special attention to East Afghanistan, though it works in other health sectors as well. The organisation also supports gyn/obs, $\mathrm{MCH}$ and part of the administration of Nangarhar University Teaching Hospital, Jalalabad. 
AFGHAN TECHNICAL CONSULTANTS (ATC)

ACBAR

<ADDRESS >- <COMMUNICATION LINES >

45D-4 OLD JAMRUD ROAD

$\mathrm{U} / \mathrm{T}, \mathrm{G} \mathrm{P}$ O BOX 1149

PESHAWAR, PAKISTAN
PHONE : $840122 / 40412$

F A X: 44780

email:
1. KEFAYATULLAH EBLAGH

2 .

3 .

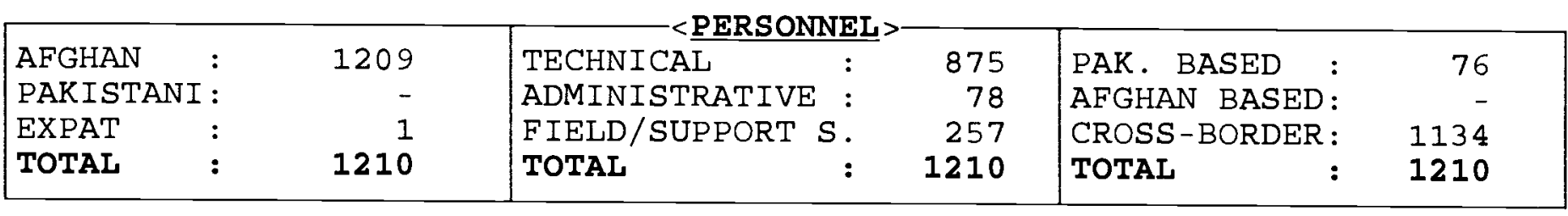

\section{SOURCES}

N UNOCHA

$\mathrm{O}$

$\mathrm{H}$

E EUROPEAN UNION

$<$ FUNDING >

\begin{tabular}{|c|c|c|c|c|}
\hline \multicolumn{5}{|c|}{ 1 $<$ SOURCES $>$} \\
\hline \multirow{6}{*}{$\begin{array}{l}\mathrm{U} \\
\mathrm{N}\end{array}$} & \multirow{5}{*}{ UNOCHA } & \multirow{6}{*}{$34 \%$} & AGR I CULTURE & \\
\hline & & & ASSISTANCE TO RETURNEES & \\
\hline & & & CONSTRUCTION (ROAD/BRIDGE) & \\
\hline & & & CONSTRUCTION (BUILDING/SHELTER) & \\
\hline & & & EDUCATION & \\
\hline & & & EMERGENCY & \\
\hline 0 & & & HEALTH & \\
\hline $\mathrm{T}$ & & & INCOME GENERATION & \\
\hline $\mathrm{H}$ & & & IRRIGATION & \\
\hline E & EUROPEAN UNION & $66 \%$ & MINE & $100 \%$ \\
\hline $\mathrm{R}$ & & & RELIEF & \\
\hline$S$ & & & OTHER & \\
\hline
\end{tabular}

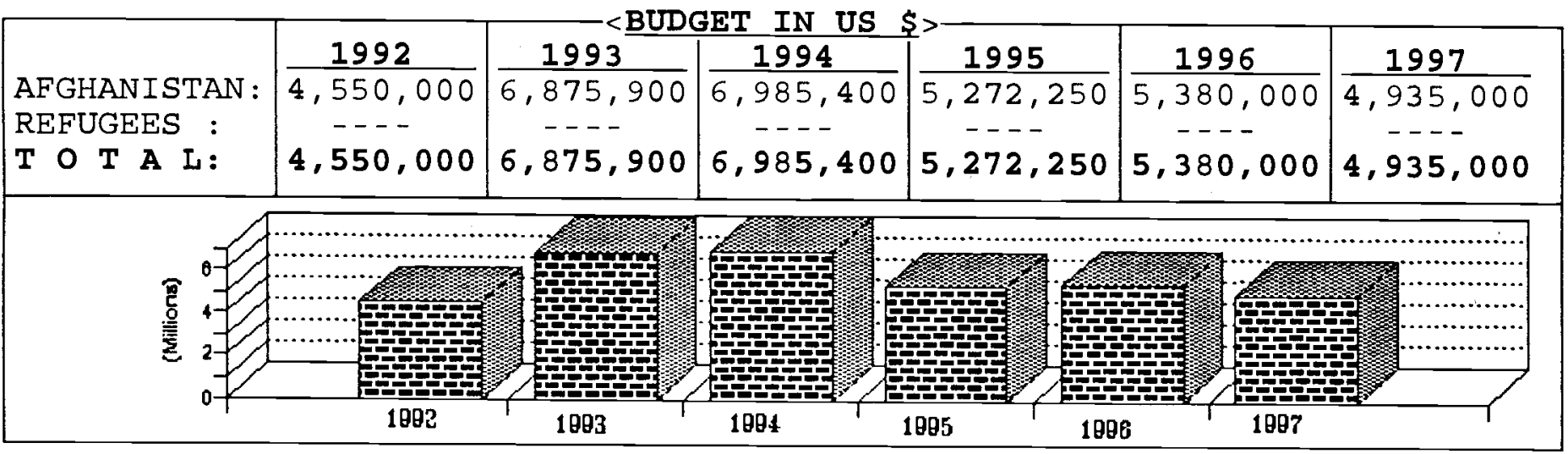

\begin{tabular}{|l|l|l||l|l|l|}
\hline PROVINCES & \multicolumn{2}{|c|}{ SECTOR } & $\%$ TARGET PROVINCES IN AFGHANISTAN> & SECTOR & \\
\hline BADAKSHAN & & & KUNAR & & \\
BADGHIS & & & KUNDUZ & & \\
BAGHLAN & & & LAGHMAN & & \\
BALKH & & & LOGAR & & 10 \\
BAMYAN & & & NIMROZ & & \\
FARAH & & & ORUZGAN & & \\
FARYAB & & & PAKTEKA & DEMINING & 10 \\
GHAZNI & & & PAKTIA & DEMINING & \\
GHOR & & & PARWAN & & \\
HELMAND & & & TAMANGAN & & \\
HERAT & & 40 & WARDAR & & \\
JAWZJAN & & 13 & ZABUL & & \\
KABUL & DEMINING & & PAKISTAN & & \\
KANDAHAR & DEMINING & & & \\
KAPISA & & & & \\
\hline
\end{tabular}




\section{AFGHAN TECHNICAL CONSULTANTS}

(ATC)

ATC is the oldest, largest impartial

humanitarian mine clearance organisation in

Afghanistan. Established in October 1989

with an initial staff of thirty five. Since then it

has undergone significant change and

expansion. It has developed into a highly

organised and effective NGO.

ATC works under the UNOCHA umbrella. The agency conducts manual mine clearance activities in both mined areas and former battlefield areas. There are two specialised explosive ordnance disposal (EOD) teams clearing bombs and other devices which normal mine clearance staff are not trained in. There are three backhoes to assist the manual teams. Mine clearance operations have been undertaken in 16 Provinces.

The agency employ some 1,300 people who make up the 22 manual demining teams, 2 EOD teams, 3 battle area clearance (BAC) teams and 3 mechanical clearance teams as well as the support staff; 95 percent of all staff work inside Afghanistan.

BAC teams were introduced to the programme in 1995 and work mainly in Kabul city.

The agency is funded by UNOCHA and EU.

Representatives from the agency have attended several International Conferences and are now on the UN list of agencies qualified in supervision and consultation of services related to mine clearance.

\section{Achievements}

Up to August 1997 mined areas in five Provinces were cleared destroying some 401,049 explosive devises and over 350 mines and other ordnance have been handed over to the teams by local commanders for destruction.

ATC is an active member of the Afghan Campaign to Ban Landmines (ACBL). 
AFGHAN WOMEN EDUCATION CENTER (AWEC)

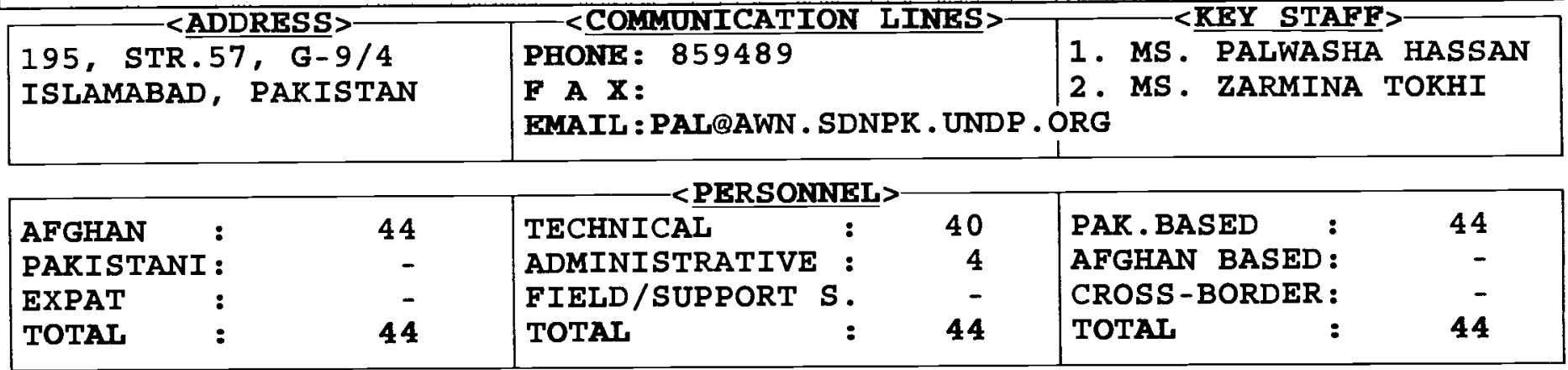

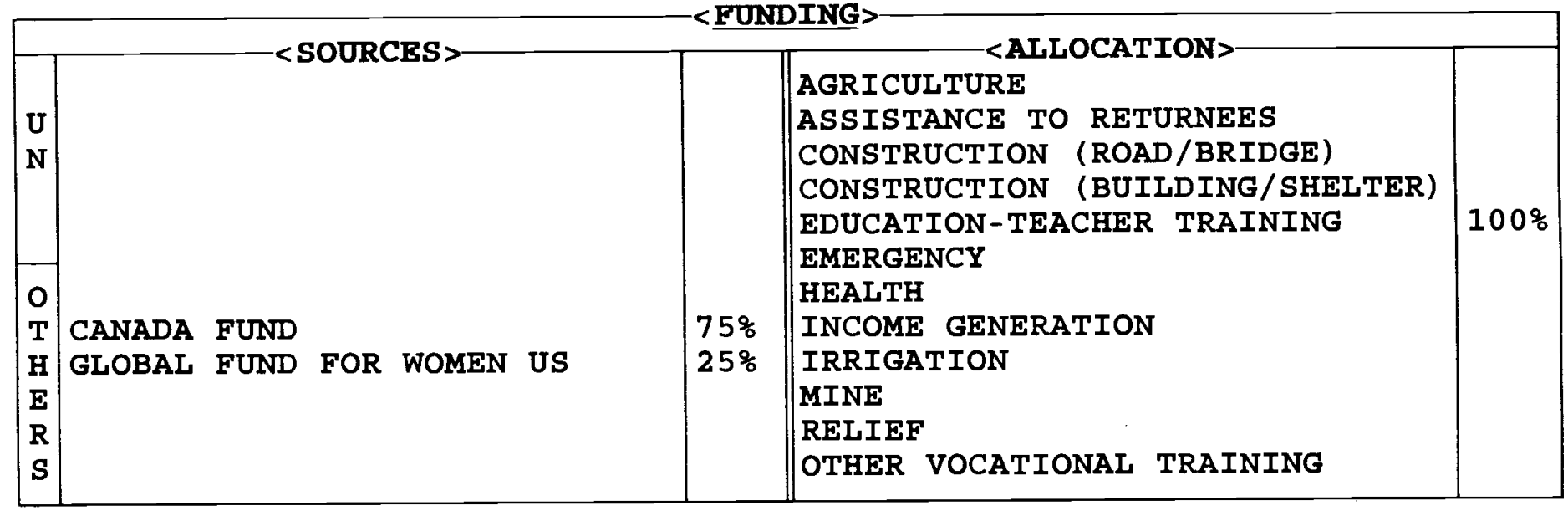

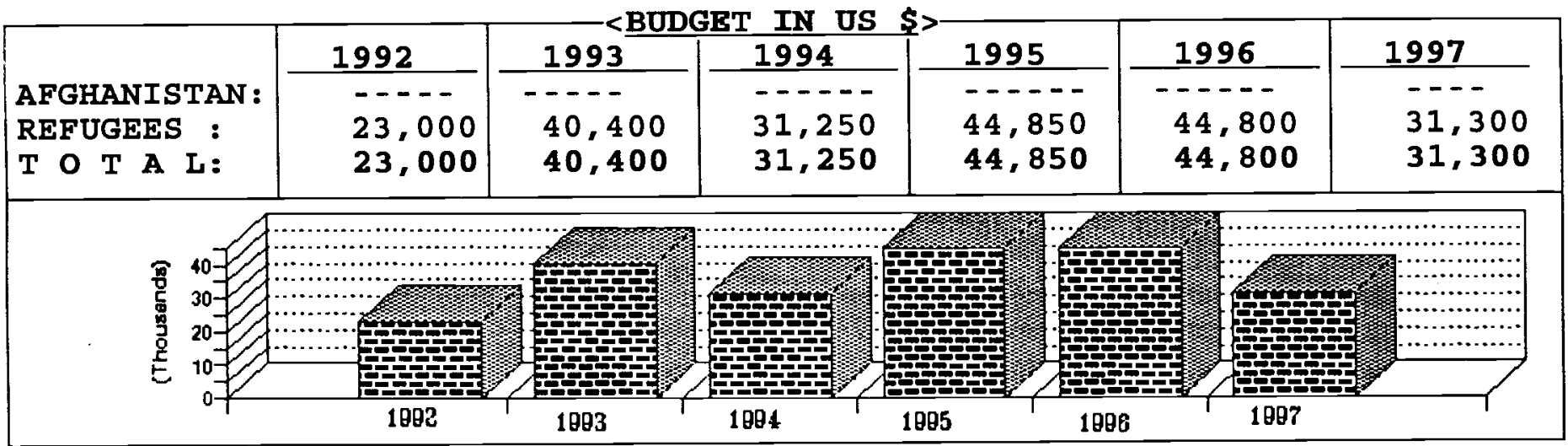

\begin{tabular}{|c|c|c|c|c|c|}
\hline PROVINCES & SECTOR & $\%$ & PROVINCES & SECTOR & $\%$ \\
\hline $\begin{array}{l}\text { BADAKSHAN } \\
\text { BADGHIS } \\
\text { BAGHLAN } \\
\text { BALKH, } \\
\text { BAMYAN } \\
\text { FARAH } \\
\text { FARYAB } \\
\text { GHAZNI } \\
\text { GHOR } \\
\text { HELMAND } \\
\text { HERAT } \\
\text { JAWZJAN } \\
\text { KABUL } \\
\text { KANDAHAR } \\
\text { KAPISA }\end{array}$ & & & $\begin{array}{l}\text { KUNAR } \\
\text { KUNDUZ } \\
\text { LAGHMAN } \\
\text { LOGAR } \\
\text { NANGARHAR } \\
\text { NIMROZ } \\
\text { ORUZGAN } \\
\text { PAKTEKA } \\
\text { PARTIA } \\
\text { PARWAN } \\
\text { SAMANGAN } \\
\text { TAKHAR } \\
\text { WARDAK } \\
\text { ZABUL } \\
\text { REFUGEES }\end{array}$ & EDUCATION & 100 \\
\hline
\end{tabular}


AFGHAN WOMEN'S EDUCATIONAL

CENTER

(AWEC)

AWEC was founded in Fcbruary 1991.

Sector of Operation

AWEC is involved mainly, in the education sector for Afghan females and is based in

Rawalpindi and Islamabad.

The agency supports a primary school, but due to unavailability of funds, has to collect fees from the students.

So far, 160 students have graduated from different courses.

AWEC conducts various types of courses such as English Languagc, Women's rights

awareness, Literacy, tailoring and English

typing.

\section{Future Objectives}

The agency plans to move to Afghanistan as soon as the situation allows.

\section{Further Information}

AWEC, besides running the above mentioned courses, has recently started classes in Dari literature. It is also able to promote the primary school, and a secondary school. The total number of students in both centres and schools is now more than 800 . 
AFGHAN WOMEN'S RESOURCE CENTER (AWRC)

ACBAR

<ADDRESS $>->$ COMMUNICATION LINES

ARBAB ROAD, OSMANIA LANE PHONE : 841552 MUMTAZ ALI SHAH HOUSE PESHAWAR， PAKISTAN

F A X: 841552

email:
1. MS SHENKY ZAHERY

2. MS P HASHEMEE

3 .

\begin{tabular}{|c|c|c|c|c|c|}
\hline AFGHAN & 30 & TECHNICAL : & 17 & PAK. BASED & 33 \\
\hline PAKISTANI : & 3 & ADMINISTRATIVE : & 7 & AFGHAN BASED : & - \\
\hline EXPAT : & - & FIELD/SUPPORT $S$. & 9 & CROSS-BORDER : & - \\
\hline TOTAL & 33 & TOTAL : & 33 & TOTAL : & 33 \\
\hline
\end{tabular}

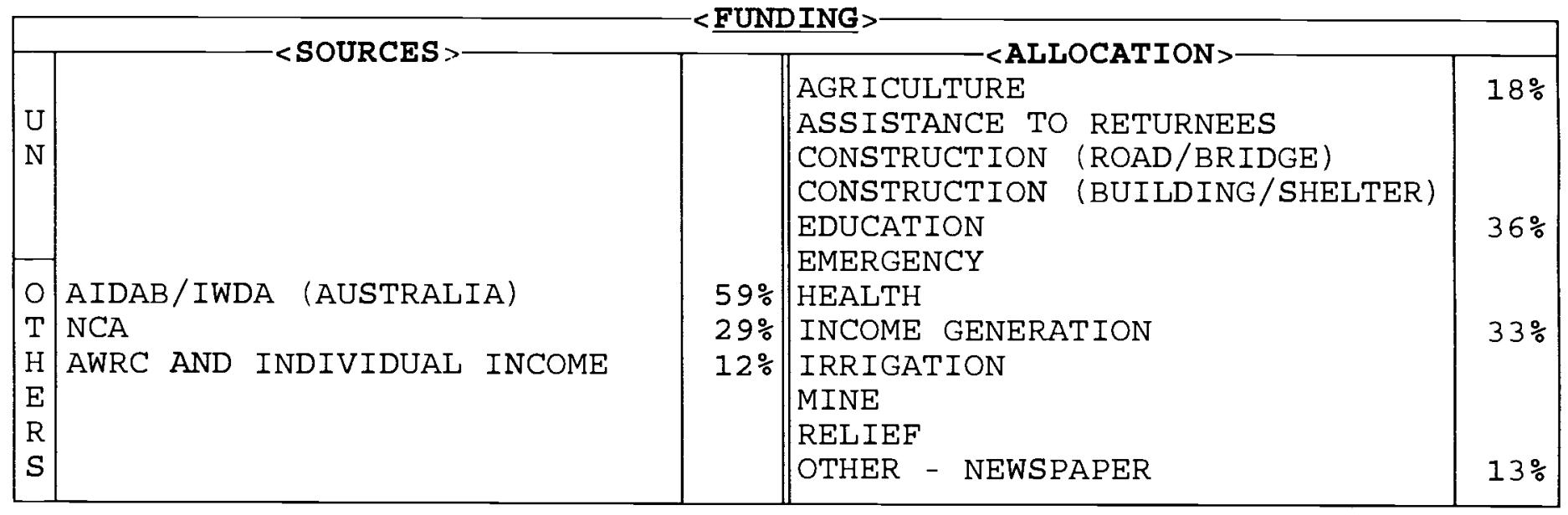

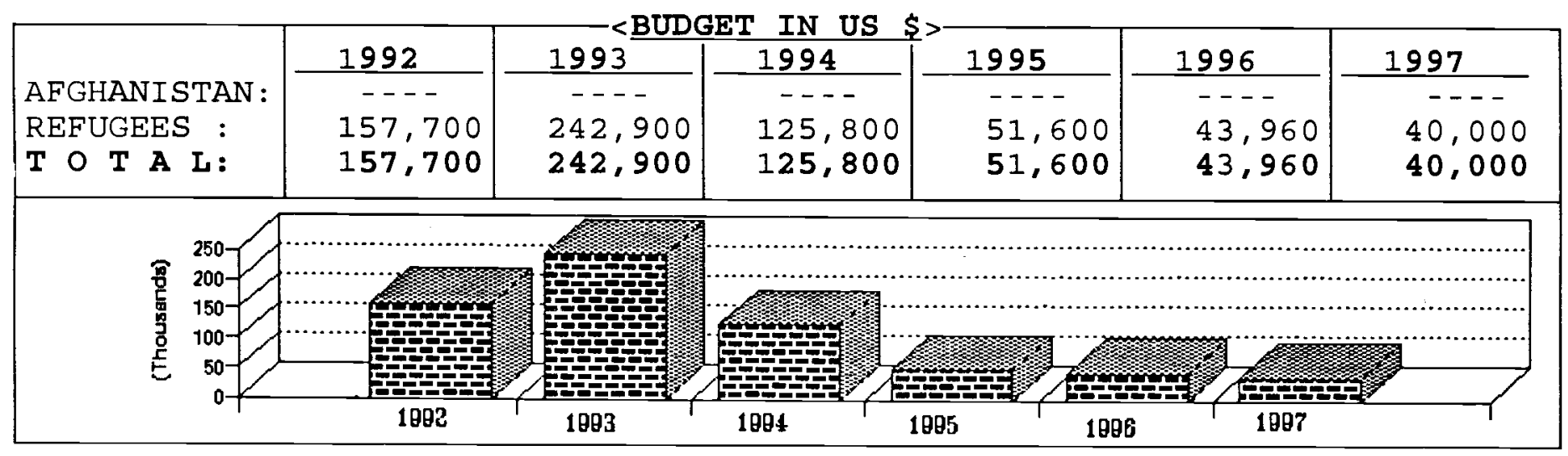

\begin{tabular}{|c|c|c|c|c|c|}
\hline PROVINCES & SECTOR & $\%$ & PROVINCES & SECTOR & $\%$ \\
\hline $\begin{array}{l}\text { BADAKSHAN } \\
\text { BADGHIS } \\
\text { BAGHLAN } \\
\text { BALKH } \\
\text { BAMYAN } \\
\text { FARAH } \\
\text { FARYAB } \\
\text { GHAZNI } \\
\text { GHOR } \\
\text { HELMAND } \\
\text { HERAT } \\
\text { JAWZJAN } \\
\text { KABUL } \\
\text { KANDAHAR } \\
\text { KAPISA }\end{array}$ & & & $\begin{array}{l}\text { KUNAR } \\
\text { KUNDUZ } \\
\text { LAGHMAN } \\
\text { LOGAR } \\
\text { NANGARHAR } \\
\text { NIMROZ } \\
\text { ORUZGAN } \\
\text { PAKTEKA } \\
\text { PAKTIA } \\
\text { PARWAN } \\
\text { SAMANGAN } \\
\text { TAKHAR } \\
\text { WARDAK } \\
\text { ZABUL } \\
\text { PAKISTAN }\end{array}$ & (1) & 100 \\
\hline
\end{tabular}




\section{AFGHAN WOMEN'S RESOURCE CENTER (AWRC)}

AWRC aims to improve literacy levels and health care amongst Afghan women, provide women with vocational skills and facilities for information, train teachers in literacy and knitting, and reach isolated women - to enable women to become self-sufficient and improve their status within the family and community. Through literacy training they will become more aware of their rights in a Muslim society and learn to explore and share ideas about how women can increase their potential and use the resources available to them. The Centre aims to provide these resources in a safe, culturally appropriate environment.

\section{Sectors of Operation}

AWRC run a project which includes the following:

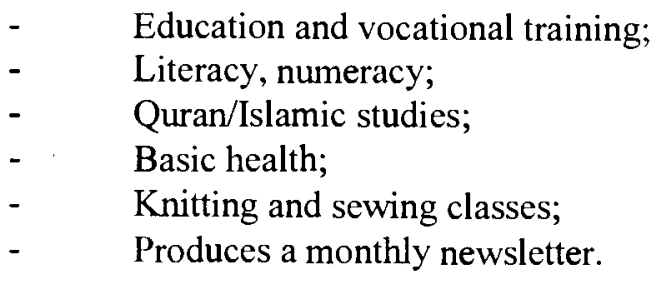

\section{Library}

Over 1,600 books and about 1,000 leaflets on different subjects e.g. health care, women's issues, literature, politics, religion and basic reading material - children and adults.

\section{Job placement office}

Facilitates contacts between Afghan women and employers and maintains a database of women's educational and employment histories. 1,590 women have registered and so far 280 have been placed in jobs.

\section{Day care center}

Takes care of 50, under six, children of staff and students.

\section{Staff training}

Includes training of the centre's administrative staff in programme planning, monitoring budgeting, proposal writing, report writing and computer use.

\section{Income-Generation - Poultry}

Female veterinarians provide training to Afghan women in poultry production, disease control and improved ways of breeding, with the objective of making them self-sufficient.

\section{Future Objectives}

AWRC aims to represent Afghan women and will continue to do so in the future in Afghanistan. Women must be involved in the reconstruction process. The agency plans to provide the same services in future, as available in Pakistan.

\section{Further information}

AWRC first opened in November 1989, as a result of much hard work by a few women committed to improving the situation of Afghan refugee women. AWRC is an organisation for women run by women. To date the Centre has trained more than 2,000 women.

In early 1991 the Centre opened a camp programme at Akora camp. 8 more outreach centers were established in camps around Peshawar. These offer training and income generation projects. There are demands for this programme to be extended.

Since June 1991 the key funding source has been the IWDA, Australia. 
AFGHAN WOMEN WELFARE DEPARTMENT (AWWD)

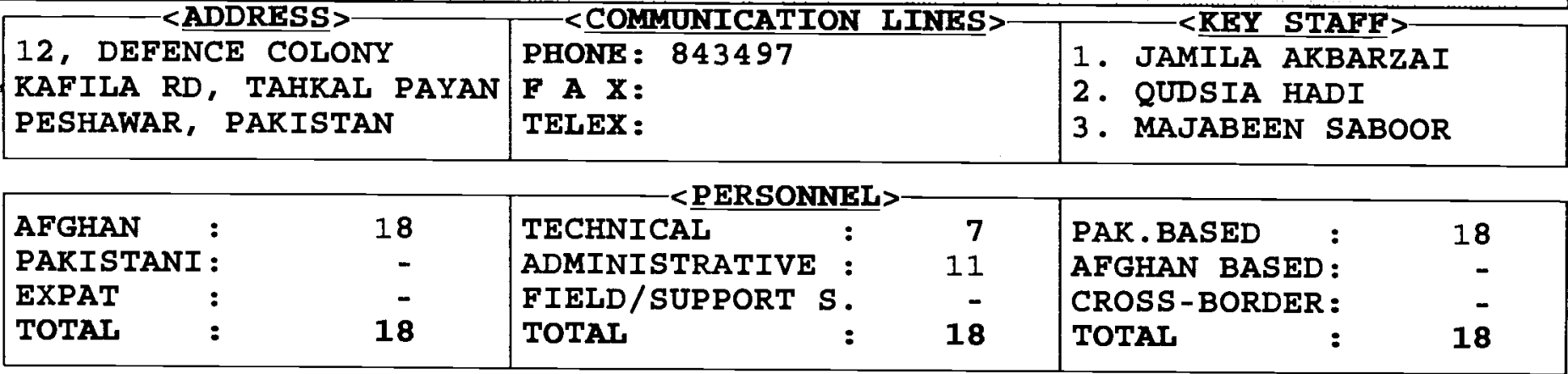

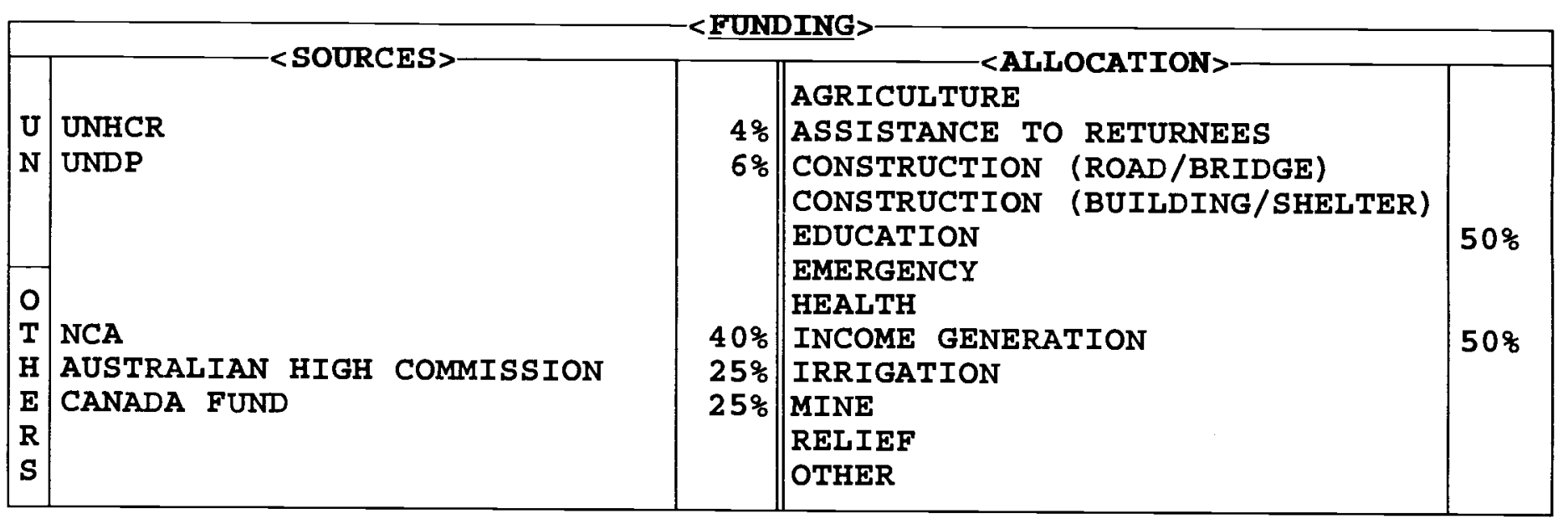

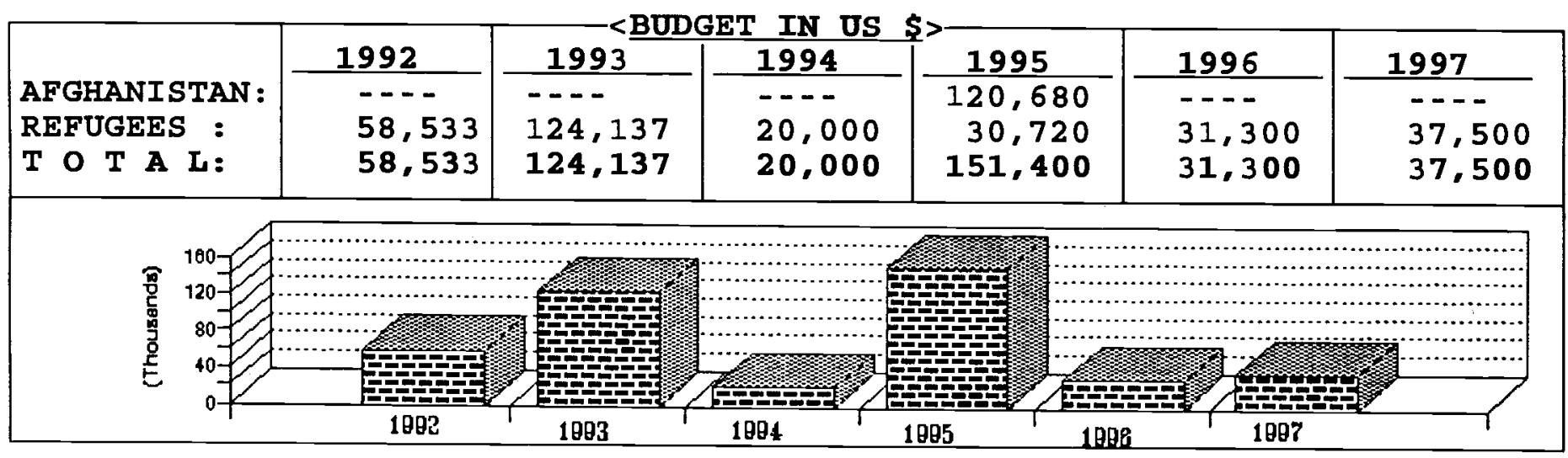

\begin{tabular}{|c|c|c|c|c|c|}
\hline PROVINCES & SECTOR & $\%$ & PROVINCES & SECTOR & $\%$ \\
\hline $\begin{array}{l}\text { BADAKSHAN } \\
\text { BADGHIS } \\
\text { BAGHLAN } \\
\text { BALKH } \\
\text { BAMYAN } \\
\text { FARAH } \\
\text { FARYAB } \\
\text { GHAZNI } \\
\text { GHOR } \\
\text { HELMAND } \\
\text { HERAT } \\
\text { JAWZJAN } \\
\text { RABUL } \\
\text { KANDAHAR } \\
\text { KAPISA }\end{array}$ & & & $\begin{array}{l}\text { KUNAR } \\
\text { KUNDUZ } \\
\text { LAGHMAN } \\
\text { LOGAR } \\
\text { NANGARHAR } \\
\text { NIMROZ } \\
\text { ORUZGAN } \\
\text { PAKTEKA } \\
\text { PARTIA } \\
\text { PARWAN } \\
\text { SAMANGAN } \\
\text { TAKHAR } \\
\text { WARDAK } \\
\text { ZABUL } \\
\text { REFUGEES }\end{array}$ & INCOME GEN/EDU & 100 \\
\hline
\end{tabular}




\section{AFGHAN WOMEN WELFARE DEPARTMENT \\ (AWWD)}

AWWD is a non affiliated Afghan women's NGO, founded in July 1990.

The objectives of the organisation are to help raise the litcracy rate of Afghan women; to provide cducational and income gencrating training opportunities for Afghan women; to elevate the status of Afghan women within the family and community; and to provide opportunitics for women to participate in the national affairs of their country.

\section{Main activities}

In Peshawar - Tailoring training, Litcracy and Health cducation, Holy Qur'an, English languagc progranme, typing and computcr training, carpct weaving, poultry training and public health training.

Inside Afghanistan - Kitchen gardening, carpet wcaving training and vulnerable displaced femalc refugee assistance projects in Jalalabad.

Projects include:

- Tailoring:

- Litcracy and health education;

- English language;

- Typing and computer training;

- Carpet wcaving;

- Poultry and Public health training;

- Soap and candle making;

- Kitchen gardening. 
BICYCLES FOR AFGHAN AMPUTEES REHABILITATION (BAAR)

\begin{tabular}{|l|l|l|}
\hline 106, GUL HAJI PLAZA, & PHONE: 42417 & <COMEY STAFF $>-$ \\
JAMRUD ROAD, & F A X: & 1. ALI. MOHAMMAD \\
PESHAWAR, PAKISTAN & TELEX: & 2. JAVED AKBAR SHAH \\
\hline
\end{tabular}

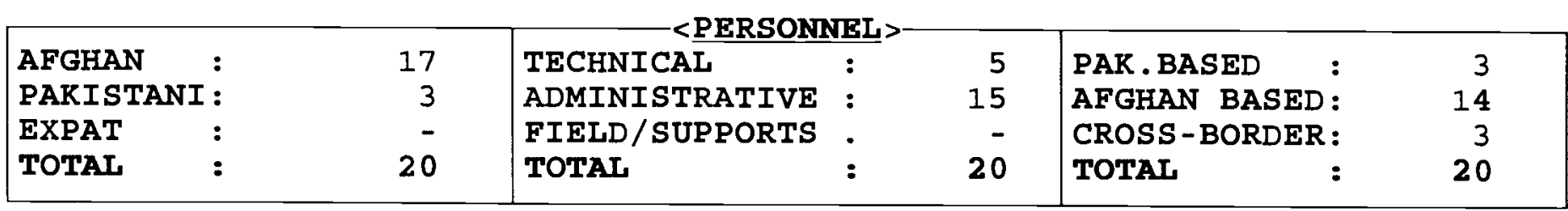

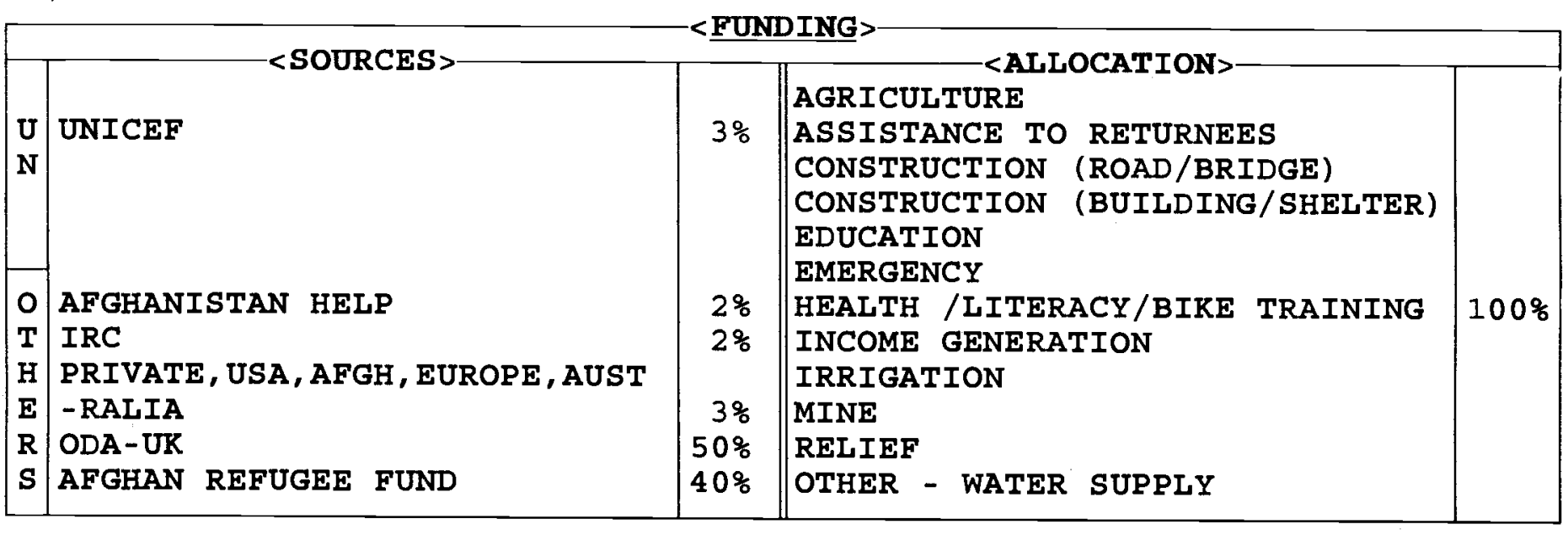

\begin{tabular}{|c|c|c|c|c|c|c|}
\hline $\begin{array}{l}\text { AFGHANISTAN: } \\
\text { REFUGEES : } \\
\text { TO T A L: }\end{array}$ & $\begin{array}{c}1992 \\
25,000 \\
25,000\end{array}$ & $\begin{array}{c}1993 \\
95,000 \\
95,000\end{array}$ & $\begin{array}{c}1994 \\
92,000 \\
--\overline{0} \\
92,000\end{array}$ & $\begin{array}{c}1995 \\
95,000 \\
95,000\end{array}$ & $\begin{array}{c}1996 \\
95,000 \\
\ldots \\
95,000\end{array}$ & $\begin{array}{r}1997 \\
92,000 \\
92,000\end{array}$ \\
\hline $\begin{array}{l}{ }^{100}= \\
{ }^{\circ 0}= \\
\\
\end{array}$ & 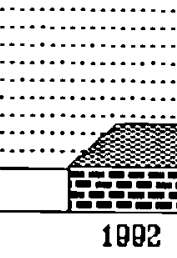 & ${ }_{1003}$ & ${ }_{1004}$ & 昰 & 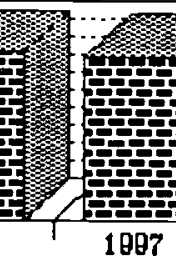 & \\
\hline
\end{tabular}

\begin{tabular}{|c|c|c|c|c|c|}
\hline PROVINCES & SECTOR & $\%$ & PROVINCES & SECTOR & $\%$ \\
\hline $\begin{array}{l}\text { BADARSHAN } \\
\text { BADGHIS } \\
\text { BAGHLAN } \\
\text { BALKH } \\
\text { BAMYAN } \\
\text { FARAH } \\
\text { FARYAB } \\
\text { GHAZNI } \\
\text { GHOR } \\
\text { HELMAND } \\
\text { HERAT } \\
\text { JAWZJAN } \\
\text { KABUL } \\
\text { KANDAHAR } \\
\text { KAPISA }\end{array}$ & $\begin{array}{l}\text { CYCLE TRAINING, EDU, } \\
\text { HEALTH }\end{array}$ & 100 & $\begin{array}{l}\text { RUNAR } \\
\text { KUNDUZ } \\
\text { LAGHMAN } \\
\text { LOGAR } \\
\text { NANGARHAR } \\
\text { NIMROZ } \\
\text { ORUZGAN } \\
\text { PAKTEKA } \\
\text { PARTIA } \\
\text { PARWAN } \\
\text { SAMANGAN } \\
\text { TAKHAR } \\
\text { WARDAR } \\
\text { ZABUL }\end{array}$ & & \\
\hline
\end{tabular}




\section{BICYCLES FOR AFGHAN AMPUTEES REHABILITATION \\ (BAAR)}

BAAR opened their offices in Kabul in 1998.

The objectives of the organisation are to assist war affected amputees. To lend medical support, education and help rehabilitate them and to make them self sufficient.

The physiotherapy department is currently understaffed but is given much assistance from SGAA. Here amputees and polio victims are treated twice a weck.

Literacy class in Pushto and Dari are undertaken to cnable the students to later apply for further training. 
BOST CONSTRUCTION UNIT (BCU)

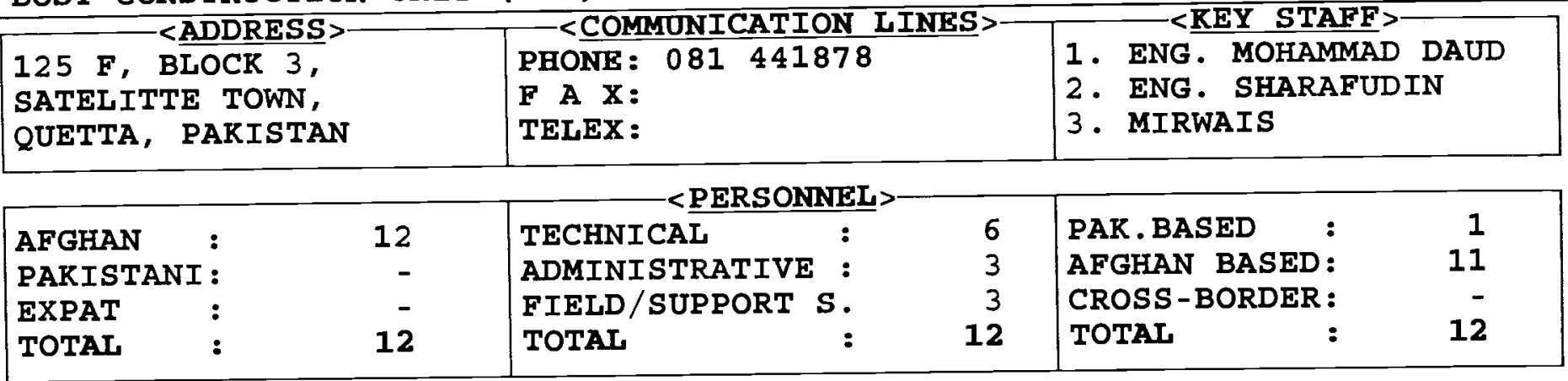

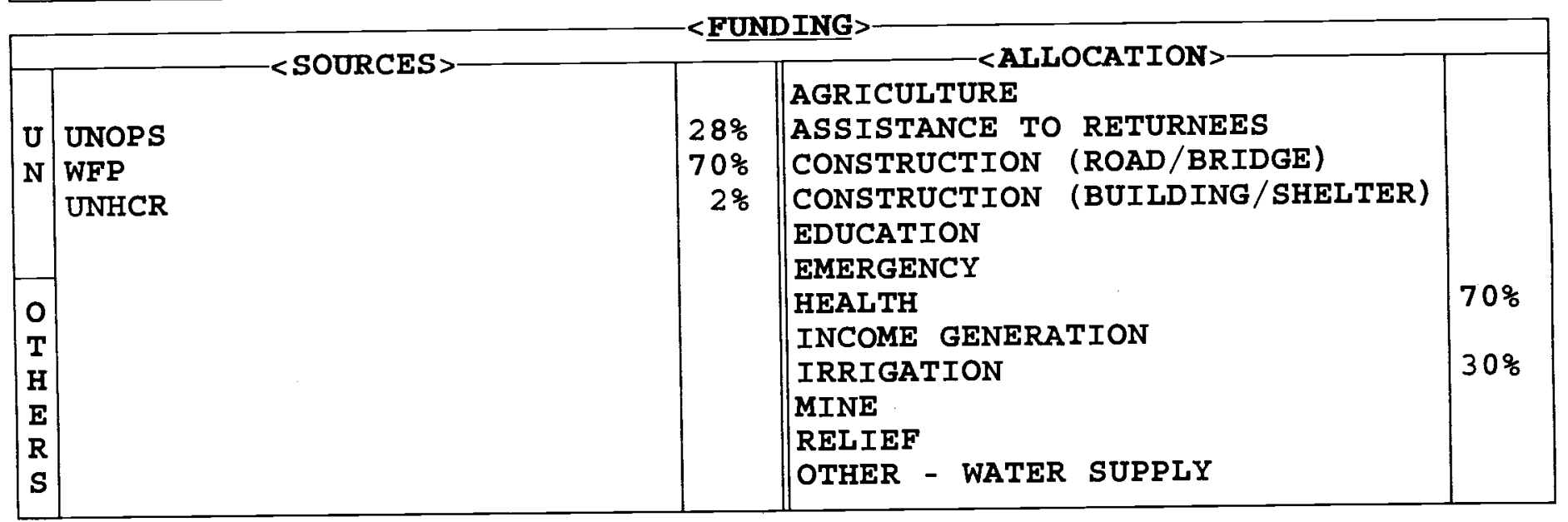

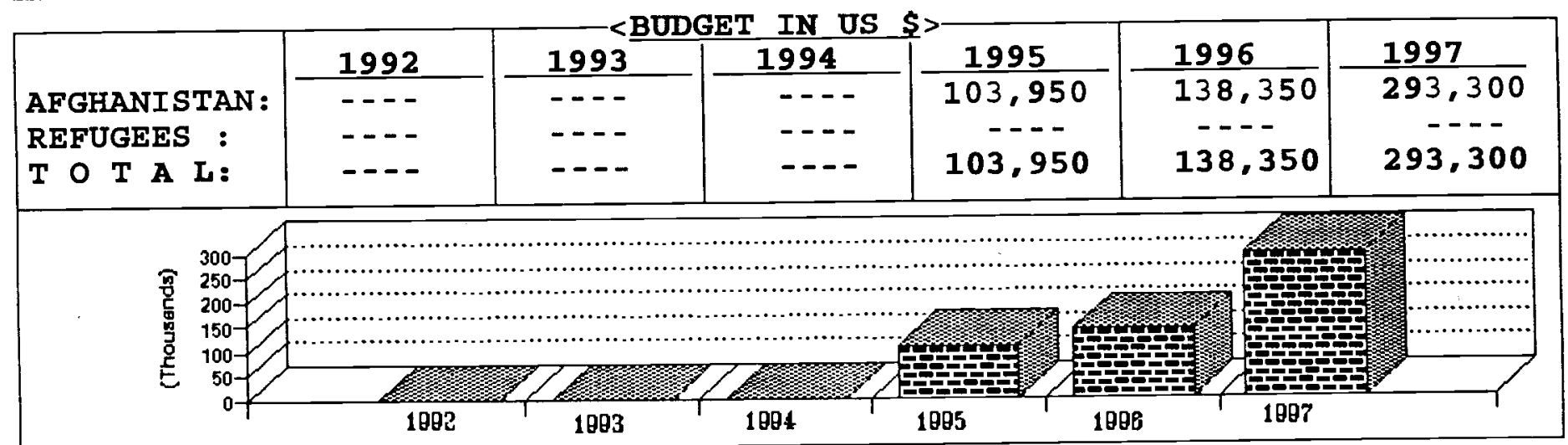

\begin{tabular}{|c|c|c|c|c|c|}
\hline PROVINCES & SECTOR & $\%$ & PROVINCES & SECTOR & \% \\
\hline $\begin{array}{l}\text { BADARSHAN } \\
\text { BADGHIS } \\
\text { BAGHLAN } \\
\text { BALKH } \\
\text { BAMYAN } \\
\text { FARAH } \\
\text { FARYAB } \\
\text { GHAZNI } \\
\text { GHOR } \\
\text { HELMAND } \\
\text { HERAT } \\
\text { JAWZJAN } \\
\text { KABUL } \\
\text { KANDAHAR } \\
\text { KAPISA }\end{array}$ & $\begin{array}{l}\text { IRRIGATION } \\
\text { IRRIGATION, EMERGENCY }\end{array}$ & . & \begin{tabular}{|l|} 
KUNAR \\
KUNDUZ \\
LAGHMAN \\
LOGAR \\
NANGARHAR \\
NIMROZ \\
ORUZGAN \\
PAKTEKA \\
PAKTIA \\
PARWAN \\
SAMANGAN \\
TARHAR \\
WARDAR \\
ZABUL
\end{tabular} & & \\
\hline
\end{tabular}




\section{BOST CONSTRUCTION UNIT \\ (BCU)}

BCU is an Afghan non-governmental, nonpolitical organization, established in 1994.

\section{Aims of BCU}

To create an engincering, architecture, $\mathrm{road} / \mathrm{bridgc}$ construction and repair works for irrigation systems and rchabilitation in Afghanistan.

- to identify rclief and rchabilitation needs.

- to help the smooth process of repatriation of Afghan refugees.

\section{Sectors of Operation}

BCU undertook:

Protection works to Babara main canal at Arghistan district of Kandahar Province.

Embankment protection work of Abazan main canal at Girrishk district of Helmand Province.

Distribution of 15,000 loaves of bread per day for four months to vulnerable city dwellers of Kandahar city with WFP. 
BAZ CONSTRUCTION UNIT FOR REHABILITATION OF AFGHANISTAN (BCURA)

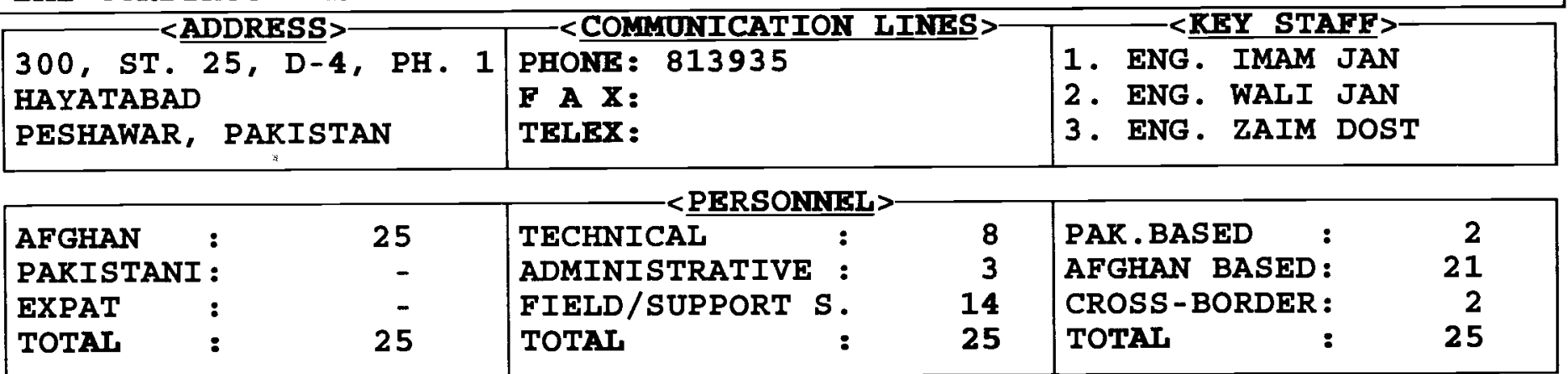

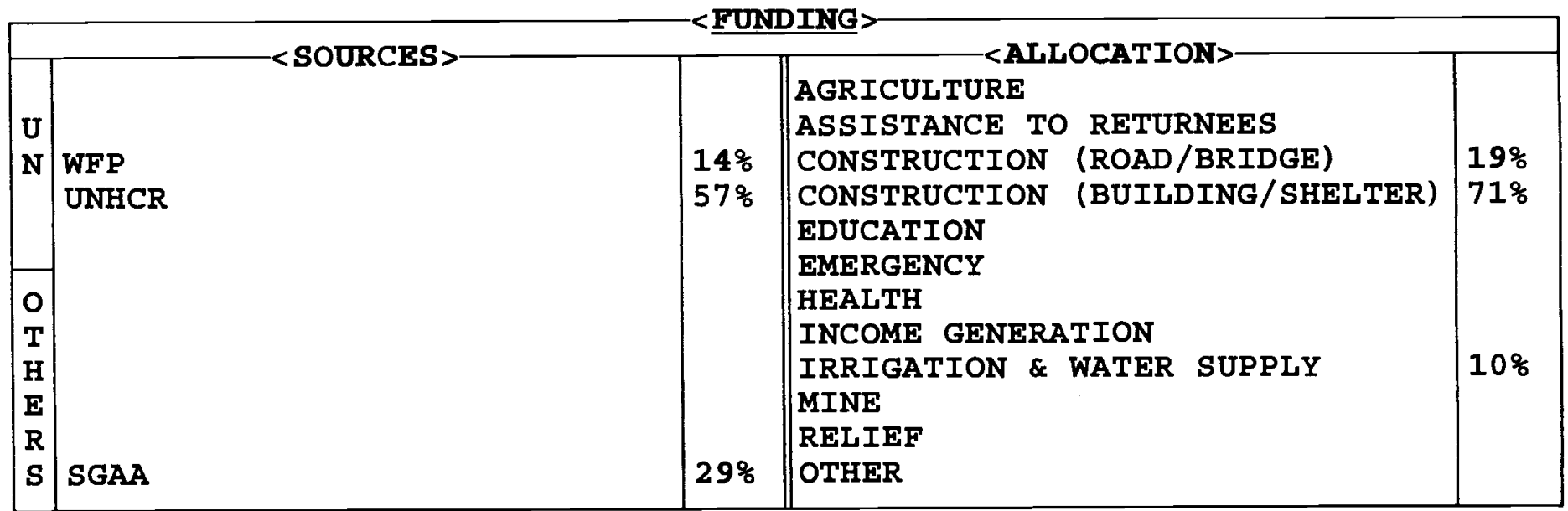

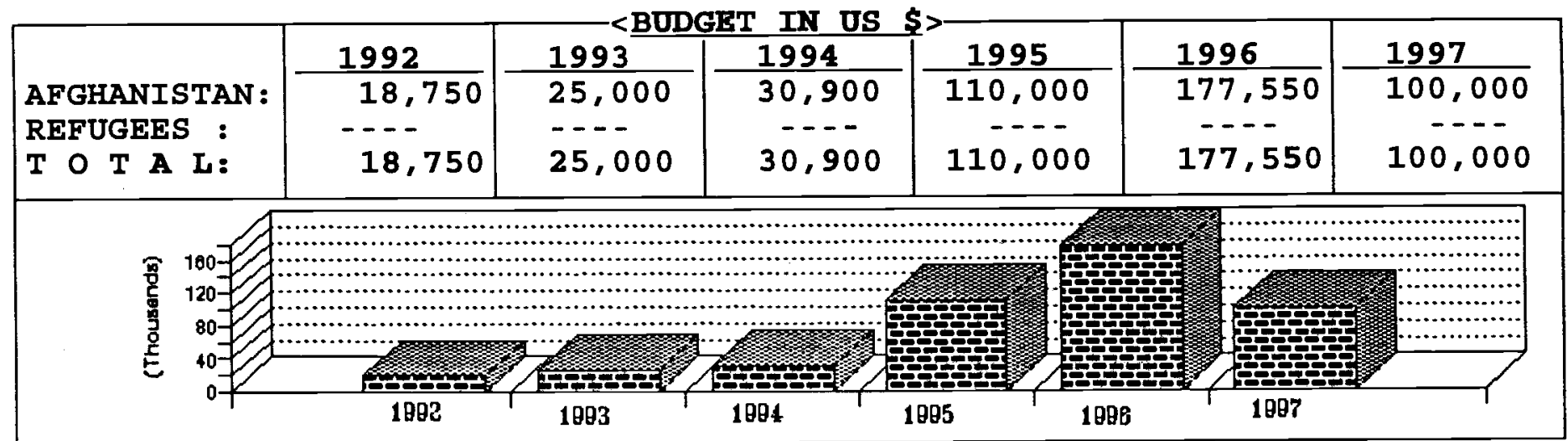

\begin{tabular}{|c|c|c|c|c|c|}
\hline PROVINCES & SECTOR & $\%$ & PROVINCES & SECTOR & $\%$ \\
\hline $\begin{array}{l}\text { BADAKSHAN } \\
\text { BADGHIS } \\
\text { BAGHLAN } \\
\text { BALKH } \\
\text { BAMYAN } \\
\text { FARAH } \\
\text { FARYAB } \\
\text { GHAZNI } \\
\text { GHOR } \\
\text { HELMAND } \\
\text { HERAT } \\
\text { JAWZJAN } \\
\text { KABUL } \\
\text { RANDAHAR } \\
\text { KAPISA }\end{array}$ & CONSTRUCTION & 5 & $\begin{array}{l}\text { KUNAR } \\
\text { RUNDUZ } \\
\text { LAGHMAN } \\
\text { LOGAR } \\
\text { NANGARHAR } \\
\text { NIMROZ } \\
\text { ORUZGAN } \\
\text { PAKTEKA } \\
\text { PAKTIA } \\
\text { PARWAN } \\
\text { SAMANGAN } \\
\text { TARHAR } \\
\text { WARDAR } \\
\text { ZABUL }\end{array}$ & $\begin{array}{l}\text { SCHOOL CONSTRUCTION } \\
\text { CONSTRUC/IRRIG } \\
\text { CONSTRUCTION } \\
\text { CONSTRUCTION }\end{array}$ & $\begin{array}{r}71 \\
4 \\
4 \\
10\end{array}$ \\
\hline
\end{tabular}




\section{BAZ CONSTRUCTION UNIT FOR REHABILITATION OF AFGHANISTAN \\ (BCURA)}

BCURA was cstablished in 1991 and is an Afghan NGO staffed with professional, well educated cxperienced and competent engineers and agrarians. It has implemented projects in different Provinces of Afghanistan, particularly in Nangarhar.

The Agency maintains cordial contacts with all local shuras and has faced no problems in implementing projects.

BCURA's projects are implemented with the full participation of the community, who are also responsible for the sccurity of its staff and property.

BCURA also works in agriculture, animal husbandry and engincering. A shoe factory has been established in Peshawar. Shoes produced at the factory are provided at a subsidised price to Afghans refugees as well as inside Afghanistan.

The main office of the agency is in Peshawar and it has a sub-office in Jalalabad.

An outline of BCURA's projects is as follows:

- cleaning of karezes in Ghazni;

- distribution of wheat in Ghazni;

- construction of a primary school in Kunar;

- distribution of rice, maize and wheat seeds and fruit trees in Nangarhar;

- canal clcaning in Nangarhar;

- road repair in Nangarhar;

- repair of a sccondary school in Nangarhar;

- cstablishment of a nursery farm in Nangarhar. 
93 , STREET 4, J-5

PHASE 111, HAYATABAD, PESHAWAR， PAKISTAN
PHONE : 817519

F A X: 817519

TELEX :
1. ENG. ABDDUL MAJID

2. ENG. H PAYEZ

3. M.HAROON JALALZAI

AFGHAN
PAKISTANI
EXPAT
TOTAL

22
-
22
$<$ SOURCES $>$

U UNHCR

N WFP

O LOCAL SOURCES

$T$ OWN SOURCES

H PRIVATE DONATION

$<$ PERSONNEL >

TECHNICAL ADMINISTRATIVE : FIELD/SUPPORT S. TOTAL

11
5
6
22

$\begin{array}{llr}\text { PAR.BASED : } & 6 \\ \text { AFGHAN BASED : } & 13 \\ \text { CROSS-BORDER : } & 3 \\ \text { TOTAL : } & \mathbf{2 2}\end{array}$

\begin{tabular}{|c|c|c|c|c|}
\hline & $-<$ SOURCES $>$ & & - <ALLOCATION> & \\
\hline & & & AGRICULTURE & \\
\hline $\mathbf{U}$ & UNHCR & $45 \%$ & ASSISTANCE TO RETURNEES & \\
\hline $\mathbf{N}$ & WFP & $14 \%$ & CONSTRUCTION (ROAD/BRIDGE) & \\
\hline & & & CONSTRUCTION (BUILDING/SHELTER) & $81 \%$ \\
\hline & & & EDUCATION & \\
\hline & & & EMERGENCY & \\
\hline 0 & LOCAL SOURCES & $10 \%$ & HEALTH & \\
\hline $\mathbf{T}$ & OWN SOURCES & $12 \%$ & INCOME GENERATION & \\
\hline $\mathrm{H}$ & PRIVATE DONATION & $19 \%$ & IRRIGATION & $19 \%$ \\
\hline $\mathbf{E}$ & & & MINE & \\
\hline $\mathbf{R}$ & & & RELIEF & \\
\hline $\mathbf{S}$ & & & OTHER & \\
\hline
\end{tabular}

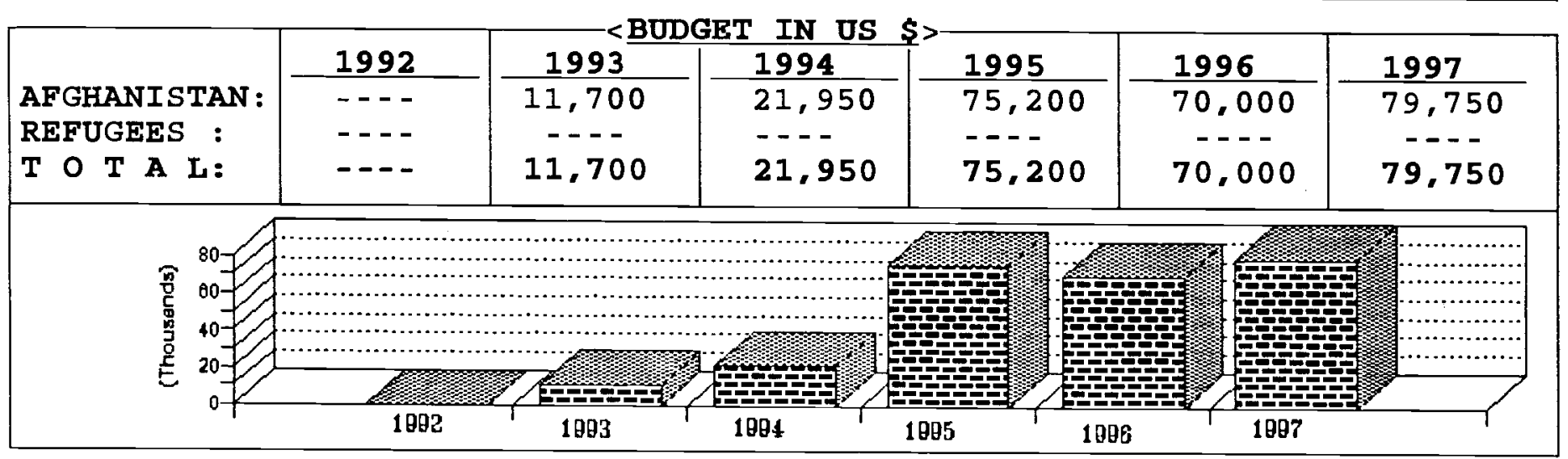

\begin{tabular}{|c|c|c|c|c|c|}
\hline PROVINCES & SECTOR & $\frac{s}{8}$ & PROVINCES & SECTOR & $\%$ \\
\hline $\begin{array}{l}\text { BADAKSHAN } \\
\text { BADGHIS } \\
\text { BAGHLAN } \\
\text { PALKH } \\
\text { BAMYAN } \\
\text { FARAH } \\
\text { FARYAB } \\
\text { GHAZNI } \\
\text { GHOR } \\
\text { HELMAND } \\
\text { HERAT } \\
\text { JAWZJAN } \\
\text { KABUL } \\
\text { KANDAHAR } \\
\text { KAPISA }\end{array}$ & CONSTRUCTION/IRRI & 19 & $\begin{array}{l}\text { KUNAR } \\
\text { KUNDUZ } \\
\text { LAGHMAN } \\
\text { LOGAR } \\
\text { NANGARHAR } \\
\text { NIMROZ } \\
\text { ORUZGAN } \\
\text { PAKTEKA } \\
\text { PAKTIA } \\
\text { PARWAN } \\
\text { SAMANGAN } \\
\text { TAKHAR } \\
\text { WARDAR } \\
\text { ZABUL }\end{array}$ & CONSTRUCTION & 81 \\
\hline
\end{tabular}




\section{BAKHTAR DEVELOPMENT AGENCY \\ (BDA)}

BDA was founded in 1992 as an Afghan nonprofit, non-partisan, non-governmental and nonpolitical humanitarian organization.

\section{BDA's aims are:}

- to contribute to rchabilitation, reconstruction and future infrastructure of Afghanistan.

It undertakes surveying, planning and actual implementation of programmes and activitics: BDA with CAWC, GRSP and ACDO have founded an umbrella called Association for Rchabilitation of Ghazni (ARG).

BDA undertook the: - rehabilitation of Mullah Hussain Karez in Qarabagh, Ghazni; through ARG umbrella.

- construction of a primary school in Musa Khan, Azro, Logar.

- construction of a health clinic in Musa Khan, Azro, Logar Province.

On going projects include:

Construction of a Community Center in Azro, Logar Province. 
8 TATARA RD, RAHATABAD $P$ O BOX 1481 PESHAWAR， PAKISTAN
PHONE : $840631 / 42955$

F A X: 841047

email:
1. DR MICHAEL HIRTH 2. PROF RAHIM ELHAM 3. NAZIR AHMAD

\begin{tabular}{|c|c|c|c|c|c|}
\hline AFGHAN $:$ & 237 & TECHNICAL : & 53 & PAK. BASED : & 264 \\
\hline PAKISTANI : & 26 & ADMINISTRATIVE : & 26 & AFGHAN BASED : & - \\
\hline EXPAT & & FIELD/SÜPPORT S. & 185 & CROSS-BORDER : & - \\
\hline TOTAL & 264 & TOTAL : & 264 & TOTAL : & 264 \\
\hline
\end{tabular}

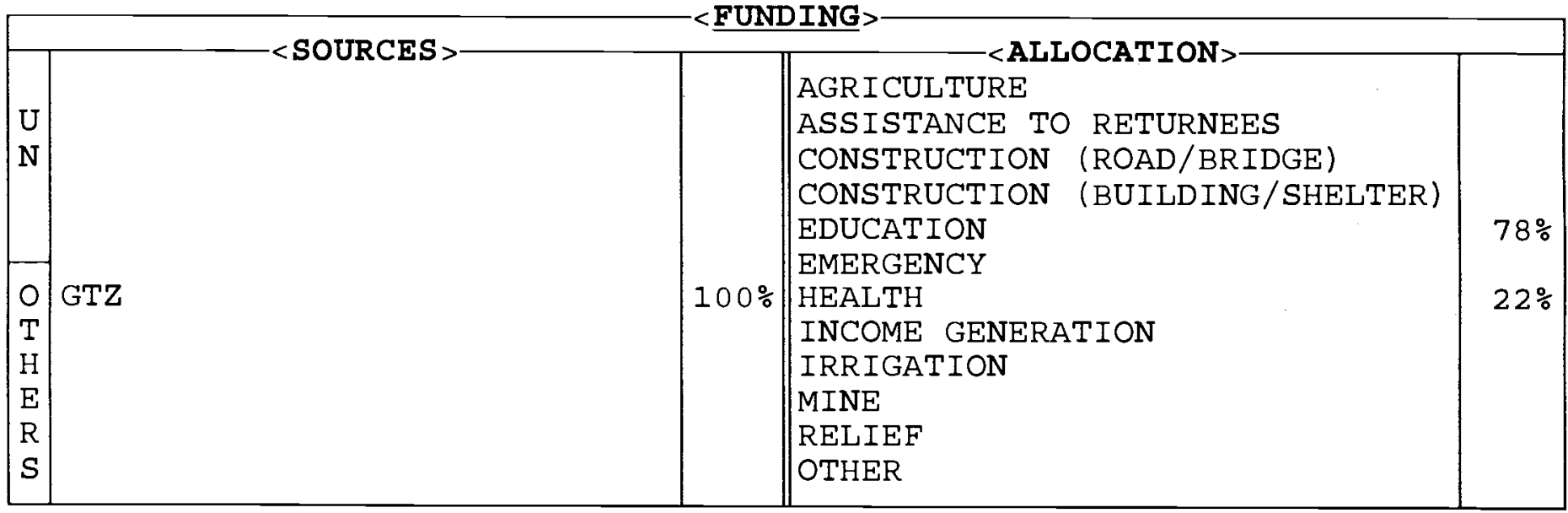

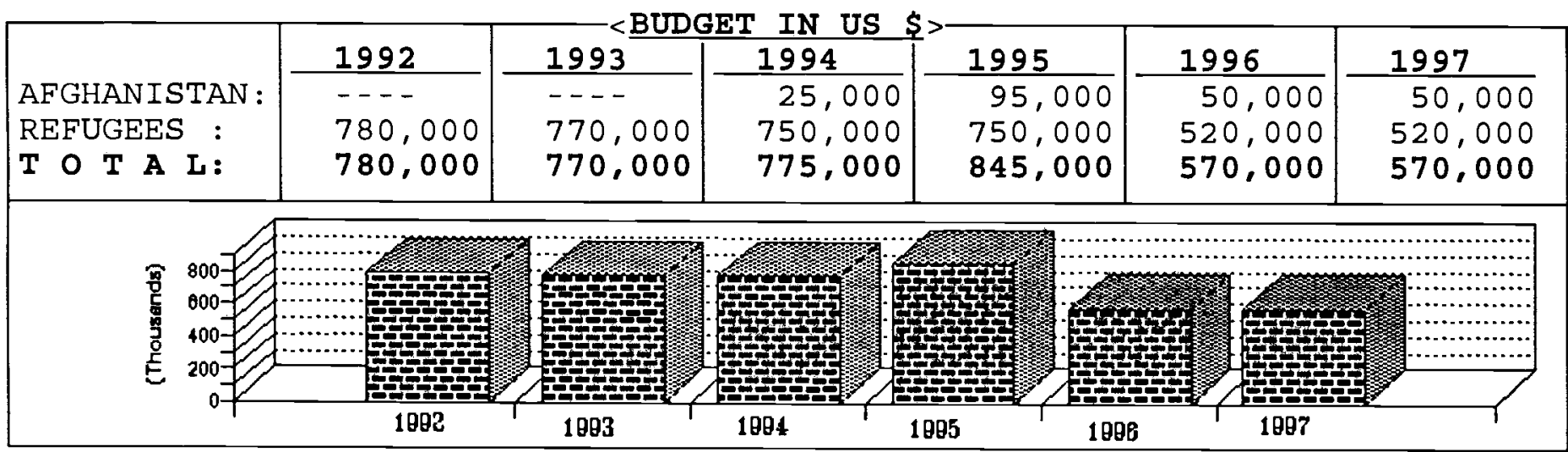

\begin{tabular}{|c|c|c|c|c|c|}
\hline PROVINCES & SECTOR & $\%$ & PROVINCES & SECTOR & $\%$ \\
\hline $\begin{array}{l}\text { BADAKSHAN } \\
\text { BADGHIS } \\
\text { BAGHLAN } \\
\text { RALKH } \\
\text { BAMYAN } \\
\text { FARAH } \\
\text { FARYAB } \\
\text { GHAZNI } \\
\text { GHOR } \\
\text { HELMAND } \\
\text { HERAT } \\
\text { JAWZJAN } \\
\text { KABUL } \\
\text { KANDAHAR } \\
\text { KAPISA }\end{array}$ & & & $\begin{array}{l}\text { KUNAR } \\
\text { KUNDUZ } \\
\text { LAGHMAN } \\
\text { LOGAR } \\
\text { NANGARHAR } \\
\text { NIMROZ } \\
\text { ORUZGAN } \\
\text { PAKTEKA } \\
\text { PAKTIA } \\
\text { PARWAN } \\
\text { SAMANGAN } \\
\text { TAKHAR } \\
\text { WARDAK } \\
\text { ZABUL } \\
\text { PAKISTAN }\end{array}$ & $\begin{array}{l}\text { EDUCATION } \\
\text { EDUCATION/HEALTH } \\
\text { EDUCATION } \\
\text { EDUCATION/HEALTH }\end{array}$ & 85 \\
\hline
\end{tabular}




\section{BASIC EDUCATION FOR AFGHAN REFUGEES (BEFARe)}

BEFARe is a governmental project, being implemented under the bilateral agreement between the Islamic Republic of Pakistan and Federal Republic of Germany, to provide educational opportunities and assistance to Afghan Refugees in NWFP. It aims at the improvement of basic education for children through formal (Primary) education for both male and female students, literacy for adults and mother and child health to Afghan females.

Project is jointly executed by the Commissioner for Afghan refugees (CAR) and the German Agency for Technical Cooperation (GTZ). The central office of the project is located in Peshawar with sub offices in Bannu, Thal, Timergara and Abbottabad and covers all Afghan refugee camps in the NWFP.

Since 1996 BEFAREe implements a project on behalf of UNHCR ("Reimbursable Technical Cooperation") in joint venture with CAR and GTZ. This covers the administrative and financial implementation of Primary Schools for Afghan refugees in NWFP. A separate project was set up by the name of Community Oriented Primary Education (COPE).

BEFARe also established Afghan German Basic Education (AG BAS-Ed), an independent Afghan NGO, to contribute to the educational rehabilitation of Afghanistan.

\section{Objectives}

The project is designed to contribute to the overall improvement of basic education for Afghan refugees with emphasis on community participation. To achieve this the project undertakes the following activities:

Formal Education: The major task, in addition to school administration, is the provision of educational support and enhanced supervision of 265 primary schools with an enrollment figure of more than 64,000 students (of which almost 10,000 are girls) and the training of teachers.
Each year about 1,700 teachers are trained (of which 250 are females). The training includes introduction of and how to apply child centered teaching/learning materials in Pashtu, mathematics and the teachers are taught how to use teacher's guides and teaching aids.

Formal Education also provides training to multiplicators of other agencies who use BEFARe's material. They are UNHCR schools in Baluchistan, AG BAS-Ed, CARE, SCA, Solidarite Afghanistan Belgium and other NGOs working inside Afghanistan.

Mother and Child Health (MCH): This programme teaches females about health issues, i.e. good health practices, problems of infertility, diet, hygiene, pregnancy, procedure for a safe and healthy child birth, breast feeding, protection of children against common fatal diseases and child development.

Since $\mathrm{MCH}$ courses started, more than 75,000 women have been reached. A Dari language version of the $\mathrm{MCH}$ course is also available to cover the non-Pashtu speaking target group.

Literacy: This project is actively engaged in running Pashtu literacy courses for males and females. To assist in the rehabilitation of Afghanistan there is now a greater need than ever before for literate people. The aim of the literacy programme is to enable the graduates to read, write, calculate and understand the simple intents of daily life. To date 15,000 participants have successfully passed the literacy courses (of which 4,000 are females).

In addition to the adult literacy courses, the project has also initiated literacy classes for "out of school" children (boys and girls) in the form of "afternoon classes" and "home schools" for boy and girls respectively. These classes were introduced for those boys and girls who "dropped out" or were too young to be admitted into the adult literacy courses and too old to start in the primary schools. 
BAKHTAR UNITY FOR RECONSTRUCTION COUNCIL (BURC)

<ADDRESS>- - COMMUNICATION LINES >

KASSI ROAD, OPPOSITE

HAJE FATEHKHAN ROAD,

PHONE : 081822767

TELEX :

1. S.A. MALIK

2. S. GULAB SHAH

3 .

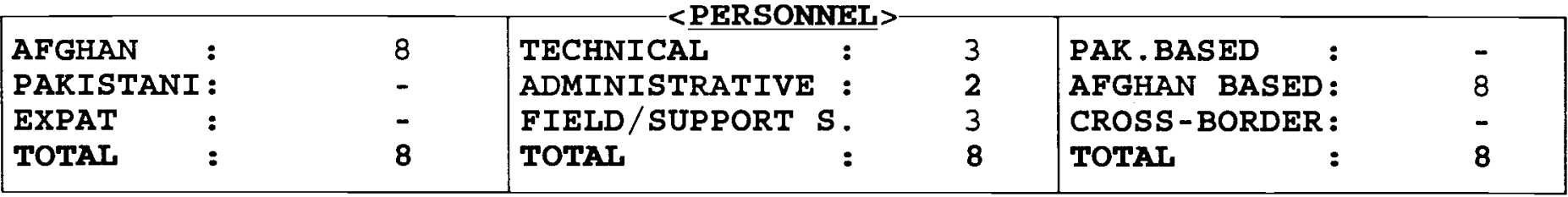

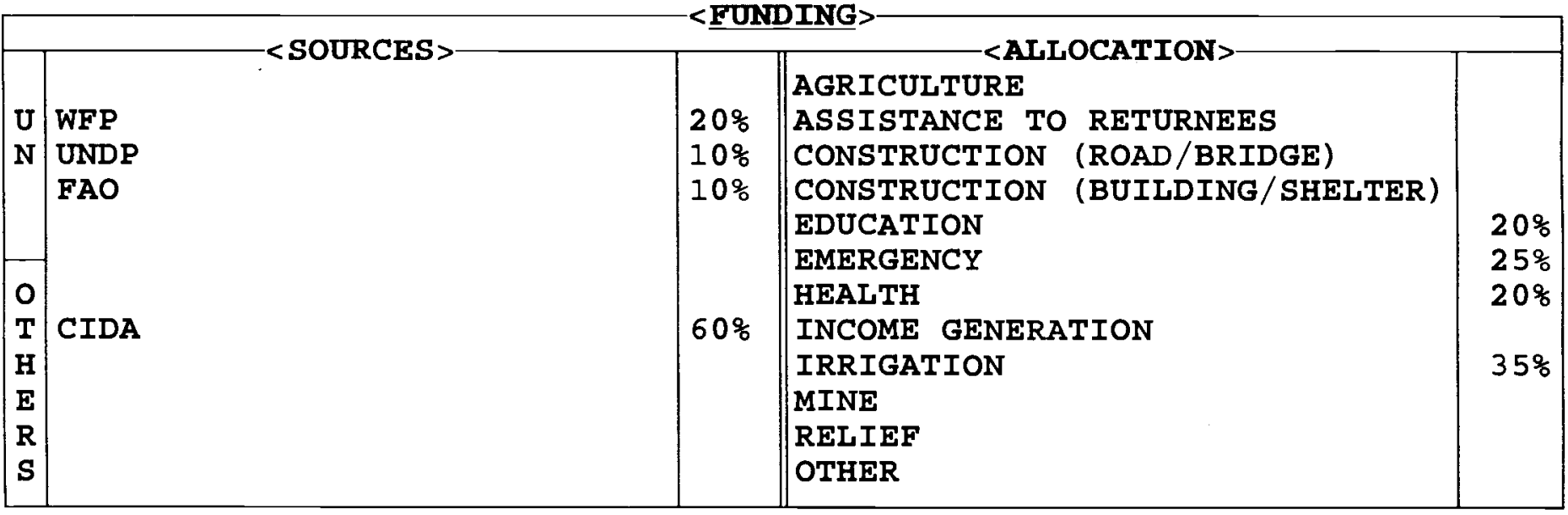

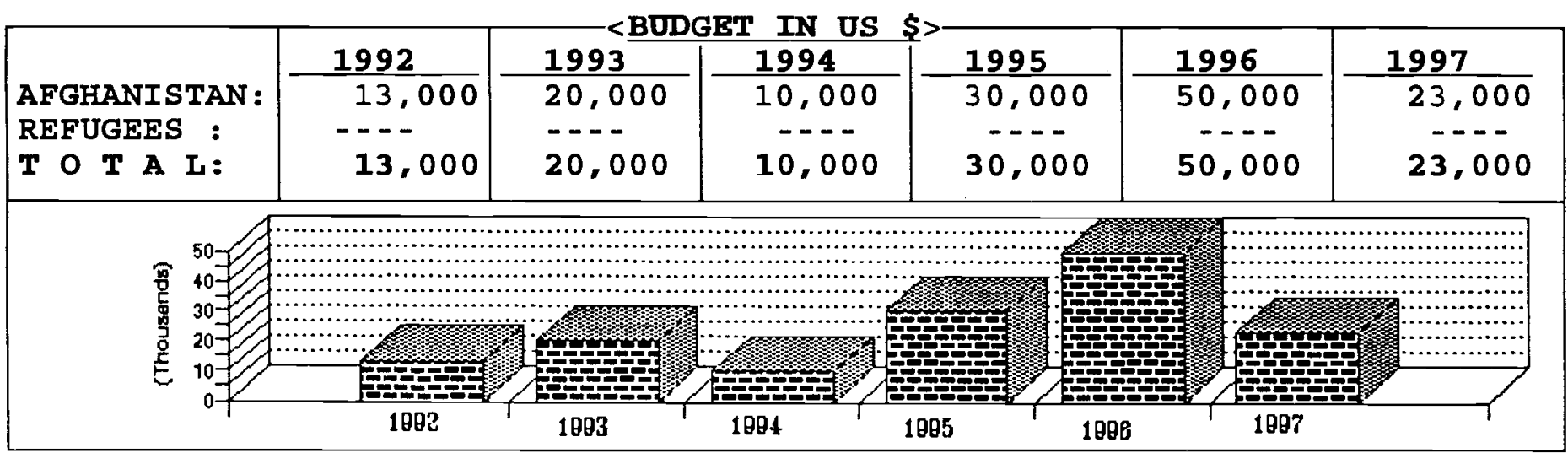

\begin{tabular}{|c|c|c|c|c|c|}
\hline PROVINCES & SECTOR & $\%$ & |PROVINCES & SECTOR & $\frac{8}{6}$ \\
\hline $\begin{array}{l}\text { BADARSHAN } \\
\text { BADGHIS } \\
\text { BAGHLAN } \\
\text { BALKH } \\
\text { BAMYAN } \\
\text { FARAH } \\
\text { FARYAB } \\
\text { GHAZNI } \\
\text { GHOR } \\
\text { HELMAND } \\
\text { HERAT } \\
\text { JAWZJAN } \\
\text { KABUL } \\
\text { KANDAHAR } \\
\text { KAPISA }\end{array}$ & $\begin{array}{l}\text { IRRIGATION } \\
\text { IRRIGATION }\end{array}$ & 15 & $\begin{array}{l}\text { KUNAR } \\
\text { KUNDUZ } \\
\text { LAGHMAN } \\
\text { LOGAR } \\
\text { NANGARHAR } \\
\text { NIMROZ } \\
\text { ORUZGAN } \\
\text { PAKTEKA } \\
\text { PAKTIA } \\
\text { PARWAN } \\
\text { SAMANGAN } \\
\text { TAKHAR } \\
\text { WARDAK } \\
\text { ZABUL }\end{array}$ & $\begin{array}{l}\text { HEALTH / EDUCATION } \\
\text { IRRIGATION }\end{array}$ & $\begin{array}{l}40 \\
10\end{array}$ \\
\hline
\end{tabular}




\section{BAKHTER UNITY RECONSTRUCTION COUNCIL \\ (BURC)}

BURC is an Afghan NGO founded in 1990 with the objective of taking part in the rehabilitation/reconstruction of Afghanistan.

It is currently working in the sectors of agriculture, health, irrigation, education and training. It intends to implement programmes in animal husbandry, construction, including roads. mine removal and relief programmes for disabled Afghans and returnces.

Agriculture: the agency is involved in seed multiplication and fertilizer distribution. It plans to provide agricultural machinery and work towards promotion of agriculture in the area by providing training to farmers. BURC also works in the rehabilitation of irrigation systems including; canals, karezes and springs.

Health: it is running a TBA/midwife training course. A total of 58 students have completed the course. A 13 bed hospital is operated in Quctta for Afghan refugecs. The hospital has an operating theatre, laboratory and two outpatient clinics for children and women.

BURC has constructed $5 \mathrm{~km}$ of road in Urozgan Province.

Some 400 familics have been repatriated to Ghor Province with the assistance of the agency.

The current target Provinces in Afghanistan are: Urozgan, Kandahar and Helmand.

A number of project proposals have been submitted to different United Nations organisations.

If the security situation improves BURC will move its central office to Kabul and open suboffices in Ghor and Kandahar Provinces. 
334-P LANE 5, PESHAWAR RD， GPO 454 RAWALPINDI， PAKISTAN
PHONE : 051864343

F A X: 051470434 email:
1. SALEEM FRANK

2. FAYYAZ GILL

\begin{tabular}{|c|c|c|c|c|c|}
\hline AFGHAN : & - & TECHN I CAL & - & PAK. BASED & 2 \\
\hline PAKISTANI : & 2 & ADMINISTRATIVE : & 2 & AFGHAN BASED : & - \\
\hline EXPAT : & - & FIELD/SUPPORT S. & - & CROSS-BORDER : & - \\
\hline TOTAL & 2 & TOTAL : & 2 & TOTAL : & 2 \\
\hline
\end{tabular}

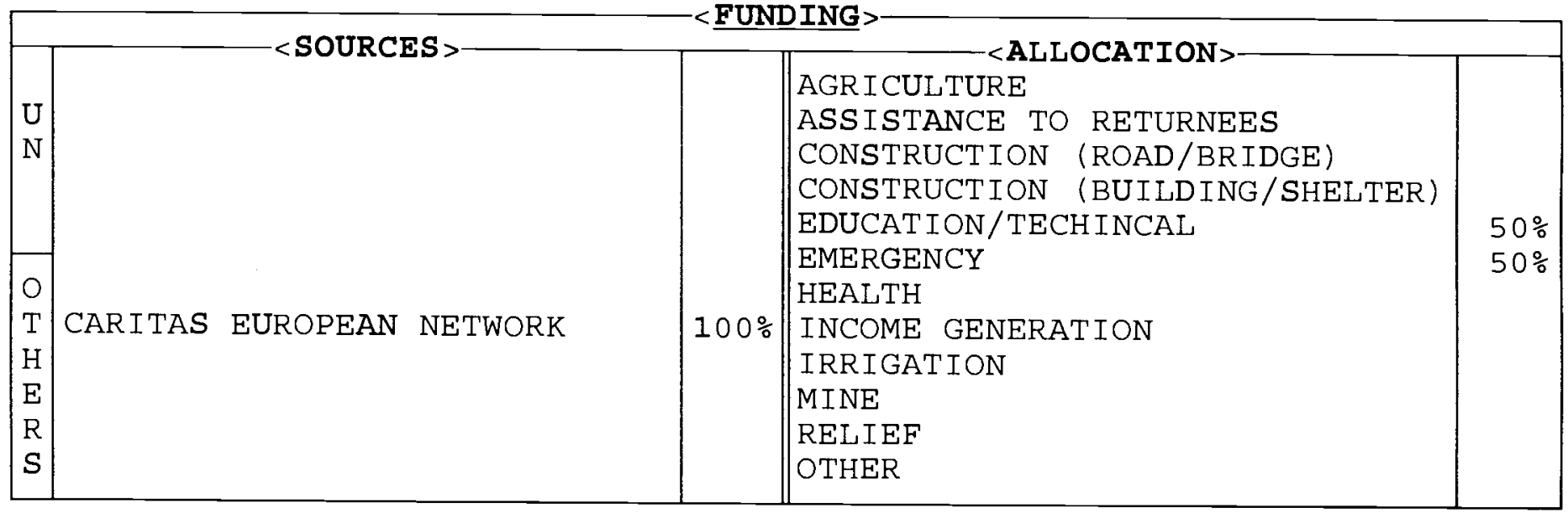

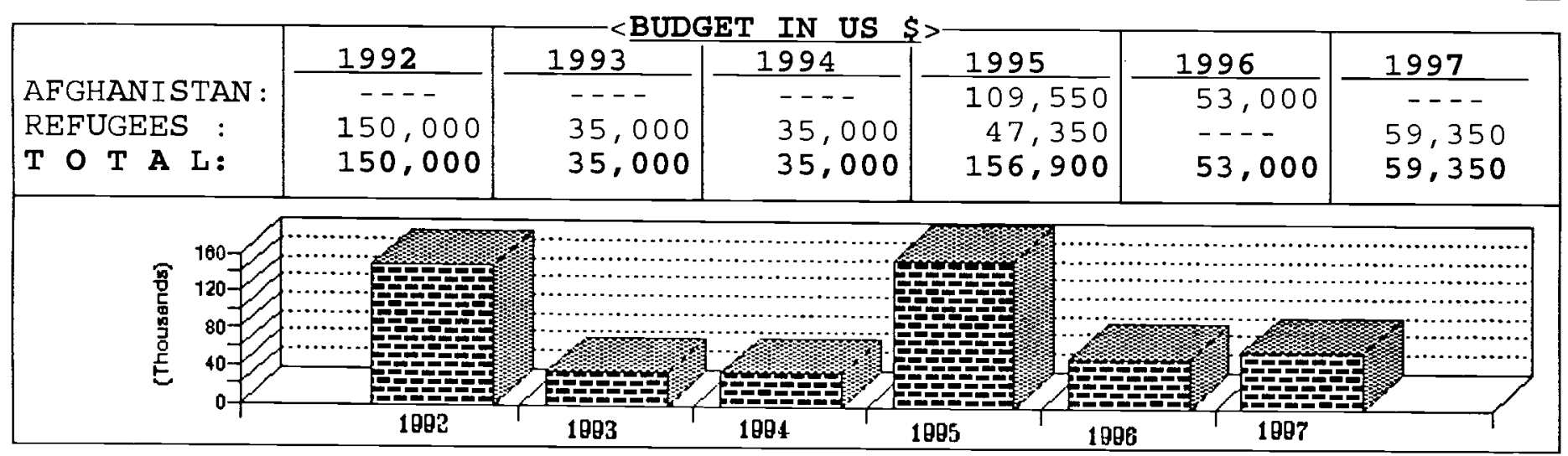

\begin{tabular}{|c|c|c|c|c|c|}
\hline PROVINCES & SECTOR & $\frac{\%}{0}$ & PROVINCES & SECTOR & $\%$ \\
\hline $\begin{array}{l}\text { BADAKSHAN } \\
\text { BADGH IS } \\
\text { BAGHLAN } \\
\text { BALKH } \\
\text { BAMYAN } \\
\text { FARAH } \\
\text { FARYAB } \\
\text { GHAZN I } \\
\text { GHOR } \\
\text { HELMAND } \\
\text { HERAT } \\
\text { JAWZJAN } \\
\text { KABUL } \\
\text { KANDAHAR } \\
\text { KAPISA }\end{array}$ & & & $\begin{array}{l}\text { KUNAR } \\
\text { KUNDUZ } \\
\text { LAGHMAN } \\
\text { LOGAR } \\
\text { NANGARHAR } \\
\text { NIMROZ } \\
\text { ORUZGAN } \\
\text { PAKTEKA } \\
\text { PAKTIA } \\
\text { PARWAN } \\
\text { SAMANGAN } \\
\text { TAKHAR } \\
\text { WARDAK } \\
\text { ZABUL } \\
\text { PAKISTAN }\end{array}$ & EDUCAT ION / EMERGENCY & $100^{\circ}$ \\
\hline
\end{tabular}




\section{CARITAS PAKISTAN \\ (CARITAS)}

CARITAS PAKISTAN was one of the first NGOs to provide assistance to Afghan refugees in Pakistan. It is a large international organisation which strives to provide justice, development, peace and emergency aid. CARITAS Afghan Refugee Project is directed from the Pakistan office, based in Rawalpindi, to manage, operate and monitor the activities related to refugees.

\section{Major aims}
- to promote and oversee social, charitable, and human development work;
- $\quad$ to help and to call for help for victims of natural/man-made disasters, medical and other emergency situations;
- $\quad$ to assist the Afghan and non Afghan refugees.

\section{Mobile Dental Unit (MDU)}

In August 1983 CARITAS started a mobile dental service for refugee communities in NWFP. This was the only service of its kind available to Afghan refugees. The MDU served over 80,000 patients over a 12 year period.

\section{Basic Health Unit (BHU)}

This met a major health need in the Jehad Kali Afghan refugee camp with the construction and setting up of a BHU functional on August 15 1987. The BHU treated over 160,000 patients over the period of 8 years.

Both MDU and BHU were terminated in December 311995.

\section{Shelter}

In 1994-95 CARITAS funded 500 mud-houses in Nasir Bagh camp for new arrivals, who migrated to Pakistan after January 11994. Some 3,682 food packages (rice, beans, sugar and green-tea) were distributed among refugees.

\section{Afghanistan Sanitation and Health Project}

In August 1994, CARIT AS launched a sanitation and health project in New Hada camp, near Jalalabad, to build 6,500 latrines to provide sanitation facilities for 50,000 IDPs. The families were responsible for digging pits, building walls and placing mud/wood roofs. Health education was provided to families to ensure that the benefits of the latrines were realised. This was a community participation project which ended in August 311995.

CARITAS Pakistan is no longer active inside Afghanistan.

\section{Ongoing Activities for New Arrivals}

Since January 1997 CARITAS has been building latrines for new arrivals in Akora Khatak camp in Nowshera District. 300 latrines have been completed. In February 1997 1,400 quilts were distributed to in Nasir Bagh and Akora Khatak camps.

\section{Future Plans}

Future plans depend on the refugee situation and the availability of funds. 
CENTRAL AFGHANISTAN WELFARE COMMITTEE (CAWC)

- ADDRESS>- - COMMUNICATION LINES>

373, STREET 12, D-3, PH 1 PHONE: 811231

HAYATABAD, UPO. BOX 1044

F A X:

<EY STAFF>

PESHAWAR, PAKISTAN

TELEX :

1. NIK MOHD AHMADI

2. DR. SHOAIB

3. ENG. M.LATIF

\begin{tabular}{|c|c|c|c|c|c|}
\hline AFGHAN : & 21 & TECHNICAL : & 10 & PAK . BASED & 5 \\
\hline PAKISTANI : & - & ADMINISTRATIVE : & 5 & AFGHAN BASED: & 14 \\
\hline EXPAT : & - & FIELD/SUPPORT S. & 6 & CROSS-BORDER: & 2 \\
\hline TOTAL & 21 & TOTAL : & 21 & TOTAL : & 21 \\
\hline
\end{tabular}

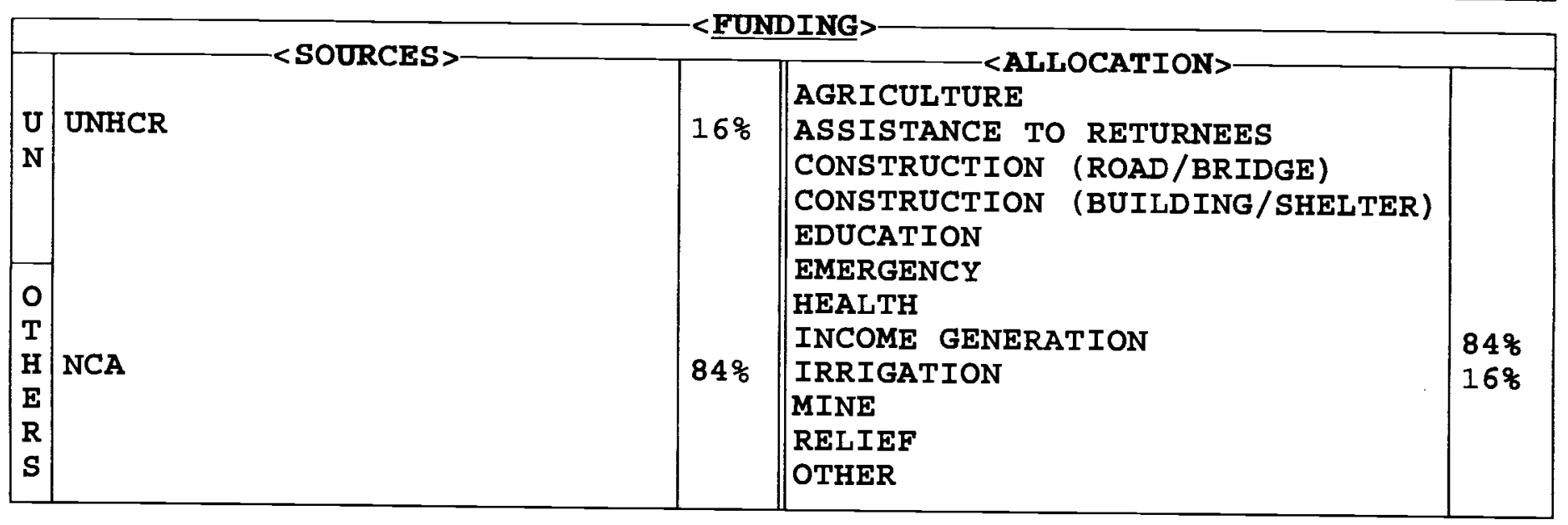

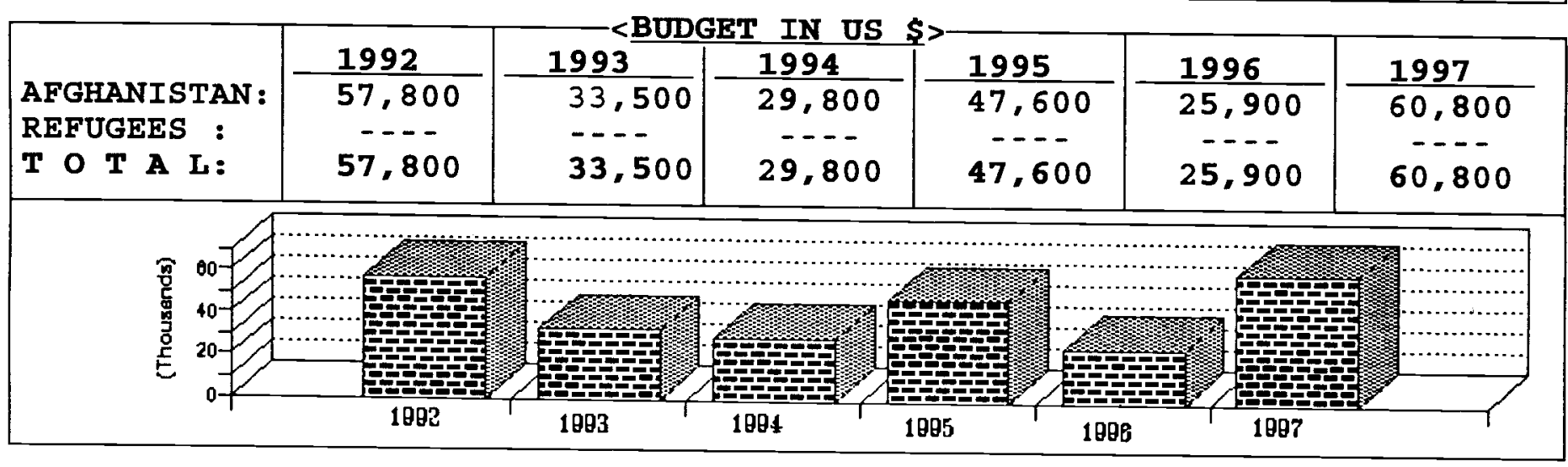

\begin{tabular}{|c|c|c|c|c|c|}
\hline PROVINCES & SECTOR & $\%$ & PROVINCES & SECTOR & $\%$ \\
\hline $\begin{array}{l}\text { BADAKSHAN } \\
\text { BADGHIS } \\
\text { BAGHLAN } \\
\text { BALKH } \\
\text { BAMYAN } \\
\text { FARAH } \\
\text { FARYAB } \\
\text { GHAZNI } \\
\text { GHOR } \\
\text { HELMAND } \\
\text { HERAT } \\
\text { JAWZJAN } \\
\text { RABUL } \\
\text { KANDAHAR } \\
\text { RAPISA }\end{array}$ & IRRIGATION & 16 & $\begin{array}{l}\text { KUNAR } \\
\text { KUNDUZ } \\
\text { LAGHMAN } \\
\text { LOGAR } \\
\text { NANGARHAR } \\
\text { NIMROZ } \\
\text { ORUZGAN } \\
\text { PAKTERA } \\
\text { PAKTIA } \\
\text { PARWAN } \\
\text { SAMANGAN } \\
\text { TAKHAR } \\
\text { WARDAR } \\
\text { ZABUL }\end{array}$ & INCOME GENERATION & 63 \\
\hline
\end{tabular}




\section{CENTRAL AFGHANISTAN WELFARE \\ COMMITTEE \\ (CAWC)}

CAWC is a non-governmental, non profit and non-political organization. It was founded in April 1992.

CAWC"s aim is to help the deprived Afghan people by implementing multi-sector rehabilitation and development projects by establishing planning, dcsigning and undertaking sustainablc cconomic and humanitarian assistancc programme.

\section{Objectives:}

The objective of CAWC is to work for the rehabilitation and development of Afghanistan and provide assistanec in the ficld of agriculture, cducation, construction irrigation and social services, It also provides and coordinate training for income gencrating programmes to cmpower the community for self-sustainable and self-cmployment. 
$-<$ ADDRESS $>-<$ COMMUNICATION LINES $>$

37 D CIRCULAR LANE

UNIVERSITY TOWN

PESHAWAR， PAKISTAN
PHONE : 842193

F A X: 842193

email:
1. ENG KAMAL NEZAMI

2. ENG M QAHIR HAIDARI

3 .

\begin{tabular}{|c|c|c|c|c|c|}
\hline AFGHAN & 24 & TECHN ICAL : & 4 & PAK. BASED & 18 \\
\hline PAKISTANI : & 2 & ADMINISTRATIVE : & 2 & AFGHAN BASED : & 8 \\
\hline EXPAT : & - & FIELD/SUPPORT S. & 20 & CROSS-BORDER : & - \\
\hline TOTAL & 26 & TOTAL : & 26 & TOTAL : & 26 \\
\hline
\end{tabular}

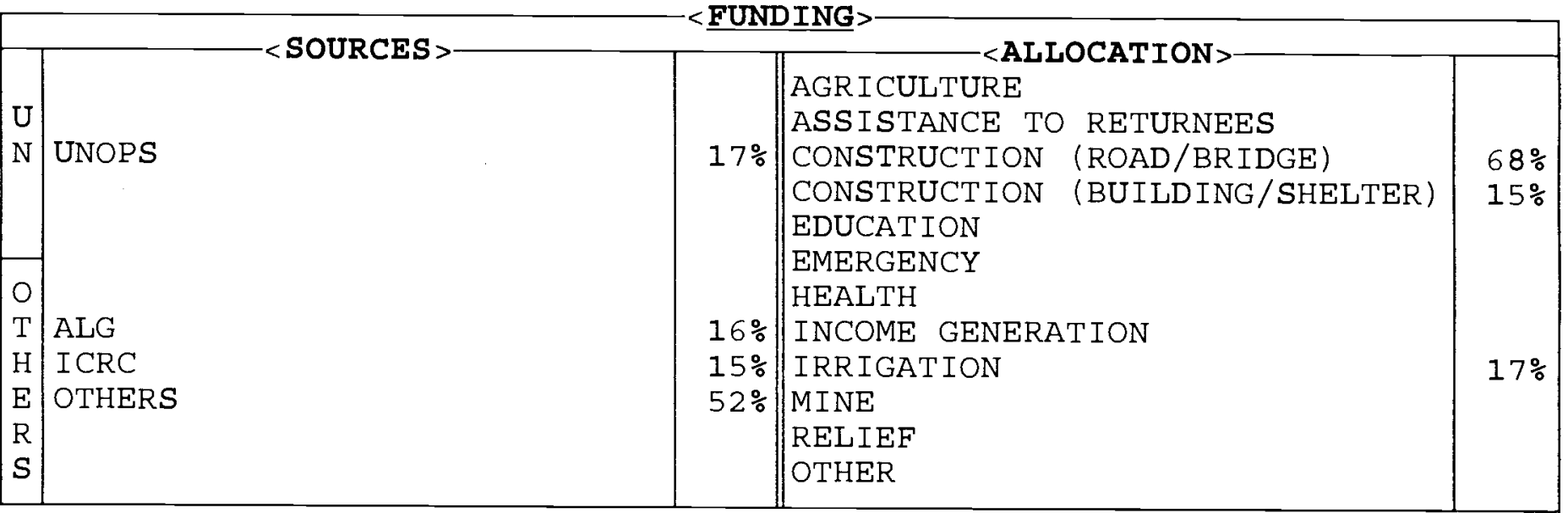

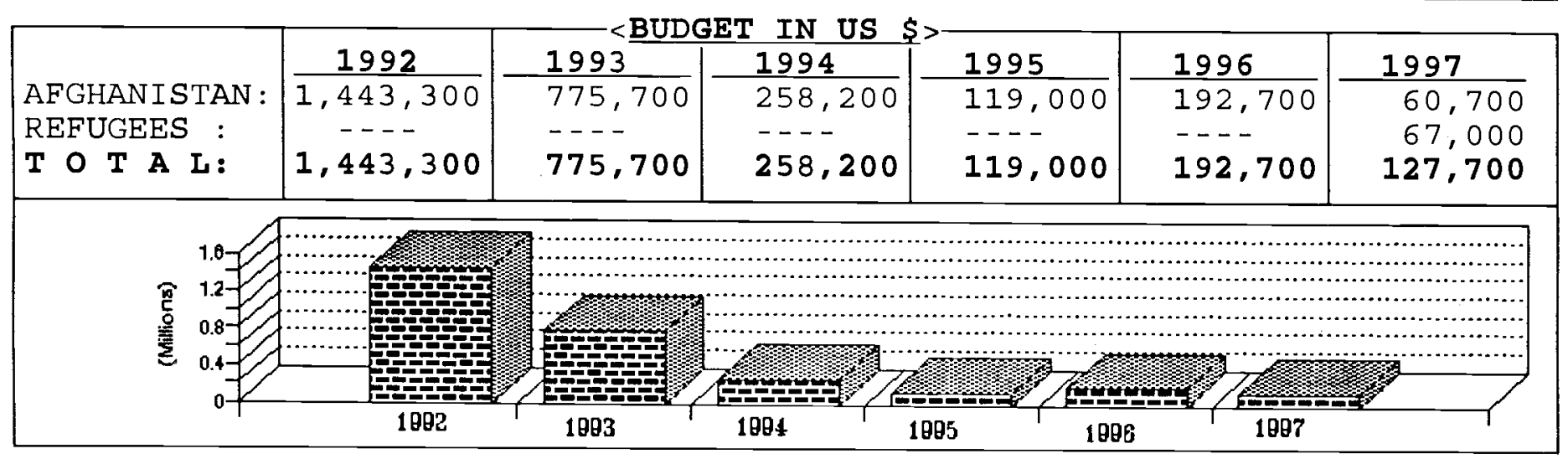

\begin{tabular}{|c|c|c|c|c|c|}
\hline PROVINCES & SECTOR & $\div$ & PROVINCES & SECTOR & $\%$ \\
\hline $\begin{array}{l}\text { BADAKSHAN } \\
\text { BADGHIS } \\
\text { BAGHLAN } \\
\text { BALKH } \\
\text { BAMYAN } \\
\text { FARAH } \\
\text { FARYAB } \\
\text { GHAZNI } \\
\text { GHOR } \\
\text { HELMAND } \\
\text { HERAT } \\
\text { JAWZJAN } \\
\text { KABUL } \\
\text { KANDAHAR } \\
\text { KAPISA }\end{array}$ & CONSTRUCTION (BRIDGE) & 16 & $\begin{array}{l}\text { KUNAR } \\
\text { KUNDUZ } \\
\text { LAGHMAN } \\
\text { LOGAR } \\
\text { NANGARHAR } \\
\text { NIMROZ } \\
\text { ORUZGAN } \\
\text { PAKTEKA } \\
\text { PAKTIA } \\
\text { PARWAN } \\
\text { SAMANGAN } \\
\text { TAKHAR } \\
\text { WARDAK } \\
\text { ZABUL } \\
\text { PAKISTAN }\end{array}$ & $\begin{array}{l}\text { IRRIGATION } \\
\text { CONSTRUCTION (SHELT) } \\
\text { CONSTRUCTION (ROAD) }\end{array}$ & 15 \\
\hline
\end{tabular}




\section{CONSULTANT BUREAU FOR \\ RECONSTRUCTION (CBR)}

CBR was founded in September 1988 inside Afghanistan.

\section{Objectives}

- To take part in construction and reconstruction of the infrastructures of the country i.e. public buildings, roads, bridges, irrigation systems and other necessary sectors.

- To participate in joint ventures with other organisations.

- To accept orders from individuals, Government departments and organisations, according to fees.

- To identify priorities set by local people, evaluate projects and submit projects to donors.

There are four types of contract possible with donor agencies:

a. Joint venture;

b. Lump sum cost contract;

c. Contract with the administration support provision; and

d. Contracts based on unit cost.

The main funding sources of CBR have been: WHO, USAID, IRC/RAP, ARCON, UNOCHA, UNDP, UNOPS, FAO, IIRO, WFP, CIDA, UNICEF and ASC.

\section{Project activities:}

- some 17 Comprehensive Health Centres $(\mathrm{CHC})$ and Basic Health Centres (BHC) have been established in seven different Provinces.

- in 1992, $25 \mathrm{~km}$ of road in Takhar Province was repaired with funds from USAID.

- in 1993, $50 \mathrm{~km}$ of road in Zeebak was repaired and $25 \mathrm{~km}$ of new road construction and $100 \mathrm{~km}$ of road repair was undertaken on the Chitral - Badakhshan road.

- in 1993, Parwan Canal was repaired, Salang irrigation systems rehabilitated and Taluqan canal cleaning completed.
- irrigation systems in Laghman, Herat, Paktia and Paktika were rehabilitated in the years between 1993 - 1997.

- from 1994 to 1997 sanitation projects have been undertaken in Hesar Shahi Camp in Jalalabad.

- the road connecting Parwan and Baghlan at the Khawak Pass was repaired.

CBR has also surveyed, designed and implemented various projects in different sectors in many Provinces of Afghanistan and Pakistan. The agency is well equipped and has a road construction unit, consisting of heavy machinery and the capacity to survey, design and implement projects in different sectors. 
COOPERATION CENTRE FOR AFGHANISTAN (CCA)

<ADDRESS >- $-<$ COMMUNICATION LINES $>$

HOUSE 420, STREET 13

PHASE I, HAYATABAD

PESHAWAR， PAKISTAN
PHONE : 816386

F A X:

email:
1. SARWAR HUSSAINI

2. SADIQ KAZMI

3. ENG SIA-UL-HAQ

\begin{tabular}{|c|c|c|c|c|c|}
\hline AFGHAN & 56 & TECHNICAL & 31 & PAK. BASED : & 10 \\
\hline PAKISTANI : & - & ADMINISTRATIVE : & 13 & AFGHAN BASED : & 46 \\
\hline EXPAT : & - & FIELD/SUPPORT S. & 12 & CROSS-BORDER : & - \\
\hline TOTAL & 56 & TOTAL : & 56 & TOTAL : & 56 \\
\hline
\end{tabular}

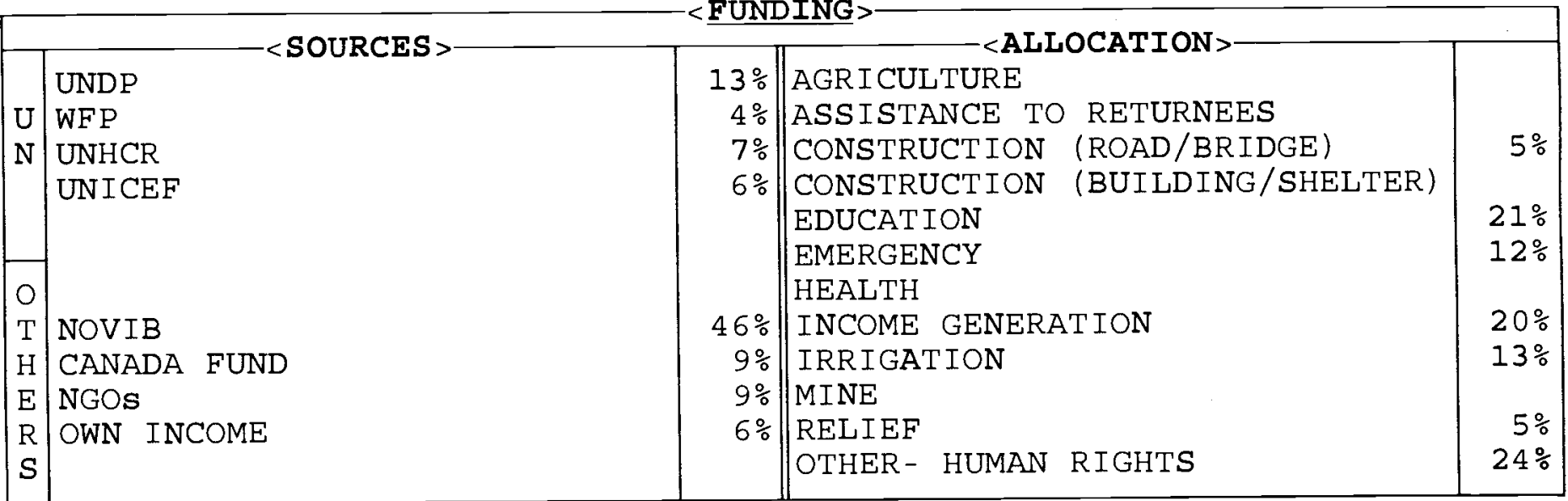

\begin{tabular}{|c|c|c|c|c|c|c|}
\hline & 1992 & 1993 & 1994 & 1995 & 1996 & 1997 \\
\hline AFGHANISTAN : & 131,300 & 154,300 & 154,300 & 230,700 & 283,000 & 250,000 \\
\hline REFUGEES : & --- & ---- & --- & ---- & --- & --- \\
\hline T O T A L: & 131,300 & 154,300 & 154,300 & 230,700 & 283,000 & 250,000 \\
\hline
\end{tabular}

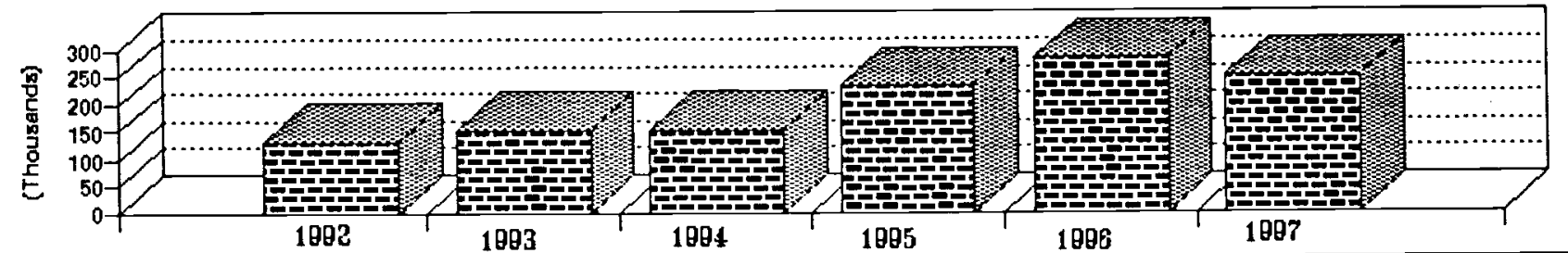

$<$ TARGET PROVINCES IN AFGHANISTAN>

\begin{tabular}{|c|c|c|c|c|c|}
\hline PROVINCES & SECTOR & $\%$ & PROVINCES & SECTOR & $\%$ \\
\hline $\begin{array}{l}\text { BADAKSHAN } \\
\text { BADGHIS } \\
\text { BAGHLAN } \\
\text { BALKH } \\
\text { BAMYAN } \\
\text { FARAH } \\
\text { FARYAB } \\
\text { GHAZNI } \\
\text { GHOR } \\
\text { HELMAND } \\
\text { HERAT } \\
\text { JAWZJAN } \\
\text { KABUL } \\
\text { KANDAHAR } \\
\text { KAPISA }\end{array}$ & $\begin{array}{l}\text { H. R. / CONST / EDUC/IRRIG } \\
\text { IN. GEN . / RELIEF } \\
\text { IN. GEN . / EMERG } \\
\\
\text { HUMAN RIGHTS } \\
\text { HUMAN RIGHTS }\end{array}$ & 19 & $\begin{array}{l}\text { KUNAR } \\
\text { KUNDUZ } \\
\text { LAGHMAN } \\
\text { LOGAR } \\
\text { NANGARHAR } \\
\text { NIMROZ } \\
\text { ORUZGAN } \\
\text { PAKTEKA } \\
\text { PAKTIA } \\
\text { PARWAN } \\
\text { SAMANGAN } \\
\text { TAKHAR } \\
\text { WARDAK } \\
\text { ZABUL } \\
\text { PAKISTAN }\end{array}$ & $\begin{array}{l}\text { RELIEF/CONST } \\
\text { HUMAN RIGHTS }\end{array}$ & 19 \\
\hline
\end{tabular}




\section{COOPERATION CENTRE FOR AFGHANISTAN (CCA)}

CCA was founded in 1990. In its early steps CCA was trying to reduce the effects of the war and strengthen the resistance power of people.

With the passage of time CCA revised its policy to just being involved in rehabilitation and emergency work; and directed its efforts towards activities aimed at developing lasting solutions to problems. In addition, CCA noticed that the work does not lead to its expected results until there is peace and respect for human rights in Afghanistan. Hence, CCA places special emphasis on human rights by undertaking the promotion of human rights project in Afghanistan in 1994.

\section{CCA's Mission}

CCA works for human rights and sustainable development in Afghanistan. These two goals inter-link and mutually support each other. For sustainable development CCA follows an integrated approach and undertakes projects and activities which are directed towards empowering the poor with special emphasis on skill training for target groups in target areas.

CCA seeks the full application of International human rights standards in Afghanistan by educating the public in human rights and monitoring the improvement of the human rights situation in the country.

CCA is committed to mobilization and maximum use of local resources. Meanwhile CCA tries to attract the attention of Donor Organisations and communities to Afghanistan by informing them about the suffering and misery of the Afghan people.

Apart from its headquarters CCA has three suboffices in Afghanistan which are located in Kabul, Mazar-e-Sharif and Bamyan cities. $\mathrm{CCA}$ also has some field offices at district level in some Provinces.

CCA publishes a journal in Persian and a news letter in English. 
HSE 95 STR $6 \mathrm{~N}-3$ PHASE 4 HAYATABAD PESHAWAR, PAKISTAN
PHONE: $817387 / 813299$

F A X: 0391290908 email:Nasir@cha.pwr.sdnpk.undp.org
1. ABDUL SALAM RAHIMI

2. ABDUL NASIR RAHIMI
$<$ PERSONNEL $>$

\begin{tabular}{|c|c|c|c|c|c|}
\hline AFGHAN & 387 & TECHN ICAL : & 222 & PAK . BASED & 37 \\
\hline PAKISTANI : & 1 & ADMINISTRATIVE : & 166 & AFGHAN BASED: & 346 \\
\hline EXPAT : & - & FIELD/SUPPORT S. & - & CROSS-BORDER : & \\
\hline TOTAL & 388 & TOTAL : & 388 & TOTAL : & 388 \\
\hline
\end{tabular}

\begin{tabular}{|c|c|c|c|c|}
\hline & $-<$ SOURCES $>$ & & $-<$ ALLOCATION $>$ & \\
\hline & & & AGR ICULTURE & $5 \%$ \\
\hline $\mathrm{U}$ & & & ASSISTANCE TO RETURNEES & \\
\hline $\mathrm{N}$ & UN & $4 \%$ & CONSTRUCTION （ROAD/BRIDGE） & $5 \%$ \\
\hline & & & CONSTRUCTION (BUILDING/SHELTER) & $2 \%$ \\
\hline & & & EDUCATION & $26 \%$ \\
\hline & & & EMERGENCY & \\
\hline 0 & & & HEALTH & $10 \%$ \\
\hline $\mathrm{T}$ & EUROPEAN UNION & $21 \%$ & INCOME GENERATION & \\
\hline $\mathrm{H}$ & NOVIB & $75 \%$ & IRR IGATION & \\
\hline $\mathrm{E}$ & & & MINE & \\
\hline $\mathrm{R}$ & & & RELIEF & \\
\hline$S$ & & & OTHER & $52 \%$ \\
\hline
\end{tabular}

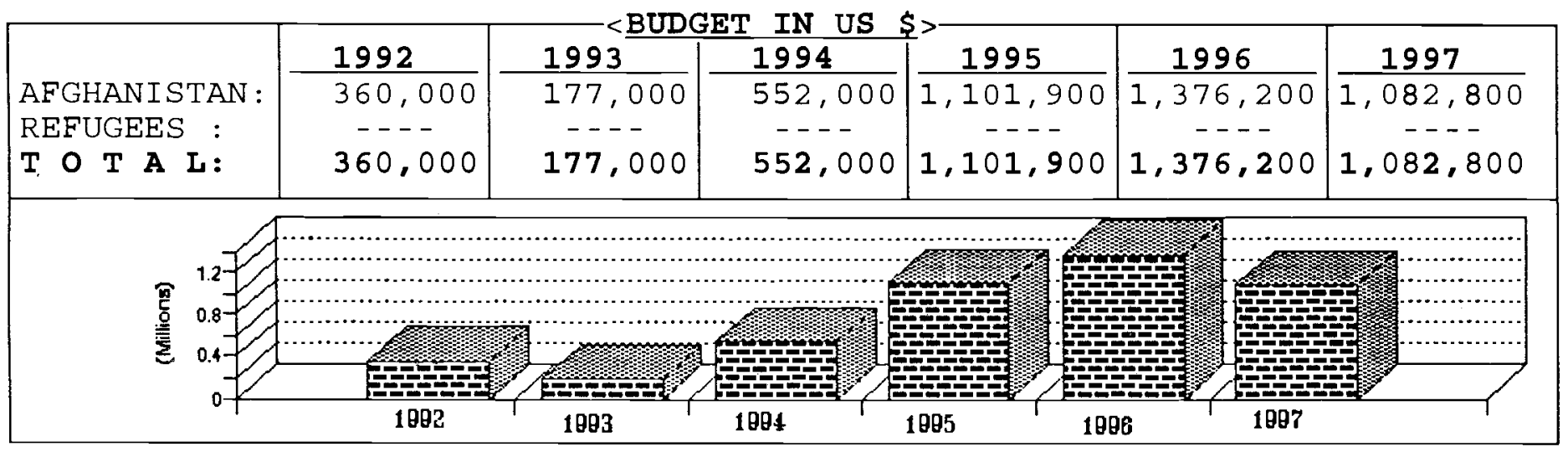

\begin{tabular}{|c|c|c|c|c|c|}
\hline PROVINCES & SECTOR & $\div$ & PROVINCES & SECTOR & $\%$ \\
\hline $\begin{array}{l}\text { BADAKSHAN } \\
\text { BADGHIS } \\
\text { BAGHLAN } \\
\text { BALKH } \\
\text { BAMYAN } \\
\text { FARAH } \\
\text { FARYAB } \\
\text { GHAZN I } \\
\text { GHOR } \\
\text { HELMAND } \\
\text { HERAT } \\
\text { JAWZJAN } \\
\text { KABUL } \\
\text { KANDAHAR } \\
\text { KAPISA }\end{array}$ & $\begin{array}{l}\text { DIS REHAB } \\
\text { AGR IC/HLTH/EDUC/CONST } \\
\text {. /DIS REHAB } \\
\text { AGR IC/HLTH/EDUC/CONST } \\
\text { AGR IC/CONST/EDUC } \\
\text { AGR IC/EDUC/CONST }\end{array}$ & 33 & $\begin{array}{l}\text { KUNAR } \\
\text { KUNDUZ } \\
\text { LAGHMAN } \\
\text { LOGAR } \\
\text { NANGARHAR } \\
\text { NIMROZ } \\
\text { ORUZGAN } \\
\text { PAKTEKA } \\
\text { PAKT IA } \\
\text { PARWAN } \\
\text { SAMANGAN } \\
\text { TAKHAR } \\
\text { WARDAK } \\
\text { ZABUL } \\
\text { REFUGEES }\end{array}$ & & \\
\hline
\end{tabular}




\section{COORDINATION OF HUMANITARIAN ASSISTANCE (CHA)}

CHA was established in 1988. The objective of the organisation is to help the development of the Afghan society through cooperation in rehabilitation, reconstruction and sustainable social and economic advancement of communities.

The agency is involved in agriculture, irrigation and infrastructure rehabilitation, health, vocational training, education and emergency relief programmes.

\section{Agriculture}

CHA is involved in nurseries, horticulture, food security, farm power and distribution of improved wheat seeds and fertilizer.

Since 1993 CHA has implemented a number of agricultural projects in Farah Province including tree distribution and nursery and poultry farms.

\section{Irrigation}

Projects include repair and cleaning of karezes and canals and construction of diversion dams.

\section{Construction}

The construction of public buildings, including clinics, schools and digging wells. Road repair projects are also implemented.

\section{Health}

In the health sector the agency is involved in organising vaccination programmes and has two $\mathrm{MCH}$ clinics and a BHC.

\section{Training}

Several vocational training centers (carpet weaving) for war-widows, have been opened, in Farah, Herat, Shindand and Kabul Provinces. An auto workshop for repairing vehicles and machinery in Farad Province is also ongoing.
The agency has 3 regional offices and 3 field offices in $A$ fghanistan with its head office in Peshawar.

CHA implements higher level education at the Faculty of Engineering and Construction Institute in Herat.

There are four training centers for English language, typing, computer, math and fine art courses in Herat, Farah, Kandahar and Kabul Provinces.

Capacity Building workshops are organised to enhance and improve Human Resource Development for CHA staff and staff of other NGOs.

The agency is carrying out a Comprehensive Disabled Afghan's programme to mobilise local communities and make them aware of the needs of the disabled within the community. The objective of this programme is to facilitate the full integration and rehabilitation of the disabled in their communities 


\begin{tabular}{|l|l|l|}
\hline HOUSE 6 PARK LANE PARK & PHONE: $40614 / 45317 / 40328$ & 1. PAUL BARKER \\
RD, U/T P O BOX 926 & F A X: 841826 & 2. ENG ASEF RAHIMI \\
PESHAWAR, PAKISTAN & email: & 3. STUART WORSLEY
\end{tabular}

\begin{tabular}{|c|c|c|c|c|c|}
\hline AFGHAN & 248 & TECHNICA & 7 & PAK. BASED & 59 \\
\hline PAKISTANI : & 8 & ADMINISTRATIVE : & 55 & AFGHAN BASED : & 202 \\
\hline EXPAT : & 5 & FIELD/SUPPORT S. & 199 & CROSS-BORDER : & - \\
\hline TOTAL & 261 & TOTAL : & 261 & TOTAL : & 261 \\
\hline
\end{tabular}
SOURCES

U WFP

$\mathrm{N}$ UNHCR

UNICEF

EU

O ECHO

$T$ CANADA FOOD GRAN BANK

H STATE OF JERSEY

E CARE USA

$\mathrm{R}$ USAID

$S$ OTHERS
$<$ FUNDING >

\begin{tabular}{|c|c|c|}
\hline & AGR ICULTURE & \\
\hline $4 \%$ & ASSISTANCE TO RETURNEES & \\
\hline $1 \%$ & CONSTRUCTION (ROAD/BRIDGE) & \\
\hline $1 \%$ & $\begin{array}{l}\text { CONSTRUCTION (BUILDING / SHELTER) } \\
\text { EDUCATION }\end{array}$ & $39 \%$ \\
\hline $20 \%$ & EMERGENCY & $1 \%$ \\
\hline $21 \%$ & HEALTH & $49 \%$ \\
\hline $20 \%$ & INCOME GENERATION & \\
\hline $27 \%$ & IRRIGATION & $11 \%$ \\
\hline $4 \%$ & MINE & \\
\hline $1 \%$ & RELIEF & \\
\hline $1 \%$ & OTHER & \\
\hline
\end{tabular}

\begin{tabular}{|c|c|c|c|c|c|c|}
\hline $\begin{array}{l}\text { AFGHANISTAN: } \\
\text { REFUGEES : } \\
\text { T O T A L: }\end{array}$ & $\begin{array}{c}\frac{1992}{9,781,800} \\
-\cdots \\
9,781,800\end{array}$ & $\begin{array}{l}\frac{1993}{3,019,400} \\
-019,400\end{array}$ & $\begin{array}{c}\frac{1994}{5,394,300} \\
\cdots \\
5,394,300\end{array}$ & {$\left[\begin{array}{c}\frac{1995}{3,142,850} \\
--- \\
3,142,850\end{array}\right.$} & $\begin{array}{c}\frac{1996}{4,513,200} \\
--- \\
4,513,200\end{array}$ & 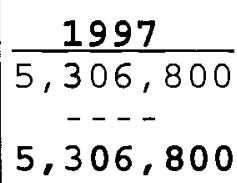 \\
\hline ر & 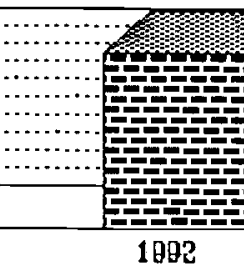 & 1).................... & 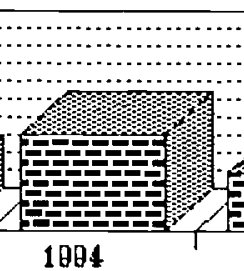 & 1805 & 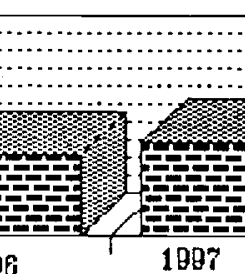 & 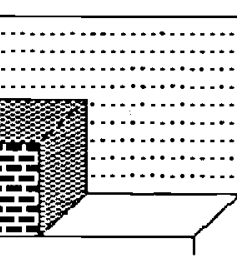 \\
\hline
\end{tabular}

\begin{tabular}{|c|c|c|c|c|c|}
\hline PROVINCES & SECTOR & $\%$ & PROVINCES & SECTOR & $\%$ \\
\hline $\begin{array}{l}\text { BADAKSHAN } \\
\text { BADGHIS } \\
\text { BAGHLAN } \\
\text { BALKH } \\
\text { BAMYAN } \\
\text { FARAH } \\
\text { FARYAB } \\
\text { GHAZNI } \\
\text { GHOR } \\
\text { HELMAND } \\
\text { HERAT } \\
\text { JAWZJAN } \\
\text { KABUL } \\
\text { KANDAHAR } \\
\text { KAPISA }\end{array}$ & $\begin{array}{l}\text { IRRIG/CONST/AGRIC } \\
\text { RELIEF/IRRIG/CONST/ }\end{array}$ & 63 & $\begin{array}{l}\text { KUNAR } \\
\text { KUNDUZ } \\
\text { LAGHMAN } \\
\text { LOGAR } \\
\text { NANGARHAR } \\
\text { NIMROZ } \\
\text { ORUZGAN } \\
\text { PAKTEKA } \\
\text { PAKTIA } \\
\text { PARWAN } \\
\text { SAMANGAN } \\
\text { TAKHAR } \\
\text { WARDAK } \\
\text { ZABUL } \\
\text { PAKISTAN }\end{array}$ & $\begin{array}{l}\text { IRRIG/CONST/AGRIC } \\
\text { IRRIG/CONST/w.S/ADUC } \\
\text { IRRIG/CONST/W.S/EDUC } \\
\text { IRRIG/AGRIC/W.S. } \\
\text { CONST/AGRIC }\end{array}$ & $\begin{array}{r}13 \\
12 \\
5\end{array}$ \\
\hline
\end{tabular}




\section{CARE INTERNATIONAL (CI)}

CARE International, founded in 1945, is an international relief and development agency working in Africa, Asia and Latin America.

Through a worldwide network CARE manages over 200 self-help projects in 40 developing countries, employing 9,500 national and international staff. CARE is non political and non sectarian.

All projects are based on the key principles of self-help and sustainability.

\section{Further Information}

CARE was involved in Afghanistan 1960-1979, providing health care and medical training. In 1988 a team was sent from Pakistan to assess the situation facing Afghan refugees upon their eventual repatriation, and to determine how CARE could best provide repatriation assistance. The Afghan Village Assistance Programme was developed soon after.

CARE-Afghanistan's mission for the Afghan village Assistance Programme is to create conditions conducive to sustained repatriation through a range of Food and cash for work activities.

\section{Sector of Operation}

Around the world, CARE provides training in primary health care, agriculture, conservation of the environment, income generation, education and brings relief during emergencies.

CARE's training activities in Afghanistan are vocational in nature. On-site training exists for each of the following activities, as well as for project management;

- Reconstruction of irrigation systems;

- $\quad$ Building of village to market roads and tracks;

Construction of village level storehouses
- Reconstruction and construction of crosion barriers;

- $\quad$ Rebuilding of low cost houses for war widowed and disabled families;

- Wheat seed production;

- Agriculture and natural resource programme work.

\section{Future training Objectives}

CARE's training plans include training unskilled workers from the project areas of Khost, Gardez, Paktika and Maidan-Shar to become carpenters, masons and iron workers. This will create work opportunities for residents in project areas, contributing to the sustainability of the project, while stimulating the economy of the project area. 
CHILDREN IN CRISIS (CIC)

$-<$ ADDRESS

140， STREET 15

WAZIR AKBAR RHAN,

KABUL, AFGHANISTAN
<COMMUNICATION LINES>

PHONE : KABUL 25703

F A $X$ : SATELLITE 00873

TELEX :
1. JACK R.BELL

2. MINA R. BELL

3. AFZAL HABIB

\begin{tabular}{|c|c|c|c|c|c|}
\hline $\begin{array}{l}\text { AFGHAN : } \\
\text { PARISTANI : } \\
\text { EXPAT : } \\
\text { TOTAL : }\end{array}$ & $\begin{array}{l}4 \\
- \\
2 \\
6\end{array}$ & $\begin{array}{l}\text { TECHNICAL : } \\
\text { ADMINISTRATIVE: } \\
\text { FIELD/SUPPORT S : } \\
\text { TOTAL }\end{array}$ & $\begin{array}{l}1 \\
2 \\
3 \\
6\end{array}$ & $\begin{array}{l}\text { PAR. BASED: } \\
\text { AFGHAN BASED: } \\
\text { CROSS-BORDER: } \\
\text { TOTAL : }\end{array}$ & $\begin{array}{l}- \\
6 \\
-\end{array}$ \\
\hline
\end{tabular}

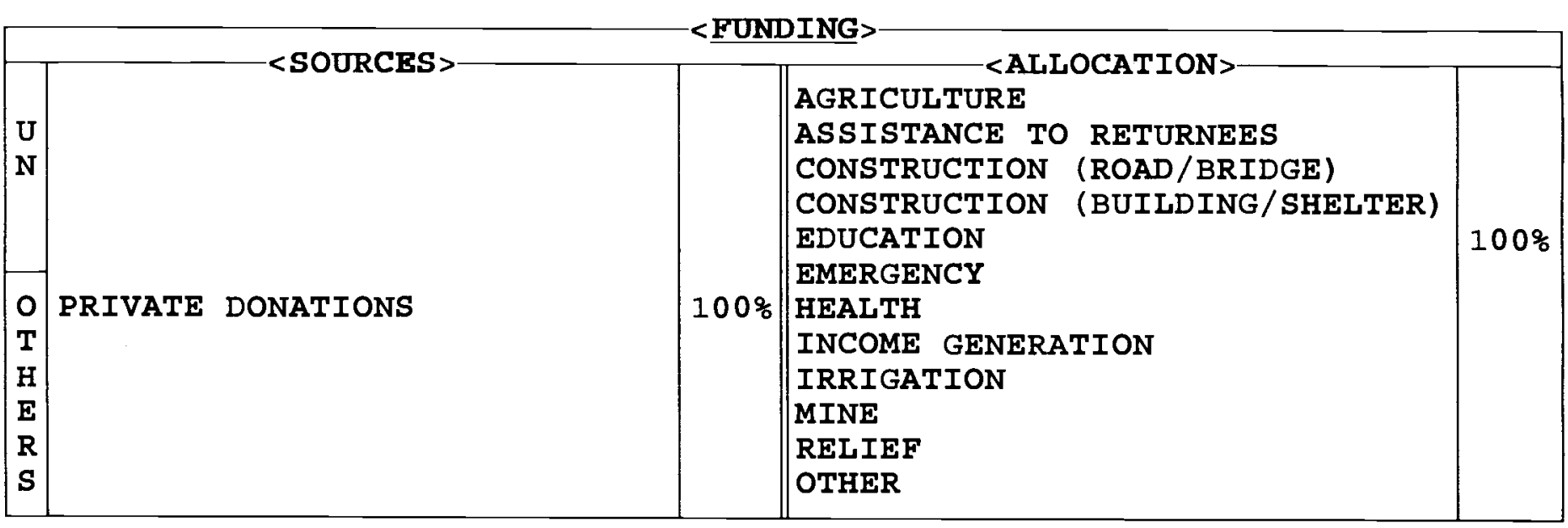

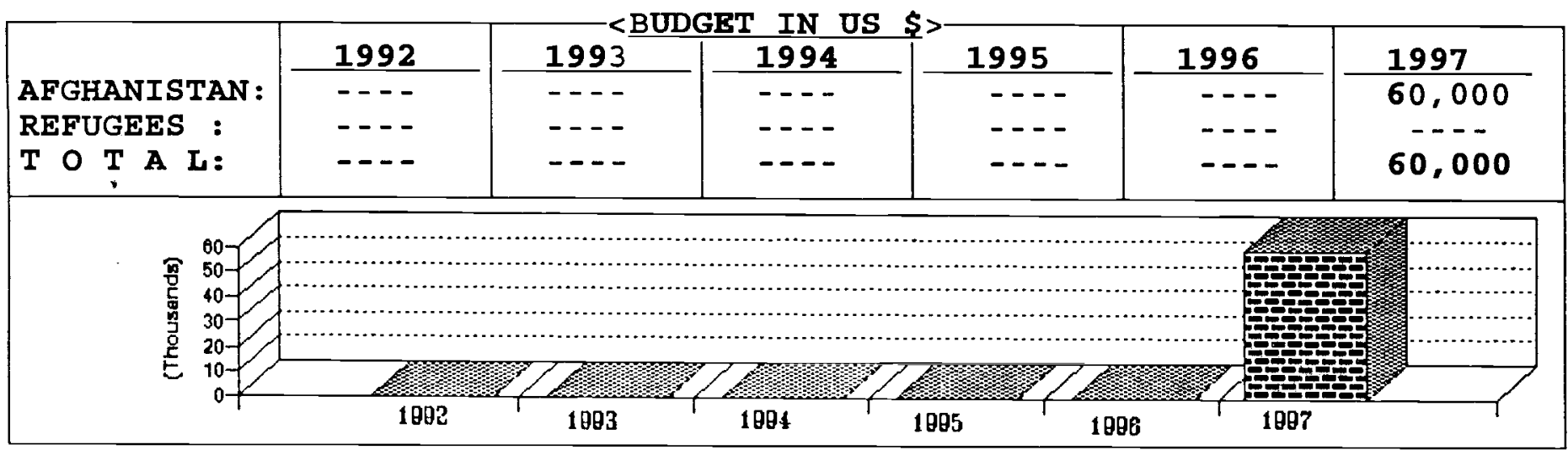

\begin{tabular}{|c|c|c|c|c|c|}
\hline PROVINCES & SECTOR & $\%$ & PROVINCES & SECTOR & $\%$ \\
\hline $\begin{array}{l}\text { BADAKSHAN } \\
\text { BADGHIS } \\
\text { BAGHLAN } \\
\text { BALKH } \\
\text { BAMYAN } \\
\text { FARAH } \\
\text { FARYAB } \\
\text { GHAZNI } \\
\text { GHOR } \\
\text { HELMAND } \\
\text { HERAT } \\
\text { JAWZJAN } \\
\text { KABUL } \\
\text { KANDAHAR } \\
\text { KAPISA }\end{array}$ & 更 & 100 & $\begin{array}{l}\text { KUNAR } \\
\text { KUNDUZ } \\
\text { LAGHMAN } \\
\text { LOGAR } \\
\text { NANGARHAR } \\
\text { NIMROZ } \\
\text { ORUZGAN } \\
\text { PARTERA } \\
\text { PARTIA } \\
\text { PARWAN } \\
\text { SAMANGAN } \\
\text { TARHAR } \\
\text { WARDAR } \\
\text { ZABUL }\end{array}$ & & \\
\hline
\end{tabular}




\section{CHILDREN IN CRISIS \\ (CIC)}

Children in Crisis established an office in Kabul in July 1997. The main focus of this office is to help the children of Afghanistan by assisting with three orphanages. The state orphanage, in Kabul with 1,100 bencficiarics is also supported by CIC. Children in Crisis intends to assist Indira Ghandi Children`s Hospital in 1998. 
HOUSE 93, STR 5, N-3 PHASE 4, HAYATABAD PESHAWAR, PAKISTAN
PHONE : 818165

F A X: 813299 email:naim@coar.pwr.sdnpk
1. ENG M NAIM SALIMEE

2. HAJI A G AHMADYAR

3. $M$ A HAIDARI

\begin{tabular}{|c|c|c|c|c|c|}
\hline AFGHAN & 91 & TECHNICAL : & 40 & PAK. BASED : & 23 \\
\hline PAKISTANI : & 2 & ADMINISTRATIVE : & 20 & AFGHAN BASED: & 72 \\
\hline EXPAT & 2 & FIELD/SUPPORT S. & 35 & CROSS-BORDER : & - \\
\hline TOTAL & 95 & TOTAL : & 95 & TOTAL : & 95 \\
\hline
\end{tabular}

\begin{tabular}{|c|c|c|c|c|}
\hline \multirow{7}{*}{$\begin{array}{l}\mathrm{U} \\
\mathrm{N}\end{array}$} & $-<$ SOURCES $>$ & & $<$-ALLOCATION $>$ & \\
\hline & \multirow{6}{*}{ FAO/WFP } & \multirow{6}{*}{$1 \%$} & AGRICULTURE & $30 \%$ \\
\hline & & & ASSISTANCE TO RETURNEES & \\
\hline & & & CONSTRUCTION （ROAD/BRIDGE) & \\
\hline & & & CONSTRUCTION (BUILDING/SHELTER) & $29 \%$ \\
\hline & & & EDUCATION & $16 \%$ \\
\hline & & & EMERGENCY & $8 \%$ \\
\hline 0 & EUROPEAN UNION & $49 \%$ & HEALTH & $7 \%$ \\
\hline $\mathrm{T}$ & NCA & $50 \%$ & INCOME GENERATION & $10 \%$ \\
\hline $\mathrm{H}$ & & & IRRIGATION & \\
\hline $\mathrm{E}$ & & & MINE & \\
\hline $\mathrm{R}$ & & & RELIEF & \\
\hline$S$ & & & OTHER & \\
\hline
\end{tabular}

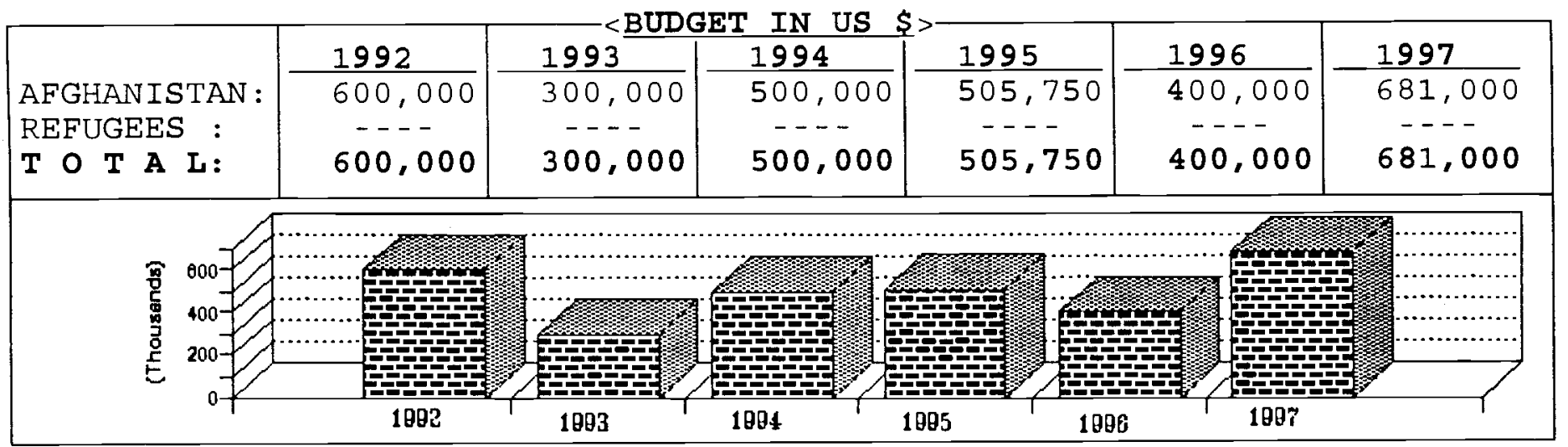

\begin{tabular}{|c|c|c|c|c|c|}
\hline PROVINCES & SECTOR & $\%$ & PROVINCES & SECTOR & $\%$ \\
\hline $\begin{array}{l}\text { BADAKSHAN } \\
\text { BADGHIS } \\
\text { BAGHLAN } \\
\text { BALKH } \\
\text { BAMYAN } \\
\text { FARAH } \\
\text { FARYAB } \\
\text { GHAZNI } \\
\text { GHOR } \\
\text { HELMAND } \\
\text { HERAT } \\
\text { JAWZJAN } \\
\text { KABUL } \\
\text { KANDAHAR } \\
\text { KAPISA. }\end{array}$ & $\begin{array}{l}\text {...CONST/ } \\
\text { AGRIC/IRRIG/HLTH/VET } \\
\text { CONST/RELIEF }\end{array}$ & . & $\begin{array}{l}\text { KUNAR } \\
\text { KUNDUZ } \\
\text { LAGHMAN } \\
\text { LOGAR } \\
\text { NANGARHAR } \\
\text { NIMROZ } \\
\text { ORUZGAN } \\
\text { PAKTEKA } \\
\text { PAKTIA } \\
\text { PARWAN } \\
\text { SAMANGAN } \\
\text { TAKHAR } \\
\text { WARDAK } \\
\text { ZABUL } \\
\text { PAKISTAN }\end{array}$ & $\begin{array}{c}\ldots \text { IN GEN/IRRIG } \\
\text { CONST/ÄGRIC/VET/HLTH }\end{array}$ & 39 \\
\hline
\end{tabular}


CoAR aims to create lucrative self-mployment opportunities for families residing in rural Afghanistan, with special emphasis on the most vulnerable, thus ensuring sustainable livelihood whilst also securing an enriched environment, and overall improved quality of life and enhanced social values.

To achieve this goal, CoAR assists local communities in realising their basic needs through the implementation of projects which require community participation. Activities having included production and infrastructure, development research, extension ofappropriate technologies, effective use of local resources and upgrading the skills of local artisans.

In 1989, a group of Afghans eager to actively participate in the reconstruction of their country, founded CoAR, an independent NGO to provide assistance to the local communities residing in the Provinces of - Logar, Wardak, Ghazni and Kabul. Since its inception, CoAR's strategy has evolved from providing cross-border, short-term emergency relief services to long-term development efforts which stress community involvement and sustainability and facilitate the gradual return of refugees. To this end, CoAR provides support to communities through the promotion of health and education facilities, agriculture, horticulture, animal husbandry and in rehabilitating irrigation systems and agricultural infrastructure.

The core component of CoAR is the Rural Development Centres (RDCs). The RDCs are semi-autonomous bodies which implement integrated rehabilitation activities in two or three surrounding districts each. CoAR is currently managing four such centres, one in each Province where CoAR is operating. The RDCs are responsible for the implementation of all field activities in the vicinity as well as maintaining good relations with the local authorities and the communities themselves.

CoAR in conjunction with other national and international organisations has developed a field research centre known as the Afghan Agricultural Experimental Centre (AAEC).
The AAEC is responsible for conducting indepth agricultural and horticultural research, the results of which are used by CoAR and its partners in determining the most appropriate products to use and strategies to implement.

During its eight years of operations, CoAR has implemented a variety of projects in all areas of rural rehabilitation, including agriculture, rural infrastructure, health and education, benefiting thousands of rural families as well as returning refugees and internally displaced persons (IDPs).

Through its rural infrastructure projects, CoAR has constructed a number of bridges, culverts and roads making markets, schools and health facilities more accessible to local populations; while its health programmes have provided support to health centres in the area. In addition various crop multiplication projects have distributed improved seed and fertiliser to needy farmers; horticultural projects have assisted farmers in establishing fruit tree nurseries; and CoAR's veterinarians have vaccinated and treated a wide range of animals preventing common diseases, drastically reducing the animal morbidity and mortality rates.

During the coming years, CoAR aims to concentrate exclusively on agriculture, animal husbandry, health and training - the four areas where assistance is vital if Afghanistan is to once again become self-sufficient.

The political situation in Afghanistan remains unstable, with regular changes in local authorities. CoAR has been able to work successfully with these authorities and anticipates this will remain true in the future, thus ensuring the smooth implementation of prospective projects. Each project is fully endorsed by the local Government and shuras prior to implementation and contacts are maintained throughout project implementation keeping the authorities informed on project progress. Furthermore, CoAR maintains communications with other NGOs and international organisations working the area so as to avoid any duplication of projects. 
130 - GUL HAJI PALZA, JAMRUD RD. UPO BOX 785 PESHAWAR, PAKISTAN
PHONE : 840169

F A X:

email :
1.DR ZANA AHMADZAI

2. DR M RAFIQ

3. ENG SUBHANULLAH
$<$ PERSONNEL $>$

\begin{tabular}{|lr|l|l}
\hline AFGHAN & 14 & TECHNICAL : \\
PAKISTANI: & 1 & ADMINISTRATIVE : \\
EXPAT & $:$ & - & FIELD/SUPPORT S : \\
TOTAL & $:$ & 15 & TOTAL
\end{tabular}

6
4
5
15

$\begin{array}{lr}\text { PAK. BASED : } & 4 \\ \text { AFGHAN BASED: } & 4 \\ \text { CROSS-BORDER: } & 7 \\ \text { TOTAL : } & 15\end{array}$

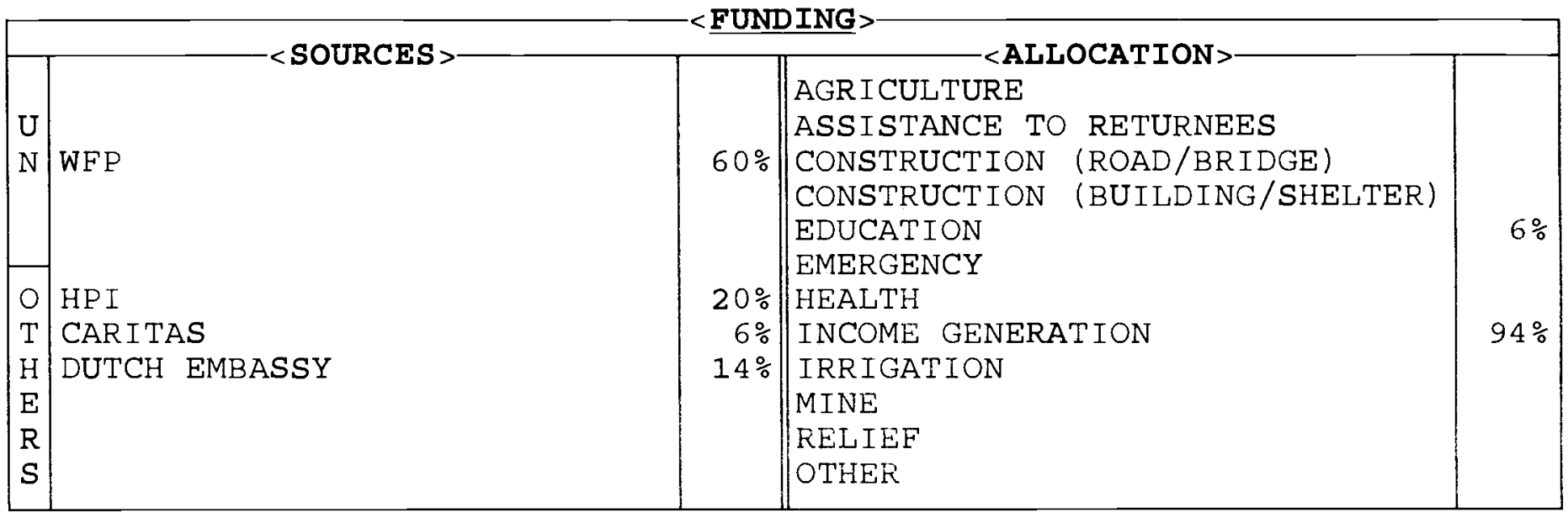

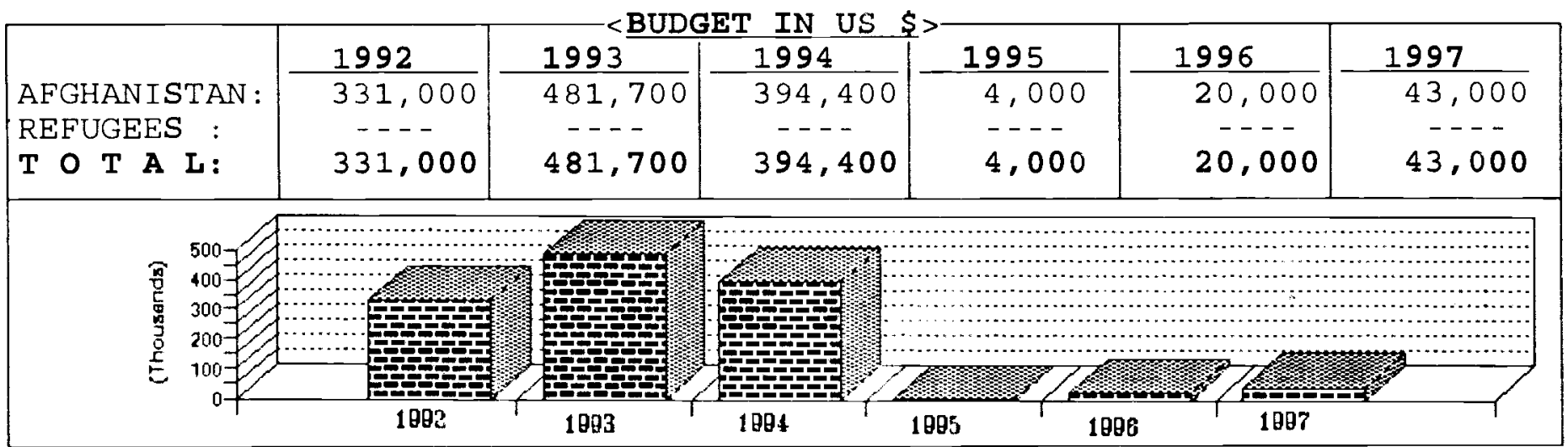

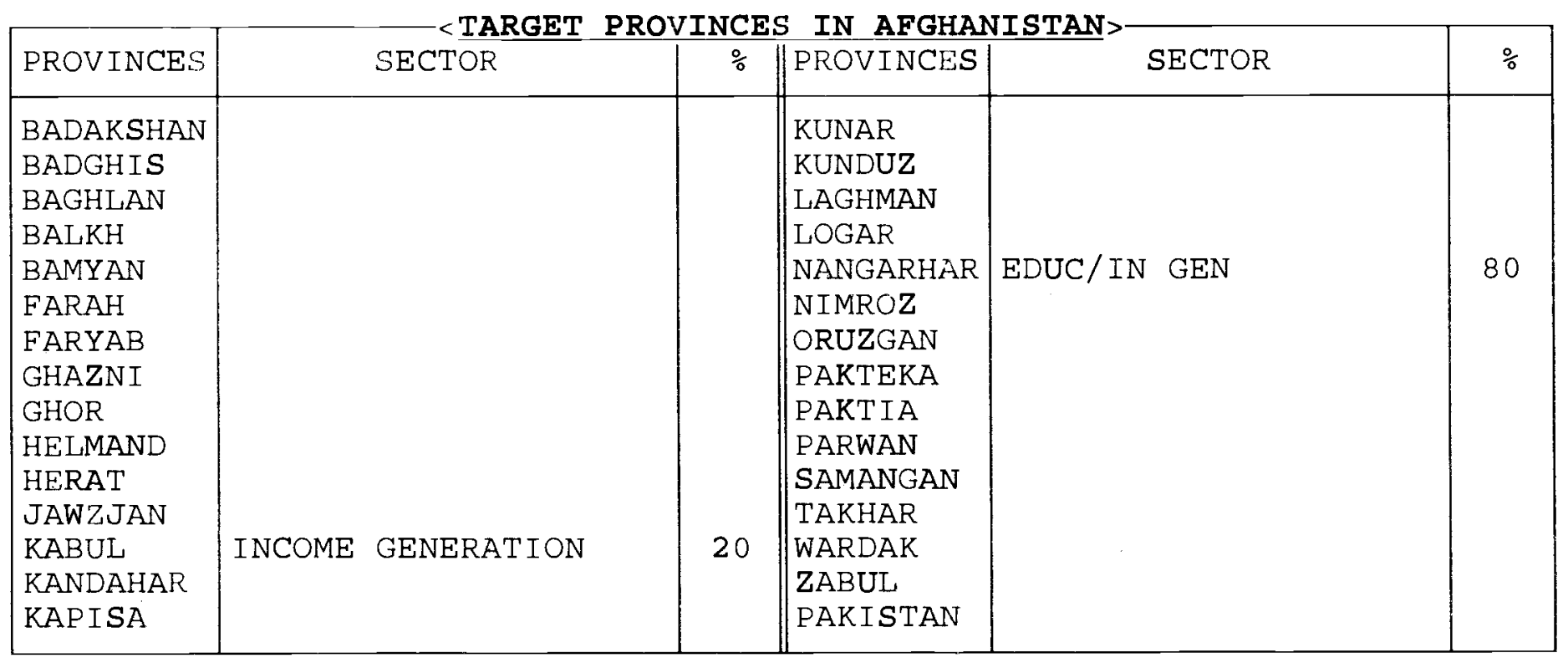


CRAA is a non governmental and non political organisation, founded in 1990 . It comprises Afghans who have experience and expertise in the planning and implementation of relief and development projects. The main office is located in Peshawar with sub-offices in Jalalabad and Kabul city.

\begin{abstract}
Aims
Anticipating the return of refugees, the organisation supports rural populace, which composes approximately 85 percent of the country's population. Rural people depend mainly on agriculture and livestock raising. CRAA help them by providing agricultural inputs, veterinary services and rehabilitating irrigation systems.
\end{abstract}

\section{Sectors of Operation \\ Agriculture}

CRAA has distributed improved seeds, fertiliser and fruit trees. Farmers have been given various types of training and technical advice.

\section{Irrigation and Water Supply}

CRAA has completed a number of irrigation (canals and karezes cleaning and rehabilitation) projects which now irrigate thousands of Jeribs of agricultural land and provide sources for drinking water to large numbers of people.

Surveys of several other irrigation projects in different areas of Nangarhar and Kunar Provinces have been conducted and project proposals submitted to donors.

\section{Veterinary and animal husbandry}

In this sector curative and preventative veterinary services have been provided by CRAA through 20 veterinary field units in 5 different Provinces. More than 200 villagers in the coverage areas were given training in basic veterinary skills and techniques. Farmers were given professional advice on livestock health and management through the network.
Improved Fayoumi chicken units were distributed to people in Kunar Province. More than 560 refugee families in Nasir Bagh new refugee camps have been provided poultry related training and Fayoumi chicken units for income generation and self reliance. 1800 women in Hisarshahi and 1000 women in New Hada camps were trained in poultry skills and Fayoumi chicks distributed. More than 750 vulnerable families (in Kabul city 300 women and 450 men) were provided training in poultry skills and Fayoumi chicks distributed.

\section{Orthopedic and Physiotherapy Services}

Artificial legs and arms were provided to disabled women, men and children in Kunar Province and Nangarhar refugee camps to make them self reliant.

\section{Narcotics Awareness Programmes}

Programmes on drugs awareness were implemented in Kunar, Nangarhar, Kandahar and Helmand Provinces. Local people were informed of the harmful consequences of drug addiction. Illicit crops cultivators were motivated to eliminate this crop and to grow other cash crops.

\section{Flood control and others}

CRAA implemented flood control projects and distributed plastic sheets in Kunar Province

\section{Education}

Distribution of books and other facilities to 3 primary schools at Mohmand Dara, Nangarhar has been undertaken to help the education of school children.

\section{Further information}

CRAA is registere with UNOCHA, ACBAR, ANCB, NWFP Home Department, Commissioner for Afghan Refugees and Afghan Government authorities. 
DANISH COMMITTEE FOR AID TO AFGHAN REFUGEES (DACAAR)

$<$ ADDRESS $>$

10 GUL MOHAR LANE, U/T

G P O BOX 855

PESHAWAR, PAKISTAN

$<$ COMMUNICATION LINES $>$

PHONE : $44237 / 40731$

F A X: 840516

TELEX : 52307 DACAAR PK

\begin{tabular}{|c|c|c|c|c|c|}
\hline AFGHAN & 750 & TECHNTCA & & & \\
\hline PAKISTANI: & 41 & ADMINISTRATIVE & 75 & AFGHAN BASED: & $\begin{array}{l}121 \\
274\end{array}$ \\
\hline EXPAT : & 8 & FIELD/SUPPORT S. & 358 & CROSS-BORDER : & 398 \\
\hline TOTAL & 799 & TOTAL : & 799 & TOTAL : & 799 \\
\hline
\end{tabular}

\begin{tabular}{|c|c|c|c|c|}
\hline & $-<$ SOURCES $>$ & & $<$ ALLOCATION $>$ & \\
\hline & & & AGR ICULTURE & $9 \%$ \\
\hline $\mathrm{U}$ & UNHCR & $14 \%$ & ASSISTANCE TO RETURNEES & \\
\hline $\mathrm{N}$ & UNICEF & $4 \%$ & CONSTRUCTION （ROAD/BRIDGE） & $6 \%$ \\
\hline & UNOCHA & $1 \%$ & CONSTRUCTION (BUILDING/SHELTER) & $23 \%$ \\
\hline 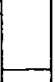 & UNDCP & $1 \%$ & $\begin{array}{l}\text { EDUCATION } \\
\text { EMERGENCY }\end{array}$ & \\
\hline 0 & DANIDA & $40 \%$ & HEALTH & $1 \%$ \\
\hline $\mathrm{T}$ & EUROPEAN UNION & $36 \%$ & INCOME GENERATION & \\
\hline $\mathrm{H}$ & GTZ & $1 \%$ & IRRIGATION \& WATER SUPPLY & $61 \%$ \\
\hline $\mathrm{E}$ & ODA/CHAID & $3 \%$ & MINE & \\
\hline $\mathrm{R}$ & & & RELIEF & \\
\hline$S$ & & & OTHER & \\
\hline
\end{tabular}

\begin{tabular}{|c|c|c|c|c|c|c|}
\hline $\begin{array}{l}\text { AFGHAN ISTAN: } \\
\text { REFUGEES : } \\
\text { T O T A L: }\end{array}$ & $\begin{array}{r}\frac{1992}{2,596,250} \\
321,600 \\
2,917,850\end{array}$ & $\begin{array}{r}\frac{1993}{4,337,350} \\
175,900 \\
4,513,250\end{array}$ & $\begin{array}{r}\frac{1994}{5,699,400} \\
212,300 \\
5,911,700\end{array}$ & $\mid \begin{array}{r}\frac{1995}{7,173,300} \\
395,700 \\
7,569,000\end{array}$ & $\begin{array}{r}\frac{1996}{4,840,450} \\
372,850 \\
5,213,300\end{array}$ & $\begin{array}{r}\frac{1997}{7,829,000} \\
141,800 \\
7,970,800\end{array}$ \\
\hline (1) & 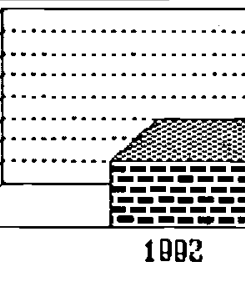 & 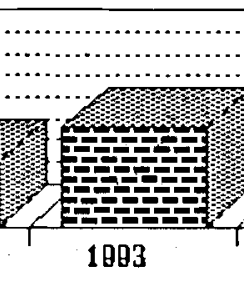 & 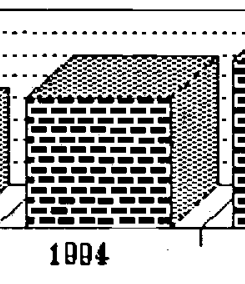 & 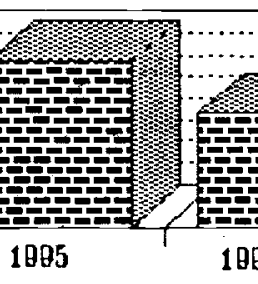 & 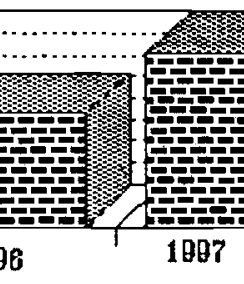 & …….......... \\
\hline
\end{tabular}

\begin{tabular}{|c|c|c|c|c|c|}
\hline PROVINCES & SECTOR & $\%$ & PROVINCES & SECTOR & $\%$ \\
\hline $\begin{array}{l}\text { BADAKSHAN } \\
\text { BADGHIS } \\
\text { BAGHLAN } \\
\text { BALKH } \\
\text { BAMYAN } \\
\text { FARAH } \\
\text { FARYAB } \\
\text { GHAZNI } \\
\text { GHOR } \\
\text { HELMAND } \\
\text { HERAT } \\
\text { JAWZJAN } \\
\text { KABUL } \\
\text { KANDAHAR } \\
\text { KAPISA }\end{array}$ & $\begin{array}{l}\text { W.S./IRRIG/AGRIC } \\
\text { W.S/IRRIG/AGRIC/HLTH } \\
\text { W.S/IRRIG/AGRIC } \\
\text { W.S. . . HLTH } \\
\text { W.S/IRRIG/AGRIC/CONST } \\
\text { W.S. } \\
\text { W.S/IRRIG/AGRIC/CONST }\end{array}$ & $\begin{array}{r}2 \\
3 \\
2 \\
9 \\
29 \\
2 \\
20\end{array}$ & $\begin{array}{l}\text { KUNAR } \\
\text { KUNDUZ } \\
\text { LAGHMAN } \\
\text { LOGAR } \\
\text { NANGARHAR } \\
\text { NIMROZ } \\
\text { ORUZGAN } \\
\text { PAKTEKA } \\
\text { PAKTIA } \\
\text { PARWAN } \\
\text { SAMANGAN } \\
\text { TAKHAR } \\
\text { WARDAK } \\
\text { ZABUL } \\
\text { PAKISTAN }\end{array}$ & $\begin{array}{l}\text {. .CONST } \\
\text { W.S/IRRIG/AGRIC/HLTH } \\
\text { W.S. } \\
\text { W.S/HLTH/CONST }\end{array}$ & $\begin{array}{r}7 \\
3 \\
10\end{array}$ \\
\hline
\end{tabular}




\section{DANISH COMMITTEE FOR AID TO AFGHAN REFUGEES (DACAAR)}

DACAAR is a consortium set up to aid Afghan refugees, composed of four Danish NGOs;

$\begin{array}{ll}- & \text { Danish People's Relief Organisation } \\ \text { - } & \text { Danish Association for International } \\ \text { Cooperation } \\ \text { - } \quad \text { Caritas Denmark and } \\ \text { Danish Refugee Council. }\end{array}$

\section{Aims of DACAAR}

To contribute to the rehabilitation of Afghanistan, through projects in Pakistan since 1984 and in Afghanistan since 1988.

\section{Sectors of Operation}

\section{Pakistan}

The DACAAR sewing project is an income generating project for Afghan refugee women who produce high quality embroidery which is tailored into various items at the finishing workshop in Peshawar. Products are sold locally as well as exported to many countries and a total of 1,000 Afghan refugee women benefit from this activity.

DACAAR Hand Pump factory, situated in Swabi was established in 1988, and employs over 100 people. The main product is the Kabul Hand Pump for wells down to 20-25 metre depth and the Indus Hand pump for deeper wells. The pumps are sold in Afghanistan and Pakistan to UNICEF, Swedish Committee and DACAAR Water Supply section, as well as private customers. In 1994 a total of 4,700 pumps were produced.

\section{Afghanistan}

DACAAR Rehabilitation East works in the Provinces of Kunar, Laghman, Nangarhar, Paktia, Ghazni, Logar, Wardak, Helmand, Kabul, Zabul and Kandahar in the following sectors:

$$
\begin{aligned}
& \text { repair of public and community } \\
& \text { buildings; } \\
& \text { production of concrete beams and } \\
& \text { lintels; } \\
& \text { provision of safe drinking water; } \\
& \text { - } \quad \text { provision of baths and latrines; } \\
& \text { - } \quad \text { repair of public roads. }
\end{aligned}
$$

DACAAR Rehabilitation West was opened in 1992 with a project office in Herat city. Activities are similar to that of DACAAR Rehabilitation East and cover the Provinces of Farah, Ghor and Herat, with plans to expand to the neighbouring Provinces.

\section{Further Information}

Water supply for refugee camps in Pakistan was started in 1986 and among many things included improvement and maintenance of shallow wells and the installation of hand pumps. Since 1992, activities have been limited to maintenance and gradually responsibility for this is being handed over to local communities. This process is planned to be completed by the end of 1996.

The agency carries out emergency work on an ad hoc basis and is presently involved in the water supply system for Hisar Shahi and New Hadda camps in Nangarhar, as well as some smaller projects in Herat Province.

repair and rehabilitation of irrigation systems;

provision of agricultural assistance; 
$139 \mathrm{~F}$, BLOCK 4, SATE TOWN P.O.BOX 548 QUETTA, PAKISTAN
PHONE : $442056-448308$

$F$ A $X: 447206$

TELEX :
1. ENG. ABDUL SATTAR

2. ABDUL SALAM MONIB

3. ABDUL AZIZ

\begin{tabular}{|c|c|c|c|c|c|}
\hline $\begin{array}{l}\text { AFGHAN : } \\
\text { PAKISTANI: } \\
\text { EXPAT : } \\
\text { TOTAL : }\end{array}$ & $\begin{array}{r}565 \\
1 \\
1 \\
567\end{array}$ & $\begin{array}{l}\text { TECHNICAL } \\
\text { ADMINISTRATIVE } \\
\text { FIELD/SUPPORT S } \\
\text { TOTAL }\end{array}$ & $\begin{array}{r}372 \\
99 \\
96 \\
567\end{array}$ & $\begin{array}{l}\text { PAR. BASED : } \\
\text { AFGHAN BASED : } \\
\text { CROSS-BORDER : } \\
\text { TOTAL : }\end{array}$ & $\begin{array}{r}45 \\
522 \\
567\end{array}$ \\
\hline
\end{tabular}

\begin{tabular}{|c|c|c|c|c|}
\hline \multirow{7}{*}{$\begin{array}{l}\mathrm{U} \\
\mathrm{N}\end{array}$} & \multirow{10}{*}{ UNOCHA } & \multirow{10}{*}{$50 \%$} & 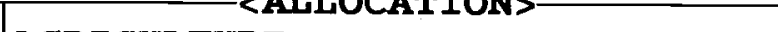 & \\
\hline & & & AGRICULTURE & \\
\hline & & & ASSISTANCE TO RETURNEES & \\
\hline & & & CONSTRUCTION（ROAD/BRIDGE） & \\
\hline & & & CONSTRUCTION (BUILDING/SHELTER) & \\
\hline & & & EDUCATION & \\
\hline & & & EMERGENCY & \\
\hline 0 & & & HEALTH & \\
\hline $\mathbf{T}$ & & & INCOME GENERATION & \\
\hline $\mathbf{H}$ & & & IRRIGATION & \\
\hline $\mathbf{E}$ & E.C & $50 \%$ & DEMINING & $100 \%$ \\
\hline $\mathbf{R}$ & & & RELIEF & \\
\hline $\mathbf{S}$ & & & OTHER & \\
\hline
\end{tabular}

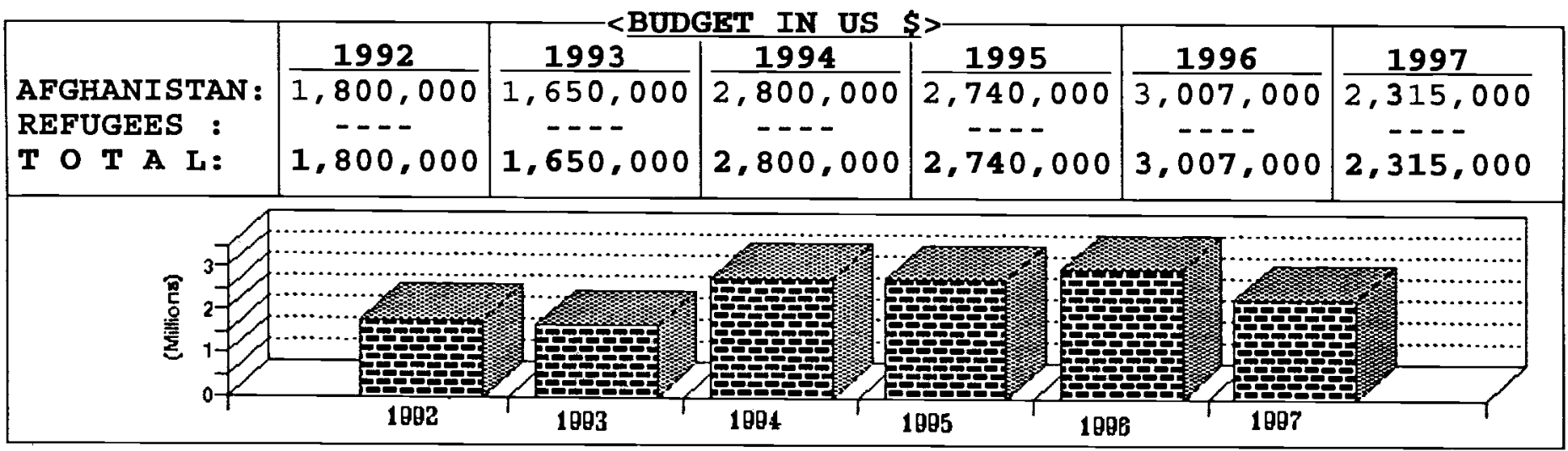

\begin{tabular}{|c|c|c|c|c|c|}
\hline PROVINCES & SECTOR & $\%$ & PROVINCES & SECTOR & $q$ \\
\hline $\begin{array}{l}\text { BADAKSHAN } \\
\text { BADGHIS } \\
\text { BAGHLAN } \\
\text { BALKH } \\
\text { BAMYAN } \\
\text { FARAH } \\
\text { FARYAB } \\
\text { GHAZNI } \\
\text { GHOR } \\
\text { HELMAND } \\
\text { HERAT } \\
\text { JAWZJAN } \\
\text { KABUL } \\
\text { KANDAHAR } \\
\text { KAPISA }\end{array}$ & $\begin{array}{l}\text { DEMINING } \\
\text { DEMINING }\end{array}$ & $\begin{array}{l}21 \\
19\end{array}$ & $\begin{array}{l}\text { KUNAR } \\
\text { KUNDUZ } \\
\text { LAGHMAN } \\
\text { LOGAR } \\
\text { NANGARHAR } \\
\text { NIMROZ } \\
\text { ORUZGAN } \\
\text { PAKTEKA } \\
\text { PAKTIA } \\
\text { PARWAN } \\
\text { SAMANGAN } \\
\text { TAKHAR } \\
\text { WARDAR } \\
\text { ZABUL }\end{array}$ & $\begin{array}{l}\text { DEMINING } \\
\text { DEMINING }\end{array}$ & $\begin{array}{l}19 \\
21\end{array}$ \\
\hline
\end{tabular}




\section{DEMINING AGENCY FOR \\ AFGHANISTAN \\ (DAFA)}

DAFA currently opcrates with 12 teams and

two Mcchanical Excavation Team (Backhoc).

\section{Objective:}

The overall aim of DAFA to remove the threat of mines and other unexploded ordinance from priority areas to allow:

the return of refugees and displaced persons to their homes, and the resumption of essential activate

The primary objectives of the project are to:

- assist in reducing the threat of mines and other unexploded ordnance from priority arcas;

- provide quick response to rescue persons trapped in minefields and other similar situations. 


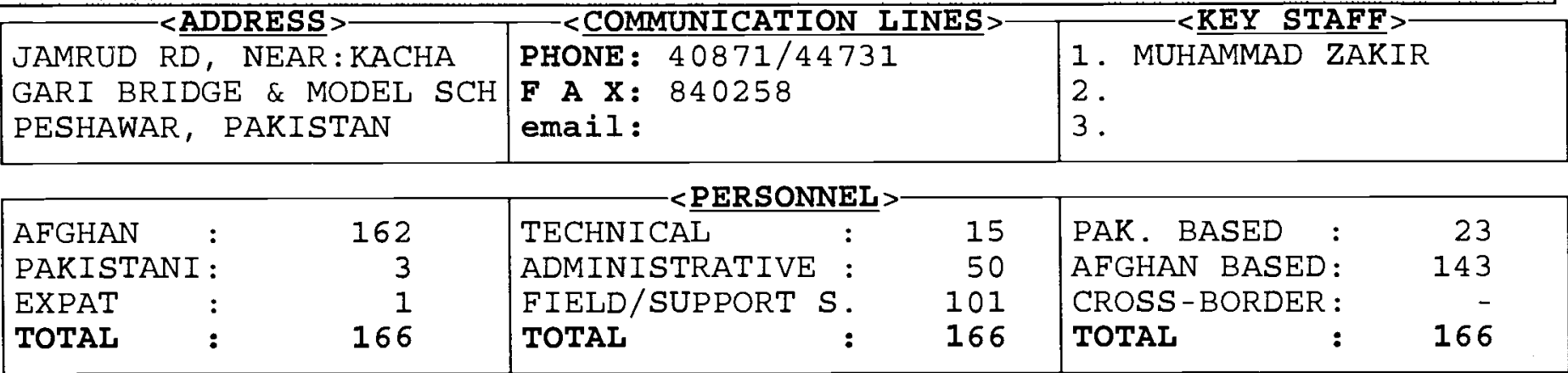

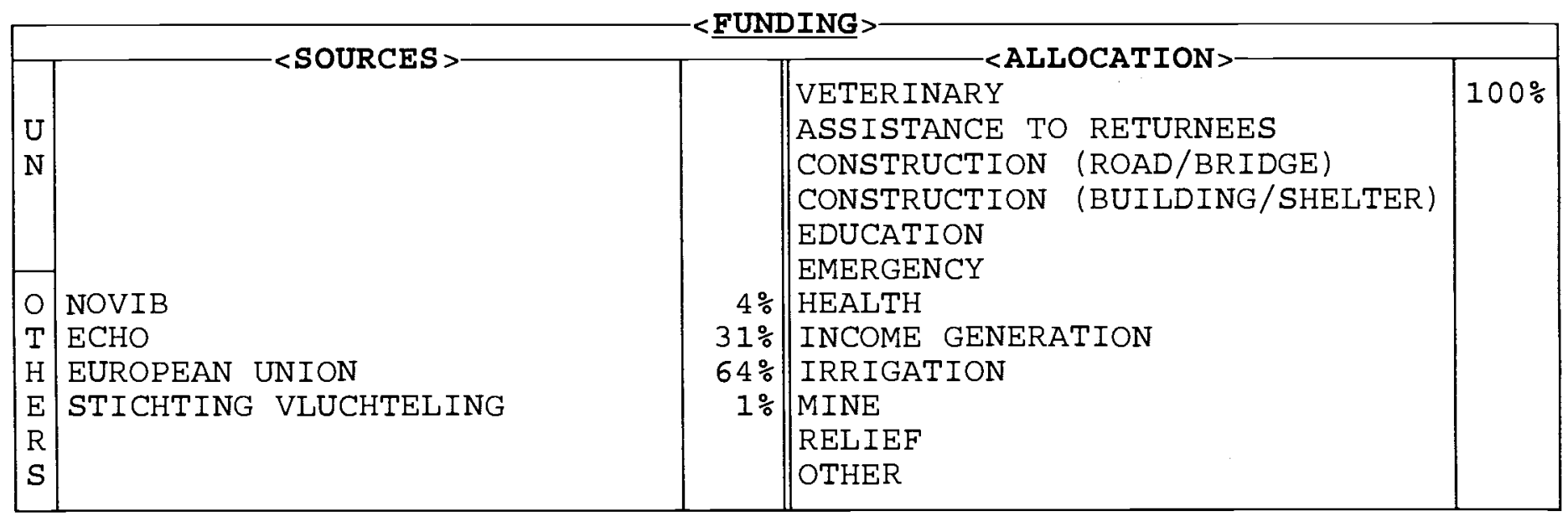

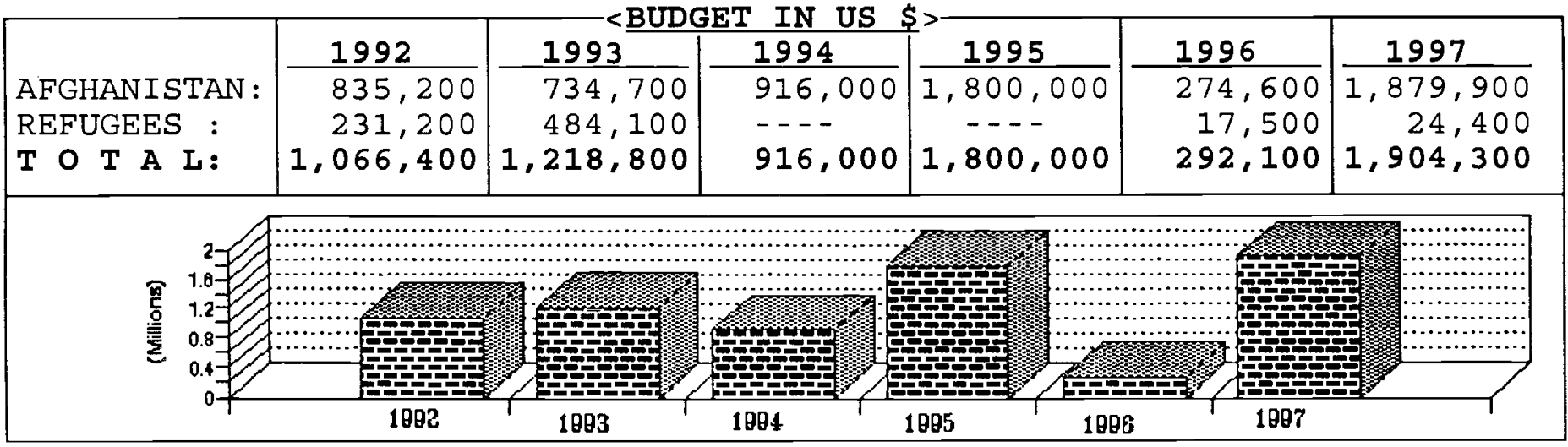

\begin{tabular}{|c|c|c|c|c|c|}
\hline PROVINCES & SECTOR & $\%$ & PROVINCES & SECTOR & $\%$ \\
\hline $\begin{array}{l}\text { BADAKSHAN } \\
\text { BADGHIS } \\
\text { BAGHLAN } \\
\text { BALKH } \\
\text { BAMYAN } \\
\text { FARAH } \\
\text { FARYAB } \\
\text { GHAZNI } \\
\text { GHOR } \\
\text { HELMAND } \\
\text { HERAT } \\
\text { JAWZJAN } \\
\text { KABUL } \\
\text { KANDAHAR } \\
\text { KAPISA }\end{array}$ & $\begin{array}{l}\text { VETERINARY } \\
\text { VETER INARY } \\
\text { VETERINARY } \\
\text { VETERINARY } \\
\text { VETERINARY }\end{array}$ & $\begin{array}{r}10 \\
9 \\
30 \\
25\end{array}$ & $\begin{array}{l}\text { KUNAR } \\
\text { KUNDUZ } \\
\text { LAGHMAN } \\
\text { LOGAR } \\
\text { NANGARHAR } \\
\text { NIMROZ } \\
\text { ORUZGAN } \\
\text { PAKTEKA } \\
\text { PAKTIA } \\
\text { PARWAN } \\
\text { SAMANGAN } \\
\text { TAKHAR } \\
\text { WARDAK } \\
\text { ZABUL } \\
\text { PAKISTAN }\end{array}$ & $\begin{array}{l}\text { VETER INARY } \\
\text { VETER INARY }\end{array}$ & 6 \\
\hline
\end{tabular}




\section{DUTCH COMMITTEE FOR \\ AFGHANISTAN VETERINARY \\ PROGRAMMES (DCA-VET)}

DCA is based in Peshawar with its head office in Lelystad, Netherlands.

Since 1985, DCA has largely concentrated assistance inside Afghanistan through cross border assistance projects. Operations started with cash for food assistance mainly in northeast Afghanistan (Panjshair). This type of assistance was, over the following years, extended to 15 areas in north, east and northeast Afghanistan.

Beginning in 1988, other types of assistance were planned in order to meet new requirements caused by the changing political-military situation. An increasing demand for more structural types of assistance in veterinary and agricultural sector was emerging and a need for programmes aimed at rehabilitation of agriculture.

A major constraint perceived by farmers was their loss of livestock, including drought animals, caused by the war, epidemic diseases and random slaughtering. Veterinary rehabilitation began in rural areas by developing a system of preventative animal health care.

DCA entered the first phase of this project in September 1988, with the establishment of the Veterinary Training and Support Center (VTSC). This Institute trains approximately 45 paravets a year for various NGOs interested in integrating animal care into their agricultural programmes. The training component of the VTSC provides refresher courses for all levels of veterinary field staff and operates an extension programme in Afghanistan.

DCA operates at district level, Veterinary Field Units (VFUs), which integrate the different levels into one coordinated structure making it possible to cover large areas and to react quickly to major out-breaks of animal diseases.

By the end of 1995 DCA expected to have established 56 field units covering the same number of districts.
January 1994, DCA started its second veterinary training centre in Herat, where approximately 45 people will be trained annually.

DCA operates 5 Veterinary Support Centres in Afghanistan. These centres issue, medicines, vaccines and equipment to veterinary field staff. Monitors and extension workers are also based at these offices.

The second phase of DCA assistance started in the early part of 1989 :
- distribution of drought animals and milk cows;
- $\quad$ breeding programmes for livestock - agriculture related programmes, such as irrigation, seed, fertilizer and tractors.

These projects have now been transferred to Helping Afghan Farmers Organisation (HAFO).

\section{Future Objectives}

Continuation of training courses for paraveterinarians;

Expansion of field activities in Afghanistan; Continuation of refresher courses for all field staff;

Continuation of extension programme for farmers. 


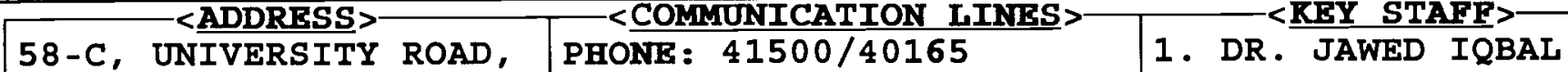
U.P.O BOX 800 PESHAWAR, PAKISTAN
F A X: 840800

2. M KALIM

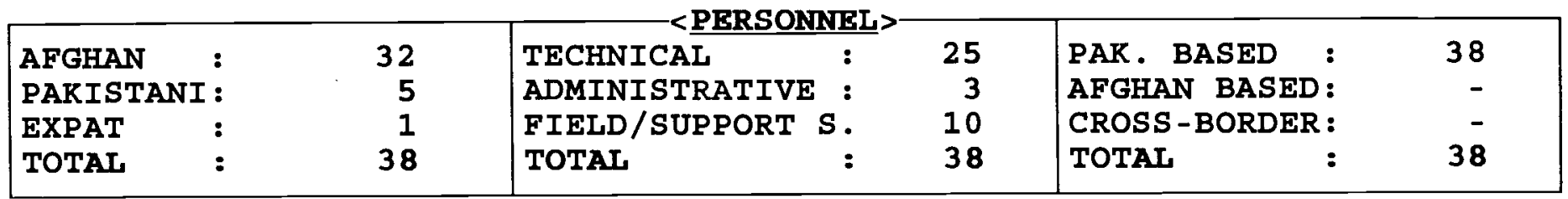

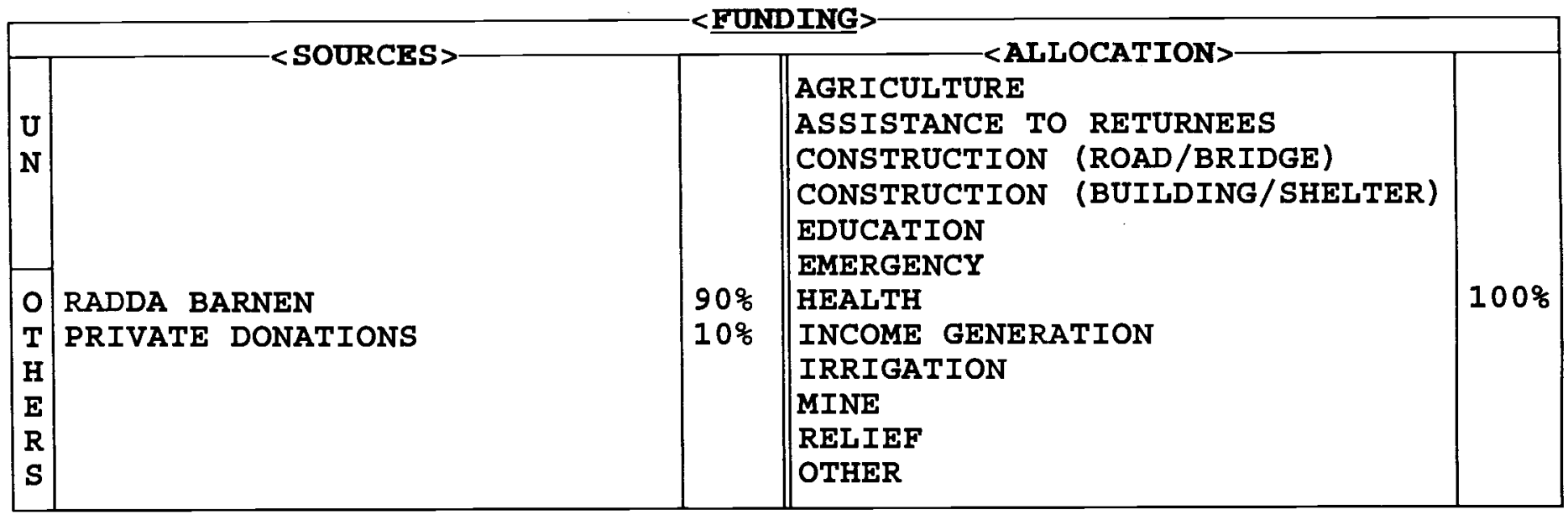

\begin{tabular}{|c|c|c|c|c|c|c|}
\hline & 1992 & 1993 & 1994 & 1995 & 1996 & 1997 \\
\hline $\begin{array}{l}\text { AFGHANISTAN: } \\
\text { REFUGEES : } \\
\text { T O T A L: }\end{array}$ & $\begin{array}{l}-\overline{-}- \\
78,600 \\
78,600\end{array}$ & $\begin{array}{l}62,850 \\
62,850\end{array}$ & $\begin{array}{l}--- \\
45,750 \\
45,750\end{array}$ & $\begin{array}{l}28,600 \\
28,600\end{array}$ & $\begin{array}{l}-\overline{-} \\
28,600 \\
28,600\end{array}$ & $\begin{array}{l}25,000 \\
25,000\end{array}$ \\
\hline
\end{tabular}

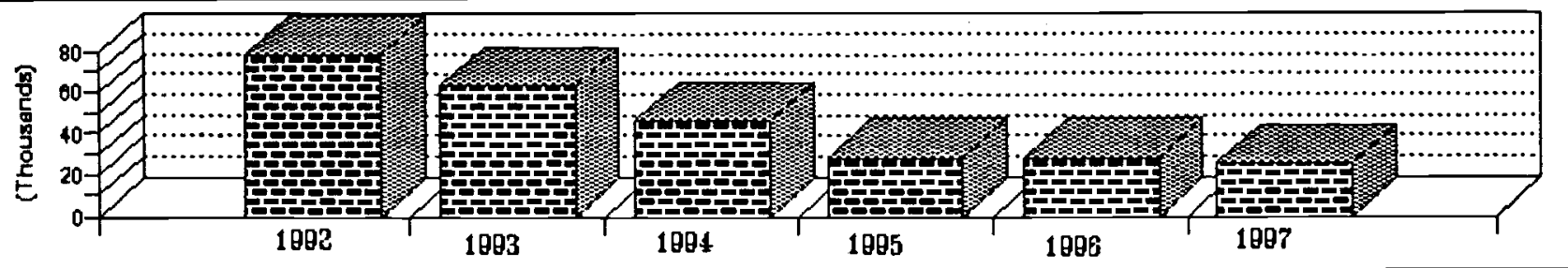

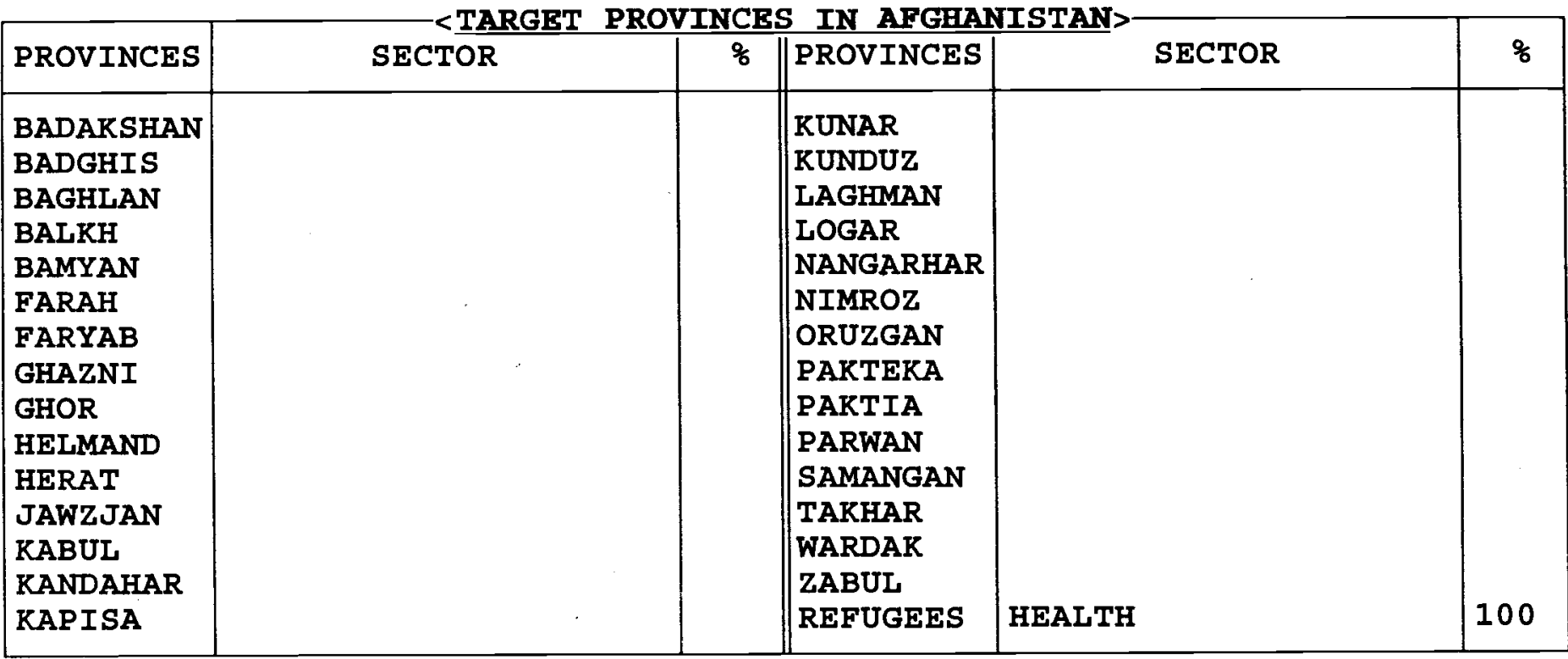




\section{DARUS SALAM}

(DS)

Darus Salam is a humanitarian trust. It's main objectives are as follows:

- to rehabilitate burnt, disabled, disfigured and mutilated people, through reconstructive surgery, physiotherapy, social services, psychiatric and education support;

- to train Afghan and Pakistani doctors in rcconstructive surgery so that they can open reconstructive surgery clinics in their areas;

- to train Afghan paramedic technicians (anaesthesia and operation room) to assist these surgeons;

- to conduct surveys on health matters in Afghanistan and Pakistan;

- to advocate the rights of children.

Darus Salam works both with refugees and cross-border. In Afghanistan it has conducted surveys of malnutrition, disability, immunization and war damage in 85 villages in Kunar and Paktia Provinces.

According to a survey, 40 percent of the disabled are children under 18 and 20 percent of all disabled persons in Afghanistan (estimated to be over one million) can have their disability corrected through reconstructive surgery. However there is no provision for this effort in the mandate of any donor agency contacted so far. 
MANZAL BAGH, HAJI ABUSH HOUSE

KANDAHAR, AFGHANISTAN

\section{PHONE : 442968}

F A X:

TELEX :
1. AHMED WALI KARZAI

2. ENG. ABDULLAH

3. ENG. NASER

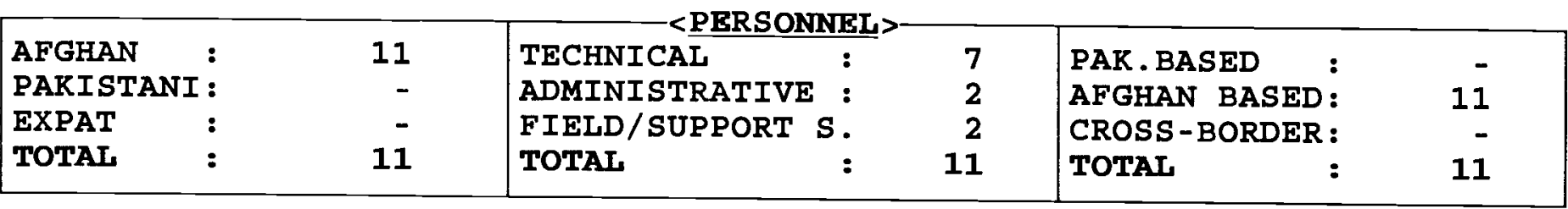

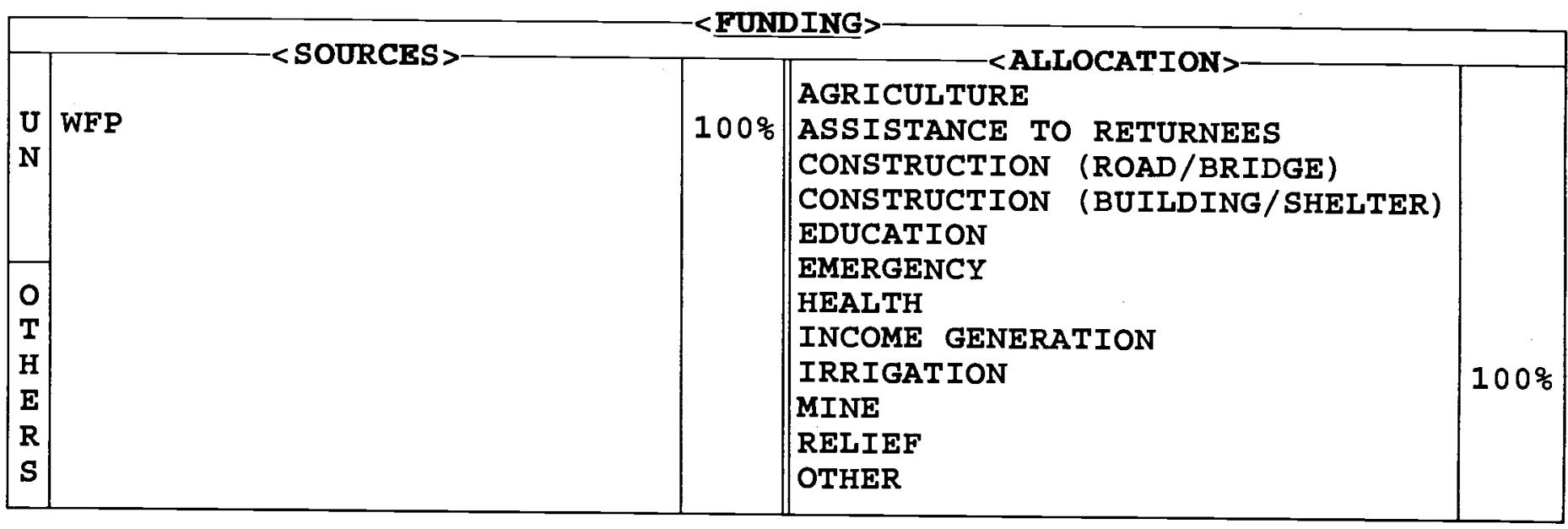

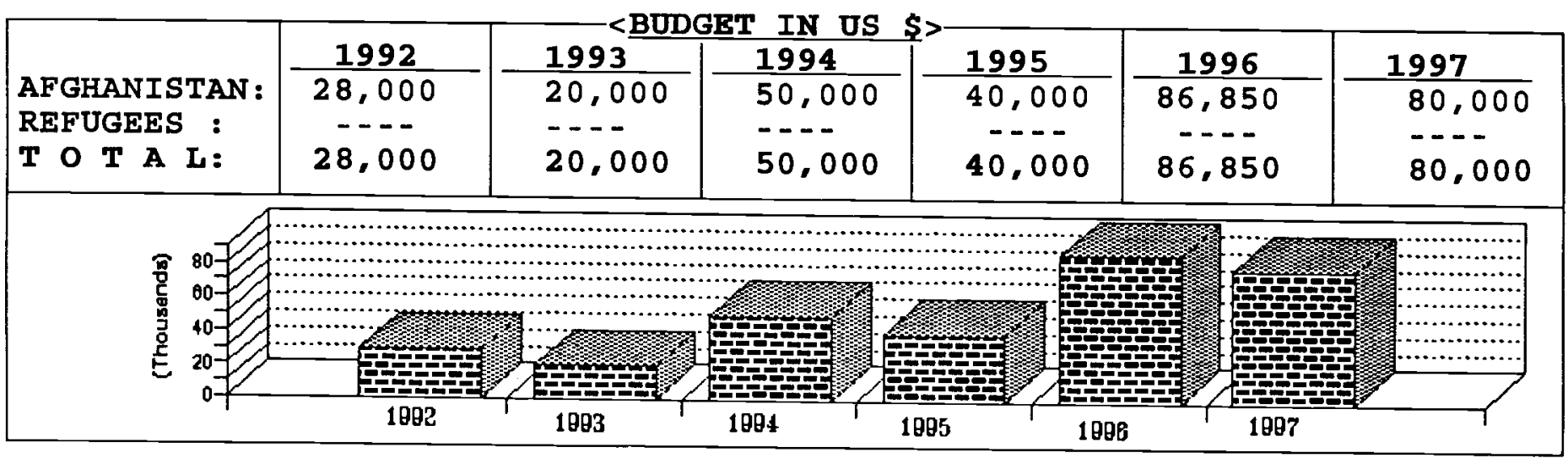

\begin{tabular}{|c|c|c|c|c|c|}
\hline PROVINCES & SECTOR & $\frac{q}{8}$ & PROVINCES & SECTOR & $\%$ \\
\hline $\begin{array}{l}\text { BADAKSHAN } \\
\text { BADGHIS } \\
\text { BAGHLAN } \\
\text { BALKH } \\
\text { BAMYAN } \\
\text { FARAH } \\
\text { FARYAB } \\
\text { GHAZNI } \\
\text { GHOR } \\
\text { HELMAND } \\
\text { HERAT } \\
\text { JAWZJAN } \\
\text { KABUL } \\
\text { KANDAHAR } \\
\text { KAPISA }\end{array}$ & 更 & 100 & $\begin{array}{l}\text { KUNAR } \\
\text { KUNDUZ } \\
\text { LAGHMAN } \\
\text { LOGAR } \\
\text { NANGARHAR } \\
\text { NIMROZ } \\
\text { ORUZGAN } \\
\text { PAKTEKA } \\
\text { PAKTIA } \\
\text { PARWAN } \\
\text { SAMANGAN } \\
\text { TARHAR } \\
\text { WARDAR } \\
\text { ZABUL }\end{array}$ & & \\
\hline
\end{tabular}


ENVIRONMENTAL AWARENESS

FOUNDATION FOR AFGHANISTAN

(EAFA)

EAFA was established in 1991. The head office was in Quetta with two sub-offices in Afghanistan. However the main office has recently moved to Kandahar.

The main fields of activity of the organisation are education and agriculture

In the future, EAFA plans to undertake drug awareness and community participation programmes. 
EMERGENCY RELIEF UNIT (ERU)

$<$ ADDRESS

2 , STREET C8/2

ZONE 2, BEHIND WFP

JALALABAD, AFGHANISTAN
PHONE :

F A X: GPO.P.BOX 69

TELEX : PESHAWAR, PAKISTAN
1. ENG. NABEE

2 .

3 .

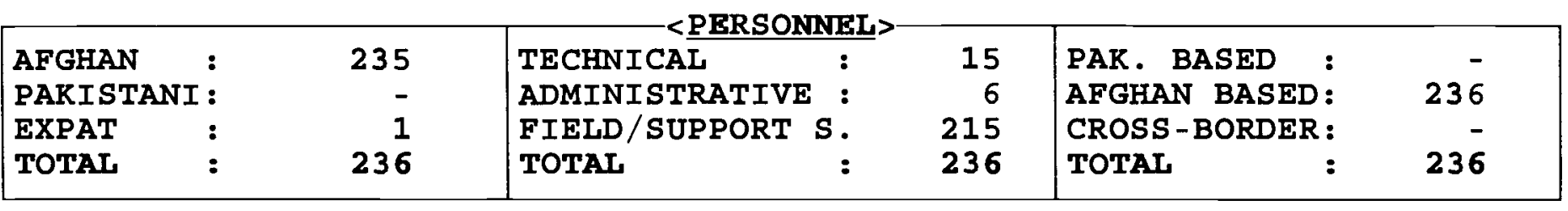

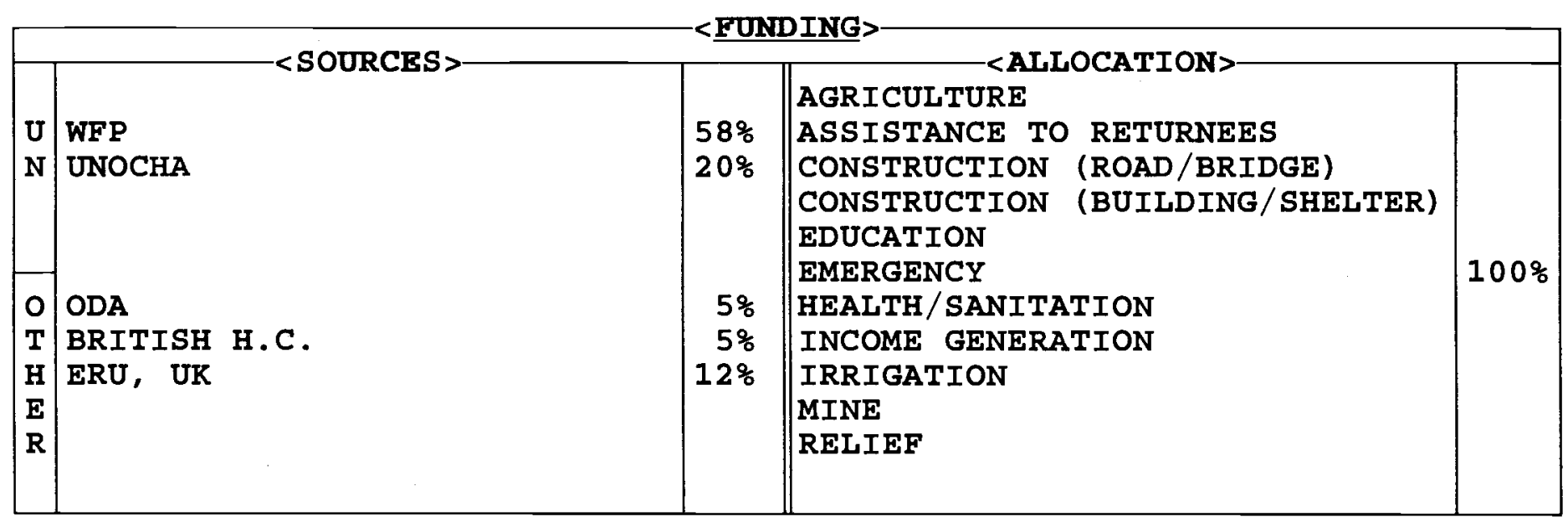

\begin{tabular}{|c|c|c|c|c|c|c|}
\hline $\begin{array}{l}\text { AFGHANISTAN : } \\
\text { REFUGEES : } \\
\text { T O T A L: }\end{array}$ & $\begin{array}{l}1992 \\
---- \\
---- \\
----\end{array}$ & $\begin{array}{l}1993 \\
--- \\
---- \\
----\end{array}$ & $\begin{array}{l}1994 \\
276,000 \\
--- \\
276,000\end{array}$ & $\begin{array}{l}1995 \\
500,000 \\
--- \\
500,000\end{array}$ & $\begin{array}{l}1996 \\
500,000 \\
500,000\end{array}$ & $\begin{array}{c}1997 \\
100,100 \\
--- \\
100,100\end{array}$ \\
\hline 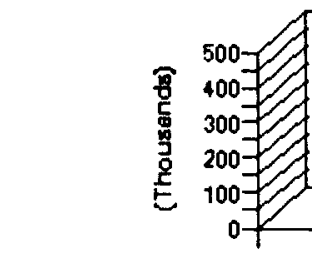 & 19 & 1007 & 6) & 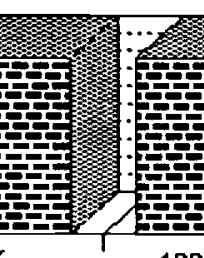 & 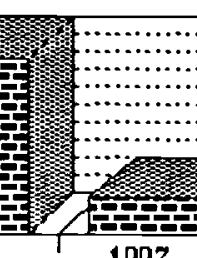 & \\
\hline
\end{tabular}

\begin{tabular}{|c|c|c|c|c|c|}
\hline PROVINCES & SECTOR & $\%$ & PROVINCES & SECTOR & $\%$ \\
\hline $\begin{array}{l}\text { BADARSHAN } \\
\text { BADGHIS } \\
\text { BAGHLAN } \\
\text { BALKH } \\
\text { BAMYAN } \\
\text { FARAH } \\
\text { FARYAB } \\
\text { GHAZNI } \\
\text { GHOR } \\
\text { HELMAND } \\
\text { HERAT } \\
\text { JAWZJAN } \\
\text { KABUL } \\
\text { KANDAHAR } \\
\text { KAPISA }\end{array}$ & & & $\begin{array}{l}\text { KUNAR } \\
\text { KUNDUZ } \\
\text { LAGHMAN } \\
\text { LOGAR } \\
\text { NANGARHAR } \\
\text { NIMROZ } \\
\text { ORUZGAN } \\
\text { PARTEKA } \\
\text { PAKTIA } \\
\text { PARWAN } \\
\text { SAMANGAN } \\
\text { TARHAR } \\
\text { WARDAK } \\
\text { ZABUL }\end{array}$ & EMERGENCY & 100 \\
\hline
\end{tabular}


EMERGENCY RELIEF UNIT

(ERU)

ERU was established in 1994, its main aim is to assist displaced people from Kabul.

Sectors of operation include:

repairing of all culverts and streets. sanitation system etc. establishment of city waste dumps. and arrangement of on going city waste removal and disposal. 
413 GUL HAJI PLAZA

W P O BOX 870

PESHAWAR, PAKISTAN
PHON: : 44404

$F$ A X:

email:
1. ENG A MANAN AMIRI

2. EING HAKIM GUL AHMADI

3. ENG H HAKIMI

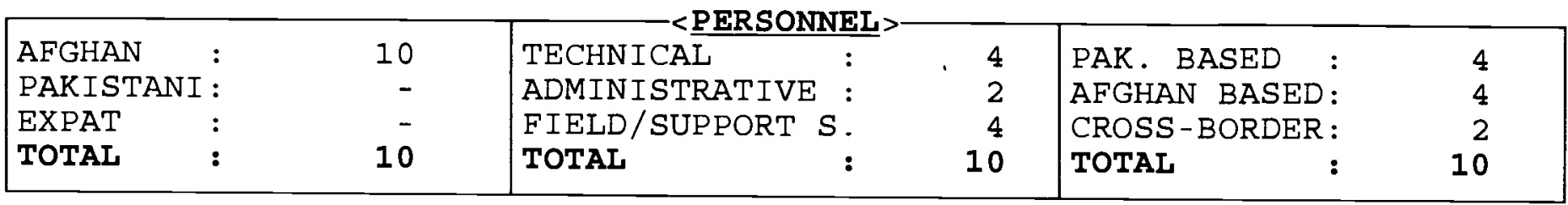

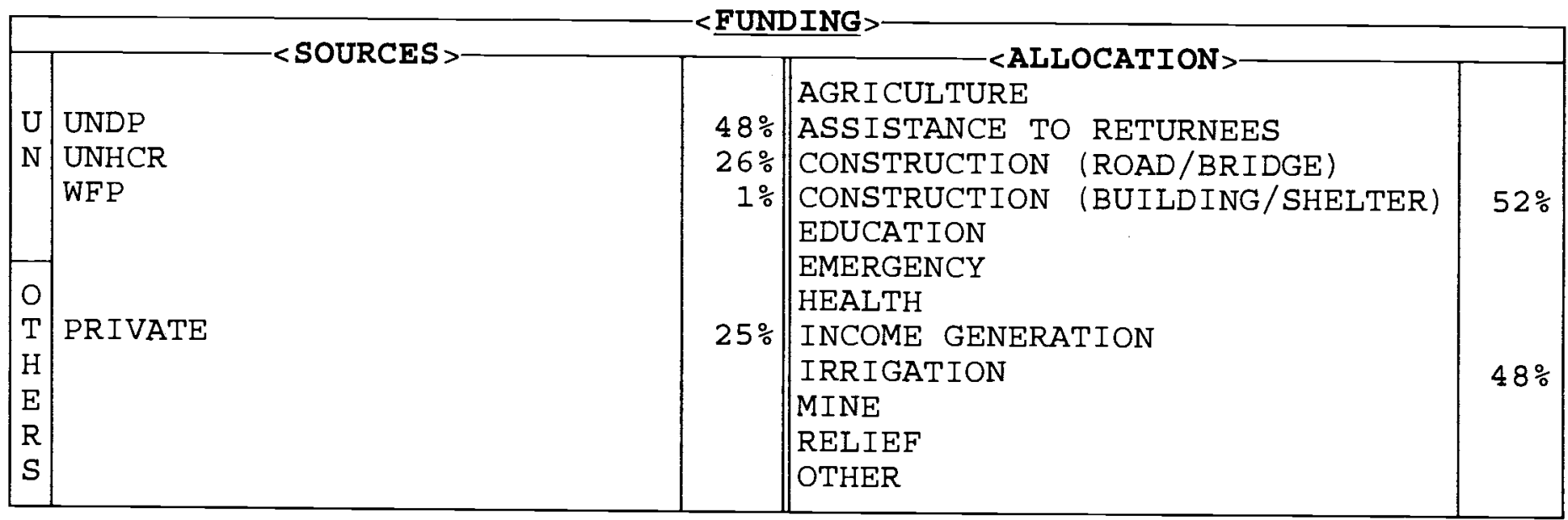

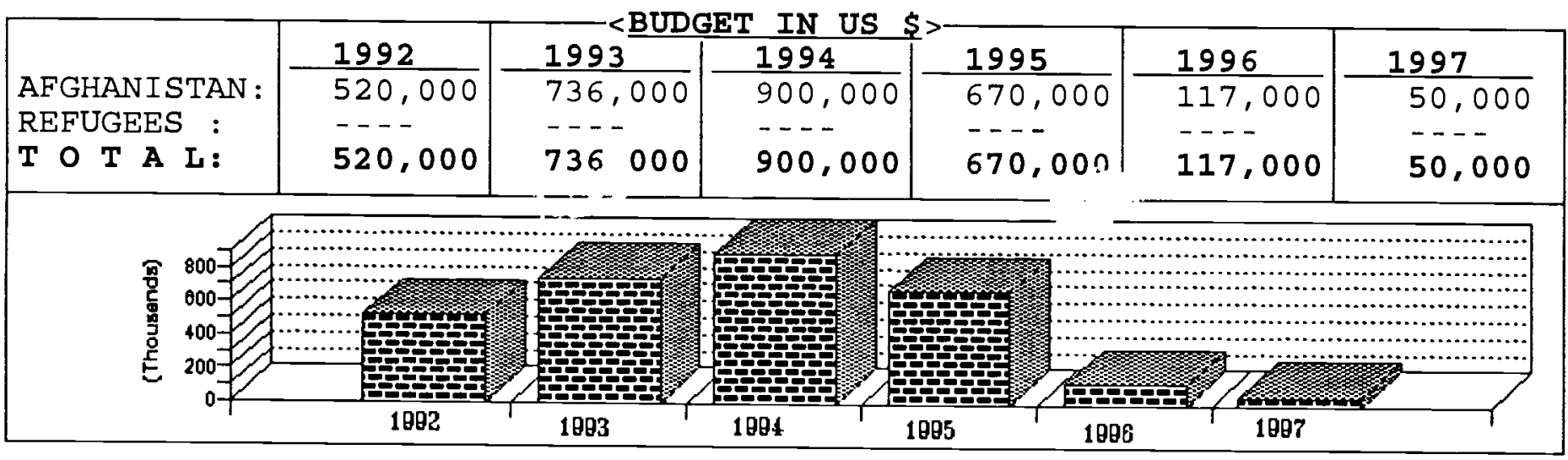

\begin{tabular}{|c|c|c|c|c|c|}
\hline PROVINCES & SECTOR & $\div$ & PROVINCES & SECTOR & $\%$ \\
\hline $\begin{array}{l}\text { BADAKSHAN } \\
\text { BADGHIS } \\
\text { BAGHLAN } \\
\text { BALKH } \\
\text { BAMYAN } \\
\text { FARAH } \\
\text { FARYAB } \\
\text { GHAZNI } \\
\text { GHOR } \\
\text { HELMAND } \\
\text { HERAT } \\
\text { JAWZJAN } \\
\text { KABUL } \\
\text { KANDAHAR } \\
\text { KAPISA }\end{array}$ & & & \begin{tabular}{|l|} 
KUNAR \\
KUNDUZ \\
LAGHMAN \\
LOGAR \\
NANGARHAR \\
NIMROZ \\
ORUZGAN \\
PAKTEKA \\
PAKTIA \\
PARWAN \\
SAMANGAN \\
TAKHAR \\
WARDAK \\
ZABUL \\
PAKISTAN
\end{tabular} & CONSTRUCTION/IRRIG & 100 \\
\hline
\end{tabular}




\section{ENGINEERING SERVICES FOR AFGHANISTAN RECONSTRUCTION (ESAR)}

ESAR is a private, non-profit, non-political, voluntary organisation, founded in 1989.

The agency implements cross-border programmes for the reconstruction and rehabilitation of Afghanistan. Main work areas:

\section{Implementation}

- Rehabilitation of shelter;

- Rehabilitation of public buildings;

- Rehabilitation of roads;

- Rehabilitation of irrigation infrastructures.

\section{Consultancy}

The agency also offers services to other NGOs and donors in the following fields:

\begin{tabular}{|c|c|}
\hline - & Survey and design of irrigation \\
\hline & Survey and design of road \\
\hline & infrastructure; \\
\hline & Design of public buildings; \\
\hline & $\begin{array}{l}\text { Cost analysis, estimation, mapping and } \\
\text { planning of projects in various sectors. }\end{array}$ \\
\hline
\end{tabular}

The following projects have been implemented:

\section{Shelter}

The organisation started work in the shelter in 1989. Most domestic housing was destroyed during the conflict. The objective of this type of project is to assist the resettlement of returnees as well as internally displaced people. Activity is mostly in the damaged populated areas of Afghanistan.

Through these projects ESAR has provided 20,000 pre-cast concrete roofing components to some 2,000 families to rebuild their homes.

This has assisted in the rehabilitation of shelter and also in the protection of the environment by saving trees.

\section{Public Buildings}

Public buildings is another sector in which ESAR has played a significant role. This sector covers warehouses, schools, villages and basic education centres. Since 1989, it has constructed 4 warehouses each of 2,000 MT capacity, 2 village basic education centres, 3 middle schools and 7 high schools in Pakteka, Wardak, Laghman, Nangarhar and Kunar Provinces. 12,000 students benefit from the rehabilitation of these education facilities.

\section{Road Sector}

The organisation has completed a number of road projects in Paktia, Wardak, Nangarhar, Ghazni and Kandahar Provinces. The total length of these access roads is $145 \mathrm{kms}$, and the beneficiaries of this work number about 300,000 (direct and indirect) inhabitants.

\section{Irrigation sector}

Rehabilitation of 25 irrigation karezes and 25 canals (92 kms), in Ghazni, Nangarhar, Kunar, Pakteka and Kandahar Provinces is completed. The beneficiaries were more than 350,000 farmers and their families.

ESAR has also conducted technical surveys and mapping for different organisations, e.g. DAI, SCA and UNDP, through its consultancy department. 
FOCUS HUMANITARIAN ASSISTANCE EUROPE (FOCUS)

OFFICE OF AKDN 12，STR-84， G6/4 ISLAMABAD， PAKISTAN
PHONE : $92-51-2761812-14$

F A X: 92-51.276815

EMMAIL : JAFFERQARFP, SDNPK . UNDP . ORG .

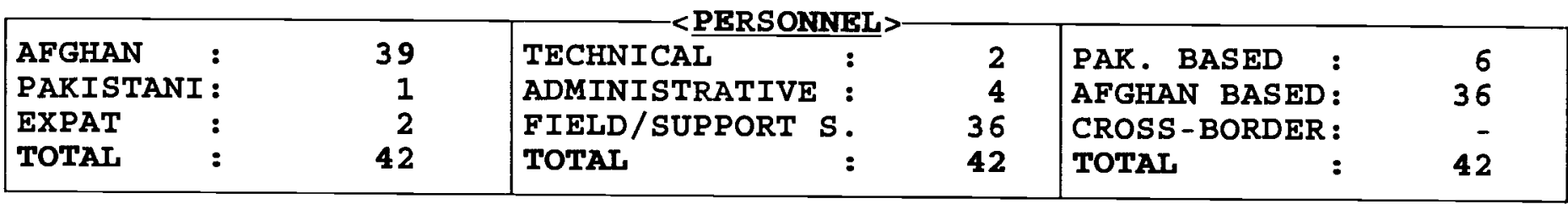

\begin{tabular}{|c|c|c|c|c|}
\hline & $-<$ SOURCES $>$ & & $-<$ ALIOCATION $>-$ & \\
\hline $\begin{array}{l} \\
\mathbf{O} \\
\mathrm{T} \\
\mathrm{H} \\
\mathrm{E} \\
\mathrm{R}\end{array}$ & PRIVATE DONATIONS & $100 \%$ & $\begin{array}{l}\text { AGRICULTURE } \\
\text { ASSISTANCE TO RETURNEES } \\
\text { CONSTRUCTION (ROAD/BRIDGE) } \\
\text { CONSTRUCTION (BUILDING/SHELTER) } \\
\text { EDUCATION } \\
\text { EMERGENCY } \\
\text { HEALTH } \\
\text { INCOME GENERATION } \\
\text { IRRIGATION } \\
\text { MINE } \\
\text { RELIEF }\end{array}$ & $\begin{array}{r}95 \% \\
5 \%\end{array}$ \\
\hline
\end{tabular}

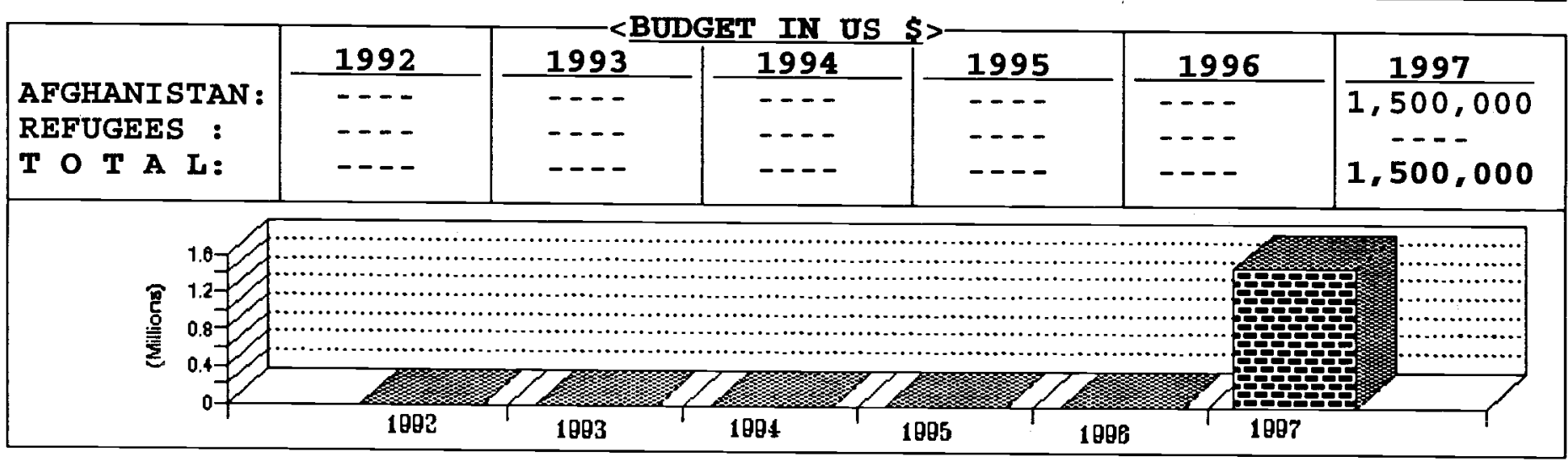

\begin{tabular}{|c|c|c|c|c|c|}
\hline PROVINCES & SECTOR & $\%$ & PROVINCES & SECTOR & $\%$ \\
\hline $\begin{array}{l}\text { BADAKSHAN } \\
\text { BADGHIS } \\
\text { BAGHLAN } \\
\text { BALKH } \\
\text { BAMYAN } \\
\text { FARAH } \\
\text { FARYAB } \\
\text { GHAZNI } \\
\text { GHOR } \\
\text { HELMAND } \\
\text { HERAT } \\
\text { JAWZJAN } \\
\text { KABUL } \\
\text { KANDAHAR } \\
\text { KAPISA }\end{array}$ & $\begin{array}{l}\text { EMERGENCY } \\
\text { EMERGENCY } \\
\text { EMERGENCY } \\
\text { EMERGENCY }\end{array}$ & $\begin{array}{r}60 \\
19 \\
1\end{array}$ & $\begin{array}{l}\text { KUNAR } \\
\text { RUNDUZ } \\
\text { LAGHMAN } \\
\text { LOGAR } \\
\text { NANGARHAR } \\
\text { NIMROZ } \\
\text { ORUZGAN } \\
\text { PARTEKA } \\
\text { PARTIA } \\
\text { PARWAN } \\
\text { SAMANGAN } \\
\text { TAKHAR } \\
\text { WARDAR } \\
\text { ZABUL }\end{array}$ & EMERGENCY & 10 \\
\hline
\end{tabular}




\section{FOCUS HUMANITARIAN ASSISTANCE \\ EUROPE (FOCUS)}

FOCUS is a non-government, non-political

organisation with its origins in Europe receiving

funding from various private donations.

The head office for the work being undertaken in Afghanistan is based in Islamabad.

\section{Sectors of operation}

Most projects are related to health and relief in various Provinces of Afghanistan.

Relief projects include agriculture and education. 
FARAA RECONSTRUCTION FOUNDATION (ERF)

- - - ADDRESS >- COMMUNICATION LINES >

I 5 NAHIA 6, MADAD

, CHAWK， KANDAHAR, AFGH

G.P. O.BOX 36 QUETTA, PAK
PHONE : 442865 (QUETTA)

F A X:

TELEX :
1. MOHAMMAD RAHIM

2. MOHAMMAD YOUNUS

3. FAZILUREHMAN

\begin{tabular}{|lr|lr|lrr|}
\hline AFGHAN : & 11 & TECHNICAL & : & 5 & PAK. BASED : & - \\
PAKISTANI : & - & ADMINISTRATIVE : & 3 & AFGHAN BASED: & 11 \\
EXPAT & $:$ & - & FIELD/SUPPORT S: & 3 & CROSS-BORDER: & - \\
TOTAL & 11 & TOTAL & $:$ & 11 & TOTAL & $\mathbf{1 1}$ \\
\hline
\end{tabular}

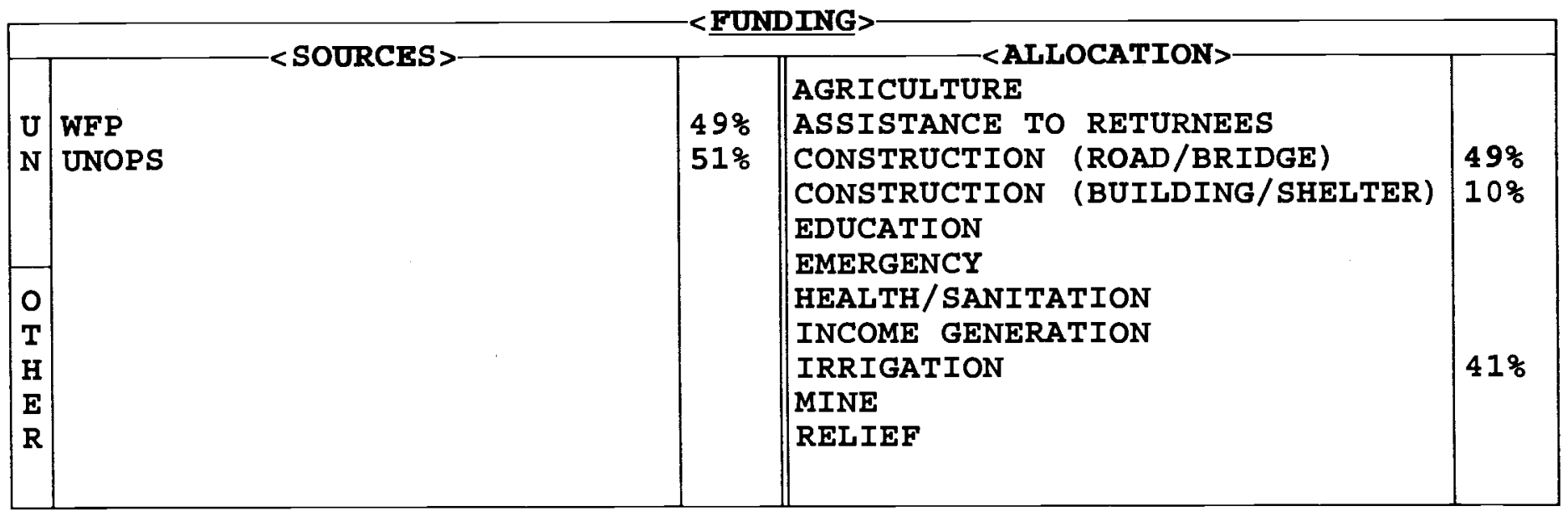

\begin{tabular}{|c|c|c|c|c|c|c|}
\hline & 1992 & 1993 & 1994 & 1995 & 1996 & 1997 \\
\hline AFGHANISTAN : & 187,500 & 306,900 & 572,000 & 414,700 & 386,500 & 100,500 \\
\hline $\begin{array}{l}\text { REFUGEES : } \\
\text { T O T A : }\end{array}$ & 187,500 & 306,900 & 572,000 & 414,700 & 386,500 & 100,500 \\
\hline
\end{tabular}

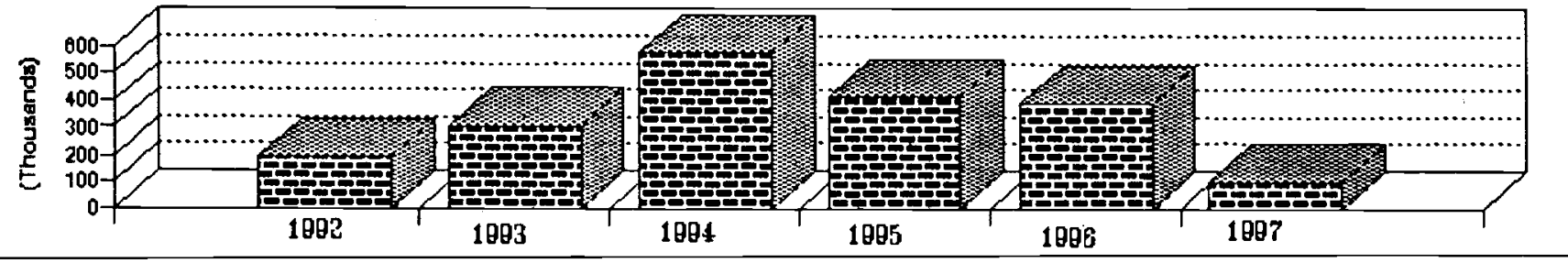

\begin{tabular}{|c|c|c|c|c|c|}
\hline PROVINCES & SECTOR & $\%$ & PROVINCES & SECTOR & $\%$ \\
\hline $\begin{array}{l}\text { BADAKSHAN } \\
\text { BADGHIS } \\
\text { BAGHLAN } \\
\text { BALKH } \\
\text { BAMYAN } \\
\text { FARAH } \\
\text { FARYAB } \\
\text { GHAZNI } \\
\text { GHOR } \\
\text { HELMAND } \\
\text { HERAT } \\
\text { JAWZJAN } \\
\text { KABUL } \\
\text { RANDAHAR } \\
\text { KAPISA }\end{array}$ & CONSTRUCTION & 10 & $\begin{array}{l}\text { KUNAR } \\
\text { KUNDUZ } \\
\text { LAGHMAN } \\
\text { LOGAR } \\
\text { NANGARHAR } \\
\text { NIMROZ } \\
\text { ORUZGAN } \\
\text { PAKTEKA } \\
\text { PAKTIA } \\
\text { PARWAN } \\
\text { SAMANGAN } \\
\text { TAKHAR } \\
\text { WARDAK } \\
\text { ZABUL }\end{array}$ & CONSTRUCTION & 49 \\
\hline
\end{tabular}




\section{FARAH RECONSTRUCTION \\ FOUNDATION \\ (FRF)}

FRF is an Afghan NGO cstablished in 1989 The elders and commanders of Farah Province and part of Nimroz Province formed the foundation, to work in the reconstruction of Afghanistan particularly Farah Province.

Past Sectors of Operation:

FRF works in the following sectors:

- Irrigation rehabilitation;

- Infrastructure reconstruction;

- Veterinary activities;

- Agriculture (seed distribution and multiplication, fertilizer distribution);

- School, road and culvert construction;

- Emergency relief and assistance to refugees.

Considcring the future needs of the country FRF decided to specialise and now limits itself to construction projects.

\section{Further information}

The current target areas of FRF are Farah, Helmand, Nimroz, Herat, Kandahar and Oruzgan Provinces. It intends to expand its programmes to other Provinces.

Due to change in WFP policy on sectoral basis in November 1996, one of FRF's road reconstruction projects in Oruzgan Province had to be suspended. 


\begin{tabular}{|c|c|c|c|c|c|}
\hline \multirow{2}{*}{\multicolumn{2}{|c|}{$\begin{array}{l}\text { 3IC CIRCULAR ROAD } \\
\text { UNIVERSITY TOWN } \\
\text { PESHAWAR, PAKISTAN }\end{array}$}} & \multicolumn{2}{|c|}{$-<$ COMMUNICATION LINES } & \multicolumn{2}{|c|}{$-<$ KEY STAFF $>-$} \\
\hline & & $\begin{array}{l}\text { PHONE : } 41815 \\
\text { F A X: } \\
\text { PHONE : }\end{array}$ & & $\begin{array}{ll}\text { 1. } & \text { RICHARD W } \\
\text { 2. ERHARD BAL } \\
\text { 3. }\end{array}$ & AMSON \\
\hline AFGHAN & & & & & \\
\hline $\begin{array}{l}\text { AFGHAN : } \\
\text { PAKISTANI: }\end{array}$ & 112 & $\begin{array}{l}\text { TECHNICAL } \\
\text { ADMINTSTRATTVE }\end{array}$ & 51 & $\begin{array}{l}\text { PAK. BASED } \\
\text { AFGHAN BASFD. }\end{array}$ & $\begin{array}{r}2 \\
775\end{array}$ \\
\hline EXPAT : & 5 & FIELD/SUPPORT $S$. & 680 & CROSS - BORDER & - \\
\hline TOTAL & 777 & TOTAL : & 777 & TOTAL & 777 \\
\hline
\end{tabular}

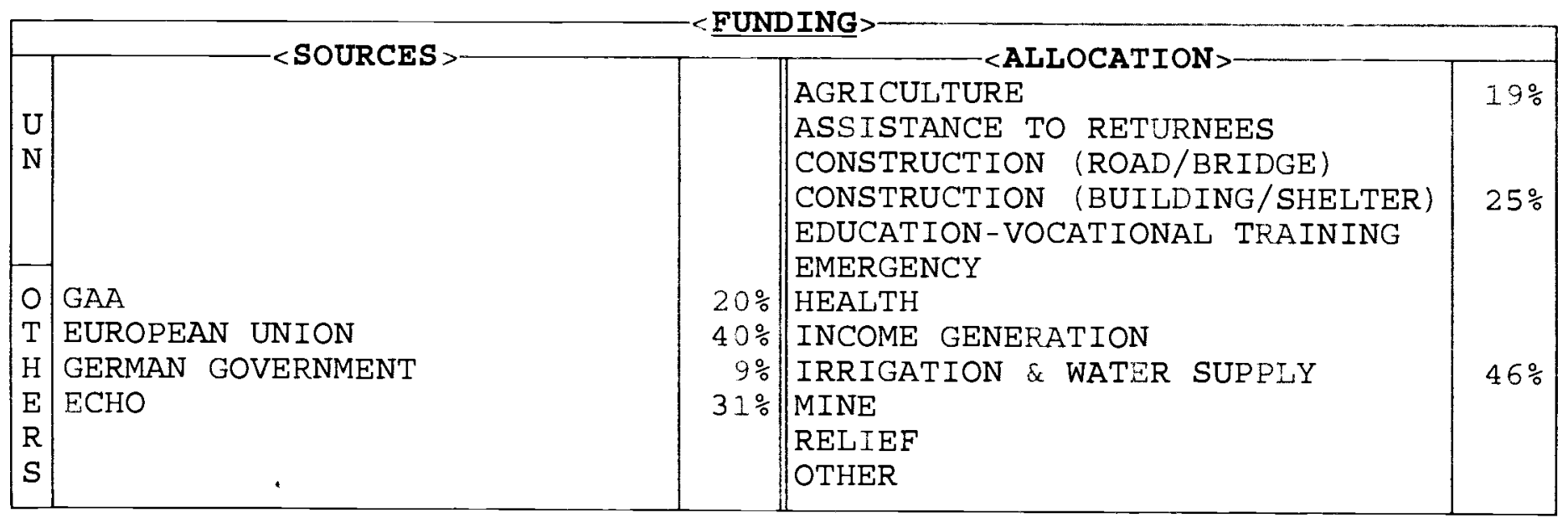

\begin{tabular}{|c|c|c|c|c|c|c|}
\hline $\begin{array}{l}\text { AFGHANISTAN: } \\
\text { REFUGEES : } \\
\text { T O T A L: }\end{array}$ & $\begin{array}{c}\frac{1992}{1,500,000} \\
\ldots \\
1,500,000\end{array}$ & $\begin{array}{l}\frac{1993}{1,000,000} \\
\cdots, 000,000\end{array}$ & $\frac{1994}{1,000,000}=$ & $\frac{1995}{2,000,000}=0$ & $\frac{1996}{3,000,000}=$ & $\begin{array}{c}\frac{1997}{4,601,000} \\
\cdots \\
4,601,000\end{array}$ \\
\hline 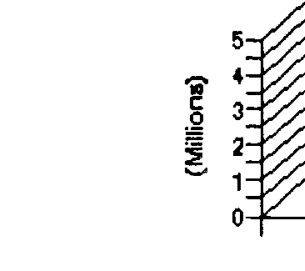 & 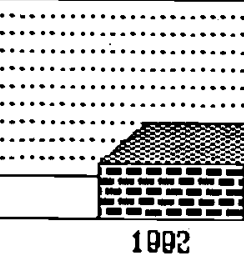 & 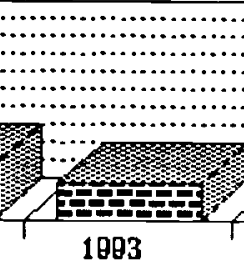 & 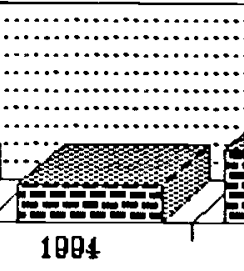 & 1005 & 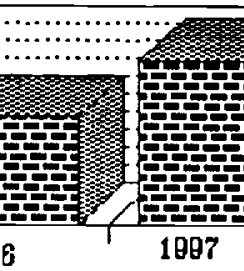 & S \\
\hline
\end{tabular}

\begin{tabular}{|c|c|c|c|c|c|}
\hline PROVINCES & SECTOR & $\%$ & PROVINCES & SECTOR & $\%$ \\
\hline $\begin{array}{l}\text { BADAKSHAN } \\
\text { BADGHIS } \\
\text { BAGHLAN } \\
\text { BALKH } \\
\text { BAMYAN } \\
\text { FARAH } \\
\text { FARYAB } \\
\text { GHAZNI } \\
\text { GHOR } \\
\text { HELMAND } \\
\text { HERAT } \\
\text { JAWZJAN } \\
\text { KABUL } \\
\text { KANDAHAR } \\
\text { KAPISA }\end{array}$ & $\begin{array}{l}\text { SANITATION } \\
\text { SHELTER/SANIT/RELIEF }\end{array}$ & 13 & $\begin{array}{l}\text { KUNAR } \\
\text { KUNDUZ } \\
\text { LAGHMAN } \\
\text { LOGAR } \\
\text { NANGARHAR } \\
\text { NIMROZ } \\
\text { ORUZGAN } \\
\text { PAKTEKA } \\
\text { PAKTIA } \\
\text { PARWAN } \\
\text { SAMANGAN } \\
\text { TAKHAR } \\
\text { WARDAK } \\
\text { ZABUL }\end{array}$ & $\begin{array}{l}\text { WATER SUPPLY } \\
\text { WATER SUPPLY } \\
\text { AGRICULTURE } \\
\text { WATER SUPPLY/AGRIC }\end{array}$ & $\begin{array}{r}5 \\
5 \\
2 \\
27\end{array}$ \\
\hline
\end{tabular}




\section{GERMAN AGRO ACTION (GAA) DEUTSCHE WELTHUNGERHILFE (DW)}

GAA is a non-governmental organisation founded in 1962 as part of an international campaign by the United Nations to combat disaster poverty and famine by means of private initiatives

The work of GAA is guided by the principle of self-help to enable people to achieve food security through their own efforts.

GAA supports development, human rights, the environment and rural development and in particular the increase of agricultural yields, with the aim of achieving freedom from hunger ad freedom for people. It fights poverty in developing countries in order to improve the living conditions of the rural population and socially weak sections of the urban population. It employs its resources directly where people are in need. GAA provides emergency aid and reconstruction aid in cases of conflict and disaster.

Work stated in Afghanistan in 1993 with one office in Kabul. The second office in Mazar was established a year later. Due to intense fighting in Kabul in 1994/95 the office in Kabul temporarily suspended its activities and moved its structure to Jalalabad. In September of 1995 the office in Kabul resumed its operations. Today there are three sub-offices each working in a different sector.

The office in Mazar primarily concerns itself with providing food for work progammes to the IDP camps and rural areas in Balkh Province, funded mainly by the European Union. During 1997 sanitation activities commenced in Mazar, funded by ECHO.

The office in Jalalabad provided sanitation and water for the IDP camps in Sarshahi and New Hada during 1994 and 1995/6 funded mainly by $\mathrm{ECHO}$. The water activity was then expanded to rural areas in Nangahar, Kunar and Laghman Provinces in order to attract refugees living in Pakistan to return to their home villages. The main water supply activity is drilling of deep wells, using their own equipment, a hand pump is then installed. Rehabilitation of irrigation and drainage systems in various districts of Nangahar and Laghman Provinces are carried out using food for work. Various food security projects have been implemented in this region. Main source of funding comes from the European Union and the German Ministry of Foreign Affairs.

The office in Kabul, before its suspension in 1994, concentrated its energies in the food sector. This involved food for work programmes in Kabul as well as food distribution to the poor and medical institutions. Since 1996 GAA Kabul works mainly in shelter, sanitation and food security. The main source of funding has been ECHO and the German Ministry of Foreign Affairs and the German Embassy, Islamabad have supported many activities. 
HOUSE 17 B GUL MOHAR LN $\mathrm{U} / \mathrm{T}$ G $\mathrm{P}$ O BOX 1230 PESHAWAR, PAKISTAN
PHONF: 42613

F A : 840348

email :
1. DR ABDUL GHAFOOR

2. MOHAMMAD YASIN

3. PIR ABID KAMAL

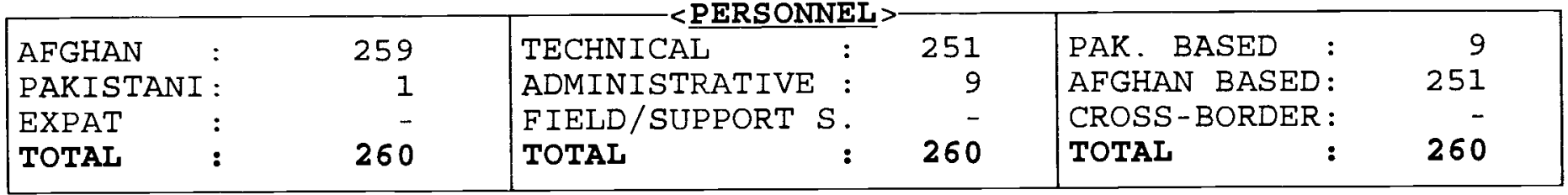

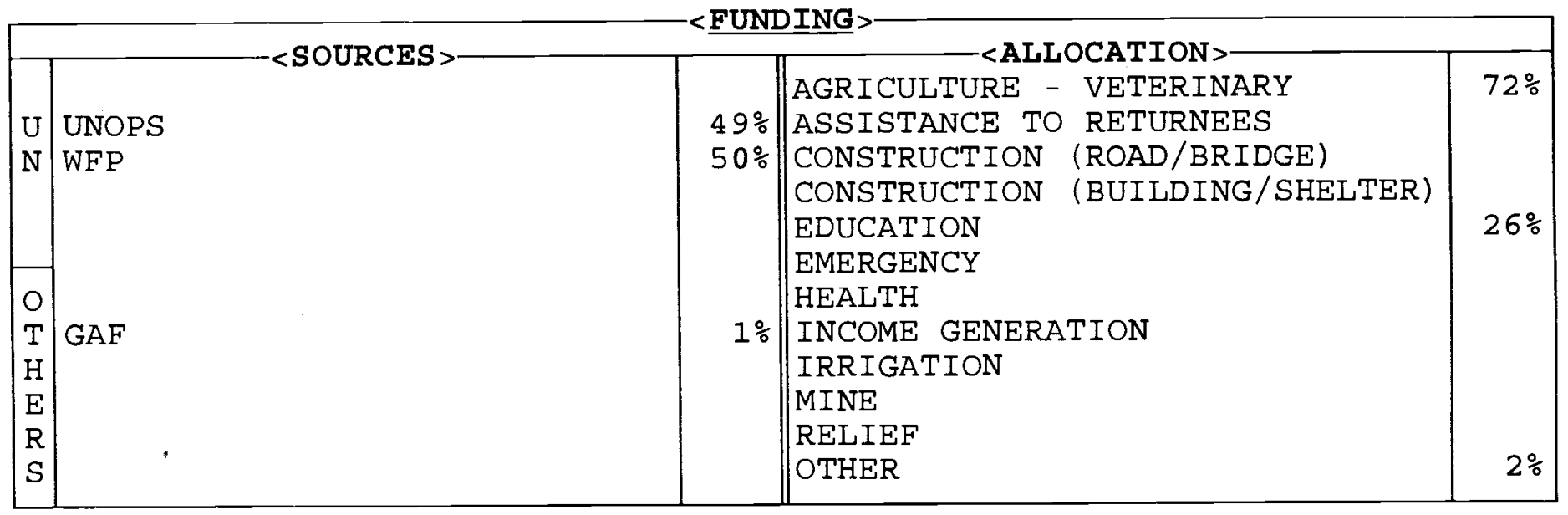

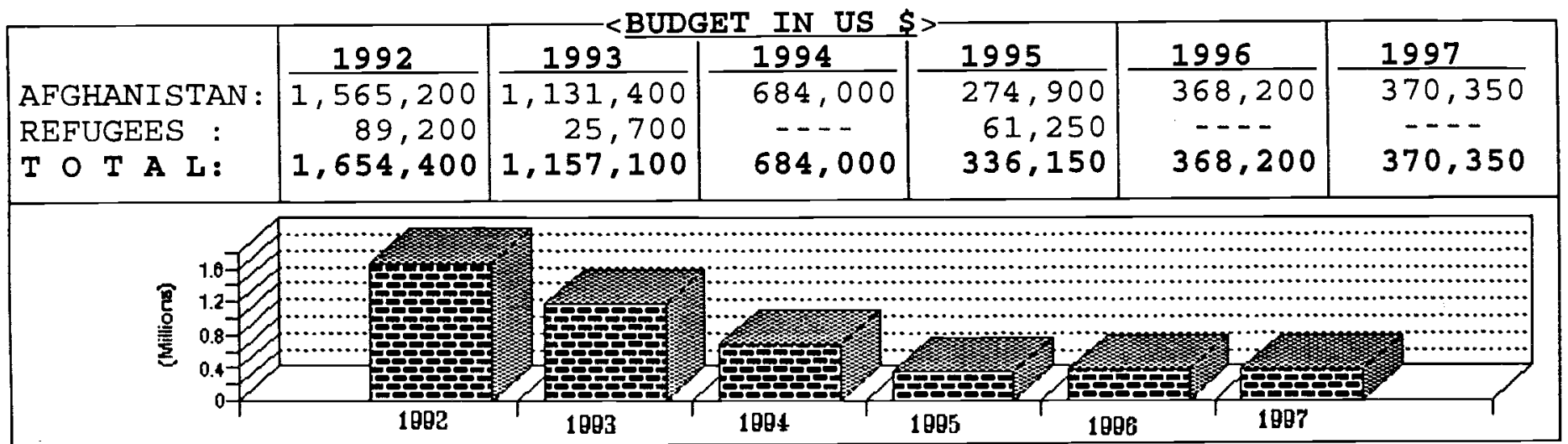

\begin{tabular}{|l|l|r||l|l|l|}
\hline \multicolumn{5}{|c|}{$<$ TARGET PROVINCES IN AFGHANISTAN> } & SECTOR \\
\hline BADAKSHAN & & $\%$ & PROVINCES & \\
BADGHIS & & & KUNAR & & \\
BAGHLAN & & & KUNDUZ & & \\
BALKH & EDUCATION & 3 & LAGHMAN & & 14 \\
BAMYAN & EDUCATION - WOMEN & 4 & NANGARHAR & VETERINARY/EDUC & 17 \\
FARAH & & & NIMROZ & & \\
FARYAB & & & ORUZGAN & & \\
GHAZNI & VETERINARY/EDUC & 17 & PAKTEKA & & \\
GHOR & & & PAKTIA & VETERINARY/EDUC \\
HELMAND & EDUCATION & 3 & PARWAN & & \\
HERAT & EDUC/AGRIC & 6 & SAMANGAN & & \\
JAWZJAN & & & TAKHAR & & \\
KABUL & VETERINARY & 14 & WARDAK & \\
KANDAHAR & EDUCATION & 3 & ZABUL & \\
KAPISA & AGRICULTURE & 2 & PAKISTAN & & \\
\hline
\end{tabular}


GAF is a non-governmental humanitarian organisation established simultaneously in the Federal Republic of Germany and Pakistan in 1986. GAF is supported by UNDP/OPS, FAO, UNICEF, HABITAT, WFP, BMZ (Federal Republic of Germany) and private donations from Germany.

\section{Aims of GAF}

GAF is an implementing agency for rehabilitation work in Afghanistan.

\section{Sectors of Operation}

Veterinary assistance:

District veterinary services cover 58 districts with 58 Veterinary Field Units (VFUs), in 5 Provinces. A total of 592 Basic Veterinary Workers (BVWs) have completed training and a further 26 will be trained. Refresher courses for 206 DVM and 137 Paravet staff have been conducted.

A total of 630 women have been trained in poultry management in Engil and Zamdajan district of Herat Province.

Refreshers courses have been held for 419 BVWs with a further course for 224 planned.

Animal Health and Livestock Production Improvement Module (PIHAM) training programme in Afghanistan. This project is to give training to veterinarians to improve the delivery of veterinary services in the project as well as give training about PIHAM in Nangarhar, Paktia, Kandahar, Herat and Mazari-Sharif. This training has been completed by 12 DVM with plans to train an additional 50 DVMs.

In 1996 a total of 3,291,152 livestock were vaccinated. De-worming and treatment against different diseases will be undertaken in approximately 4,032,000 livestock in 1997.
Paravet training is undertaken be NGO staff and GAF staff.. Some trainees have opened their own private practices.

\section{Agriculture}

- a fruit tree nursery has been completed in Said Khil of Paktia Province.

- a summer seed crop multiplication project has been completed in Surkhrod, Nangarhar.

- a set of seven tractors operates in Herat, rental to farmers is on an hourly basis.

Fruit and amenity tree private nurseries have been established in 5 districts of Kapisa and 10 districts of Herat Province.

\section{Future objectives}

The Agriculture Department will expand its crop production programme and is planning to establish fruit and forest nurseries inside Afghanistan.

\section{Further information}

It is proposed to establish 4 veterinary laboratories in Kandahar, Khost, Ghazni and Mazar-i-Sharif.

A proposal for a goat milk farm has been submitted

Survey of a school in Kakakhil, Kapisa has been completed and a proposal for reconstruction submitted.

GAF is also interested in working for the disabled people to enable them to generate their own income. Plans for this are under way and a programme is due to commence in Kabul in the near future.

More attention will be given to basic health care and a poultry management programme for women in rural areas. 
HOUSE <ADDRESS>- -COMMUNICATION LINES>

F-6/1

ISLAMABAD, PAKISTAN
PHONT: 051275490

F A X: 051272605

email:
1. RON WARD

2. LASHON WILSON

3 .

\begin{tabular}{|c|c|c|c|c|c|}
\hline AFGHAN : & 14 & TECHN ICAL & 2 & PAK. BASED : & - \\
\hline PAKISTANI : & - & ADMINISTRATIVE : & 2 & AFGHAN BASED: & 18 \\
\hline EXPAT : & 4 & FIELD/SUPPORT S. & 14 & CROSS-BORDER : & - \\
\hline TOTAL & 18 & TOTAL : & 18 & TOTAL : & 18 \\
\hline
\end{tabular}

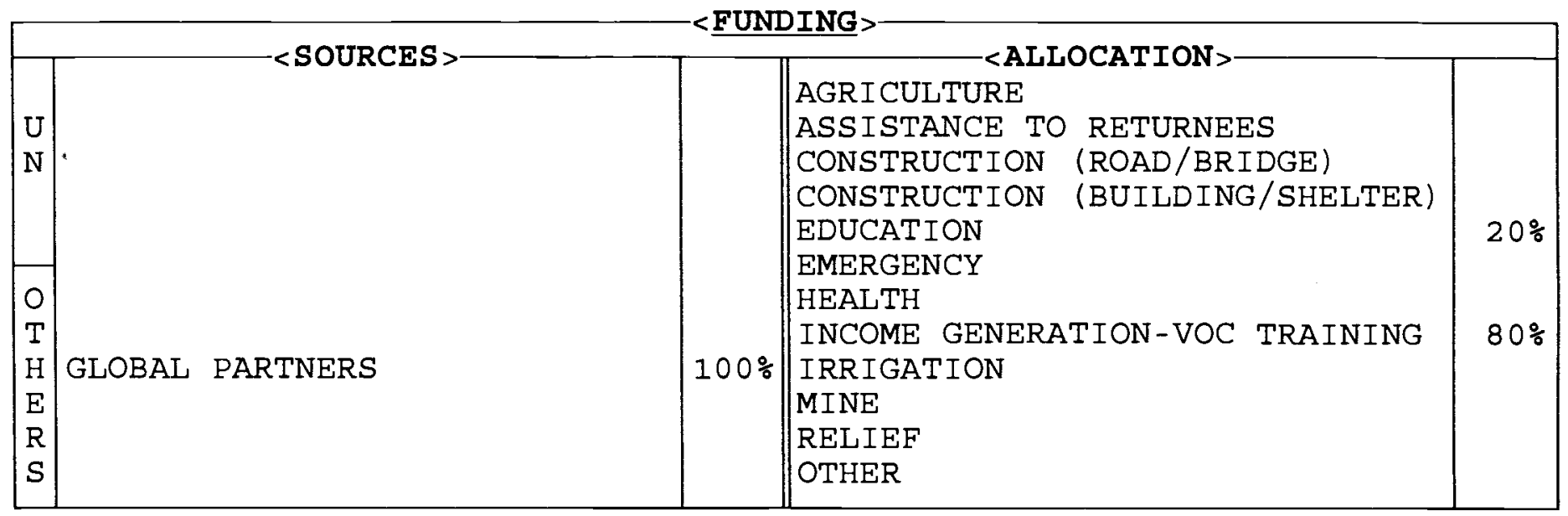

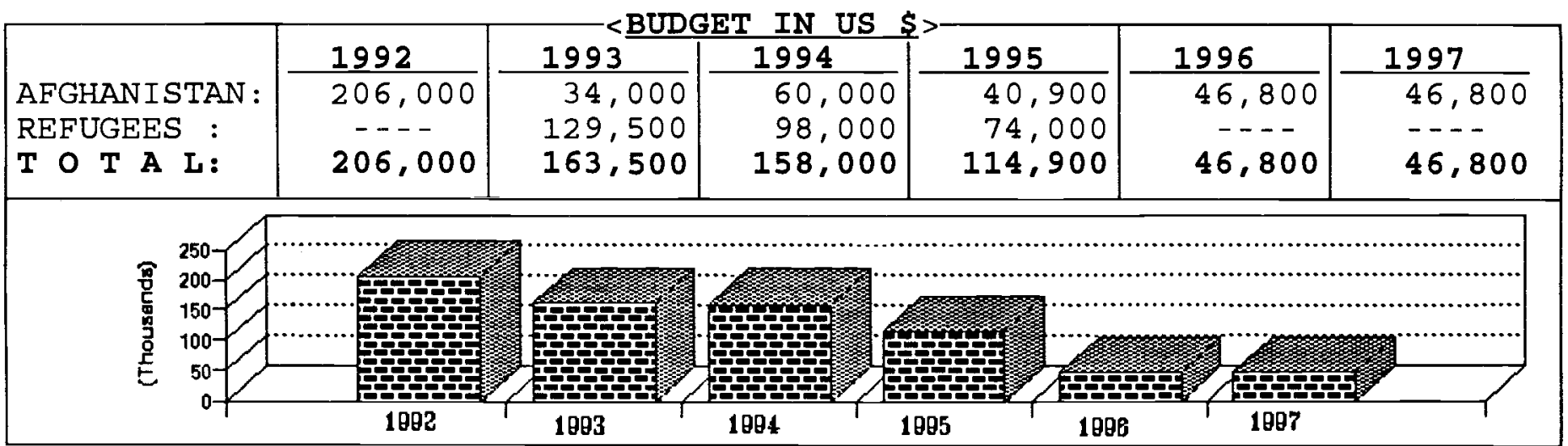

\begin{tabular}{|c|c|c|c|c|c|}
\hline PROVINCES & SECTOR & $\%$ & PROVINCES & SECTOR & $\%$ \\
\hline $\begin{array}{l}\text { BADAKSHAN } \\
\text { BADGHIS } \\
\text { BAGHLAN } \\
\text { BALKH } \\
\text { BAMYAN } \\
\text { FARAH } \\
\text { FARYAB } \\
\text { GHAZNI } \\
\text { GHOR } \\
\text { HELMAND } \\
\text { HERAT } \\
\text { JAWZJAN } \\
\text { KABUL } \\
\text { KANDAHAR } \\
\text { KAPISA }\end{array}$ & $\begin{array}{l}\text { VOCATIONAL TRAINING } \\
\text { EDUCATION }\end{array}$ & $\begin{array}{l}80 \\
20\end{array}$ & $\begin{array}{l}\text { KUNAR } \\
\text { KUNDUZ } \\
\text { LAGHMAN } \\
\text { LOGAR } \\
\text { NANGARHAR } \\
\text { NIMROZ } \\
\text { ORUZGAN } \\
\text { PAKTEKA } \\
\text { PAKTIA } \\
\text { PARWAN } \\
\text { SAMANGAN } \\
\text { TAKHAR } \\
\text { WARDAK } \\
\text { ZABUL } \\
\text { PAKISTAN }\end{array}$ & & \\
\hline
\end{tabular}




\section{GLOBAL PARTNERS UK (GP-UK)}

GP is a charitable organisation, set up to provide benevolent services to the developing world. It is committed to providing resources and services which prevent poverty and preserve human life. It also facilitates international cooperative efforts for educational, agricultural, environmental, health related, disabled vocational training and other projects.

Global Partners provides technical assistance through a variety of consultancy programmes and encourages the training of national workers.

GP has offices or sponsored work in Cyprus, Turkey Northern Iraq (Kurdistan), Afghanistan, Hong Kong, China, Singapore and Indonesia.

The organisation is registered in the United Kingdom and Pakistan. It is a UK based agency which began work in 1991 largely in response to the plight of Kurdish refugees in Northern Iraq. GP-UK initially provided a channel for resources and technicians to assist the Kurdish areas of Iraq. Even today it continues its Northern Iraq projects.

The agency has worked for Afghanistan since 1991. In Afghanistan, as in every other country in which it operates, GP serves as a purely nonprofit charity for the purpose of funding and implementing humanitarian assistance.

Activities undertaken include distribution of emergency relief assistance, both, in the refugee camps in Pakistan and to the displaced in Jalalabad/Sarobi. Support is also given to an elementary school in Malestan of Ghazni; and animal vaccination campaign in Malestan and disabled vocational training in Puli Khumri and surrounding areas. It is also teaching English for specific purposes through an English language Institute in Mazar-i-Sharif. 
192, MANAN RD, A ONE H.SCHEME, P.O.BOX 55 QUETTA, PAKISTAN
<COMMUNICATION LINES>

PHONE : 092-81-820-894

F A X: 092-81-820-894

F A $X$ : 092-81-444-793C/OHI3. FARIDON ANADI

\begin{tabular}{|lr|lr|lrr|}
\hline AFGHAN : & 105 & TECHNICAL & RERSONNEL> & 47 & PAK.BASED : & 7 \\
PAKISTANI: & - & ADMINISTRATIVE : & 13 & AFGHAN BASED: & 103 \\
EXPAT $:$ & 5 & FIELD/SUPPORT S. & 50 & CROSS -BORDER: & - \\
TOTAL : & 110 & TOTAL & 110 & TOTAL & $:$ & 110 \\
\hline
\end{tabular}

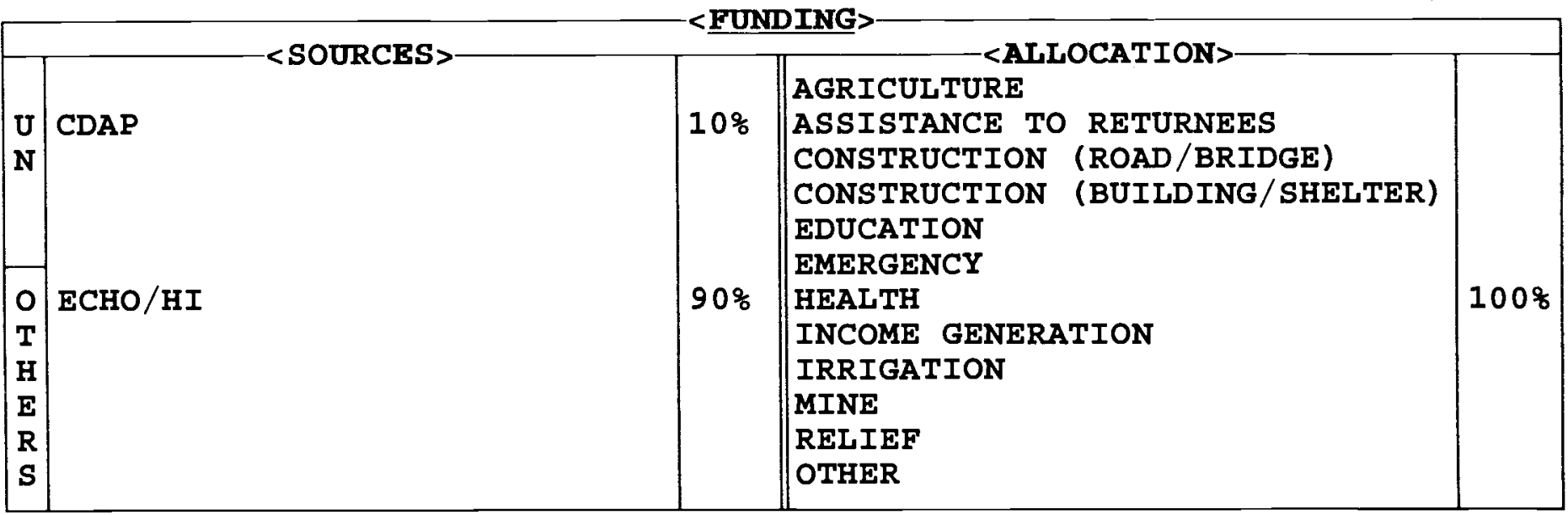

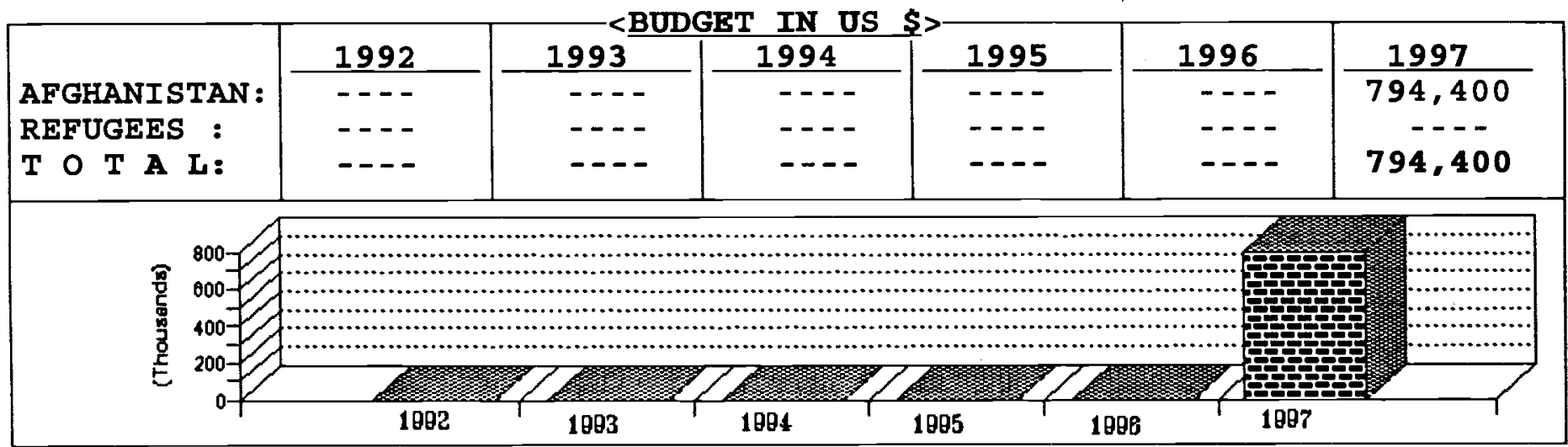

<TARGET PROVINCES IN AFGHANISTAN>

\begin{tabular}{|c|c|c|c|c|c|}
\hline PROVINCES & SECTOR & $\%$ & PROVINCES & SECTOR & $\%$ \\
\hline $\begin{array}{l}\text { BADAKSHAN } \\
\text { BADGHIS } \\
\text { BAGHLAN } \\
\text { BALKH } \\
\text { BAMYAN } \\
\text { FARAH } \\
\text { FARYAB } \\
\text { GHAZNI } \\
\text { GHOR } \\
\text { HELMAND } \\
\text { HERAT } \\
\text { JAWZJAN } \\
\text { KABUL } \\
\text { KANDAHAR } \\
\text { KAPISA }\end{array}$ & HELATH & 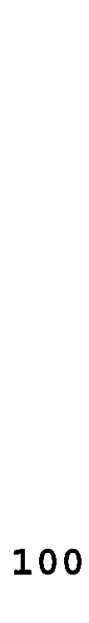 & $\begin{array}{l}\text { KUNAR } \\
\text { KUNDUZ } \\
\text { LAGHMAN } \\
\text { LOGAR } \\
\text { NANGARHAR } \\
\text { NIMROZ } \\
\text { ORUZGAN } \\
\text { PAKTEKA } \\
\text { PAKTIA } \\
\text { PARWAN } \\
\text { SAMANGAN } \\
\text { TAKHAR } \\
\text { WARDAK } \\
\text { ZABUL }\end{array}$ & & \\
\hline
\end{tabular}




\section{GUARDIANS}

GUARDIANS is an Afghan non-political, non-partisan, non-profitable and nongovernmental organisation established in 1993.

The main goal of the organisation is to provide opportunities to disabled to improve their prospects and encourage and assist them to be able to lead full lives in the community.

A library has been established in Quetta, Pakistan for Afghan refugees. To help them understand what is happening in their own country and the rest of the world.

In 1995 the Institute of Orthopaedics was opened in Kandahar. The Institute has the following departments:

Prosthetics; orthotics; orthopaedic shoes; casting; plaster modification; walking aids; wheelchairs; component production; central registration; stores; female physiotherapy; male physiotherapy; gymnasium; leather department and male and female physiotherapy and orthopaedic training.

The staff includes Afghan specialists in orthopaedics, physiotherapy as well as expatriate specialists from $\mathrm{HCI}$.

Since July 1997 the CDAP programme for community based rehabilitation has been implemented by Guardians in 5 districts of Kandahar.

A training programme for physiotherapists has recently been established in Quetta, with funding from Canada Fund.

Further training of physiotherapists and orthopaedic technologists in ongoing with a special emphasis on women's training. 
HELP THE AFGHANS FOUNDATION (HAF)

< ADDRESS $>-<$ COMMUNICATION LINES $>$

ACBAR

10 B PARK LANE, U/T

P O BOX 819

PESHAWAR， PAKISTAN

PHONE : 840621

F A X: 840621

email:
1. DR ANTONY V/D BUNT

2 .

3 .

\begin{tabular}{|c|c|c|c|c|c|}
\hline $\begin{array}{l}\text { AFGHAN : } \\
\text { PAKISTANI: } \\
\text { EXPAT : } \\
\text { TOTAL : }\end{array}$ & $\begin{array}{l}2 \\
4 \\
1 \\
7\end{array}$ & $\begin{array}{l}\text { TECHNICAL : } \\
\text { ADMINISTRATIVE : } \\
\text { FIELD/SUPPORT S: } \\
\text { TOTAL }\end{array}$ & $\begin{array}{l}1 \\
4 \\
2 \\
7\end{array}$ & $\begin{array}{l}\text { PAK. BASED : } \\
\text { AFGHAN BASED : } \\
\text { CROSS-BORDER : } \\
\text { TOTAL : }\end{array}$ & $\begin{array}{l}6 \\
1 \\
- \\
7\end{array}$ \\
\hline
\end{tabular}

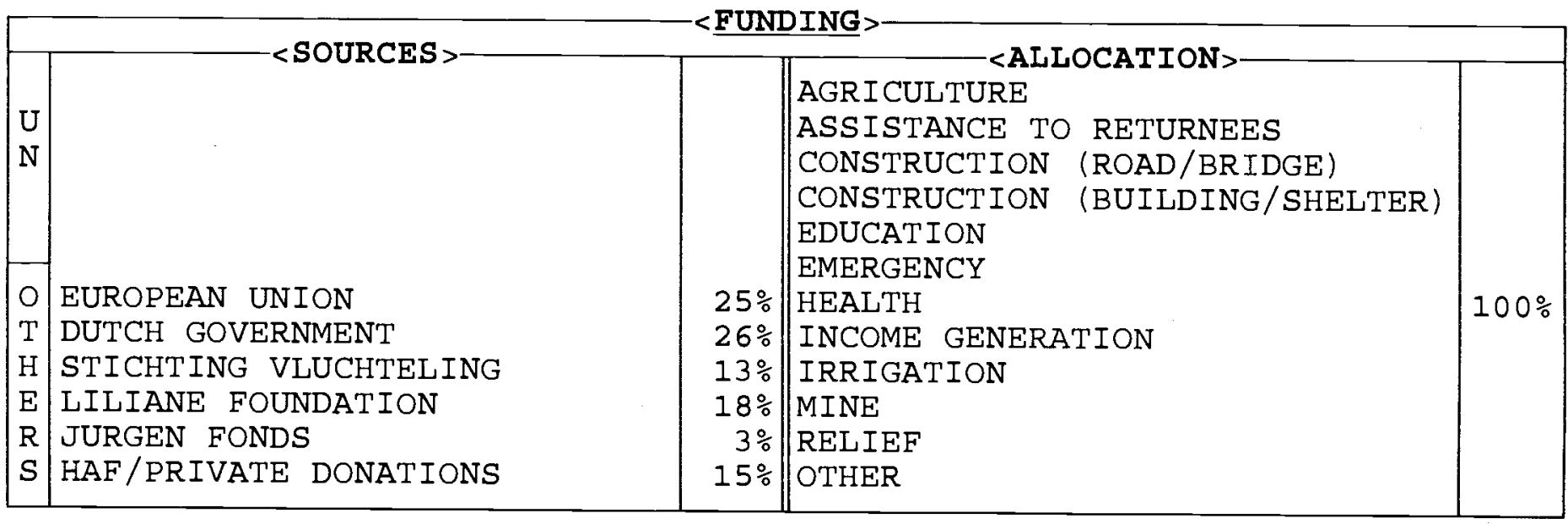

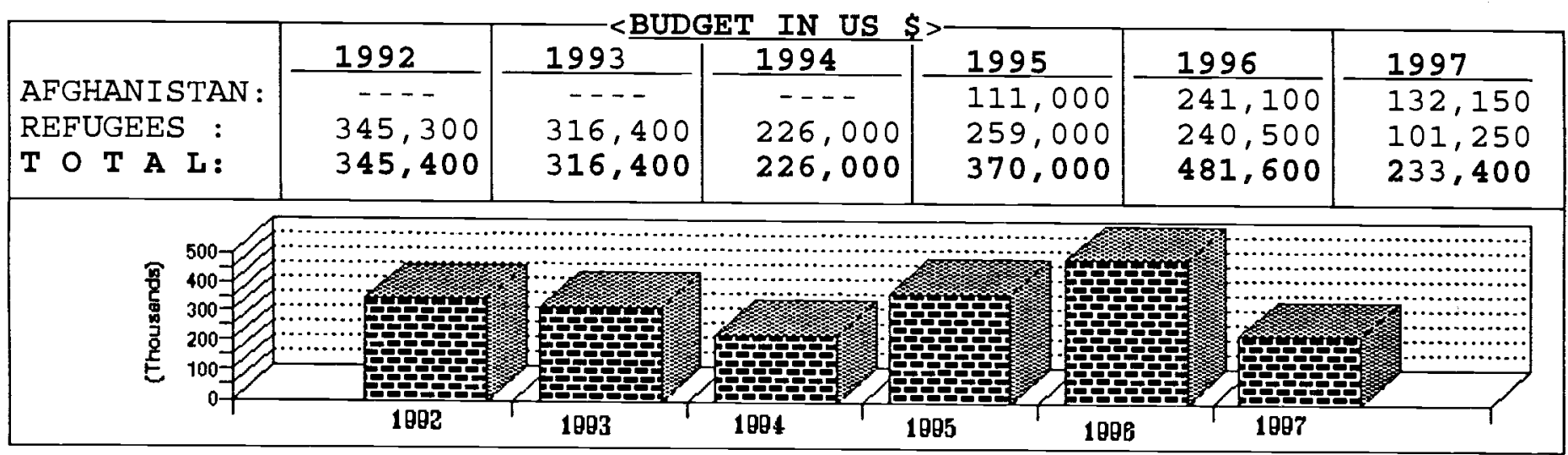

\begin{tabular}{|c|c|c|c|c|c|}
\hline PROVINCES & SECTOR & $\%$ & PROVINCES & SECTOR & $\div$ \\
\hline $\begin{array}{l}\text { BADAKSHAN } \\
\text { BADGHIS } \\
\text { BAGHLAN } \\
\text { BALKH } \\
\text { BAMYAN } \\
\text { FARAH } \\
\text { FARYAB } \\
\text { GHAZNI } \\
\text { GHOR } \\
\text { HELMAND } \\
\text { HERAT } \\
\text { JAWZJAN } \\
\text { KABUL } \\
\text { KANDAHAR } \\
\text { KAPISA }\end{array}$ & & & $\begin{array}{l}\text { KUNAR } \\
\text { KUNDUZ } \\
\text { LAGHMAN } \\
\text { LOGAR } \\
\text { NANGARHAR } \\
\text { NIMROZ } \\
\text { ORUZGAN } \\
\text { PAKTEKA } \\
\text { PAKTIA } \\
\text { PARWAN } \\
\text { SAMANGAN } \\
\text { TAKHAR } \\
\text { WARDAK } \\
\text { ZABUL } \\
\text { PAKISTAN }\end{array}$ & $\begin{array}{l}\text { HEALTH } \\
\text { HEALTH }\end{array}$ & 57 \\
\hline
\end{tabular}


HAF was established in 1984 in The Hague, The Netherlands, as a relief agency for refugees from the Afghanistan war. Women, children and disabled were selected as the target groups and it was decided to fund Afghan registered NGOs where suitable in Pakistan.

\section{Sectors of Operation:}

1986-1993: HAF supported the children's clinic of AHSAO in Peshawar. With cosponsorship by HELP of Germany (1987-1991 incl.) and NCA/NRC (1992), OPD (basic services) and IPD (40 beds) were provided.

1988: HAF funded 2 BHUs in Aza Khel camp, Peshawar, implemented by AHSAO. In 1989 with the assistance of SCA and UNICEF, a $\mathrm{MCH}$ programme was started. This included a TBA training and midwifery service. Since January 1994 AOGH replaced AHSAO (100 patients per day).

1987-1993: HAF co-funded the AOGH Hospital, including a perinatal unit started up in 1990 with AHSAO in Peshawar and since October 1994 re-started in AOGH Jalalabad.

Since 1989 HAF also funds orthopaedic operations for children performed by Dr. AlSayyah (20 operations per month).

Since March 1994, HAF has funded RADA dental teams in New Nasir Bagh and Aza Khel Camps, Peshawar and Hisar Shahi camp and New Hadda Farm camp, Jalalabad.

Since July 1996, instead of the latter, HAF has co-funded with NCA/NRC the ENT Unit of the University Hospital of Jalalabad.

January 1994 - December 1995: HAF in cooperation with MRCA and SGAA funded a paediatric department with OPD ( 80 patients per day), rehydration/emergency ( 5 beds) and IPD ( 15 beds) in the ITC Hospital, Hayatabad.
Since January 1994, HAF has co-funded with UNHCR and co-implemented with AOGH the new Nasir Bagh BHU (125 patients/day).

September 1994 - December 1995, HAF funded the SGAA Orthopaedic OPD (weekly) in the hospital, Hayatabad, with Dr. Al-Sayyah (orthopaedic surgeon) as consultant.

Since July 1995, HAF funds, monitors and manages the Paediatric Unit of the University Hospital of Jalalabad ( 50 OPD patients per day and 50 IPD beds).

\section{Further information}

HAF has also:

- provided medicines, bandages (for Kabul via MSF-Holland), and medical equipment and funded a vaccination programme in Afghanistan, through AVICEN;

- contributed towards the purchase of equipment for SERVE (SSBA) in Afghanistan, and donated funds to ARF MCH Clinic, Hayatabad;

- built a school in Munda Camp through ARF and equipped schools;

- supported income generation and training of the disabled in Pakistan through OV tailoring and carpentry courses;

- distributed food in Pakistan through AHSAO and in Afghanistan through ARF and AAA;

- supplied cooking utensils to Kabuli refugees in Aza Khel Camp through UNHCR and Pakistan Red Crescent (PRC) and solar ovens to Kabul through SERVE.

\section{Future objectives}

In 1998, HAF plans to continue reduction of funding to health projects in Pakistan and increase to those in Afghanistan. 
HELPING AFGHAN FARMERS ORGANISATION (HAFO)

$<$ ADDRESS $>-<-<$ COMMUNICATION LINES $>$ 53-B PARK AVENUE UNIVERSITY TOWN PESHAWAR, PAKISTAN

PHONE: 44677

F $\mathbf{A}$ :

emai1:

\begin{tabular}{|c|c|c|c|c|c|}
\hline AFGHAN & 48 & TECHNICAL & 16 & PAK. BASED & 13 \\
\hline PAKISTANI: & - & ADMINISTRATIVE : & 22 & AFGHAN BASED: & 31 \\
\hline EXPAT : & - & FIELD/SUPPORT S. & 10 & CROSS-BORDER : & 4 \\
\hline TOTAL & 48 & TOTAL : & 48 & TOTAL : & 48 \\
\hline
\end{tabular}

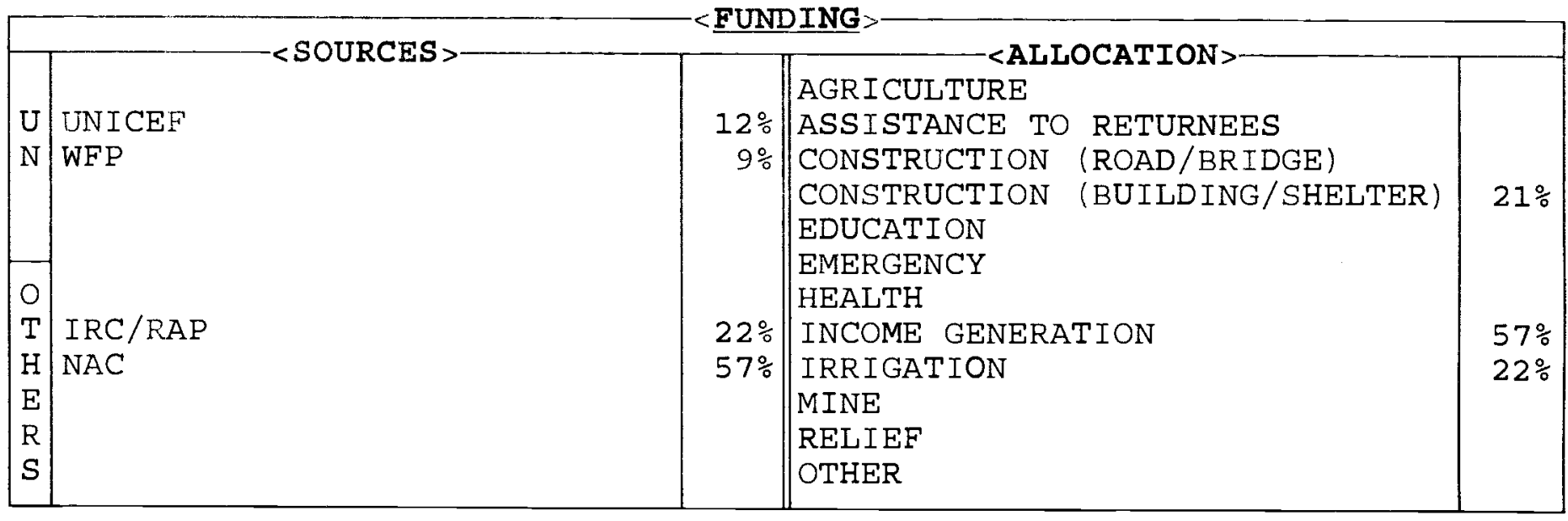

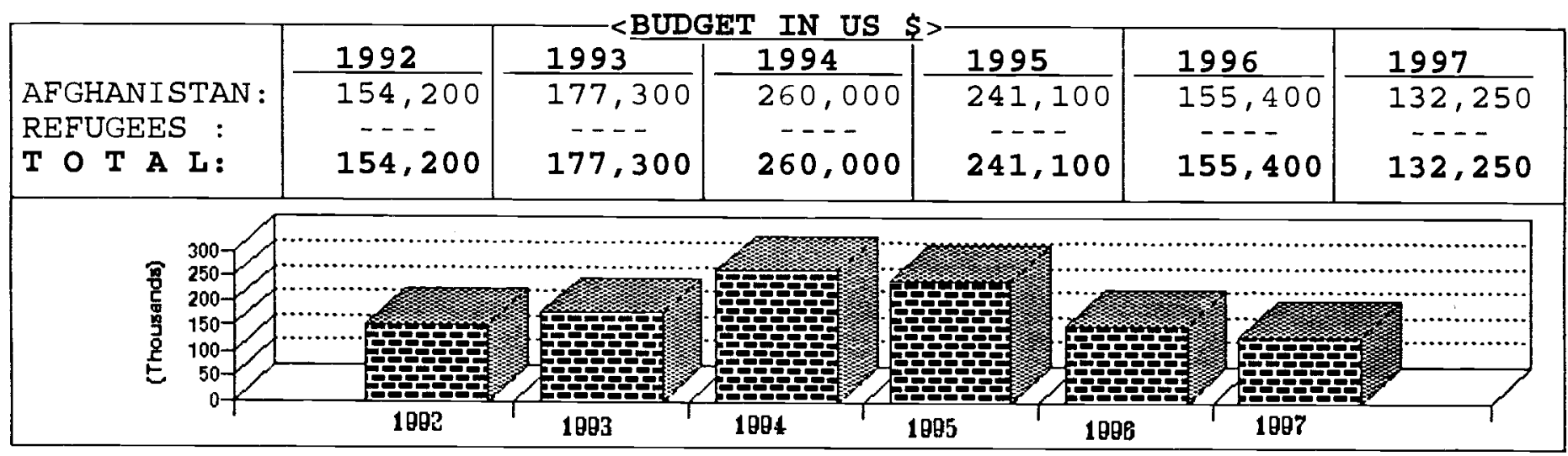

\begin{tabular}{|c|c|c|c|c|c|}
\hline PROVINCES & SECTOR & $\%$ & PROVINCES & SECTOR & $\%$ \\
\hline $\begin{array}{l}\text { BADAKSHAN } \\
\text { BADGHIS } \\
\text { BAGHLAN } \\
\text { BALKH } \\
\text { BAMYAN } \\
\text { FARAH } \\
\text { FARYAB } \\
\text { GHAZN I } \\
\text { GHOR } \\
\text { HELMAND } \\
\text { HERAT } \\
\text { JAWZJAN } \\
\text { KABUL } \\
\text { KANDAHAR } \\
\text { KAPISA }\end{array}$ & $\begin{array}{l}\text { IN. GEN/IRRIG/CONST } \\
\text { IRRIG/CONST }\end{array}$ & $\begin{array}{l}79 \\
21\end{array}$ & $\begin{array}{l}\text { KUNAR } \\
\text { KUNDUZ } \\
\text { LAGHMAN } \\
\text { LOGAR } \\
\text { NANGARHAR } \\
\text { NIMROZ } \\
\text { ORUZGAN } \\
\text { PAKTEKA } \\
\text { PAKTIA } \\
\text { PARWAN } \\
\text { SAMANGAN } \\
\text { TAKHAR } \\
\text { WARDAK } \\
\text { ZABUL } \\
\text { PAKISTAN }\end{array}$ & & \\
\hline
\end{tabular}




\section{HELP THE AFGHAN FARMERS ORGANISATION (HAFO)}

$\mathrm{HAFO}$ is an indigenous $\mathrm{Afghan} N \mathrm{NGO}$ providing assistance to the Afghan population in Afghanistan. HAFO began as an offshoot from a foreign relief agency, the Dutch Committee for Afghanistan (DCA). When the Dutch Committee found itself unable to continue certain programmes, some senior Afghan staff who were responsible for those programmes decided to form their own NGO to continue the work.

The agency was founded in August 1990. Since then it has grown considerably and developed its own policies and strategies.

HAFO has projects in irrigation, agricultural rehabilitation, vocational education and animal husbandry in Helmand, Kandahar, Ghazni.

HAFO conducted some surveys in Wardak and Logar Provinces for future activities and intends to extend its programmes to those Provinces.

The Engineering department has one coordinator show coordinates the irrigation and construction projects. Vocational training department also has its own coordinator with engineers who are responsible for implementation of Vocation Training centres inside Afghanistan.

The agency has field offices in Ghazni, Kandahar and Lashkargah - Helmand.

HAFO plans to bring more land back into cultivation and to restore pre-war agricultural productivity and self-sufficiency.

It aims to improve local breeds, increase animal products and provide adequate water for drinking and irrigation.

It will also provide training for the people in technical fields in the areas where the agency is active. 
HUMAN CONCERN INTERNATIONAT (HCI)

ACBAR

$39 \mathrm{D} S \mathrm{~J}$ AFGHANI ROAD

$\mathrm{U} / \mathrm{T}$ P O BOX 880

PESHAWAR, PAKISTAN
PHONE: 840524

F A X: 840544

email:
1. S W HASAN

2. ALI NAWAZ

3 .

\begin{tabular}{|c|c|c|c|c|c|}
\hline AFGHAN & 63 & TECHNICAL : & 35 & PAK. BASED : & 50 \\
\hline PAKISTANI : & 7 & ADMINISTRATIVE : & 25 & AFGHAN BASED: & 18 \\
\hline EXPAT : & - & FIELD/SUPPORT $S$. & 10 & CROSS-BORDER : & 2 \\
\hline TOTAL & 70 & TOTAL : & 70 & TOTAL : & 70 \\
\hline
\end{tabular}

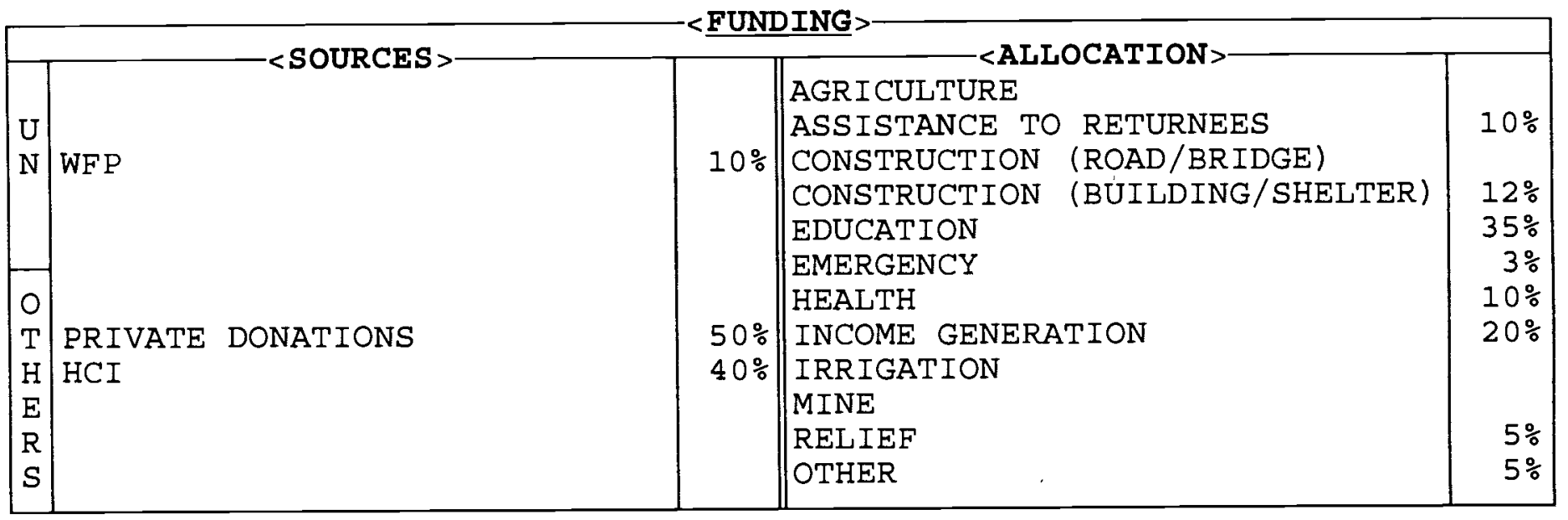

\begin{tabular}{|c|c|c|c|c|c|c|}
\hline $\begin{array}{l}\text { AFGHANISTAN : } \\
\text { REFUGEES : } \\
\text { T O T A L: }\end{array}$ & $\begin{array}{l}1992 \\
493,200 \\
463,400 \\
956,600\end{array}$ & $\begin{array}{l}1993 \\
400,000 \\
300,000 \\
700,000\end{array}$ & $\begin{array}{l}1994 \\
214,700 \\
276,800 \\
491,500\end{array}$ & $\begin{array}{l}1995 \\
138,700 \\
262,600 \\
401,300\end{array}$ & $\begin{array}{l}\frac{1996}{103,700} \\
196,300 \\
300,000\end{array}$ & $\begin{array}{l}1997 \\
70,000 \\
200,000 \\
270,000\end{array}$ \\
\hline 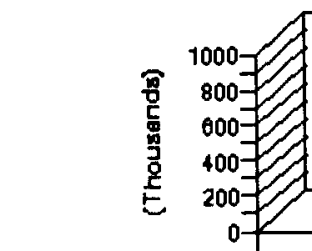 & :.:. & 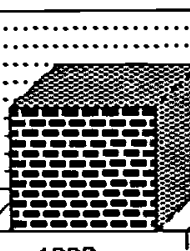 & & 모도 & 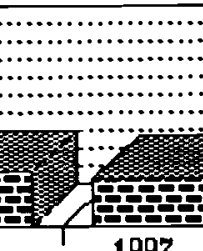 & ri: \\
\hline
\end{tabular}

\begin{tabular}{|c|c|c|c|c|c|}
\hline PROVINCES & SECTOR & $\%$ & PROVINCES & SECTOR & $\%$ \\
\hline $\begin{array}{l}\text { BADAKSHAN } \\
\text { BADGHIS } \\
\text { BAGHLAN } \\
\text { BALKH } \\
\text { BAMYAN } \\
\text { FARAH } \\
\text { FARYAB } \\
\text { GHAZNI } \\
\text { GHOR } \\
\text { HELMAND } \\
\text { HERAT } \\
\text { JAWZJAN } \\
\text { KABUL } \\
\text { KANDAHAR } \\
\text { KAPISA }\end{array}$ & EMERGENCY & 5 & $\begin{array}{l}\text { KUNAR } \\
\text { KUNDUZ } \\
\text { LAGHMAN } \\
\text { LOGAR } \\
\text { NANGARHAR } \\
\text { NIMROZ } \\
\text { ORUZGAN } \\
\text { PAKTEKA } \\
\text { PAKTIA } \\
\text { PARWAN } \\
\text { SAMANGAN } \\
\text { TAKHAR } \\
\text { WARDAK } \\
\text { ZABUL } \\
\text { PAKISTAN }\end{array}$ & $\begin{array}{l}\text { RELIEF / EDUCATION } \\
\text { INCOME GENERATION } \\
\text { EDUC/IN. GEN/HLTH / REL }\end{array}$ & 20 \\
\hline
\end{tabular}


HCI was established in 1980 in Canada.

Human Concern International started operations for Afghan refugees and Afghanistan in January 1984.

\section{Aims of HCI}

Main aims and objectives are to alleviate

Human suffering.

\section{Sectors of Operation}

- Engineering;

- Agriculture;

- $\quad$ Preventative health care;

- Income generating;

- Vocational training;

- Education.

HCI has implemented many projects in Pakistan and inside Afghanistan for Afghan refugees.

In Pakistan:

- Technical assistance;

- Primary education;

- Religious education;

- $\quad$ Mother Child Health Care;

- Handicrafts;

- Tube well and mosques in Akora

Khattak, Shamshato and other camps.

In Afghanistan:

As in ACBAR "Database of NGO Activities".

\section{Further Information}

$\mathrm{HCI}$ has also provided the following services:

- emergency feeding and winter clothes to displaced families in Kabul and surrounding areas;

- mobile clinic services to displaced people from Kabul and surrounding areas;

- the Jalalabad Poly Clinic Hospital at Farm Hada;
- irrigation system repair in Mandozai Khost consisting of three large canals i.e. Darkoti canal, Hasanzai canal and Shbikhai canals;

- emergency feeding programmes for displaced people in Jalalabad, Mumtaz Bagh, Hada Farm;

- Khost airport repair; runway and check-posts;

- rehabilitation of Nangarhar farms, 1st phase;

- disabled Vocational training centre in Jalalabad;

- widows Vocational Centre in Angur Bagh Jalalabad. 


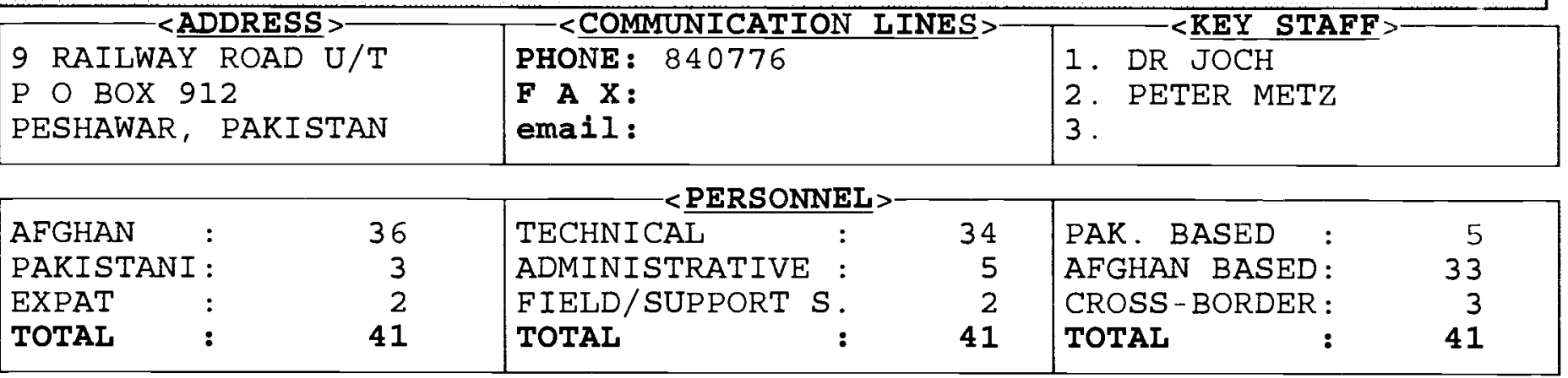

\begin{tabular}{|c|c|c|c|c|}
\hline & - <SOURCES & & $-<$ ALLOCATION $>-$ & \\
\hline & & & AGRICULTURE & $15 \%$ \\
\hline $\mathrm{U}$ & & & ASSISTANCE TO RETURNEES & \\
\hline $\mathrm{N}$ & & & CONSTRUCTION （ROAD/BRIDGE） & \\
\hline & & & CONSTRUCTION (BUILDING/SHELTER) & $30 \%$ \\
\hline & & & EDUCATION & \\
\hline & & & EMERGENCY & $2 \%$ \\
\hline 0 & EUROPEAN UNION & $60 \%$ & HEALTH & $30 \%$ \\
\hline $\mathrm{T}$ & PRIVATE DONATIONS & $10 \%$ & INCOME GENERATION & $3 \%$ \\
\hline $\mathrm{H}$ & GERMAN GOVERNMENT & $30 \%$ & IRRIGATION & $20 \%$ \\
\hline $\mathrm{E}$ & & & MINE & \\
\hline $\mathrm{R}$ & & & RELIEF & \\
\hline$S$ & & & OTHER & \\
\hline
\end{tabular}

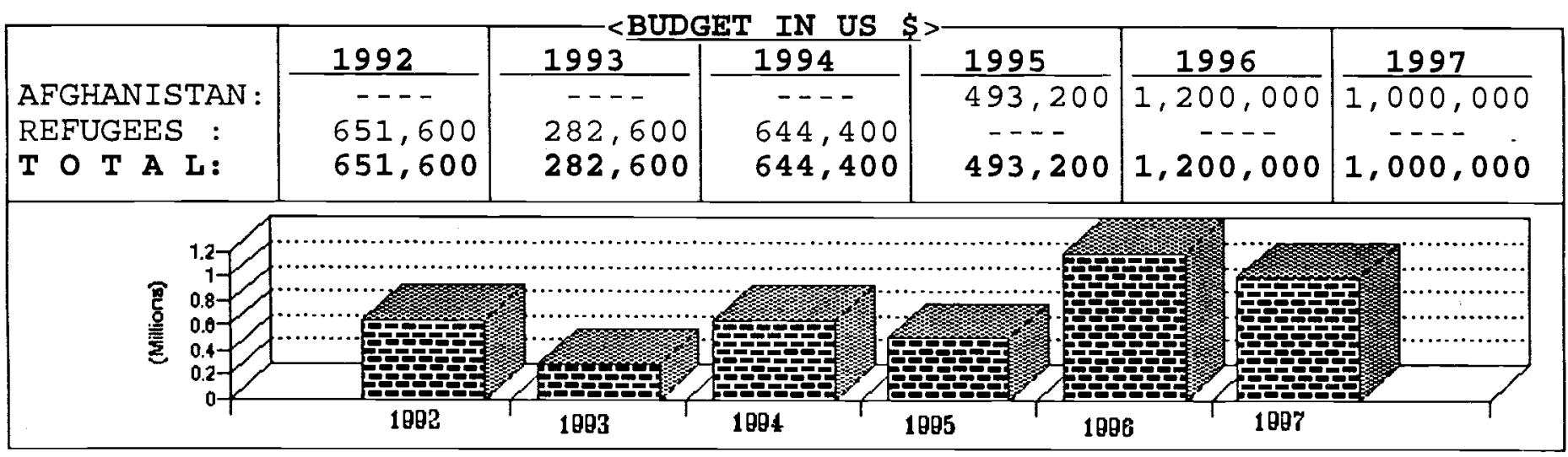

\begin{tabular}{|c|c|c|c|c|c|}
\hline PROVINCES & SECTOR & $\%$ & PROVINCES & SECTOR & $\%$ \\
\hline $\begin{array}{l}\text { BADAKSHAN } \\
\text { BADGHIS } \\
\text { BAGHLAN } \\
\text { BALKH } \\
\text { BAMYAN } \\
\text { FARAH } \\
\text { FARYAB } \\
\text { GHAZNI } \\
\text { GHOR } \\
\text { HELMAND } \\
\text { HERAT } \\
\text { JAWZJAN } \\
\text { KABUL } \\
\text { KANDAHAR } \\
\text { KAPISA }\end{array}$ & $\begin{array}{l}\text { INCOME GENERATION } \\
\text { IRRIGATION } \\
\text { CONST/IRRIG/EMERG. } \\
\text { IRRIGATION }\end{array}$ & 5 & $\begin{array}{l}\text { KUNAR } \\
\text { KUNDUZ } \\
\text { LAGHMAN } \\
\text { LOGAR } \\
\text { NANGARHAR } \\
\text { NIMROZ } \\
\text { ORUZGAN } \\
\text { PAKTEKA } \\
\text { PAKTIA } \\
\text { PARWAN } \\
\text { SAMANGAN } \\
\text { TAKHAR } \\
\text { WARDAK } \\
\text { ZABUL } \\
\text { PAKISTAN }\end{array}$ & $\begin{array}{l}\text { HLTH/IRRIG/AGRIC } \\
\text { IRRIGATION } \\
\text { IRRIGATION }\end{array}$ & 10 \\
\hline
\end{tabular}




\section{HELP GERMANY (HG)}

HELP was founded in 1981 as a fund raising agency.

\section{Aims of HELP}

It's main aim was to provide aid for Afghan refugees but is now active inside Afghanistan. HELP receives funds from private donors, the $\mathrm{EU}$ and the German Government.

From 1981 - 1992 HELP has mainly supported a dozen Afghan NGOs besides direct emergency aid to camps. Nowadays HELP has the following activities inside Afghanistan.

\section{HELP/Interplast Surgery for Afghans}

This projects started in November 1989 with German Government funds and since May 1992 is funded by EU. In September 1995, Dr. Joch shifted the Hospital and OPD from Peshawar to Jalalabad.

Every year four teams of plastic-, hand- and micro-surgeons come to operate on patients suffering from: war injuries; remaining deformities of face, hands, arms, feet, legs; scare contracture after burns; congenital / acquired malformations (e.g. children with cleft-lip, club-foot, post-polio-paralysis).

\section{Shelter Programme Kabul}

HELP received EU funding to support concrete girder production in Kabul in cooperation with AREA in 1996.

\section{Community based Rehabilitation}

In August 1996, HELP started a CBR programme (mainly irrigation) in various villages with funds from the German Government. Several Afghan NGOs were involved in the implementation of, so far, 18 projects. 


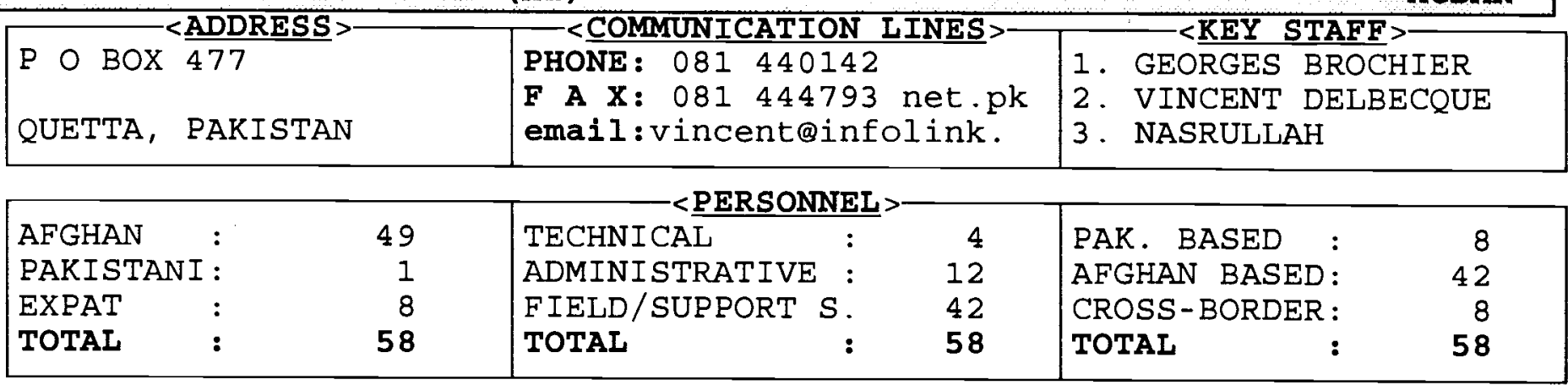

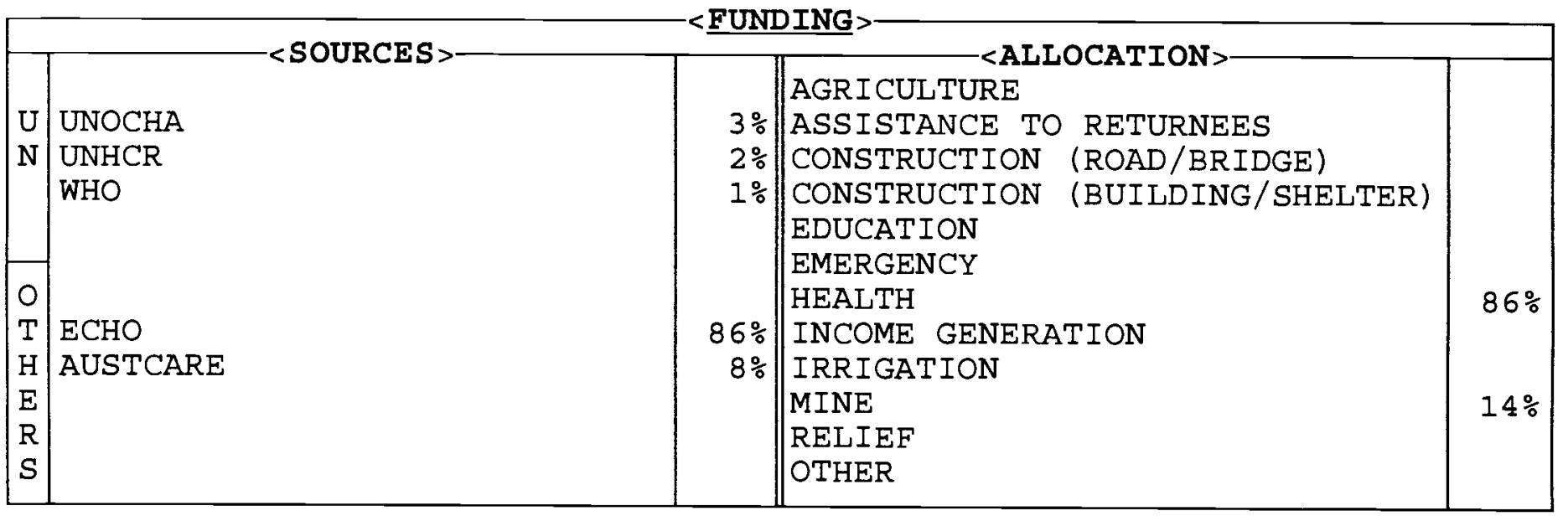

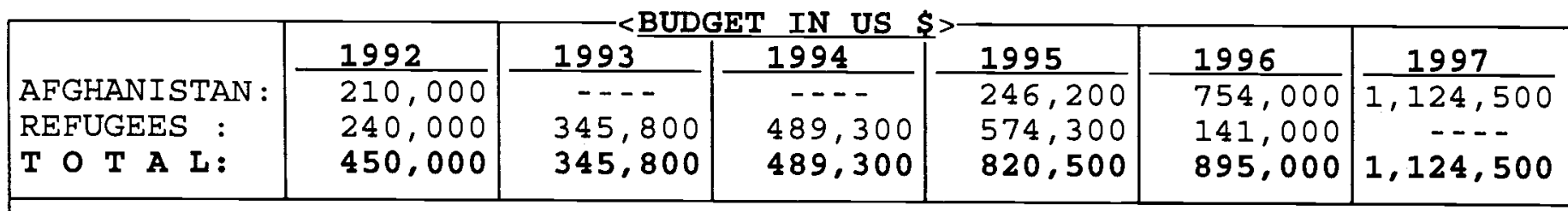

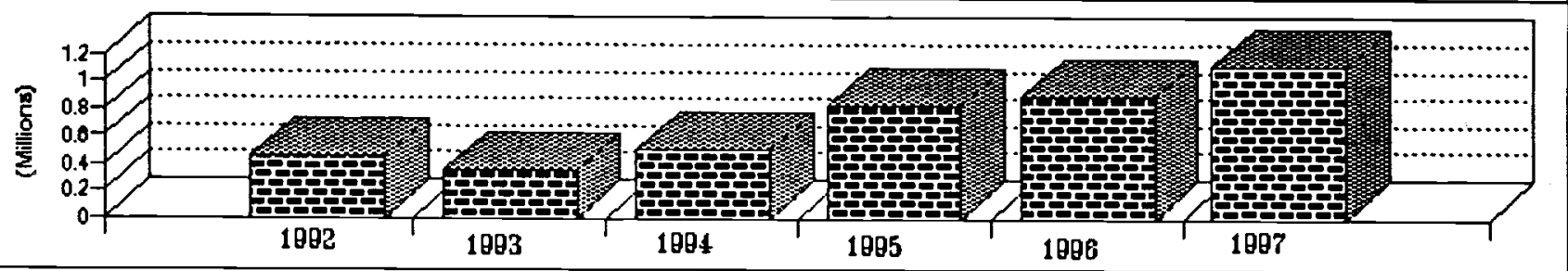

\begin{tabular}{|c|c|c|c|c|c|}
\hline PROVINCES & SECTOR & $\%$ & PROVINCES & SECTOR & $\%$ \\
\hline $\begin{array}{l}\text { BADAKSHAN } \\
\text { BADGHIS } \\
\text { BAGHLAN } \\
\text { BALKH } \\
\text { BAMYAN } \\
\text { FARAH } \\
\text { FARYAB } \\
\text { GHAZNI } \\
\text { GHOR } \\
\text { HELMAND } \\
\text { HERAT } \\
\text { JAWZJAN } \\
\text { KABUL } \\
\text { KANDAHAR } \\
\text { KAPISA }\end{array}$ & 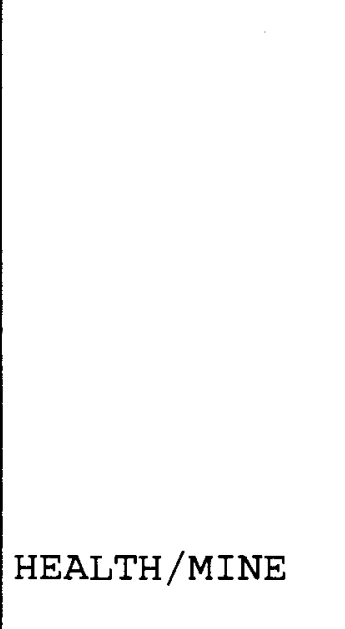 & 99 & $\begin{array}{l}\text { KUNAR } \\
\text { KUNDUZ } \\
\text { LAGHMAN } \\
\text { LOGAR } \\
\text { NANGARHAR } \\
\text { NIMROZ } \\
\text { ORUZGAN } \\
\text { PAKTEKA } \\
\text { PAKTIA } \\
\text { PARWAN } \\
\text { SAMANGAN } \\
\text { TAKHAR } \\
\text { WARDAK } \\
\text { ZABUL } \\
\text { PAKISTAN }\end{array}$ & HEALTH/MINE & 1 \\
\hline
\end{tabular}


Handicap International is an international NGO. The organisation receives funds from the EU and private donors. HI is a neutral, nonpolitical and non governmental agency.

Founded 15 year ago by two French doctors working in Thailand with Cambodian refugees. They met a lot of people injured after stepping on anti-personnel mines and decided they wanted to help.

Step by step HI provided more services to disabled people. Currently many teams are working in rehabilitation programmes to help people walk again (lower limb amputee, polio children.) and to take part in social life. Workshops are set up to produce artificial limbs and other devices to compensate for body weakness.

The main aim of the organisation is:

- to train local staff in physiotherapy and in the fabrication of orthopaedic devices;

- to set up activities;

- to hand over these activities to the local government, public health or local organisations.

This is why activities are implemented according to the local needs, agreement and collaboration with local authorities and local organisations.

Currently the organisation is operational in 25 countries employing some 140 expatriate staff, teaching the many national staff how to treat disabled with simple methods and techniques.

\section{Pakistan and Afghanistan:}

HI has been working for 10 years in Quetta (Orthopaedic Workshop) and around Pishin, Lorolai Dalbandine areas for Afghan refugees. Until 1995 technical and financial support was given to Al Khidmai Hospital in Quetta when it was handed over to MCI.
Activities in Kandahar commenced in January 1996:

- support and Afghan NGO GUARDIANS (previously ART) who produce prostheses;

- since July $1997 \mathrm{HI}$ and GUARDIAN's workshops integrated and now produce orthotics and prostheses;

- involved in Mine Awareness Programme - Community Based Mine Awareness Programme (CBMAP) in the Provinces of Kandahar, Zabul and intend to expand this programme to other Provinces.

A survey lasting two months was undertaken to gather information on the disabled. The survey took place in Shawalico, Dand, Arghandab, Panjwai Districts and Kandahar City. It was discovered that 2 in every 100 of the general population ( 1 per 4 households) are disabled. Young men were the victims of war and the children were generally victims of poliomyelitis.

Technical, financial and administrative support is given to Guardians as well as training physiotherapists and orthotic and prosthetic production.

Priority is given to the training and organisation of the workshop.

Separate units are available for male and female patients, workers and trainees. Three women are currently following the PTA training and 2 will graduate in December 1997.

A Community Based Rehabilitation programme is running in collaboration with Guardians and UNCDAP. Guardians implement the progranme, CDAP gives expertise, methodologies and experience and $\mathrm{HI}$ gives financial support and will provide physiotherapy training in 1998. 


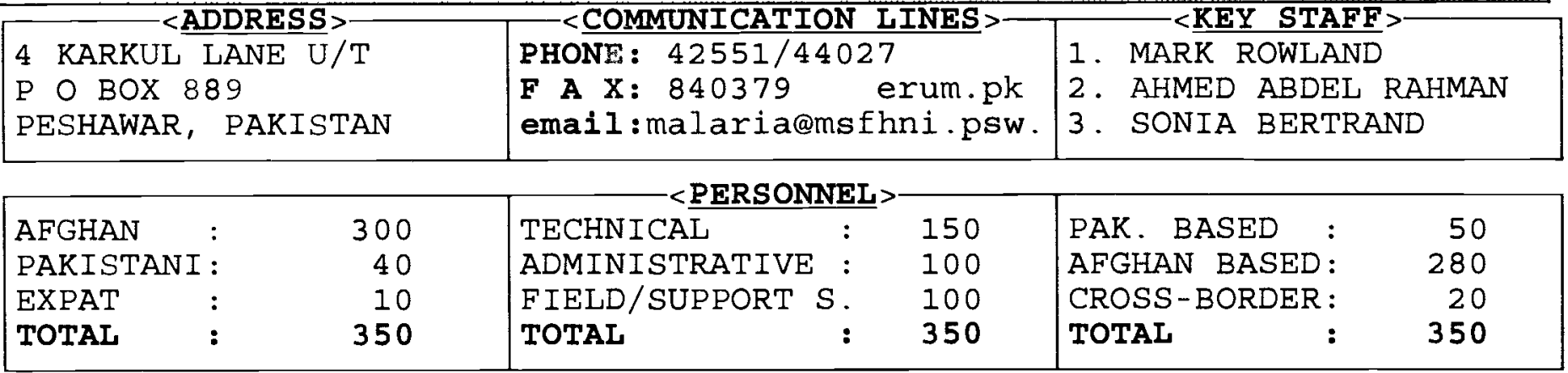

\begin{tabular}{|c|c|c|c|c|}
\hline & & & - <ALLUCAIIUN $>$ & \\
\hline $\mathrm{UT}$ & WFP & $1 \%$ & AGRICULIURE & \\
\hline & & & & \\
\hline $\mathbf{N}$ & UNDCP & $1 \%$ & CONSTRUCTION （ROAD/BRIDGE） & \\
\hline & WHO & $1 \%$ & $\begin{array}{l}\text { CONSTRUCTION (BUILDING/SHELTER) } \\
\text { EDUCATION } \\
\text { EMERGENCY }\end{array}$ & \\
\hline 0 & EUROPEAN UNION & $66 \%$ & HEALTH & $99 \%$ \\
\hline $\mathrm{T}$ & MSF & $18 \%$ & INCOME GENERATION & \\
\hline $\mathrm{H}$ & HEALTHNET INTERNATIONAL & $6 \%$ & IRRIGATION \& WATER SUPPLY & $1 \%$ \\
\hline $\mathrm{E}$ & $\mathrm{NCA}$ & $5 \%$ & MINE & \\
\hline $\mathrm{R}$ & GAA & $1 \%$ & RELIEF & \\
\hline $\mathrm{S}$ & & & OTHER & \\
\hline
\end{tabular}

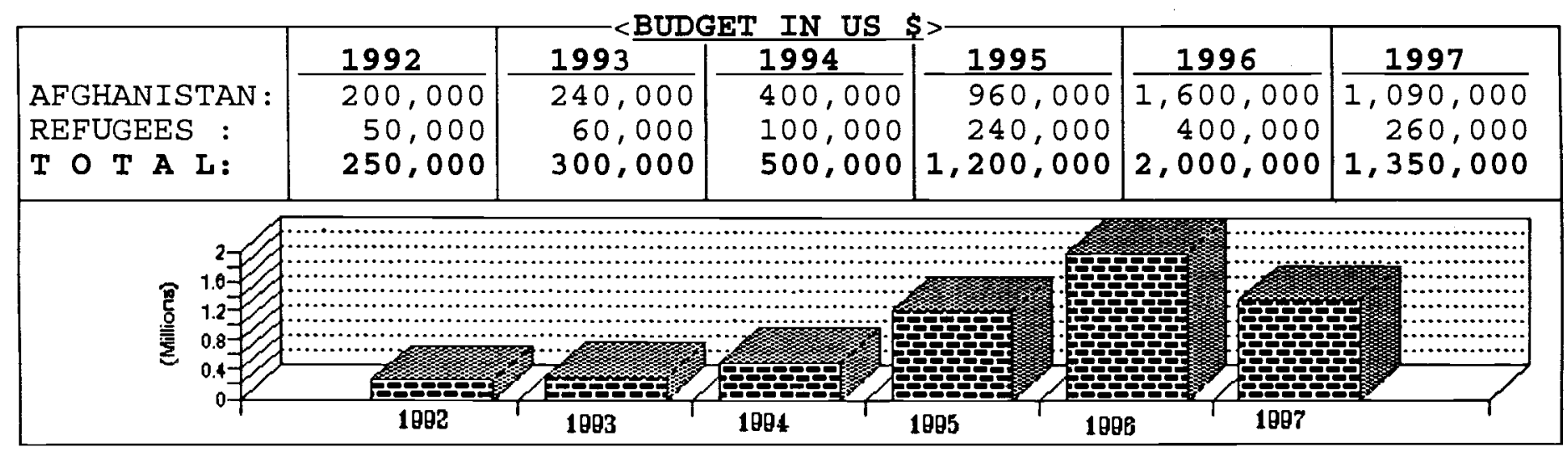

\begin{tabular}{|c|c|c|c|c|c|}
\hline PROVINCES & SECTOR & $\%$ & PROVINCES & SECTOR & $\%$ \\
\hline $\begin{array}{l}\text { BADAKSHAN } \\
\text { BADGHIS } \\
\text { BAGHLAN } \\
\text { BALKH } \\
\text { BAMYAN } \\
\text { FARAH } \\
\text { FARYAB } \\
\text { GHAZNI } \\
\text { GHOR } \\
\text { HELMAND } \\
\text { HERAT } \\
\text { JAWZJAN } \\
\text { KABUL } \\
\text { KANDAHAR } \\
\text { KAPISA }\end{array}$ & 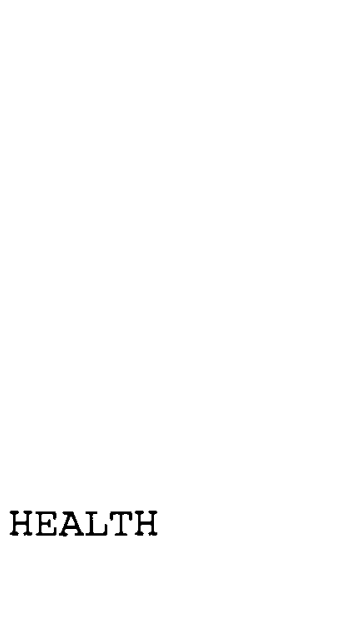 & 8 & $\begin{array}{l}\text { KUNAR } \\
\text { KUNDUZ } \\
\text { LAGHMAN } \\
\text { LOGAR } \\
\text { NANGARHAR } \\
\text { NIMROZ } \\
\text { ORUZGAN } \\
\text { PAKTEKA } \\
\text { PAKTIA } \\
\text { PARWAN } \\
\text { SAMANGAN } \\
\text { TAKHAR } \\
\text { WARDAK } \\
\text { ZABUL } \\
\text { PAKISTAN }\end{array}$ & $\begin{array}{l}\text { HEALTH } \\
\text { HEALTH } \\
\text { HEALTH/WATER SUPPLY } \\
\text { HEALTH } \\
\text { HEALTH }\end{array}$ & $\begin{array}{r}2 \\
2 \\
68\end{array}$ \\
\hline
\end{tabular}


HEALTHNET INTERNATIONAL

(HNI)

Healthnet International was originally part of Medecins Sans Frontieres (MSF) Holland. In 1993, due to the nature of their work in the Health Sector they decided to form a separate organisation.

HNI are presently operating in several Provinces of Afghanistan, one of their programmes being Malaria Control. In Kabul the programme concentrates its efforts on the control and cure of Leishmaniasis.

In Nangarhar seven basic health centres and one hospital are operational. The aim of this PHC programme is to develop a health structure and referral system. 
ADDRESS >

MAIL TO G P O BOX 32 PESHAWAR, PAKISTAN OFFICE IN JALALABAD
PHONE : 2570 - JALALABAD

F A X:

email :
1. HAJI GHULAM H MERZAI

2. HAJI MUNAWAR KHAN

3. NAZIFULLAH

\begin{tabular}{|c|c|c|c|c|c|}
\hline AFGHAN : & 17 & TECHNICAL : & 5 & PAK. BASED : & - \\
\hline PAKISTANI : & - & ADMINISTRATIVE & 2 & AFGHAN BASED : & 7 \\
\hline EXPAT : & - & FIELD/SUPPORT S. & 10 & CROSS-BORDER : & 10 \\
\hline TOTAL & 17 & TOTAL : & 17 & TOTAL : & 17 \\
\hline
\end{tabular}

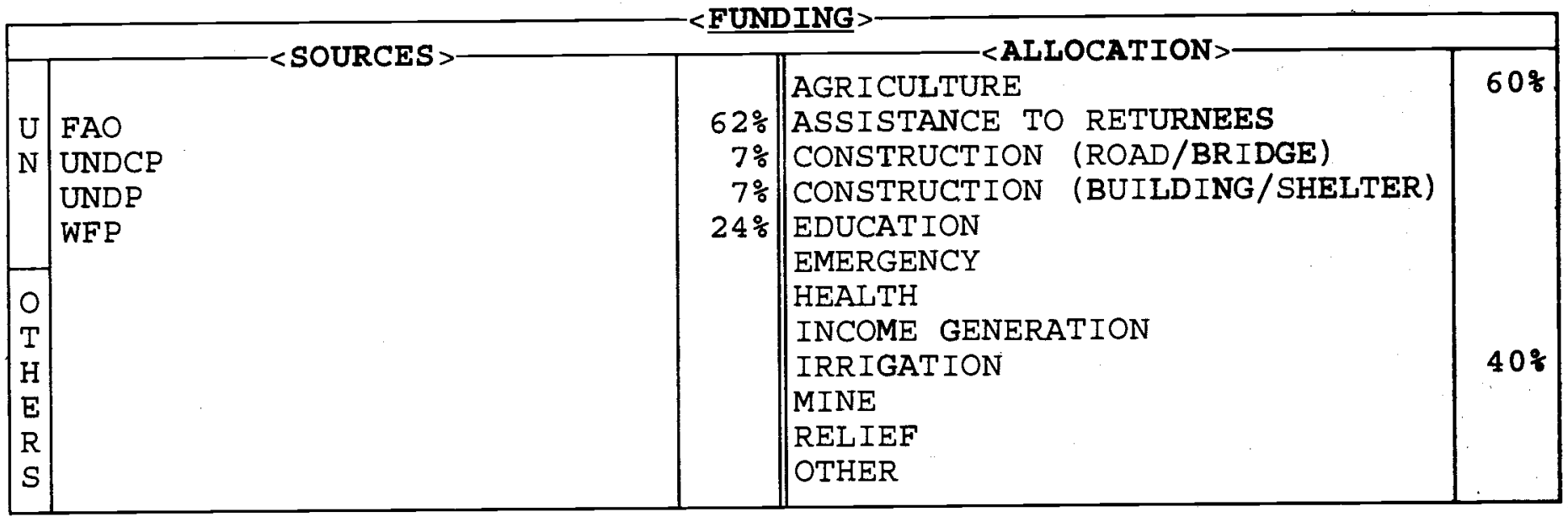

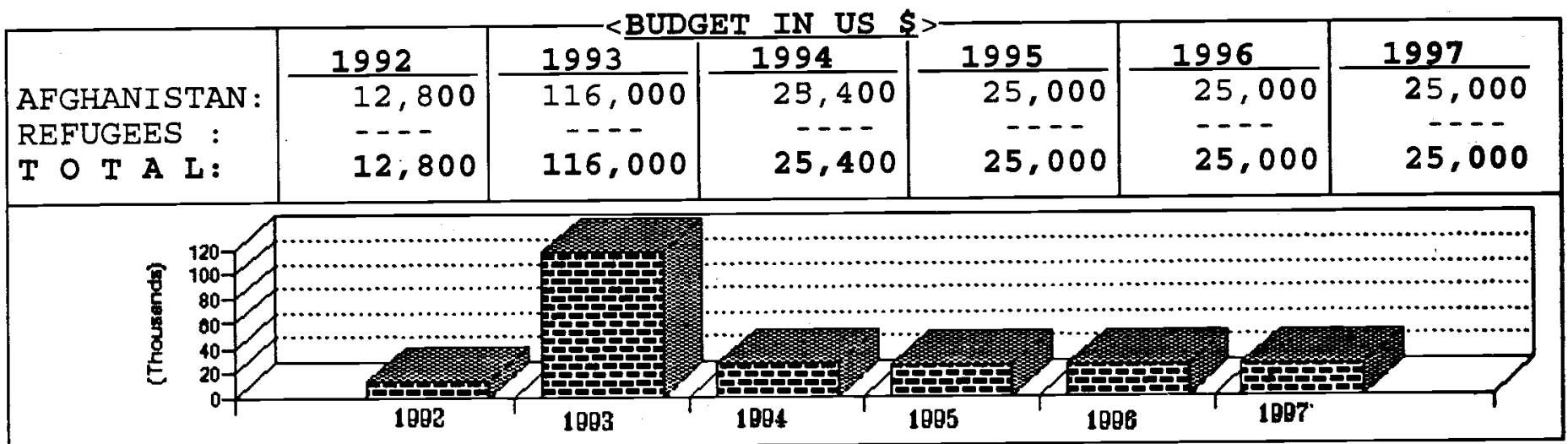

\begin{tabular}{|c|c|c|c|c|c|}
\hline PROVINCES & SECTOR & $\frac{\%}{0}$ & PROVINCES & SECTOR & $\%$ \\
\hline $\begin{array}{l}\text { BADAKSHAN } \\
\text { BADGHIS } \\
\text { BAGHLAN } \\
\text { BALKH } \\
\text { BAMYAN } \\
\text { FARAH } \\
\text { FARYAB } \\
\text { GHAZNI } \\
\text { GHOR } \\
\text { HELMAND } \\
\text { HERAT } \\
\text { JAWZJAN } \\
\text { KABUL } \\
\text { KANDAHAR } \\
\text { KAPISA }\end{array}$ & (1) & $\begin{array}{l}15 \\
10\end{array}$ & $\begin{array}{l}\text { KUNAR } \\
\text { KUNDUZ } \\
\text { LAGHMAN } \\
\text { LOGAR } \\
\text { NANGARHAR } \\
\text { NIMROZ } \\
\text { ORUZGAN } \\
\text { PAKTEKA } \\
\text { PAKTIA } \\
\text { PARWAN } \\
\text { SAMANGAN } \\
\text { TAKHAR } \\
\text { WARDAK } \\
\text { ZABUL } \\
\text { PAKISTAN }\end{array}$ & $\begin{array}{l}\text { AGRIC/IRRIG } \\
\text { AGRIC/IRRIG } \\
\text { AGRIC/IRRIG }\end{array}$ & $\begin{array}{l}30 \\
30 \\
15\end{array}$ \\
\hline
\end{tabular}


HRP is an Afghan non-Governmental and nonpolitical organisation established in 1991. The aim of the organisation is to take an active part in reconstruction and rehabilitation affairs in war torn Afghanistan.

The agency has applied for registration to the Government of Pakistan and has a certificate of application from the Commissionerate for Afghan Refugees (CAR).

Over the past years, HRP has been working as an implementing partner of WFP in connection with the rehabilitation of irrigation systems in eastern Afghanistan; and with FAO, UNDP, UNDCP (ISRA-UMBRELLA) in connection with seed multiplication in the northern and eastern Provinces of Afghanistan.

A Board of Directors consisting of nine prominent Afghans holds quarterly and annual meetings to take decisions and assess the progress of the NGO. HRP plans to extend its work in different parts of Afghanistan and has already submitted proposals to donor agencies. HRP's main fields of work are:

construction:

irrigation;

agriculture; and

drug control. 
HALO TRUST (HT)

<ADDRESS>- $-<$ COMMUNICATION LINES

KRC STREET, SHAHR-E-NAW PHONE: 32934

KABUL, AFGHANISTAN T $\mathbf{E}$ L:

F A :

1. DR FARID HOMOUYOUN

2. ALEX GRINLING

3. ENG. KHALIL

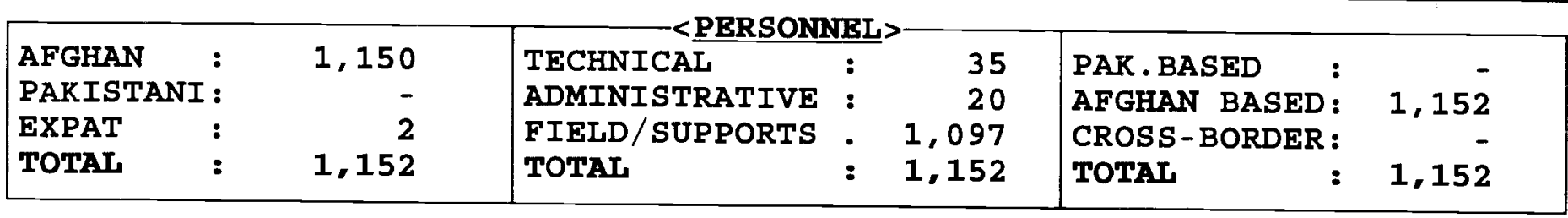

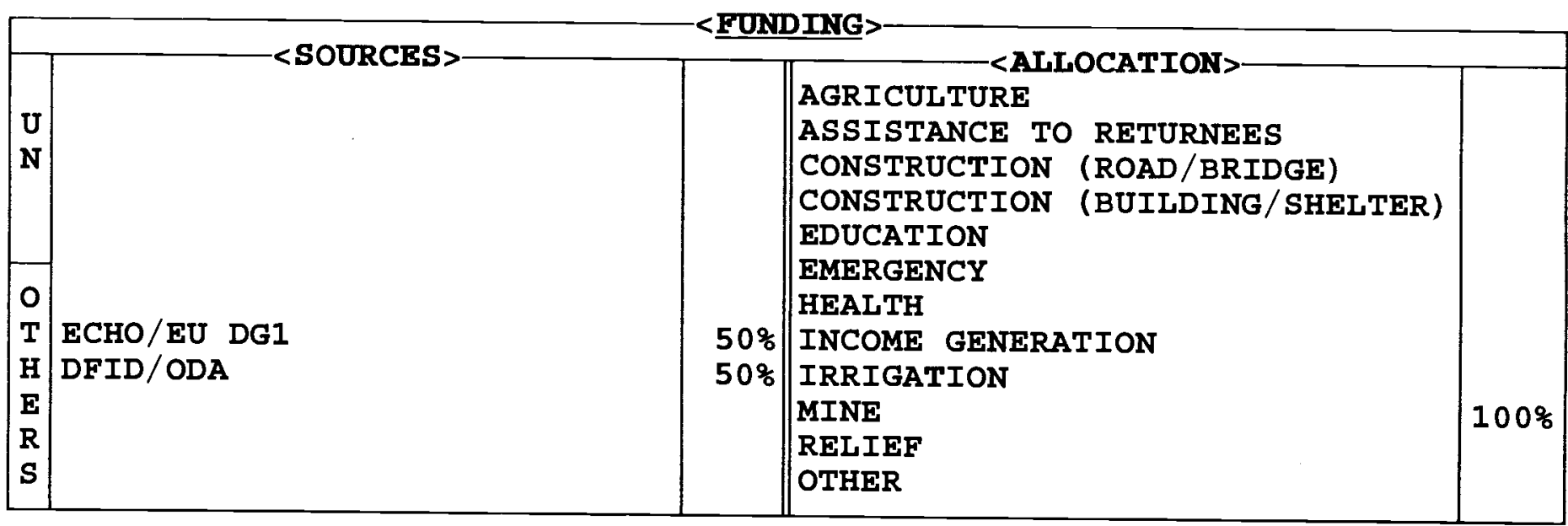

\begin{tabular}{|c|c|c|c|c|c|c|}
\hline $\begin{array}{l}\text { AFGHANISTAN: } \\
\text { REFUGEES : } \\
\text { T O T A L: }\end{array}$ & $\begin{array}{l}\frac{1992}{400,000} \\
\cdots-- \\
400,000\end{array}$ & $\begin{array}{c}1993 \\
600,000 \\
-.- \\
600,000\end{array}$ & $\begin{array}{c}\frac{1994}{1,000,000} \\
1,000,000\end{array}$ & 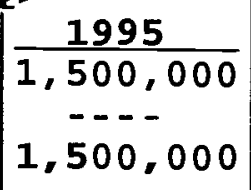 & $\begin{array}{c}\frac{1996}{1,310,000} \\
\ldots-- \\
1,310,000\end{array}$ & $\begin{array}{c}\frac{1997}{2,000,000} \\
2,000,000\end{array}$ \\
\hline 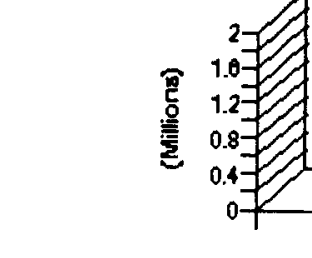 & 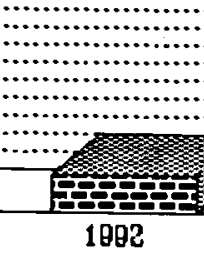 & 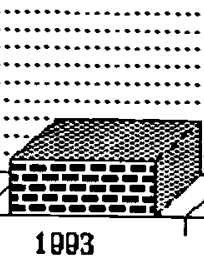 & 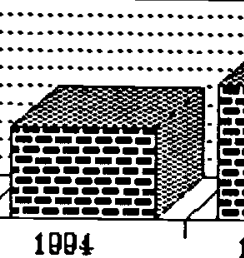 & 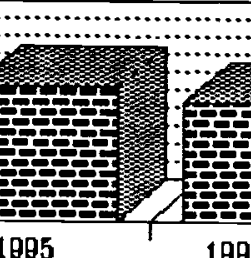 & 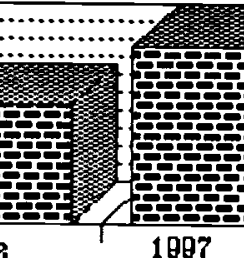 & 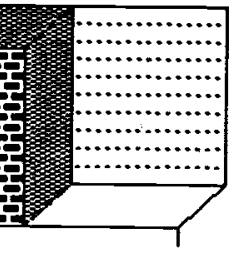 \\
\hline
\end{tabular}

\begin{tabular}{|c|c|c|c|c|c|}
\hline PROVINCES & SECTOR & $\%$ & PROVINCES & SECTOR & $\%$ \\
\hline $\begin{array}{l}\text { BADAKSHAN } \\
\text { BADGHIS } \\
\text { BAGHLAN } \\
\text { BALKH } \\
\text { BAMYAN } \\
\text { FARAH } \\
\text { FARYAB } \\
\text { GHAZNI } \\
\text { GHOR } \\
\text { HELMAND } \\
\text { HERAT } \\
\text { JAWZJAN } \\
\text { RABUL } \\
\text { KANDAHAR } \\
\text { RAPISA }\end{array}$ & $\begin{array}{l}\text { DEMINING } \\
\text { DEMINING } \\
\text { DEMINING }\end{array}$ & $\begin{array}{r}12 \\
3\end{array}$ & $\begin{array}{l}\text { KUNAR } \\
\text { KUNDUZ } \\
\text { LAGHMAN } \\
\text { LOGAR } \\
\text { NANGARHAR } \\
\text { NIMROZ } \\
\text { ORUZGAN } \\
\text { PAKTEKA } \\
\text { PAKTIA } \\
\text { PARWAN } \\
\text { SAMANGAN } \\
\text { TAKHAR } \\
\text { WARDAK } \\
\text { ZABUL }\end{array}$ & DEMINING & 6 \\
\hline
\end{tabular}




\section{HALO TRUST}

(HT)

HALO established its office in Kabul in 1988.

The main component of the agency is mine clearance. Mine awareness course are also available to NGOs and their staff, on request. Demining focuses on the areas of Kabul, Shomali Valley and Northern Afghanistan.

A limited medical programme with a mother and child clinic and two mobile clinics are available in Kabul. An eye clinic is being run in Puli-

Khumri, this clinic can provide minor surgery.

\section{Staffing:}

There are some $\mathbf{4 0}$ doctors and medics to provide medical coverage for the teams during working hours.

In Kabul there are 20 manual demining teams, 2 survey teams, 1 EOD team and 4 mechanical mine clearance teams operation. These teams work mainly in West Kabul base out of a sub location in Koti Sangi. There is a standby team on duty 24 hours a day to deal with any emergencies.

In Puli-Khumri there are 5 manual teams, 1 survey team and 1 EOD team. The teams based here work mainly in the remote Northern Salang, Kunduz, Baghlan and Mazar areas.

The Jebel Seraj office is responsible for the Shomali Valley with 6 manual teams and 1 EOD team.

Future

It is hoped to expand the mechanical clearance in Kabul with an additional 4 teams. 
ISLAMIC ASSOCIATION OF AFGHAN ARCHITECTS AND ENGINEERS (IAAAE)

ANCB

$<$ ADDRESS $>$

27, E 2, STR 2, LALAZAR RD, HAYATABAD PESHAWAR, PAKISTAN
COMMUNICATION LINES>

PHONE : 811441810630

F A X: 810630

TELEX :
1. ENG. G. H. MUTAWADDI

2 .

3 .

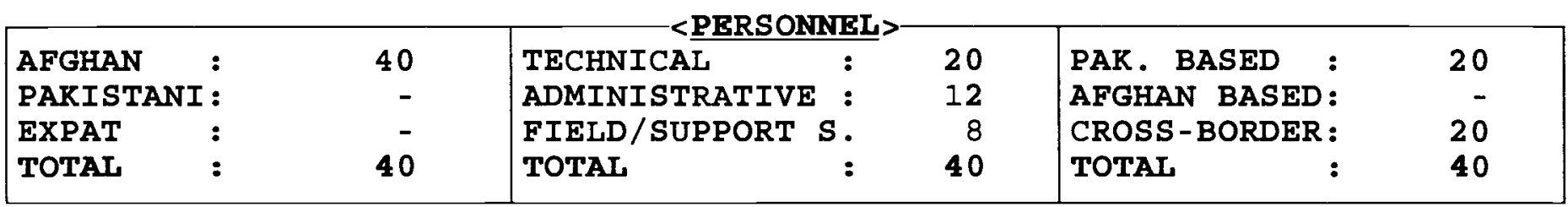

<SOURCES>

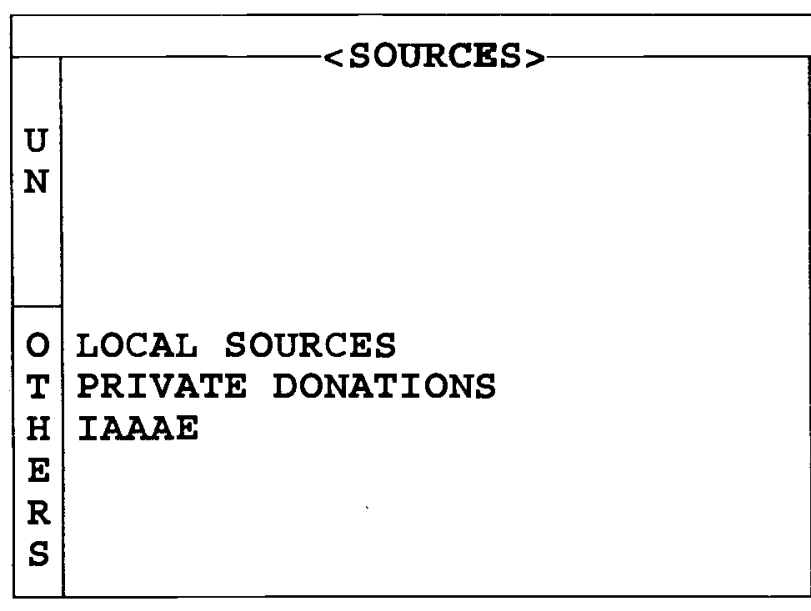

< FUNDING>

\begin{tabular}{|l||l|l|}
\hline \multicolumn{1}{|l|}{} & AGRICULTURE & \\
& ASSISTANCE TO RETURNEES & $20 \%$ \\
& CONSTRUCTION (ROAD/BRIDGE) & $10 \%$ \\
& CONSTRUCTION (BUILDING/SHELTER) & $60 \%$ \\
EDUCATION & \\
$20 \%$ & $\begin{array}{l}\text { EMERGENCY } \\
\text { HEALTH }\end{array}$ & \\
$50 \%$ & $\begin{array}{l}\text { INCOME GENERATION } \\
\text { IRRIGATION } \\
\text { MINE } \\
\text { RELIEF } \\
\text { OTHER }\end{array}$ & $10 \%$ \\
\hline
\end{tabular}

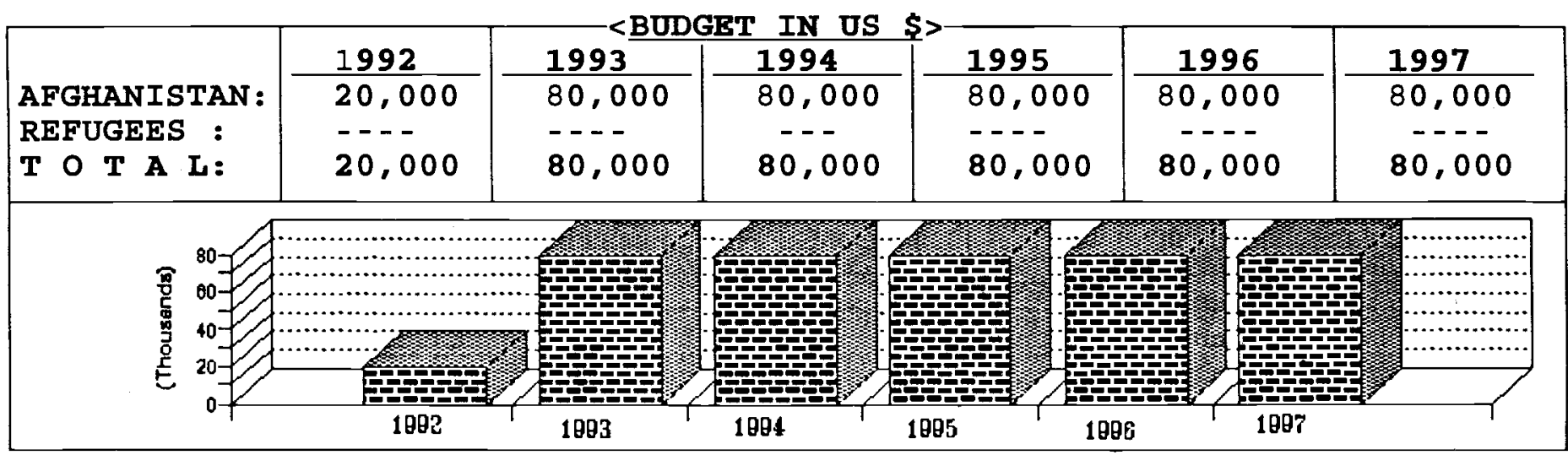

\begin{tabular}{|c|c|c|c|c|c|}
\hline PROVINCES & SECTOR & $\%$ & PROVINCES & SECTOR & $\frac{q}{6}$ \\
\hline $\begin{array}{l}\text { BADARSHAN } \\
\text { BADGHIS } \\
\text { BAGHLAN } \\
\text { BALKH } \\
\text { BAMYAN } \\
\text { FARAH } \\
\text { FARYAB } \\
\text { GHAZNI } \\
\text { GHOR } \\
\text { HELMAND } \\
\text { HERAT } \\
\text { JAWZJAN } \\
\text { KABUL } \\
\text { KANDAHAR } \\
\text { KAPISA }\end{array}$ & 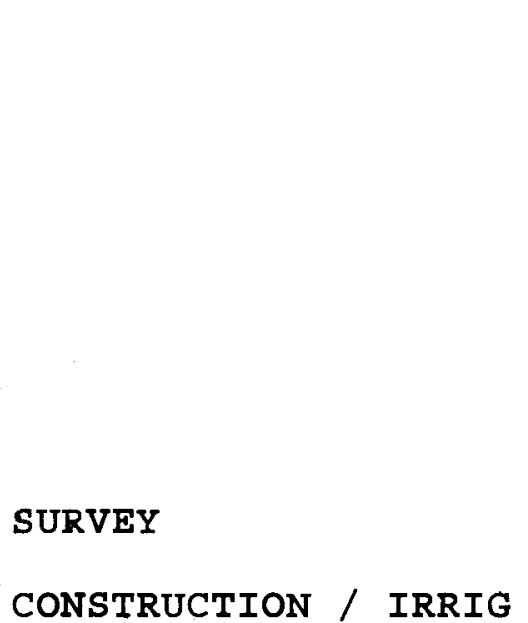 & $\begin{array}{l}12 \\
36\end{array}$ & $\begin{array}{l}\text { KUNAR } \\
\text { KUNDUZ } \\
\text { LAGHMAN } \\
\text { LOGAR } \\
\text { NANGARHAR } \\
\text { NIMROZ } \\
\text { ORUZGAN } \\
\text { PAKTEKA } \\
\text { PAKTIA } \\
\text { PARWAN } \\
\text { SAMANGAN } \\
\text { TAKHAR } \\
\text { WARDAR } \\
\text { ZABUL }\end{array}$ & $\begin{array}{l}\text { CONSTRUCTION } \\
\text { CONSTRUCTION } \\
\text { CONSTRUCTION / IRRIG }\end{array}$ & 20 \\
\hline
\end{tabular}




\section{ISLAMIC ASSOCIATION OF AFGHAN ARCHITECTS AND ENGINEERS (IAAAE)}

IAAAE was established in 1983 in Peshawar, Pakistan

The organisation has cooperative relations with all Jehadic parties of Afghanistan but maintains a ncutral policy and is not affiliated with anyone.

It has Membership of:

- Federation of Engineering Institutions of Islamic nations as the representative of Afghanistan. The Chairman is an Executive Comnittee nember;

- the Federation of Engineering Institutions of South \& Central Asia.

\section{Aims of IAAAE}

- to serve Afghanistan in reconstruction activities through the coordination of cngincering associates;

- to organise and assist qualified professional staff:

- to upgrade the technical standard and scientific knowledge of engineers by launching seminars, conferences and courses;

- to provide cducational facilities for Afghans who have not completed their enginecring degree duc to the war;

- to seek job opportunities for enginecrs and architects;

- to cstablish an atmosphere of harmony and coopcration among enginecrs and links with other professional and scientific socictics abroad;

- technical advice to those who are dealing with reconstruction programmes in Afghanistan;

- to cstablish primary schools and high schools for the displaced Afghan boys and girls;

- to design and supervise reconstruction projects inside Afghanistan;
- to work on environmental protection;

- to evaluate the curriculums of educational and technical institutes and centres;

- to transfer and exchange information on new techniques of engineering between Afghanistan and other countries;

- to be in contact with foreign and International coordinators for engineering activities. 


\begin{tabular}{|l|l|l|}
\hline 71, STR D, BLOCK 5, & PHONE:(081) 444780 & 1. DR. A. BAQI HAQANI \\
SATTELITE TOWN, & F A X: & 2. HAJI MOHD WAISE \\
QUETTA, PAKISTAN & TELEX: & 3. DR. MOHD ZAKIR KAKAR \\
\hline
\end{tabular}

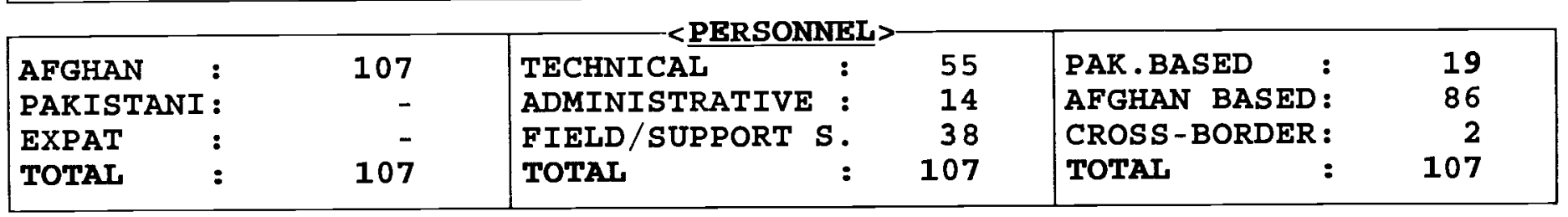

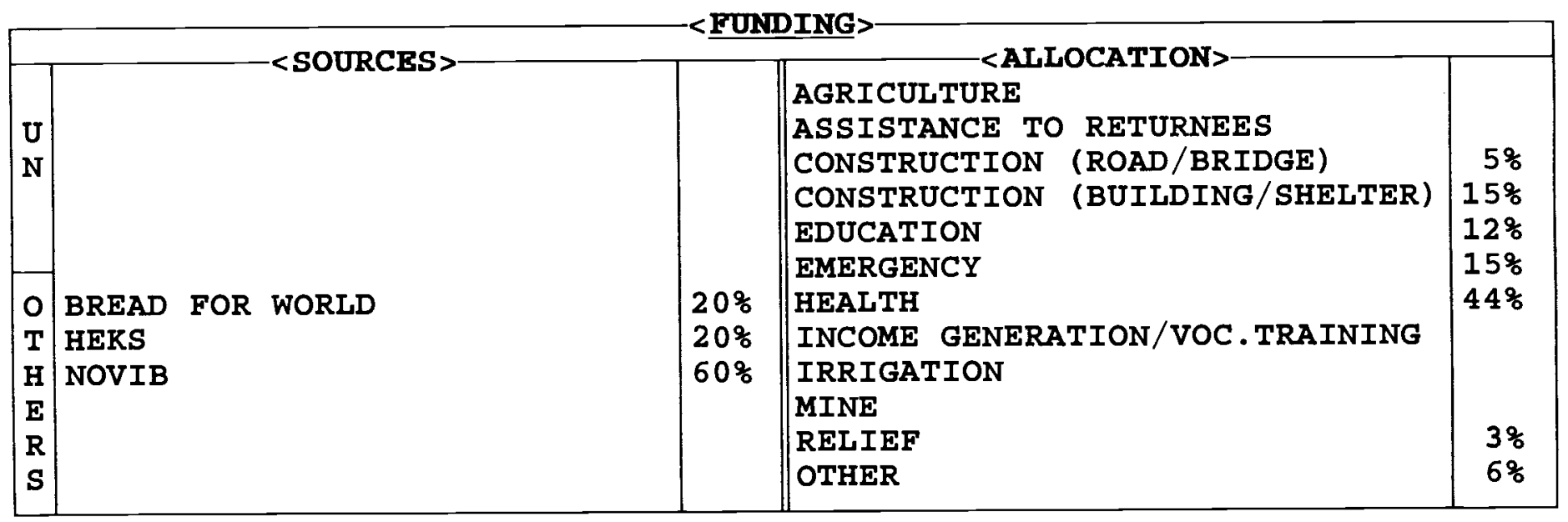

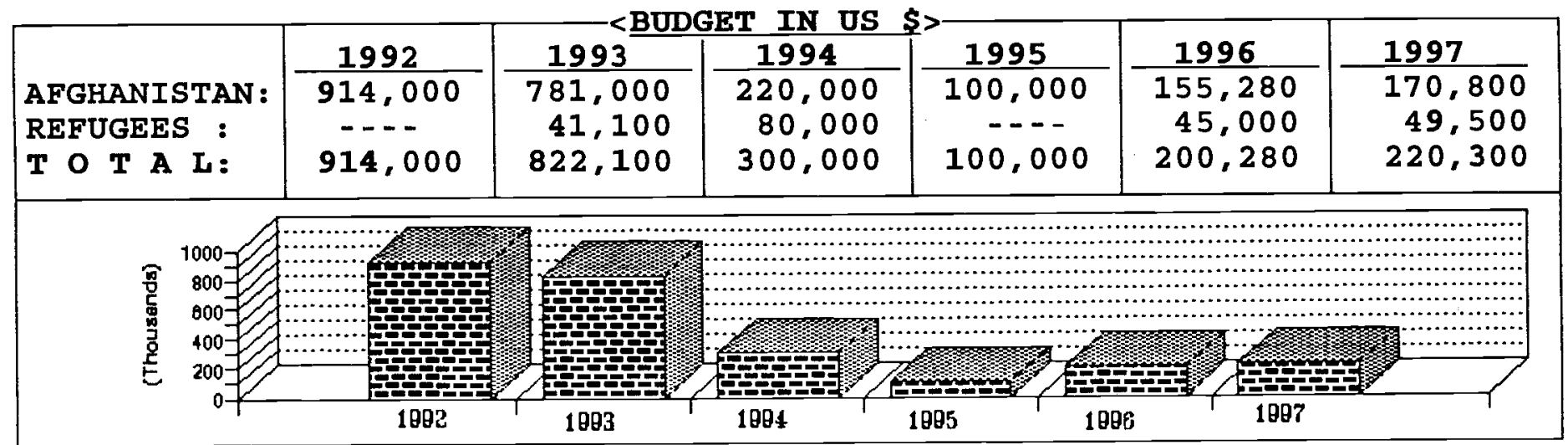

\begin{tabular}{|c|c|c|c|c|c|}
\hline PROVINCES & SECTOR & $\%$ & PROVINCES & SECTOR & $\%$ \\
\hline $\begin{array}{l}\text { BADAKSHAN } \\
\text { BADGHIS } \\
\text { BAGHLAN } \\
\text { BALKH } \\
\text { BAMYAN } \\
\text { FARAH } \\
\text { FARYAB } \\
\text { GHAZNI - - } \\
\text { GHOR } \\
\text { HELMAND - - } \\
\text { HERAT } \\
\text { JAWZJAN } \\
\text { KABUL } \\
\text { KANDAHAR } \\
\text { KAPISA }\end{array}$ & $\begin{array}{l}\text { HEALTH, EDU, HANDICAP } \\
\text { HEALTH REGULAR+EMERG } \\
\text { HEALTH / EDUCATION }\end{array}$ & $\begin{array}{r}23 \\
9\end{array}$ & $\begin{array}{l}\text { KUNAR } \\
\text { KUNDUZ } \\
\text { LAGHMAN } \\
\text { LOGAR } \\
\text { NANGARHAR } \\
\text { NIMROZ } \\
\text { ORUZGAN } \\
\text { PAKTEKA } \\
\text { PAKTIA } \\
\text { PARWAN } \\
\text { SAMANGAN } \\
\text { TAKHAR } \\
\text { WARDAR } \\
\text { ZABUL } \\
\text { REFUGEES }\end{array}$ & $x^{2}$ & 14 \\
\hline
\end{tabular}




\section{ISLAMIC AID HEALTH CENTRE}

(IAHC)

IAHC is an impartial non-governmental organisation cstablished in Quetta, Pakistan in 1981.

\section{Sector of operation}

IAHC distributed some 30 tons of second hand clothes to children and adults living in the camps in Quetta and Peshawar.

With the co-operation of Commissioner for Afghan Refugces, IAHC distributed some 700 MT of food-stuff to Afghan refugees in the camps in Quetta and Peshawar.

IAHC has distributed 46 various types of diesel engine-water -pumps to needy farmers to promote land production in the war affected areas in Afghanistan.

In 1990, 100 MT of secd-wheat was distributed to farmers in Musa Qala of Helmand province.

\section{Health}

There are several BHU clinics within communities to deal with day to day illness. 
INTERNATIONAI ASSISTANCE MISSION (IAM)

<ADDRESS $>$

LANE 1, STR-15, WAZIR AKBAR KHAN, P.O.BOX 625 KABUL, AFGHANISTAN
PHONE : KABUL 25723

F A X: $873 \quad 682 \quad 340252$

TELEX: c/OIAM 842634 PESH
1. MR. BRUCE GIBBS

2. MR. HARRI LAMMI

\begin{tabular}{|c|c|c|c|c|c|}
\hline AFGHAN : & 193 & TECHNICAL & 203 & PAK. BASED & 4 \\
\hline PAKISTANI : & - & ADMINISTRATIVE : & 37 & AFGHAN BASED: & 310 \\
\hline EXPAT : & 121 & FIELD/SUPPORT $\mathrm{S}$. & 74 & CROSS-BORDER: & - \\
\hline TOTAL & 314 & TOTAL : & 314 & TOTAL : & 314 \\
\hline
\end{tabular}

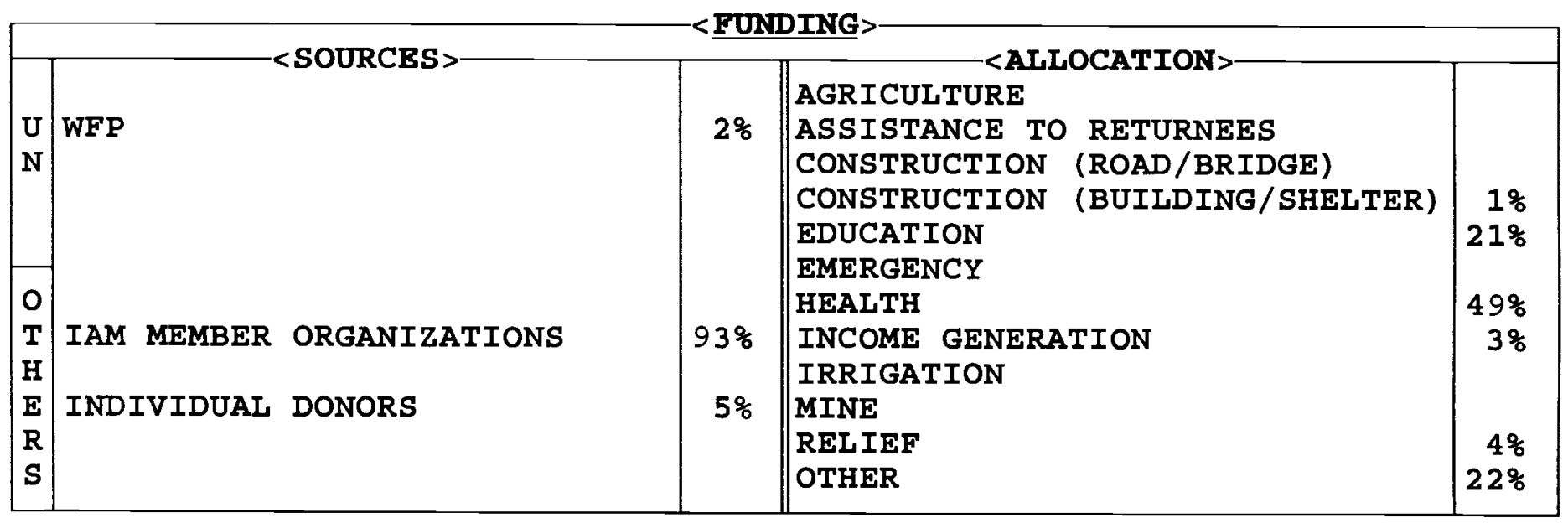

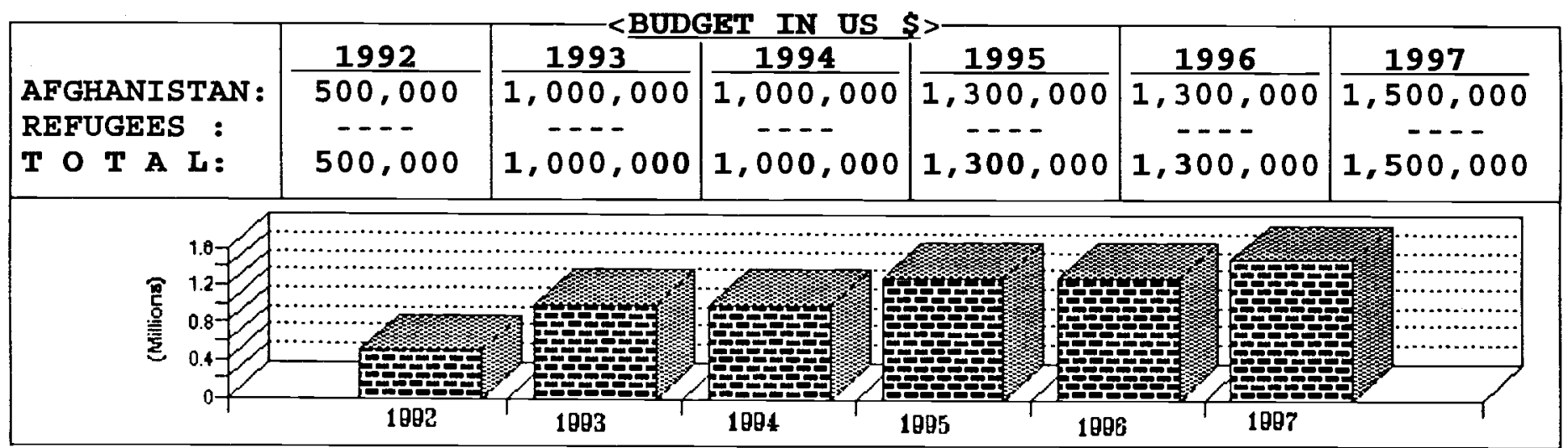

\begin{tabular}{|c|c|c|c|c|c|}
\hline PROVINCES & SECTOR & $\%$ & |PROVINCES & SECTOR & $\%$ \\
\hline $\begin{array}{l}\text { BADAKSHAN } \\
\text { BADGHIS } \\
\text { BAGHLAN } \\
\text { BALKH } \\
\text { BAMYAN } \\
\text { FARAH } \\
\text { FARYAB } \\
\text { GHAZNI } \\
\text { GHOR } \\
\text { HELMAND } \\
\text { HERAT } \\
\text { JAWZJAN } \\
\text { RABUL } \\
\text { KANDAHAR } \\
\text { KAPISA }\end{array}$ & $\begin{array}{l}\text { OTHER } \\
\text { HEALTH/OTHER/IN GEN } \\
\\
\text { HEALTH/RELIEF/EDU. } \\
\text { OTHER } \\
\text { HEALTH / EDUC/RELIEF } \\
\text { \& INCOME GEN. }\end{array}$ & $\begin{array}{r}1 \\
21\end{array}$ & $\begin{array}{l}\text { KUNAR } \\
\text { KUNDUZ } \\
\text { LAGHMAN } \\
\text { LOGAR } \\
\text { NANGARHAR } \\
\text { NIMROZ } \\
\text { ORUZGAN } \\
\text { PAKTEKA } \\
\text { PAKTIA } \\
\text { PARWAN } \\
\text { SAMANGAN } \\
\text { TAKHAR } \\
\text { WARDAK } \\
\text { ZABUL }\end{array}$ & OTHER/RELIEF & 6 \\
\hline
\end{tabular}




\section{INTERNATIONAL ASSISTANCE MISSION \\ (IAM)}

IAM was founded in 1966 and has worked in Afghanistan since then continuously. All expatriate pcrsomel serve as unpaid volunteers, seconded from 26 Member Agencies in 12 different countries. It is working in the areas of Health, Education and Rehabilitation and Economic Development.

\section{Sectors of Operation}

Health

- NOOR Eye Hospital and clinics;

- Mobile cye car, 1 day clinic and two weck cye camps;

- Maternal and Child Health care, in cooperation with the MOPH. This clinic secs over 100 patients daily;

- Secondment of expatriate surgeon to train doctors in Government hospitals;

- Secondment of Nurses to Government hospitals.

\section{Mazar-i-Sharif}

- Mazar Ophthalmic Centre;

- Maternal Child Health - community based programme;

- Secondment of expatriate doctor to teach in medical university.

Herat

- Herat Ophthalmic Centre.

\section{Education and Rehabilitation}

Kabul

- Physiotherapy School of Kabul (2 year course for Physiotherapy, teacher training course supporting government hospital - Physiotherapy department):

- Education \& Rchabilitation

Programme for people with visual impairment; - Vocational Rehabilitation Unit for training people with disabilities;

- English as a Foreign Language (EFL)

programmc.

\section{Mazar-i-Sharif}

- Education \& Rehabilitation

Programmc for people with visual impairment.
Herat

- Physiotherapy School;

- Vocational training programme;

- English as a Foreign Language (EFL)

programme.

\section{Economic Development \\ Kabul/Charikar}

- Solar water heater project;

- Micro-hydro power project in village near to Charikar.

\section{Mazar-i-Sharif}

- Community based development programme working with target communities near Mazar and Puli - Khumri.

Herat

- Community based development programme working with target community near to Herat city.

\section{Future Objectives}

IAM plans to commence a new Skills Development Programme in Farah in 1998 and a community based Rehabilitation Programme in Herat Region.

\section{Further Information}

From its international Headquarters in Kabul, the IAM operates in Mazar-i-Sharif, Herat, and Jalalabad. There is a small logistical support office in Peshawar. 
IbnSina (PUBLIC HEALTH PROGRAMME FOR AFGHANISTAN)

ACBAR

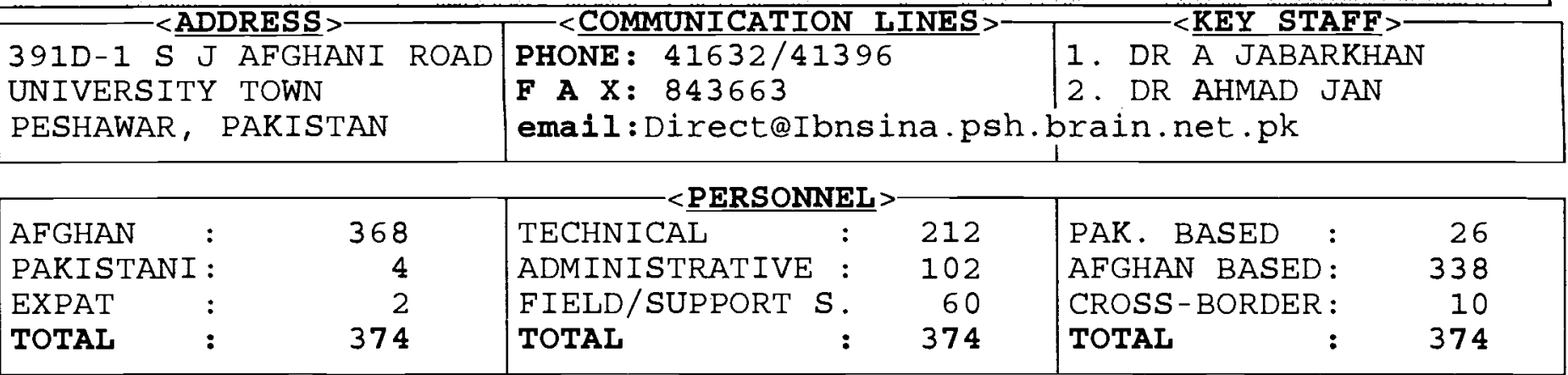

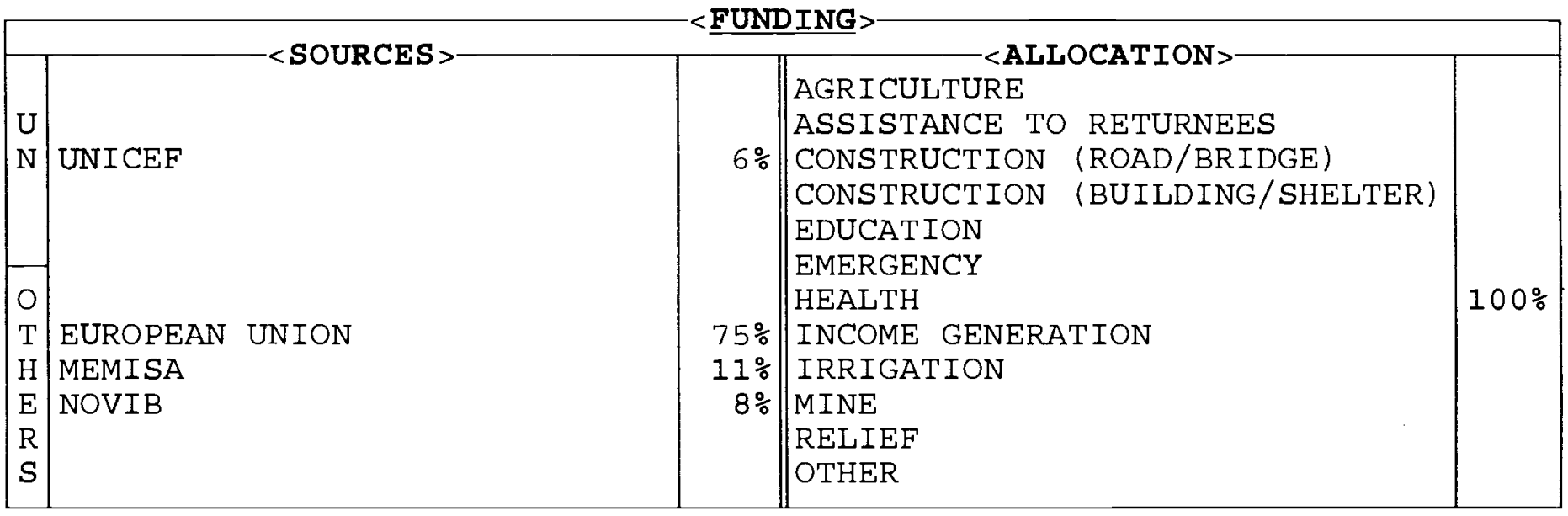

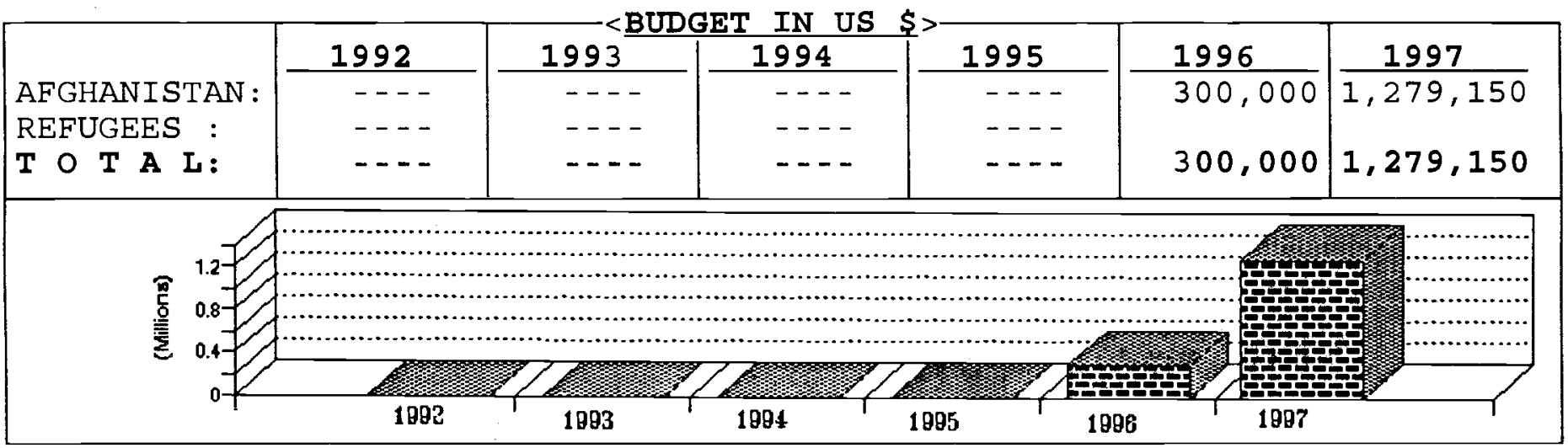

\begin{tabular}{|c|c|c|c|c|c|}
\hline PROVINCES & SECTOR & $\%$ & PROVINCES & SECTOR & $\%$ \\
\hline $\begin{array}{l}\text { BADAKSHAN } \\
\text { BADGHIS } \\
\text { BAGHLAN } \\
\text { BALKH } \\
\text { BAMYAN } \\
\text { FARAH } \\
\text { FARYAB } \\
\text { GHAZN I } \\
\text { GHOR } \\
\text { HELMAND } \\
\text { HERAT } \\
\text { JAWZJAN } \\
\text { KABUL } \\
\text { KANDAHAR } \\
\text { KAPISA }\end{array}$ & $\begin{array}{l}\text { HEALTH } \\
\text { HEALTH } \\
\text { HEALTH } \\
\text { HEALTH } \\
\text { HEALTH }\end{array}$ & $\begin{array}{r}19 \% \\
22 \% \\
2 \% \\
4 \% \\
\\
20 \%\end{array}$ & $\begin{array}{l}\text { KUNAR } \\
\text { KUNDUZ } \\
\text { LAGHMAN } \\
\text { LOGAR } \\
\text { NANGARHAR } \\
\text { NIMROZ } \\
\text { ORUZGAN } \\
\text { PAKTEKA } \\
\text { PAKTIA } \\
\text { PARWAN } \\
\text { SAMANGAN } \\
\text { TAKHAR } \\
\text { WARDAK } \\
\text { ZABUL } \\
\text { PAKISTAN }\end{array}$ & $\begin{array}{l}\text { HEALTH } \\
\text { HEALTH } \\
\text { HEALTH } \\
\text { HEALTH } \\
\text { HEALTH } \\
\text { HEALTH } \\
\text { HEALTH }\end{array}$ & $\begin{array}{r}3 \\
13 \\
2 \\
4\end{array}$ \\
\hline
\end{tabular}




\section{IBN SINA}

IbnSina is a non-governmental, non-political, humanitarian organisation, providing health services to the people in four regions (12 Provinces) in Afghanistan.

In 1983 Avicen was founded as an AfghanFrench NGO, which initiated an extensive EPI programme in Afghanistan. In 1993 Avicen divided its activities into a long term and short term component. For the implementation of the long term programme (EPI and PHC activities) an independent Afghan entity, IbnSina, was created.

In November 1996, IbnSina became a completely independent Afghan NGO with an Afghan board of directors, operating the full EPI/PHC programme.

The organisation has an Afghan Directorate and is managed by experienced Afghan staff. At present there are 2 Dutch expatriate consultants (PHC and Finance/Operations) from MEMISA, a Dutch NGO attached to the programme.

Since becoming an Afghan NGO, a Board of Trustees, a Constitution, new internal rules and regulations and a financial monitoring system have been put in place.

The programme is funded by MEMISA, NOVIB (both Dutch funding organisations) and UNICEF. MEMISA has already applied on behalf of the organisation to the EU to secure funds for the PHC programme for a period of 18 months, beginning July 1997.

IbnSina operates EPI programmes in 12 Provinces of Afghanistan covering a population of 2.9 million including children aged up 2 years and women between the ages of 15-45. Training courses are conducted for vaccinators in 6 regions: Nangarhar, Kabul, Ghazni, Kandahar, Herat and Takhar.
A Primary Health Care Programme of some 40 health facilities, mainly mother and child health care clinics are running. The PHC programme provides health care services to Afghan people in 9 Provinces: Kandahar, Zabul, Helmand, Ghazni, Parwan, Wardak, Bamyan, Nangarhar and Laghman.

The organisation plans to continue all of its programmes in the future. 
ITALIAN COOPERATION FOR DEVELOPMENT (ICD)

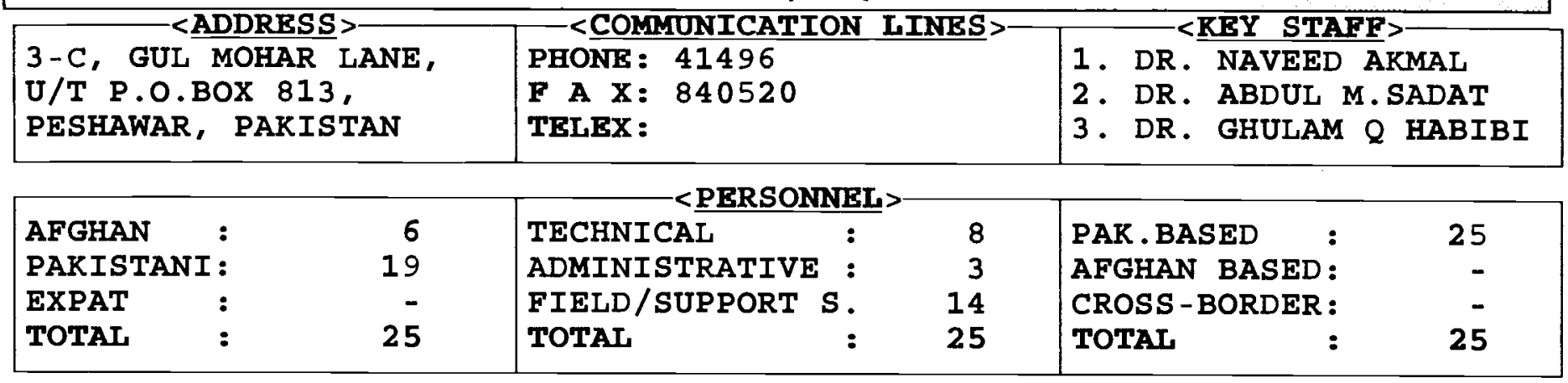

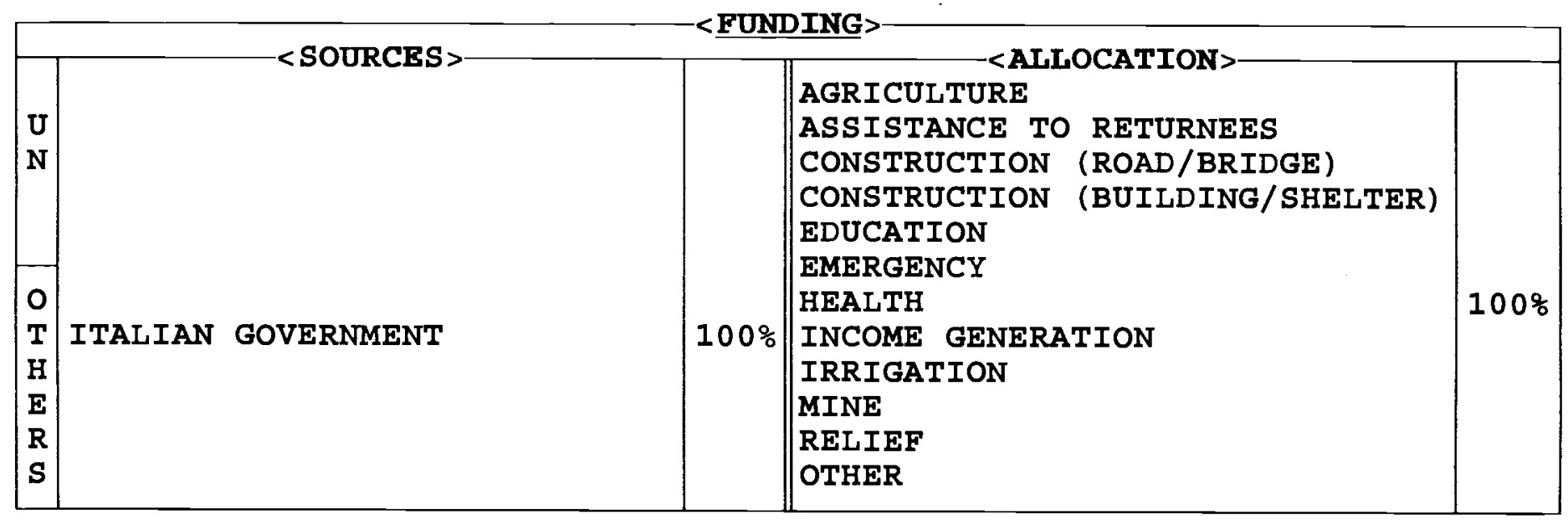

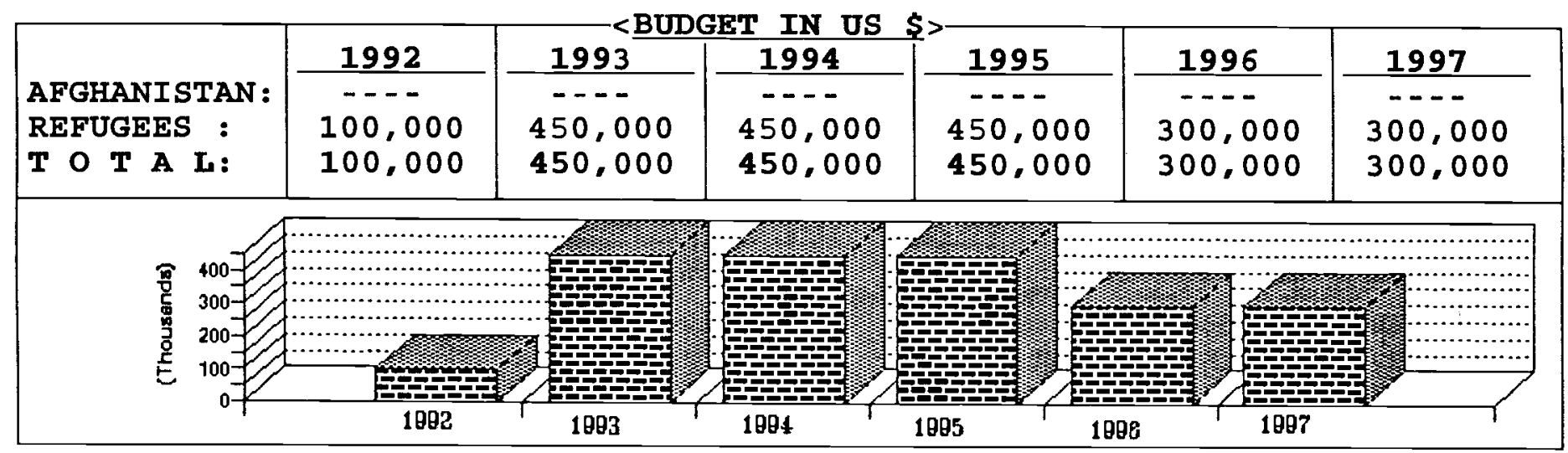

\begin{tabular}{|c|c|c|c|c|c|}
\hline PROVINCES & SECTOR & $\%$ & PROVINCES & SECTOR & \% \\
\hline $\begin{array}{l}\text { BADAKSHAN } \\
\text { BADGHIS } \\
\text { BAGHLAN } \\
\text { BALKH } \\
\text { BAMYAN } \\
\text { FARAH } \\
\text { FARYAB } \\
\text { GHAZNI } \\
\text { GHOR } \\
\text { HELMAND } \\
\text { HERAT } \\
\text { JAWZJAN } \\
\text { KABUL } \\
\text { KANDAHAR } \\
\text { KAPISA }\end{array}$ & & & $\begin{array}{l}\text { KUNAR } \\
\text { KUNDUZ } \\
\text { LAGHMAN } \\
\text { LOGAR } \\
\text { NANGARHAR } \\
\text { NIMROZ } \\
\text { ORUZGAN } \\
\text { PAKTEKA } \\
\text { PAKTIA } \\
\text { PARWAN } \\
\text { SAMANGAN } \\
\text { TARHAR } \\
\text { WARDAR } \\
\text { ZABUL } \\
\text { REFUGEES }\end{array}$ & HEALTH & 100 \\
\hline
\end{tabular}




\section{ITALIAN COOPERATION FOR DEVELOPMENT \\ (ICD)}

ICD started the "Tuberculosis Control Programme among the Afghan Refugees in NWFP", in 1984. Soon the programme was operative throughout the Province, having its headquarters in Pcshawar.

\section{Aims of ICD}

Its main purpose is to control the spread of TB among Afghan refugees in NWFP.

\section{Sectors of operation}

Develop guidelines for TB case finding; holding training of medical officers of microscopists; establishment of a provincial reference laboratory supply of binocular microscopcs, anti-TB drugs and diagnostic material, $x$-ray material; establishment of a surveillance system; supervision and research.

\section{Ongoing activities}

- supply of anti-TB drugs and diagnostic material;

- supervision of the BHUs and peripheral laboratories, computerised data processing; - analysis of the case findings and treatment indicators;

- monthly and annual reporting;

- slide cross-checking, culture and susceptibility testing;

- minor service of the microscopes of the peripheral laboratories;

- evaluation and refresher courses for microscopists;

- studies on primary and acquired multiple drug resistance;

- slides cross-checking and training of microscopists are extended to support tubcrculosis activitics inside Afghanistan;
- a training centre has been established which trains microscopists in basic courses as well as refresher course. These are conducted according to specific guidelines, with accompanying technical advice.

In 1992 the programme was extended to support a number of Pakistani health facilities, with the aim of integrating tuberculosis health care in NWFP.

The Italian Co-operation for Development (ICD) belongs to the Direzione General della Cooperazione allo Sviluppo (DGCS) the Department of the Ministry of Foreign Affairs appointed for the provision for technical aid to other countries. 
INTERNATIONAI FEDERATION OF THE RED CROSSERED CRESCENT SOCIETIES (IFRCS)

(IFRC) $43 \mathrm{D}$,

S.J.AFGHANI ROAD, U/T PESHAWAR, PAKISTAN
PHONE : 843116

F A X: 843116

TELEX :
1. AVIS WARMINTON

2. EBRAHIM FAGHINI

3 .

\begin{tabular}{|c|c|c|c|c|c|}
\hline AFGHAN : & 150 & TECHNICAL & 83 & PAK. BASED : & 9 \\
\hline PAKISTANI: & 8 & ADMINISTRATIVE : & 45 & AFGHAN BASED: & 154 \\
\hline EXPAT : & & FIELD/SUPPORT S. & 35 & CROSS-BORDER : & - \\
\hline TOTAL & 163 & TOTAL : & 163 & TOTAL : & 163 \\
\hline
\end{tabular}

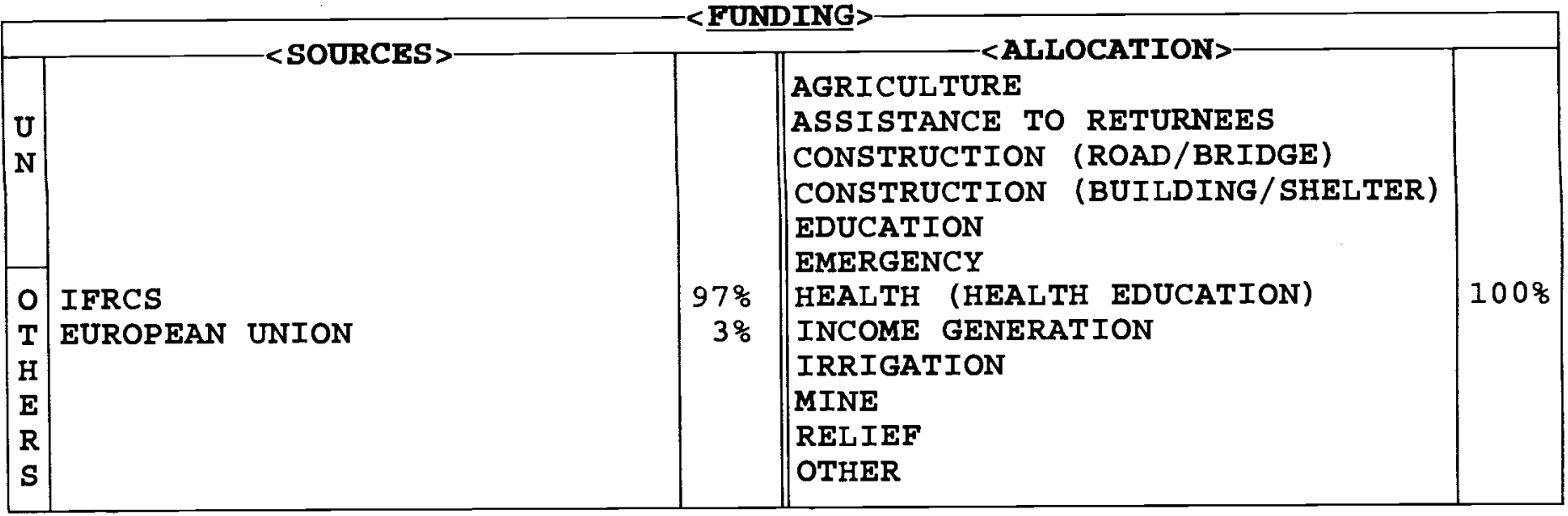

\begin{tabular}{|c|c|c|c|c|c|c|}
\hline & & & & & & \\
\hline & 1992 & $\frac{1993}{1090}$ & $\frac{1994}{290}$ & $\frac{1995}{2500}$ & $\frac{1996}{200}$ & $\frac{1997}{2}$ \\
\hline REFUGEES : & $1,012,000$ & $2,025,000$ & 985,000 & 35000 & 300000 & 3000.000 \\
\hline $\mathbf{T} O \mathbf{T} \mathbf{A} \mathrm{L}:$ & $3,012,000$ & $3,225,000$ & $2,985,000$ & $3,500,000$ & & $3,000,000$ \\
\hline
\end{tabular}

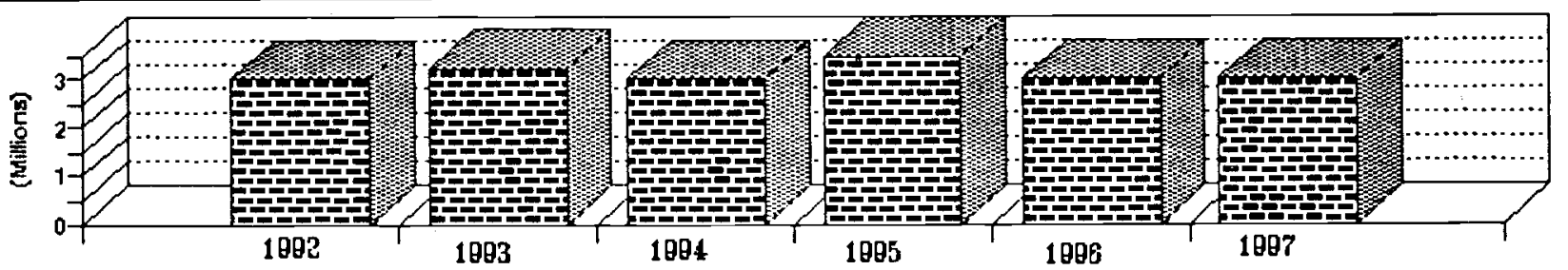

\begin{tabular}{|c|c|c|c|c|c|}
\hline PROVINCES & SECTOR & $\%$ & PROVINCES & SECTOR & $\%$ \\
\hline BADAKSHAN & HEALTH & 3 & KUNAR & HEALTH/RELIEF & 4 \\
\hline BADGHIS & HEALTH & 4 & KUNDUZ & HEALTH & 4 \\
\hline BAGHLAN & HEALTH & 2 & LAGHMAN & HEALTH & 4 \\
\hline BALKH & HEALTH/RELIEF & 4 & LOGAR & HEALTH & 3 \\
\hline BAMYAN & HEALTH/RELIEF & 3 & NANGARHAR & HEALTH/RELIEF & 3 \\
\hline FARAH & HEALTH/RELIEF & 4 & NIMROZ & HEALTH/RELIEF & 3 \\
\hline FARYAB & HEALTH & 4 & ORUZGAN & HEALTH & 3 \\
\hline GHAZNI & HEALTH & 4 & PAKTEKA & HEALTH & 3 \\
\hline GHOR & HEALTH & 4 & PAKTIA & HEALTH/RELIEF & 3 \\
\hline HELMAND & HEALTH & 3 & PARWAN & HEALTH & 2 \\
\hline HERAT & HEALTH & 4 & SAMANGAN & HEALTH & 4 \\
\hline JAWZJAN & HEALTH & 4 & TAKHAR & HEALTH & 3 \\
\hline KABUL & HEALTH / RELIEF & 5 & WARDAR & HEALTH & 3 \\
\hline KANDAHAR & HEALTH & 4 & ZABUL & HEALTH & 3 \\
\hline KAPISA & HEALTH/RELIEF & 3 & & & \\
\hline
\end{tabular}




\section{INTERNATIONAL FEDERATION OF \\ RED CROSS AND RED ¿RESCENT \\ SOCIETIES \\ (IFRCS)}

Founded in 1934, the Afghan Red Crescent (ARCS) joined IFRCS in 1956. Since 1989, IFRCS has supported ARCS, particularly in the more stable arcas of Afghanistan where longer term development is possible.

Aims of IFRCS are to maintain and strengthen existing services, devcloping ARCS' structure and programmes throughout Afghanistan - an Emergency Assistance Programme directly supporting the ARCS

ARCS has re-established active branches in 29 Provinces

\section{Programmes:}

Basic Health Teacher Training Programme

(BHTTP): provides comprehensive basic health cducation to teachers from targeted schools through intensive 10 day courses. Teachers return to their schools with tcaching aids and run regular courses.

Outpatient Medical clinic programmes: started in its present form in 1990 and Federation support will continue for at least another two years until ARCS income generation scheme is sufficient to raise full support. 40 clinics were reached during 1995.

Community based First Aid programme: commenced early 1996 and the first phase was be for 6 months and recommendations will be made for the future. F/A programmes have been done in an ad-hoc manner with no national objectives. The CB manual for ASIA has been translated into Dari and Pashtu, so that the training components are ready.

\section{Institutional Development:}

has becn going on for morc than two ycars but the main task of setting up an effective and proper finance/administration system will start early 1996. A development delegate is assigned to work in the National HQ.
Rehabilitation/Welfare (Marastoon): ongoing programme with support required for at least a further two years. ARCS runs Marastoon programmes for handicapped and disadvantaged.

Relief programme (incl. assist. to displaced): covers - disaster relief, population movements and support to the most vulnerable. The annual winter programme provides aid to branches in remote mountain areas with blankets, clothing and medicines before winter. With the deterioration of the socio-economic situation the category of most vulnerable has increased dramatically and ARCS needs continuing support from national societies for day-to-day support to poverty stricken people in terms of providing clothing, blankets and cash for local purchases of essential food items. A radio nctwork system was completed during 1995 to aid communications.

In 1995 ARCS assisted 1,219,388 people. 803,927 received medical assistance through 40 clinics in 28 Provinces; 558,434 relief items; and 1,400 health training. 1,158 benefited from F/A and youth courses.

\section{Future Objectives}

To continue to support existing programmes and expand to areas not yet covered and increase programmes to assist the most needy. 
HSE 17, ST 2, SECTOR E2 PHONE: 813935

LALUZAR ROAD PH 2, HAYA F A X:

TABAD, PESHAWAR PAKISTAN email:
1. ENG RAZ

2. ENG SHEER HUSSAIN

3. MR AMARUDDIN

\begin{tabular}{|c|c|c|c|c|c|}
\hline AFGHAN & 7 & TECHNICAL & 4 & PAK. BASED : & - \\
\hline PAKISTANI : & - & ADMINISTRATIVE : & 1 & AFGHAN BASED: & 7 \\
\hline EXPAT : & - & FIELD/SUPPORT $S$. & 2 & CROSS-BORDER : & - \\
\hline TOTAL & 7 & TOTAL : & 7 & TOTAL : & 7 \\
\hline
\end{tabular}

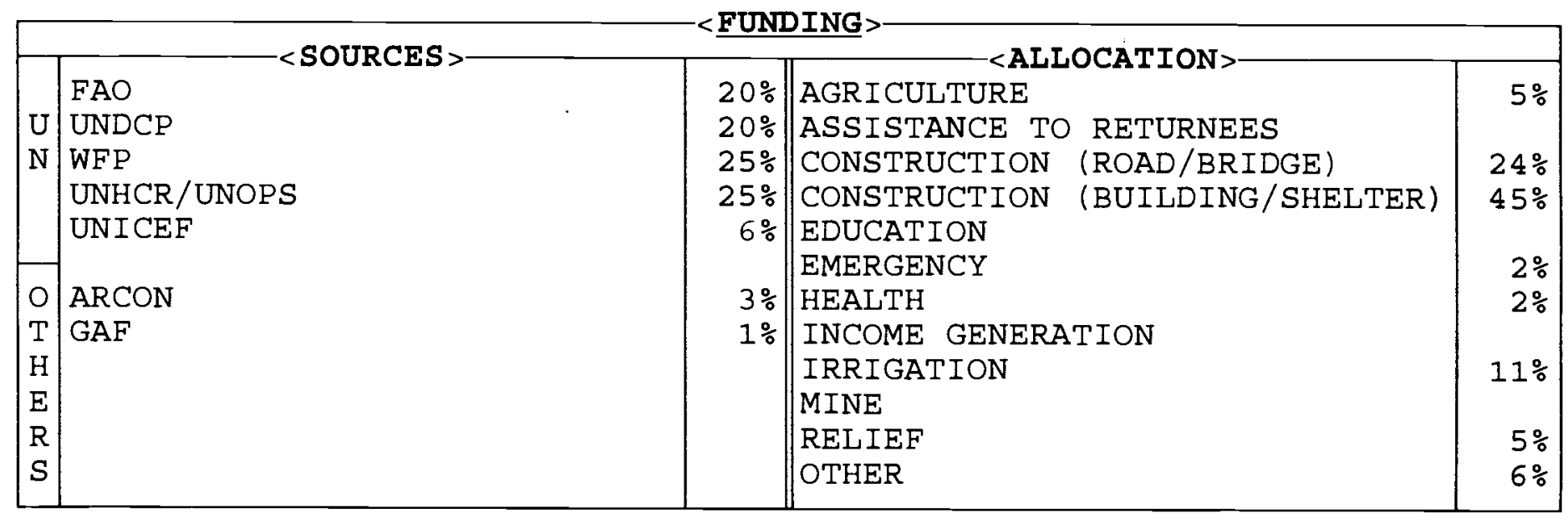

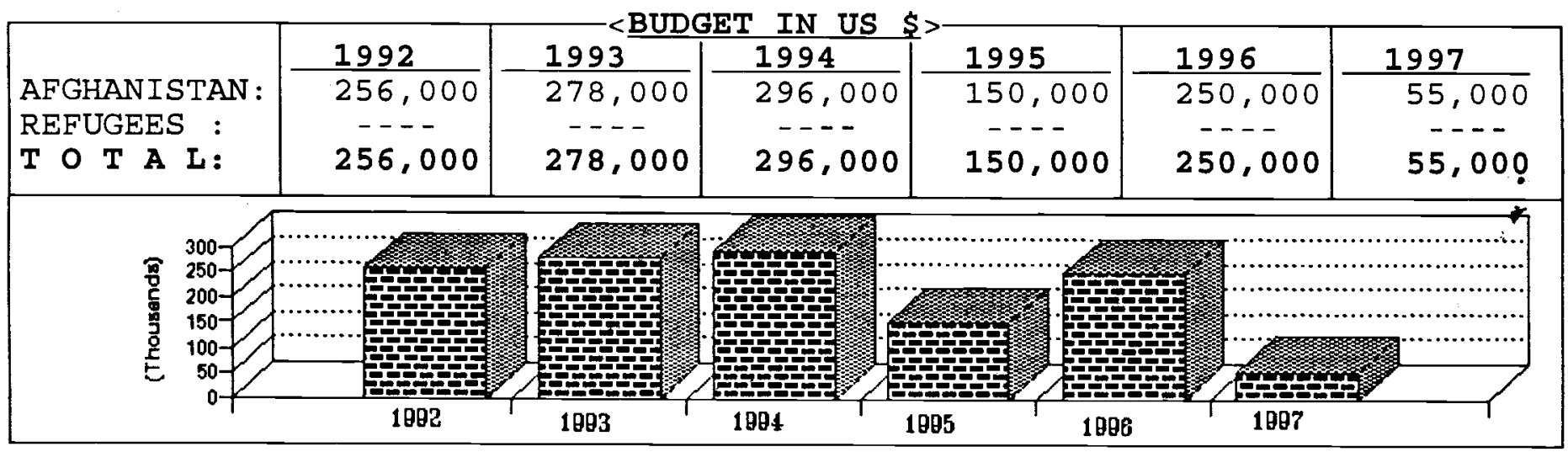

\begin{tabular}{|c|c|c|c|c|c|}
\hline PROVINCES & SECTOR & $\%$ & PROVINCES & SECTOR & $\%$ \\
\hline $\begin{array}{l}\text { BADAKSHAN } \\
\text { BADGHIS } \\
\text { BAGHLAN } \\
\text { BALKH } \\
\text { BAMYAN } \\
\text { FARAH } \\
\text { FARYAB } \\
\text { GHAZNI } \\
\text { GHOR } \\
\text { HELMAND } \\
\text { HERAT } \\
\text { JAWZJAN } \\
\text { KABUL } \\
\text { KANDAHAR } \\
\text { KAPISA }\end{array}$ & & & $\begin{array}{l}\text { KUNAR } \\
\text { KUNDUZ } \\
\text { LAGHMAN } \\
\text { LOGAR } \\
\text { NANGARHAR } \\
\text { NIMROZ } \\
\text { ORUZGAN } \\
\text { PAKTEKA } \\
\text { PAKTIA } \\
\text { PARWAN } \\
\text { SAMANGAN } \\
\text { TAKHAR } \\
\text { WARDAK } \\
\text { ZABUL } \\
\text { PAKISTAN }\end{array}$ & $\begin{array}{l}\text { CONSTRUCTION } \\
\text { REL/IRRIG/AGRIC } \\
\text { CONST } \\
\text { CONST/IRRIG/AGRIC } \\
\\
\text { CONST/IRRIG } \\
\text { CONSTRUCTION }\end{array}$ & $\begin{array}{r}6 \\
25 \\
3 \\
47 \\
\\
3 \\
15 \\
1\end{array}$ \\
\hline
\end{tabular}




\section{INDEPENDENT HUMANITARIAN \\ SERVICES ASSOCIATION \\ (IHSAN)}

IHSAN is an Afghan NGO staffed by professional, well educated, experienced and competent engineers, agrarians and qualified doctors.

\section{Aims of IHSAN}

The Association was established in 1991 with the basic objective of working for the rehabilitation and reconstruction of Afghanistan.

\section{Sectors of Operation}

- the first project was an orthopaedic workshop in Peshawar. The workshop produced orthopaedic appliances for disabled Afghans.

- later, IHSAN expanded its activities and started implementation of cross-border rehabilitation programmes.

Over the past six years IHSAN has implemented a number of projects in different Provinces but mainly in Nangarhar. The sectors vary from provision of relief commodities to Kabul displaced families in Jalalabad / Sarobi, to rehabilitation of irrigation channels (karezes and canals), construction of school buildings and provision of agriculture inputs (seeds, fertilizer and fruit trees).

IHSAN maintains close contacts with local shuras and has no problems in implementing in the field. Local communities have helped IHSAN in undertaking projects by taking part in decision making and maintaining security for IHSAN staff and property at projects sites.

\section{Future Objectives}

- to meet its main objectives, IHSAN became a member of Ariana Development Bureau (ADB), an umbrella organisation comprising of five Afghan NGOs.
- the umbrella will create better cooperation and coordination amongst the member NGOs, which will enhance the implementation capability of the organisation and will expand rehabilitation activities. 


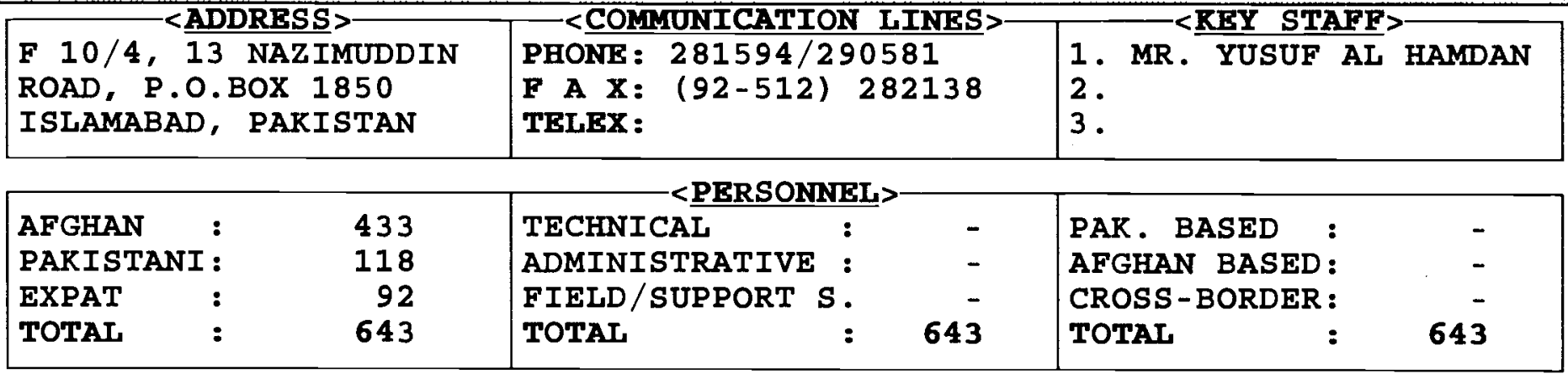

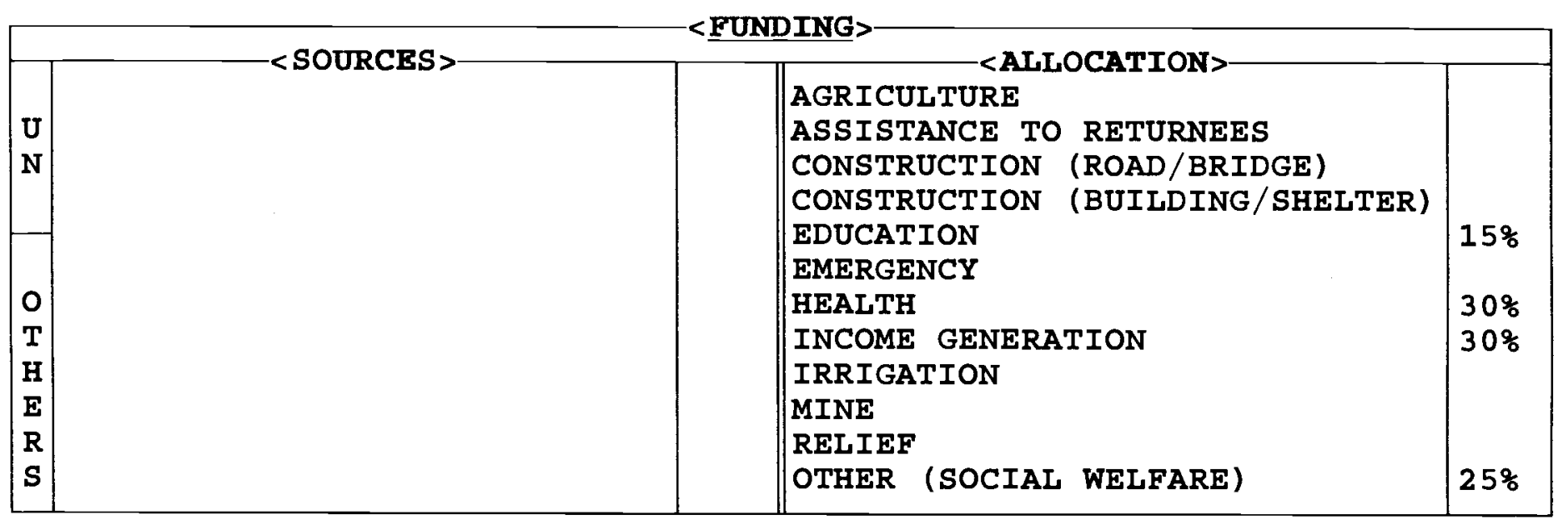

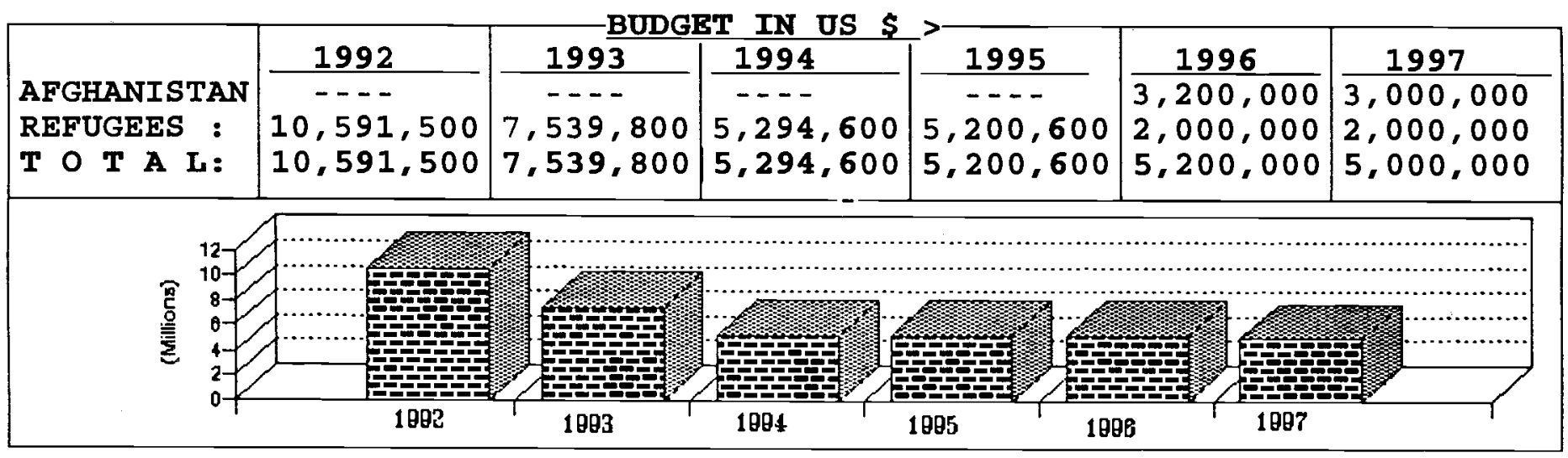

\begin{tabular}{|c|c|c|c|c|c|}
\hline PROVINCES & SECTOR & $\%$ & PROVINCES & SECTOR & q \\
\hline $\begin{array}{l}\text { BADAKSHAN } \\
\text { BADGHIS } \\
\text { BAGHLAN } \\
\text { BALKH } \\
\text { BAMYAN } \\
\text { FARAH } \\
\text { FARYAB } \\
\text { GHAZNI } \\
\text { GHOR } \\
\text { HELMAND } \\
\text { HERAT } \\
\text { JAWZJAN } \\
\text { KABUL } \\
\text { KANDAHAR } \\
\text { KAPISA }\end{array}$ & EDU/HEALTH/I. G. / SO.W. & 10 & $\begin{array}{l}\text { KUNAR } \\
\text { RUNDUZ } \\
\text { LAGHMAN } \\
\text { LOGAR } \\
\text { NANGARHAR } \\
\text { NIMROZ } \\
\text { ORUZGAN } \\
\text { PARTERA } \\
\text { PARTIA } \\
\text { PARWAN } \\
\text { SAMANGAN } \\
\text { TARHAR } \\
\text { WARDAR } \\
\text { ZABUL } \\
\text { REFUGEES }\end{array}$ & $\begin{array}{l}\text { EDU/HEALTH/I . G. / SO.W. } \\
\text { EDU/HEALTH/I . G. /SO.W. } \\
\text { EDU/HEALTH/I . G. / SO.W. }\end{array}$ & 20 \\
\hline
\end{tabular}




\section{INTERNATIONAL ISLAMIC RELIEF ORGANISATION \\ (IIRO)}

IIRO is a non-governmental organisation hcadquartered in Jeddah, Saudi Arabia. IIRO has bcen working for Afghan refugees in Pakistan, Iran and inside the country for several years.

IIRO's areas of work include health, education/training, orphan care and social welfare.

A health institute is run in Peshawar, which trains approximately 75 Afghans in four different sections (X-ray, anesthesia, laboratory and preventative medicine). IIRO opcrates four hospitals for Afghan refugees;

1 A 30 bed hospital for females and children in Miranshah.

2 A 40 bed hospital for males in Miranshah.

3 A 40 bed hospital for females and children in Dara, Peshawar.

4 A 40 bed hospital for females and children in Quetta. Baluchistan.

IIRO runs a dental clinic and an $\mathrm{MCH}$ clinic in Shamshatu camp, a dental clinic in Warsak, a clinic in Kohat arc, an $\mathrm{NCH}$ clinic in Gilgit and a BHU in Khardand, Kurran Agcncy.

In Afghanistan, IIRO opcrates 3 hospitals:

- a 40 bed hospital in Khost, Paktia.

- an 18 bed hospital in Parwan Province.

- a 14 bed hospital in Jawzjan Province.

Rc-establishment work in a hospital in Jalalabad is in progress.
IIRO also supports the following health facilities in different parts of Afghanistan:

- a BHU and a first aid post in Paktia Province.

- 3 BHUs and 2 first aid posts in Laghman

Province.

- 4 first aid posts in Kabul.

- 6 BHUs in Kunar Province.

- 7 BHUs and 2 first aid posts in Nangarhar

Province.

- a first aid post in Farah.

-5 first aid posts in Herat.

- 2 first aid posts in Ghor.

- a BHU in Kunduz Province.

- 3 first aid posts in Jawzjan Province.

IIRO has an orphan support programme through which more than 11,000 Afghan orphans and 300 widows in Pakistan, Iran and Afghanistan are given monthly financial assistance to support their families.

The agency also runs a higher education institute in Hayatabad called Islamic Academy for Science and Technology. The academy offers courses for B.A. and M.Sc. degrees. 24 schools and 45 Quranic centres are supported by IIRO in different refugees camps and Provinces of Afghanistan.

New rehabilitation programmes e.g. irrigation system rehabilitation are under consideration. 
12-C CHINAR ROAD U/T

$G$ P O BOX 504

PESHAWAR, PAKISTAN
PHONE : $43310 / 41274 / 43242$

F A X: 840283

email:
1. JOOP HENDRIKX

2. ERIC VAN DER LEE

3 .

\begin{tabular}{lrr}
\hline AFGHAN : & 1,123 \\
PAKISTANI : & 98 \\
EXPAT & $:$ & 9 \\
TOTAL & $:$ & 1,230
\end{tabular}

$<$ PERSONNEL $>$

TECHNICAL : 936 ADMINISTRATIVE : 74 FIELD/SUPPORT S. 220 TOTAL

: 1,230

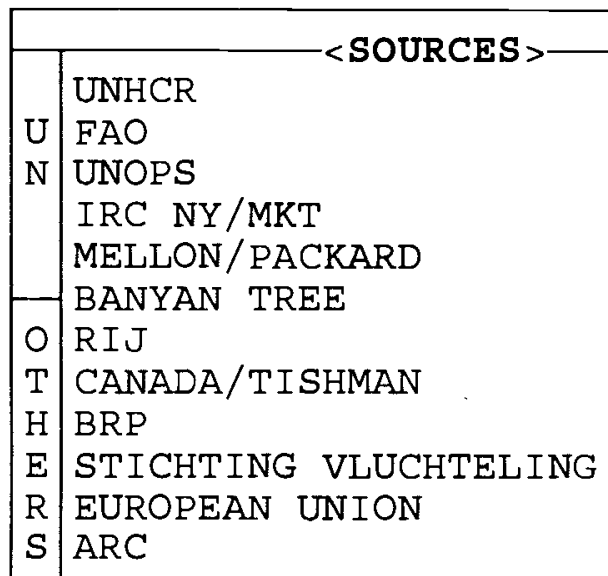

$<$ FUNDING $>$

\begin{tabular}{r||l}
\hline $17 \%$ & AGRICULTURE \\
$2 \%$ & ASSISTANCE TO RETURNEES \\
$1 \%$ & CONSTRUCTION (ROAD/BRIDGE) \\
$9 \%$ & CONSTRUCTION (BUILDING/SHELTER) \\
$1 \%$ & EDUCATION \\
$1 \%$ & EMERGENCY \\
$1 \%$ & HEALTH \\
$1 \%$ & INCOME GENERATION \\
$12 \%$ & IRRIGATION \\
$22 \%$ & MINE \\
$32 \%$ & RELIEF \\
$1 \%$ & OTHER \\
\hline
\end{tabular}

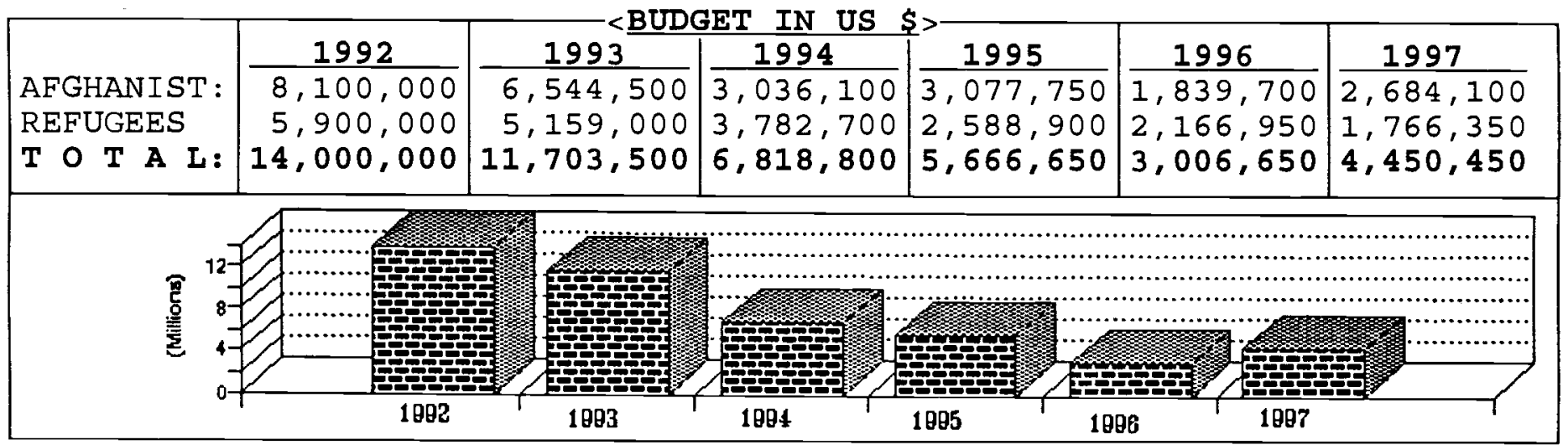

\begin{tabular}{|c|c|c|c|c|c|}
\hline PROVINCES & SECTOR & $\%$ & PROVINCES & SECTOR & $\%$ \\
\hline $\begin{array}{l}\text { BADAKSHAN } \\
\text { BADGHIS } \\
\text { BAGHLAN } \\
\text { BALKH } \\
\text { BAMYAN } \\
\text { FARAH } \\
\text { FARYAB } \\
\text { GHAZNI } \\
\text { GHOR } \\
\text { HELMAND } \\
\text { HERAT } \\
\text { JAWZJAN } \\
\text { KABUL } \\
\text { KANDAHAR } \\
\text { KAPISA }\end{array}$ & $\begin{array}{l}\text { IRRIG/AGRIC } \\
\text { IRRIG/AGRIC }\end{array}$ & 10 & $\begin{array}{l}\text { KUNAR } \\
\text { KUNDUZ } \\
\text { LAGHMAN } \\
\text { LOGAR } \\
\text { NANGARHAR } \\
\text { NIMROZ } \\
\text { ORUZGAN } \\
\text { PAKTEKA } \\
\text { PAKTIA } \\
\text { PARWAN } \\
\text { SAMANGAN } \\
\text { TAKHAR } \\
\text { WARDAK } \\
\text { ZABUL } \\
\text { PAKISTAN }\end{array}$ & $\begin{array}{l}\text { AGRICULTURE _. GEN } \\
\text { AGRIC/IRRIG/EDUC/IN } \\
\text { EDUCATION } \\
\text { IRRIGATION } \\
\\
\text { IRRIG/EDUC/HLTH/IN. }\end{array}$ & $\begin{array}{r}2 \\
26 \\
3 \\
3\end{array}$ \\
\hline
\end{tabular}




\section{INTERNATIONAL RESCUE COMMITTEE (IRC)}

IRC was founded in the United States in 1933 at the request of Albert Einstein to assist opponents of the Nazi regime. Since then it has grown into the leading non-sectarian voluntary organisation providing relief to refugees and the dispossessed worldwide.

\section{Mission of IRC}

From the beginning IRC's mission has been to help victims of racial, religious and ethnic persecution and oppression and those uprooted by war, violence and famine, to survive and rebuild their lives. IRC's work has also evolved to include aid to displaced people within their national borders and to former refugees following repatriation to their countries of origin.

\section{Sectors of operation}

- preventative/curative medical programme for refugees in the HanguThal area camps in Pakistan;

- $\quad$ male and female primary education programmes for Afghan refugees in Pakistan and IDPs and returnees in Afghanistan, including textbook development/distribution, school administrator training, teacher training in pedagogy and various subject matters, school support and teacher and school monitoring/supervision;

secondary education for males focusing on mathematics and science, textbook development/distribution and teacher training in Pakistan and Afghanistan;

pre-school teacher training in early childhood development and pre-school support for Afghan female refugees in Pakistan;

English language and health education training for female refugees in Pakistan;
- vocational training, credit-scheme and income generation programmes for vulnerable male and female refugees in NWFP;

- $\quad$ water supply, EPI and sanitation programmes in refugee camps in Pakistan and villages in Afghanistan;

- $\quad$ agriculture and irrigation, small business training and sustainable food security programmes in Afghanistan;

- $\quad$ self-reliant health education resource centre;

- $\quad$ gabion production in Afghanistan;

- $\quad$ grant award and management of rehabilitation activities through Afghan NGOs.

\section{Further information}

IRC began its work in Pakistan in 1980 with an emergency medical programme in response to the influx of Afghan refugees. The refugee programme has now grown into one of the largest operations of its kind.

In 1988 IRC initiated its first cross-border rehabilitation programmes which now reach into some 15 Provinces from which most of the Afghan refugees in NWFP originate. Since then, IRC's emphasis has been increasingly shifting to physical and social rehabilitation activities in Afghanistan, based on strong community involvement, with a concomitant scaling down of its Pakistan activities.

With a view toward long-term sustainability of refugee programmes, IRC keeps the concept of community contribution to the medical and educational service which refugee communities receive, charging modest fees for health care services and basic schooling and requiring refugee participation in the form of labour for the conduct of certain outreach services. 
$68 \mathrm{D}-2 \mathrm{~S} \mathrm{~J}$ AFGHANI ROAD $\mathrm{U} / \mathrm{T} \quad \mathrm{P} O \mathrm{BOX} 887$ PESHAWAR， PAKISTAN
PHONE : $42245 / 840365 / 42549 / 1$. JAFFAR AHMAD MAKI

F A X: 840429

email: 52383 ISRA
2. A AZIZ ABOBAKAR

3. MAROOF KHAN

\begin{tabular}{|c|c|c|c|c|c|}
\hline AFGHAN : & 95 & TECHNICAL & 30 & BASED & 27 \\
\hline PAKISTANI : & 13 & ADMINISTRATIVE : & 67 & AFGHAN BASED: & 61 \\
\hline EXPAT : & 3 & FIELD/SUPPORT S. & 14 & CROSS-BORDER: & 23 \\
\hline TOTAL & 111 & TOTAL : & 111 & TOTAL : & 111 \\
\hline
\end{tabular}

\begin{tabular}{|c|c|c|c|c|}
\hline & & & $-<$ ALLOCATION $>-$ & \\
\hline & & & AGR ICULTURE & $31 \div$ \\
\hline $\mathrm{U}$ & FAO & $10 \%$ & ASSISTANCE TO RETURNEES & \\
\hline $\mathrm{N}$ & WFP & $8 \%$ & CONSTRUCTION (ROAD/BRIDGE) & \\
\hline & UNICEF & $5 \%$ & CONSTRUCTION (BUILDING/SHELTER) & $2 \%$ \\
\hline & UNHCR & $8 \%$ & EDUCATION & $12 \%$ \\
\hline 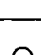 & & & EMERGENCY & $2 \%$ \\
\hline 0 & & & HEALTH & $9 \%$ \\
\hline $\mathrm{T}$ & ISRA & $20 \%$ & INCOME GENERATION & $3 \%$ \\
\hline $\mathrm{H}$ & DONATIONS & $49 \%$ & IRRIGATION & \\
\hline E & & & MINE & \\
\hline $\mathrm{R}$ & & & RELIEF & $38 \%$ \\
\hline$S$ & & & OTHER & $3 \%$ \\
\hline
\end{tabular}

\begin{tabular}{|c|c|c|c|c|c|c|}
\hline \multirow{4}{*}{$\begin{array}{l}\text { AFGHANISTAN : } \\
\text { REFUGEES : } \\
\text { T O T A L: }\end{array}$} & & & & & & \\
\hline & 1992 & 1993 & 1994 & 1995 & 1996 & 1997 \\
\hline & $2,200,000$ & $2,200,000$ & $2,000,000$ & $\overline{1,518,200}$ & $\overline{1,348,900}$ & $1,000,000$ \\
\hline & $3,000,000$ & $2,000,000$ & $2,000,000$ & 576,700 & 190,000 & --- \\
\hline $1 \quad I A$ & $5,200,000$ & $4,200,000$ & $4,000,000$ & $2,094,900$ & $1,538,900$ & $1,000,000$ \\
\hline
\end{tabular}

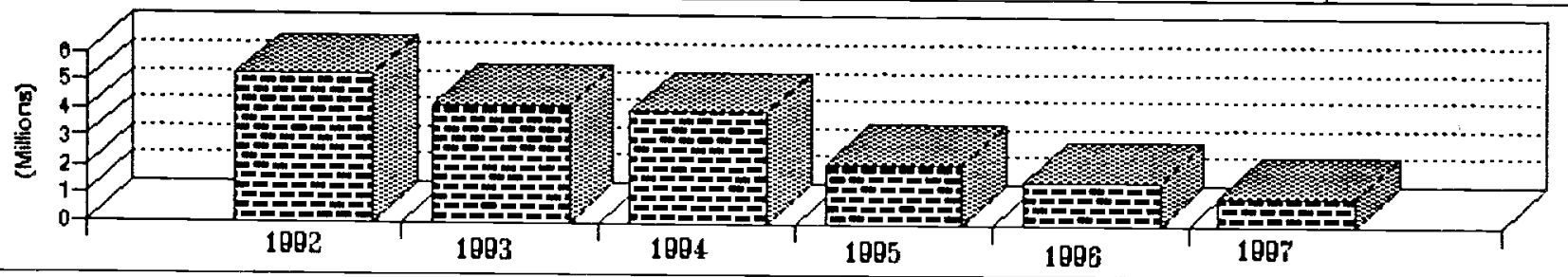

\begin{tabular}{|c|c|c|c|c|c|}
\hline PROVINCES & SECTOR & $\%$ & PROVINCES & SECTOR & $\%$ \\
\hline $\begin{array}{l}\text { BADAKSHAN } \\
\text { BADGHIS } \\
\text { BAGHLAN } \\
\text { BALKH } \\
\text { BAMYAN } \\
\text { FARAH } \\
\text { FARYAB } \\
\text { GHAZNI } \\
\text { GHOR } \\
\text { HELMAND } \\
\text { HERAT } \\
\text { JAWZJAN } \\
\text { KABUL } \\
\text { KANDAHAR } \\
\text { KAPISA }\end{array}$ & $\begin{array}{l}\text { SOC. WELFARE/AGRIC } \\
\text { EMERGENCY/AGRIC } \\
\text { AGRICULTURE }\end{array}$ & 3 & $\begin{array}{l}\text { KUNAR } \\
\text { KUNDUZ } \\
\text { LAGHMAN } \\
\text { LOGAR } \\
\text { NANGARHAR } \\
\text { NIMROZ } \\
\text { ORUZGAN } \\
\text { PAKTEKA } \\
\text { PAKTIA } \\
\text { PARWAN } \\
\text { SAMANGAN } \\
\text { TAKHAR } \\
\text { WARDAK } \\
\text { ZABUL } \\
\text { PAKISTAN }\end{array}$ & $\begin{array}{l}\text { AGR ICULTURE } \\
\text { AGRI / CONS / EDUC / HLTH } \\
\text { AGRI CULTURE } \\
\text { AGRI / EDUC/HLTH / S.W. } \\
\text { HEALTH / SOC. WELFARE }\end{array}$ & $\begin{array}{r}11 \\
2 \\
5 \\
15 \\
22\end{array}$ \\
\hline
\end{tabular}




\section{ISLAMIC RELIEF AGENCY}

(ISRA)

ISRA is an International NGO offering aid, irrespective of cast, creed, religion, colour or race to those affected by natural disasters and physical disruption or foreign aggression and who are forced to take refuge in other countries. Work for Afghan refugees began 1984.

ISRA has four main departments:

\section{HEALTH:}

- six clinics operate in 5 Afghan Provinces and a clinic in Peshawar for refugees;

- two drop-in centres for vulnerable children (orphans, disabled, destitute and street working children) in Laghman and Khost. These two centres provide hygiene, basic education and vocational training to approximately 1,000 children;

- ISRA donates medicines and medical equipment to different hospitals in Afghanistan.

\section{EDUCATION:}

- between 1985 and 1992 ISRA supported several primary schools in different refugee camps, providing education to 5,000 students;

- two vocational training centres for women were operated in Quetta and Peshawar; and a vocational Centre for boys was operated in Sardar Garhi, Peshawar, providing courses in 8 different trades for 700 boys of 200 widows;

- these Vocational training centres for boys and women have been moved to Jalalabad;

- the project of vocation training for boys was successfully completed in March 1996 and funds are being sought for its continuation;

- the women vocational training centre continued during much of 1996 , but the programme is presently suspended due to the policy of the local authorities regarding women programmes. Contacts are kept with the local authorities regarding reopening of this centre.
- an Institute was set up which trained over 3,000 Afghans in teacher training, office management, type writing, book keeping and tailoring.

- in 1992 ISRA set up a number of primary schools in Laghman, Wardak, Logar, Nangarhar and Khost, for over 800 students.

- a middle school in Chawki, Kunar is also operational.

\section{SOCIAL WELFARE:}

The key project of ISRA. Seven thousand orphans have been registered so far. Two centres for orphans in NWFP and seven more inside Afghanistan are now operating.

\section{RURAL DEVELOPMENT:}

- 10 nurseries in Kabul, Logar, Kunar and Paghman have been established.

- seed production and processing in Kunar.

- vegetable crop seeds are being produced.

- farmers are being trained on improved techniques for sulphur drying and packing.

- pest control and powdery mildew control programmes have been undertaken.

- a school construction was completed and together with ESAR a clinic was built in Khost.

- more than 5,000 farmers in 11 Provinces have been offered agricultural training programmes. 
JAPAN AFGEAN MEDICAL SERVICES (JAMS)

\begin{tabular}{|l|l|l|}
\hline 58 C, UNIVERSITY RD, U/T & PHONE: 44350-41500 & 1.DR. SHAHWALI WALIZARIF \\
U.P.O.BOX 847 & F A X: 841167 & 2. HAJI MOHD YAQUB SAFI \\
PESHAWAR, PAKISTAN & TELEX: & 3. WAZIR BIG
\end{tabular}

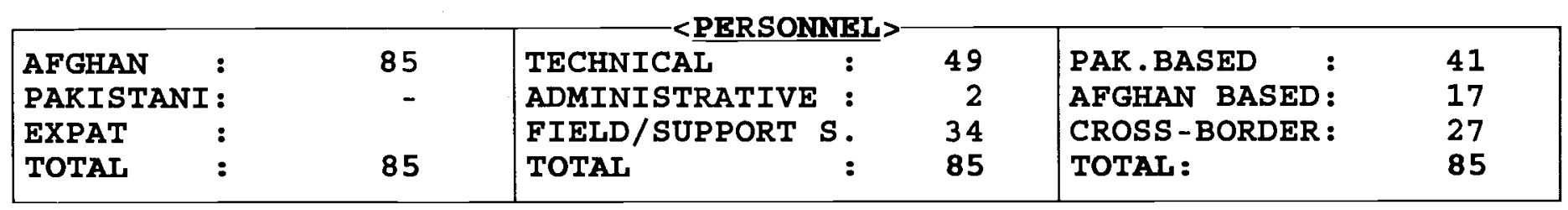

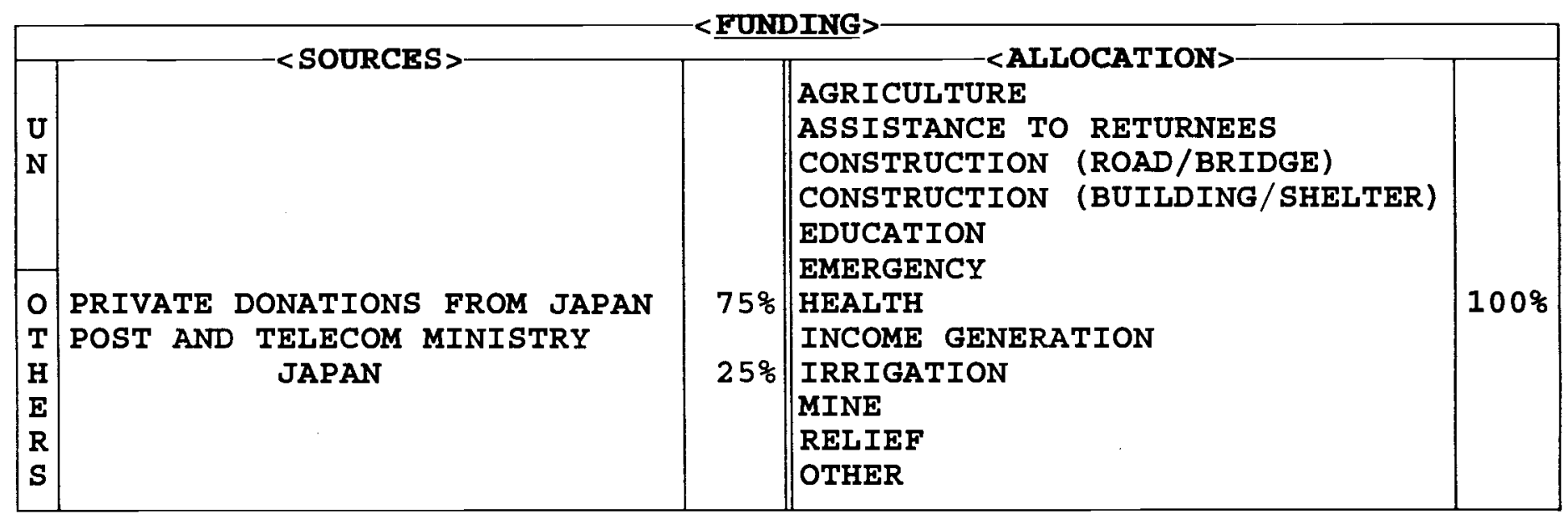

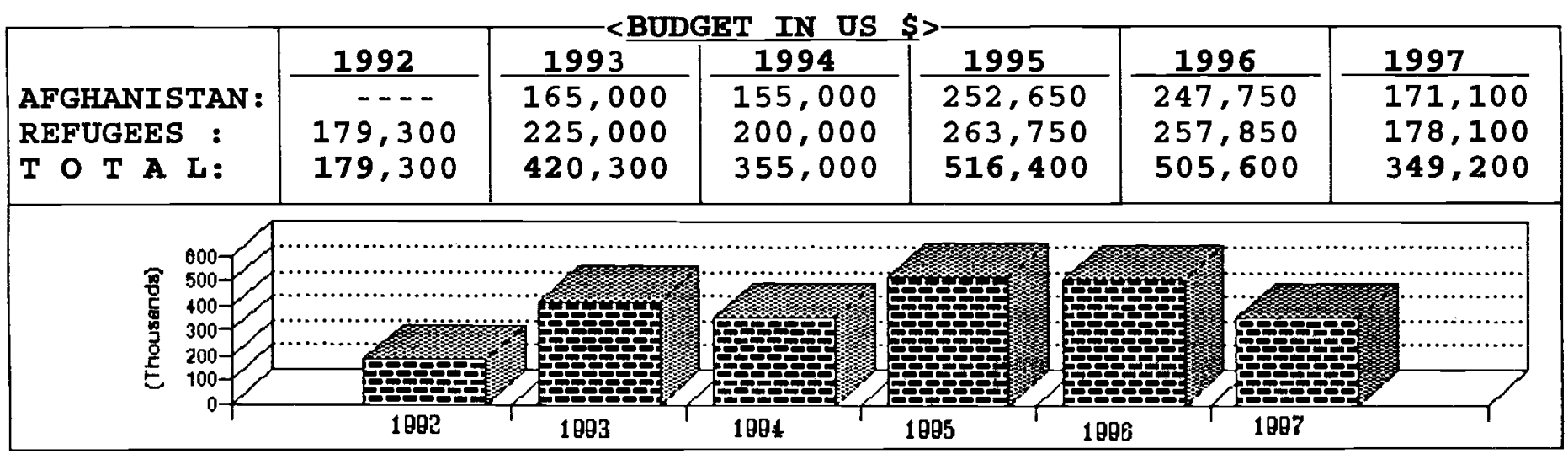

\begin{tabular}{|c|c|c|c|c|c|}
\hline PROVINCES & SECTOR & $\%$ & |PROVINCES & SECTOR & $\%$ \\
\hline $\begin{array}{l}\text { BADAKSHAN } \\
\text { BADGHIS } \\
\text { BAGHLAN } \\
\text { BALKH } \\
\text { BAMYAN } \\
\text { FARAH } \\
\text { FARYAB } \\
\text { GHAZNI } \\
\text { GHOR } \\
\text { HELMAND } \\
\text { HERAT } \\
\text { JAWZJAN } \\
\text { KABUL } \\
\text { KANDAHAR } \\
\text { KAPISA }\end{array}$ & & & $\begin{array}{l}\text { KUNAR } \\
\text { KUNDUZ } \\
\text { LAGHMAN } \\
\text { LOGAR } \\
\text { NANGARHAR } \\
\text { NIMROZ } \\
\text { NURESTAN } \\
\text { PAKTEKA } \\
\text { PAKTIA } \\
\text { PARWAN } \\
\text { SAMANGAN } \\
\text { TAKHAR } \\
\text { WARDAK } \\
\text { ZABUL } \\
\text { REFUGEES }\end{array}$ & $\begin{array}{l}\text { HEALTH } \\
\text { HEALTH }\end{array}$ & $\begin{array}{l}18 \\
16\end{array}$ \\
\hline
\end{tabular}


JAMS was founded in October 1986 as an Afghan Leprosy Service. In the beginning it operated as an extension programme for leprosy control in NWFP of Pakistan. The service was in response to the influx of Afghan refugees and an increase of registered leprosy patients .

Initially, activity in the camps was primarily the treatment of skin discases and leprosy. Howcver, since it was difficult to look after only leprosy patients, apart from other infectious diseases, JAMS expanded its activity to include other common diseases, minor and reconstructive surgery and at this point the agency namc changed (Scptcmber 1988).

The organisation operates a 45 bed hospital, a daily OPD and conducts a medical survey programme in camps as a regular outreach programme. JAMS has supplied its hospital /clinics with a laboratory with modern diagnostic equipment. Expatriate doctors have joined the team and provide education and information to enhance the knowledge and capabilities of doctors and medical assistants.

A clinic and a mobile health facility are operating in Malakand camp.

A medical training course began in January 1989. In another training programme which began in September 1989, medical workers were traincd to work in the rural areas of Afghanistan. Currently JAMS offer a four month training in tropical diseases to 18 Afghan doctors.

In late 1991, JAMS started cross-border operations by opening a clinic in Dara Noor, Nangarhar. The clinic receives $180 / 250$ patients a day. A TB control programme will soon be added to the clinic to follow the TB treatment for returnees who have been registered with TB control programmes in Peshawar.

In January 1993, one clinic in Dare-Pech (Sinzoy) in Kunar Province was established. It operates daily, an OPD, treating 120 to 180 pationts
In April 1994, one clinic in Wama district of Nooristan was established, which operates an OPD for $80 / 100$ patients daily.

These clinics are equipped with functioning laboratories and a pharmacy, in addition to nursing activities and an MD doctor.

JAMS has set up a pain clinic (acupuncture) which helps patients without medicines, and has established a stomatology unit to help medical patients.

In September 1995, JAMS set up two mobile clinics in Kunar which travel from village to village on a daily basis - specialising in leprosy and dermatologic diseases with one medical doctor, one laboratory technician, one nurse and three non medical staff each.

JAMS uses the following equipment:

- X-Ray machines

- ECG machines

- EEG machines

- Ultrasonography

- EGD

- Pathology

- Microbiology

JAMS offers its facilities free of charge. 


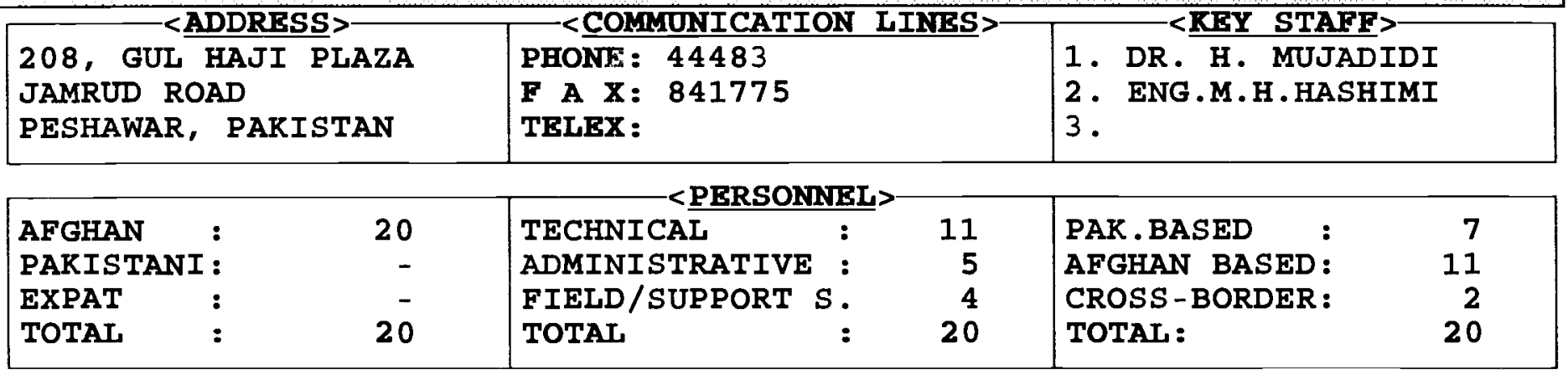

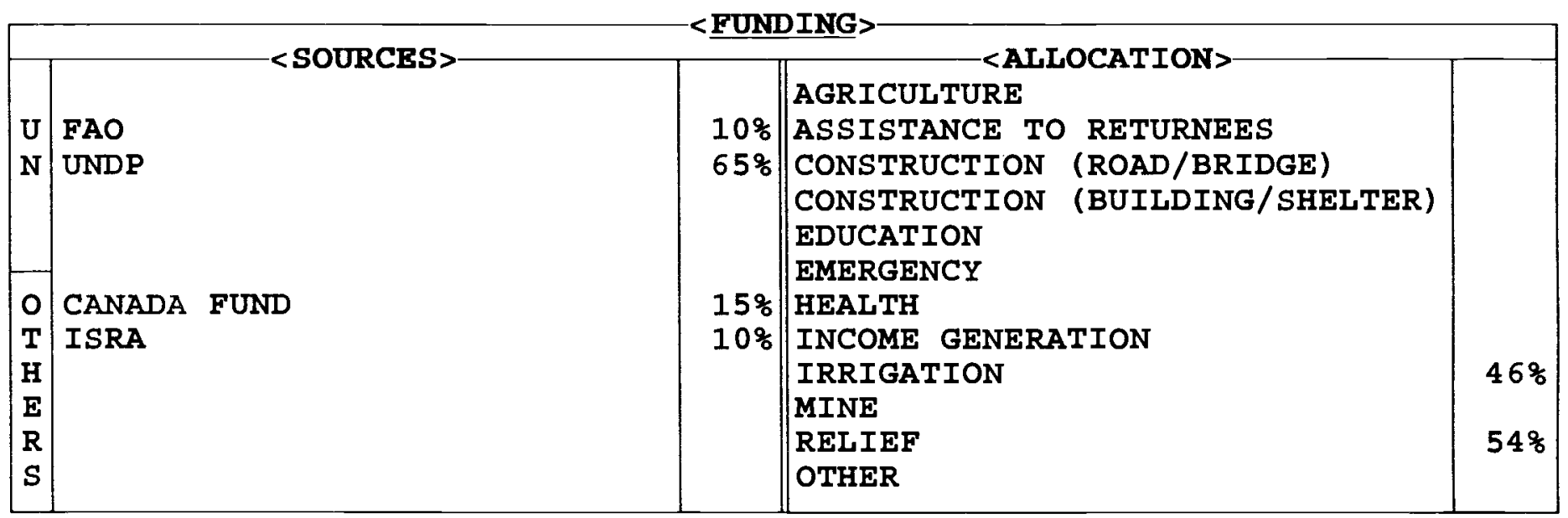

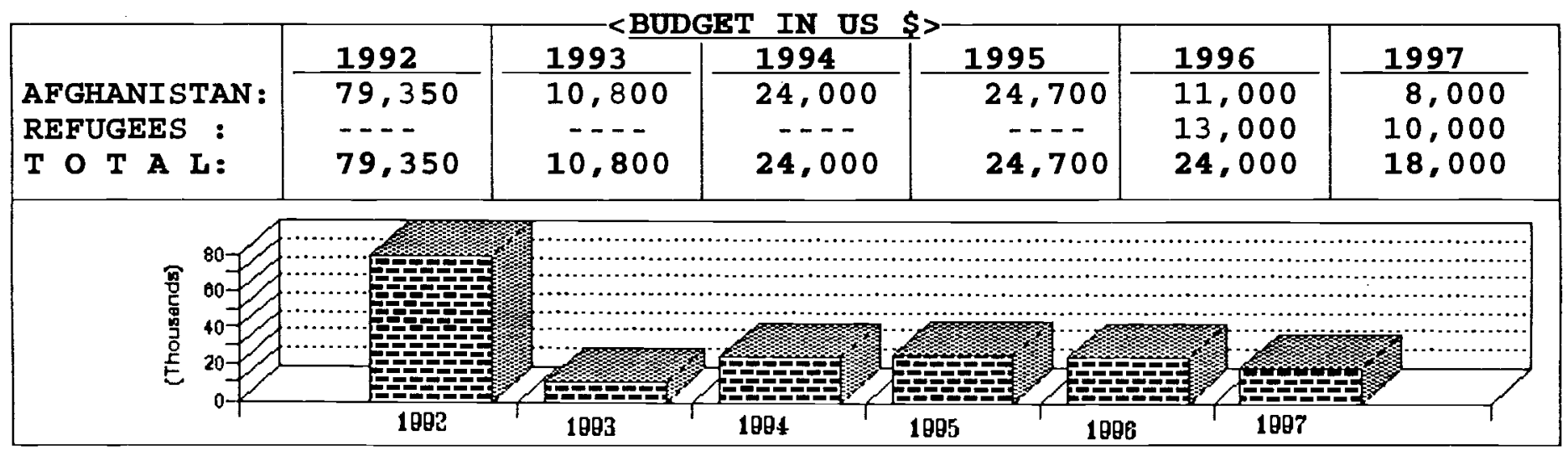

\begin{tabular}{|c|c|c|c|c|c|}
\hline PROVINCES & SECTOR & $\%$ & PROVINCES & SECTOR & $\%$ \\
\hline $\begin{array}{l}\text { BADAKSHAN } \\
\text { BADGHIS } \\
\text { BAGHLAN } \\
\text { BALKH } \\
\text { BAMYAN } \\
\text { FARAH } \\
\text { FARYAB } \\
\text { GHAZNI } \\
\text { GHOR } \\
\text { HELMAND } \\
\text { HERAT } \\
\text { JAWZJAN } \\
\text { KABUL } \\
\text { KANDAHAR } \\
\text { KAPISA }\end{array}$ & & & $\begin{array}{l}\text { KUNAR } \\
\text { KUNDUZ } \\
\text { LAGHMAN } \\
\text { LOGAR } \\
\text { NANGARHAR } \\
\text { NIMROZ } \\
\text { NURESTAN } \\
\text { PARTEKA } \\
\text { PAKTIA } \\
\text { PARWAN } \\
\text { SAMANGAN } \\
\text { TAKHAR } \\
\text { WARDAK } \\
\text { ZABUL } \\
\text { REFUGEES }\end{array}$ & (1) & 46 \\
\hline
\end{tabular}


JCE is an Afghan NGO founded in 1990. It's main objective is to contribute to the rchabilitation and reconstruction of Afghanistan.

\section{Long term Objectives}

- To work on the rehabilitation of agriculture infrastructure in

Afghanistan to help restore agriculture productivity:

- To rebuild destroyed irrigation, housing, buildings and schools;

- To train Afghans in the skills and technology needed to carry out rehabilitation efforts now in progress and for the future;

- To develop an organisation capable of continuing to provide rural rehabilitation services in

Afghanistan.

In $1991 \mathrm{JCE}$ expanded its activities to new Provinces, funded by ARCON, UNDP, ISRA, FAO, Canada Fund and some private donations.

\section{Nangarhar:}

In Nangarhar the agency works in Renaw, Parchaw, Anbarkhana, Momand Dara, Anbar kana, Kama daka, Behsood and Lalpur areas. Activities cover seed and fertilizer distribution, provision of traction services, rehabilitation of irrigation systems (cleaning of karezes and building retaining walls and dikes) and construction of public buildings such as schools, mosques and clinics.

\section{Kunar:}

In Saw Kunar JCE has constructed ropecarricrs over the Kunar river. In Saw and Asmar district of Kunar a primary school has been constructed.

\section{Paktia:}

In Khost, JCE has an agriculture programme which includes provision of agriculture inputs (improved wheat seed and fertilizer). In Paktia JCE works in Shabak, Ballawat-e-Balla and Ballawat-e-Payan, Khurami, Lund lakan, Loud ladan and Scrkay areas.
Activities include seed and fertilizer distribution, rehabilitation of irrigation and construction of public buildings.

\section{Takhar:}

In the capital of Takhar, JCE has built a madrasa (religious school) building.

\section{Peshawar:}

Hazrat Jee Baba mosque has been constructed by JCE.

\section{Laghman:}

In Alinger district of Laghman JCE constructed Shakhatary wash culvert.

Repairing of Lamkay wash siphons, construction of a flume at Jan Wealla and flume of Sowakay on Godakhar; construction of a wash crossing and retaining walls.

Since $1990 \mathrm{JCE}$ has been registered with UNOCHA and ANCB. 
JAPANESB INTERNATIONAL FRIENDSHIP AND WELFARE FOUNDATION (JIFP)

-ADDRESS>- $>$ COMMUNICATION LINES $>-1$ KFY STAFF>-

1, RAHMAN BABA ROAD UNIVERSITY TOWN PESHAWAR, PAKISTAN

PHONE : 41278

F A X: 41278

TELEX :
1. DR. M. RAZEM AHMADYAR

2. DR. M.AKBAR AHMADYAR

3. DR. SAIFUDDIN NASAFI

\begin{tabular}{|c|c|c|c|c|c|}
\hline $\begin{array}{l}\text { AFGHAN : } \\
\text { PAKISTANI : }\end{array}$ & $\begin{array}{r}17 \\
2\end{array}$ & $\begin{array}{l}\text { TECHNICAL : } \\
\text { ADMINISTRATIVE : }\end{array}$ & $\begin{array}{r}19 \\
2\end{array}$ & $\begin{array}{l}\text { PAK. BASED : } \\
\text { AFGHAN BASED: }\end{array}$ & $\begin{array}{l}21 \\
-\end{array}$ \\
\hline EXPAT : & $\begin{array}{r}2 \\
21\end{array}$ & $\begin{array}{l}\text { FIELD/SUPPORT } S \text { : } \\
\text { TOTAY }\end{array}$ & $2 \overline{1}$ & $\begin{array}{l}\text { CROSS-BORDER : } \\
\text { TOTAL : }\end{array}$ & $2 \overline{1}$ \\
\hline
\end{tabular}

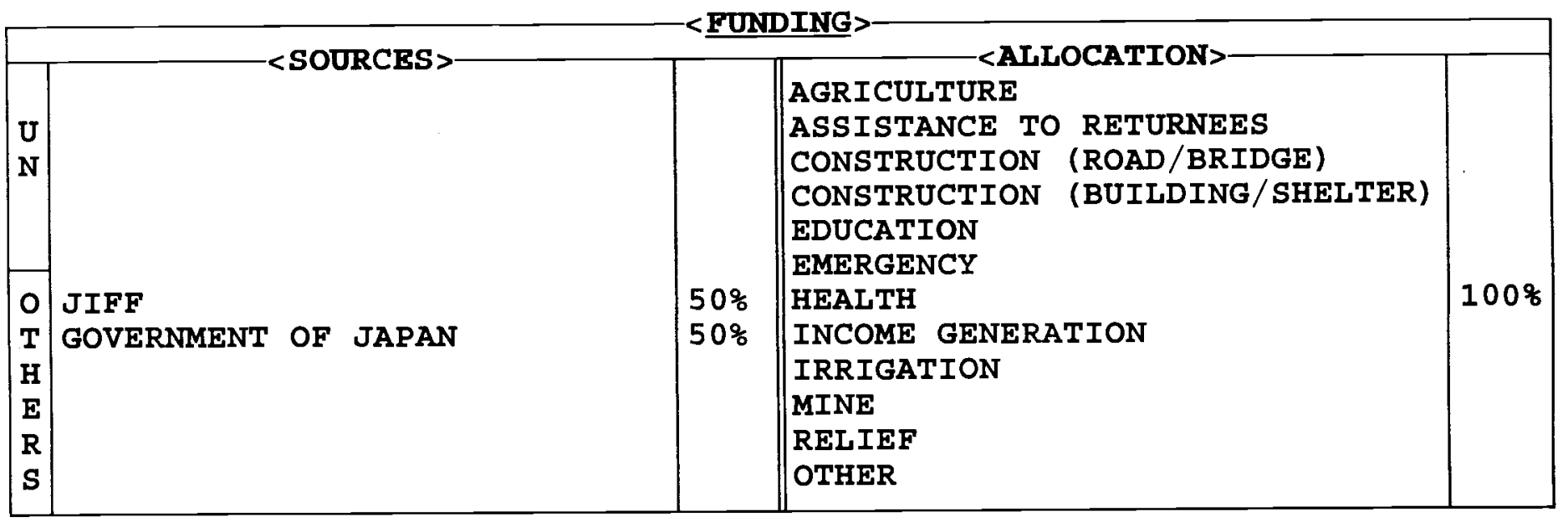

\begin{tabular}{|c|c|c|c|c|c|c|c|}
\hline \multirow{2}{*}{\multicolumn{2}{|c|}{$\begin{array}{l}\text { AFGHANISTAN : } \\
\text { REFUGEES : } \\
\text { T O T A L: }\end{array}$}} & 1992 & 1993 & 1994 & 1995 & 1996 & 1997 \\
\hline & & $\begin{array}{l}20 \overline{0}, 000 \\
200,000\end{array}$ & $\begin{array}{l}10 \overline{1} \\
100,000 \\
100,000\end{array}$ & $\begin{array}{l}1--\overline{1} \\
100,000 \\
100,000\end{array}$ & $\begin{array}{l}1 \overline{--\overline{0}} \\
100,000 \\
100,000\end{array}$ & $\begin{array}{l}1 \overline{--} \\
100,000 \\
100,000\end{array}$ & $\begin{array}{l}-\overline{-} \\
100,000 \\
100,000\end{array}$ \\
\hline \multirow{2}{*}{\multicolumn{2}{|c|}{ 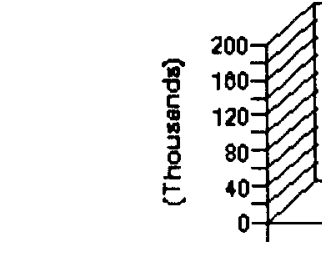 }} & 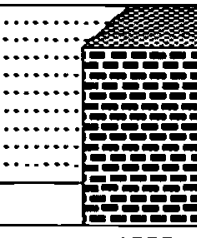 & :368888 & 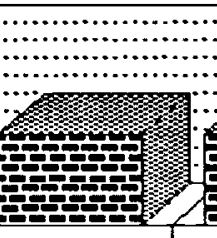 & 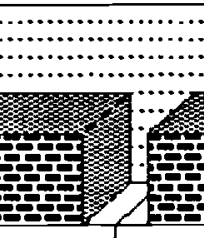 & 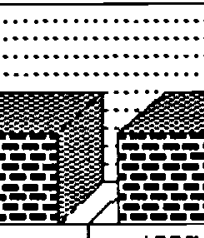 & \\
\hline & & 1802 & 1083 & 1004 & $1 \theta$ & 1897 & \\
\hline
\end{tabular}

<TARGET PROVINCES IN AFGHANISTAN>

\begin{tabular}{|c|c|c|c|c|c|}
\hline PROVINCES & SECTOR & $\frac{9}{6}$ & PROVINCES & SECTOR & $\frac{9}{6}$ \\
\hline $\begin{array}{l}\text { BADAKSHAN } \\
\text { BADGHIS } \\
\text { BAGHLAN } \\
\text { BALKH } \\
\text { BAMYAN } \\
\text { FARAH } \\
\text { FARYAB } \\
\text { GHAZNI } \\
\text { GHOR } \\
\text { HELMAND } \\
\text { HERAT } \\
\text { JAWZJAN } \\
\text { KABUL } \\
\text { KANDAHAR } \\
\text { KAPISA }\end{array}$ & & & $\begin{array}{l}\text { KUNAR } \\
\text { KUNDUZ } \\
\text { LAGHMAN } \\
\text { LOGAR } \\
\text { NANGARHAR } \\
\text { NIMROZ } \\
\text { ORUZGAN } \\
\text { PAKTEKA } \\
\text { PAKTIA } \\
\text { PARWAN } \\
\text { SAMANGAN } \\
\text { TAKHAR } \\
\text { WARDAK } \\
\text { ZABUL } \\
\text { REFUGEES }\end{array}$ & HEALTH & 100 \\
\hline
\end{tabular}




\section{JAPANESE INTERNATIONAL WELFARE FOUNDATION (JIFF)}

JIFF established a Physiotherapy Centre in Peshawar in August 1991 to provide rehabilitative treatment to those patients whose surgical treatment was performed abroad under International Organization for Migration /Afghan Medical Program (IOM/AMP) and JIFF.

After one year of successful operation of the unit in Peshawar the Japanese Government commenced its financial assistance to this project through the Ministry of Post and Telecommunications.

The Physiotherapy Centre assists $250-350$ patients, daily (50 - 100 children, $110-150$ women and $90-145 \mathrm{men}$ ).

There are several departments within the centre:

- Medical OPD for adult male and female;

- Male and female physiotherapy;

- Electrotherapy

- Children's OPD;

- Children's physiotherapy;

- X-ray;

- Dispensary

- Female Health Education

- Health Educator Training Programmes for female patients and mothers.

This is the only centralised centre dealing with physiotherapy in NWFP for Afghan refugecs, equipped with the latest technology. 
JACOB'S WELL MEDICAL MISSION (JWMM)

<ADDRESS>-

MRCA/RSU, MAIWAND HOSP . PHONE : KABUL 26047

P.O.BOX 5558

KABUL, AFGHANISTAN
F A X: 812819 PESHAWAR TELEX :
1. KHALILULLAH

2. DR. KARIM

3. DR. ULFAT

\begin{tabular}{|c|c|c|c|c|c|}
\hline $\begin{array}{l}\text { AFGHAN : } \\
\text { PAKISTANI : }\end{array}$ & $\begin{array}{r}22 \\
-\end{array}$ & $\begin{array}{ll}\text { TECHNICAL } & : \\
\text { ADMINISTRATIVE : }\end{array}$ & $\begin{array}{r}10 \\
2\end{array}$ & $\begin{array}{l}\text { PAK. BASED : } \\
\text { AFGHAN BASED: }\end{array}$ & $2 \overline{2}$ \\
\hline EXPAT : & - & FIELD/SUPPORT S. & 10 & CROSS-BORDER : & - \\
\hline TOTAL & 22 & TOTAL : & 22 & TOTAL : & 22 \\
\hline
\end{tabular}

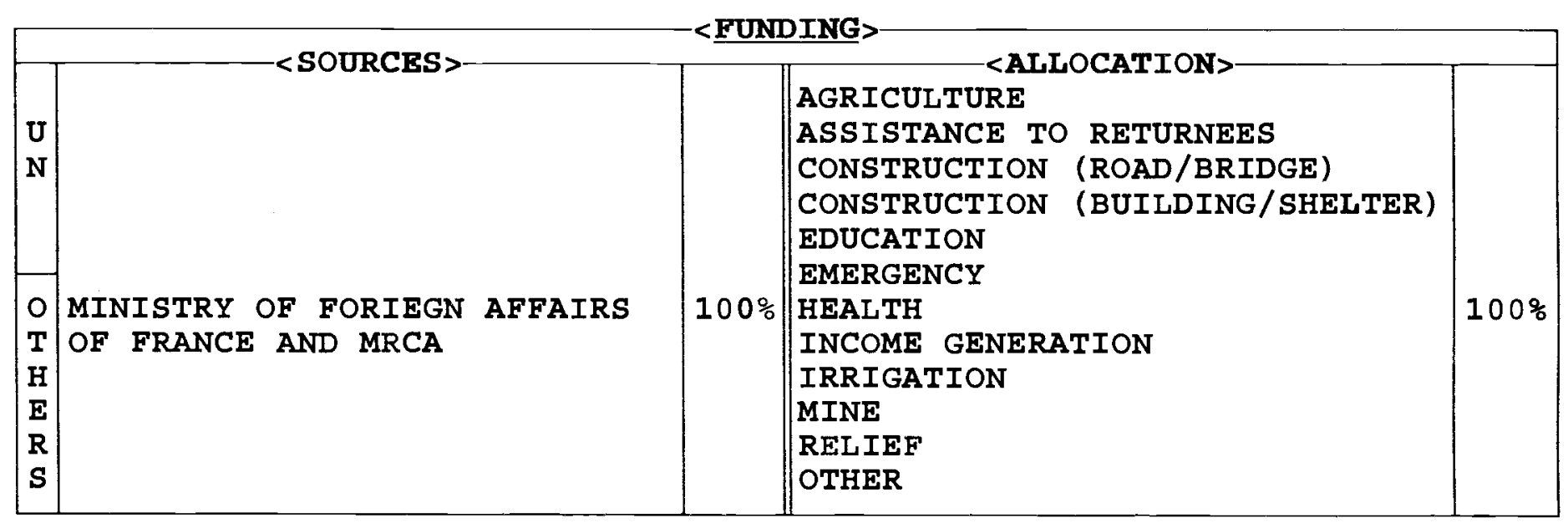

\begin{tabular}{|c|c|c|c|c|c|c|}
\hline $\begin{array}{l}\text { AFGHANISTAN : } \\
\text { REFUGEES : } \\
\text { T O T A L: }\end{array}$ & $\begin{array}{c}1992 \\
40,000 \\
\overline{-0} \\
40,000\end{array}$ & $\begin{array}{l}1993 \\
40,000 \\
40,000\end{array}$ & $\begin{array}{l}1994 \\
40,000 \\
40,000\end{array}$ & $\begin{array}{c}1995 \\
300,000 \\
-- \\
300,000\end{array}$ & $\begin{array}{c}\frac{1996}{300,000} \\
300,000\end{array}$ & $\begin{array}{c}1997 \\
300,000 \\
\cdots \\
300,000\end{array}$ \\
\hline 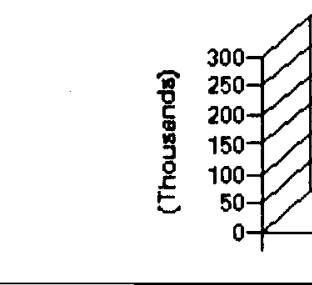 & $\frac{88}{1802}$ & 1083 & 1004 & 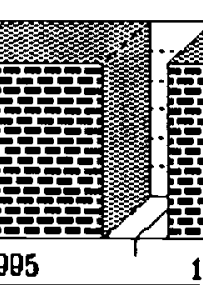 & 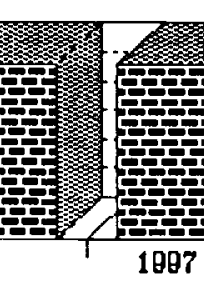 & - \\
\hline
\end{tabular}

\begin{tabular}{|c|c|c|c|c|c|}
\hline PROVINCES & SECTOR & g & PROVINCES & SECTOR & $\%$ \\
\hline $\begin{array}{l}\text { BADAKSHAN } \\
\text { BADGHIS } \\
\text { BAGHLAN } \\
\text { BALKH } \\
\text { BAMYAN } \\
\text { FARAH } \\
\text { FARYAB } \\
\text { GHAZNI } \\
\text { GHOR } \\
\text { HELMAND } \\
\text { HERAT } \\
\text { JAWZJAN } \\
\text { KABUL } \\
\text { RANDAHAR } \\
\text { KAPISA }\end{array}$ & HEALTH & 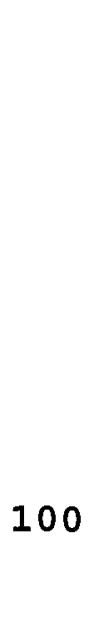 & $\begin{array}{l}\text { KUNAR } \\
\text { KUNDUZ } \\
\text { LAGHMAN } \\
\text { LOGAR } \\
\text { NANGARHAR } \\
\text { NIMROZ } \\
\text { ORUZGAN } \\
\text { PAKTEKA } \\
\text { PAKTIA } \\
\text { PARWAN } \\
\text { SAMANGAN } \\
\text { TAKHAR } \\
\text { WARDAK } \\
\text { ZABUL }\end{array}$ & & \\
\hline
\end{tabular}


JACOB'S WELL MEDICAL MISSION

(JWMM)

JWMM is a British charity organisation which has been working in Afghanistan for the past 4 years, operating mainly in Kabul.

JWMM works through Afghan Red Crescent Socicty (ARCS) and provides medicines and medical instruments to different hospitals and clinics in Kabul city. 


\begin{tabular}{|l|l|l|l|}
\hline ABDARA CHOWK, JAMRUD RD & PHONE:841306/844654 & 1. DR. AREY STAFF>- AHMED E. AHMED \\
P O BOX 782 & F A X:091 840521 & 2. DR. GULSHER ABID \\
PESHAWAR, PAKISTAN & TELEX: & 3.
\end{tabular}

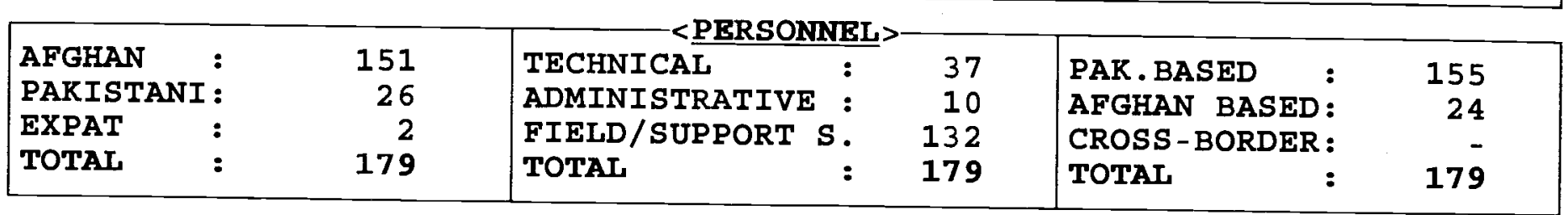

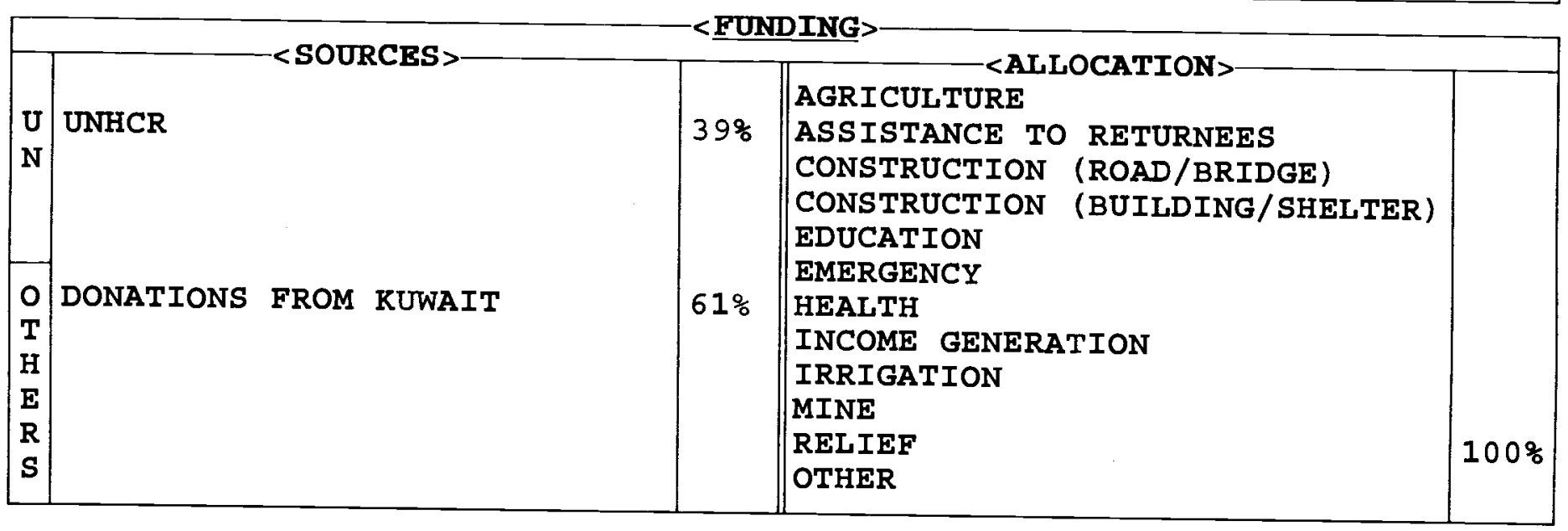

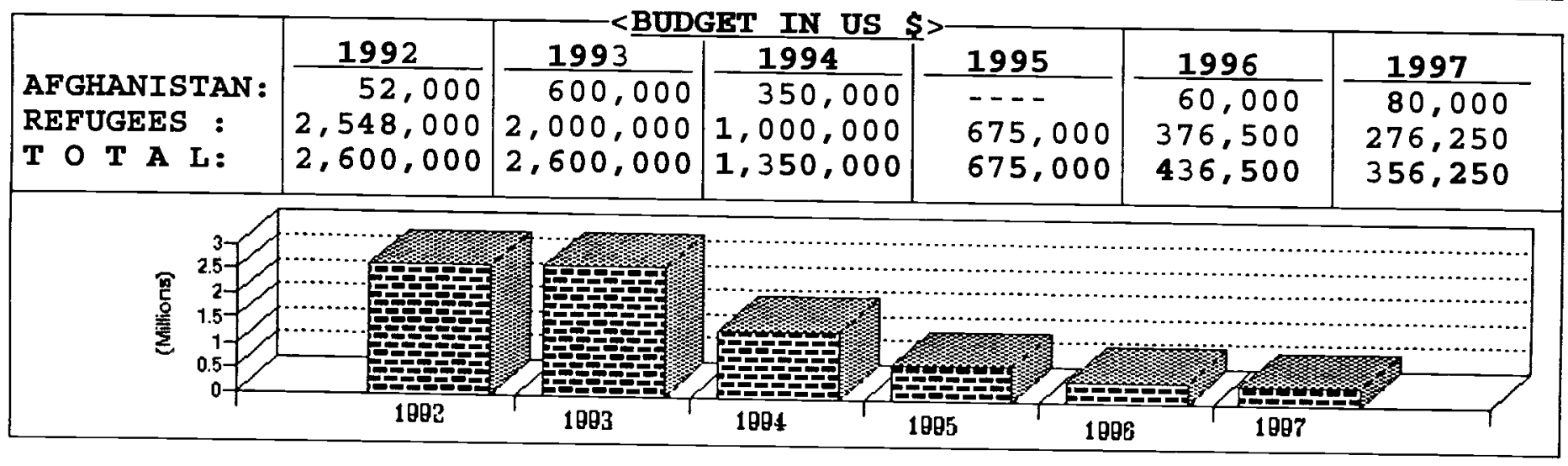

\begin{tabular}{|c|c|c|c|c|c|}
\hline PROVINCES & SECTOR & $\%$ & PROVINCES & SECTOR & $\%$ \\
\hline $\begin{array}{l}\text { BADAKSHAN } \\
\text { BADGHIS } \\
\text { BAGHLAN } \\
\text { BALKH } \\
\text { BAMYAN } \\
\text { FARAH } \\
\text { FARYAB } \\
\text { GHAZNI } \\
\text { GHOR } \\
\text { HELMAND } \\
\text { HERAT } \\
\text { JAWZJAN } \\
\text { KABUL } \\
\text { KANDAHAR } \\
\text { KAPISA }\end{array}$ & $\begin{array}{l}\text { RELIEF } \\
\text { RELIEF }\end{array}$ & 11 & \begin{tabular}{|l|} 
KUNAR \\
KUNDUZ \\
LAGHMAN \\
LOGAR \\
NANGARHAR \\
NIMROZ \\
ORUZGAN \\
PAKTEKA \\
PAKTIA \\
PARWAN \\
SAMANGAN \\
TAKHAR \\
WARDAR \\
ZABUL \\
REFUGEES
\end{tabular} & 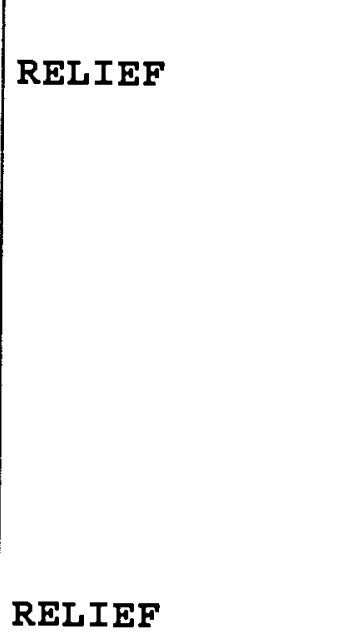 & 1 \\
\hline
\end{tabular}


KUWAIT JOINT RELIEF COMMITTEE

(KJRC)

KJRC (previously known as Kuwait Red

Crescent Socicty (KRCS)) established its office

in Pcshawar in 1983 and started various projects

for Afghan refugees.

\section{Sector of operation}

Health

Kuwait Surgical Hospital, Peshawar:

A 150 bed surgical hospital functioning since 1985. The departments include neuro-surgery, plastic surgery, general orthopaedic surgery, opthalmology, OT, sterilisation department, $\mathrm{x}$ ray, ICU, laboratory.

There exists a reaching program through which Pakistan and Afghan medical staff are given training in different sections in clinical tutorials, discussions and ward rounds.

KJRC also ran a first aid school, training Afghans as OT assistants, physiotherapy/ orthopacdic technicians and lab technicians. A total of 325 graduated.

\section{Social services}

$\mathrm{KJRC}$ distributed refugees relief items including blankets, clothing, assorted food-stuff, tents, Holy Quran and writing materials.

As part of its relief operation, 356 wells were dug for drinking water in different TRV's in NWFP.

\section{Education}

Ten mosques and two schools were constructed and many others repaired by the agency. It translated and printed important Islamic books in Persian/Pashto and distributed to Afghans.

Scholarships arranged to help Afghan students to continue medical studics in different Pakistani Medical Colleges (discontinued in 1995).

KJRC established a rehabilitation centre (18 beds) in Kabul (physiotherapy and paraplegic units) in 1996. 
KOH-I-NOOR FOUNDATION (RNF)

1 < <ADDRESS>- - CCOMUNICATION LINES > 1, 2ND FLOOR, KHYBER VIEW PLAZA, ABDARA RD PESHAWAR, PAKISTAN
PHONE : 843303

F A X:

TELEX:
1. HAJI M. DAUD ARSALA

2 . AMANULLAH SALEEM

3.MS . FATIMA SATTAR

\begin{tabular}{|c|c|c|c|c|c|}
\hline $\begin{array}{l}\text { AFGHAN : } \\
\text { PAKISTANI : } \\
\text { EXPAT : } \\
\text { TOTAL }\end{array}$ & $\begin{array}{r}50 \\
- \\
50\end{array}$ & $\begin{array}{l}\text { TECHNICAL : } \\
\text { ADMINISTRATIVE : } \\
\text { FIELD/SUPPORT S. } \\
\text { TOTAL }\end{array}$ & $\begin{array}{r}10 \\
4 \\
36 \\
50\end{array}$ & $\begin{array}{l}\text { PAK. BASED : } \\
\text { AFGHAN BASED : } \\
\text { CROSS-BORDER : } \\
\text { TOTAL : }\end{array}$ & $\begin{array}{r}6 \\
44 \\
- \\
50\end{array}$ \\
\hline
\end{tabular}

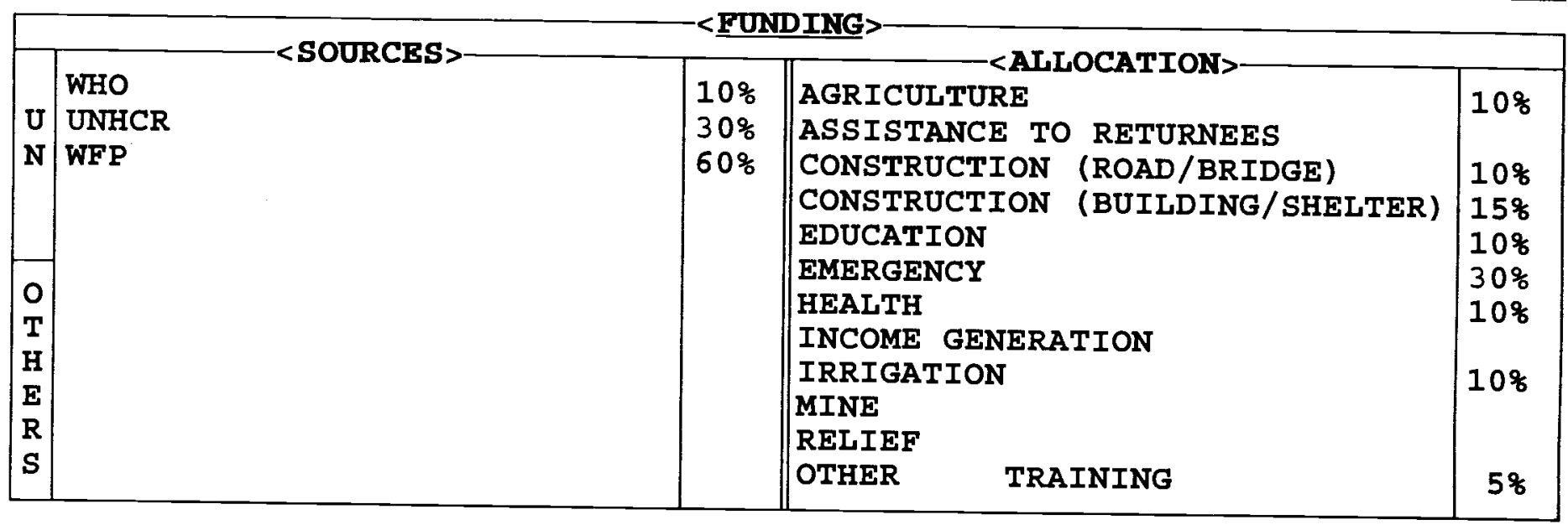

\begin{tabular}{|c|c|c|c|c|c|c|}
\hline $\begin{array}{l}\text { AFGHANISTAN : } \\
\text { REFUGEES : } \\
\text { T O T A L: }\end{array}$ & $\begin{array}{l}\frac{1992}{150,500} \\
--- \\
150,500\end{array}$ & \begin{tabular}{l}
1993 \\
146,300 \\
\hdashline 146,300
\end{tabular} & $\begin{array}{c}1994 \\
724,600 \\
--- \\
724,600\end{array}$ & $\begin{array}{c}1995 \\
897,000 \\
897,000\end{array}$ & $\begin{array}{c}1996 \\
345,900 \\
-- \\
345,900\end{array}$ & $\begin{array}{c}\frac{1997}{300,000} \\
\overline{300,000}\end{array}$ \\
\hline 要 $800=$ & $\frac{{ }_{10}}{1082}$ & 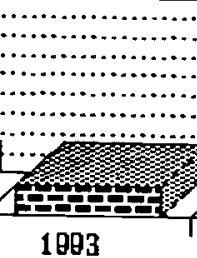 & 1004 & 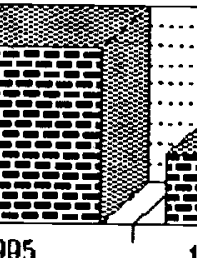 & $\frac{1}{1807}$ & 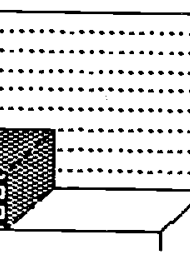 \\
\hline
\end{tabular}

\begin{tabular}{|c|c|c|c|c|c|}
\hline PROVINCES & SECTOR & \% & PROVINCES & SECTOR & $\%$ \\
\hline $\begin{array}{l}\text { BADAKSHAN } \\
\text { BADGHIS } \\
\text { BAGHLAN } \\
\text { BALKH } \\
\text { BAMYAN } \\
\text { FARAH } \\
\text { FARYAB } \\
\text { GHAZNI } \\
\text { GHOR } \\
\text { HELMAND } \\
\text { HERAT } \\
\text { JAWZJAN } \\
\text { RABUL } \\
\text { RANDAHAR } \\
\text { RAPISA }\end{array}$ & CONST/TRAINING/EMERG. & 20 & \begin{tabular}{|l|} 
KUNAR \\
KUNDUZ \\
LAGHMAN \\
LOGAR \\
NANGARHAR \\
NIMROZ \\
ORUZGAN \\
PAKTERA \\
PAKTIA \\
PARWAN \\
SAMANGAN \\
TAKHAR \\
WARDAR \\
ZABUL
\end{tabular} & $\begin{array}{l}\text { AGR/HEALTH/IRRIG } \\
\text {. CONST/EMERGENCY } \\
\text { FOOD DISTRIBUTION }\end{array}$ & 80 \\
\hline
\end{tabular}


The Koh-i-Noor Foundation for Afghanistan is an indigenous, humanitarian, Afghan, nongovernmental, non-commercial, non-political organisation which took over the projects of the Council for International Development (CID) in July 1991

The KNF main office is in Peshawar with a sub-office in Jalalabad. The operation progranme of KNF is in the sectors of health, agriculture, irrigation, education, emergency and rehabilitation and relief commodities distribution.

\section{KNF Specialisation Areas}

- Reconstruction Activitics

- Agriculture Programme

- Irrigation system repair

- Relief and emergency Programme

- Education and Training.

\section{Reconstruction}

With cooperation of UNHCR, WFP, UNDCP and FAO the construction and repair of roads, clinic buildings and mosques were implemented by the KNF.

\section{Agriculture Programme}

In the past KNF implemented several projects in the State Farms of Ghazi Abad, Baktikot district, including field crops, horticulture and farm maintenance.

KNF has distributed improved secds to farmers in Eshpora, Surkhrod, Lalpur, Lakhi and Pacheer/Agam areas of Nangarhar Province. A tree plantation project was completed in Surkhrod district with WFP assistance.

The Nursery programme of fruit and forest trees in Nimla/ Sherzad district is ongoing.

\section{Medical Services}

Basic health centres wcre operated in Deh Bala and Surkhrod areas. Currently KNF runs Saber Clinic in Pacheer/ Agam district. A mobile clinic for gynaecology and obstetrics operates in five districts of Nangarhar Province.
Medicines and medical equipment is provided to 3 doctors, 3 nurses, 1 vaccinator and 1 drug/health educator. These teams treat some 3,000 patients per month.

\section{Irrigation Programme}

KNF has completed a canal rehabilitation programme in Nangarhar Province. Other irrigation projects in Dara-i-Noor, Surkhrod and Chaperhar have also been completed.

\section{Relief and Emergency Programme}

KNF has distributed hundreds of tons of food wheat to displaced families in different parts of Nangarhar Province. A Bakery programme is ongoing in Jalalabad for displaced people.

\section{Education and Training Programme}

KNF has trained 100 teachers from different districts on drug awareness. These teachers will take their knowledge to the community to try and eradicate drug abuse

\section{Further Information}

KNF established a sub-office in Kabul city in April 1995.

\section{Future Objectives}

KNF plan to continue their work in reconstruction, training, health and agriculture in Kabul and Nangarhar Provinces. 
1, ARBAB ROAD, U/T P.O.BOX 906

PESHAWAR, PAKISTAN
PHONE : 840021,42595

F A X: 840533

TELEX :
1. MUZAMIL MOHAMMAD

2. AHMAD KHALAF

3. RIAZ NAWAZ

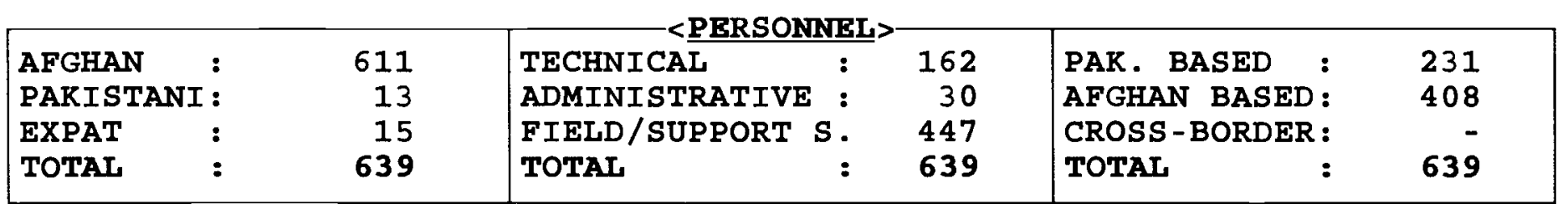

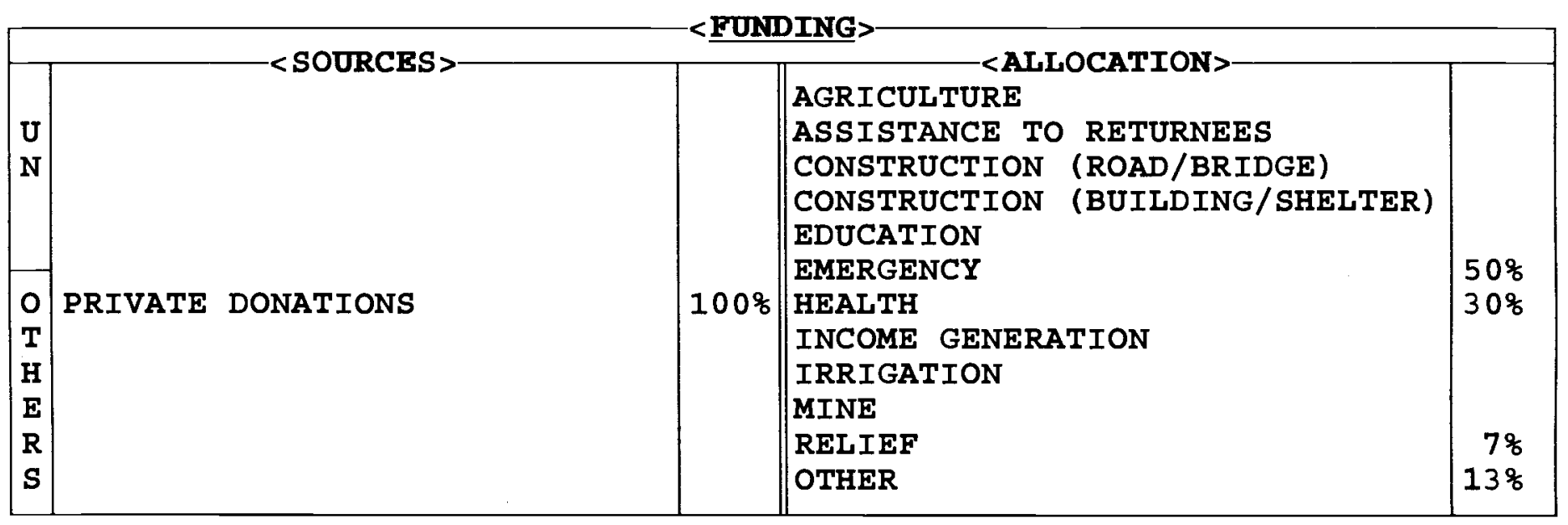

\begin{tabular}{|c|c|c|c|c|c|c|}
\hline & 1992 & 1993 & 1994 & 1995 & 1996 & 1997 \\
\hline AFGHANISTAN : & $1,224,000$ & $2,291,600$ & 666,760 & 750,000 & 631,900 & 535,900 \\
\hline $\begin{array}{l}\text { REFUGEES : } \\
\text { T O T A L: }\end{array}$ & $\begin{array}{l}2,670,000 \\
3,894,000\end{array}$ & $\begin{array}{l}3,437,450 \\
5,729,050\end{array}$ & $\begin{array}{l}1,000,140 \\
1,666,900\end{array}$ & $\begin{array}{r}916,700 \\
1,666,700\end{array}$ & $\begin{array}{r}909,300 \\
1,541,200\end{array}$ & $\begin{array}{l}1,031,750 \\
1,567,650\end{array}$ \\
\hline
\end{tabular}

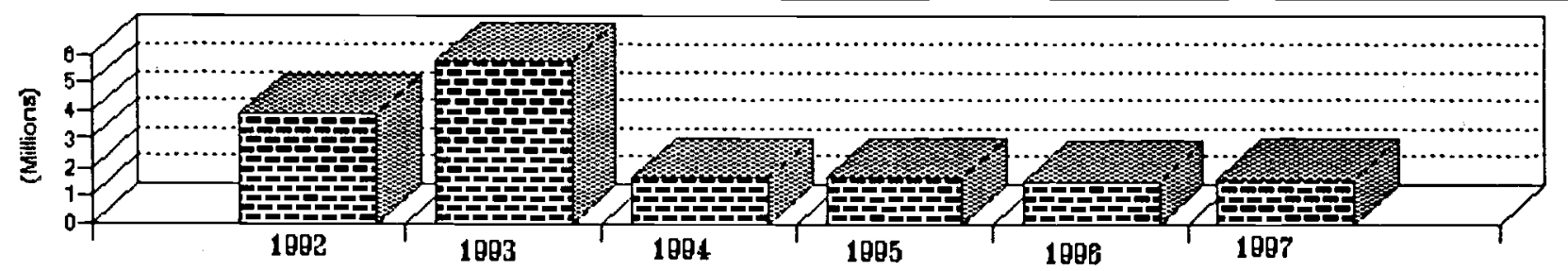

\begin{tabular}{|c|c|c|c|c|c|}
\hline PROVINCES & SECTOR & $\%$ & PROVINCES & SECTOR & $\frac{9}{6}$ \\
\hline $\begin{array}{l}\text { BADAKSHAN } \\
\text { BADGHIS } \\
\text { BAGHLAN } \\
\text { BALKH } \\
\text { BAMYAN } \\
\text { FARAH } \\
\text { GARDEZ } \\
\text { GHAZNI } \\
\text { GHOR } \\
\text { HELMAND } \\
\text { HERAT } \\
\text { JAWZJAN } \\
\text { KABUL } \\
\text { KANDAHAR } \\
\text { KAPISA }\end{array}$ & EDUCATION & 2 & $\begin{array}{l}\text { KUNAR } \\
\text { KUNDUZ } \\
\text { LAGHMAN } \\
\text { LOGAR } \\
\text { NANGARHAR } \\
\text { NIMROZ } \\
\text { ORUZGAN } \\
\text { PAKTEKA } \\
\text { PAKTIA } \\
\text { PARWAN } \\
\text { SAMANGAN } \\
\text { TAKHAR } \\
\text { WARDAK } \\
\text { ZABUL } \\
\text { REFUGEES }\end{array}$ & $\begin{array}{l}\text { HEALTH/EDUCATION } \\
\text { EDUCATION } \\
\text { HEALTH/EDUCATION } \\
\text { HEALTH/EDU/WATER SUP }\end{array}$ & $\begin{array}{l}25 \\
65\end{array}$ \\
\hline
\end{tabular}




\section{LAJNAT AL-DAWA AL-ISLAMIAH}

(LDI)

LDI is an Islamic charity organisation working for Afghans for the past several years. LDI has been working in the ficlds of health, education and relief.

Health: LDI runs facilities, both for refugees and in Afghanistan;

- a 200 bed hospital in Peshawar;

- a hospital in Sadda - Kohat;

- a comprehensive clinic in Landi Kotal, one in Ghazni and three in Wardak;

- a hospital in Tangi, Wardak;

- a hospital in Sharan, Pakteka.

LDI also supports 6 clinics of different types (comprehensive clinics to basic health posts) in 3 Provinces of Afghanistan.

A medical training programme was conducted in Peshawar, but this was discontinued in 1990. The programme trained Afghans in X-ray, laboratory, anesthesia and operating theatre work.

Education: LDI support 10 secondary and 2 primary schools and a teacher training Institute in Pakistan. The agency also supports 4 Quranic centres. Education activities include training electricians (51 trained so far); publication services, which translate and print literature into Farsi and Pushto; and a cultural centre, (collection of printed, audio and visual materials).

Lectures are organised in the refugee camps.

In Afghanistan, LDI supports two secondary schools and 8 primary /middle schools (5 for girls) in the Provinces of Paktia, Ghazni and Wardak.

LDI as part of its relief operation, has a drinking water programme which builds tubewells in refugee camps. 


\section{$<$ ADDRESS}

2 AFZAL ROAD, OLD BARA ROAD, UNIVERSTIY TOWN PESHAWAR， PAKISTAN
PHONE : 845393

F A X: 845393

email:

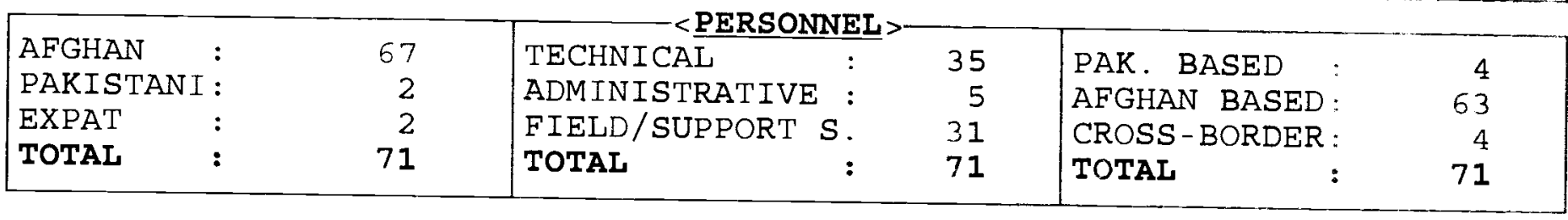

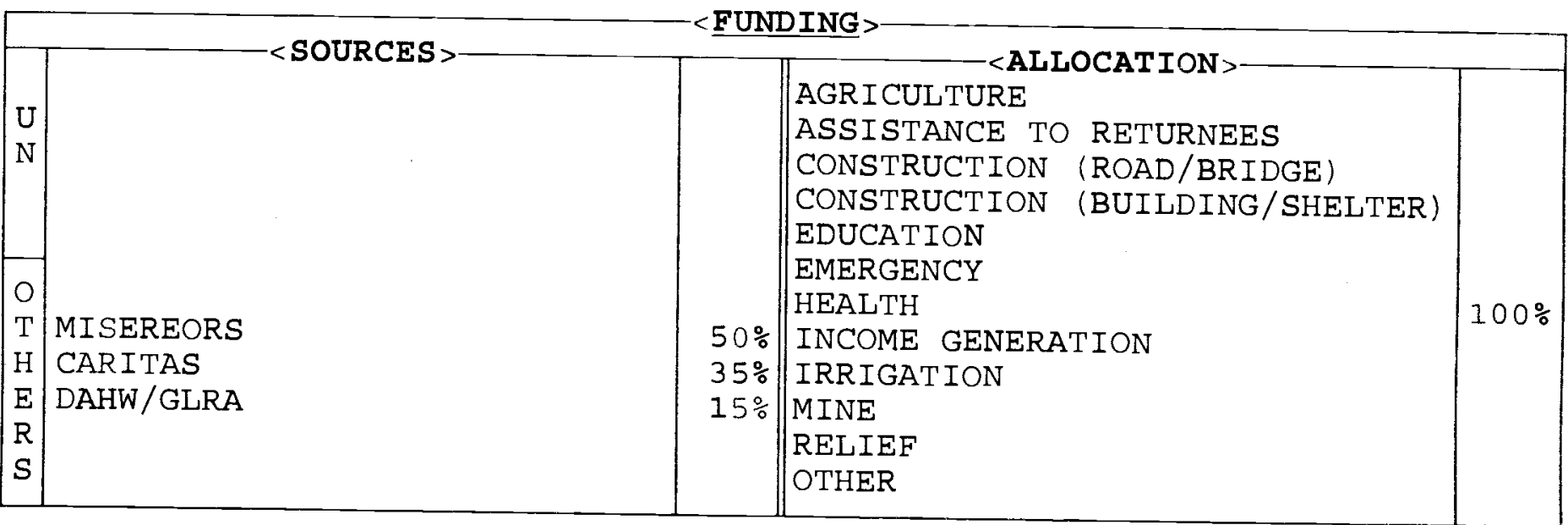

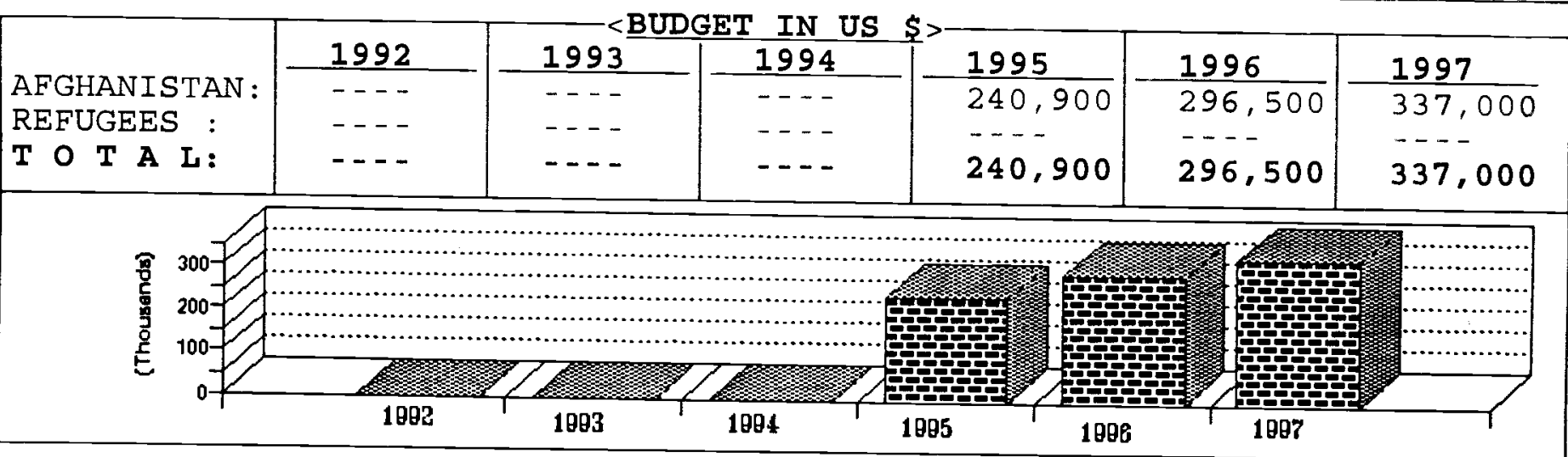

\begin{tabular}{|c|c|c|c|c|c|}
\hline PROVINCES & SECTOR & $\%$ & PROVINCES & SECTOR & $\%$ \\
\hline $\begin{array}{l}\text { BADAKSHAN } \\
\text { BADGHIS } \\
\text { BAGHLAN } \\
\text { BALKH } \\
\text { BAMYAN } \\
\text { FARAH } \\
\text { FARYAB } \\
\text { GHAZNI } \\
\text { GHOR } \\
\text { HELMAND } \\
\text { HERAT } \\
\text { JAWZJAN } \\
\text { KABUL } \\
\text { KANDAHAR } \\
\text { KAPISA }\end{array}$ & $\begin{array}{l}\text { HEALTH } \\
\text { HEALTH } \\
\text { HEALTH } \\
\text { HEALTH }\end{array}$ & $\begin{array}{l}11 \\
25 \\
\\
21 \\
15\end{array}$ & \begin{tabular}{|l} 
KUNAR \\
KUNDUZ \\
LAGHMAN \\
LOGAR \\
NANGARHAR \\
NIMROZ \\
ORUZGAN \\
PAKTEKA \\
PAKTIA \\
PARWAN \\
SAMANGAN \\
TAKHAR \\
WARDAK \\
ZABUL \\
PAKISTAN
\end{tabular} & 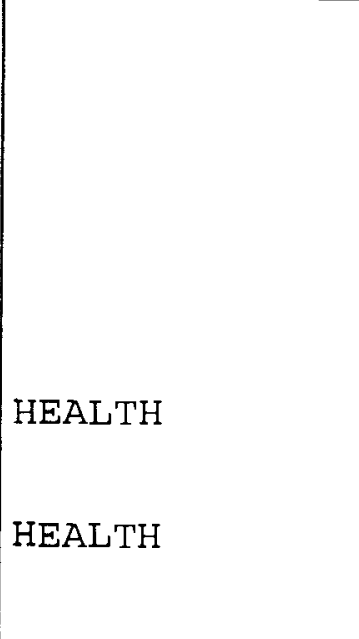 & 11 \\
\hline
\end{tabular}




\section{LEPCO}

LEPCO was originally working in Pakistan with the Afghan refugees and 1984 moved some programmes to Afghanistan. The head office is at present in Mazar-i-Sharif with a sub office in Peshawar.

LEPCO is active in the health-care sector, especially and mainly in the field of tuberculosis and leprosy control. The major aims are to:

- $\quad$ reduce the prevalence and incidence of leprosy to such an extent that leprosy no longer remains a public health problem in Hazarajat;

- prevent physical impairments, deformities and disabilities which could be caused by leprosy in all patients newly detected in Hazarajat;

- $\quad$ to prevent further deterioration of disabilities caused by leprosy in all leprosy patients with disabilities registered in Hazarajat;

- $\quad$ to set up in co-operation with other organizations a TB control programme covering the northern regions of Afghanistan and Hazarajat with a case detection rate for sputum positive TB of at least 70 percent of the annual incidence and a cure rate of at least 85 percent.

For several years now, the nine LEPCO clinics have been providing general health-care as well as TB and leprosy care mostly in Hazarajat. Their TB activities need to be strengthened. This will be done through training of clinic staff and more frequent supervisory visits by the medical officers.

Recently, in March 1997, a TB Task-force was established in Mazar-i-Sharif in which experts from the Ministry of Health of northern Afghanistan, WHO and several NGOs try to coordinate efforts aimed at tackling the TB problem in northern Afghanistan. In this Taskforce LEPCO plays an active part.
The intention is to set up a TB control structure in Mazar and surrounding areas. This will later be extended to the remaining Provinces of northern Afghanistan. For this structure, existing health facilities will be used. Training of staff, close supervision and supervision of good quality TB drugs free of charge are the key elements.

LEPCO plan to establish a TB control programme in Hazarajat using already existing general health facilities and other NGOs.

All these activities will be implemented in accordance with the policies of WHO/ILEP where leprosy is concerned and WHO/IUATLD (International Union Against Tuberculosis and Lung Diseases) where tuberculosis is concerned. 
53 C-II GULMOHAR LANE UNIVERSITY TOWN PESHAWAR， PAKISTAN
PHONE : 840546

F A X: 840234

email:
1. DR J-F CAUTAIN

2. FRANK LAMENDOUR

3. ESMAT SAIFI

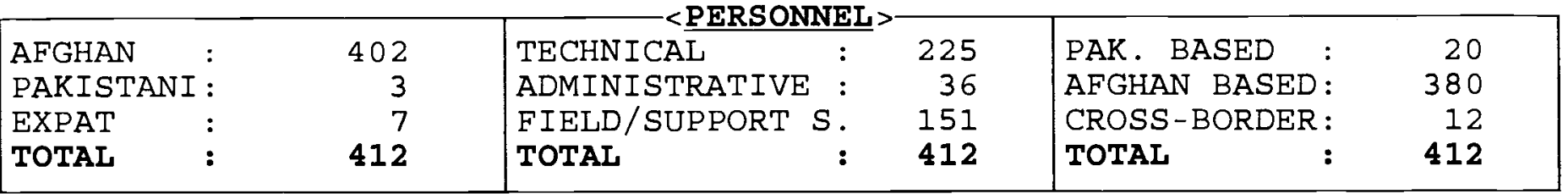

\begin{tabular}{|c|c|c|c|c|}
\hline \multicolumn{5}{|c|}{$<$ SOURCES $>$} \\
\hline & & & AGR I CULTURE & $27 \%$ \\
\hline $\mathrm{U}$ & FAO & $2 \%$ & ASSISTANCE TO RETURNEES & $30 \%$ \\
\hline $\mathrm{N}$ & UNOPS & $1 \%$ & CONSTRUCTION （ROAD/BRIDGE） & \\
\hline & WEP & $8 \div$ & CONSTRUCTION (BUILDING/SHELTER) & $5 \%$ \\
\hline & & & $\begin{array}{l}\text { EDUCATION } \\
\text { EMERGENCY }\end{array}$ & $25 \%$ \\
\hline 0 & & & HEALTH & \\
\hline $\mathrm{T}$ & EUROPEAN UNION & $56 \%$ & INCOME GENERATION & \\
\hline $\mathrm{H}$ & FRENCH GOVERNMENT & $9 \%$ & IRRIGATION & $13 \%$ \\
\hline $\mathrm{E}$ & ECHO & $22 \%$ & MINE & \\
\hline $\mathrm{R}$ & NCA & $1 \%$ & RELIEF & \\
\hline$S$ & GAA & $1 \%$ & OTHER & \\
\hline
\end{tabular}

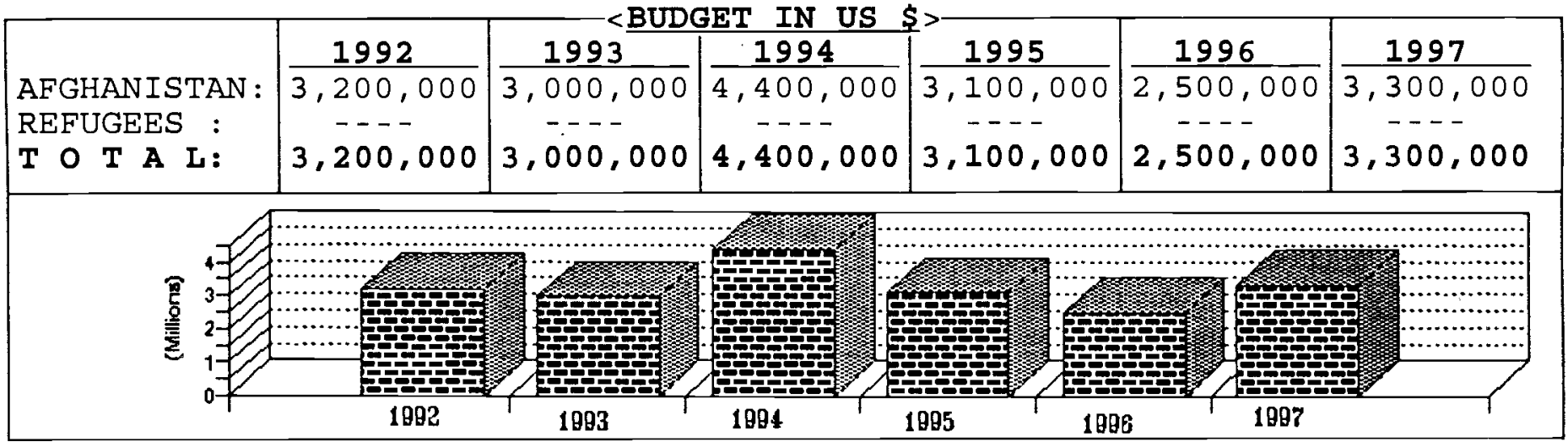

\begin{tabular}{|c|c|c|c|c|c|}
\hline PROVINCES & SECTOR & $\%$ & PROVINCES & D & $\%$ \\
\hline $\begin{array}{l}\text { BADAKSHAN } \\
\text { BADGHIS } \\
\text { BAGHLAN } \\
\text { BALKH } \\
\text { BAMYAN } \\
\text { FARAH } \\
\text { FARYAB } \\
\text { GHAZNI } \\
\text { GHOR } \\
\text { HELMAND } \\
\text { HERAT } \\
\text { JAWZJAN } \\
\text { KABUL } \\
\text { KANDAHAR } \\
\text { KAPISA }\end{array}$ & & & $\begin{array}{l}\text { KUNAR } \\
\text { KUNDUZ } \\
\text { LAGHMAN } \\
\text { LOGAR } \\
\text { NANGARHAR } \\
\text { NIMROZ } \\
\text { ORUZGAN } \\
\text { PAKTEKA } \\
\text { PAKTIA } \\
\text { PARWAN } \\
\text { SAMANGAN } \\
\text { TAKHAR } \\
\text { WARDAK } \\
\text { ZABUL } \\
\text { PAKISTAN }\end{array}$ & $\begin{array}{l}\text { AGRIC/VET/CONST/FOR } \\
\text { AGRIC/VET/RET . / IRRIG } \\
\text { AGRIC/RET . / IRRIG } \\
\text { AGRICULTURE }\end{array}$ & $\begin{array}{l}20 \\
30 \\
40\end{array}$ \\
\hline
\end{tabular}




\section{MADERA}

MADERA (Mission d'Aide au Developpement des Economies Rurales en Afghanistan) is a European NGO founded in 1988 when, it took over the agro-pastoral programme initiated by BIA (Bureau Internationale Afghanistan).

MADERA has a strong involvement in Laghman and Kunar Provinces including the high valleys of Kamdesh, Waygal and Upper Peck where few NGOs are working.

In 1992 MADERA established a new programme in Wardak Province, Markaz Behsud and Gardandewal districts in agriculture; and late 1993, it set up a Division for Rehabilitation to assist the return of refugees to Nangarhar and Laghman devastated areas, through an integrated approach (construction of flood control works, canal repair, land clearing/ploughing facilities, supply of seeds/fertilisers).

In 1994/95 MADERA provided emergency relief - drinking water and various commodities (blankets, tents...) to displaced people of Hisar Shahi and Hada camps in Nangarhar Province.

\section{General strategy}

- $\quad$ to link present rehabilitation concerns with a long term development perspective.

- MADERA has always paid special attention to the establishment of mutual understanding and clear agreement with local people through a ban on any favouritism towards any tribe, village or faction.

A network of 26 permanent centres allows a deep entrenchment of MADERA's activities; this was recently re-organised to fit administrative divisions. Highly experienced Afghan and expatriate staff are hired on a long term basis; most working for several years within MADERA.

\section{Future direction}

In 1996 MADERA conducted a large survey at the village level in Nangarhar, South Kunar and South Laghman to study the potential for returnees and the rehabilitation needs. On the basis of this study, target zones with high potential for returnees have been identified.

In 1997 MADERA wants to establish, with a core of NGOs, integrated programmes in these target zones to enable returnees to resettle themselves in the best conditions. This integrated approach will involve NGOs working in different sectors such as health (AMI, Healthnet International), education (SCA, SAB), drinking water (GAA, DACAAR), community building (SRC).

The local population will be active partners and will play a greater role in their own development. MADERA will also require local contributions e.g. voluntary labour for certain projects. Emphasis will be on extension of new techniques and know-how in agriculture, livestock and forestry. MADERA will also use participative rural appraisal methods to better assess the needs and address specific problems.

Finally MADERA will make Nooristan Province and Hazarajat, priority targets for future programmes. 
MULTI-ACTIVITY RURAL REHZ ILIATION FOUNDATION (MARUF)

ACBAR

18 B SPEEN ZAR PLAZA UNIVERSITY TOWN PESHAWAR，PAKISTAN
PHONE : 44986

F A X: 44986

email :
1. ARCHT A H LATIFY

2. ABDUL MUJEEB

3. ENG NOOR UL HAQ

\begin{tabular}{|c|c|c|c|c|c|}
\hline AFGHAN & 60 & TECHNICAL : & 14 & PAK. BASED & 5 \\
\hline PAKISTANI & 1 & ADMINISTRATIVE : & 10 & AFGHAN BASED: & 50 \\
\hline EXPAT & - & FIELD/SUPPORT S. & 37 & CROSS-BORDER : & 6 \\
\hline TOTAL & 61 & TOTAL : & 61 & TOTAL : & 61 \\
\hline
\end{tabular}

\begin{tabular}{|c|c|c|c|c|}
\hline & $-<$ SOURCES & & $<$ ALLOCATION $>$ & \\
\hline UT & & & & \\
\hline & & $2 \%$ & ASSISIANCE IO REIURINEES & \\
\hline $\mathrm{N}$ & UNHCR & $10 \%$ & CONSTRUCTION （ROAD/BRIDGE） & \\
\hline & WFP & $28 \%$ & CONSTRUCTION (BUILDING/SHELTER) & $34 \%$ \\
\hline & UNOPS & $2 \%$ & EDUCATION & \\
\hline - & & & EMERGENCY & \\
\hline 0 & & & HEALTH & \\
\hline $\mathrm{T}$ & GTZ/NSP & $9 \%$ & INCOME GENERATION & $10 \%$ \\
\hline $\mathrm{H}$ & CANADA FUND & $4 \%$ & IRRIGATION \& WATER SUPPLY & $77 \%$ \\
\hline $\mathrm{E}$ & PRIVATE DONATIONS & $15 \%$ & MINE & \\
\hline $\mathrm{R}$ & & & RELIEF & \\
\hline $\mathrm{S}$ & & & OTHER & \\
\hline
\end{tabular}

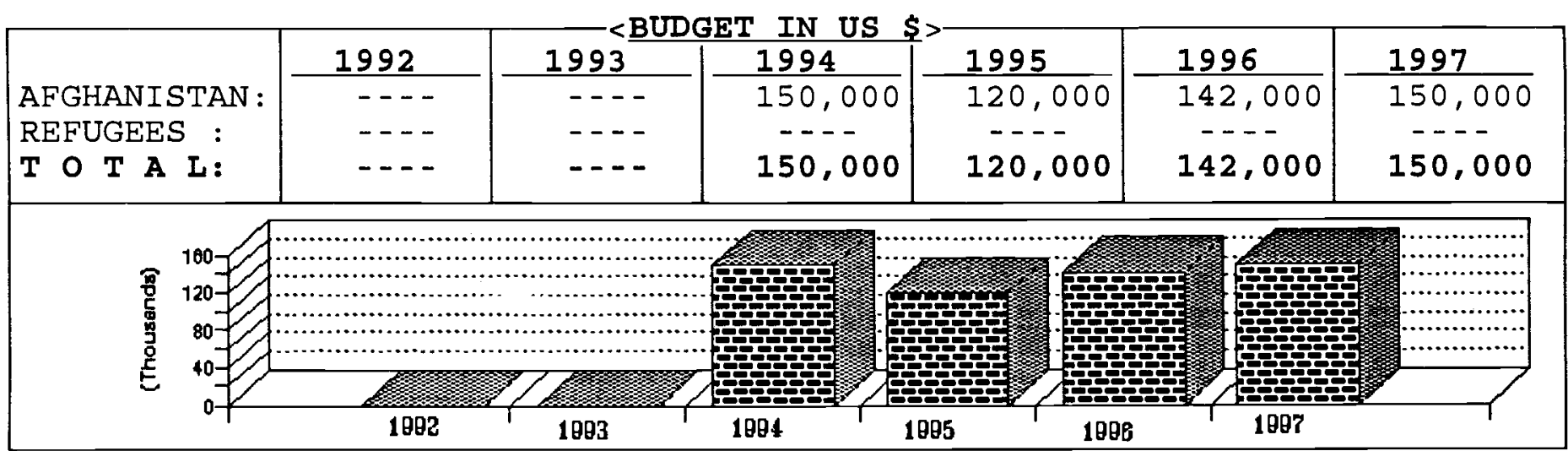

\begin{tabular}{|c|c|c|c|c|c|}
\hline PROVINCES & SECTOR & $\%$ & PROVINCES & SECTOR & $\%$ \\
\hline $\begin{array}{l}\text { BADAKSHAN } \\
\text { BADGHIS } \\
\text { BAGHLAN } \\
\text { BALKH } \\
\text { BAMYAN } \\
\text { FARAH } \\
\text { FARYAB } \\
\text { GHAZNI } \\
\text { GHOR } \\
\text { HELMAND } \\
\text { HERAT } \\
\text { JAWZJAN } \\
\text { KABUL } \\
\text { KANDAHAR } \\
\text { KAPISA }\end{array}$ & INCOME GENERATION & 10 & $\begin{array}{l}\text { KUNAR } \\
\text { KUNDUZ } \\
\text { LAGHMAN } \\
\text { LOGAR } \\
\text { NANGARHAR } \\
\text { NIMROZ } \\
\text { ORUZGAN } \\
\text { PAKTEKA } \\
\text { PAKTIA } \\
\text { PARWAN } \\
\text { SAMANGAN } \\
\text { TAKHAR } \\
\text { WARDAK } \\
\text { ZABUL } \\
\text { PAKISTAN }\end{array}$ & $\begin{array}{l}\text { CONSTRUCTION } \\
\text { CONST/IRRIG } \\
\text { CONST/IRRIG/SANIT } \\
\text { WATER SUPPLY/CONST }\end{array}$ & $\begin{array}{r}4 \\
18 \\
22\end{array}$ \\
\hline
\end{tabular}




\section{MULTI-ACTIVITY RURAL REHABILITATION FOUNDATION \\ (MARUF)}

MARUF is an Afghan NGO with qualified

staff, established with the support of

GTZ/DESP.

\section{Aims of MARUF}

Its main objectives are to contribute to the retonstruction and rehabilitation of

Afghanistan, with the active participation of the community in the implementation of projects, according to community priorities.

\section{Sectors of Operation}

Reconstruction

Rehabilitation and reconstruction of public

buildings, such as schools, clinics and

administrative offices.

Rehabilitation of secondary roads.

\section{Social Services}

Shelter, with low cost and environmentally sound construction technologies; by using local improved material and locally available skills.

Rehabilitation of water supply and improvement of sanitation systems and other public health activities, including community awareness regarding health education.

\section{Training}

Human Resource development, by training people in the fields of masonry, carpentry, leather work, tailoring and poultry farming.

\section{Irrigation}

Rehabilitation of irrigation systems.

\section{Others}

Providing consultancy for all agencies in the fields of building designs, supervisory and monitoring tasks in Pakistan and Afghanistan.

Consultancy in the field of problem analysis on project implementation and planning new phases, using ZOPP system, which is common in GTZ, in Pakistan and Afghanistan.

\section{Future Objectives}

Future objectives include the restoration of monuments.

\section{Further Information}

MARUF is registered with:

Nangarhar Shura, Kunduz, Badakshan and the Ministry of Rural Development in Kabul, Afghanistan

Regional Offices: Nangarhar, Khost, Kabul and Kunduz. 
COMMUNICATION LINES>

391, D- 4, ST 27, PHSE I PHONE: 810391/810540 HAYATABAD, GPO BOX 655 PESHAWAR, PAKISTAN
F A X:

TELEX:
1. S.A. TAHSEEN

2 .

3 .

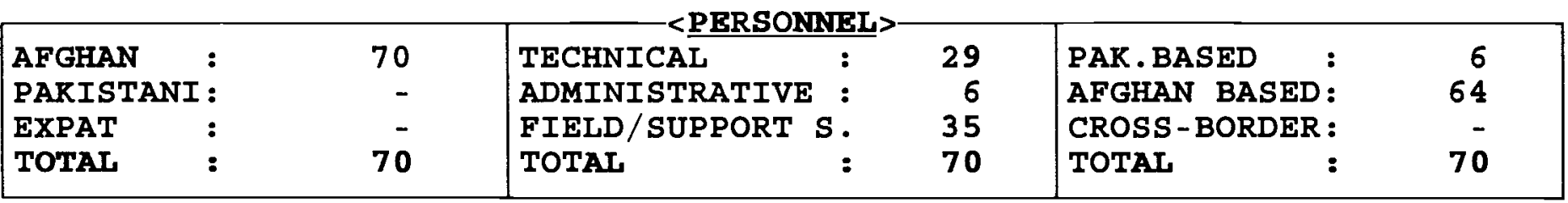

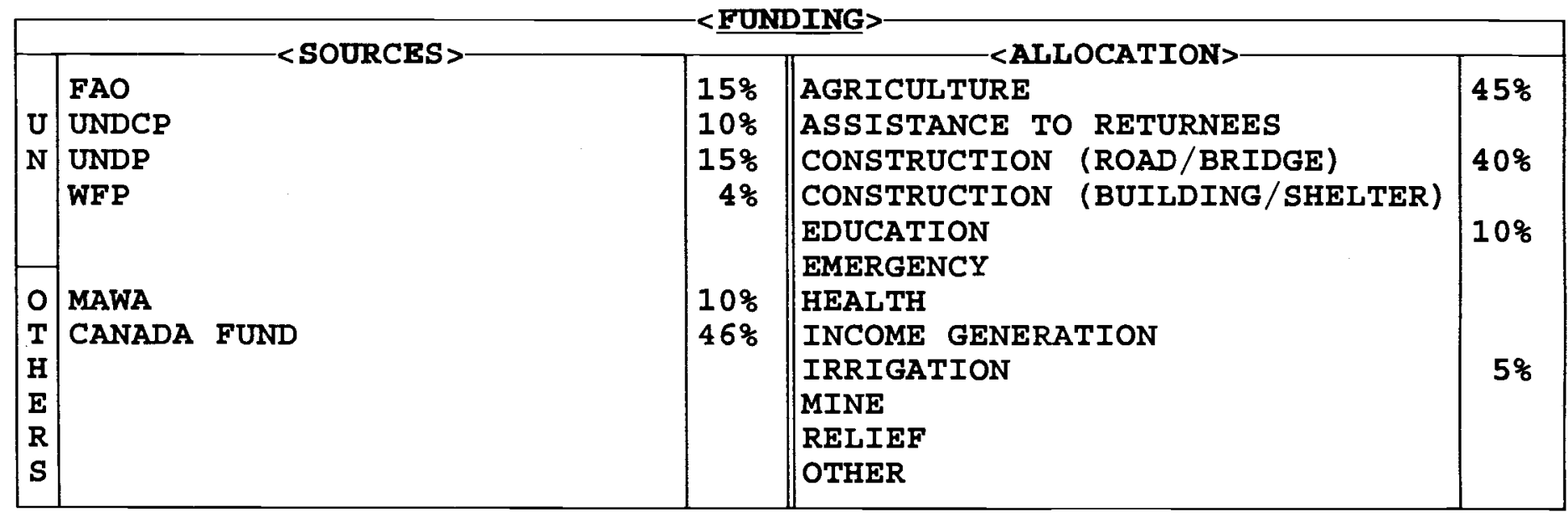

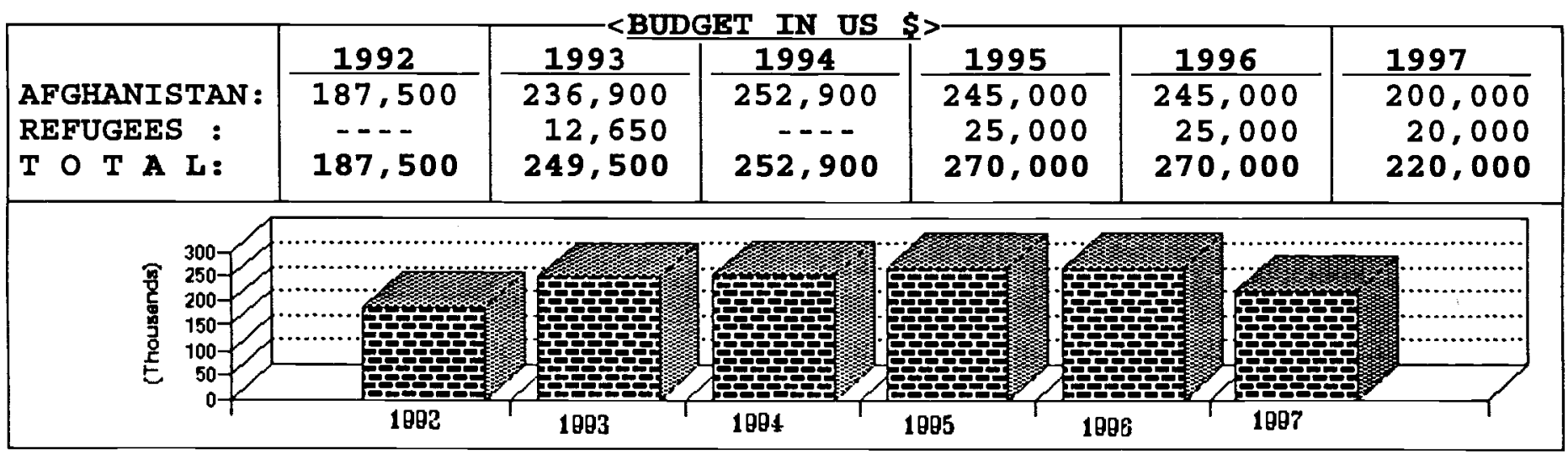

\begin{tabular}{|c|c|c|c|c|c|}
\hline PROVINCES & SECTOR & $\%$ & PROVINCES & SECTOR & $\%$ \\
\hline $\begin{array}{l}\text { BADAKSHAN } \\
\text { BADGHIS } \\
\text { BAGHLAN } \\
\text { BALKH } \\
\text { BAMYAN } \\
\text { FARAH } \\
\text { FARYAB } \\
\text { GHAZNI } \\
\text { GHOR } \\
\text { HELMAND } \\
\text { HERAT } \\
\text { JAWZJAN } \\
\text { KABUL } \\
\text { KANDAHAR } \\
\text { KAPISA }\end{array}$ & IRRIGATION & 5 & $\begin{array}{l}\text { KUNAR } \\
\text { KUNDUZ } \\
\text { LAGHMAN } \\
\text { LOGAR } \\
\text { NANGARHAR } \\
\text { NIMROZ } \\
\text { ORUZGAN } \\
\text { PAKTEKA } \\
\text { PAKTIA } \\
\text { PARWAN } \\
\text { SAMANGAN } \\
\text { TAKHAR } \\
\text { WARDAK } \\
\text { ZABUL } \\
\text { REFUGEE }\end{array}$ & $\begin{array}{l}\text { AGRICULTURE / CONST } \\
\\
\text { EDUCATION }\end{array}$ & . \\
\hline
\end{tabular}


MUSLIM ASSISTANCE AND WELFARE

ASSOCIATION

(MAWA)

MAWA is an Afghan NGO set up in 1989. The main purpose of this association is to take part in the rchabilitation and reconstruction of

Afghanistan

The agency works in the sectors of agriculture, construction, handicrafts, education and health. It has completed about 30 agricultural and construction projects in Nangarhar and Logar Provinces. Ten projects are ongoing. Thirty six projects are in the planning process.

In the refugee sector. MAWA has training centres for men and women in Hayatabad where courses are offered in lapidary and gem cutting.

The agency's main office is in Peshawar. It has a sub-office in Mazina village of Roday district and another office in Jalalabad. 
MERCY CORPS INTERNATIONAL (MCI)

P.O.BOX 314

QUETTA,

PAKISTAN
PHONE : 442863

F A X: 449473

TELEX :
1. MARK PONT

2. RAHMATULLAH

3 .

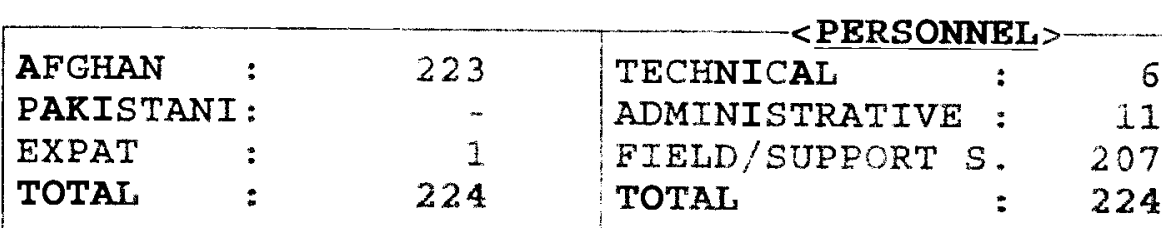

PAK.BASED

AFGHAN BASED:

CROSS-BORDER :

TOTAL
215

224
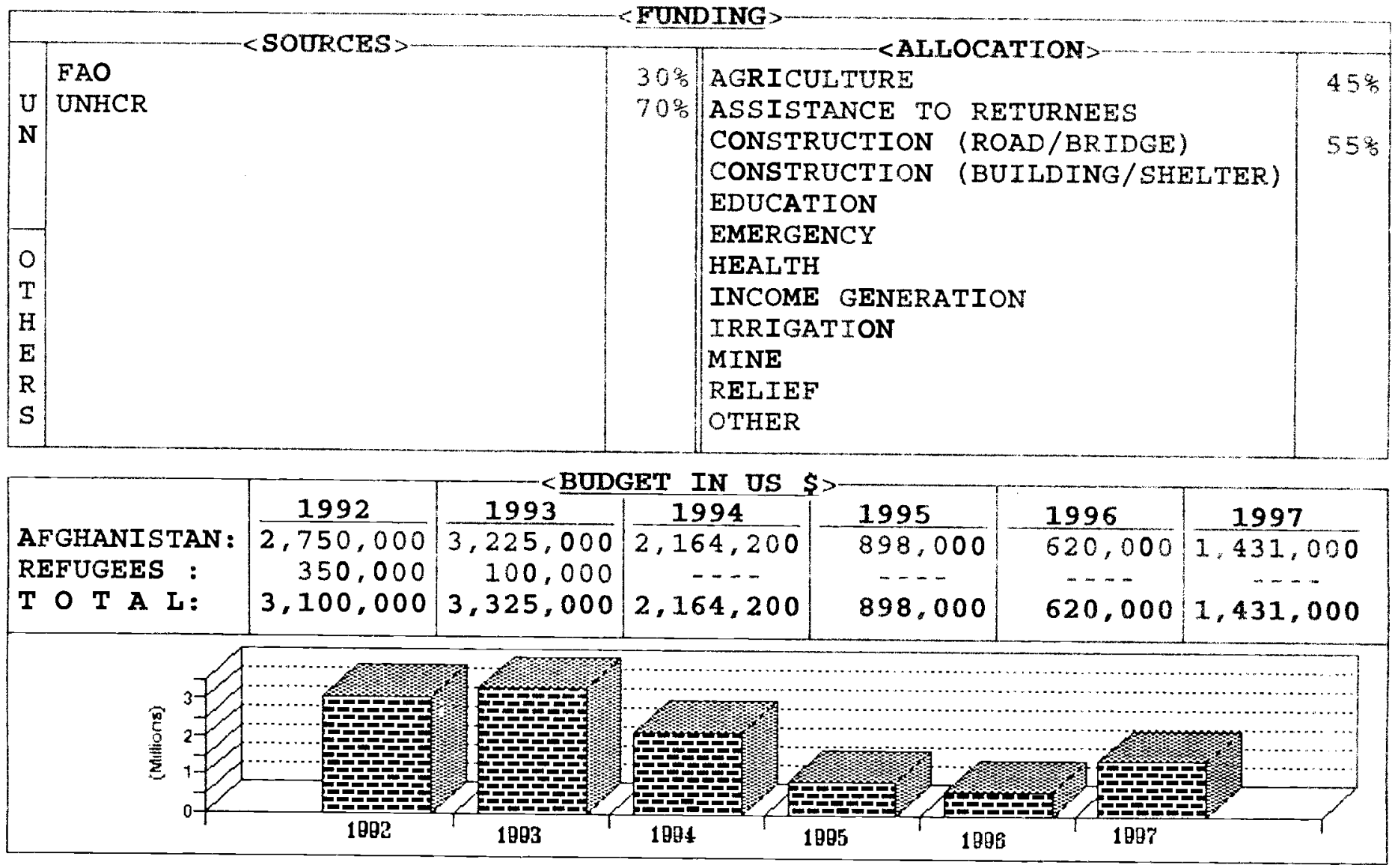

\begin{tabular}{|c|c|c|c|c|c|}
\hline PROVINCES & SECTOR & $\%$ & PROVINCES & SECTOR & $\%$ \\
\hline $\begin{array}{l}\text { BADAKSHAN } \\
\text { BADGHIS } \\
\text { BAGHLAN } \\
\text { BALKH } \\
\text { BAMYAN } \\
\text { FARAH } \\
\text { FARYAB } \\
\text { GHAZNI } \\
\text { GHOR } \\
\text { HELMAND } \\
\text { HERAT } \\
\text { JAWZJAN } \\
\text { RABUL } \\
\text { RANDAHAR } \\
\text { RAPISA }\end{array}$ & $\begin{array}{l}\text { AGRIC/CONST } \\
\text { AGRIC / CONST } \\
\text { AGRIC / CONST }\end{array}$ & 30 & $\begin{array}{l}\text { KUNAR } \\
\text { KUNDUZ } \\
\text { LAGHMAN } \\
\text { LOGAR } \\
\text { NANGARHAR } \\
\text { NIMROZ } \\
\text { ORUZGAN } \\
\text { PAKTEKA } \\
\text { PAKTIA } \\
\text { PARWAN } \\
\text { SAMANGAN } \\
\text { TAKHAR } \\
\text { WARDAK } \\
\text { ZABUL }\end{array}$ & & \\
\hline
\end{tabular}




\section{MERCY CORPS INTERNATIONAL \\ (MCI)}

MCl has a history of involvement in cross-border assistance in war-torn areas. Its first major project was in Sudan. It is also currently working in Honduras and the Philippines.

MCI began implementing its medical work in Quetta in 1986 and its agriculture projects in July 1988.

The medical work in Quetta began in response to the needs of the war-wounded and civilian population in south western Afghanistan and to the demands for a health infrastructure for the returning refugee population. Further expansion of $\mathrm{MCl}$ assistance, including agriculture, was to provide related assistance to the same population.

\section{Health}

The initial aim of the medical programme was to train students, selected from inside Afghanistan, in either a threc-month Basic Health Worker course or in a more advanced six-month course, offering first aid nursing skills, preventative and primary health carc, as well as training in onc of 6 speciality areas e.g. X-ray.

These trained workers were then sent back to Afghanistan to staff medical facilities that $\mathrm{MCI}$ supports

MCI now runs one-ycar courscs for advanced medical assistants. The students are often selected from among those who have previously attended shorter courses. The end of the course includes three months on a specialised area, but with onc significant area of expansion in the coursc e.g. mother/child health training.

MCI has 44 clinics with $\mathrm{MCl}$ trained workers in each. Training is ongoing. The medical training programmes place strong emphasis on the integration of thcory and practical work.

All students are taught the specifics of preventative health care and how to provide such care within their own unique cultural and social environment.
$\mathrm{MCI}$ has begun refresher and supervision missions conducted at clinics by its training doctors.

\section{Agriculture}

The purpose of the agricultural programme is to provide rehabilitation for existing villages and facilities in south western Afghanistan which have been severely damaged or destroyed by war.

Types of projects in this sector are:

irrigation, sanitation, road repair, improvement in areas of agronomy, animal husbandry, rebuilding houses and public buildings and providing discretionary funds to individuals for survival assistance. 
HOUSE 294, STREET 56

F $10 / 4$

ISLAMABAD, PAKISTAN
<COMMUNICATION LINES>

PHONE : $051211451-66$

F A X: 051297775 .org 2. ATTIQULLAH

email:mcpa@mcpa-afg.sdnpk 3. QADEEN TARIQ

\begin{tabular}{|c|c|c|c|c|c|}
\hline AFGHAN & 230 & TECHNICAL : & 148 & PAK. BASED & 39 \\
\hline PAKISTANI : & 4 & ADMINISTRATIVE : & 29 & AFGHAN BASED: & 169 \\
\hline EXPAT : & - & FIELD/SUPPORT S. & 57 & CROSS-BORDER : & 26 \\
\hline TOTAL & 234 & TOTAL : & 234 & TOTAL : & 234 \\
\hline
\end{tabular}

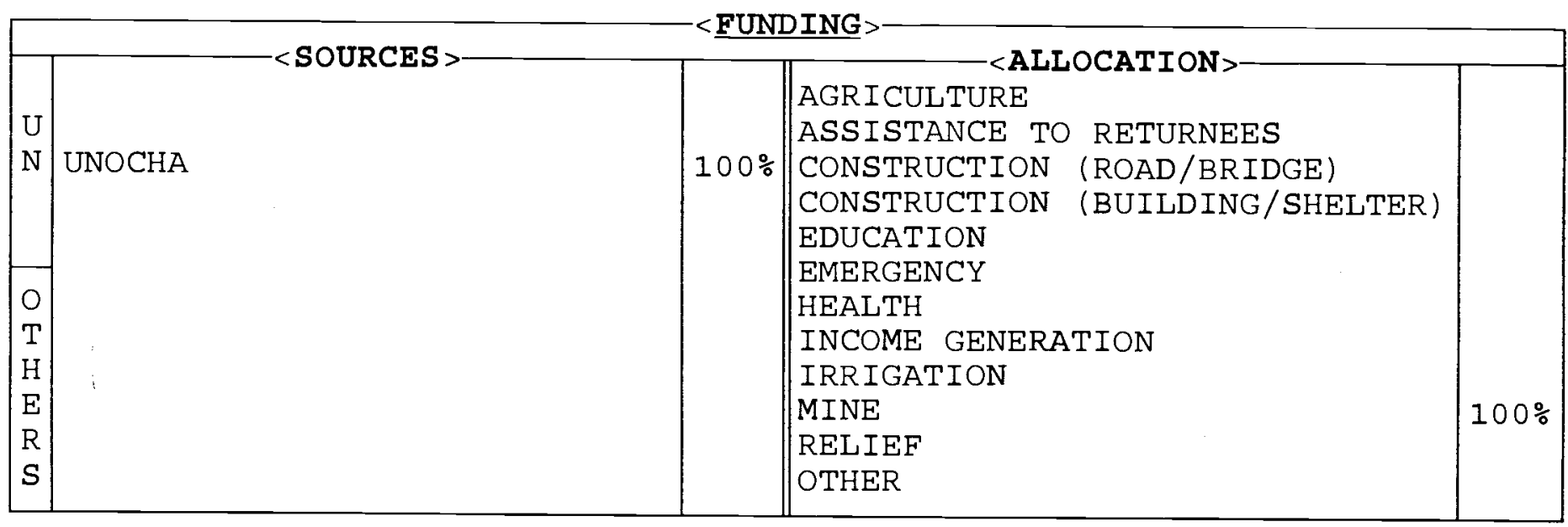

\begin{tabular}{|c|c|c|c|c|c|c|}
\hline $\begin{array}{l}\text { AFGHANISTAN: } \\
\text { REFUGEES : } \\
\text { T O T A L : }\end{array}$ & $\begin{array}{l}\frac{1992}{800,000} \\
---- \\
800,000\end{array}$ & $\begin{array}{c}\frac{1993}{2,460,000} \\
2,460,000\end{array}$ & $\begin{array}{c}\frac{1994}{2,460,000} \\
--- \\
2,460,000\end{array}$ & $\begin{array}{l}\frac{1995}{1,832,600} \\
1,832,600\end{array}$ & $\begin{array}{l}\frac{1996}{1,999,400} \\
1,999,400\end{array}$ & $\begin{array}{l}\frac{1997}{956,000} \\
956,000\end{array}$ \\
\hline 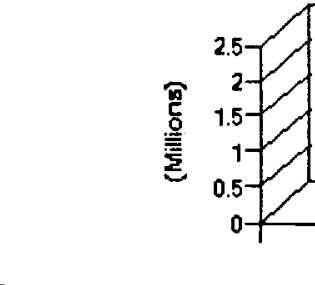 & $\frac{1002}{100}$ & 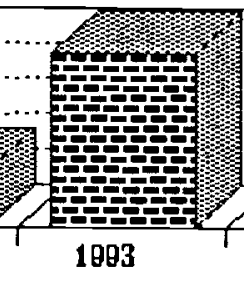 & 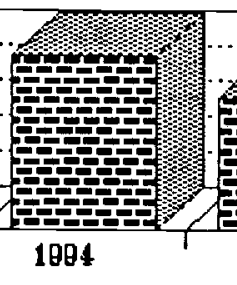 & 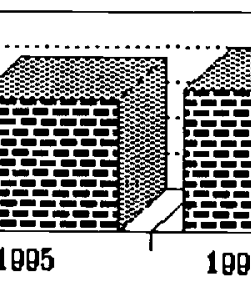 & $\frac{1}{1807}$ & \\
\hline
\end{tabular}

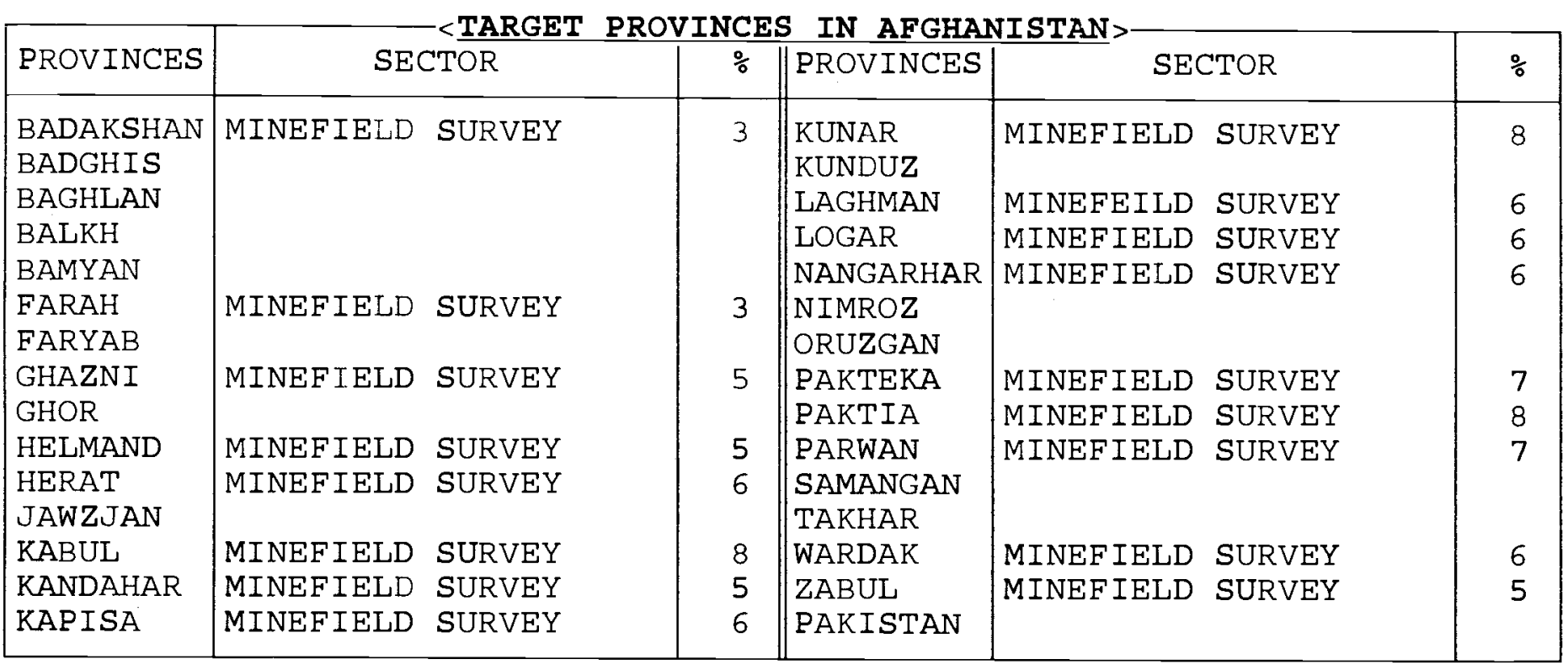




\section{MINE CLEARANCE PLANNING AGENCY (MCPA)}

MCPA is an Afghan NGO set up in early 1990. The organisation has the financial support of UNOCHA and the European Union. MCPA has its Headquarters in Islamabad with suboffices in Peshawar, Quetta and Kabul.

\section{Aims}

The main directions of the agency's work are:

survey, marking and mapping of
minefields;
- $\quad$ planning of demining operations;
- $\quad \begin{aligned} & \text { training of deminers and minefield } \\ & \text { surveyors; and }\end{aligned}$
advocacy.

\section{Sectors of Operation}

- technical survey of mined areas in Afghanistan and their identification to the demining agencies (ATC, OMAR and DAFA);

- preparation and provision of minefield maps and updated information about the mined and cleared areas. MCPA has made its own unique mapping system;

- training of new deminers/ surveyors, monitoring of the demining activities and conducting revision courses for the existing survey/demining teams as well as training of new deminers;

- recording and analyzing the data. A database has been designed where all the data about the Mine Clearance Programme is stored and analyzed for planning and management purposes;

- advance operation planning of demining activities in consultation with UNOCHA and other mine clearance agencies;

- technical and advisory support to the Islamic State of Afghanistan, provincial councils and other implementing agencies;
- nationwide survey of the mine situation in Afghanistan;

- assisting UNOCHA in the planning and coordination of demining activities.

\section{Future Objectives}

The agency wants to continue, depending on the funds available and to play a vital role in the Afghan demining programme. Preference would be to the survey of the priority areas and marking of mined areas. MCPA acts also as the coordinating agency for Afghan Campaign to Ban Landmines (ACBL), pursuing ACBL activities at national and international level.

With the vast experience in mine related activities, MCPA is ready to respond to requests for minefield survey, training and mine clearance worldwide.

\section{Further Information}

MCPA runs the operations room of Demining Headquarters in Islamabad and the Demining Offices in Peshawar, Quetta and Kabul. MCPA is a member of ACBAR, ANCB and SWABAC (1994).

MCPA has an excellent reputation both internationally and with the Afghan authorities. The agency was represented at the second International Conference of NGOs on Landmines in Geneva; Landmines Conference in Phnom Penh; and the UN sponsored International Meeting on Mine Clearance and Review Conference on the 1980 Convention of Conventional Weapons, Vienna.

MCPA also entered an agreement with the Vietnam Veterans of America Foundation (VVAF) to assist them in researching the socioeconomic impacts of landmines in Afghanistan. 
JADDRESS $>$

JAMAL FOOD INDUSTRY

MUMRIZ CHOWK PO BOX1324

PESHAWAR, PAKISTAN
PHONE : 229236

F A X: 229179

email:
$<$ KEY STAFF $>$

1. MOHD SHOHAB HAKIMI

2. MOHAMMAD ARIF

3. M YUNUS GHAZNAVI

\begin{tabular}{|c|c|c|c|c|c|}
\hline AFGHAN & 561 & TECHN ICAL & - & PAK. BASED : & 50 \\
\hline PAKISTANI & 12 & ADMINISTRATIVE : & 50 & AFGHAN BASED: & 21 \\
\hline EXPAT & 1 & FIELD/SUPPORT S. & 524 & CROSS-BORDER : & 503 \\
\hline TOTAL & 574 & TOTAL : & 574 & TOTAL : & 574 \\
\hline
\end{tabular}

\begin{tabular}{|c|c|c|c|c|}
\hline & $-\ldots$ SOURCES $>$ & & LOCATION & \\
\hline & & & AGR I CULTURE & \\
\hline $\mathrm{U}$ & & & ASSISTANCE TO RETURNEES & \\
\hline $\mathrm{N}$ & UNOCHA & $100 \%$ & CONSTRUCTION (ROAD/BRIDGE) & \\
\hline & & & CONSTRUCTION (BUILDING/SHELTER) & \\
\hline & & & EDUCATION & \\
\hline & & & EMERGENCY & \\
\hline 0 & & & HEALTH & \\
\hline $\mathrm{T}$ & & & INCOME GENERATION & \\
\hline $\mathrm{H}$ & & & IFRIGATION & \\
\hline $\mathrm{E}$ & & & MT:LE & $100 \%$ \\
\hline $\mathbf{R}$ & & & RELIEF & \\
\hline $\mathbf{S}$ & & & OTHER & \\
\hline
\end{tabular}

\begin{tabular}{|c|c|c|c|c|c|c|}
\hline $\begin{array}{l}\text { AFGHANISTAN : } \\
\text { REFUGEES : } \\
\text { T O T A L: }\end{array}$ & $\begin{array}{l}\frac{1992}{1,250,000} \\
-250,000\end{array}$ & $\frac{1993}{2,000,000}=$ & $\begin{array}{c}\frac{1994}{1,612,000} \\
1,612,000\end{array}$ & {$\left[\begin{array}{l}\frac{1995}{2,200,000} \\
2,200,000\end{array}\right.$} & $\frac{1996}{2,300,000}=$ & 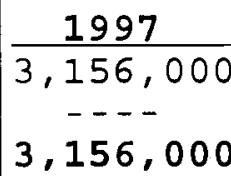 \\
\hline 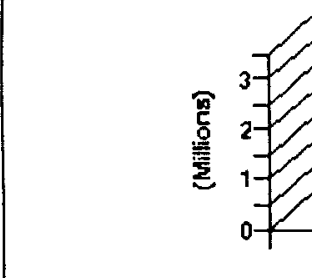 & 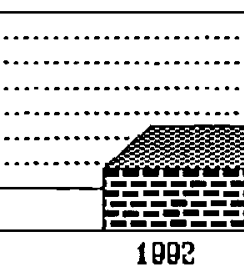 & 1893 & 1084 & 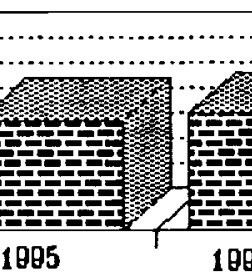 & 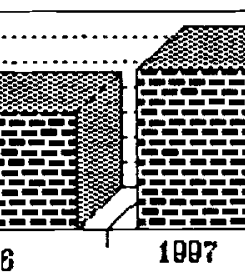 & . \\
\hline
\end{tabular}

\begin{tabular}{|c|c|c|c|c|c|}
\hline PROVINCES & SECTOR & $\%$ & PROVINCES & SECTOR & $\%$ \\
\hline $\begin{array}{l}\text { BADAKSHAN } \\
\text { BADGHIS } \\
\text { BAGHLAN } \\
\text { BALKH } \\
\text { BAMYAN } \\
\text { FARAH } \\
\text { FARYAB } \\
\text { GHAZN I } \\
\text { GHOR } \\
\text { HELMAND } \\
\text { HERAT } \\
\text { JAWZJAN } \\
\text { KABUL } \\
\text { KANDAHAR } \\
\text { KAPISA }\end{array}$ & $\begin{array}{l}\text { DEMINING } \\
\text { DEMINING } \\
\text { DEMINING } \\
\text { DEMINING } \\
\text { DEMINING }\end{array}$ & $\begin{array}{r}5 \\
5 \\
13 \\
\\
29 \\
14\end{array}$ & $\begin{array}{l}\text { KUNAR } \\
\text { KUNDUZ } \\
\text { LAGHMAN } \\
\text { LOGAR } \\
\text { NANGARHAR } \\
\text { NIMROZ } \\
\text { ORUZGAN } \\
\text { PAKTEKA } \\
\text { PAKTIA } \\
\text { PARWAN } \\
\text { SAMANGAN } \\
\text { TAKHAR } \\
\text { WARDAK } \\
\text { ZABUL } \\
\text { PAKISTAN }\end{array}$ & $\begin{array}{l}\text { DEMINING } \\
\text { DEMINING } \\
\text { DEMIN ING } \\
\text { DEMIN ING }\end{array}$ & $\begin{array}{l}7 \\
6\end{array}$ \\
\hline
\end{tabular}




\section{MINE DETECTION DOG CENTRE (MDC)}

MDC was established in 1989 by the United States Agency for International Development (USAID) and in 1992 a Memorandum of Understanding was signed by USAID and WOCHA to transter MDC technical and funding responsibilities to UNOCHA from Jamary 1993. However USAID continued to fun tor the hist 18 monts atter the VOU tos signed.

\begin{abstract}
Aims
To de-mine Afghanistan and to encourage refugees 10 return and start work in their homoland.
\end{abstract}

\section{Objectives}

The overali am of the project is to contribute to the goals and objectives of the INOCHA Whe Action Campaign to reduce the threat ot mines and other unexpioded ordnane from priority areas to allow the return of refugees and displaced people to their homes and the resumption of essential economic activity.

The primary objectives are to clear priority areas by deploying Mine Dog Croups so that the threat of mines and UXO is eliminated and to assist survey teams in minefield boundary reduction.

The secondary objectives are to contribute to the development of techniques for the use of dogs in the mine locating role and to continue the local dog breeding development programme.

\section{Achievements}

The management and operation of MDC are consistent with goals on the agreement and fulfill the requirements of the UN Mine Clearance Plan (MCP).

During the first half of 1997, Mine Dog Groups (MDGs) cleared 7.1 million square metres of mined area, of grazing, residential, agricultural land and roads. During 1996 the number of MDGs was increased from 10 to 15 .
Mine Dog Sets (MDSs) support survey teams in Mine Field boundary reduction. There are 15 MDSs.

The current dog population of the MDr is 103 irained dogs. 50 young dogs, bred at MOC and 8 puppes, donated by Handicap Intermational III). Al young dogs and puppies are wner traning,

Thes snite dogs have ben selected to whinue the breeding programme and is is hoped to increase the number of pupples by $10-15$ by the end of 1997 .

\section{International relations}

Many contacts have been made with oganisations in other countries interested in breeding, training, or using dogs in mine clearance. This enable, an exchange of infomation and experiences and can only lead to improvements world wide. 
- CADDRESS>- COMMUNICATION LINES>

LANE $Z$, STREET 15, WAZIR AKBAR KHAN KABUL, AFGHANISTAN
PHONE : 00873761292130

F A X: 00873761292132

TELEX :
1. $<$ KEY STAFF $>$

1. CAROLE DROMER

2. LAVRENT BERCK

3. DR. NAZIR

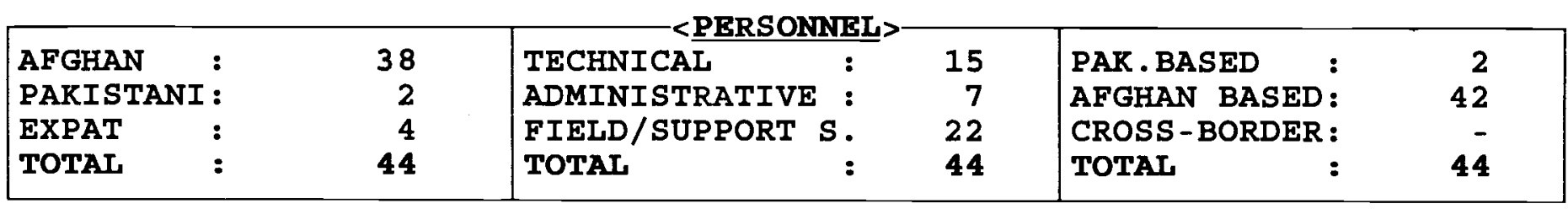

\begin{tabular}{|c|c|c|c|c|}
\hline & <SOURCES> & & <ALLOCATION & \\
\hline & UNHCR & $10 \%$ & AGRICULTURE & \\
\hline $\mathrm{U}$ & WFP & $10 \%$ & ASSISTANCE TO RETURNEES & \\
\hline $\mathbf{N}$ & & & CONSTRUCTION（ROAD/BRIDGE） & \\
\hline & & & CONSTRUCTION (BUILDING/SHELTER) & \\
\hline & & & EDUCATION & \\
\hline & & & EMERGENCY & \\
\hline 0 & & $80 \%$ & HEALTH & $100 \%$ \\
\hline $\mathbf{T}$ & EUROPEAN UNION & & INCOME GENERATION & \\
\hline $\mathbf{H}$ & & & IRRIGATION & \\
\hline $\mathbf{E}$ & & & MINE & \\
\hline $\mathbf{R}$ & & & RELIEF & \\
\hline $\mathbf{S}$ & & & OTHER & \\
\hline
\end{tabular}

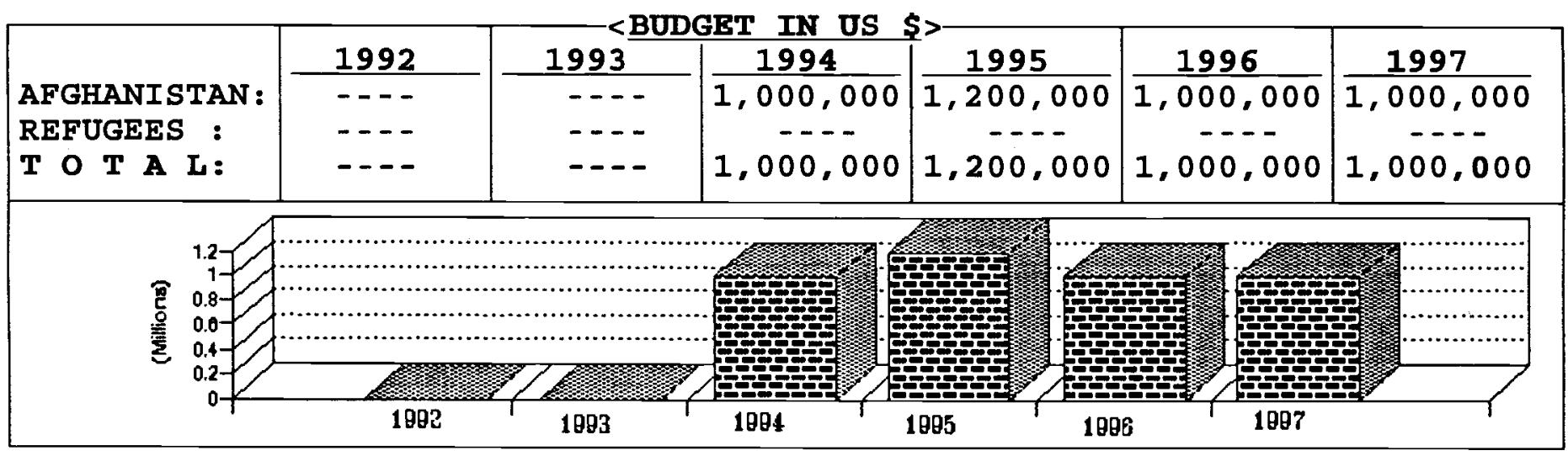

\begin{tabular}{|c|c|c|c|c|c|}
\hline PROVINCES & SECTOR & $\%$ & PROVINCES & SECTOR & $\%$ \\
\hline $\begin{array}{l}\text { BADAKSHAN } \\
\text { BADGHIS } \\
\text { BAGHLAN } \\
\text { BALKH } \\
\text { BAMYAN } \\
\text { FARAH } \\
\text { FARYAB } \\
\text { GHAZNI } \\
\text { GHOR } \\
\text { HELMAND } \\
\text { HERAT } \\
\text { JAWZJAN } \\
\text { KABUL } \\
\text { KANDAHAR } \\
\text { KAPISA }\end{array}$ & $\begin{array}{l}\text { HEALTH } \\
\text { HEALTH } \\
\text { HEALTH } \\
\text { HEALTH }\end{array}$ & $\begin{array}{r}45 \\
45 \\
5\end{array}$ & $\begin{array}{l}\text { KUNAR } \\
\text { KUNDUZ } \\
\text { LAGHMAN } \\
\text { LOGAR } \\
\text { NANGARHAR } \\
\text { NIMROZ } \\
\text { ORUZGAN } \\
\text { PAKTEKA } \\
\text { PAKTIA } \\
\text { PARWAN } \\
\text { SAMANGAN } \\
\text { TAKHAR } \\
\text { WARDAK } \\
\text { ZABUL }\end{array}$ & & \\
\hline
\end{tabular}




\section{MEDICINS DU MONDE \\ (MDM)}

MDM is a non-profit volunteer French

humanitarian organisation founded in 1979 , which now ficlds fifty two missions in more then forty countries throughout the world.

MDM today represents more than onc thousand skilled doctors, nurses and medical technicians, active in assisting pcople in all continents, including.

MDM has becn in Afghanistan since early 1980 and since then has provided assistance to Jerhatu Hospital, Wardak.

\section{Operations}

- In Herat Province MDM supports the Regional Hospital (300 beds), has rehabilitated the operation theater and surgical supplics, and supplics several other departments

- Threc dispensarics are being run in three camps for displaced people and returnecs in cooperation with FICR

\section{Qala e Now}

Have recently completed the two year rehabilitation of the hospital

\section{Farah}

In the process of rehabilitatıng the hospital and will focus on mother and child health care.

MDM arc working in several other Provinces supporting, rchabilitation and supplying several hospitals, clinics and health centres. 
68, T LANE, STR 15, WAZIR AKBAR KHAN RABUL， AFGHANISTAN
PHO

FAX : +873 $682 \quad 286522$

TELEX :
<EFY STAFF>

1. MR. CLARKE GOURLAY

2. DR. MARILYNN

3 .

\begin{tabular}{|c|c|c|c|c|c|}
\hline $\begin{array}{l}\text { AFGHAN : } \\
\text { PAKISTANI: } \\
\text { EXPAT : } \\
\text { TOTAL : }\end{array}$ & $\begin{array}{r}45 \\
- \\
14 \\
59\end{array}$ & $\begin{array}{l}\text { TECHNICAL : } \\
\text { ADMINISTRATIVE : } \\
\text { FIELD/SUPPORT S: } \\
\text { TOTAL }\end{array}$ & $\begin{array}{r}12 \\
8 \\
39 \\
59\end{array}$ & $\begin{array}{l}\text { PAK.BASED: } \\
\text { AFGHAN BASED: } \\
\text { CROSS-BORDER: } \\
\text { TOTAL : }\end{array}$ & $\begin{array}{r}5 \overline{-} \\
5 \overline{-}\end{array}$ \\
\hline
\end{tabular}

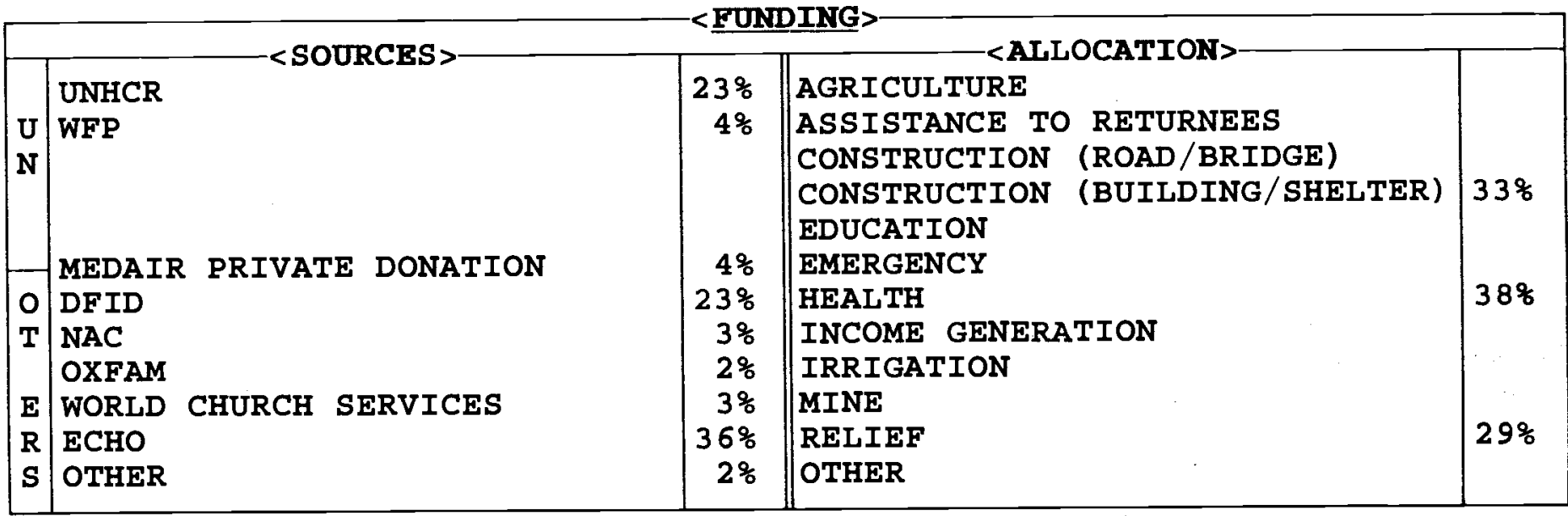

\begin{tabular}{|c|c|c|c|c|c|c|}
\hline & 1992 & 1993 & 1994 & 1995 & 1996 & 1997 \\
\hline AFGHANISTAN : & --- & $\ldots$ & $\ldots$ & $\ldots$ & 163,000 & $2,000,000$ \\
\hline REFUGEES : & $-\cdots$ & --- & $-\cdots$ & --- & 1630 & , 0 nanan \\
\hline T O T A L: & ---- & $\ldots-0$ & ---- & --- & 163,000 & $2,000,000$ \\
\hline
\end{tabular}

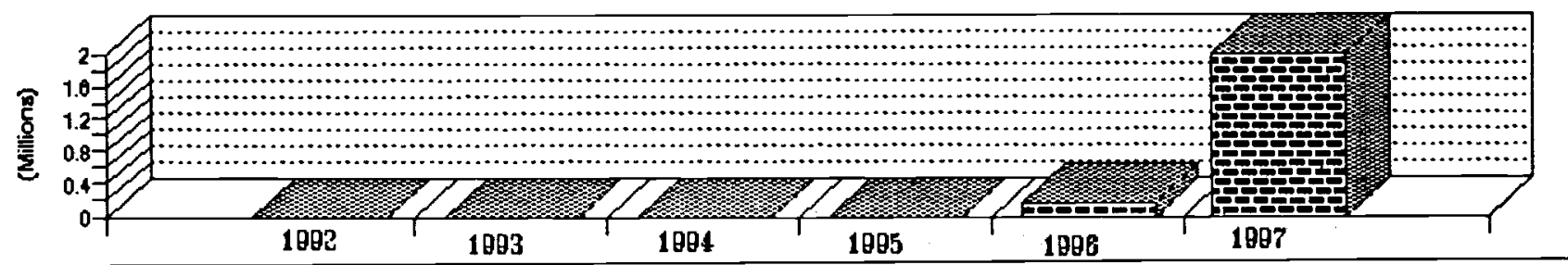

\begin{tabular}{|c|c|c|c|c|c|}
\hline PROVINCES & SECT $\overline{O R}$ & $\%$ & PROVINCES & SECTOR & $\%$ \\
\hline $\begin{array}{l}\text { BADAKSHAN } \\
\text { BADGHIS } \\
\text { BAGHLAN } \\
\text { BALKH } \\
\text { BAMYAN } \\
\text { FARAH } \\
\text { FARYAB } \\
\text { GHAZNI } \\
\text { GHOR } \\
\text { HELMAND } \\
\text { HERAT } \\
\text { JAWZJAN } \\
\text { KABUL } \\
\text { KANDAHAR } \\
\text { KAPISA }\end{array}$ & 1 & 87 & $\begin{array}{l}\text { KUNAR } \\
\text { KUNDUZ } \\
\text { LAGHMAN } \\
\text { LOGAR } \\
\text { NANGARHAR } \\
\text { NIMROZ } \\
\text { ORUZGAN } \\
\text { PAKTEKA } \\
\text { PAKTIA } \\
\text { PARWAN } \\
\text { SAMANGAN } \\
\text { TAKHAR } \\
\text { WARDAK } \\
\text { ZABUL }\end{array}$ & SHELTER & 13 \\
\hline
\end{tabular}




\section{MEDAIR}

An international organisation based in Kabul to assist in the rehabilitation of services in

Afghanistan.

The main sector of operation is Health -

Tuberculosis control - in several Provinces of the country.

Construction and supply of non food relief

goods is also a major concern of the organisation 
7 B GUL MOHAR ROAD UNIVERSITY TOWN PESHAWAR， PAKISTAN
PHONE : $41543 / 842572$

F A X: 842572 email:merlin@ibm.psw.erum 3 .

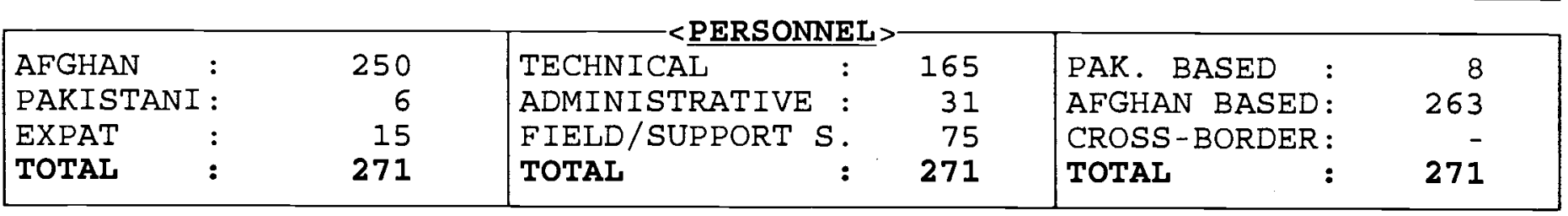

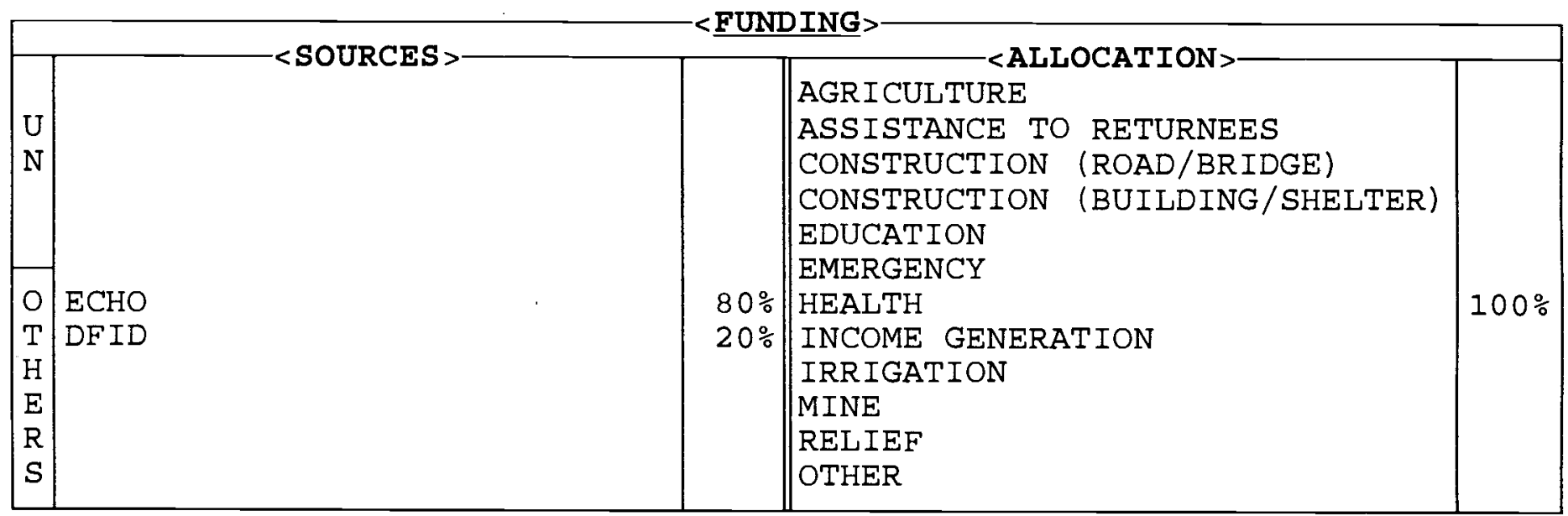

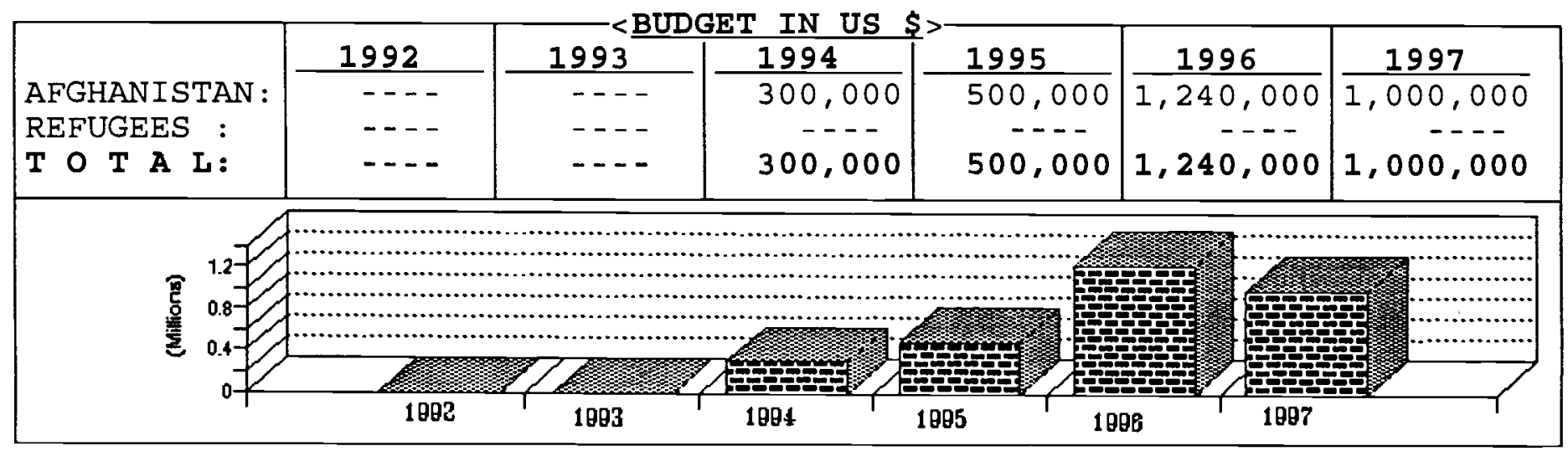

\begin{tabular}{|c|c|c|c|c|c|}
\hline PROVINCES & SECTOR & $\%$ & PROVINCES & SECTOR & $\%$ \\
\hline $\begin{array}{l}\text { BADAKSHAN } \\
\text { BADGHIS } \\
\text { BAGHLAN } \\
\text { BALKH } \\
\text { BAMYAN } \\
\text { FARAH } \\
\text { FARYAB } \\
\text { GHAZNI } \\
\text { GHOR } \\
\text { HELMAND } \\
\text { HERAT } \\
\text { JAWZJAN } \\
\text { KABUL } \\
\text { KANDAHAR } \\
\text { KAPISA }\end{array}$ & $\begin{array}{l}\text { HEALTH } \\
\text { HEALTH } \\
\text { HEALTH }\end{array}$ & $\begin{array}{l}30 \\
35 \\
\\
\\
35\end{array}$ & $\begin{array}{l}\text { KUNAR } \\
\text { KUNDUZ } \\
\text { LAGHMAN } \\
\text { LOGAR } \\
\text { NANGARHAR } \\
\text { NIMROZ } \\
\text { ORUZGAN } \\
\text { PAKTEKA } \\
\text { PAKTIA } \\
\text { PARWAN } \\
\text { SAMANGAN } \\
\text { TAKHAR } \\
\text { WARDAK } \\
\text { ZABUL } \\
\text { PAKISTAN }\end{array}$ & & \\
\hline
\end{tabular}




\section{MEDICAL EMERGENCY RELIEF \\ INTERNATIONAL (MERLIN)}

MERLIN is a British based NGO established in 1993. It began its operations in Afghanistan in Kandahar Province in February 1995 and subsequently moved its programme to Farah Province in 1996 and opened a new programme in Badakshan Province. It has recently established small liaison office in Peshawar.

MERLIN works exclusively in the health sector and in Afghanistan its programmes are in the emergency and rehabilitation phases of relief. MERLIN registered with the Ministry of Public Health for the Islamic Emirate of Afghanistan in July 1997.

Programme activities typically include:

\footnotetext{
- $\quad$ drug and medical equipment distribution;

- $\quad$ physical rehabilitation of district clinics and hospitals;

- $\quad$ clinical and TBA training;

- $\quad$ heath surveillance;

- $\quad$ medical emergency preparedness;

- $\quad$ nutritional programmes;

- water and sanitation programmes;

- $\quad$ surgical nurse training.
}

During 1997-1998 MERLIN expects to be operating three programmes in Afghanistan, with an emphasis in the provision of medical assistance to the civilian populations of rural districts and emergency preparedness. The programmes intend support to the Afghanistan Ministry of Public Health and work in conjunction with the staff of this Ministry in these Provinces. 
MATHAND RECONSTRUCTION COUNCII (MRC)

\begin{tabular}{|l|l|l|}
\hline SHAHR - I-NAW, NEAR OPS & PHONE: & COWUNICATION LINES $>$ HAJI BASHAR \\
OFFICE, KANDAHAR, & F A X: & KEY STAFF \\
AFGHANISTAN & TELEX: & 3. SHER MOHAMMAD \\
\end{tabular}

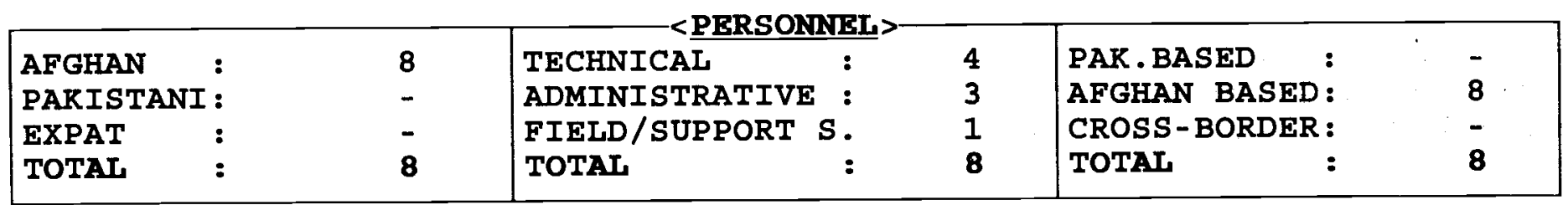

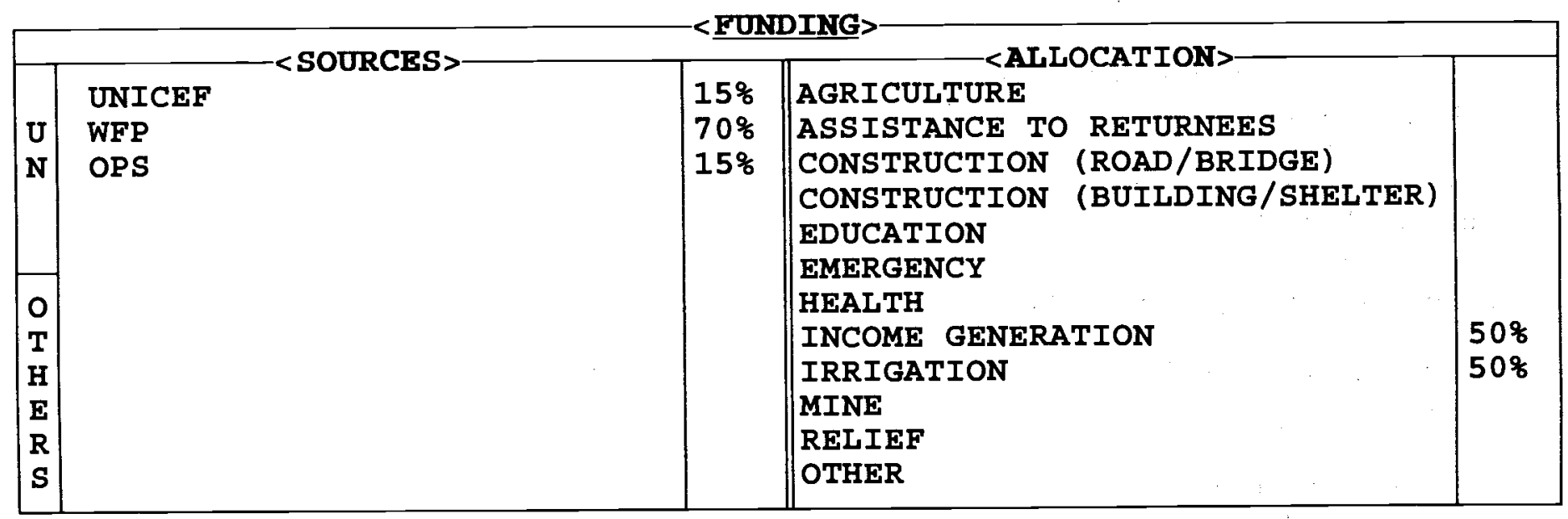

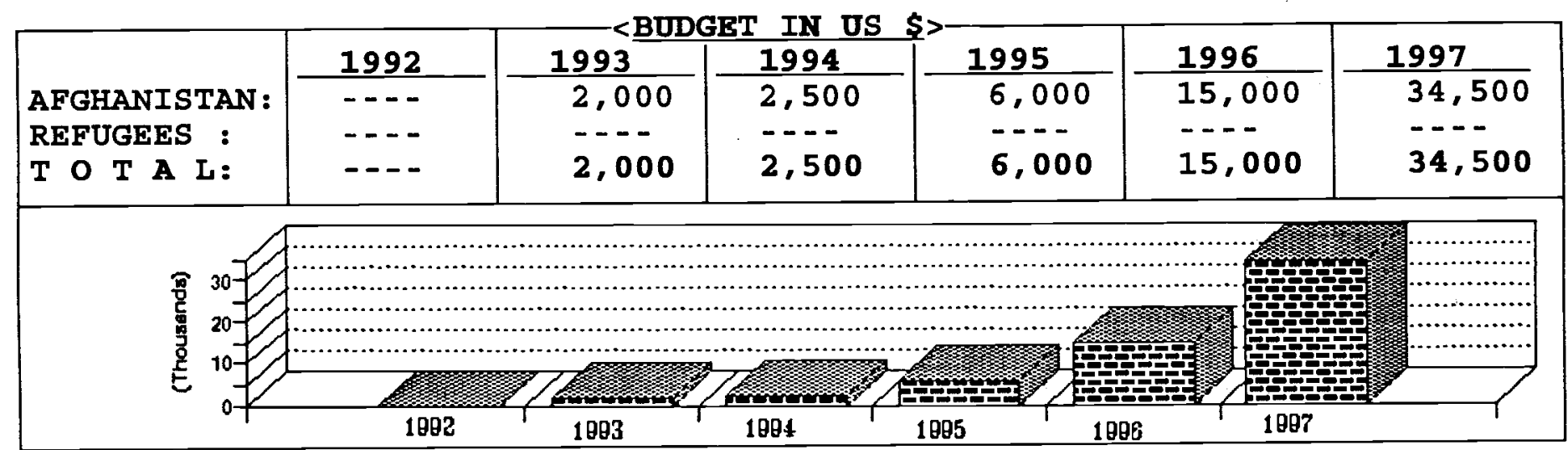

\begin{tabular}{|c|c|c|c|c|c|}
\hline PROVINCES & SECTOR & 采 & PROVINCES & SECTOR & $\%$ \\
\hline $\begin{array}{l}\text { BADAKSHAN } \\
\text { BADGHIS } \\
\text { BAGHLAN } \\
\text { BALKH } \\
\text { BAMYAN } \\
\text { FARAH } \\
\text { FARYAB } \\
\text { GHAZNI } \\
\text { GHOR } \\
\text { HELMAND } \\
\text { HERAT } \\
\text { JAWZJAN } \\
\text { RABUL } \\
\text { KANDAHAR } \\
\text { KAPISA }\end{array}$ & INCOME GEN/IRRIG & 100 & \begin{tabular}{|l|} 
KUNAR \\
KUNDUZ \\
LAGHMAN \\
LOGAR \\
NANGARHAR \\
NIMROZ \\
ORUZGAN \\
PAKTEKA \\
PAKTIA \\
PARWAN \\
SAMANGAN \\
TAKHAR \\
WARDAR \\
ZABUL \\
REFUGEES
\end{tabular} & $\therefore$ & \\
\hline
\end{tabular}




\section{MAIWAND RECONSTRUCTION COUNCIL \\ (MRC)}

MRC was set up in June 1993 in Quetta. Its fields of activity are agriculture and irrigation.

It has a sub-office in Maiwand, Kandahar and plans to expand its activitics to include cducation, health and construction in all Provinecs of Afghanistan.

The agency has submitted a number of proposals to UN agencics and is awaiting their approval

So far MRC has worked in the field of canal clcaning in Kandahar Province which was partially funded by UNHCR and partially self funded. 
MEDICAL REFRESHER COURSES FOR AFGHANS (MRCA)

<ADDRESS>- CCOMMUNICATION LINES> 34, ADM ENCLAVE, SECT A3 PHONE: 812456/7 812819 PHASE - 5, HAYATABAD, $F$ A X: 812819 1. AFMAD S. ZAFAR PESHAWAR, PAKISTAN TELEX :

2 .

3 .

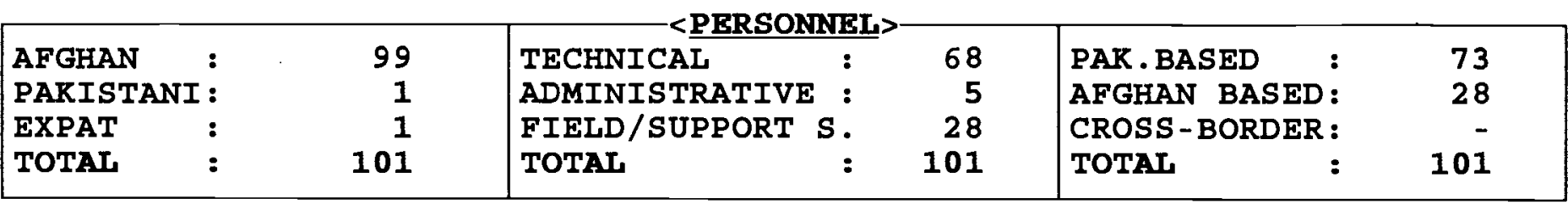

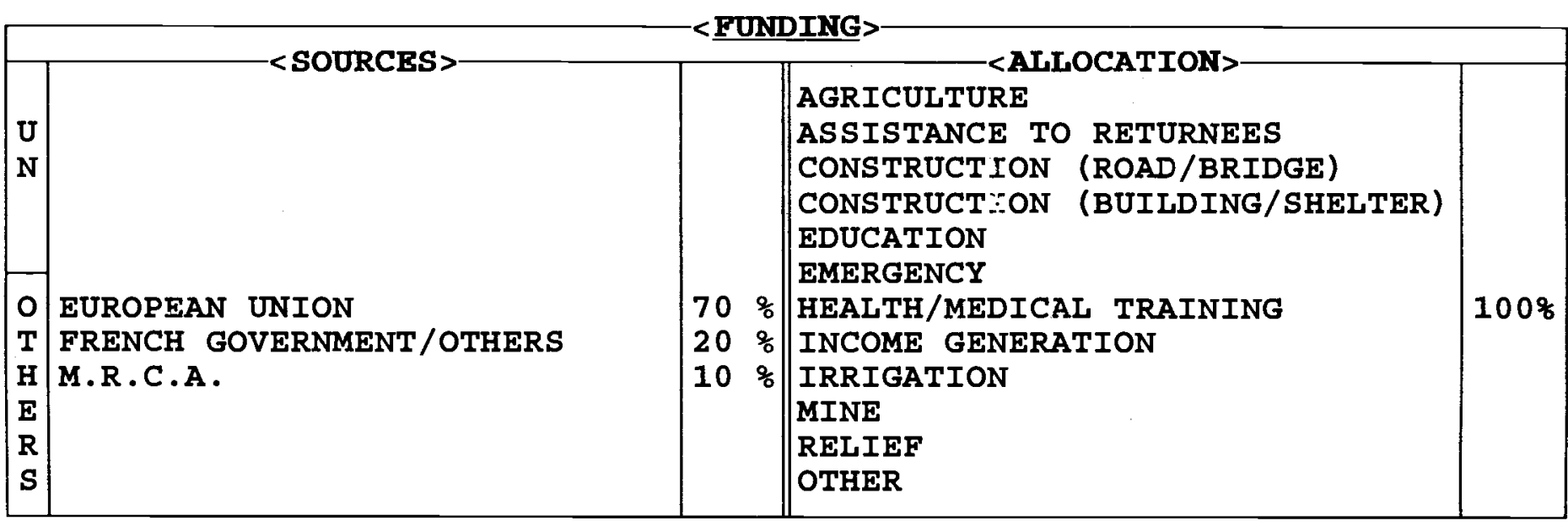

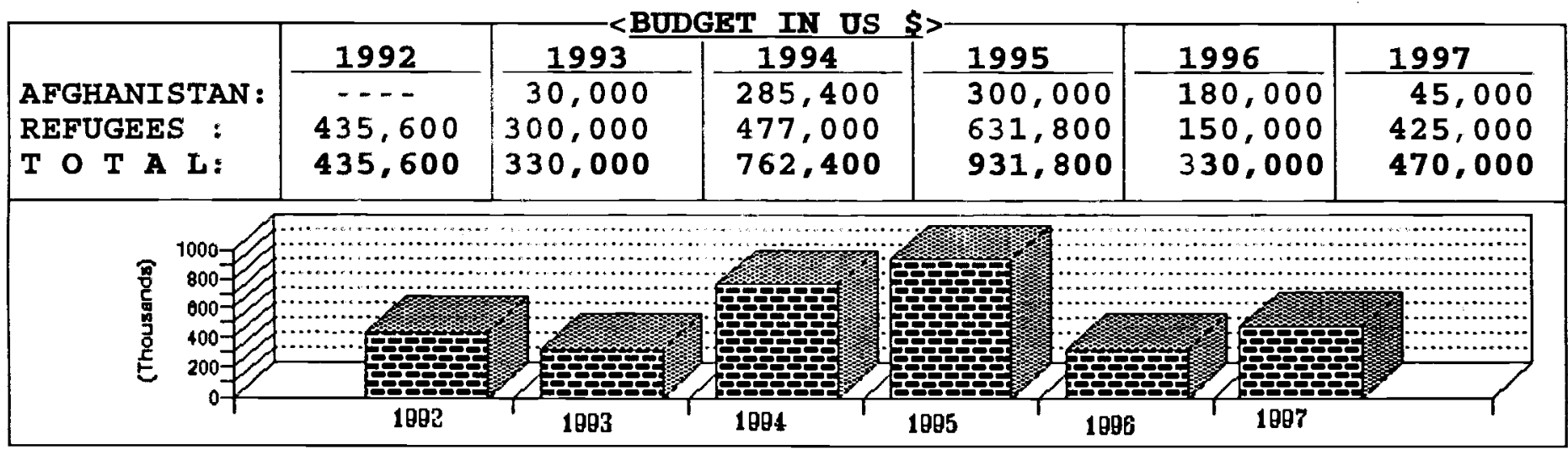

\begin{tabular}{|c|c|c|c|c|c|}
\hline PROVINCES & SECTOR & $\%$ & PROVINCES & SECTOR & $\%$ \\
\hline $\begin{array}{l}\text { BADAKSHAN } \\
\text { BADGHIS } \\
\text { BAGHLAN } \\
\text { BALKH } \\
\text { BAMYAN } \\
\text { FARAH } \\
\text { FARYAB } \\
\text { GHAZNI } \\
\text { GHOR } \\
\text { HELMAND } \\
\text { HERAT } \\
\text { JAWZJAN } \\
\text { KABUL } \\
\text { KANDAHAR } \\
\text { KAPISA }\end{array}$ & HEALTH & 20 & \begin{tabular}{|l|} 
KUNAR \\
KUNDUZ \\
LAGHMAN \\
LOGAR \\
NANGARHAR \\
NIMROZ \\
ORUZGAN \\
PAKTEKA \\
PAKTIA \\
PARWAN \\
SAMANGAN \\
TAKHAR \\
WARDAK \\
ZABUL \\
REFUGEES
\end{tabular} & HEALTH/MEDICAL TRAIN. & 80 \\
\hline
\end{tabular}




\section{MEDICAL REFRESHER COURSES FOR \\ AFGHANS \\ (MRCA)}

MRCA is a non-profit NGO created in 1986 by a French nurse, Miss Arielle Calmejanne, in

Peshawar.

Her two main goals at the time were:

- to develop a surgical unit in

Peshawar, in order to provide care to the numerous Afghan refugees in the Provinces as well as to the war wounded;

- organising spccialised medical training for Afghans using the surgical unit as a pedagogic field.

Since then, the MRCA has developed its curative and training activities in various directions and is now operating in Peshawar, 45 surgical beds ( 2 operating theaters, general, Orthopaedic, Urology and Gynaecological surgery) 2 dental clinics, a 20 bed paediatric ward with the facilities of a modern hospital i.e. X-ray and laboratory.

During 1995 MRCA changed its focus toward women and children with the opening of Gynaecology ante natal IPD and OPD dept. In 1996 a Child Development Centre was opened to cater to the needs of neurologically impaired children.

In early 1994, with the latest wave of Kabuli refugees, MRCA “afghanized" its senior medical staff by recruiting highly qualified professionals. This move, as well as reducing the brain drain, is aiming to create a pool of highly trained people. In this way, the future needs of the people can be better served.

MRCA is acting as a funding agency for the Chak I Wardak Hospital project implemented the German organisation CPHA and also operates a hospital for Reconstructive surgery in Kabul.

In 1995, MRCA remains unique in its medical training ficld. Although there are other organisations involved in the medical field,
MRCA is believed to be the only source in Afghanistan and Pakistan for specialised refresher training in surgery, anaesthesia, $\mathrm{X}$ Rays, dentistry, surgical and ward nursing in an integrated teaching hospital structure.

Following the developments in Pakistan and Afghanistan MRCA plans to develop its interventions for the benefit of the most vulnerable targets in 1997.

Funded by the EU and French Government targets for the next 12 months will be:

$-3,200$ patients receiving surgical consultation.;

- 1680 patients receiving gynaecological consultation

- 11520 patients receiving dental treatment;

- 19200 children receiving paediatric consultation;

- 672 children rehydrated in our day hospital service;

- 120 trainees referred by medical

organisations for various diagnosis. 
MARUF RELIEF ORGANIZATION FOR RECNST. OF AFGHANISTAN (MRORA)

GADI STREET, CAP

MADAT CHOWK,

KANDAHAR, AFGHANISTAN
PHONE :

$F$ A X:

TELEX :
1. HABIBULLAH

2. BISMILLAH KHAN

3 .

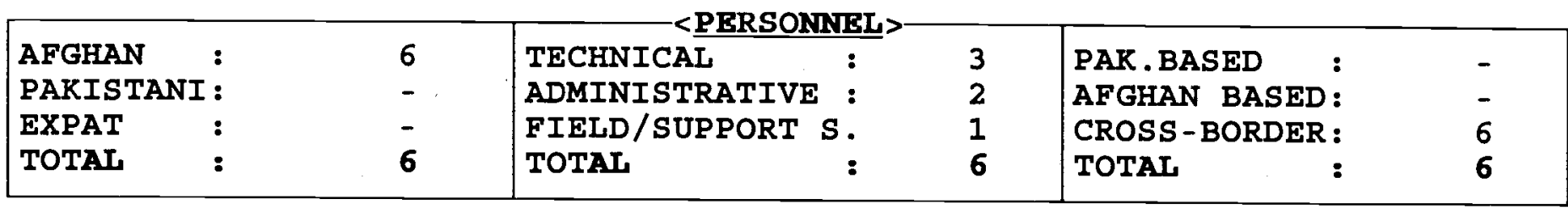

$<$ SOURCES >

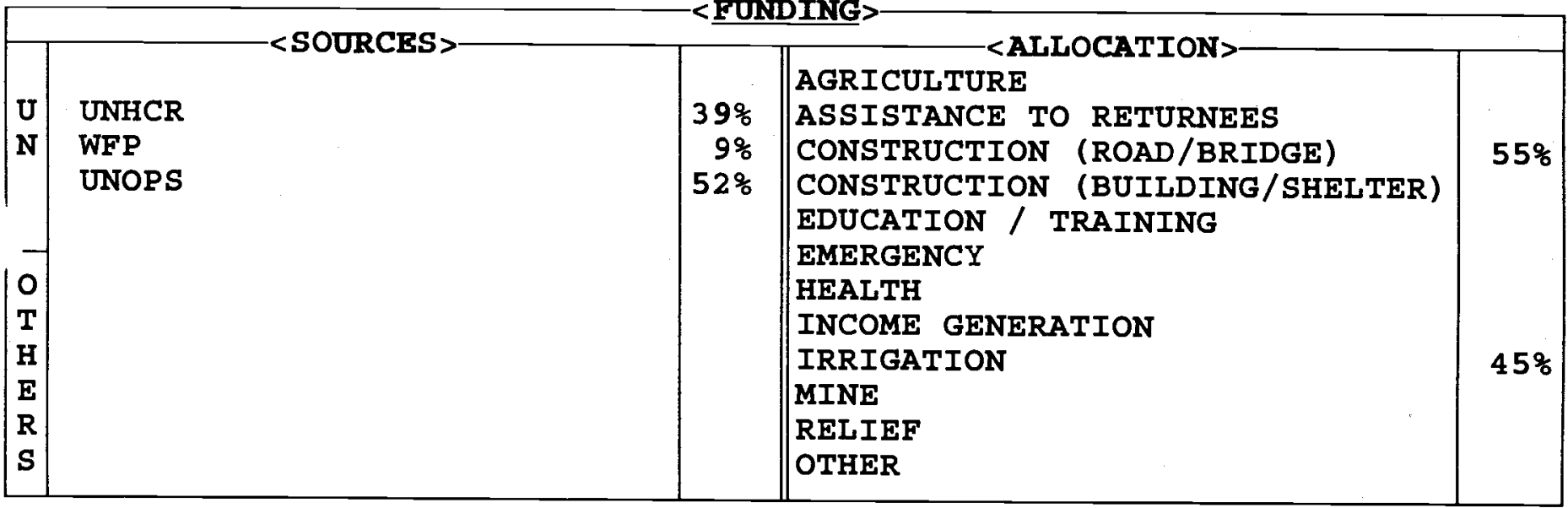

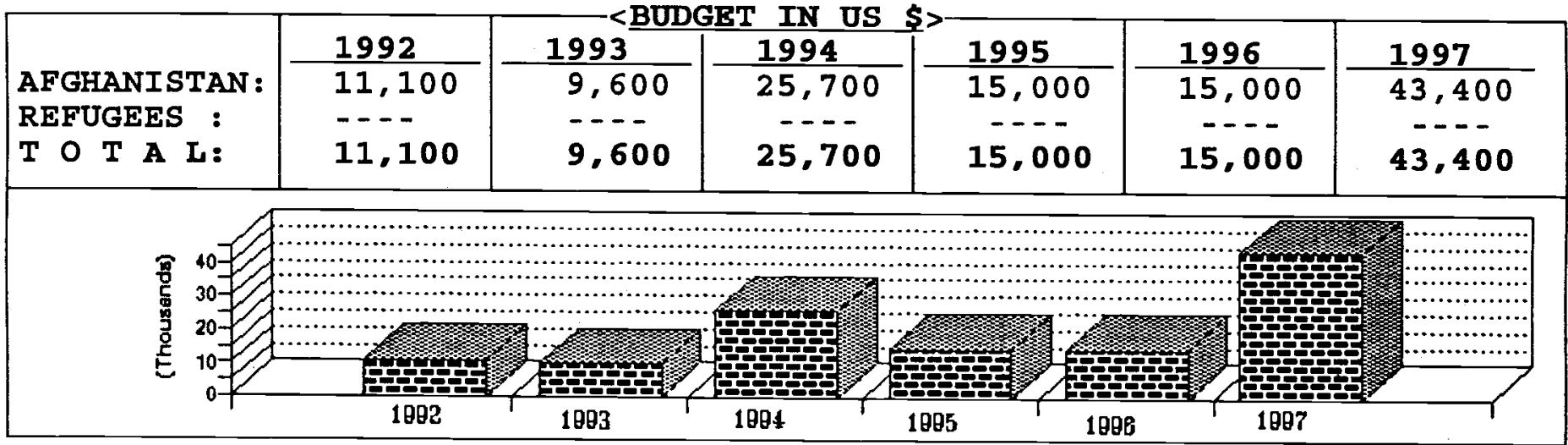

\begin{tabular}{|c|c|c|c|c|c|}
\hline PROVINCES & SECTOR & $\%$ & PROVINCES & SECTOR & $\%$ \\
\hline $\begin{array}{l}\text { BADAKSHAN } \\
\text { BADGHIS } \\
\text { BAGHLAN } \\
\text { BALKH } \\
\text { BAMYAN } \\
\text { FARAH } \\
\text { FARYAB } \\
\text { GHAZNI } \\
\text { GHOR } \\
\text { HELMAND } \\
\text { HERAT } \\
\text { JAWZJAN } \\
\text { KABUL } \\
\text { KANDAHAR } \\
\text { KAPISA }\end{array}$ & 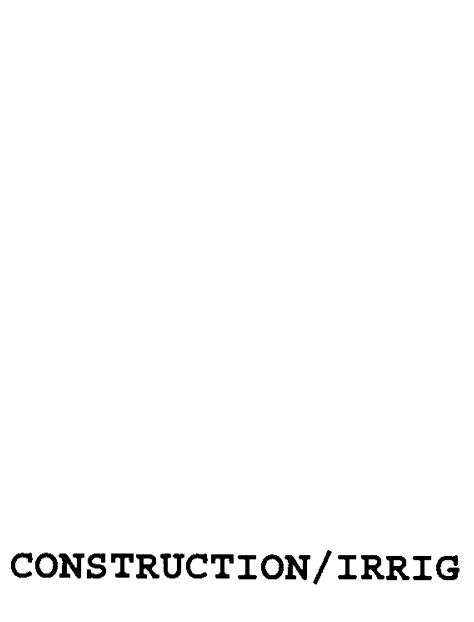 & 100 & $\begin{array}{l}\text { KUNAR } \\
\text { KUNDUZ } \\
\text { LAGEMAN } \\
\text { LOGAR } \\
\text { NANGARHAR } \\
\text { NIMROZ } \\
\text { ORUZGAN } \\
\text { PAKTEKA } \\
\text { PAKTIA } \\
\text { PARWAN } \\
\text { SAMANGAN } \\
\text { TAKHAR } \\
\text { WARDAK } \\
\text { ZABUL }\end{array}$ & & \\
\hline
\end{tabular}




\section{MARUF RELIEF ORGANISATION FOR RECONSTRUCTION OF AFGHANISTAN (MRORA)}

MRORA is an Afghan non-governmental, nonpolitical organisation, established in Pakistan in 1989 to carry out irrigation, agricultural, construction, education and health projects.

The head office recently moved to Kandahar. The agency is registered with UNOCHA and SAFRON and is a member of SWABAC.

\section{Projects completed}

- Karez Cleaning: cleaning of 14 karezes in Kandahar through funds from UNDP/OPS, WFP and RONCO/USAID;

- Crop sced production: wheat, maize, mung beans and cotton sced production were carricd out in Kandahar and Helmand through funds from FAO and UNDP/OPS;

- Saplings projects: werc carried out in Kandahar with FAO funds;

- Schools: two tent schools were opcrated in Kandahar and one school was reconstructed in Were district with UNESCO funds;

- Relicf goods: distribution of 6 tents and 10 tarpaulins for two clinics in Maruf funded by RONCO/USAID;

- Refugee: returning refugee projects in the north of Afghanistan, through IOM funds;

- Training: training courses for master trainers were carried out in Maruf, Kandahar; - Awareness creation courses on drug abuse to NGOs and tribal elders in Quetta, funded by UNDCP.

\section{Projects ongoing}

- School construction in Maruf funded by

Canadian High Commission;

- Training workshops on drug abuse for religious elders in Kandahar funded by UNDCP.

MRORA has proposed a number of projects to different donors, some of which will be approved soon.

The agency has the capacity to implement a number of projects simultaneously. 
MEDICINS SANS FRONTIERES (MSF)

34-A, CIRCULAR RD, U/T P.O.BOX 889 PESHAWAR, PAKISTAN

\section{(Mas)}

PHONE : 0091-843154-842918

F A X: 0091-840251

EMAIL :msf-hOmsf . pwr . sdnpk . unsp . org 3.ERIC CERCIAT

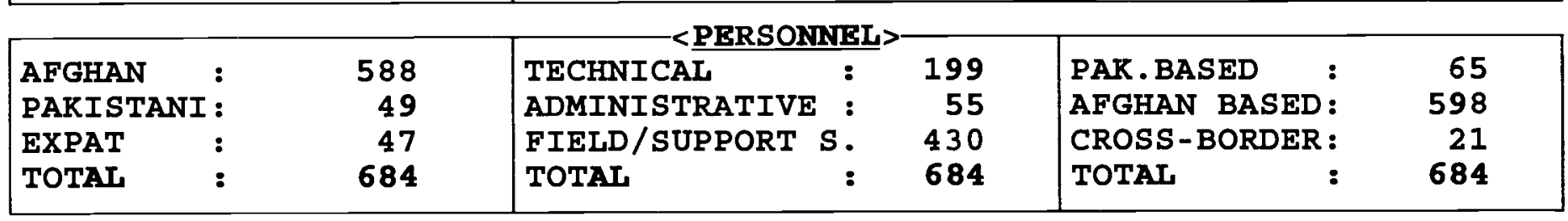

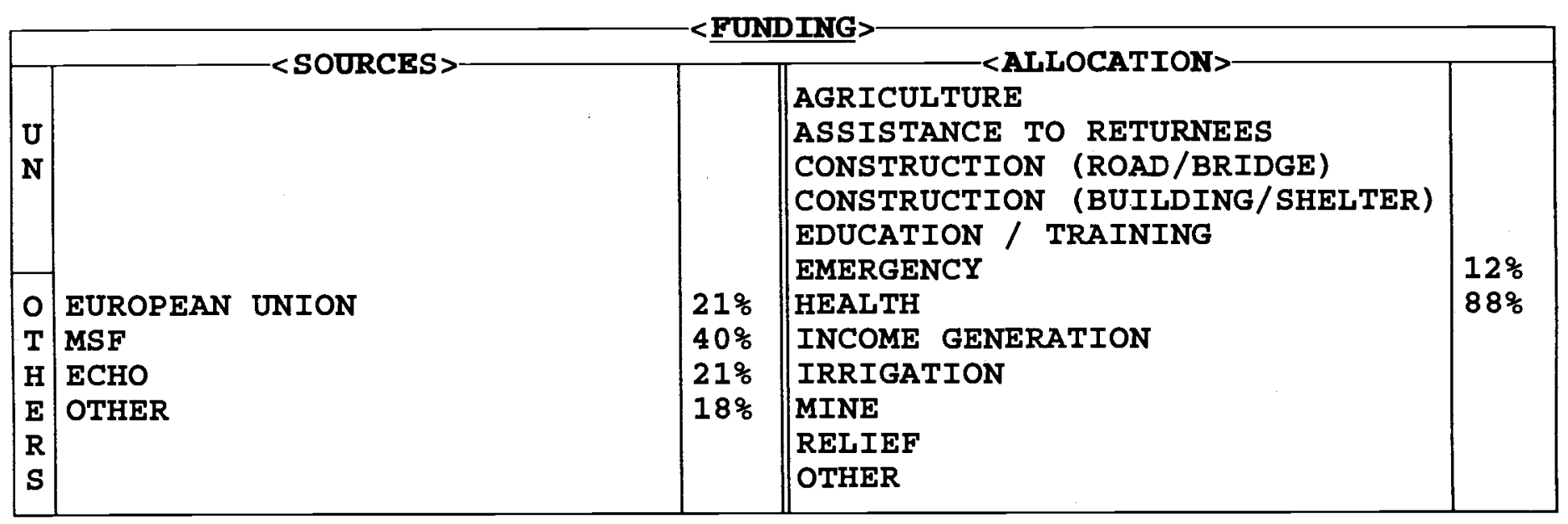

\begin{tabular}{|c|c|c|c|c|c|c|}
\hline $\begin{array}{l}\text { AFGHANISTAN : } \\
\text { REFUGEES : } \\
\text { T O T A L: }\end{array}$ & $\begin{array}{r}1992 \\
5,000,000 \\
200,000 \\
5,200,000\end{array}$ & $\begin{array}{r}1993 \\
5,000,000 \\
200,000 \\
5,200,000\end{array}$ & $\begin{array}{r}1994 \\
6,865,000 \\
205,950 \\
7,070,950\end{array}$ & {$\left[\begin{array}{r}1995 \\
7,094,600 \\
949,850 \\
8,044,450\end{array}\right.$} & $\begin{array}{r}1996 \\
5,706,400 \\
300,300 \\
6,006,700\end{array}$ & $\begin{array}{r}\frac{1997}{5,000,000} \\
200,000 \\
5,200,000\end{array}$ \\
\hline $\begin{array}{l}1 \\
-1\end{array}$ & $\frac{1}{\text { ……........ }}$ & 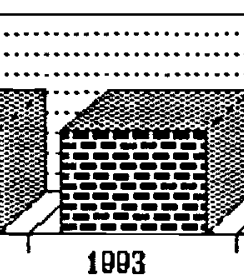 & 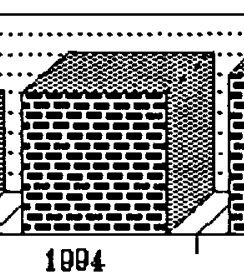 & 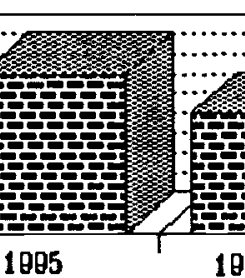 & 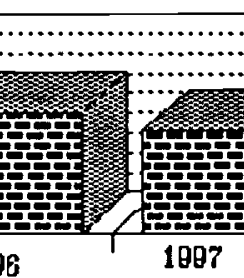 & …... \\
\hline
\end{tabular}

\begin{tabular}{|c|c|c|c|c|c|}
\hline PROVINCES & SECTOR & $\%$ & PROVINCES & SECTOR & $\%$ \\
\hline $\begin{array}{l}\text { BADARSHAN } \\
\text { BADGHIS } \\
\text { BAGHLAN } \\
\text { BALKH } \\
\text { BAMYAN } \\
\text { FARAH } \\
\text { FARYAB } \\
\text { GHAZNI } \\
\text { GHOR } \\
\text { HELMAND } \\
\text { HERAT } \\
\text { JAWZJAN } \\
\text { RABUL } \\
\text { KANDAHAR } \\
\text { RAPISA }\end{array}$ & $\begin{array}{l}\text { HEALTH } \\
\text { HEALTH } \\
\text { HEALTH } \\
\text { HEALTH } \\
\text { HEALTH } \\
\text { HEALTH/EMERGENCY } \\
\text { HEALTH/EMERGENCY }\end{array}$ & $\begin{array}{r}5 \\
16 \\
1\end{array}$ & $\begin{array}{l}\text { KUNAR } \\
\text { KUNDUZ } \\
\text { LAGHMAN } \\
\text { LOGAR } \\
\text { NANGARHAR } \\
\text { NIMROZ } \\
\text { ORUZGAN } \\
\text { PAKTEKA } \\
\text { PAKTIA } \\
\text { PARWAN } \\
\text { SAMANGAN } \\
\text { TAKHAR } \\
\text { WARDAK } \\
\text { ZABUL } \\
\text { REFUGEES }\end{array}$ & $\begin{array}{l}\text { HEALTH } \\
\text { HEALTH } \\
\text { HEALTH } \\
\text { HEALTH/EMERGENCY } \\
\text { HEALTH } \\
\text { HEALTH } \\
\text { HEALTH } \\
\text { HEALTH }\end{array}$ & $\begin{array}{r}2 \\
4 \\
3 \\
23 \\
18 \\
3\end{array}$ \\
\hline
\end{tabular}


MSF is a private, non-profit, international organisation, whose objective is to provide medical aid to populations in crisis, without discrimination.

The organisation relies on volunteer health professionals and is independent of all States or institutions, as well as of all political, economic or religious influences.

MSF was established in 1971 by doctors determined to offer emergency assistance wherever wars and man-made disasters occur in the world. Its guiding principles are laid down in a charter to which all members of the organisation subscribe

During more than 20 ycars of relief work around the world, Medecins Sans Frontieres has gained a wide range of expertise, and developed techniques and strategies of intervention that allow it to pool rapidly the logistic and human resources necessary to provide efficient aid.

MSF also implements programmes involving post-emergency rehabilitation of health structures and can provide technical advisers to district, regional or national health authorities.

Largely supported by private donors, the organisation is able to maintain great interventional flexibility and independence in its choicc of operations.

Moreover, in bearing witness to violations of basic humanitarian principles and denouncing them publicly, MSF volunteers implement a vital part of their humanitarian commitment. In 1994, 3,000 voluntecrs from 45 nations worked in 80 countries.

MSF's present programme in Afghanistan includes the rehabilitation and support to various hospitals, clinics and the basic health care system all over Afghanistan.
The organisation is also active in public health assistance to refugees, returnees and internal displaced as well as containing outbreaks of cholera in various regions. It remains ready and willing to intervene in cases of acute health care emergency in all parts of Afghanistan.

MSF has main offices in Kabul, Mazar-iSharif, Jalalabad and Kandahar. A representative office for MSF is based in Peshawar for the Afghan and Pakistan projects. 
MUSLIY SISTERS' ORGANISATION OF AFGHANISTAN (MSOA)

27, STREET 2, G 1 PHASE 2, HAYATABD PESHAWAR, PAKISTAN
PHONE : $817404 / 816878$

$F$ A X: 817534 TELEX:
KFY STAFF>

1. FAZEL RAFMAN MINHAJ

2. MS.BARLIAM TARIN

3 .

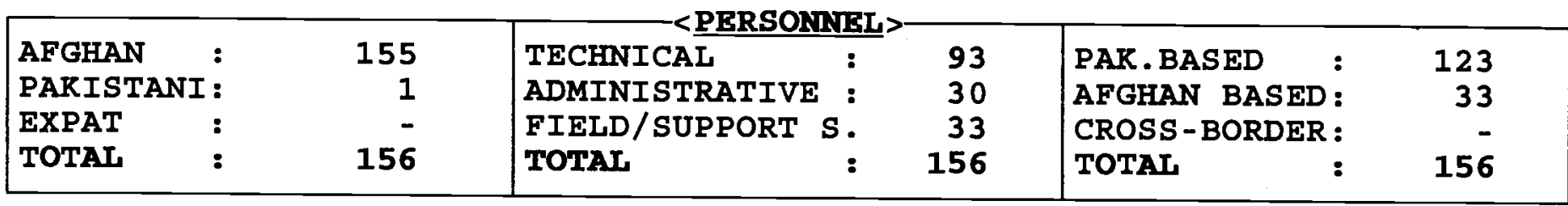

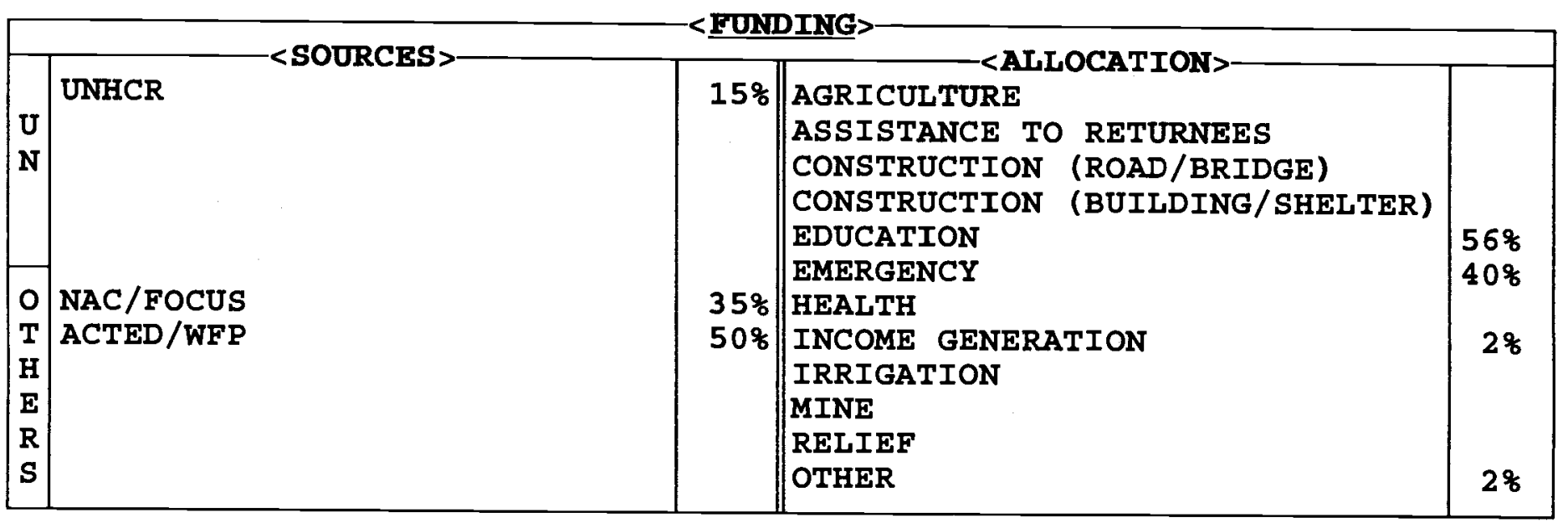

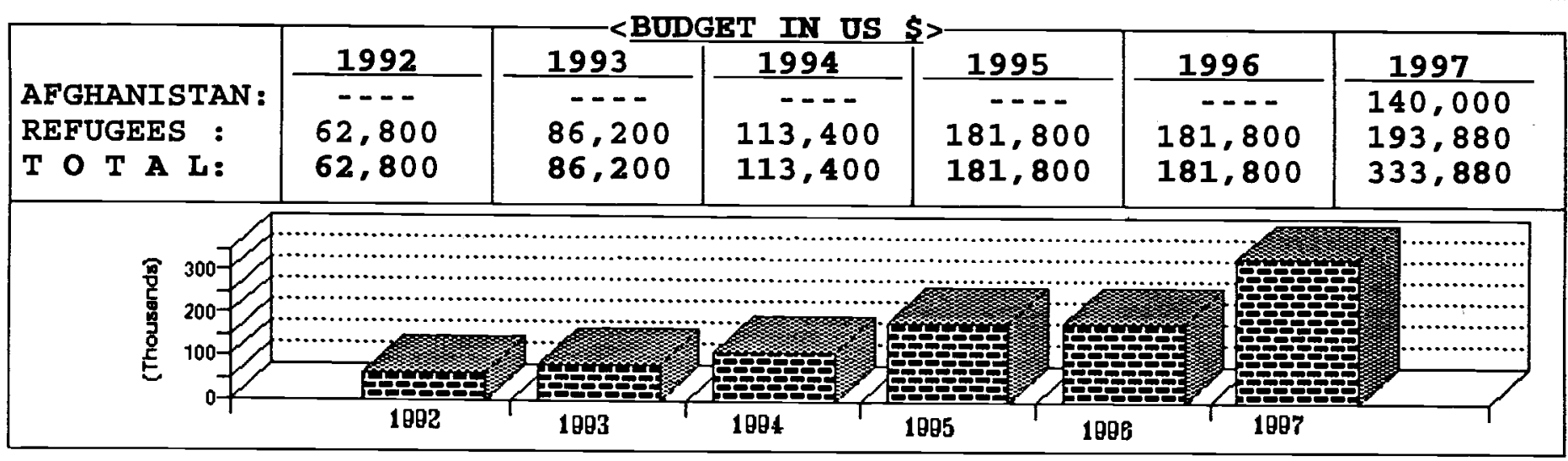

\begin{tabular}{|c|c|c|c|c|c|}
\hline PROVINCES & SECTOR & $\frac{8}{0}$ & PROVINCES & SECTOR & $\frac{9}{6}$ \\
\hline $\begin{array}{l}\text { BADAKSHAN } \\
\text { BADGHIS } \\
\text { BAGHLAN } \\
\text { BALKH } \\
\text { BAMYAN } \\
\text { FARAH } \\
\text { FARYAB } \\
\text { GHAZNI } \\
\text { GHOR } \\
\text { HELMAND } \\
\text { HERAT } \\
\text { JAWZJAN } \\
\text { RABUL } \\
\text { KANDAHAR } \\
\text { KAPISA }\end{array}$ & EMER/IN GEN/OTHER & 42 & $\begin{array}{l}\text { KUNAR } \\
\text { KUNDUZ } \\
\text { LAGHMAN } \\
\text { LOGAR } \\
\text { NANGARHAR } \\
\text { NIMROZ } \\
\text { ORUZGAN } \\
\text { PAKTEKA } \\
\text { PAKTIA } \\
\text { PARWAN } \\
\text { SAMANGAN } \\
\text { TAKHAR } \\
\text { WARDAK } \\
\text { ZABUL } \\
\text { REFUGEES }\end{array}$ & 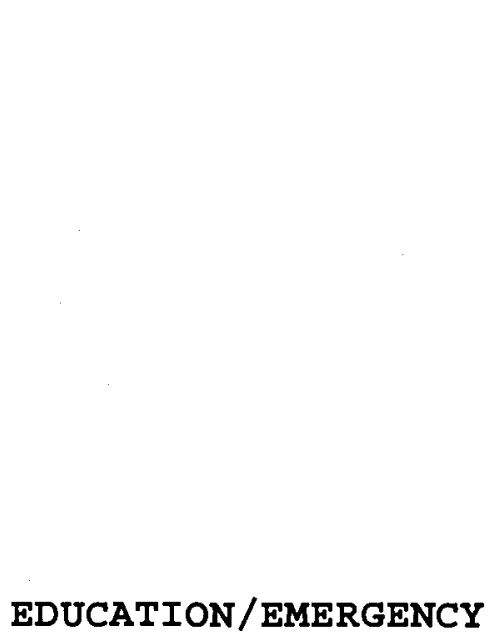 & 58 \\
\hline
\end{tabular}


MUSLIM SISTERS' ORGANISATION OF

AFGHANISTAN

(MSOA)

MSOA is an indigenous, Afghan nongovernmental organisation established in 1978 in Kabul. By 1983 MSOA opened its first school, Ummahat-ul-Momineen Girls Higher Secondary School in Peshawar.

The agency is mainly involved in the sector of education. In 1990 MSOA opened the first university for Afghan refugee women in Hayatabad.

MSOA has several components in its organisational structure.

\section{Executive Committee}

This is comprised of a president, vice-president, gencral secretary, vice-general secretary and public relations for the following committees: education, foreign and pubic relations, health, finance, culture, social welfare and planning.

\section{Advisory Board}

Comprises of Afghan elders who advise the executive committee.

\section{Scientific Board}

Advises in specialised subjects e.g. medicine.

MSOA is active in Pakistan and Afghanistan. 


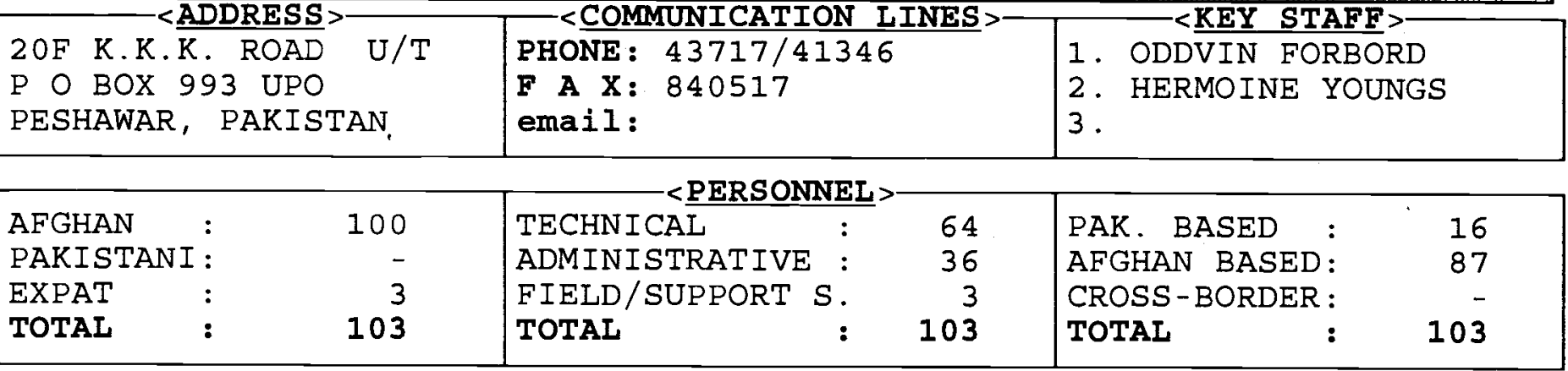

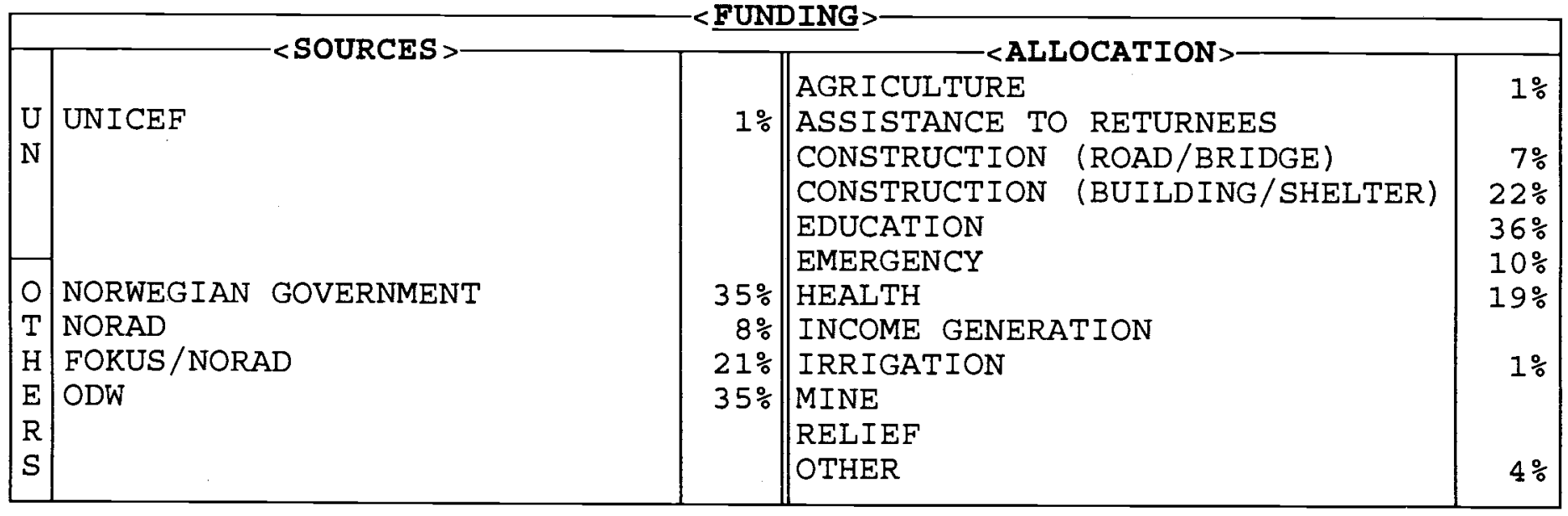

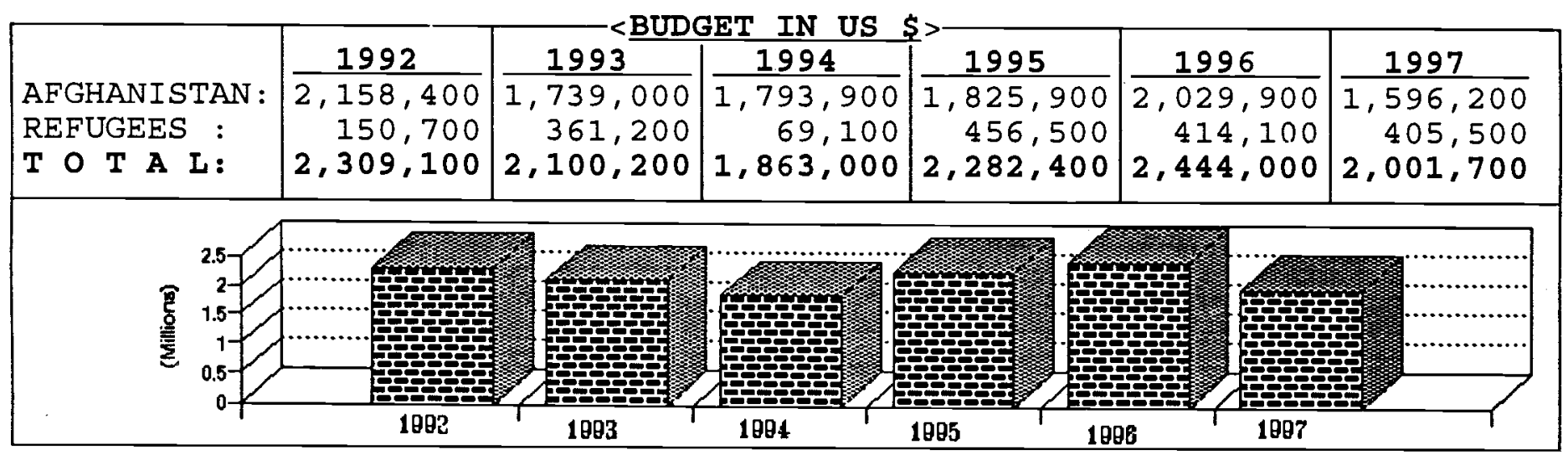

\begin{tabular}{|c|c|c|c|c|c|}
\hline PROVINCES & SECTOR & $\%$ & PROVINCES & SECTOR & $\%$ \\
\hline $\begin{array}{l}\text { BADAKSHAN } \\
\text { BADGHIS } \\
\text { BAGHLAN } \\
\text { BALKH } \\
\text { BAMYAN } \\
\text { FARAH } \\
\text { FARYAB } \\
\text { GHAZNI } \\
\text { GHOR } \\
\text { HELMAND } \\
\text { HERAT } \\
\text { JAWZJAN } \\
\text { KABUL } \\
\text { KANDAHAR } \\
\text { KAPISA }\end{array}$ & $\begin{array}{l}\text { EDUC/HEALTH/CONST } \\
\text { EMER/HEALTH/CONST }\end{array}$ & 11 & $\begin{array}{l}\text { KUNAR } \\
\text { KUNDUZ } \\
\text { LAGHMAN } \\
\text { LOGAR } \\
\text { NANGARHAR } \\
\text { NIMROZ } \\
\text { ORUZGAN } \\
\text { PAKTEKA } \\
\text { PAKTIA } \\
\text { PARWAN } \\
\text { SAMANGAN } \\
\text { TAKHAR } \\
\text { WARDAK } \\
\text { ZABUL } \\
\text { PAKISTAN }\end{array}$ & $\begin{array}{l}\text { HEALTH/CONSTRUCTION } \\
\text { HEALTH } \\
\text { HEALTH } \\
\text { AGR ICULTURE }\end{array}$ & 22 \\
\hline
\end{tabular}




\section{NORWEGIAN AFGHANISTAN COMMITTEE (NAC)}

NAC was founded in 1979 in response to the Soviet invasion. The aim was to provide support to the Afghan people through political pressure in Norway and internationally and also financial support.

The work of NAC started with medical support and cash-for-food programmes. Later, activities developed into projects and programmes in the health, education, agriculture, and

reconstruction sectors.

\section{Emergency Aid}

Emergency operations in Ghazni, Badakshan, Kabul and Jalalabad.

\section{Health}

Support to local health systems, midwife pilot projects, vaccination programmes, Hospitals and Clinics in Ghazni and Nooristan.

\section{Education}

Direct support to 43 schools.

\section{Reconstruction}

Irrigation system rehabilitation and school reconstruction.

Reconstruction of Clinics and Hospitals.

\section{Agriculture}

Wheat trials, seed multiplication, vegetable production, crop protection and forest protection.

NAC also maintains limited support to refugees in Peshawar by assisting girls schools and medical training courses.

Inside Afghanistan, the agency runs projects in many Provinces but its major working areas are Paktia, Ghazni, Nooristan and Badakhshan. Its aim is to run multi-sectoral community development projects in these areas.
NAC works in cooperation with several other NGOs but primarily implements its own projects. It works with local communities and in agreement with the local authorities.

NAC have two sub-offices inside Afghanistan, one regional office in Ghazni and one in Badakshan. A small liaison office is maintained in Kabul city. 
84-E REHMAN BABA ROAD

UNIVERSITY TOWN

PESHAWAR, PAKISTAN
PHONE : $4.5267 / 41226$

F A X: 840304

email:nca@afghan.psh.brain.net.pk

\begin{tabular}{|lr|lr}
\hline AFGHAN : & 23 & TECHNICAL & \multicolumn{2}{l}{ : } & 6 \\
PAKISTANI : & 10 & ADMINISTRATIVE : & 12 \\
EXPAT $:$ & 2 & FIELD/SUPPORT S: & 17 \\
TOTAL $:$ & 35 & TOTAL : & 35
\end{tabular}

1. JAN AHLANDER

2. TORILD BORUD
SOURCES

$\mathrm{U}$

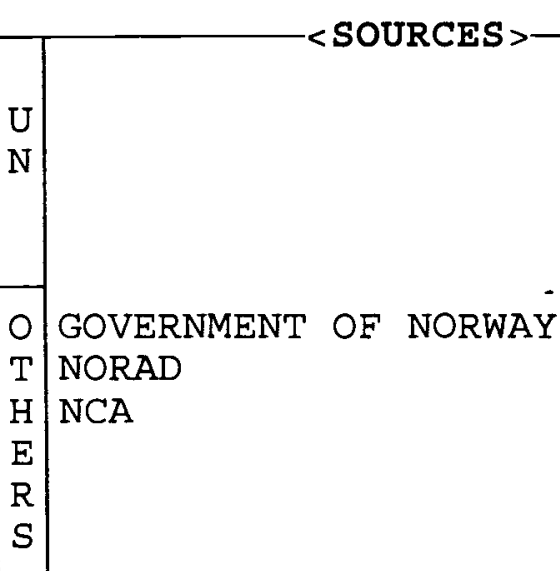

$<$ FUNDING $>$

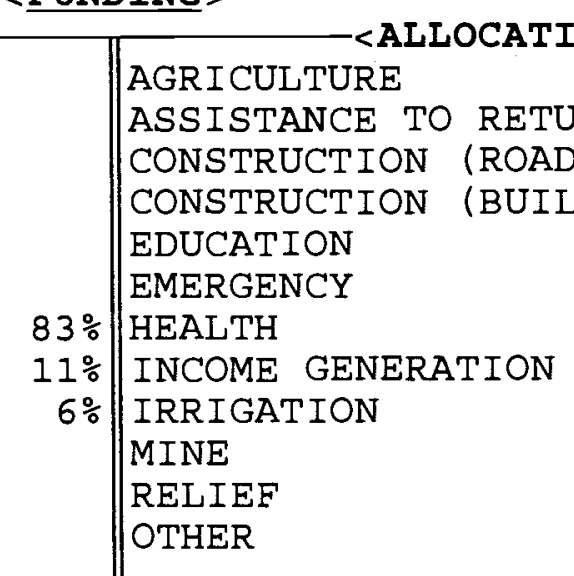

$\begin{array}{lr}\text { PAK. BASED : } & 17 \\ \text { AFGHAN BASED: } & 18 \\ \text { CROSS-BORDER: } & - \\ \text { TOTAL : } & \mathbf{3 5}\end{array}$

17

18

35

\begin{tabular}{|c|c|c|c|c|c|c|}
\hline & & & 7009 & & & \\
\hline AFGHANT STAN & $\frac{1354}{26000}$ & 1353 & & 1950 & 1950 & $\frac{1301}{3204000}$ \\
\hline REFUGEES : & $\begin{array}{l}3,260,000 \\
3\end{array}$ & $2,871,000$ & ח & $4,988,100$ & $4,089,500$ & $\begin{array}{r}3,204,000 \\
7,600\end{array}$ \\
\hline T O T A L: & $6,520,000$ & $5,220,000$ & $3,500,000$ & $5,084,300$ & $4,354,850$ & $3,211,600$ \\
\hline
\end{tabular}

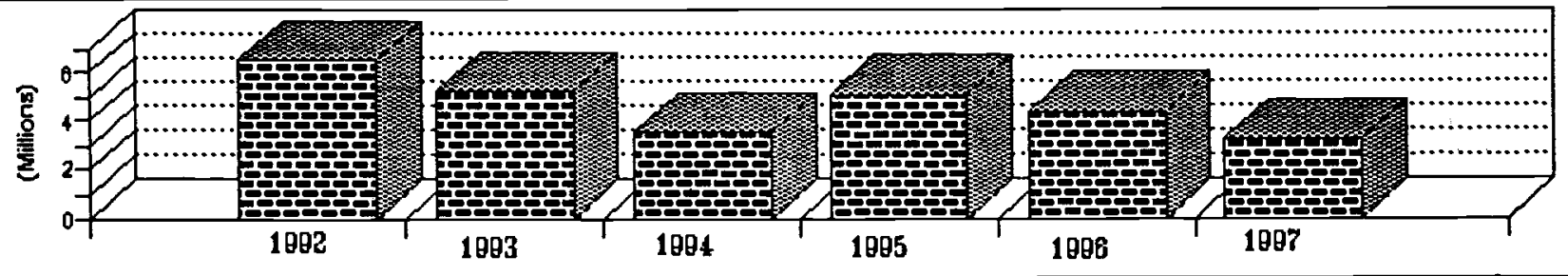

\begin{tabular}{|c|c|c|c|c|c|}
\hline PROVINCES & SECTOR & $\%$ & PROVINCES & SECTOR & $\%$ \\
\hline $\begin{array}{l}\text { BADAKSHAN } \\
\text { BADGHIS } \\
\text { BAGHLAN } \\
\text { BALKH } \\
\text { BAMYAN } \\
\text { FARAH } \\
\text { FARYAB } \\
\text { GHAZNI } \\
\text { GHOR } \\
\text { HELMAND } \\
\text { HERAT } \\
\text { JAWZJAN } \\
\text { KABUL } \\
\text { KANDAHAR } \\
\text { KAPISA }\end{array}$ & $\begin{array}{l}\text { AGRIC/IN. GEN/CONST } \\
\text { HEALTH } \\
\text { IN.GEN/VOC. TRN } \\
\text { EDUC/AGRIC/CONST } \\
\text { AGRIC/IN. GEN/CONST/ } \\
\text { CONST / EDUC/HLTH . . EDUC } \\
\text { AGRIC/CONST/EDUC/ }\end{array}$ & & $\begin{array}{l}\text { KUNAR } \\
\text { KUNDUZ } \\
\text { LAGHMAN } \\
\text { LOGAR } \\
\text { NANGARHAR } \\
\text { NIMROZ } \\
\text { ORUZGAN } \\
\text { PAKTEKA } \\
\text { PAKTIA } \\
\text { PARWAN } \\
\text { SAMANGAN } \\
\text { TAKHAR } \\
\text { WARDAK } \\
\text { ZABUL } \\
\text { PAKISTAN }\end{array}$ & $\begin{array}{l}\text { HEALTH } \\
\text { CONST/IN.GEN/OTHER } \\
\text { AGRICULTURE } \\
\text { HEALTH } \\
\text { EDUC/AGRIC/MICRO HYD } \\
\text { CONST/AGRIC/W.S. } \\
\text { CONST/AGRIC/IRRIG/ } \\
\text {. IN.GEN } \\
\text { AGRIC/IRRIG/W.S. } \\
\text { EDUC/AGRIC/CONST } \\
\text { AGRIC/EDUC/IN. GEN/ } \\
\text { AGRIC/EDUC/CONST }\end{array}$ & \\
\hline
\end{tabular}


NCA is a donor agency working with a number of Afghan and International partners for the rehabilitation and development of Afghanistan as well as rendering relief assistance to refugees and the internally displaced people.

\section{Objectives and Main Activities in 1996}

In the plans of NCA there are 3 different objectives, partner objectives $(\mathrm{P})$, grassroots objectives $(G)$ and internal objectives $(I)$. The different $P, G$ and $I$ are listed in the 1995-97 long-term plan. Priorities for 1997 are mentioned below.

\section{A. Support to Partners}

To assist partners:

- to improve skills to effectively plan, implement and evaluate programmes based on participatory principles;

- $\quad$ to develop long-term plans for at least 3 years;

- $\quad$ to improve financial management practices;

- $\quad$ to understand the root causes of poverty;

- $\quad$ how to increase basic agricultural production;

- $\quad$ to establish sustainable incoming generating activities;

- $\quad$ to increase health awareness and education standards.

\section{Human Development}

NCA with enough knowledge and competence within the organisation to play an advisory role:

- to monitor, evaluate and advise;

- to ensure a smooth flow of information and communication;

- to understand policies and objectives of programmes.

\section{Emergency Relief}

Ensure the local population participate in the planning and implementation of emergency activities.

\section{Repatriation/Rehabilitation}

Health and basic education should be an integral part of all projects to ensure their sustainability;

Community involvement in decision making of projects and inputs;

Target groups are refugees and internally displaced people.

\section{Sectors of Operation}

The organisation has been a donor, nonimplementing agency working with a number of Afghan organisations (NPO/RRAA, ADA, CoAR, ATA, RADA etc.), some international and $U N$ agencies.

NCA finance projects in various sectors such as health, irrigation, agriculture, water, sanitation, rehabilitation, income generation, education, energy environment as well as emergency relief projects.

\section{Further Information}

The Afghanistan programme has been run by Norwegian Church Aid (NCA). Norwegian Refugee Council phased out its Afghan programme January 1996. 
NORWEGIAN PROJECT OFFICE (NPO/RRAA)

- - ADDRESS $>-<$ COMMUNICATION LINES $>$

15 B OLD JAMRUD ROAD

UNIVERSITY TOWN

PESHAWAR， PAKISTAN

PHONE : 41129/45210/41107

F A X : 840107

email:
1. DUR MOHD FAZIL

2. DR K DAWLATY

3. ENG MOHD YONUS

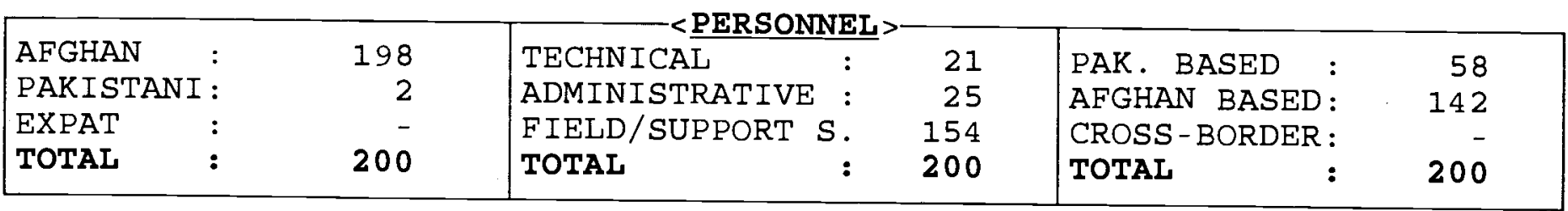

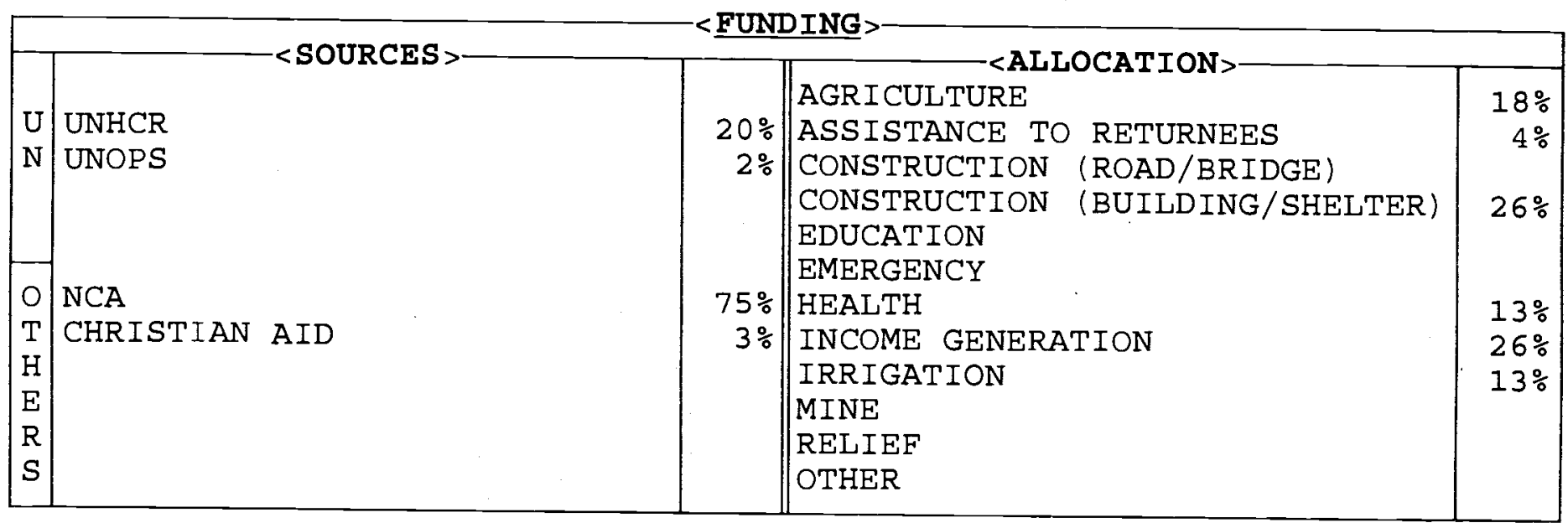

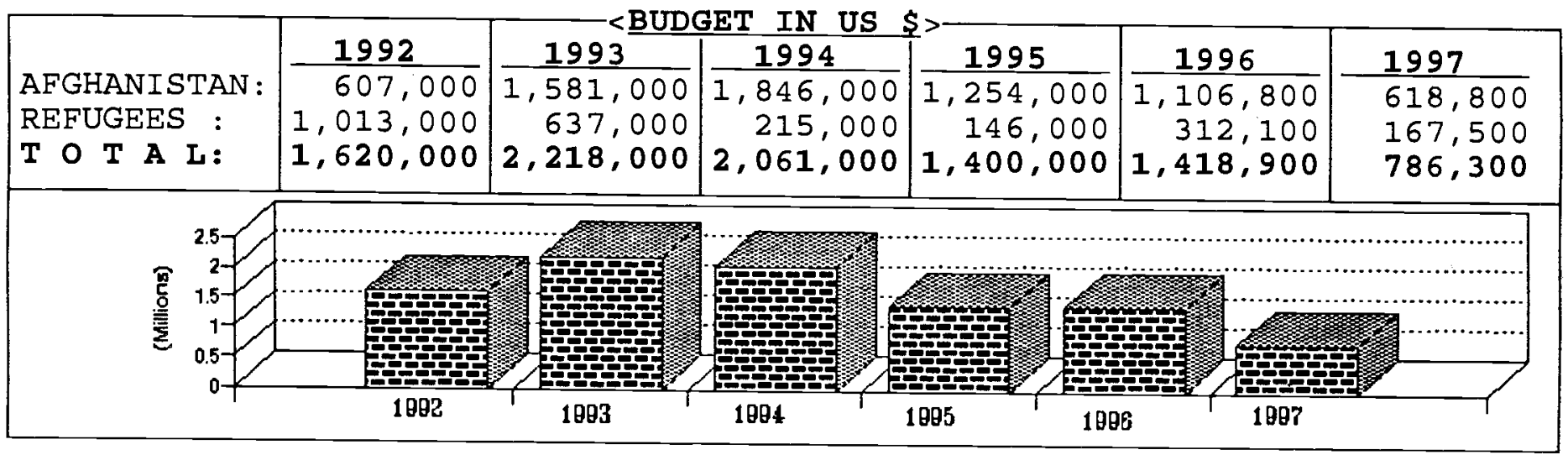

\begin{tabular}{|c|c|c|c|c|c|}
\hline PROVINCES & SECTOR & $\%$ & PROVINCES & SECTOR & $\%$ \\
\hline $\begin{array}{l}\text { BADAKSHAN } \\
\text { BADGHIS } \\
\text { BAGHLAN } \\
\text { BALKH } \\
\text { BAMYAN } \\
\text { FARAH } \\
\text { FARYAB } \\
\text { GHAZNI } \\
\text { GHOR } \\
\text { HELMAND } \\
\text { HERAT } \\
\text { JAWZJAN } \\
\text { KABUL } \\
\text { KANDAHAR } \\
\text { KAPISA }\end{array}$ & $\begin{array}{l}\text { IRRIG/CONST/WS/IN . GEN } \\
\text { CONST/WS/AGRIG } \\
\text { AGRIC/CONST/WS/HLTH }\end{array}$ & $\begin{array}{l}11 \\
10\end{array}$ & $\begin{array}{l}\text { KUNAR } \\
\text { KUNDUZ } \\
\text { LAGHMAN } \\
\text { LOGAR } \\
\text { NANGARHAR } \\
\text { NIMROZ } \\
\text { ORUZGAN } \\
\text { PAKTEKA } \\
\text { PAKTIA } \\
\text { PARWAN } \\
\text { SAMANGAN } \\
\text { TAKHAR } \\
\text { WARDAK } \\
\text { ZABUL } \\
\text { PAKISTAN }\end{array}$ & $\begin{array}{l}\text { IRRIG/CONST / IN. GEN } \\
\text { AGRIC/IN. GEN } \\
\text { IN. GEN/AGRIC/CONST } \\
\text { AGRICULTURE }\end{array}$ & $\begin{array}{r}7 \\
15 \\
20\end{array}$ \\
\hline
\end{tabular}




\section{NORWEGIAN PROJECT OFFICE / \\ RURAL REHABILITATION \\ ASSOCIATION FOR \\ AFGHANISTAN (NPO/RRAA)}

NP0/RRAA was originally established in Peshawar, Pakistan at the beginning of 1990 through taking over some projects previously implemented by ARC.

Due to the massive repatriation of refugees in 1992 NPO/RRAA transferred or expanded most projects into Afghanistan. Only a limited number of projects remained in Pakistan to serve the neediest refugees. The agency created four regional offices in four different zones i.e. South east, East, South and North, located in Jalalabad, Gardez, Mazar and Herat.

From 1990-94 the agency was associated with and supervised by Norwegian Church Aid/ Norwegian Refugee Council (NCA/NRC). In 1994 it became an Afghan NGO changing its name to Rural Rehabilitation Association for Afghanistan (RRAA) which was later modified to NPO/RRAA.

Policies revolve round the principal goal of integrated rural rehabilitation/ development. Community participation, community contribution, targeting the neediest groups of the community, no free assistance, cooperation and coordination with local authorities, related NGOs and UN agencies.

\section{Short term Objectives}

- $\quad$ to encourage repatriation of external and internal refugees;

- $\quad$ to prevent urbanization;

- $\quad$ to support vulnerable families and groups regardless of sex and ethnic background;

- $\quad$ to contribute toward rehabilitation and development of the rural areas;

to provide opportunities for the return of a normal life to have an impact on restoration of peace and tranquillity.

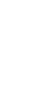

The key sectors of NPO/RRAA's activities are:

- Income Generation

- Skills training

- Construction

- Agriculture

- Water supply

- Relief supply

- Education

Projects in Pakistan include income generation for women and the disabled.

\section{Cross-border projects consist of:}

- income generation, construction, shelter, road rehabilitation, agriculture, irrigation, veterinary, poultry, horticulture, water supply, community support, emergency relief and education. 


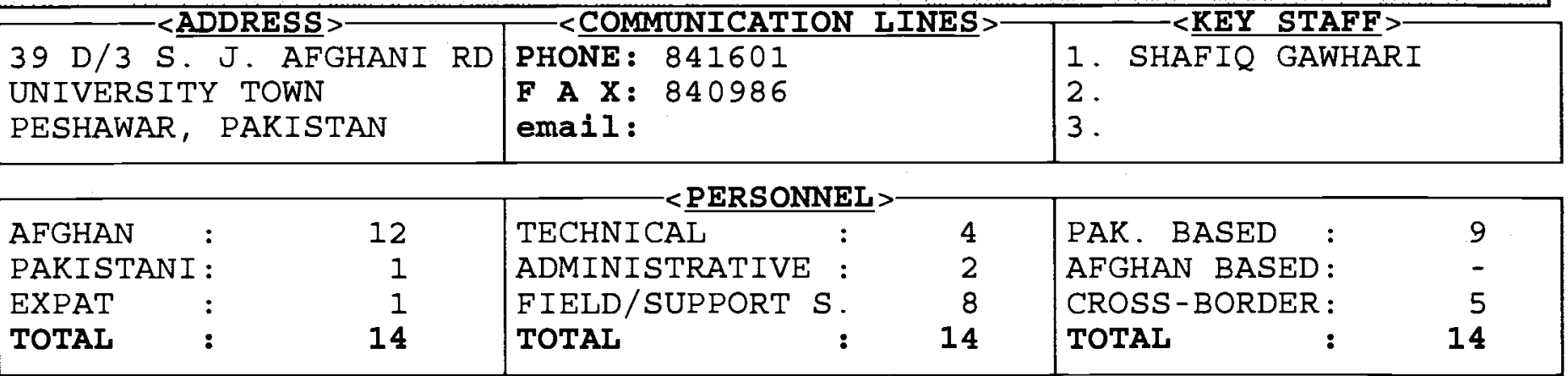

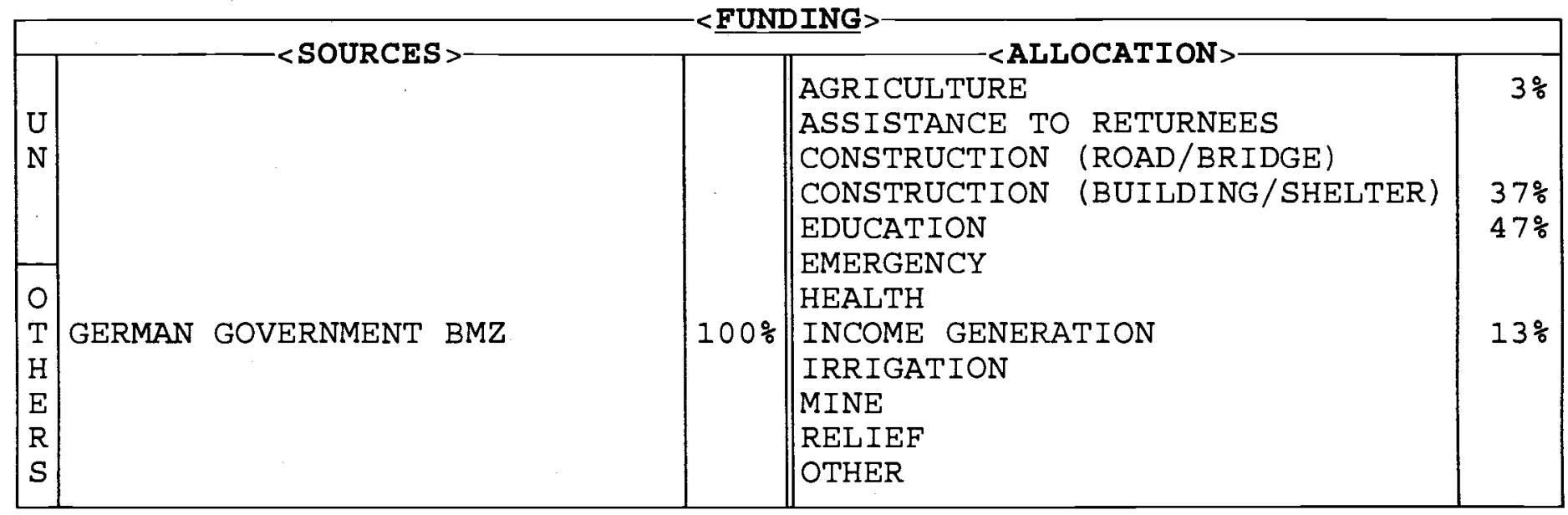

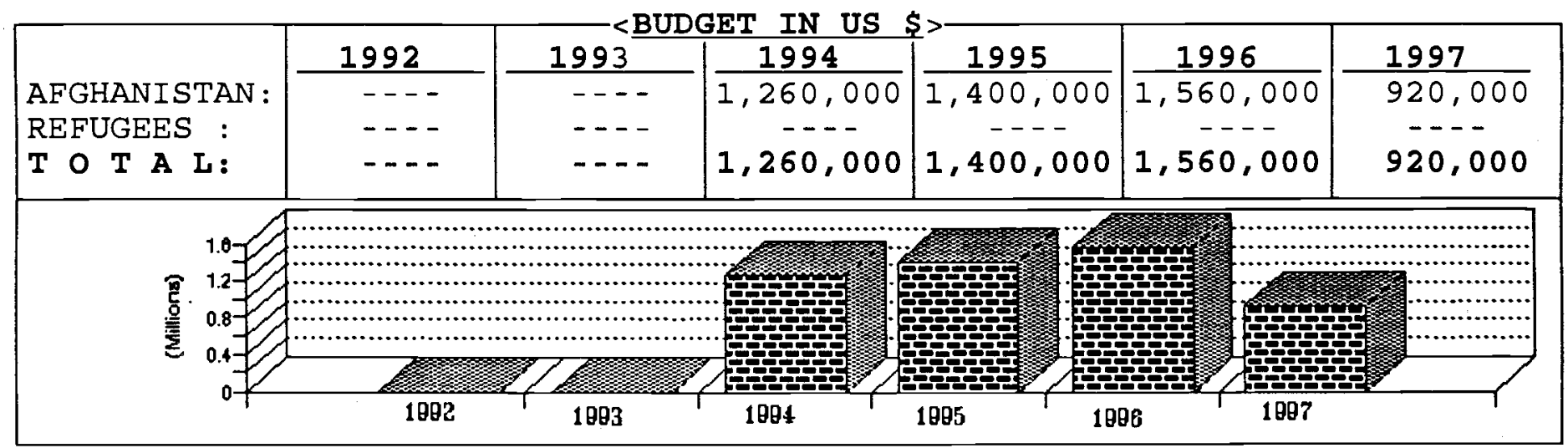

\begin{tabular}{|c|c|c|c|c|c|}
\hline PROVINCES & SECTOR & $\%$ & PROVINCES & SECTOR & $\%$ \\
\hline $\begin{array}{l}\text { BADAKSHAN } \\
\text { BADGHIS } \\
\text { BAGHLAN } \\
\text { BALKH } \\
\text { BAMYAN } \\
\text { FARAH } \\
\text { FARYAB } \\
\text { GHAZNI } \\
\text { GHOR } \\
\text { HELMAND } \\
\text { HERAT } \\
\text { JAWZJAN } \\
\text { KABUL } \\
\text { KANDAHAR } \\
\text { KAPISA }\end{array}$ & $\begin{array}{l}\text { EDUCATION } \\
\text { IN. GEN } \\
\text { CONSTRUCTION/IN. GEN } \\
\text { AGRICULTURE } \\
\text { CONST/EDUC } \\
\text { COSNT/IN. GEN }\end{array}$ & $\begin{array}{r}2 \\
1 \\
6 \\
2 \\
2 \\
23\end{array}$ & $\begin{array}{l}\text { KUNAR } \\
\text { KUNDUZ } \\
\text { LAGHMAN } \\
\text { LOGAR } \\
\text { NANGARHAR } \\
\text { NIMROZ } \\
\text { ORUZGAN } \\
\text { PAKTEKA } \\
\text { PAKTIA } \\
\text { PARWAN } \\
\text { SAMANGAN } \\
\text { TAKHAR } \\
\text { WARDAK } \\
\text { ZABUL } \\
\text { PAKISTAN }\end{array}$ & $\begin{array}{l}\text { IN. GEN } \\
\text { CONSTRUCTION } \\
\text { EDUCATION/IN. GEN } \\
\text { CONST/EDUC } \\
\text { CONST/EDUC } \\
\text { EDUC/IN . GEN / HLTH } \\
\text { CONSTRUCTION } \\
\text { HEALTH/CONSTRUCTION }\end{array}$ & $\begin{array}{r}7 \\
6 \\
1 \\
16 \\
2 \\
16 \\
4\end{array}$ \\
\hline
\end{tabular}




\section{EMERGENCY AND RELIEF \\ PROGRAMME FOR AFGHANISTAN \\ (NSP/GTZ)}

The Emergency and Relief programme for Afghanistan (NSP) is a project of the German Agency for Technical Co-operation (GTZ).

GTZ is the main implementing organisation for Technical Assistance granted by the German Government to developing countries.

NSP was set up in January 1994 in Germany. It was established in conjunction with a skills development and training programme for Afghan refugees living in Germany (FKP).

The first projects were identified during appraisal missions conducted by Afghans seconded by FKP. Based on identified needs and project proposals received, NSP requested various NGOs to implement these projects.

Since January 1994, NSP has been co-operating with 20 mainly Afghan NGOs and has implemented about 60 projects in Afghanistan.

Since January 1996, NSP operates its own office in Peshawar. This office runs an umbrella programme covering different sectors emphasizing vocational training, basic education, health and infrastructure.

NSP personnel identify needs in Afghanistan and co-ordinate needs-related project approaches with local authorities/communities as well as other organisations working in the target area.

Finally NSP requests NGOs to undertake project implementation. During the implementation process, NSP conducts close monitoring and also provides advisory services to local authorities/communities and implementing partners. The current project phase ends December 1997. 
ORGANIZATION FOR MINE-CLEARANCE AND AFGHAN RLAABILITATION (OMAR) <ADDRESS $>$ $15, \mathrm{D}-1$, PHASE-1, HAYATABAD, P.O.BOX 1433 PESHAWAR, PAKISTAN PHONE : 812084,814599

F A : 812085

2. MR. ZEKRIA PAYAB

email:omer@oscar.pwr.sdnpk.undp.org 3.MR.M. ARIF

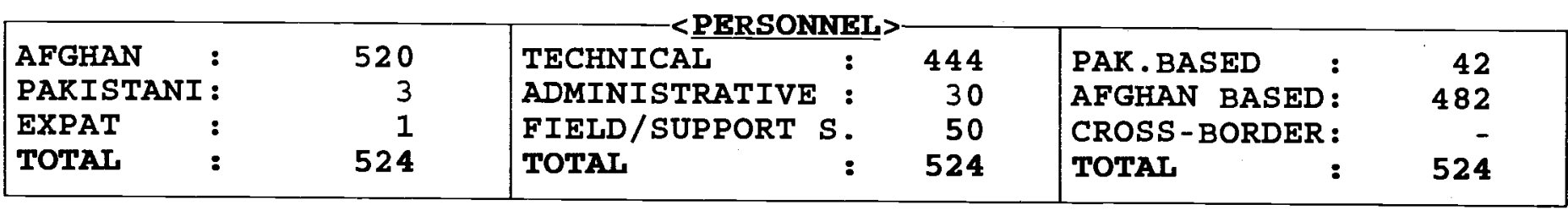

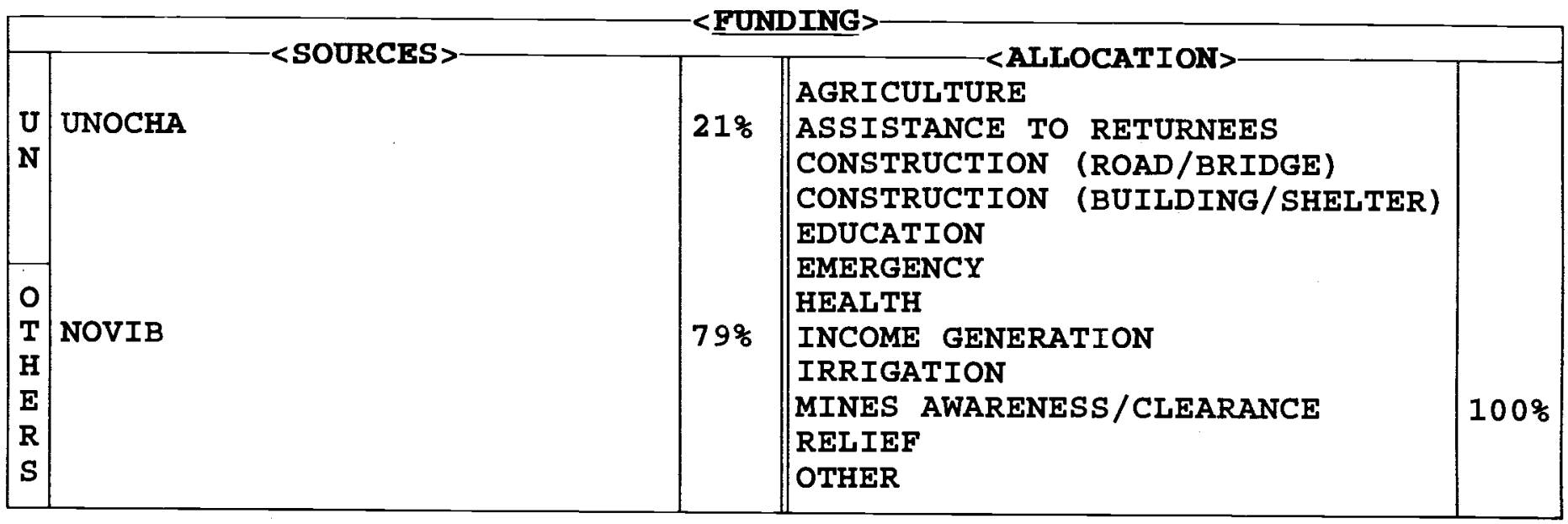

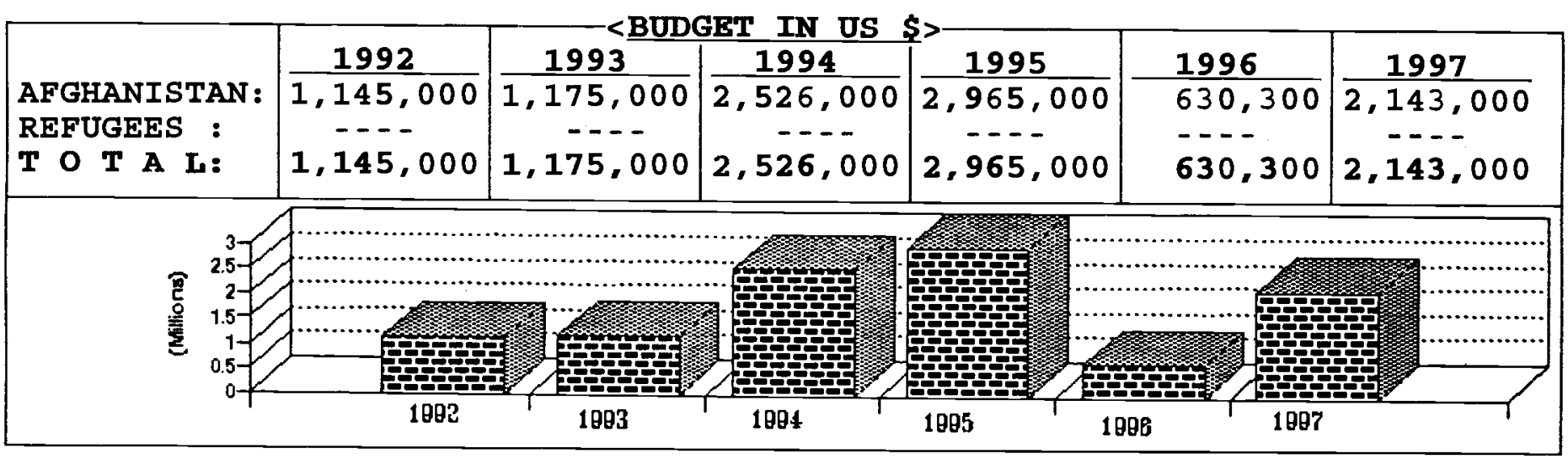

\begin{tabular}{|c|c|c|c|c|c|c|}
\hline PROVINCES & & SECTOR & $\%$ & PROVINCES & SECTOR & $\%$ \\
\hline $\begin{array}{l}\text { BADAKSHAN } \\
\text { BADGHIS } \\
\text { BAGHLAN } \\
\text { BALKH } \\
\text { BAMYAN } \\
\text { FARAH } \\
\text { FARYAB } \\
\text { GHAZNI } \\
\text { GHOR } \\
\text { HELMAND } \\
\text { HERAT } \\
\text { JAWZJAN } \\
\text { RABUL } \\
\text { KANDAHAR } \\
\text { KAPISA }\end{array}$ & $\begin{array}{l}\text { MINE } \\
\text { MINE } \\
\text { MINE } \\
\text { MINE } \\
\text { MINE } \\
\text { MINE }\end{array}$ & $\begin{array}{l}\text { AWARENESS / CLEAR. } \\
\text { AWARENESS } \\
\text { AWARENESS / CLEAR. } \\
\text { AWAR . / CLEARANCE } \\
\text { AWARENESS / CLEAR. } \\
\text { AWARENESS/CLEAR. }\end{array}$ & $\begin{array}{r}5 \\
1 \\
2 \\
54 \\
\\
14 \\
12\end{array}$ & $\begin{array}{l}\text { KUNAR } \\
\text { KUNDUZ } \\
\text { LAGHMAN } \\
\text { LOGAR } \\
\text { NANGARHAR } \\
\text { NIMROZ } \\
\text { ORUZGAN } \\
\text { PAKTEKA } \\
\text { PAKTIA } \\
\text { PARWAN } \\
\text { SAMANGAN } \\
\text { TAKHAR } \\
\text { WARDAR } \\
\text { ZABUL }\end{array}$ & 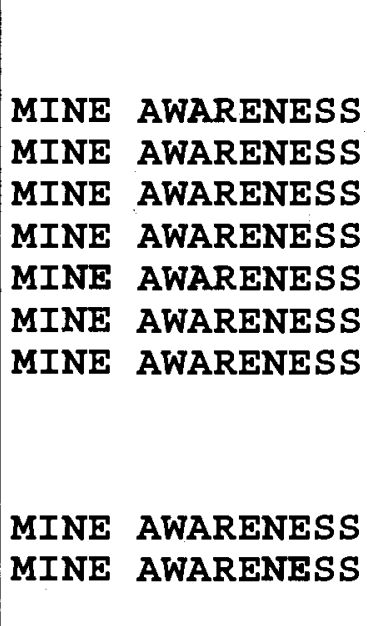 & $\begin{array}{l}1 \\
1 \\
1 \\
1 \\
1 \\
1\end{array}$ \\
\hline
\end{tabular}




\section{ORGANISATION FOR MINE \\ CLEARANCE AND AFGHAN \\ REHABILITATION \\ (OMAR)}

OMAR is an Afghan NGO established in late 1990.

\section{Sector of Operation}

The agency took over the Mine Awareness

Programme (MAP) which was operated by IRC.

The agency offers different types of mine awareness courses including: 6 hour basic course, 12 day potential teacher trainer's course, women's one hour basic safety course and the women's three hour basic course. Training aids and publications on mine awarencss are also distributed.

By the end of 1991, OMAR completed its mine awareness training in the refugee camps in Pakistan (NWFP and Baluchistan). Now, OMAR has mine awareness courses and campaigns inside Afghanistan.

Most of its resources were concentrated in demining of the first security belt around Herat city, which was previously a residential area. This was a dangerous task for the deminers as the area consisted of collapsed houses and rubble. This area has now been completely cleared of mines, leaving enormous social and economic benefits.

The first security belt contained houses, roads, agricultural and grazing land and was cleared of mines by May 1994. Thousands of houses have new been built in this area.

\section{Further Information}

The OMAR programmes are part of the efforts to enable Afghans to return to their homcland and resume normal life; to become self sufficient and live normal lives.
Courses and campaigns have been and are being conducted in the Provinces of Farah, Herat, Kabul, Kandahar, Kapisa, Logar, Parwan and Wardak.

OMAR started mine clearance activities in Herat, Farah and Badghis, Western Afghanistan, in August 1992 with one demining team. It now has eight teams, all currently working there. 


\begin{tabular}{|c|c|c|}
\hline $\begin{array}{l}\mathrm{F} 27 \mathrm{~K} \mathrm{~K} \mathrm{~K} \mathrm{ROAD} \quad \mathrm{U} / \mathrm{T} \\
\mathrm{P} O \mathrm{O} \text { BOX } 594 \\
\text { PESHAWAR, PAKISTAN }\end{array}$ & $\begin{array}{l}\text { <COMMUNICATION LINES }> \\
\text { PHONE: } 841280 / 45504 / 845637 \\
\text { F A X: } 841089 \text { net.pk } \\
\text { email:ora@ora.psh.brain. }\end{array}$ & $\begin{array}{ll}\text { 1. } & \text { DR TONI GEY STAFF }> \\
\text { 2. } & \text { PHIL SIMPSON } \\
\text { 3. } & \text { QASIM FARANI }\end{array}$ \\
\hline $\begin{array}{l}\text { AFGHAN : } \\
\text { PAKISTANI: } \\
\text { EXPAT : } \\
\text { TOTAL }\end{array}$ & $\begin{array}{ll}\text { TECHNICAL } & : \\
\text { ADMINISTRATIVE }: \\
\text { FIELD/SUPPORT S: } \\
\text { TOTAL }\end{array}$ & $\begin{array}{l}\text { PAK. BASED : } \\
\text { AFGHAN BASED : } \\
\text { CROSS-BORDER : } \\
\text { TOTAL : }\end{array}$ \\
\hline
\end{tabular}

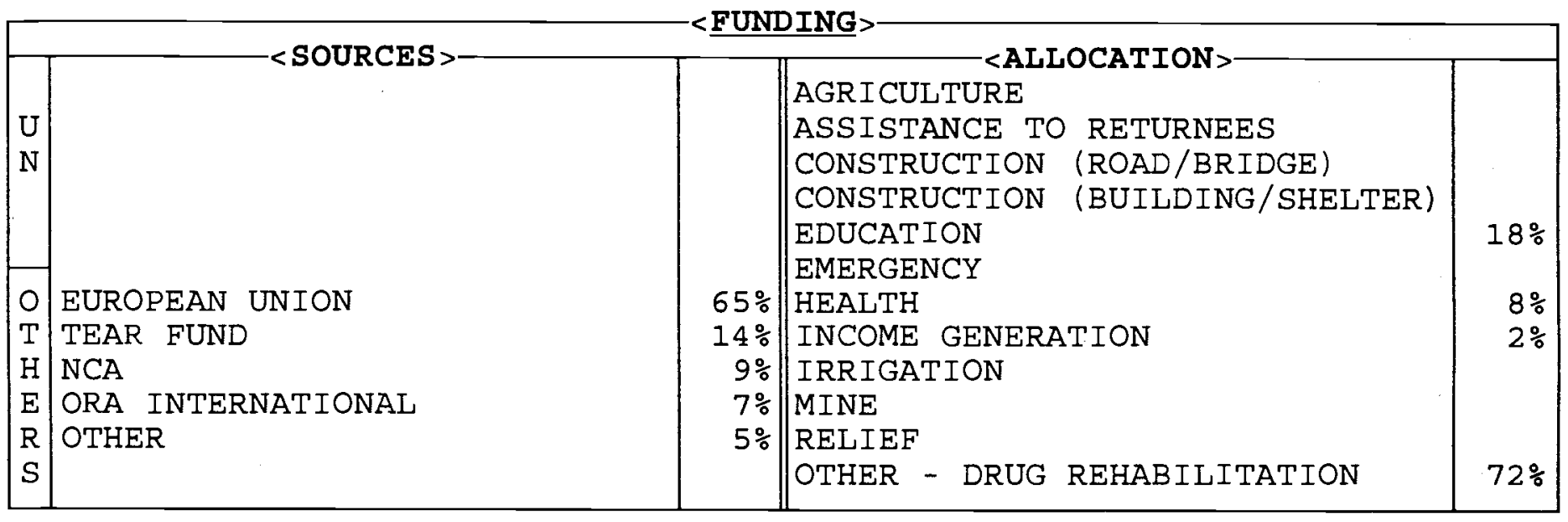

\begin{tabular}{|l|c|c|c|c|c|c|}
\hline & 1992 & 1993 & 1994 & 1995 & 1996 & 1997 \\
AFGHANISTAN : & $-\ldots$ & 70,200 & 66,500 & 74,300 & 113,500 & 189,000 \\
REFUGEES : & 51,400 & 24,000 & 97,700 & 136,400 & 163,500 & 214,000 \\
T O T A L: & 51,400 & 94,200 & 164,200 & 210,700 & 277,000 & 403,000 \\
\hline
\end{tabular}

\begin{tabular}{|c|c|c|c|c|c|}
\hline PROVINCES & SECTOR & $\%$ & PROVINCES & SECTOR & $\%$ \\
\hline $\begin{array}{l}\text { BADAKSHAN } \\
\text { BADGHIS } \\
\text { BAGHLAN } \\
\text { BALKH } \\
\text { BAMYAN } \\
\text { FARAH } \\
\text { FARYAB } \\
\text { GHAZNI } \\
\text { GHOR } \\
\text { HELMAND } \\
\text { HERAT } \\
\text { JAWZJAN } \\
\text { KABUL } \\
\text { KANDAHAR } \\
\text { KAPISA }\end{array}$ & $\begin{array}{l}\text { DRUG REHABILITATION } \\
\text { HEALTH }\end{array}$ & 34 & $\begin{array}{l}\text { KUNAR } \\
\text { KUNDUZ } \\
\text { LAGHMAN } \\
\text { LOGAR } \\
\text { NANGARHAR } \\
\text { NIMROZ } \\
\text { ORUZGAN } \\
\text { PAKTEKA } \\
\text { PAKTIA } \\
\text { PARWAN } \\
\text { SAMANGAN } \\
\text { TAKHAR } \\
\text { WARDAK } \\
\text { ZABUL } \\
\text { PAKISTAN }\end{array}$ & $\begin{array}{l}\text { EDUCATION } \\
\text { DRUG REHAB / EDUC }\end{array}$ & 53 \\
\hline
\end{tabular}

